1997

\title{
Son of Heaven and Heavenly Qaghan: Sui-Tang China and its Neighbors
}

Yihong Pan

Follow this and additional works at: https:// cedar.wwu.edu/easpress

Part of the Asian History Commons

\section{Recommended Citation}

Pan, Yihong, "Son of Heaven and Heavenly Qaghan: Sui-Tang China and its Neighbors" (1997). East Asian Studies Press. 6. https://cedar.wwu.edu/easpress/6

This Book is brought to you for free and open access by the Books and Monographs at Western CEDAR. It has been accepted for inclusion in East Asian Studies Press by an authorized administrator of Western CEDAR. For more information, please contact westerncedar@wwu.edu. 
Son of Heaven and Heavenly Qaghan:

Sui-Tang China and its Neighbors 
Center for East Asian Studies

Western Washington University

Studies on East Asia, Volume 20

Son of Heaven and Heavenly Qaghan:

Sui-Tang China and its Neighbors

by Pan Yihong

The Center for East Asian Studies publishes scholarly works on topics relating to China, Japan, Korea, and Mongolia

Editor:

Editor-in-chief, Edward H. Kaplan

volume editors, Edward H. Kaplan and Scott Pearce 


\title{
Son of Heaven and Heavenly
}

\author{
Qaghan:
}

Sui-Tang China and its Neighbors

\author{
Pan Yihong
}

Western Washington 
Copyright 1997

by

Center for East Asian Studies

Western Washington University

Bellingham, Washington 98225-9056

\begin{abstract}
All rights reserved. No part of this publication may be reproduced or transmitted in any form or by any means, electronic or mechanical, including photocopy, recording, or any information storage or retrieval system, without permission in writing from the publisher.
\end{abstract}

Library of Congress Cataloging-in-Publication Data

Son of Heaven and Heavenly Qaghan:

Sui-Tang China and its Neighbors

by Pan Yihong

xviii, 428 p. (Studies on East Asia; v. 20)

Includes bibliographical references and index

ISBN 0-914584-20-0 : \$35.00 (est.)

1. China--Foreign relations--Asia, Central. 2. Asia, Central--Foreign relations. 3. China--Foreign relations--To 1644. 4. China--History--Sui dynasty, 581-618. 5. China--History--T'ang dynasty, 618-907. I. Title. II. Series.

DS747.46.P35 1997

97-29484

327.51058--dc21

CIP

Manufactured in the United States of America 


\section{To my parents}

\section{Pan Zaiwei and Wang Yaokun}

謹以此書獻給我的父母

潘在微, 王瑤琨 


\section{Acknowledgments}

This book has grown out of my Ph.D. dissertation at the University of British Columbia, but I must also thank the many people who have helped me along the way and without whom I could not have brought the work to completion.

I would first like to thank my professors during my M.A. days in China, Xia Xiurui and Wu Yugan, for their intellectual inspiration and guidance in my initial explorations in the field of Chinese external relations; next my teachers and advisers at U.B.C., Edwin G. Pulleyblank, Alexander Woodside, Donald Baker, Jo-shui Chen, and Daniel Overmyer, for their careful reading and detailed comments on the work in progress, and for their generous support. I would like to express my thanks in particular to my supervisor, Professor Pulleyblank, who helped with the research, read carefully almost each of the many drafts of the manuscript both before and after the completion of the dissertation, and made invaluable suggestions and criticisms. His dedication to scholarship and his intellectual integrity made me realize that the study of history is a way of life and not merely a job. He is not only a strict supervisor but also an understanding friend.

I am also indebted to my friends: to Dr. Gareth Sparham for his reading and editing of the early drafts of the dissertation, and to Ms. Wang Yufei and Dr. Hu Bangbo for their excellent drawing of all the maps in this book. My colleagues in the History Department at Miami University extended their support and encouragement in the difficult task of turning the dissertation into a book. The staff of the Library of Asian Studies of U.B.C. were always there to help. I would like to thank in particular Mr. T. Gonnami for his help in rendering into the Latin alphabet Japanese names and the titles of articles and books.

I am much indebted to the University of British Columbia for the graduate fellowship which enabled me to pursue my $\mathrm{Ph} . \mathrm{D}$. studies from 1984 to 1988; and also to Miami University for a summer scholarship in 1993 to help in turning the dissertation into a book.

Parts of Chapters 5, 7 and 10 have appeared in my articles "The Sino-Tibetan Treaties in the Tang Dynasty," T'oung Pao, 78, pp. 116-161, and "Early Chinese Settlement Policies Toward the Nomads," Asia Major, 3rd ser., vol. 5, part 2, pp. 41-78. 
Finally, I must thank my editors at Western Washington University's Center for East Asian Studies, Dr. Scott Pearce and especially Dr. Edward Kaplan, whose meticulous copy editing and pleasant cooperation made the book what it is now. In the end, of course, I myself am personally responsible for the contents of the book, including any errors that remain.

Pan Yihong Oxford, Ohio August 1997 


\section{CONTENTS}

Acknowledgments.

Explanatory Notes.....................................................................

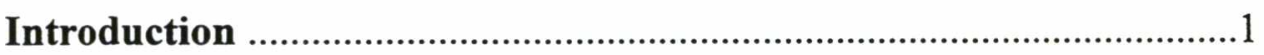

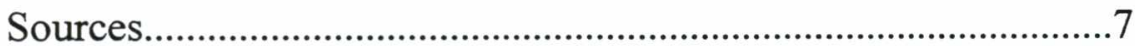

1. Background: Chinese Foreign Policy before the Sui Period: Theory

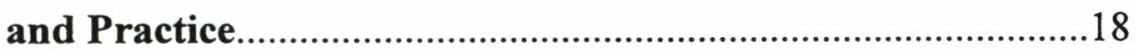

Formation and Implications of the Myth of the Chinese World Order............................................................19

The Tribute System During the Han Dynasty.................................24

Other World Views_-Practicality and Flexibility...........................28

Challenges to the Chinese World Order:

Disunion and Non-Chinese Rule.........................................31

The Nomadic Legacy of the Northern Dynasties.............................32

Creating a Multiethnic State...............................................32

Non-Chinese Rulers in China and the Nomads

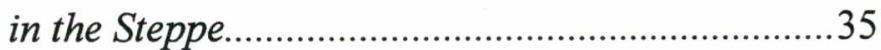

The Non-Chinese Military Legacy........................................36

The Patronage of Buddhism.................................................36

China's Neighbors.........................................................................3

The Nomadic Threat from the Steppe.................................39

Xiongnu...............................................................42

Wuhuan and Xianbei ...............................................43

Xianbei Regimes in North China............................44

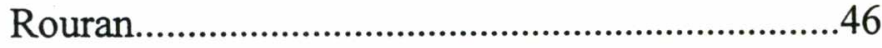

Tujue Turks..........................................................48

Gaoche.................................................................49

The Western Regions...........................................................50

Manchuria in the Northeast ................................................54 
The Western Mountain Borderlands and Tibet..................56

The South and Southwest...................................................57

General Policy Measures Towards Non-Chinese States.................58

2. How Foreign Affairs were Handled During Sui and Tang ............66

The Decision-Making Process........................................................66

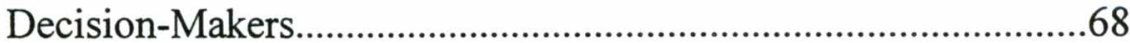

Central Government Offices for Dealing with Foreigners.............75

Sources of Information on Foreign Countries..............................81

3. The Sui Dynasty: A United Empire Restored and Lost...................95

Emperor Wen.....................................................................95

Military and Frontier Organization..............................................98

Zhangsun Sheng and his Divide and Rule Turkish Strategy.......100

The Eastern Turks as Tributaries of Sui......................................102

Dividing the Eastern Turks and Attacking the Western Turks....104

The Non-interventionist Policy

Towards the Tuyuhun Kingdom....................................107

A War of Deterrence Against Koguryǒ......................................108

Advance on the Southern Frontier..............................................111

Emperor Yang.........................................................................112

Keeping the Eastern Turks as Sui Tributaries...............................114

Southern Expeditions.................................................................115

Pei Ju as Foreign Policy Adviser...............................................116

Defeat of the Tuyuhun Kingdom and Opening the Western Regions.......................................................118

Success in Subduing the Western Turks.....................................120

Three Wars of Aggression Against Koguryǒ................................121

The Siege of Yanmen..................................................................127

The Foreign Policies of the Two Emperors Compared.................128

\section{Tang's Internal Evolution and its Foreign Policy ...........................133}

Gaozu: Dynastic Consolidation..................................................133

Building Frontier Defenses......................................................133 


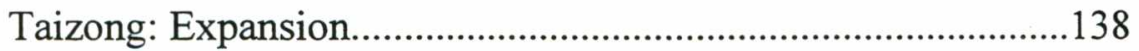

The Making of Foreign Policy under Taizong..............................141

Gaozong and Empress Wu: from Expansion to Defense..............144

Chief Ministers with Experience in Frontier Affairs under Gaozong and Empress Wu......................................147

Xuanzong: from Defense to Aggression..........................................150

Suzong and Daizong: the An Lushan Rebellion

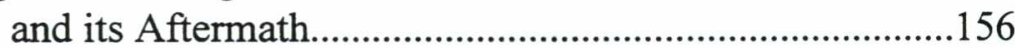

Dezong: Increasing Influence of the Inner Court and Military System.........................................................161

Abortive Reform under Shunzong................................................163

Temporary Recovery under Xianzong...........................................164

Decline and Disintegration..........................................................165

\section{Tang and the First Turkish Empire:}

From Appeasement to Conquest............................................168

The Rise of Li Yuan and the Initial Alliance with the Turks........169

Gaozu's Appeasement Policy

in the Face of Turkish Aggression......................................171

Using the Tuyuhun Against Li Gui..............................................175

Taizong's Conquest of the Eastern Turks in 630.........................176

Taizong as Heavenly Qaghan......................................................179

Debate on the Policy of Resettling the Turks...............................183

The Resettlement of the Turks........................................................187

Adjustments in the Turkish Settlement.........................................188

The Conquest of the Xueyantuo in 646.......................................190

Resettlement of the Xueyantuo and Other Tiele Tribes................192

Tang Expansion into the Western Regions...................................193

Gaozong's Conquest of the Western Turks...................................195

The System of jimi fuzhou and the Protectorate............................197

6. Tang and Korea: Expansion and Withdrawal................................204

Gaozu's Peaceful Communication with Korea..............................207

Taizong's Peace with Korea, 627-640..........................................209 
The Decision for War Against Koguryǒ, 641-643.......................210

The Three Campaigns Against Koguryǒ, 644-648......................215

The Conquest of Paekche in 660 ............................................217

The Conquest of Koguryǒ in 668...............................................221

Tang's Withdrawal from the Korean Peninsula in 676................222

Curbing the Parhae State..............................................................227

\section{Competition Between Tang and Tibet}

Before the An Lushan Rebellion...........................................231

The Tibetan Challenge................................................................231

Taizong: Subduing the Tuyuhun.................................................235

The First Encounter with Tibet and Achievement of Peace

through the Marriage of Princess Wencheng, 634-660................236

Confrontations with Tibet over the Tuyuhun, 660-680...............239

Competition in the Southwest and over the Western Regions, 670-705.........................243

The First Treaty with Tibet and the Marriage of

Princess Jincheng, 706-710............................................247

Conflicts and Negotiations, 712-719.......................................250

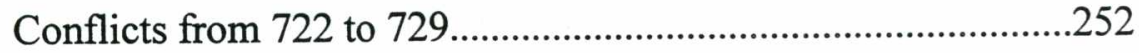

The Second Treaty with Tibet in 732 .......................................253

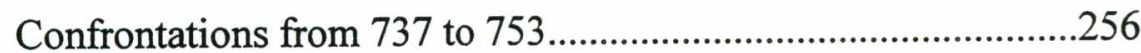

From Supporting Nanzhao's Unification

to Aggression against Nanzhao.

\section{China, the Second Turkish Empire}

and the Western Turks, 679-755..........................................262

The Restoration of the Second Turkish Empire..........................262

Empress Wu: Compromise for Peace...........................................265

Zhongzong: Building of the Three Shouxiang Fortresses and Alliance with the Türgish.........................................269

Xuanzong: Bäg Chor's Final defeat, 712-716............................272

Continuation of the Settlement Policy.........................................2274

Peace with the Eastern Turks, 717-740......................................276 
The End of the Second Turkish Empire, 741-745.....................278

Bringing the Khitan and $\mathrm{Xi}$ under Chinese Control....................279

Xuanzong: Making the Türgish Allies........................................281

Encounters with the Arabs.......................................................283

9. Tang and the Uighurs: An Unstable Alliance...............................287

The Tradition of Alliance Between China and the Uighurs Before 745 ...........................................287

Suzong: Securing the Uighur Alliance.....................................292

Daizong: The Appeasement Policy's Effect and Expense............296

Dezong: Deterioration in Tang-Uighur Relations, 779-787.........301

Alliance with the Uighurs Against Tibet, 787-804.....................303

The Uighur Alliance Kept: Reasons and Effects, 805-840..........306

End of the Uighur Empire: China Abandons the

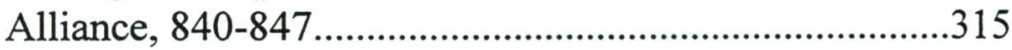

10. Tang, Tibet and Nanzhao in the Post-An Lushan Period.............322

Coping with the Tibetan Invasions, 756-764 ...............................322

Tibetan Support for Pugu Huaien's Rebellion in 764-765

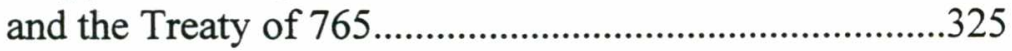

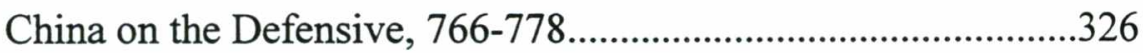

Dezong: Alliance with Tibet, 779-783 ..........................................327

Tibetan Assistance in Tang's Suppression of the Rebellion of 783-784 ...............................................330

The Breakdown of the Tibetan Alliance, 784-787.......................332

Alliance with Nanzhao and the Uighurs against Tibet.................335

Making Peace with Tibet, 806-822 .............................................337

The Weizhou Incident in 831 .....................................................340

Peace and War with Nanzhao...................................................341

11. Characteristics of Foreign Policy During the Sui-Tang Period...347

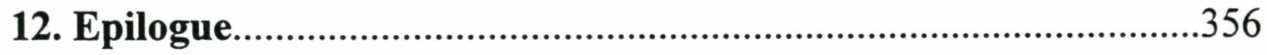

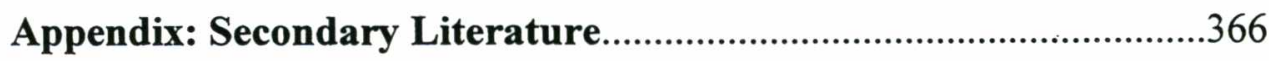

The Chinese Tribute System.....................................................366

The Nomadic Peoples and Sui-Tang China..................................368 


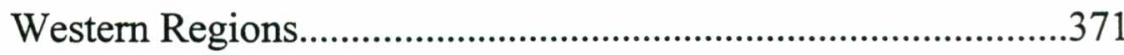

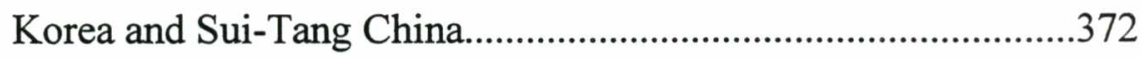

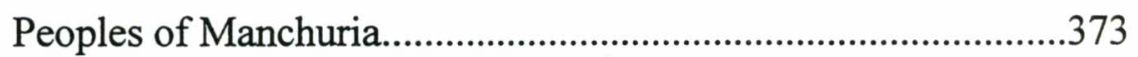

Tibet and Sui-Tang China............................................................373

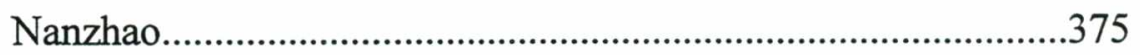

The Frontier Military System in Sui-Tang China........................375

\section{Tables}

Table 1: Sui-Tang Emperors and Major Events

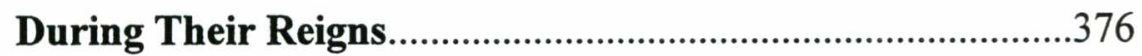

Table 2: Tribute Missions of the Three Korean Kingdoms

to Sui and Tang (from 581 to 712)..........................................380

Table 3: Participation in Tang Expeditions by

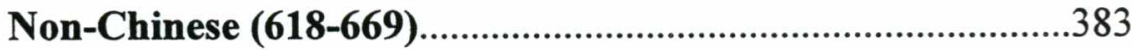

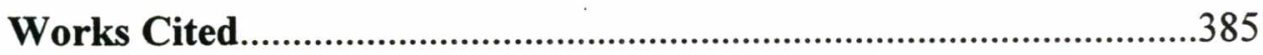

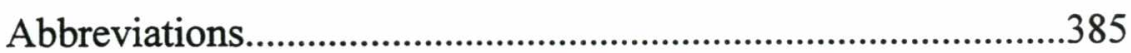

Traditional Chinese Works Listed by Titles................................386

Modern Works Listed by Authors............................................389

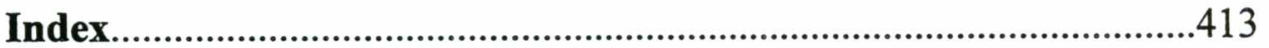

\section{Maps}

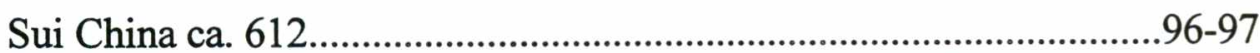

Tang China ca. 669...................................................................134-135

Korea and Northeast China ca. 650 .....................................................205

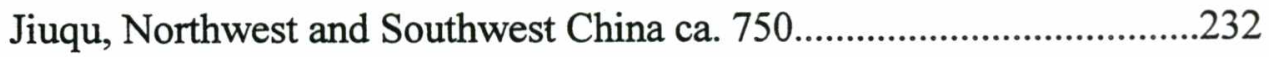

Tang China and its Neighbors ca. 820 .........................................288-289 


\section{Explanatory Notes}

1. The pinyin system is used for transcribing Chinese. In the quotations from English works, except in titles of books and articles and names of authors, other forms of romanization are always changed into pinyin.

2. A full reference to all the books and articles cited in the body of this work and their abbreviated titles is given alphabetically in the three subdivisions of the Works Cited sections at the end. Section one is Abbreviations. Section two is Traditional Chinese Works Listed by Titles. And section three is Modern Works Listed by Authors.

3. Chinese years are converted to the western calendar according to the year to which the greater part of the Chinese year corresponds. The conversion is based on Wan Guoding 1978.

4. Translation of Chinese official titles is based on Hucker 1985, except for the following terms: $d u d u$ (area commander), fanzhen (regional commands), qing (chamberlain), and zaixiang (chief minister).

5. In the transcription of Tibetan names: $\dot{n}$ becomes ng; ń becomes ny; ź becomes zh; ś becomes sh. 


\section{Introduction}

The conquest of the last of the Southern Dynasties by Sui in 589 brought to an end the Period of Disunion which had started with the collapse of Han in 220 C.E. The Sui dynasty was short-lived but laid the foundation for the Tang (618-907), an age of outstanding political and cultural achievement to which later generations looked back with nostalgia.

The Sui-Tang period of over three centuries stands as a high point in the development of Chinese civilization. It not only restored the unity of the Chinese empire, it enlarged this concept which had been born in early Zhou, idealized by the Confucian thinkers of the Warring States and given definite form in Qin and Han. At the end of Tang the pattern of unity was again challenged, but the ideal persisted and has remained very much alive to the present day.

The Sui and early Tang rulers greatly rationalized the government, introducing more sophisticated bureaucratic, legal, financial and military systems. Construction of the canal linking north and south under Emperor Yang of Sui and the long period of internal peace that lasted with few interruptions from the accession of Tang Taizong in 627 to the middle of the eighth century, as well as the opening up of contacts with Western Asia, greatly stimulated economic development and social change, preparing the way for the momentous transformations that came to fruition in the following Song period, when Chinese civilization was in many respects in advance of the rest of the world.

However, in political terms, the An Lushan rebellion from 755 to 763 marked a downward turning point. The unity of the country was challenged by struggles between the central authority and the semiautonomous provincial governors, especially those near the northern borders. At the center new generations of civil service examination graduates competed with the aristocratic bureaucrats, and weak emperors fell under the influence of powerful eunuchs. And yet, technological progress, development of the south, and flourishing trade continued to foster urbanization and the growth of a money economy, bringing about a commercial revolution that reached its height in Song. 
The triumphs and disasters of the three centuries of Sui and Tang are also clearly reflected in China's foreign relations. With their mixed Chinese and nomadic ancestry, and as the direct heirs of the once alien rulers of North China as well as the unifiers of North and South, the Sui and early Tang rulers inherited the rich tradition of Chinese literate culture as well as a vigorous non-Chinese, nomadic spirit.

During the preceding three centuries of political disunity, alien rule in North China had challenged the universal rulership of traditional Chinese political theory. While undergoing a gradual process of sinicization, the non-Chinese northern regimes influenced Chinese society profoundly through their attempts to establish the political basis for a multiethnic empire and their patronage of the foreign religion of Buddhism, while preserving their military vigor and alien social customs. Political disunity within China proper encouraged the different regimes in both northern and southern China to look more outward. The southern regimes looked towards the sea, increasing their maritime contacts with Southeast Asian countries. The northern regimes looked to sophisticated trading partners on the steppe land in the north and the Western Regions in the west.

Despite coming out of so novel a background, the Sui and early Tang rulers were ambitious to restore a unified empire on the Han model when Chinese rule had stretched far and wide into the surrounding regions against far less sophisticated cultures than Sui and Tang faced. After initial successes, the Sui attempt at landward expansion ended in disaster, whereas in 630 Tang Taizong succeeded in conquering the Eastern Turks, who had previously dominated the Mongolian steppe, and assumed the title Heavenly Qaghan. This let him claim to be something more than just a Chinese Son of Heaven extending his rule from his own Chinese inner group to certain non-Chinese outer groups. He could now claim to be Heaven's ordained ruler of nomadic peoples on their own terms, like the Turkish qaghans. For a while Taizong, a ruler with a unique breadth of vision, attempted to bring about a real universal empire, one with both Chinese and non-Chinese subjects directly under a Son of Heaven and Heavenly Qaghan combined in one person.

This vision was also given substance through incorporation of nonChinese into the Chinese administrative apparatus and the use of nonChinese nomadic troops as a major component in the Tang forces that sought to extend their conquests both east and west. By the late 650's Taizong's successor, Gaozong, had succeeded in extending Tang boundaries 
to an extent that was seldom matched before or afterwards in Chinese history, and spread the name of the Heavenly Qaghan far and wide.

However, this success only compounded the perpetual problem of how to maintain such an empire and how to preserve its rulers' internal security. From the 670's on, the Tang regime had to steadily retreat from its claims to so overextended a territory and switch the emphasis in its foreign policy to building up strong defenses for its overextended frontiers. By the late 730's China's frontiers were defended by strong fortresses and large armies, including many non-Chinese among both the troops and the generals.

With the backing of the emperor, the non-Chinese generals in particular were encouraged to push beyond the frontiers into the surrounding areas, but this new form of power also proved to have been overextended and soon collapsed. These strong frontier armies were developed at the cost of the defenses of the capital. One of the frontier commanders, An Lushan, half Turk and half Sogdian, took advantage of the weakness at the center and rose in revolt in 755 .

After a bitter struggle and only with the assistance of western allies, especially the Uighurs, who despatched troops to assist the Heavenly Qaghan, the Tang dynasty survived, but China's status as a great power was much diminished. The central government maintained a weak control over China internally, while externally it had to cope with a formidable challenge from Tibet, which had occupied that part of Chinese territory which allowed it to pose a permanent threat to the Tang capital, while the Uighur empire and later the Nanzhao kingdom demanded equality with China. As remarkable as was Taizong's attempt to build a universal empire, still more remarkable was the attitude of equality towards other states embodied in their policies and strategies by Tang rulers a century later, which ensured Tang's survival for another century and half.

Compared to Han, whose only major organized rival was the Xiongnu nomadic empire, Sui and Tang China faced a more complex international situation, one in which a number of states had been established in neighboring areas. The nomadic empires centered in the Mongolian steppe lands of first the Turks and then (from 740) the Uighurs continued to pose a serious threat. Farther east were the forest nomad Khitan and $\mathrm{Xi}$ confederations in Manchuria. These were states less formidable militarily than were those of the steppe nomads but they could maintain their independence by alternating alliances with the Chinese and the steppe nomadic 
powers, and thus sometimes posed a threat to China's northeastern frontier.

On the Korean peninsula, the situation contrasted with that during Han times, when there was at the beginning only a loosely organized kingdom in the north and no strong political regimes farther south. Three kingdoms, Koguryǒ, Paekche and Silla, had developed during the postHan Period of Disunion, with Koguryor, the closest to China, as a significant power on the international scene. In their competition for political supremacy these Korean states formed alliances with one another, or with the outside forces of China or Japan. Success of China's endeavor to conquer the peninsula before the 670 's was to a large extent determined by the internal struggles on the peninsula.

On China's northwestern frontier was the Tuyuhun kingdom in modern Qinghai. Tibet, immediately to the west of China, rose to be a powerful rival in the early seventh century. Especially from the 750's onwards, it challenged the Chinese empire as no power from that quarter had ever done before or was ever to do again. In the Western Regions, the oasis states were a bone of contention between the Turks, China and Tibet. From the eighth century on, the Arab empire expanded to become one more contender for control of Central Asia, exerting its impact on the political situation in the region. Later in the same century the Nanzhao kingdom in the southwest evolved into a buffer state between Tang and Tibet, further complicating the frontier situation.

These states all had particular ways of life, partly determined by geography and natural resources. These ranged from nearly pure nomadism, to mixtures in various proportions of nomadism and agriculture, and nearly pure reliance on agriculture, which determined, to a large extent, their economic and political needs vis-à-vis China. Each presented a unique case which had to be taken into account in the formation of China's policies towards them.

Beyond those regimes in direct contact with China, other countries, ranging from Japan to Southeast Asia, India, and West Asia enlarged their commercial and cultural contacts with China as compared with earlier times. Interactions between China and these countries through diplomatic envoys, merchants, and travelers with religious or cultural purposes gave China under the Tang its most cosmopolitan flavor in all of premodern history. Significant state to state relationships with such countries were, however, few and will not often be referred to in this book. It is well known that foreign trade flourished under Tang and the government 
worked out a set of policies and regulations regarding foreign trade and merchants. It is problematic to what extent either foreign or Chinese merchants engaged in foreign trade observed these rules, but that is more a matter for economic historians than historians of diplomacy. It deserves study in depth by the former, and will not be dealt with in this book.

Regardless of historical and geographical context, rulers of different types of political units, whether tribes, city-states, empires, or modern nations, have had fundamentally the same objectives in dealing with their neighbors-ranging from their own security to expansion against their neighbors - and have defended their interests by similar techniques, mainly the use of force and the construction of alliances. ${ }^{1}$ Traditional China was no exception. There was, however, a whole set of particular theories and practices developed during China's long history of foreign contacts, which may be analyzed under two major headings: ideological purity, and practicality and flexibility. Any understanding of the foreign policy of imperial China must take these into account.

In exploring Sui-Tang foreign relations, we shall seek to illustrate the interplay of the twin aspects of ideological purity and practicality in reaching and implementing foreign policy decisions. We shall try to determine when and how these principles clashed with or were reconciled with each other, how they provided justifications for and theoretical support to decisions, and how both affected the decision-making process at moments of Chinese strength and weakness. Both aspects must be taken into account to fully explain Chinese foreign policy.

Ideological purity refers to the traditional, ideal pattern that, from the Chinese point of view, should govern relationships between China and other states. It was based on a cosmological view of the state that emerged from, and evolved in, the particular environment of China and posited a hierarchical and fundamentally sinocentric order to the Chinese known world. It emphasized the all-embracing rule of the Chinese emperor, the Son of Heaven, who was supposedly the only legitimate ruler of, not only China, but All-under-Heaven. This pattern was embodied in the ceremonial rituals used under the tribute system. Such an ideology imposed political pressures on the Chinese rulers not only to maintain security on the frontiers but also to exert their influence over the areas beyond the frontiers.

${ }^{1}$ Holsti 1983, p. 4. 
By practicality and flexibility is meant a basic pragmatism which provided China's imperial rulers justification, for ignoring or bypassing considerations of ideological purity and conducting foreign relations on an equal footing with their neighbors. It allowed for acceptance of the need to retreat from the claims of Chinese superiority, and even permitted payment of tribute to "barbarians." Such measures could be carried out as long as they were seen to be entirely motivated by concern for China's own security and stability.

More specifically, we shall examine to what extent Sui-Tang foreign policies were unique as well as consistent with those of other periods in traditional China's history. We will ask what specific policies China adopted in each situation as it arose? What were the motives and objectives, the strengths and weaknesses, and what were both the intended and unintended effects of these policies?

In discussing the process of making of foreign policy, we will need to address the following questions: How were decisions arrived at? To what extent did the Chinese have the initiative? How did China's internal situation in successive periods influence foreign policy-making? What was the relationship between the frontier defense system and foreign policy? How and to what extent was foreign policy influenced by domestic political issues and economic pressures?

In terms of the external setting, what were the strategic interests of and issues motivating foreign countries that influenced their relations with China? How did the domestic situation in each foreign state influence its decision-makers and hence its relations with China and other countries? How did these foreign initiatives in turn influence China's actions towards these countries? Under what circumstances did China try to take the initiative in international politics; under what circumstances did it simply respond to other countries' actions and objectives?

Finally, we need to examine the roles and relative importance of the various participants in decision-making. These included the emperor, his chief ministers, certain influential eunuchs, civil and military officials at the central and local levels, non-Chinese officials, and Chinese imperial princesses who had been sent off to marry foreign rulers. How did the often clashing, sometimes synergizing ambitions, personalities, values and understanding and assessment of reality of this congeries of officials of various factions and their clients influence foreign policy decisionmaking? 


\section{Sources}

The principal primary sources for Sui and Tang history are, first of all, the standard histories, namely the Suishu and the two Tang histories, the Jiu Tangshu and the Xin Tangshu. ${ }^{2}$ Other basic works that have been used in this study are listed below in chronological order.

The Da Tang Chuangye Qijuzhu (Diary of the Founding of the Great Tang Dynasty), an unofficial court journal of Gaozu, compiled by Wen Daya covering the period from 617 to 626. As a chronological resumé of events concerning Li Yuan and his founding of the Tang dynasty from 615 up to the assumption of the throne by the new emperor, the book may be regarded as the first historical record of Tang. ${ }^{3}$

The Zhenguan Zhengyao (Important Principles of Government from the Zhenguan Period), a collection of Tang Taizong's discussions with his ministers, the memorials and suggestions from the ministers, and administrative measures of the period, collected and edited by Wu Jing. The book was completed around $720 .^{4}$ It was later translated into the Khitan, Tangut, Jurchen, Mongolian and Manchu languages as a guide for the government, and was appreciated by all subsequent non-Han conquerors of China from Liao to Qing. ${ }^{5}$

The Wenguan Cilin, a collection of edicts and memorials completed in 658, edited by $\mathrm{Xu}$ Jingzong and others, is in a thousand chapters. ${ }^{6}$ It is lost, but some parts are collected in a Japanese edition.

The Tang Liudian, in thirty chapters, completed in 738 and presented to the throne by Chief Minister Li Linfu in $739 .{ }^{7}$ It is an important work on government institutions and contains materials on such agencies as the Court of State Ceremonials (honglu si) and on administration and

\footnotetext{
${ }^{2}$ The primary sources for Tang are analyzed in a thorough and comprehensive way in the introduction to Robert des Rotours 1932, with additional material in his 1947 work. See also Twitchett 1992, who describes in detail the development of official historiography during Tang. He also provides a valuable analysis of the sources for the Basic Annals and the Monographs of the Jiu Tangshu. He does not discuss the sources of information for the chapters on foreign countries, for which see Chapter 2 below.

${ }^{3}$ For a detailed study of the book, see Bingham 1937, pp. 568-74; Twitchett 1992, pp. $38-42$, with references to earlier literature.

${ }^{4}$ ZGZY 1978, pp. 1-2.

${ }^{5}$ Franke and Twitchett 1994, p. 33.

${ }^{6}$ Twitchett 1992, p. 98.

${ }^{7}$ Twitchett 1992, pp. 101-3.
} 
taxation in the subordinated area commands and prefectures (jimi fuzhou) under the Ministry of Revenue.

The Tongdian, compiled by Du You from 766 to 801 . An institutional history, it continued and enlarged the Zhengdian of Liu Zhi. ${ }^{8}$ The Tang sections in the chapters on foreign countries were presumably taken from materials compiled in the Bureau of Historiography. It has the fullest account of the negotiation between Tang official Guo Yuanzhen and Tibetan general Mgar Khri 'bring during Empress Wu's time. ${ }^{9}$ Du You also incorporated many materials from other sources, including a book written by his nephew, Du Huan, who was taken captive in the famous battle at the Talas River between Tang and the Arabs in 751 and did not return to Tang until ten years later. ${ }^{10}$

The Tang Huiyao, compiled by Wang $\mathrm{Pu}$ and presented to the throne in 961 at the beginning of Song. An administrative encyclopedia, it combines the Huiyao of Su Mian, presented to the throne in 804, and the $X u$ Huiyao of Yang Shaofu, presented in 853, with the addition of a very small amount of material for the period after $852 .{ }^{11}$ It has the most complete record of the discussions held early in Taizong's reign concerning the resettlement of those Turks who had submitted to Tang rule. ${ }^{12}$

The Cefu Yuangui, compiled by Wang Qinruo, Yang Yi and others during Song under an imperial commission from 1005 to 1013. It is an historical encyclopedia. The material concerning the Tang period was from the veritable records and Tang histories. ${ }^{13}$ Therefore, it contains more original sources than the Jiu Tangshu and the Xin Tangshu and more complete versions of documents abridged in other sources. With its organization of a variety of material under different topics, such as the section on foreign vassals (waichen bu), the Cefu Yuangui is particularly useful for study of foreign relations. It records tributary missions from foreign countries which other histories have chosen not to mention. One example deals with the Turks. According to the Cefu Yuangui, during Tang Gaozu's reign, the Turks sent tributary missions to the Tang court almost every year. In the basic annals of Gaozu and the accounts of the Turks in

${ }^{8}$ Li Zongye 1982, pp. 307-9; Twitchett 1992, pp. 104-7.

${ }^{9}$ TD 190, pp. 1023-4.

${ }^{10}$ TD 191, p. $1029 ; 192$, p. 1034.

${ }^{11}$ Twitchett 1956, p. $51 ; 1992$, pp. 109-16.

${ }^{12}$ THY 73, pp. 1312-4.

${ }^{13}$ Liu Naihe 1983, pp. 1-28; Twitchett 1992, pp. 117-8. 
the Jiu Tangshu and Xin Tangshu, on the other hand, it is reported that the Turks made incursions across the Tang frontier almost every year, but records about the Turkish tributary missions are not complete. Some of the Turkish missions might have just come to the Chinese court to deliver messages, but the fact that they were still recorded as tributary missions implies that the foreigners had to conform to the rituals of the tribute system laid down by the Chinese in order to be received at the Chinese court at all.

The Tang Da Zhaoling $J i$ was compiled by Song Minqiu, whose preface is dated $1070 .{ }^{14}$ Some passages from the edicts included in the collection are referred to in the two Tang official histories and in the Zizhi Tongjian. The work is useful for studying the format and rhetoric of Tang documents.

The Zizhi Tongjian, compiled by a group of Song historians with Sima Guang as the chief editor from 1065 to 1084 . When compiling the Tang section (chapters 185 to 265), Sima Guang consulted all the materials available at the time, including the histories mentioned above and also a great many other works. It is well recognized that the Zizhi Tongjian is superior to all other histories of the Tang period in terms of the amount of material consulted, analysis of original sources and clarity of expression.

The Zizhi Tongjian Kaoyi is a series of notes made by Sima Guang while editing his history which frequently quotes from books that are now lost and provides clues as to the sources for information in his history. The Kaoyi consults many works which touch on Tang foreign relations, most of which are no longer extant. For instance, it uses the Fenyangwang Jiazhuan (Family Biography of the Prince of Fenyang) (= Guogong Jiazhuan, or Family Biography of Lord Guo), in eight chapters, a family biography of Guo Ziyi (696-781) by Chen Hong, a long-time staff officer under Guo. Guo Ziyi was a very important high-ranking military official involved in many battles in alliance with the Uighurs during the campaign to suppress the An Lushan rebellion and also participated in wars against the Tibetans. The Kaoyi often refers to this work for its eye-witness accounts. This work contained the only information for one episode involving the Uighurs, and was used by the Tongjian. ${ }^{15}$ Unfortunately the work no longer exists.

\footnotetext{
${ }^{14}$ Twitchett 1992, p. 100.

${ }^{15}$ ZZTJ 225, p. 7236.
} 
Also used by the Kaoyi is Yehou Jiazhuan (Family Biography of the Marquis of $Y e$ ), in ten chapters. It is a family biography of the Chief Minister Li Mi (722-789), by his son Li Fan. Although the work contains much unreliable information, since Li Fan intentionally glorified his father, ${ }^{16}$ in some matters dealing with the Uighurs and Tibet, the Kaoyi refers to the work as an additional contemporary record. It is also an important source for the study of the militia (fubing) system. ${ }^{17}$ The work does not exist integrally, but its fragments are included in the Shuofu and other collective works.

The Beihuang Junzhang Lu (Record of Chieftains of the Northern Wilderness), in three chapters, also written by Li Fan, is referred to by the Kaoyi in one or two places. The work is lost, but from the title, one can see that it was an historical record concerning the non-Chinese chieftains to the north of Tang.

Also referred to by the Kaoyi is the Duan Xiushi Biezhuan (= Duangong Jiazhuan, or Separate Biography of Lord Duan), in two chapters, a family biography of Duan Xiushi (718-783), compiled in the Bureau of Historiography by Ma Yu, who was the Vice Director of the Imperial Library during the Yuanhe period (806-819). Duan Xiushi was also a high-ranking military official who was involved in frontier affairs, particularly those involving the Tibetans. It is another case where the family biography provided additional information. The work no longer exists.

The Tang Tongji, compiled by Chen Yue, was a chronological account of Chinese history from the beginning of Tang until 823, in one hundred chapters. But by Song there were only forty chapters left, the work ending at the time of Empress Wu. ${ }^{18}$ The Kaoyi refers to this work often. For one incident involving Tibet, it was the only source and the Tongjian incorporates all the information it provides. ${ }^{19}$ Since the work is no longer extant and not much information can be found about the writer, we are unable to tell more about it.

The Bu Guoshi, in six or ten chapters, was compiled by Lin En, who was a presented scholar (jinshi) of the time of Xizong (874-888). The work no longer exists, but at the time when the Zizhi Tongjian was com-

\footnotetext{
${ }^{16}$ ZZTJ 231, p. 7456; Junzhai Dushuzhi 9; Mackerras 1972, p. 3; p. 156, note 159.

${ }^{17}$ Pulleyblank 1955, p. 142, note 9; Lai 1986, pp. 4-5. For more on this work, see Dien 1974.

${ }^{18}$ Zhizhai Shulu Jieti 4.

${ }^{19}$ ZZTJ 205, p. 6493.
} 
piled, it was an important source for the later part of the Tang dynasty for which few other materials were available. It had detailed accounts of events concerning Tibet at the end of the first Tibetan kingdom. For one event involving Tibet, it provided the sole source and the Tongjian followed it. $^{20}$

Collected works of such Tang officials as Zhang Jiuling, Lu Zhi , Bai Juyi, and Li Deyu comprise another category of sources. These works typically contain the full texts of official letters to foreign rulers on behalf of the emperors, and memorials on foreign policy written by their subjects. $^{21}$

The writings of such officials are also included in the Quan Tangwen (Complete Tang Essays), compiled during the Qing dynasty. It is a useful supplementary source for imperial edicts, official letters, and essays of the Tang dynasty usually provided in more complete form than the extracts quoted in the Tang histories.

In the Quan Tangshi (Complete Tang Poetry), compiled during the Qing dynasty, are many poems lamenting the hardships of frontier soldiers, foreign invasions and some poems commenting on Tang's marriage alliance policy.

There is a considerable amount of material on Tang history among the documents discovered in Dunhuang and Turfan. I have found, however, that they do not have much relevance for high level foreign affairs, so they are not referred to in the book.

The biases in the Chinese accounts of foreign countries are obvious. $^{22}$ It was assumed that Chinese culture was superior, and therefore all non-Chinese are referred to as "barbarians" who have to be transformed by Chinese civilization. Nomadic peoples are constantly described as having human faces but animal hearts, as being greedy and unrestrained in their behavior, incapable of understanding reason - as "monkeys wearing hats," or "dwarf-slaves."

Based on the idea that the Chinese Son of Heaven was to rule Allunder-Heaven, all foreign states were treated as tributary to China. Their contacts with China were routinely recorded as journeys to pay homage

\footnotetext{
${ }^{20}$ ZZTJ 246, p. 7938.

${ }^{21}$ For Zhang Jiuling and his works, see Herbert 1978; for Lu Zhi, see Chiu-Duke 1992; for Bai Juyi and his letters to Tibetan leaders, see Kolmas 1966; for Li Deyu, see Drompp 1986.

${ }^{22}$ See examples in Mackerras 1972, p. 5; Eberhard 1982, pp. 100-4.
} 
and tribute to the Chinese Son of Heaven, using the rhetoric and vocabulary of the tribute system, and their envoys were made to conform to the rituals required by the tribute system.

Feelings of cultural superiority and their sinocentric viewpoint often hindered Chinese from understanding their neighbors and helped to perpetuate misconceptions about and feelings of hostility toward them. Inevitably the Chinese looked at the outside world from a Chinese point of view. Historians usually recorded only those peoples that had direct contact with China and events that affected China's foreign relations in various ways without giving due attention to record what was important to these peoples themselves. They also showed bias in the way they justified Chinese aggressions as defensive actions or as proper extensions of the influence of the Chinese Son of Heaven. ${ }^{23}$

One can never expect historians, who must necessarily select and omit, to give a complete and objective account of everything that happened. It must, however, also be pointed out that in their attitudes towards their neighbors, especially the nomads, the traditional Chinese were not unique; nor were they worse than other peoples. ${ }^{24}$ Furthermore, the traditions established by the ancient models that they followed guaranteed a considerable degree of objectivity and reliability to Chinese historical writing. Histories were not freely created compositions by individual authors, but were compiled primarily by copying and excerpting earlier works, mainly official documents, with any comments by the historian added separately from the main texts. ${ }^{25}$ While this "scissors and paste" method had its own dangers and limitations, it did have the effect of minimizing distortions created by hindsight after the event. Being originally composed for practical purposes, these documents could not afford to be too much distorted by ideological considerations. More will be said in Chapter 2 about the ways in which the information about foreign countries that eventually found its way into the official histories was gathered.

Nor did Confucian historians always, or typically, uncritically accept Chinese aggression against foreign peoples. They often openly condemned aggressive wars, which caused suffering to the people. Han dynasty records speak highly of the civilized people of Da Qin (presumably

\footnotetext{
${ }^{23}$ Eberhard 1982, p. 116.

${ }^{24} \mathrm{See}$ examples of comments on nomads in western sources in Sinor 1990a, pp. 4-5; pp. 17-8.

${ }^{25}$ Gardner 1938; Yang Lien-sheng 1961; Twitchett 1961; 1992; Wang Gungwu 1973.
} 
the eastern Roman empire) and these records constitute a fuller account than any Roman or Greek account of China. ${ }^{26}$

Nor do Confucian accounts hide the fact that at various times China had to recognize neighboring peoples as equals. ${ }^{27}$ The Chinese accounts are full of episodes of tension between ideological purity and pragmatism in foreign relations. It is wrong to say the Chinese "did not try to understand the culture, attitudes, and beliefs of their neighbors. ${ }^{28}$ As Chapter 2 notes, the Chinese were interested in collecting information on foreign countries, both for the practical and important purpose of decisionmaking, and out of curiosity and desire for knowledge. Subjects dealt with in accounts of foreign countries range from climate, geographical conditions and products, to social customs, defining the family, marriage and women's status, narratives of religious practices, political organization, legends and traditions, and the history of a people's contacts with China. The Chinese official histories and numerous other historical records, in spite of their biases and shortcomings, are invaluable not only for the history of China's foreign relations but also for the histories of China's neighboring peoples.

Though much less complete and comprehensive than the material in Chinese sources, there exist important historical documents from some of China's neighbors that corroborate, contradict or supplement the Chinese historical record of relations with foreign states during Sui and Tang. Sources of this type listed below provide a non-Chinese perspective which cannot be neglected.

1. Old Turkish inscriptions of the eighth century. In his Tujue Jishi, Cen Zhongmian provides annotated Chinese translations of the three most important of these, the Tonyukuk, Kül Tigin and Bilgä inscriptions. I have also used Talat Tekin, A Grammar of Orkhon Turkic, which has an English translation without annotation of these three inscriptions and two other inscriptions, those of Ongin and Küli Chor. These inscriptions show the Turkish perspectives on their history and relations with China while also reflecting the influence of the Chinese cosmic order on the Turks. ${ }^{29}$ Mori Masao has a study on the language and phrases of the Turkish inscriptions and their implications. Lin Enxian has a survey of the discovery and back-

\footnotetext{
${ }^{26}$ Fitzgerald 1964, p. 8; Yang Lien-sheng 1968, p. 20.

${ }^{27}$ Yang Lien-sheng 1968, p. 20.

${ }^{28}$ Eberhard 1982, p. 101.

${ }^{29}$ See for example, Bazin 1963.
} 
ground of five Old Turkish inscriptions including those from the Tujue Turks and the Uighurs. ${ }^{30}$

2. Of Korean traditional histories in Chinese, the one most relevant to my study is the Samguk Sagi (The Historical Record of the Three Kingdoms), which was compiled in the twelfth century by Kim Pu-sik, and covers the period from the beginning of the three kingdoms to the fall of unified Silla in 938. While Kim drew a large amount of material from Chinese sources he also used quite a few native records, especially in the biographies section. ${ }^{31}$ The Samguk Yusa compiled by Iryǒn towards the end of the thirteenth century is also an important history but it does not have an immediate bearing on my study and it includes more myth and other less believable tales than does the Samguk Sagi .

3. Inscriptions of the Uighurs. The Shine-usu inscription in Old Turkish script gives an account of Moyanchuo Qaghan (reign 747-759). It has been translated into Chinese, with annotations by Wang Jingru. ${ }^{32}$ The other important inscription was found in Karabalghasun. It has three parts, one in Chinese, one in Sogdian and one in Old Turkish, and was written in the ninth century. The Chinese part is best preserved. In my book I use the annotated text in Haneda Töru's comprehensive study of the Uighurs during Tang. 33

4. The major sources in Tibetan for the Tufan period (early seventh to mid-ninth century) are in three forms: inscriptions, manuscripts, and wooden tablets. ${ }^{34}$ Such Tibetan documents were collected in three volumes by F. W. Thomas. ${ }^{35}$ Those that are the most important to my study of Tang-Tibetan relations, especially the study of the treaties concluded by the two sides, are the $821 / 822$ inscription in Tibetan and Chinese scripts, and the Old Tibetan Annals and the Old Tibetan Chronicle found at Dunhuang. For the inscription, I use mainly the translations and annotations by H. E. Richardson in Ancient Historical edicts at Lhasa and the Mu Tsung/Khri Gtsug Lde Brtsan Treaty of A. D. 821-822, from the Inscription at Lhasa, the translation by Li Fang-kuei in "The inscription of the Sino-Tibetan treaty of 821-822," and the version in Wang Yao's Tufan Jinshi $\mathrm{Lu}$. The works of Richardson and Wang Yao also discuss another

\footnotetext{
${ }^{30}$ Mori Masao 1978, pp. 208-53; Lin Enxian 1988, pp. 314-30.

31 Jamieson 1969, pp. 5-17; Gardiner 1970.

32 Wang Jingru 1938.

${ }^{33}$ Haneda 1957.

${ }^{34}$ For a summary of these sources see Wang Yao 1982, pp. 2-7; Lin Guanqun 1985.

${ }^{35}$ Thomas 1935, 1951 and 1955.
} 
important document, the "Ngan Lam Stag Sgra Klu Khong inscription." Wang Yao's book is a study of all thirteen Tibetan inscriptions of the Tufan period still extant. He also has Chinese translations of the two Tibetan historical works, ${ }^{36}$ and a study of the wooden tablets of the Tufan period discovered in Xinjiang. ${ }^{37}$

These sources provide a non-Chinese perspective which one cannot afford to neglect. A good example is found in the Turkish inscriptions. In mid-seventh century the Turks were incorporated into the Chinese area command-prefecture system. In contrast to the Chinese attitude which treated this as a triumph for Taizong as the Heavenly Qaghan, this period was considered retrospectively by the Turks as a time of national subjugation and humiliation. The Turkish inscriptions record:

Their sons worthy of becoming lords became slaves, and their daughters worthy of becoming ladies became servants to the Chinese people. The Turkish lords abandoned their Turkish titles. Those lords who were in China held the Chinese titles and obeyed the Chinese emperor and gave their services to him for fifty years. ${ }^{38}$

Another example is found in the Korean history the Samguk Sagi, in which Kim Pu-sik commented that according to Liu Gongquan (772?860 ?), Taizong twice showed his tremendous fear of Koguryǒ's force during battles occurring in 645. However neither the Jiu Tangshu, nor the Xin Tangshu or the Zizhi Tongjian mention this, perhaps in accordance with the traditional practice of proper concealment. ${ }^{39}$ The Korean histories record many more details of the internal relations among the three Korean states. Similarly, while the Chinese paid special attention to the treaties with Tibet, the Old Tibetan Annals and the Old Tibetan Chronicle make no mention of these treaties, and yet contain detailed records of treaties concluded among themselves. Such discrepancies are not difficult to understand: these non-Chinese peoples had their own internal set of problems; their alliances and rivals were often more immediate and important concerns than their relations with the distant Chinese court.

\footnotetext{
${ }^{36}$ Wang Yao 1979.

${ }^{37}$ Wang Yao 1982; Wang Yao and Chen Jian 1986.

38 "The Kül Tigin Inscription." See Tekin 1968, translation, p. 264.

${ }^{39}$ SGSG 22, King Pojang 8. I cannot find any information about Liu Gongquan's book. The monographs of bibliographies in the JTS and XTS do not list Liu's book.
} 
A comparative study of the non-Chinese sources shows that foreign records generally corroborate but sometimes supplement the Chinese sources. For example, the Samguk Sagi says that upon the conquest of Paekche in 660 the Chinese planned to invade Silla, which had been an ally of China. ${ }^{40}$ This Korean work also contains a letter written by the king of Silla to the Chinese in 671, which states that in 648 Taizong had promised that when Tang had subdued Koguryǒ and Paekche, the territory south of P'yǒngyang and the land of Paekche would be given to Silla. ${ }^{41}$ The Chinese sources nowhere refer to these matters. Whether the Korean sources are reliable is unclear.

The numerous traditional sources are bound to contain discrepancies and contradictions. Both traditional and modern scholars have paid particular attention to this question. Sima Guang's Kaoyi was an important innovation in this respect, and this tradition matured during the Qing period, when three Qing scholars Wang Mingsheng, Qian Daxin and Zhao Yi made detailed textual studies and analyses of the Tang histories. ${ }^{42}$

In modern times, the Tang historical works have been given close attention by scholars in both east and west. For Sui-Tang foreign relations, Edouard Chavannes' Documents sur les Tou-Kiue [Turcs] Occidentaux and Cen Zhongmian's Xi Tujue Shiliao Buque ji Kaozheng and Tujue Jishi are comprehensive in their collections of materials and have detailed annotations. On Korea, the Chōsen shi, by Japanese scholars, is a collection of highlights from all available materials in Chinese, Korean and Japanese traditional sources arranged in chronological order. The editor notes discrepancies when they occur but does not go into a detailed discussion of them.

There has not been a comprehensive collection of traditional sources on the Uighurs but important works with emphasis on annotation are: Haneda Tōru, "Tōdai kaikotsushi no kenkyū"; Colin Mackerras, The Uighur Empire, and Feng Jiasheng and others, Weiwuerzu Shiliao Jianbian. On the Western Regions, Ise Sentarō's Chūgoku Seiiki Keieishi Kenkyu is comprehensive and critical in its treatment of primary sources.

Materials about the relations between Tang and Tibet are more abundant in both the Chinese and Tibetan languages than are materials

\footnotetext{
${ }^{40}$ SGSG 42, "Biography of Kim Yusin, Part II."

${ }^{41}$ SGSG 7, pp. 1-7; Jamieson 1969, pp. 15-6; pp. 63-6.

42 Shiqishi Shangque by Wang Mingsheng; Nianershi Kaoyi by Qian Daxin; Nianershi Zhaji by Zhao Yi.
} 
about the above-mentioned peoples. Several collections of Chinese sources in official histories, Zizhi Tongjian and Cefu Yuangui are available. ${ }^{43}$ In his Kodai Chibetto shi Kenkyū, Sato Hisashi provides a detailed study of primary sources in both Chinese and Tibetan concerning the Tang period. The Xin Tangshu Tufanzhuan Jianzheng by Wang Zhong is an annotated work with references to Tibetan and other Chinese sources. Yamaguchi Zuiho in his Toban Ōkoku Seiritsu shi no Kenkyū has carried further the study of the sources about the history of early Tibet, and Beckwith in his The Tibetan Empire in Central Asia refers to sources in Tibetan, Arabic, Old Turkish, and Chinese. While these works are referred to in my book, I also use other modern works and note the important discrepancies in sources wherever necessary.

${ }^{43}$ Chen Xiezhang and others 1982; Su Jinren 1982; Su Jinren and Xiao Lianzi 1981. 


\section{Chapter 1}

\section{Background: Chinese Foreign Policy before the Sui Period: Theory and Practice}

In this chapter we examine the rich traditions of foreign policymaking inherited from their predecessors by the Sui-Tang rulers. First we look back to the distant past when Chinese civilization first took shape in the Yellow River basin of North China. In contrast to the variety of competing literate civilizations that came into existence in Western Asia and neighboring regions of Europe and North Africa during the bronze age, the Chinese enjoyed a monopoly of literacy in East Asia until well into the present era and, however much they may have derived indirectly from cultures farther west before the Qin unification in 221 B.C.E.- the first hints of the use of metal, the cultivation of wheat and barley in addition to millet and rice, the horse-drawn chariot-they were not consciously aware of the existence of organized states in other parts of the world.

It was natural, therefore, for them to assume that they occupied the center of the world and that they were surrounded by less favored "barbarian" peoples. Out of this developed the traditional sinocentric world view of orthodox Confucian thinking, which became the official ideology of the Chinese state down to the twentieth century. This ideology was embodied in the tribute system during Han, but by then, as we shall see, more realistic and pragmatic competing views towards non-Chinese peoples had also emerged - anti-sinocentric theories, realistic estimates of China's limitations, and exclusionary, inward-looking attitudes. More profound challenges to the concept of a sinocentric world order and more sophisticated reinterpretations of this concept arose when non-Chinese dynasties emerged in North China during post-Han times. These contributed an equally sophisticated but non-Chinese component to the legacy inherited by the Sui-Tang rulers from the Period of Disunion. We also discuss the evolution since Han of the various non-Chinese peoples surrounding China, presenting Sui and Tang with new as well as old problems.

Finally we survey some general policy measures the Chinese evolved for dealing with their neighbors: aggressive military action, 
strengthening of frontier defenses, forming of alliances, appeasement, and incorporation and assimilation. These had all been tried by previous Chinese rulers, and so were available for use by the Sui-Tang policy-makers in their new context.

\section{Formation and Implications of the Myth of the Chinese World Order}

The hierarchical principle of the Mandate of Heaven was devised by the early Zhou rulers to justify their conquest of Shang at the end of the second millennium B.C.E. It called for the universal rule of the Son of Heaven over All-under-Heaven (tianxia). "The king leaves nothing and nobody outside his realm" (wangzhe wuwai). ${ }^{1}$ This universal power was matched by the ruler's responsibility for the welfare of the people.

Based on their already existing clan structure, the Zhou established a system called fengiian in Chinese and sometimes translated into English as "feudal," but perhaps better (or also) described as patrimonial. The most reliable of these so-called feudal lords (zhuhou) were established in strategic places, especially on the periphery as "a fence and screen for Zhou."2 These feudal lords were linked by blood or marriage to the Zhou house. They had the obligation to carry out military activities ordered by the monarch, and to provide revenue as tribute to the king. Most important of all, their presence throughout the Zhou realm was intended to display the power of Zhou and to contribute to the stability of the Zhou authority. ${ }^{3}$

To ensure order in the political system and the unity of the Zhou house, a set of institutions, systems, stipulations, and ceremonial rules"the rules of propriety" (li -were worked out. These rules served as the foundation for the hierarchical structure of the Zhou realm, a structure which governed the relations of the extended family and regulated the relations between ruler and nobles. Within this structure, everyone was to act in accordance with the rules of propriety in proportion to his or her position, so that harmony could be maintained. ${ }^{4}$

During the Spring and Autumn period (722-481 B.C.E.) these Zhou political institutions disintegrated as a result of the increasing power

\footnotetext{
${ }^{1}$ Gongyangzhuan, p. 4, Yin 1/6; p. 35, Huan 8/6; p. 125, Xi 24/4; p. 232, Cheng 12/1.

2 Zuozhuan (Xi 24), 189::192.

${ }^{3}$ A detailed study of the feudal system is presented in Creel 1970, pp. 317-87. See also Lee 1980, chapters 1-3.

${ }^{4}$ This ideal of harmony is stated in the Zuozhuan (Zhao 26), 715::718-719.
} 
of the feudal states on the one hand, and the decay in the political and military might of the Zhou monarchy on the other.

Some modern scholars hold that during this time the Chinese feudal states were independent of the Zhou king and dealt with one another as sovereign equals regardless of their size. Even treaties made with "barbarians" outside the Zhou system were negotiated on a footing of equality since the treaties allowed these "barbarians" to retain their independence. ${ }^{5}$ The actual situation, however, was much more complex. It is true that forms of interaction between states were effectively as if among sovereign equals, equal in the sense that one state could not exert authority over the others except by force. Nevertheless, the predominant attitude was not egalitarian. The Chinese states still attempted to maintain the old hierarchical order, with the Zhou king as the supreme ruler. He was represented or supported by the strongest of the feudal lords, who, as "hegemon" ( $b a)$, assumed the power to assemble other feudal lords in a "treaty league" or "covenant" (meng). The dominant-subordinate form of relationship between the Zhou king and his feudal lords was still reflected in such a covenant. Small states were to pay respect and to serve the larger ones, who in turn would show benevolence to the smaller ones. The $b a$ acted for the king and was in charge of collecting tribute for the royal house. 6

By the time of the Warring States period (480-222 B.C.E.), as a result of wars, cunning diplomacy, and continuous annexations, only seven major powers survived. Relations among these great powers were more on an equal basis. The small states had either been "swallowed up" by bigger ones or become dependents of them. These seven powers struggled among themselves for supremacy, each trying to conquer the whole of the Chinese world by force of arms.

With the further decline of the Zhou house it was no longer deemed necessary to claim to be supporting the Son of Heaven. Rulers of all seven states assumed the title of king, a title which had formerly belonged solely to the Zhou Son of Heaven. This was a sign of the more equal basis on which they dealt with each other. In 288 B.C.E. the kings of the states of Qin and Qi even called themselves Emperor of the West and Emperor of the East, respectively, attempting to divide China into two spheres of power. They soon abandoned this plan, however, because the

\footnotetext{
${ }^{5}$ Hong 1971, pp. 26-35; Walker 1953, p. 25.

${ }^{6}$ Zuozhuan (Xi 7), 148::149.
} 
time was not ripe for so revolutionary a step. Nevertheless there was even a suggestion, some two years later, that the king of Yan be made Northern Emperor, the king of Qin Western Emperor, and the king of Zhao Central Emperor. ${ }^{7}$ Had such notions taken root, China might have gone the way of Europe or India and remained permanently divided into a pluralistic world of competing states. But China was eventually unified under the First Emperor of Qin in 221 B.C.E. and the ideal of unity has dominated Chinese political thinking from that time onward.

In spite of the political disunity of the Warring States period, the idea of the absolute superiority of the Son of Heaven and the idea that stability could only be achieved through political unification of the Chinese people had become so deeply rooted that the concept of equality among sovereign states simply could not find much acceptance. The Chinese clung to their belief in a hierarchical order for their world and fought among themselves for supremacy.

The dominant schools of political thought, whether traditionalist like the Confucians or iconoclastic like the Legalists, all aimed at providing recipes for unifying China under a single ruler. The Confucians were the most wholehearted in their insistence on the need to look back to the founders of Zhou to provide a model for the ideal pattern of relationships between the Son of Heaven and his subjects, both Chinese and nonChinese. In such works as the Yugong, the Guoyu, the Zhouli, and the $X u n z i$, detailed rules and regulations, which had supposedly existed in the early Zhou, were set out to adjust relations between the Son of Heaven and his subjects, including the non-Chinese, in the framework of a system of five or nine concentric zones, from the Son of Heaven in the middle, through the various classes of feudal lords to the outer "barbarians."

Inhabitants of each zone were to come and pay tribute to the king at specific intervals in what was known as the tribute system which was to regulate relations between the Zhou Son of Heaven and his dependencies. The lords of the outermost "barrier kingdoms or beyond" (fanguo) were to come once in a generation. ${ }^{8}$ The Zhouli or Rites of Zhou, an idealized reconstruction of Zhou institutions probably dating from the Warring States period, especially canonized the ideology of the Chinese world order and

\footnotetext{
${ }^{7}$ Bodde 1938, p. 128.

${ }^{8}$ Shangshu, "Yugong," p. 18, sections 33-9; Guoyu, "Zhouyu," p. 2; Zhouli Zhushu 37, pp. 1339-41; Xunzi Jijie, "Zhenglun," pp. 219-20. Yü Ying-shih (1986, pp. 379-80) also has a brief discussion of the zone-system.
} 
established the idea of a unified Chinese empire with the Chinese in the center and the non-Chinese constituting a defense line around it. ${ }^{9}$ Fictitious as this reconstruction may have been, there did exist during early Zhou times a tribute system with court visits and payment of tribute by dependent states to the Zhou Son of Heaven. ${ }^{10}$ In particular, the concept of universal kingship was an extremely potent myth, one providing both an explanation of actual behavior and a rationale for later rulers to appeal to in formulating their foreign policies. It was, for example, often used as a justification for military conquest of non-Chinese for the sake of frontier security and for territorial expansion and cultural imperialism.

While the idea that "the king leaves nothing and nobody outside his realm" became one basic principle, there also developed an equally prevalent principle: "having the various states of Xia within, and keeping the Yi and Di barbarians without" (nei zhu-Xia er wai Yi-Di). ${ }^{11}$

The Chinese world order was sinocentric in nature. At one level, sinocentrism was based on racial differentiation. The Western Zhou had a clear sense of community. They identified themselves with the Xia, a people who, according to the Chinese tradition, established the first dynasty. ${ }^{12}$ The Zhou people, though adopting the Shang culture, political ideas and institutions, merged the Shang into a "new" larger grouping of people who differentiated themselves from other peoples. The Zhou referred to themselves and the Shang and their Xia predecessors as the Zhu Xia, "all the Xia," or Hua-Xia, a name that is still used for the Chinese people today, and which distinguishes them from non-Chinese.

As for the non-Hua-Xia people or non-Chinese, the Chinese did not have a single term for them. Instead several words were used, the most frequent and general ones being Man, Yi, Rong, and $\mathrm{Di}^{13}$ These nonChinese lived amongst, and in areas surrounding, the Chinese states and frequently engaged in wars with the Chinese. The Chinese looked down on them in the same way as the Hellenes looked down on the barbaroi. The word "barbarian" is therefore often used in English works to translate these terms for non-Chinese.

\footnotetext{
${ }^{9}$ For more information on the tribute system see Zhouli Zhushu under the titles of Dazai, Dazongbo, Dasima, Zhifangshi, Huaifangshi, Daxingren, Xiaoxingren and Xiangxu.

${ }^{10}$ Lee 1980, chapter 4.

${ }^{11}$ Gongyangzhuan, p. 239, Cheng 15/12.

12 Creel 1970, p. 203.

${ }^{13}$ Creel 1970, pp. 197-202.
} 
Sinocentrism was, however, based more on cultural than racial differences. The languages of non-Hua-Xia people were different from Chinese. Though most of these people were eventually sinicized, their remnants are still sizable even today, inhabiting, as minority ethnic groups with their own languages, the upland regions of southern, southwestern and western China. ${ }^{14}$ Differences between the Chinese and non-Chinese also existed in material culture: clothing, food, style of hair, etc.

To the Chinese, such differences were not just a matter of external appearances, but also revealed differences in the level of civilization. The Liji records: "Where the statutory measures and the [fashion of] clothes had been changed, it was held to be rebellion, and the disobedient ruler was banished." 15 In 307 B.C.E., when the king of the State of Zhao decided to adopt the dress of the $\mathrm{Hu}$, a nomadic non-Chinese people, so as to facilitate horse-riding, he was strongly opposed by his uncle and other members of his court. They insisted that for Chinese to adopt the clothing of others would be tantamount to abandoning the old doctrine and the Way, to going against the will of the people and the wisdom of the learned, and to departing from the Central (that is, the Chinese) States. ${ }^{16}$

The third cultural difference was defined by the Zhou rules of propriety. These were believed to serve as the underpinnings of the institutions of the Chinese states, providing the basis for their social organization and their behavioral norms. They were not followed by the non-Chinese and, according to the traditional explanation, were not required of them since they did not qualify as civilized people. During the Spring and Autumn period, for example, the state of Chu referred to itself as Man-Yi and called their ruler king, and the States of $\mathrm{Wu}$ and Yue also took the title of king, which would have been unacceptable for one of the Zhou states.

To the Chinese their own culture represented a higher level of civilization. One important non-racist idea that derived from this sense of cultural superiority was that the non-Chinese could become Chinese by accepting Chinese culture. In the course of the Spring and Autumn and Warring States periods, the "barbarians" who had been interspersed among the Chinese states were either ejected or gradually became sinicized, as

\footnotetext{
${ }^{14}$ Pulleyblank 1983, pp. 411-2.

${ }^{15}$ Liji "Wangzhi," BK. III, p. 217, No. 15.

${ }^{16}$ SJ 43, pp. $1806-8$.
} 
they accepted Chinese culture and the Zhou rules of propriety. ${ }^{17}$ The idea that Chinese civilization could be extended to other peoples in this way was passed on to later times and was applied as a justification for the cultural assimilation of still more remote non-Chinese.

But when hostilities with them prevailed, the Chinese called the non-Chinese birds and beasts or wolves with human faces. They applied the sinocentric principle to draw a boundary between themselves and the "barbarians". Already in early Zhou times the Chinese considered themselves as occupying the Central States (or Middle Kingdom) at the center of the world. ${ }^{18}$ In the Zuozhuan the Central States refer to the Chinese states as opposed to "barbarian" realms. ${ }^{19}$ Any Chinese struggle against invading "barbarians" was by definition a just war, a war to defend internal order.

After the steppe frontier was reached and the Chinese were confronted by the new menace of the steppe nomads, an attempt was made to establish an actual physical boundary to separate what was China and what was not. During the fourth and third centuries B.C.E., the states of Qin, Zhao and Yan built walls against the Hu nomadic "barbarians," and these were partially linked and extended by the Qin dynasty after its unification. $^{20}$

\section{The Tribute System During the Han Dynasty}

After the unification by Qin, the First Emperor lost no time in expanding his territory by a series of military campaigns. Through his success in driving the northern nomads, the Xiongnu, beyond the Ordos Bend of the Yellow River, and in bringing the southern and southwestern border areas under Chinese control, it seemed that the rule of the Son of Heaven was indeed extended to All-under-Heaven. The Chinese rulers were not, however, able to impose the tribute system immediately as a result of this success.

\footnotetext{
${ }^{17}$ For a discussion on the origin of the myth of Chinese superiority, see Wang Gungwu 1968, pp. 36-8.

${ }^{18}$ In the bronze inscription dated the fifth year of King Cheng of the Zhou dynasty (ca. 1020 B.C.E.) the word "Middle Kingdoms" or "Central States" (Zhongguo) is first found referring to the royal domain, see Tang Lan 1976, p. 60.

19 The word "Middle Land" or "Middle Plain" (Zhongyuan) is also used in the Zuozhuan to refer to the Zhou realm. See Zuozhuan (Xi 23), 185::187.

${ }^{20}$ Yü Ying-shih 1990, p. 118; Waldron 1990, pp. 13-4.
} 
The total collapse of the Qin empire in 207 B.C.E. threw China into disunity and civil wars. It was only more than half a century later that under Emperor Wu (r. 140-87 B.C.E.) of the Han dynasty (206 B.C.E.-220 C.E.) a reunified China could resume the offensive against the nomadic Xiongnu, and once again expand into the southwestern and southern frontier regions, as well as for the first time into the Korean peninsula to the northeast.

Through the famous exploration of Central Asia by Zhang Qian early in Emperor Wu's reign, Chinese contacts with other countries were greatly enlarged. Knowledge of foreign lands, gained via the transcontinental Silk Road to the northwest and then via the maritime trade route to the south, broadened the Chinese view of the world, but this broadening of horizons did not alter the belief that China was the center to which other peoples should come, and that Chinese civilization was superior to all others.

The expansion resulted, rather, in an extension of Chinese political and cultural influence and in the development of the tribute system, which helped consolidate the Chinese belief in the inevitability of their ideal world order. It also contributed to the weakening of the Xiongnu. In 51 B.C.E , after the Xiongnu empire was split into rival Southern and Northern states, the ruler of the Southern Xiongnu arrived at the Han court, and accepted tributary status .

Based on this framework and on a whole set of rhetorical propositions and vocabulary formed in pre-Qin times, the tribute system was fully developed in the Han dynasty. States along the Silk Road as far distant as India or Parthia are recorded as having despatched tribute-bearing envoys to the Han court. Practices under the tribute system as they pertained to Chinese relations with non-Chinese were as follows:

1) Rulers of non-Chinese states or their envoys came to the Han court to pay homage.

2) They presented symbolic tribute in the form of local products.

3) The Chinese emperor gave them imperial gifts in return.

4) The emperor conferred on the foreign rulers titles of nobility and bestowed seals on them and sometimes on their officials.

5) The foreign rulers sent their sons to China as hostages in return for Chinese protection against outside aggression.

6) The foreign rulers offered military service to the Chinese in return for Chinese goods. 
The essential part of the practice consisted of items 1, 2, and 3. Any state, so long as it sent missions with gifts to the court, was recorded as a tributary. The tribute system thus developed into a network embracing all foreign states which paid official visits to Han.

To the Chinese rulers, the tribute system structured an ideal pattern for their relations with other peoples. It was, however, not a rigid pattern. Since the "acceptance of imperial rule" involved not only different levels of "acceptance," but also different categories of "rule," which varied from one group of people to another, different practices were applied to countries according to their distance from China and their relative importance in Chinese frontier considerations. All six practices under the tribute system were applied to the Southern Xiongnu and some oasis states in the Western Regions during Han. Just the first two or three requirements were applied to Japan. $^{21}$

The tribute system, which regulated Chinese relations with nonChinese, was an extension of the hierarchical system existing within China itself. During Han, princes and nobles were given feudal titles as rulers of their own regional and local states labeled as quasi-fiefs by the Son of Heaven. Ceremonial rituals and various laws were imposed to control these supposed vassals. They were to come to court regularly to pay homage and tribute. ${ }^{22}$ Han commanderies administered directly by officials appointed by the central government were also expected to present tribute to the court in addition to regular taxes. ${ }^{23}$

Compared with the tribute system as it operated with foreign countries, however, there was a distinct difference. Failure of the Chinese local states or commanderies to present tribute, or failure to pay court visits at regular intervals implied an act of disobedience. In contrast, for the non-Chinese who were outer subjects, tribute was not compulsory. Though the absence of tribute payment could be, and was, used as a justification for Chinese aggression against non-Chinese peoples, the Han court would not feel obliged to launch a punitive attack if tribute was not regularly forthcoming. This policy towards non-Chinese tributaries was based on the maxim of "not interfering in the administration of those who had not been influenced by the rules of proper conduct." This policy was shaped

\footnotetext{
${ }^{21}$ Yü Ying-shih 1967, p. 189. For a detailed examination of these practices, see Pan Yihong 1991, pp. 205-11.

${ }^{22}$ Zhang Weihua 1980, pp. 185-244.

${ }^{23} H S$ 1B, p. 70; HHS 1B, pp. 60-1.
} 
specifically as a response to the Xiongnu on the eve of the arrival at court of the Southern Xiongnu ruler, Huhanye Chanyu, ${ }^{24}$ but it became a general policy towards all non-Chinese during the Han period.

Non-Chinese had their own motives for establishing relations with China, even if this implied an inferior status. Through receiving official titles from the Chinese emperor they could obtain Chinese political or even military support to enhance their own power, especially when they faced political rivals at home. Non-Chinese rulers also benefited economically from tribute and trade with China.

The payment of tribute in return for Chinese imperial gifts served the function of trade by political means, and appeared more like "gift trade" to the non-Chinese. It was usually equal in an economic sense since the Chinese tried to return gifts of the same, if not higher value as the tribute goods offered. Imperial gifts together with other financial support and the essential goods the non-Chinese obtained in this kind of "tribute trade" with the Chinese compensated for the less than exalted position they occupied in the tribute system. ${ }^{25}$ The tribute-bearing missions from foreign countries were often accompanied by private merchants who came seeking purely economic profits. These merchants would be provided protection inside China and opportunities to trade in the capital.

In his book The Grand Strategy of the Roman Empire, Edward N. Luttwak describes two models of empire, the "hegemonic" and the "territorial." The hegemonic empire is centered around a central zone of direct control, and includes 1) an "inner zone of diplomatic control," consisting of a series of client states surrounding the central zone, and 2) an "outer zone of influence," surrounding the inner zone. In the outer zone, client tribes defer to the power of the empire but are not under its direct control. Client states in the hegemonic empire function as buffer states in the system of imperial security. Their most important function, by virtue of their very existence, was to absorb the burden of providing peripheral security against border infiltration and other low-intensity threats. ${ }^{26}$

The Chinese model of empire bears some resemblance to this hegemonic system. During the Han dynasty, some non-Chinese were brought

${ }^{24}$ HS 8, p. 270. The pronunciation chanyu is given in Guangyun which has three readings for the character chan :1. dan; 2. chan in chanyu, as in Chan Buddhism; 3. shan as a place name, same as "abdicate"; see also Pulleyblank 1991, p. 48.

${ }_{25}^{25}$ Rossabi 1983, pp. 3-4.

${ }^{26}$ Luttwak 1976, pp. 19-30. Somers (1986, p. 98) gives a clear outline of these two models. 
into the Chinese commandery-district system as part of what Luttwak characterizes as a territorial empire; some were incorporated into the Chinese hegemonic empire, with each state having different responsibilities to and connections with the Chinese suzerain, including, in some cases, military tasks. The Chinese tribute system also served to build a model of universal empire covering countries whose rulers sent embassies to China's court and received Chinese titles. Larger than Luttwak's hegemonic empire, this universal model embraced all kinds of states.

\section{Other World Views-Practicality and Flexibility}

While the sinocentric and hierarchical world view we have described above was generally dominant in Chinese ruling circles and especially so in the writing of the Standard Histories, it is important to note the existence of other views towards non-Chinese. During pre-Qin times scholars and philosophers of some non-Confucian schools held different ideas about society and the world.

The Agricultural School (nong jia) believed that rulers of worth should cultivate their own land, eat what they produced, and prepare their own meals while carrying on the affairs of government. Followers of this school even saw no need for Sage Kings. Asserting that both ruler and subject should plough together in the fields, they overthrew the order of upper and lower classes. ${ }^{27}$

Hui Shi (ca. 370-310 B.C.E.), the leading thinker of the School of the Dialecticians (mingjia), talked about China as being at the center of the world which, according to one interpretation, might suggest the idea that the earth is spherical, and according to another interpretation, may imply that there were vast regions beyond the bounds of contemporary geographical knowledge. ${ }^{28}$ Zou Yan (ca. 305-240 B.C.E.), the leading thinker of the School of Yin and Yang and of Five Phases, did not agree with the sinocentric idea. He maintained that there were "nine large continents" ( $d a$ jiuzhou) in the world and each was divided into nine regions. What scholars called the Middle Kingdom was held to be but one part in eighty-one of the whole world. ${ }^{29}$

Apart from such unorthodox theorizing, in their everyday dealings with foreigners the Chinese often recognized the limits of their strength

\footnotetext{
${ }^{27}$ Fung Yu-lan 1952, p. 144.

${ }^{28}$ Needham 1956, p. 192.

${ }^{29}$ SJ 74, p. 2344; Fung Yu-lan 1952, pp. 160-1.
} 
and adopted pragmatic attitudes, which provided imperial rulers with justification for conducting foreign relations on an equal footing with their neighbors, or even for paying tribute to "barbarians." They used the principle of "having the various states of Xia within, and keeping the Yi and Di barbarians without" as a perfect ideological basis for retreat from claims of Chinese superiority and for adopting whatever measures were expedient for achieving China's own security and stability.

A prime example of Chinese pragmatism occurred in early Han when the powerful nomadic Xiongnu empire challenged Chinese superiority and authority. The Han court, which had not yet consolidated its power within China itself, adopted a policy of appeasement, and concluded peace treaties with the Xiongnu. The items in the earliest of these treaties were:

1) A Chinese princess was to be married to the chanyu,

2) Chinese annual payments of silk, liquor, rice and other kinds of food were to be made to the Xiongnu,

3) the Han and Xiongnu were to be "brotherly" states, and

4) the Great Wall was to be the border between Han and Xiongnu. $^{30}$

This was the famous policy of "marriage alliance" (heqin), although the giving of a Chinese princess in marriage was usually not its only feature. As one can see from the agreement, it was the Chinese who paid tribute to the nomadic Xiongnu empire. Until the beginning of Emperor Wu's reign (140-87 B.C.E.), heqin continued to be the main policy governing Chinese contacts with the Xiongnu. Although the whole practice was considered humiliating, economically costly, and unbearable by the Chinese ruling group, it did win time for Han to recover and to build up its economic and military strength, which in the end enabled Emperor Wu to engage in active diplomacy and military expansion aimed at defeating the Xiongnu.

Though, as supporters of the idea of the universal authority of the Son of Heaven, Confucianists might have been expected to approve of active measures to enforce it, Han Confucian scholars in practice mostly argued that a wise ruler should concentrate on defense against "barbarian" incursions and not try to extend his rule into their territory. In 135 B.C.E. Liu An, the Prince of Huainan, presented a memorial to Emperor Wu op-

${ }^{30}$ Yü Ying-shih 1967, pp. 41-2. 
posing a military expedition against Min Yue in the south: "From the time of the Three Dynasties, the Hu and Yue have not gone so far as to receive our calendar; it is not that they are strong and could not be subdued and our awe could not control them; it is because we consider their land to be uninhabitable and the people to be impossible to govern. It is not worthwhile to disturb China over them.",31

In the Discourses on Salt and Iron which record the famous debate on salt and iron monopoly policy in 81 B.C.E., Confucian scholars severely condemned the Qin and Han aggressions into foreign lands and advocated a pragmatic, inward-looking attitude for two reasons. First, they argued, these imperialistic endeavors damaged the welfare of the people, needlessly cost human lives and suffering, exhausted the economic resources of the state and yet could not drive the nomads away. Second, the conquered territories were useless either because they could not increase government revenues or because the maintenance of Chinese control over the areas depended on draining China's own economic, military and political power and therefore control could not be kept up permanently. Rejecting the use of military force to subdue the non-Chinese, they insisted on the Confucian idea: "If remote people are not submissive, all the influences of civil culture and virtue are to be cultivated to attract them to be so." 32

The Confucian historian Ban $\mathrm{Gu}$ also expressed this attitude, stating that the "barbarians" were outer people and therefore the sage kings of ancient times reared them like "birds" and "beasts," neither making treaties with, nor attacking them; that since their land could not be ploughed and made to produce food, and since one could not keep their people as subjects, they should be guarded against and kept at a distance, and punished only when they came to invade. ${ }^{33}$

When Buddhism came to China during the first century C.E. it challenged all aspects of the native culture, including the sinocentric view. The Buddhist concept of "madhyadesa", referring to "middle country," that is India, was translated as "zhongguo," the same word meaning

${ }^{31}$ HS 64A, p. 2777.

${ }^{32}$ Yan Tie Lun Jiaozhu 1, p. 2, quoting Lunyu "Jishi;" 4, pp. 114-6; 7, pp. 262-5, and passim. For a translation of the work, see Gale 1931.

${ }^{33}$ HS 94B, pp. 3833-4. Part of the translation is from Yang Lien-sheng 1968, p. 23. 
"Middle Kingdom" used to refer to China. This locution appears frequently in Chinese Buddhist writings. ${ }^{34}$

This Buddhist usurpation of the concept of centrality did not have much direct impact on the Chinese, but because of their much expanded contacts with foreign peoples, especially their close neighbors, the Chinese showed great interest in the outside world from the Han dynasty onwards. As is set out more fully in Chapter 2, information was continuously collected on foreign countries from Chinese envoys, Chinese frontier officials, foreign envoys to the Chinese court, and monks who had traveled abroad. Surely such intercultural links had some impact on Chinese thinking, ${ }^{35}$ for it is obvious that the Han and especially post-Han Chinese were trying to expand their knowledge of the larger world, and that they knew and spoke highly of other great civilizations in India, Persia and at least the eastern part of the Roman empire.

\section{Challenges to the Chinese World Order: Disunion and Non-Chinese Rule}

During the Period of Disunion, which lasted from the collapse of the Han dynasty in 220 to the reunification by Sui in 589, China was divided, first into three Chinese states, the so-called Three Kingdoms, and then after a brief period of unification by Western Jin (266-311), into a succession of Chinese dynasties in the south and the so-called Sixteen Kingdoms, ruled by various "barbarian" groups in the north. In 439 the Northern Wei, founded by the Tuoba lineage of the Xianbei "barbarians," unified north China and eventually competed with the contemporary southern dynasties for rule over all of China. About a hundred years later, Northern Wei was split into two rival dynasties: Eastern Wei, (534-550) with its successor Northern Qi (550-559), and Western Wei (535-556), with its successor Northern Zhou (557-581). The Sui dynasty that unified China in 589 was the direct successor of the Northern Zhou.

The long-term existence of disunion within China challenged the idea of universal kingship, the basic concept underlying the Chinese world order. There is an almost unanimous opinion in Tang historical writings that not one of the Sixteen Kingdoms was legitimate. The period before the Tuoba Wei's unification was, they reasoned, simply a time of alien

\footnotetext{
${ }^{34}$ Zürcher 1959, p. 266.

${ }^{35}$ An example of such a conclusion is found in Fitzgerald 1964, p. 9.
} 
usurpation, a heaven-sent punishment for the decay and lack of virtue of the Western Jin rulers. ${ }^{36}$

The legitimacy of the Northern Wei was a more controversial issue. Sui, Tang and Song scholars offered three different opinions: 1) the non-Chinese regimes were as legitimate as native ones as long as they cherished native Chinese culture and preserved it for posterity; 2) the Tuoba Wei were "barbarians" who did not practice propriety and righteousness, and therefore their rule was illegitimate; 3) legitimacy was always a variable depending on whether one did or did not rule over a unified empire. Any regime, be it Chinese or non-Chinese, was illegitimate if it did not rule over the whole empire. ${ }^{37}$

During this period the "barbarians" in North China unavoidably underwent a process of sinicization and eventually were largely assimilated. All along the non-Chinese rulers utilized prevailing Chinese political theories to establish themselves and to cultivate a belief in the legitimacy of their rule in the minds of the population at large. They also preserved Chinese political traditions and norms. Their official histories were compiled by Chinese historians, who followed traditional rhetoric and patterns in recording court documents. In dealing with their neighbors, dynasties of non-Chinese origin like Former Qin in the Sixteen Kingdoms period and Northern Wei accepted the tribute system, with its hierarchical relationship between suzerain and subordinate, as the norm.

\section{The Nomadic Legacy of the Northern Dynasties}

As much as the non-Chinese rulers quickly became sinicized, they also introduced new perspectives which enriched Chinese tradition. These non-Chinese elements were visible in Sui's constitutional order and contributed to the strength and glories of the Tang dynasty, as Chen Yinke has shown in his insightful studies. ${ }^{38}$

\section{Creating a Multiethnic State}

In consolidating their states, the non-Chinese rulers often resettled large numbers of non-Chinese, either directly from the steppe or from other parts of North China, into their territory. Especially around the Chinese capitals these new comers mixed with the Chinese, thus creating

${ }^{36}$ JS 122, p. 3072.

${ }^{37}$ See Rao Zongyi 1976; Zhao Lingyang, 1976; Wechsler 1985, pp. 16-8.

${ }^{38}$ Chen Yinke 1971. 
multiethnic states. To establish their legitimacy, they promoted in their propaganda the idea of a universal empire in which non-Chinese and Chinese could exist side by side. In justifying his revolt against the Western Jin dynasty in 304, the Xiongnu leader, Liu Yuan, claimed that no ruler could be permanent and that even though, according to some traditions, $\mathrm{Yu}$ (of the legendary Xia dynasty) was said to have come from the Rong and King Wen (of the Zhou dynasty) was said to have come from the Eastern Yi, these sage rulers had derived their rule from Virtue ( $D e$ 德). In spite of defending his "barbarian" origins in this way to win over the Chinese, Liu Yuan also claimed descent from the Liu imperial clan of the Han dynasty and named his rebel kingdom Han. ${ }^{39}$

In trying to persuade a Jin official to join him, Murong Wei, another non-Chinese leader of one of the Sixteen Kingdoms, argued that his wish was to restore the Jin regime; Chinese who shared the same aim should support him without being troubled by the difference between Chinese and Yi. He too appealed to the traditions about the "barbarian" origins of the sage kings, Yu and Wen, arguing that the only concern should be about one's intentions and that differences in customs should not stand in the way of winning people's support. ${ }^{40}$ Murong Wei belonged to the Murong lineage of the Xianbei, who founded successive Yan kingdoms centered on Hebei. They established a dual organization, with their tribal armies kept under the Xianbei elite and a Chinese style bureaucracy staffed by Chinese civil officials. This was an attempt to combine the strengths of Chinese administration with nomadic military power. ${ }^{41}$ While such a dual organization was intended to preserve the ethnic identity of the nomads, it could not prevent their eventual assimilation into -Chinese life.

It was the Western Wei dynasty (535-556) under Yuwen Tai that made the most thoroughgoing effort to fuse the ethnic differences of nonChinese and Chinese on a basis of equality and create a truly universal empire. Chen Yinke points out that Western Wei's northwestern location gave it an inferior economic and military base and weaker claim to legitimacy as ruler of China than the contemporary regimes, Eastern Wei in the north and Liang in the south. Yuwen Tai therefore felt it necessary to find a new way to fuse his Xianbei tribes and other non-Chinese groups with the Chinese to form a single entity, united by one system of beliefs and

\footnotetext{
${ }^{39}$ JS 101, p. 2649.

40 JS 108, p. 2813.

${ }^{41}$ Barfield 1989, pp. 104-5.
} 
sharing a single cultural identity. In the interests of gaining legitimacy for his planned conquest of the south, Emperor Xiaowen (r. 471-499) of the Northern Wei had attempted to sinicize the Xianbei aristocracy at his court, but his one-sided reform lost the support of the Xianbei warriors left behind on the frontier. ${ }^{42}$ Yuwen Tai adopted a variety of different measures to achieve his new program.

The centerpiece of his plan was to take advantage of his location in the Wei Valley, the heartland of the ancient Zhou dynasty. Though a backwater economically and culturally in the sixth century compared to both the lower Yangtze, where the southern, Chinese dynasties were in charge, and the Central Plain in the lower Yellow River Valley, where the rival Eastern Wei regime carried on the tradition of undivided Northern Wei, the northwest was where the institutions revered in the Confucian classics had first taken shape. The change of the dynastic name from Western Wei to Zhou which symbolized this appeal to Chinese tradition did not formally take place until after the death of Yuwen Tai but was already foreshadowed by his attempt to reform the administrative structure on the model of the Zhouli. ${ }^{43}$ Yuwen Tai's Confucian adviser, Su Chuo (498-556), also tried to substitute the archaic style of the Book of Documents (Shujing) for the "decadent" current style when composing government documents. ${ }^{44}$

$\mathrm{Su}$ Chuo has also been credited with having influenced the setting up of the military system known as the fubing, or "territorially administered soldiery" which incorporated a large number of the northwestern Chinese military elite with their local contingents of soldiers into the military forces of Western Wei. The essential aspects of the system at this time were as follows: 1) the soldiers, who were from hereditary military families, were exempted from taxes and corvée and expected to provide some of their own gear; 2) each of the units was placed under one of the ninety-six territorial military bureaus, which were ultimately under the control of the central government. ${ }^{45}$

Another of Yuwen Tai's measures was to restore the surnames of those non-Chinese who had previously under Emperor Xiaowen adopted Chinese surnames. At the same time, all Chinese high-ranking military

\footnotetext{
${ }^{42}$ Chen Yinke 1971, pp. 117-8.

${ }^{43}$ ZS 2, p. 36; ZZTJ 166, p. 5140.

${ }^{44}$ Goodrich 1953, p. 2.

${ }^{45}$ Goodrich 1953, pp. 50-1; Gu Jiguang 1962, pp. 50-6; Wright 1979, p. 98.
} 
officers were given non-Chinese surnames. All soldiers serving under a particular officer were to assume the surname of that officer. Chen Yinke argues that this adoption of Xianbei surnames in the military was aimed at fusing the Chinese with the non-Chinese. ${ }^{46}$ Another opinion is that the primary aim was to maintain and strengthen Xianbei identity. ${ }^{47}$ Whatever the conscious motive, this policy had the effect of combining Xianbei tribal tradition and Chinese military practice, thus drawing strength from both sides. Moreover, it brought these territorially-based forces under the control of the central government, allowing them to function effectively in Northern Zhou's conquest of Northern Qi, in the Sui unification of China and in providing forces for the founding of Tang, as well as aiding in its consolidation and expansion. ${ }^{48}$

\section{Non-Chinese Rulers in China and the Nomads in the Steppe}

Their own nomadic heritage conditioned the approach of the Northern rulers towards other nomads who remained on the steppe. That they viewed the nomads as part of their own group is shown in a 429 Northern Wei discussion on the feasibility of a military campaign against the Rouran. Cui Hao, an important Chinese adviser at the court, taking the standpoint of his nomadic lord, rejected the traditional Chinese idea that such a campaign was a waste since the steppe land could not be used for agriculture and the Rouran could not be made subjects. Cui argued that this view was a cliché from the Han period. The Rouran were rebellious slaves and should be punished. Then their land could be opened up for agriculture, their nobles could marry Wei princesses and the men of lower rank could be made generals. ${ }^{49}$

The Northern Wei had a clear understanding of the complicated relations among different groups of nomads, such as the Rouran, Chile or Gaoche, and were able to take the initiative to form marriage or strategic alliances with one against another of them at different times. In command of superior cavalry troops, the Northern Wei rulers could inflict more effective blows on their nomadic rivals than the Han Chinese rulers were

\footnotetext{
${ }^{46}$ Chen Yinke 1971, p. 118.

${ }^{47}$ Dien 1977, p. 137; Wright 1979, pp. 98-9.

${ }^{48}$ For the Xianbei elements in the system, see Chen Yinke 1971, pp. 82-93; Gu Jiguang 1962, pp. 92-5.

${ }^{49}$ WS 35 , pp. 815-8.
} 
ever able to do. ${ }^{50}$ Knowledge of the nomads' internal organization and strategy inherited from their non-Chinese background later helped the Sui and early Tang rulers to stir up dissension among the nomads. They also used non-Chinese allies in their campaigns.

\section{The Non-Chinese Military Legacy}

The military vigor of the horse-riding Tuoba ruling class was passed on to the Sui-Tang rulers. The Northern Wei emperors before 500 all took personal command of their armies during wartime. When at peace, they often went on hunting or inspection tours, organized regular military parades and esteemed military skills. In the disunited China of their day, military strength was the foundation on which the leaders of the Eastern and Western Wei and later of the Sui and Tang based their power. The military tradition was maintained in numerous families which provided generations of soldiers to the Northern dynasties and to the Sui and early Tang regimes. The tradition of the emperor's personal participation in war was continued by the Sui Emperor Yang, and by Tang Taizong. Northern women were influenced by nomadic traditions too. Two wives of Gao Huan, the actual ruler of the Eastern Wei, were excellent archers. ${ }^{51}$ Princess Pingyang, the daughter of $\mathrm{Li}$ Yuan, organized troops and battles that assisted her father's founding of the Tang dynasty. ${ }^{52}$ As witnessed by tomb murals, Tang women played polo from horseback.

\section{The Patronage of Buddhism}

The most obvious non-Chinese contribution to Chinese culture during the Period of Disunion was the spread of Buddhism. When chronic disunity undermined the orthodox status of Confucianism, Buddhism spread rapidly to fill the resulting vacuum and took root in both North and

${ }^{50}$ WS 103 . In his study of the nomadic power, Barfield (1989, pp. 122-4) discusses some differences in the Tuobas' approach to the nomads as compared with a Chinese dynasty. Some of his points are not, however, accurate. For example, he says that the Tuobas' policy did not depend on destroying their nomadic enemies. This cannot be verified. The Tuoba did not destroy their enemies only because they were unable to. Barfield also says that Wei tried to control the steppe by removing most of the nomadic population to within its frontiers so as to use them as a military force and that such strategy would have been rejected by a Chinese dynasty. He forgets that the Han dynasty resettled the Xiongnu inside or near the frontiers and used their military force to defend against other nomads outside the frontier.

${ }^{51} B S 14$, p. 518.

52 JTS 58, pp. 2315-6. 
South. The Northern rulers soon became patrons of Buddhism, because, among other reasons, it was foreign and it provided them an alternative belief system to the Confucianism which was being urged on them by their Chinese advisers. They used Buddhist monks as political, diplomatic, and military advisers because the monks were totally dependent on the rulers' favor and had no family ties. These monks were also much valued because they often claimed to be able to prophesy the outcome of battles and the success of projected expeditions. ${ }^{53}$

Accounts by Buddhist travelers to the Western Regions and India, together with other Buddhist writings, broadened the minds of the Chinese. The most famous travel account was by Faxian who left China by land in 399, went to India to obtain Buddhist sutras and returned to China by sea in 414. His book, Foguo Ji (A Record of Buddhistic Kingdoms), is still extant and is an important source for information about India at that period. ${ }^{54}$ It refers to central India as the Middle Kingdom (Zhongguo) and comments: "In it the cold and heat are finely tempered, and there is neither hoarfrost or snow. The people are numerous and happy." 55 Chinese scholars of the Qing period commented indignantly: "The book takes India as the Middle Kingdom and China as periphery because the Buddhist monks want to make their religion respectable. The absurdity is not worth arguing with. ${ }^{, 56}$ Other books by Buddhist monks are discussed in Chapter Two.

The religious tolerance of the Northern rulers anticipated the great inflow of foreign religions and culture into China during the Tang dynasty. Acceptance of a foreign religion during much of China's middle period proves wrong the stereotype that the Chinese were always ethnocentric. More important, Buddhism was the first religion in China that cut through the lines separating the classes, unifying peasantry and elite in both North and South, among Chinese and non-Chinese. When added to the unifying force of the written language, Confucianism and Daoism, Buddhism contributed to the eventual reunification of China. The Sui and Tang emperors, while claiming to be Sons of Heaven in Confucian terms, also relied heavily on this alien religion to enhance their legitimacy, unlike their Han

\footnotetext{
${ }^{53}$ Wright 1959, p. 57; Ch'en 1964, pp. 78-80.

${ }^{54}$ For more discussion on Faxian, see Ch'en 1964, pp. 89-2.

${ }^{55}$ Foguo Ji, p. 6. For a translation, see Legge 1965, p. 42.

${ }^{56}$ Foguo Ji, p. 1, quoting Siku Quanshu Tiyao.
} 
predecessors, whose position had been rationalized solely in terms of the ideas and symbols of native traditions. ${ }^{57}$

\section{China's Neighbors}

The Qin-Han unification established the tradition of unity under a centralized government as well as the limits of China's geographical reach. Sustained contact with its northern neighbors placed China in a new environment. To the north, the rise of the nomadic steppe empire of the Xiongnu mirrored the agricultural empire of Qin and Han. This confronted the Chinese for the first time with an organized non-Chinese polity that could successfully demand to be treated on a basis of equality.

In a sense this was the beginning of "foreign affairs" in Chinese history. Though even during the Spring and Autumn period, the Chinese states had from time to time included non-Chinese tribal units in sworn treaties or otherwise used diplomacy rather than war in dealing with them, this was considered just a stage in the ongoing process by which such peoples were gradually to be absorbed and sinicized. By the time of the Qin unification we no longer hear of "barbarian" Yi in Shandong and the Huai valley, Di in Shanxi or Man in the former territory of Chu in the Yangtze basin. Further south, much the same kind of process has continued to the present day.

The northern steppes and the mountainous and desert lands to the west were not, however, amenable to gradual absorption in this way and throughout pre-modern history remained hostile to the incursion of a Chinese civilization based on intensive agriculture.

In his insightful study of China's relations with its periphery, Lattimore devised a grand scheme based on ecological/environmental principles, which divides East and Central Asia into five ecological regions: the Chinese agricultural region; the Manchurian steppe, comprising both agricultural and forest land; the Mongolian steppe land; Chinese Turkestan's oases and desert; and Tibet, where both agriculture and nomadism were practiced. The boundaries between each region were not fixed lines, but rather zones within which could be found cultural and ecological features of both regions. These marginal zones often became less buffers than the locations of military and cultural competition between China and its neighbors. China expanded into these marginal regions not just via migra-

${ }^{57}$ Wright 1959 , pp. 66-70. 
tion or cultural diffusion, but also by military means. ${ }^{58}$ Different powers in each region raised different challenges to China in its role as the Middle Kingdom, and throughout its history China responded to these challenges with different kinds of policy measures.

\section{The Nomadic Threat from the Steppe}

In China's foreign policy the most abiding factor was the formidable threat of the nomadic peoples based on the Mongolian steppe. "Barbarian" invasions from the north were a major headache for the Chinese even in early Zhou times. With the coming of horse-rider nomadism to the eastern steppe during the Warring States period, China faced a more serious and intractable northern frontier problem, and one that lasted through late imperial times.

Modern scholars have offered various explanations for the ongoing conflicts between nomadic and agricultural societies, the constant nomadic raids and incursions across the frontiers of agrarian society, a phenomenon not just limited to China. ${ }^{59}$ One underlying cause for the incessant conflicts between pastoral nomadism and agricultural society lay in the fact that they and the agricultural Chinese were in competition over the marginal regions where either agriculture and pastoralism could be practiced. ${ }^{60}$ Another was the need of the nomads for agricultural products in order to sustain their economy and political structure.

Sechin Jagchid holds that nomads depended on sedentary China for grain to supplement their diet, for silk and cotton cloth to provide beauty and comfort, and for manufactured goods such as plows to break up the soil or to transform into weapons. If the nomads could not obtain these products through peaceful mechanisms of trade, bestowals, or court-tocourt intermarriage arrangements, he concludes, they would be provoked into war. Often it was the ineffectiveness of Chinese dynasties and the Chinese sense of cultural superiority that broke down the peaceful mechanisms. ${ }^{61}$ Jagchid, however, underplays the role of the military advantage that the nomads enjoyed, and gives insufficient attention to the fact that even when the nomads could obtain goods from China by peace-

\footnotetext{
${ }^{58}$ Lattimore 1951, passim.

${ }^{59}$ Xiao Qiqing (1972) has a clear summary of these several explanations. See also Jagchid 1989, pp. 1-16; Waldron 1990, pp. 35-6.

${ }^{60}$ Lattimore 1951, passim.

${ }^{61}$ Jagchid 1989, p. 1; p. 165 and passim. See also Jagchid and Hyer 1979, pp. 300-1.
} 
ful means, they were tempted to raid the Chinese borders to seize Chinese products.

Nor does Jagchid give due weight to the fact that the nomads were normally more interested in trade than sedentary societies were. ${ }^{62}$ Chinese agreement to trade with the nomads was often obtained only under pressure. Such trade was not necessarily economically profitable for China's government. On the contrary, it tended to deplete the court's revenues. ${ }^{63}$ In the tributary trade, under which foreign envoys presented tribute to the Chinese court, which in turn gave presents to the foreigners, the amount returned often exceeded the value of the tribute. Moreover, if trade could not prevent the nomads from incursions, the Chinese court would have to consider other alternatives, as happened in Han relations with the Xiongnu.

A. M. Khazanov gives a more nuanced and balanced analysis in his comprehensive study of pastoral nomadism. In agreement with Jagchid he argues that "nomads could never exist on their own without the outside world and its non-nomadic society." "64 Limited by their one-sided, specialized economy, the nomads needed products from sedentary society for their economic survival and for political stability, that is, for the aristocracy to sustain their control. To acquire these goods, Khazanov points out, different methods were used, including sedentarization, trade and mediatory trade, submission to sedentary societies by offering military service in return for payment of goods, and use of force whenever possible; raids and pillage were important supplementary means of livelihood. Nomads could also subjugate the sedentary population and make them pay tribute. Until the modern period, sedentary states were unable to find any permanent solution to the military problem of how to defend themselves against the raids of nomads. ${ }^{65}$

Thomas Barfield argues that to the nomadic peoples, trade was not only for the sake of improving their standard of living or for establishing themselves as the intermediaries in profitable commercial activity between East and West, but also because Chinese goods were needed to maintain the large ruling class and nomadic state power. Barfield observes that in order to deal with their larger and more highly organized sedentary neigh-

\footnotetext{
${ }^{62}$ Khazanov 1994, p. 202.

${ }^{63}$ Yü Ying-shih 1967, p. 12; p. 49; pp. 60-4; Ecsedy 1968, pp. 142-5.

${ }^{64}$ Khazanov 1994, p. 3.

${ }^{65}$ Khazanov 1994, pp. 222-3, and chapter 4.
} 
bors, the nomads had to develop a new form of state organization, one more complex than would be needed to handle livestock problems and political disputes within a nomadic society.

Such nomadic states maintained themselves by exploiting China's sedentary economy, and not by exploiting the production of scattered sheepherders. They did not attempt to conquer Chinese territory. Nor did they have the necessary administrative institutions to govern an agricultural society. The nomadic rulers' strategy was, through continuous raids and plundering or through providing military assistance to Chinese regimes, to use their strength to bargain with China for large quantities of Chinese goods as subsidies and force China to accommodate their demands for trade. ${ }^{66}$

When the nomads were strong they followed an "outer frontier strategy," 70 forcing the Chinese into accommodating their demands for subsidies and trade; when they were weak they chose an "inner frontier strategy" of submission to China in exchange for Chinese assistance in accumulating goods to allow their rulers to recover their strength. ${ }^{68}$

Barfield seems to neglect two important points: one is that the nomadic "inner frontier" strategy also benefitted China and that is why China accepted the nomads' submission. The other is that there was a basic flaw embodied in the inner frontier strategy: by receiving support from China, the nomads could lose their independence and fail to restore their power on the steppe. This is what happened to the Southern Xiongnu during the Later Han dynasty. In his The Perilous Frontier Barfield applies his theory rather mechanically to all the nomadic regimes after the Xiongnu. This oversimplifies the complex history of China's interactions with the nomads.

In a more recent article based on archaeological studies, Nicola Di Cosmo stresses that the Xiongnu maintained their empire through political control and economic exploitation of sedentary communities and states from the oases of the Tarim Basin to Inner Mongolia, northern Mongolia, southern Siberia and Manchuria. Chinese goods further buttressed the power of the Xiongnu aristocracy. They were threatened not only by the Han Emperor Wu's cessation of payment of goods, but also by his efforts

\footnotetext{
${ }^{66}$ Barfield 1981; 1989, pp. 8-9 and passim.

${ }^{67}$ Barfield 1989, p. 91.

${ }^{68}$ Barfield 1989, p. 63.
} 
to cut off their control over these sedentary communities in the Western Regions and in Manchuria. ${ }^{69}$

Khazanov, Barfield and Di Cosmo examine the nomads' relations with agrarian society from the nomadic point of view. In this chapter and later chapters I focus on the Chinese side to see how in the context of the rise and fall of the nomadic Turkish and Uighur powers the Chinese attempted to respond to the various strategies of the nomadic political rulership, and to evaluate the strengths and weaknesses as well as the various effects of the strategies and policies adopted by both nomadic powers and by China.

\section{Xiongnu}

The first organized nomadic power on the Mongolian steppe was the Xiongnu coalition. After unifying China, the First Emperor of Qin drove the Xiongnu north beyond the Great Bend of the Yellow River. But with the collapse of the Qin, the Xiongnu empire eventually established itself as a rival great power, challenging the Han dynasty's superiority and authority even inside the border zone. The early Han emperors followed an appeasement policy towards the Xiongnu. By the time of Emperor Wu, however, China enjoyed great prosperity, which enabled Emperor Wu to engage in prolonged wars against them.

However, it was not until Emperor Xuan's reign, after the Xiongnu empire was split into Southern and Northern rival states, and Huhanye Chanyu of the Southern Xiongnu, arrived in 51 B.C.E. at the Han court, that Han succeeded in making the Xiongnu accept the status of a tributary. The Han court provided economic and military assistance to the Southern Xiongnu in order to use them against their Northern cousins. The Northern Xiongnu were severely defeated by the Chinese in 36 B.C.E. The Southern Xiongnu had at first moved southward, close to the Han frontier, so as to have easy access to Han resources, but returned to the steppe shortly after 43 B.C.E. and restored their former power.

Even before this time, the Han government had set up dependent states to resettle Xiongnu who had come to the Han frontiers in the Ordos region and in the Gansu corridor to submit. When China was thrown into civil war at the end of Wang Mang's rule, ambitious people in the northwest sought an alliance with the Xiongnu for assistance in seeking power. The Xiongnu did not intend to occupy agricultural territory themselves.

${ }^{69} \mathrm{Di}$ Cosmo 1994. 
Instead they chose to take advantage of the situation to make raids and to try to establish a pro-Xiongnu regime in China.

When China was reunified by the Later Han dynasty, in its early days it did not have much advantage over the Xiongnu. In 48 C.E., however, the Xiongnu empire was again split between the Southern and Northern rivals. The Southern Xiongnu adopted a pro-Han policy and became a Han tributary. They moved inside the Han border and, unlike what had happened in Former Han times, they gradually lost their independence and were never able to restore their power in the steppe. The Northern Xiongnu met their final defeat, first at the hands of the Xianbei, another nomadic people, and then by the joined forces of Han and the Southern Xiongnu in $91 .^{70}$

\section{Wuhuan and Xianbei}

The Xiongnu's hope of restoring their former greatness was crushed by the nomadic proto-Mongolian Xianbei people, who, together with the Wuhuan, were referred to as the Eastern $\mathrm{Hu}$ in late Warring States and early Han times. Formerly subjects and foes of the Xiongnu empire, they inhabited the area from the Mongolian steppe to east of the Greater Xing'an Mountains. Their economy was less completely dependent on nomadism than that of the Xiongnu and included agriculture as well as herding of livestock. During the Han period the Wuhuan submitted to China and were resettled on the frontier, acting as watchmen for the Chinese, but they rebelled from time to time. The Wuhuan actively involved themselves in the civil wars at the end of Han. Eventually some of them were incorporated into China; but the Wuhuan as a whole ceased to be a real threat.

During the first century C.E. the Xianbei alternated their allegiance between the Xiongnu and Han. To maintain their power; they sometimes sought Chinese recognition and assistance and helped the Han in wars against the Northern Xiongnu. When the Northern Xiongnu ceased to be a major power, the Xianbei occupied their territory and incorporated over ten thousand tents of their people. During the mid-second century, under their brilliant war leader, Tanshihuai, the Xianbei expanded all the way west to Central Asia, succeeding the Xiongnu as holders of the powerful

\footnotetext{
${ }^{70}$ For a more detailed description of the Xiongnu, see Yü Ying-shih 1967; 1990; Pan Yihong 1992b.

${ }^{71}$ For a detailed study of the Wuhuan in the Han period, see Crespigny 1984, chapter 9.
} 
nomadic empire of this region. It appears that part of the Wuhuan tribe also joined in this western conquest.

Unlike the Xiongnu, Tanshihuai relied solely on constant raids across Chinese frontiers and did not seek to make treaty arrangements. Tanshihuai refused a proposal of marriage alliance from the Han court soon after 166. The political organization of the Xianbei was still in a primitive stage; Tanshihuai's power derived from his ability as a war leader rather than from a hereditary tradition. Because his authority was based on his leadership in wars, he had no authority to make peace with China. To make peace with China would terminate his power as a war leader. His death around 180 ended the short-lived Xianbei empire. The Xianbei disintegrated into various tribal groups, and never became a unified steppe power. ${ }^{72}$ They instead turned toward China.

\section{Xianbei Regimes in North China}

In the course of time, some of the Xianbei tribal groups succeeded in forming political entities of a more lasting kind. In the third century the Murong in the Liao River valley served as auxiliaries under the Three Kingdoms Wei and their leaders received titles of investiture from both Wei and the succeeding Jin dynasty. During the civil wars of Western Jin, they provided a refuge for Chinese peasants and officials and took advantage of the situation to form their own regime with a civil administration run by Chinese officials, but with military control kept in their own hands. After the uprising of the Southern Xiongnu leader Liu Yuan in 304, which brought about the end of Jin rule in North China, the Murong, at first professing loyalty to the restored Eastern Jin dynasty south of the Yangtze, began to intervene in Chinese affairs, and in 337 established the kingdom known as Former Yan. They developed the ambition to reunite the whole of China; but their state was soon in chaos and dissolved under the attacks of the Jin and other non-Chinese in $370 .^{73}$ The remaining Murong royal leaders founded three short-lived states: Western Yan (384-394), Later Yan (384-409) in Hebei and Southern Yan (398-410) in Henan.

The Tuoba, who in the end were the most successful of the Xianbei groups, were similar to the Murong in that they first appeared as a tribe on the frontier, in this case on the northern border of Shanxi. For their assistance in providing auxiliaries to Jin, their leader received Chinese investi-

\footnotetext{
${ }^{72}$ HHS 89; see also Pulleyblank 1983, pp. 452-4; Barfield 1989, pp. 87-90.

${ }^{73}$ JS 108-111.
} 
ture, first, as Duke of Dai in 310, then as King of Dai in 314. In the chaos that followed the withrawal of Jin power from the north, they established a regime in northern Shanxi. In 376 they were conquered by Fu Jian, of the Tibeto-Burman Di nationality, whose Former Qin kingdom centered on Chang' an briefly succeeded in reuniting all of North China.

After the disastrous failure of Fu Jian's expedition against Eastern Jin at the Battle of the Fei River in 383, Tuoba Gui reestablished himself as King of Dai, and soon changed his state's name to Wei. By 439 the Tuoba Wei had conquered the other contending non-Chinese regimes and achieved a more lasting unification of North China. The Tuoba were able to create an effective military and clan organization and, with the help of Chinese officials, learned how to exploit the agricultural lands that they had conquered. For nearly a century they confronted successive native Chinese states in the south. ${ }^{74}$

Farther west in Gansu the Qifu branch of the Xianbei established a state known as Western Qin that lasted from 385 to 431 and the Tufa founded Southern Liang, which lasted from 397 to $414 .^{75}$ More successful were the Tuyuhun, a branch of the Murong Xianbei, who moved westward and established a tribal state around Lake Koko Nor in the present Qinghai province at the beginning of the fourth century. They had already received some cultural influence from the Chinese. Their administration was based on the Chinese model and made use of Chinese writing. Gradually they incorporated the local Tibeto-Burman Di and Qiang people.

During the fifth century the Tuyuhun strengthened their power through active interaction with both the southern and northern courts in China, obtaining trading benefits and political support. In addition to their adept manipulation of sedentary region politics, the Tuyuhun achieved relative stability based on combining a nomadic economy with some agriculture and profitable commercial links with both the Chinese and with Central Asia.

In $444-45$, hard pressed by the Northern Wei, the Tuyuhun fled westward and occupied a weaker oasis state, Khotan, in the Tarim Basin, an important point on the Silk Road. Later they returned to their original territory, but their influence in the eastern section of the Tarim Basin continued and enabled them to control the caravan trade routes passing through that region. We read in Chinese sources that the Tuyuhun rulers

\footnotetext{
${ }^{74}$ WS $1,2$.

${ }^{75}$ JS $125,126$.
} 
relied on rich families and merchants to meet their financial needs, and that in 553, when a Tuyuhun mission returning from Northern Qi was attacked by the Northern Zhou prefect of Liangzhou he captured 240 merchants, 600 camels and mules and silk products amounting to ten thousand rolls. ${ }^{76}$ Well protected by their distance from political and war centers in China, they were able to maintain their state until the seventh century.

Rouran

While the Tuoba Wei rulers occupied themselves with governing an agricultural China and became more and more sinicized, control of the steppe was taken over by the Rouran nomads. Their founder is said to have originally been a slave of the Tuoba. Though there is no explicit statement in the sources to show that they were of Xianbei origin, there is evidence that, like the Xianbei and Wuhuan, they spoke a language of the Mongolian type. ${ }^{77}$ After several generations, at the beginning of the fifth century, the Rouran leader declared himself qaghan, the title later used by the Turks for the supreme ruler of the steppe, but also used among the Qifu and Tuyuhun. ${ }^{78}$ They became a vigorous power, extending their control over the Mongolian steppe and Manchuria. They also became a fierce adversary of Northern Wei, constantly raiding the Chinese frontier. ${ }^{79}$

The Northern Wei won a major victory over the Rouran in 429. In order to maintain peaceful relations the two sides arranged reciprocal marriages: Wei sent a princess to wed the Rouran qaghan in 434, while the Wei emperor himself married the qaghan's younger sister. But peace did not last long and conflicts continued until 449, when Wei won another decisive victory over the Rouran. In 506 the Rouran asked Wei for a peace agreement, but Wei insisted that the Rouran could expect no better fate than to become Wei subjects.

In 520 after internal struggles among the Rouran, Anagui Qaghan went to the Wei for protection. Following the Han pattern of resettlement of nomads who had submitted, the Wei court resettled him and his people outside the Wei frontiers north of Shanxi and another rival group of the Rouran in present Gansu, both to serve as part of the defense for Wei.

${ }^{76} B S$ 96, pp. 3178-87; Molè 1970, xii-xvi; his translation of the $B S 96$.

${ }^{77}$ Pelliot 1921; see also a note by Pelliot inserted in a book review in T'oung Pao 29 (1932) p. 261.

${ }^{78}$ Molè 1970, xxvii, pp. 68-71.

${ }^{79}$ WS 103. 
Three years later, when the rebellion of the Six Garrisons of the Wei broke out, Anagui and his cavalry assisted in its suppression.

As a consequence, the balance of power began to tip in favor of the Rouran. To reward the Rouran for their assistance, the Wei court provided rich gifts and in 528 issued an edict granting privileged treatment to Anagui. He personally was not expected to refer to himself as "subject" when presenting documents to the Wei court.

Anagui reorganized his government based on the Chinese model and the Rouran became a strong power once again. He employed Chinese as his advisers and insisted on equal standing with Wei in the official correspondence between the two. In 533 Wei permitted the marriage of a Wei princess to the qaghan's son. The marriage, however, was called off after the split of the Northern Wei into the Eastern and the Western Wei. Enfeebled by their struggles with each other, both of the new states competed to conclude marriage alliances with the Rouran so as to maintain peace on their borders and concentrate their efforts against each other and their southern enemies. The relationship between the Rouran and the Wei states in North China became more equal, as shown by the fact that the rulers of the Western and Eastern Wei took Rouran princesses as empresses, rather than just sending their women to the Rouran. ${ }^{80}$

Eastern Wei and the Rouran contracted three marriages: in 540 Eastern Wei agreed to send a princess to marry Anagui's son; in 542 Anagui asked to send his granddaughter to wed the son of the powerful minister Gao Huan. Wei agreed. ${ }^{81}$ Apprehensive of the Rouran's strength, Gao Huan requested a Rouran princess for another son, to which Anagui replied that the marriage would be possible only if Gao himself wedded his daughter. After some hesitation, Gao agreed. The marriage took place in 546. After Gao Huan's death, following nomadic practice, Gao's eldest son married the Rouran princess. ${ }^{82}$

Western Wei also contracted reciprocal marriages with the Rouran. A Wei princess was sent to wed the brother of Anagui and in 538, at the request of Anagui, the emperor dismissed his Tuyuhun empress and took

\footnotetext{
${ }^{80}$ WS 103; BS 98.

${ }^{81}$ WS 103, p. 2303 ; $B S 98$, p. 3265.

${ }^{82}$ This is according to $B Q S 9$, p. $124 ; B S 14$, p. $517-8$. The $B S 98$ (p. 3265) does not give these details.
} 
Anagui's daughter as empress. The Rouran were still not content and pressed the emperor to force the previous empress to commit suicide. ${ }^{83}$

Just when Anagui's power was at its height another nomadic power rose. This was the Tujue (Türk) state of the Ashina clan (hereafter referred to as the Turks), in the face of whose attack Anagui committed suicide in $552 .^{84}$

\section{Tujue Turks}

The sudden emergence of the Turks, who had not been heard of previously but who subsequently gave their name to all the Turkic speaking peoples, is wrapped in obscurity. They are said to have once been blacksmith slaves of the Rouran. Sometime before 546 their chief, Tumen (Bumïn), initiated trading relations with the Western Wei dynasty. When they became stronger, the Turks broke away from the Rouran and turned to Western Wei for political support. In 551 the two regimes, who both considered the Rouran a major enemy, formed a marriage alliance. A year later the Turks were able to defeat the Rouran. They asked the Western Wei to execute all the Rouran refugees, a grisly task which Western Wei carried out. The Northern Qi (successor of the Eastern Wei) at first adopted a pro-Rouran policy against the Turks but soon abandoned the Rouran, who were hopelessly weak by then. ${ }^{85}$

In 552, Bumïn set himself up as Yili Qaghan. From 562 to 576, his younger brother Shidianmi (Istämi) ruled west of Altai as the chief of the western part of the empire. Actively engaging themselves in intermediary trade between China and the Eastern Roman empire and in the conquest of other peoples, the Turks built a steppe empire extending westward from the Mongol Plateau into Central Asia, including its oasis states, and had commercial contact with the Ephthalites, Byzantium and Sassanid Persia. Having replaced the Rouran, they next turned to North China, posing a great threat to the Northern Zhou (successor of Western Wei) and Northern Qi dynastic regimes. ${ }^{86}$

As in their relations with the Rouran, the two Northern dynasties each had to buy off the Turks with frequent payments of silk and other

\footnotetext{
${ }^{83}$ BS 13, pp. 506-7; 98, p. 3246; ZZTJ 158, p. 4892.

${ }^{84}$ BS 98, pp. 3266-7.

${ }^{85}$ BS 98, pp. 3266-7; 99, pp. 3285-9; Ma Changshou 1957, pp. 12-8.

${ }^{86}$ Chavannes 1969, pp. 160-3; Ma Changshou 1957, pp. 16-20; Wright 1979, p. 107; Sinor 1990b, pp. 295-305.
} 
products, and each had to compete to contract marriages with the Turks, all for the purpose of preventing the Turks from launching invasions and from assisting the other power. In 561, when Yuwen Yong came to the throne as emperor of Northern Zhou, he despatched three groups of envoys to the Turks. In spite of interference from the Northern Qi envoys, the missions succeeded in securing a Turkish princess for marriage to Yuwen himself. In the reigns after Yong's death, this Turkish empress was shown great favor and given honorific titles.

The Turks also assisted the Zhou in battles against Qi. ${ }^{87}$ For its part, Northern Qi had to "empty its storehouses to supply the Turks." After Qi's conquest by Northern Zhou in 577, a Qi prince fled to the Turks. The qaghan then declared him to be the Qi emperor and planned to take revenge on his behalf. After several attacks, however, the qaghan decided it was not worthwhile to support Qi any further. Instead, he proposed a marriage alliance to Zhou, to which Zhou agreed on the condition that the Turks hand over the Qi prince. The Turks felt obliged to comply. In 580 Princess Qianjin of Zhou was sent to marry Shetu Qaghan. ${ }^{88}$

The Turkish problem was to last into the following Sui and Tang dynasties until the mid-eighth century.

\section{Gaoche}

Another nomadic participant group in China's constant competitions with the Rouran and the Turks were the Gaoche, meaning "High Carts." They belonged to the Tiele tribes, who spoke a Turkic language but had been known to the Chinese much earlier than the Tujue. The name Tiele can be traced back to the Dingling who first appear in the Shiji as one of the northern peoples conquered by the Xiongnu when they first established their empire at the beginning of the second century B.C.E. From the fourth to the sixth centuries the name appears in various formsDingling, Chile, Tiele, and Gaoche. ${ }^{89}$ Though sometimes subjugated by larger nomadic powers such as Xiongnu and Rouran, the Gaoche or Tiele people had always maintained a tribal identity of their own. Their allegiance in the competitions between China and its nomadic rivals was often an important factor for the side they joined. During the fifth and sixth

\footnotetext{
${ }^{87}$ ZS 9, p. 144; BS 99, p. 3289.

${ }^{88}$ BS 99, p. 3290; SUIS 51, p. 1329. Lin Enxian (1988, p. 210) says that Qianjin was first married to Tabo (Taspar) Qaghan and then to Shetu. The supreme qaghan then was Tabo, but it was Shetu who requested the marriage.

${ }^{89}$ Pulleyblank forthcoming and 1990a.
} 
centuries, they established their independence from the Rouran and were in constant contact with the Northern Wei regime, sometimes as allies against the Rouran. When the first Turkish empire was founded in 552, the Tiele were brought under its rule. The Tiele tribes would later play a decisive role in the Sui and Tang competitions with the Turks. It was from the Tiele that the Uighurs emerged and from the mid-eighth century replaced the Turks as masters of the steppe.

\section{The Western Regions}

To the west and southwest of the Mongolian steppes lay what the Han Chinese referred to as the Western Regions, which is what Europeans used to call Chinese Turkestan and is presently China's Xinjiang autonomous region. From early times there had emerged in this region small oasis states based on a mixed economy of agriculture, animal husbandry and trade. The region's people had a distinctive ethnic and cultural identity. They spoke Indo-European languages and the Chinese described them as having deep eyes and high noses. Their towns developed as trading centers along the two major branches of the cross-continental Silk Road that started from northwest China, passed through the Gansu corridor, then divided and went north or south of the Taklamakan Desert and crossed the Pamirs, after which they merged into routes heading toward South and West Asia.

Never during China's long imperial history did these oasis states pose a threat to the Chinese in the way the nomads did, as they were never able to form a united political entity. And yet the Western Regions were often an important target over which China contended with other states, first the Xiongnu, then from Sui onwards, the Turks and Tibet, and in later times, the Mongols, and Russia.

As far as recorded history is concerned, Chinese contact with the region started under Emperor Wu of Han with the famous expedition of Zhang Qian to the west in about 138 B.C.E.. Zhang's aim was primarily military and strategic: to seek an alliance with the Yuezhi, traditional nomad enemies of the Xiongnu who had moved to the west. The expedition failed in its immediate goal but in the end it had more significant results. Apart from the new knowledge that it brought, it led to Han expansion in that direction, aimed at depriving the Xiongnu of an important resource and making contact with the newly discovered world beyond. In 59 B.C.E. the Han set up the Protectorate of Western Regions (Xiyu duhufu ) as its instrument for controling the region. 
The military significance of this region was obvious. Whenever the Chinese lost control over it, as during the interregnum between Former and Later Han, the Xiongnu would take over, thereby strengthening them in their competition with the Chinese. Another danger was that if the Xiongnu occupied the area they might enter into an alliance with the Qiang, the hostile "barbarians" living in Qinghai to the south, thereby posing a threat to the four commanderies that Han had established in the Hexi region in present Gansu and Ningxia.

The other significant consequence of the opening to the west was that it potentially connected China with South and West Asia. Maintenance of Chinese control over the Western Regions ensured the eventual opening of trade and diplomatic communications between China and these newly discovered countries. The trade brought impressive economic benefits; private merchants made handsome profits and emperors and their ministers were provided with luxuries and exotic goods by tribute-bearing missions to the Chinese court. Politically, the coming of foreign envoys from afar symbolized their acceptance of the rule of the Son of Heaven whose legitimacy within China remained bound up with the fiction that he was a world ruler.

Maintenance of Chinese control over the Western Regions, however, proved to be very costly. Nomads could more easily and naturally exert such control with their mobile and constantly ready military force and their geographical proximity. When China became weakened internally, it often had to withdraw from this extended frontier. Economic contact with the Western Regions mostly benefited emperors and a minority of private individuals rather than the state treasuries; so even if emperors and their courtiers retained enthusiasm for expansion to the west, Confucian bureaucrats strongly opposed such endeavors at the time and their criticisms were echoed by later Confucian historians. Yet the Han expansion into the Western Regions, together with its expansion into the Korean Peninsula, set up a goal for later rulers to reach and a model for them to emulate.

The oasis states in the Western Regions, through their contacts with China and the contending nomadic powers, became experienced in dealing with them and learned to play off one against the other so as to maintain their own political autonomy. They often took initiatives in the complex international environment, forming alliances or seeking military protection, or organizing resistance to foreign control. They played active roles which no larger power could afford to ignore. As foci where different 
cultures coming from various directions met, they were able to in turn transmit some of these cultural elements to others while retaining their own cultural identities. ${ }^{90}$

During the period of Disunion, Liangzhou was an important center for East-West communications. Located in present Gansu, west of the Yellow River's Great Bend, it controlled the Gansu corridor and was the gateway to the Western Regions. When China was in political turmoil, foreign merchants or envoys continued to arrive in Liangzhou and some continued on into China proper under the protection of the Liangzhou regime. Control of Liangzhou changed frequently from Chinese to nonChinese hands before the Northern Wei's unification of the North, but all of its rulers tried to keep up and expand their contacts with the oasis states in the Western Regions through peaceful embassies or military expeditions. The benefits Liangzhou's rulers sought from trade with, or direct control over, the Western Regions were not just political prestige or the obtaining of luxury goods. These links were important for the survival or consolidation of their regimes. ${ }^{91}$ The most famous expedition during this period was the one despatched from Chang'an in 383 by Fu Jian of the Former Qin state, who had briefly reunited the whole of North China and was about to lead the disastrous expedition against Eastern Jin that ended in his downfall. From his point of view, conquering the Western regions was a necessary part of fulfilling the Mandate of Heaven that he had accepted. $^{92}$

In addition to keeping open trade and diplomatic communications with the Western Regions, another major accomplishment of the various regimes in Liangzhou was the establishment of direct control of Gaochang (Karakhoja ) near Turfan, the first city on the northern branch of the Silk Road in the Western Regions. In 344 the Zhang power in Liangzhou (whose successor founded the Former Liang state, 354-376) established a commandery in Gaochang. The Former Qin state (351-394) continued to have an administration there. After Lü Guang founded his Later Liang state (386-403), he considered Gaochang to be a base for further westward

\footnotetext{
${ }^{90}$ Ise has a comprehensive study on China's interactions with the Western Regions from early Han to mid-Tang. For the Han period, see Ise 1968, pp. 1-21; pp. 37-89. See also Yü Ying-shih 1990 for the significance of the Western Regions in Han's relations with the Xiongnu.

${ }^{91}$ For a more detailed account, see Ise 1968, pp. 95-116.

${ }^{92}$ Mather 1959, p. 1.
} 
expansion, appointed his son as the Protector-general of the Western Regions and stationed him in Gaochang. ${ }^{93}$

Another highly significant development resulting from uninterrupted communications with the Western Regions and beyond was the inflow of Buddhism. When it was first introduced to China in the first century C.E. Buddhism spread along the routes of trade between Central Asia and China proper, and inside China the religion moved along the main routes of internal trade and communication. ${ }^{94}$ Through a report by a Chinese monk who had traveled to Qiuci (Kucha), Fu Jian in 379 heard about Kumarajiva, a famous Buddhist monk then living there. One of the objectives of Fu Jian's expedition to the Western Regions in 383 was to bring Kumarajiva back to China. Lü Guang, the general whom he sent to accomplish this task, succeeded in defeating Kucha and subduing other states. He brought Kumarajiva back with him, but learning that Fu Jian had been fatally defeated in the Battle of the Fei River, kept the monk in Liangzhou for seventeen years. Kumarajiva was finally brought to Chang'an in 401 , by which time he had fully mastered the Chinese written language, which allowed him to become the greatest translator of Buddhist texts into Chinese. ${ }^{95}$

Since the Rouran nomadic empire by this time had already extended its influence to the Western Regions as far as Ephthalites beyond the Pamirs, the early Northern Wei rulers adopted an aggressive policy towards the Western Regions to weaken the Rouran, but also for the sake of political prestige and trading benefits.. In 435 and 436 Wei sent several diplomatic missions to the region and, in 445 and 448 , launched military expeditions to subdue Shanshan (Loulan), Yanqi (Karashahr) and Qiuci (Kucha). In 448 Wei appointed a Chinese as Commandant of Western Rong (Xirong xiaowei) in Shanshan, the first city state on the southern branch of the Silk Road beyond the Yumen Pass, and ran it like a regular tax paying commandery. During the same period, Northern Wei also launched direct attacks against the Rouran and conducted five military campaigns (in 444, 445, 460, 470 and 473) against the Tuyuhun, because the Tuyuhun had contacts with the Rouran and the Liu-Song dynasty, and they controlled the route south from the Western Regions.

\footnotetext{
${ }^{93}$ Ise 1968, pp. 95-114.

${ }^{94}$ Wright 1959 , p. 32.

${ }^{95}$ Mather 1959, pp. 2-10; Ch'en, K. 1964, pp. 82-3.
} 
Northern Wei relaxed its efforts in the Western Regions after 470. It appears that Shanshan was no longer under direct Wei control. In 471 Wei refused to assist Yutian (Khotan) against an invasion of the Rouran. In 516 the Wei emperor sent envoys into the region to acquire Buddhist texts, but apart from this Wei and the later Northern dynasties did not initiate any activities there. In contrast, countries in Central Asia continued to send envoys to Wei. ${ }^{96}$

\section{Manchuria in the Northeast}

Northeast of the North China Plain is the area known in English language works as Manchuria, at present the three provinces of Northeast China. Like the Western Regions, Manchuria was an area of mixed economies and ethnic groups, but it was ecologically more complex. The Liaodong region in southern Manchuria, comprising the Liao River plain and the Liaodong peninsula, was suitable for agriculture. Liaodong's agricultural land tempted Chinese states to expand into the region, but since it was physically isolated from China by mountains and seas, the major link to the North China Plain being the Shanhai Pass, Chinese control in the region was not stable. Manchuria's open western plains were partly suitable for pastrolism and partly for agriculture. Nomads from the contiguous Mongolian steppe were often tempted to move down to subjugate the various native peoples. In the mountains and forests of the rest of Manchuria lived various groups of fishing-hunting communities.

Chinese expansion into the Liaodong region was first carried out by the state of Yan in the Warring States period and later by the Qin dynasty, which established a political administration over Chosǒn, a confederation of walled town states in the basin of the Liao and Datong (Korean Taedong) Rivers. In early Han a Chinese (or perhaps a Korean) known as Wei Man, associated with the King of Yan, rebelled, and fled to Chosǒn, where he succeeded in establishing his rule. ${ }^{97}$ In 109 B.C.E. Emperor Wu of the Han dynasty decided to attack Chosǒn. His strategic purpose was to

${ }^{96}$ WS 102; Ise 1968, pp. 117-44.

${ }^{97} S J 115$, p. 2985, which merely associates Wei Man with Yan. Lee Ki-baik (1984, pp. 16-7) questions whether Wei Man was in fact a Chinese on the ground that his hair style was different from that of the Chinese, and because he dressed in Chosonn style when he went to Chosǒn. He could, therefore, have been either a Sinicized Korean or a Koreanized Chinese. The distinction would not have been as important then as it would be now to modern nationalistic Chinese and Koreans. 
"cut off the left arm of the Xiongnu,",98 that is, to cut off any possible alliance between Chosǒn and the Xiongnu, who were expanding eastward in that direction. The attack was a success and, as a result, Chosorn was incorporated into the Chinese commandery-district system under four commanderies, Lelang, Zhenfan, Lintun and Xuantu, ${ }^{99}$ all north of the Han River. ${ }^{100}$

One major unintended effect of the Han commandery system, which eventually ended at the beginning of the fourth century, was to stimulate the formation of native political powers. The state of Koguryǒ, which straddled the present boundary between Manchuria and Korea, captured Lelang, and another Korean state, Paekche, captured Daifang commandery. ${ }^{101}$ Koguryǒ was a semi-nomadic state that rose around 37 B.C.E. in Manchuria. It competed with the Murong and eventually annexed another Manchurian regime, Puyǒ and Liaodong in the fourth century C.E., expanding its sphere from Manchuria to the northern half of the Korean peninsula. ${ }^{102}$

During the Period of Disunion, while China was under various regimes, most of the Korean peninsula was sub-divided into three states: Koguryǒ, Paekche, and Silla. Paekche was established by invaders from Puyǒ by the third century C.E. out of the walled town states in the southwestern part of the peninsula. Silla emerged as a strong power which evolved from the state of Saro in the southeast. ${ }^{103}$ Both of these states were populated by agrarian people with economies similar to that of China. The three Korean kingdoms, especially Koguryǒ and Paekche, were continually fighting each other over territory and therefore were interested in gaining Chinese support in their struggles.

Through the tribute system, particularly the system of investiture, by which political titles were bestowed by the Chinese court on foreign

\footnotetext{
${ }^{98} H S 73$, p. 3162.

${ }^{99}$ SJ 115 , p. 2989 ; HS 6, p. $194 ; 95$, pp. $3865-7$. HS 28 (p. 1626) says that Xuantu commandery was set up in 107 B.C.E., which might not be correct according to other sources.

${ }^{100}$ In 82 B.C.E. Zhenfan and Lintun were abolished, and were partly incorporated into Lelang and Xuantu. See $H S$ 7, p. 223; HHS 85, p. 2817.

${ }^{101}$ Nishijima 1983, p. 419. Daifang commandery was set up at the beginning of the third century C.E. in the western part of Lelang.

${ }^{102}$ Lee Ki-baik 1984, pp. 22-4.

${ }^{103}$ WS 100, p. 2217 ; Lee Ki-baik 1984, pp. 36-7; pp. 40-2. Ledyard (1975, p. 234), however, dates the conquest as between 352 and 372 .
} 
rulers, these states entered into a vassal-suzerain relationship with various regimes in China proper. Koguryǒ had relations with regimes in both North and South China and received official investiture several times, the first time from the Former Yan in 355. It had contacts with the Rouran as well. Paekche first appears in Chinese historical records in 372, when it sent a mission to the Eastern Jin and a Jin official title was conferred on its king. It, too, pursued an outward-looking policy through which it obtained political investiture from both the northern and southern regimes in the following centuries. Silla sent its first official mission to the Former Qin in 377. It did not join the political investiture system until the sixth century but Chinese influence is obvious in the forms of its state institutions. ${ }^{104}$ Each of the three states was in reality independent of China, ruled solely by its own aristocracy, but in their constitutional and cultural forms all three kingdoms showed enthusiasm for the introduction of Chinese ways.

\section{The Western Mountain Borderlands and Tibet}

Lattimore's fifth region, Tibet, is separated from China proper by mountainous regions that are largely unsuited either to intensive agriculture of the Chinese type or to the extensive pastoral transhumance practiced by the nomads of Mongolia. It remained outside the Chinese sphere of influence and is scarcely referred to in Chinese sources until the Tang period when a Tibetan kingdom suddenly erupted and became a major power, contending not only directly with China but also with the contemporary nomadic powers for control of Central Asia, as we shall see in later chapters.

The intermediate lands were occupied by Tibeto-Burman speaking peoples known collectively to the Chinese as Qiang or Di (first tone-to be distinguished from $\mathrm{Di}$, second tone, the non-Chinese people of ancient Shanxi), who lived in small unorganized tribal bands of hunters or small scale pastoralists. During Han they caused trouble from time to time by raiding their Chinese neighbors, sometimes provoked by oppressive treatment by Chinese officials. In the chaos at the end of Han, Qiang and Di living in the Nanshan Mountains moved into the Wei valley in considerable numbers and played a notable part in the "barbarian" overrunning of North China during the fourth century. ${ }^{105}$ The most famous of these was

\footnotetext{
${ }^{104}$ Inoue 1972, pp. 82-3; Nishijima 1983, pp. 420-8.

${ }^{105}$ For a detailed study of Qiang during the Han period, see Crespigny 1984, chapters 2 to 4 .
} 
Fu Jian, a much sinicized Di whose Former Qin kingdom's success in briefly uniting North China has been referred to above.

There was also a considerable Tibeto-Burman element in the Tuyuhun polity in Qinghai.

The Tibeto-Burman inhabitants of West China's borderlands came into their own with the formation of the Nanzhao kingdom in Yunnan during Tang and the Tangut (Dangxiang Qiang) Western Xia kingdom in Gansu and Ningxia during Northern Song.

\section{The South and Southwest}

In contrast to the "hard" intractable steppe frontier to the north, the "soft" southern frontier, where the land was suitable for Chinese-style agriculture, remained open to Chinese expansion and occupation throughout the imperial period. Sinification proceeded as in pre-Qin times, partly by absorption of the previous non-Chinese inhabitants and partly by immigration of Chinese peasants from the north. The unification and expansion of the Qin and Han dynasties meant the establishment of Chinese administration in all parts of south China, along the coast as far south as Hanoi in present northern Vietnam, and southwest into present Yunnan and Sichuan. The territories of non-Chinese aboriginal peoples were organized into the Chinese commandery-district system but were governed by their own chieftains who attached themselves to Chinese local government. They did not always submit peacefully to Chinese rule, and often caused disturbances that had to be forcibly put down, but control over them was regarded as a matter of internal security rather than "foreign affairs."

Chinese expansion into these areas during Han, like the expansion into the Western Regions, was also partly motivated by interest in making contact with foreign countries and establishing trading relationships. The opening to the west inaugurated by Zhang Qian brought back not only knowledge of India but also the idea that India could be reached by way of a southwesterly route through Sichuan. Efforts were then made to open up contacts in that direction. ${ }^{106}$ By no means were moves made only by land. The Han period also saw the beginnings of seaborne trade to India and the West.

China's political center moved to the south during the Period of Disunion, with the capital of the Southern dynasties being located in Nanjing. Ever larger numbers of Chinese farmers migrated to the south. As a

${ }^{106}$ HS 95, p. 3841. 
result the formerly underdeveloped South China underwent a gradual economic advance with population growth, agricultural, commercial and manufacturing development. Finally, during the Tang period, the South replaced the North as the economic center of China.

The Southern dynasties had contacts with more countries in Southeast Asia than had their Han predecessor. Buddhism was now a bond between China and these countries, while private trade and trade through tribute-bearing missions provided a more practical motive for contact, and also contributed to the flourishing of seaborne trade during the Tang dynasty. The Southern dynasties retained some administrative control over the aboriginal peoples in frontier regions, but as in previous times, their administration was not stable, being affected by ethnic conflicts stated in political and economic terms. The Chinese were not able to establish a systematically firm control over these people until the early twentieth century.

\section{General Policy Measures Towards Non-Chinese States}

To the rulers of China, the tribute system, though ideal in conception, was inadequate in practice to deal with the many problems that arose in their intercourse with foreign states. To conclude this survey of the background to Sui-Tang diplomacy, it is useful to summarize the various policies, combining pragmatism with ideology, that had been developed over the years by imperial governments to deal with such matters before the Sui-Tang period. ${ }^{107}$ The salient points of these measures are as follows.

1. Aggressive military action to expand Chinese territory.

War has always been the ultimate means to settle internal and external political conflicts in human affairs. Aggressive behavior towards neighbors is the common experience of mankind. Chinese history is not exceptional in this respect, but Chinese expansionist rulers did not openly glorify conquest as a legitimate ambition for its own sake; they always sought to give moral justification for their conquests.

The early Zhou rulers justified their overthrow of Shang with the Mandate of Heaven doctrine. Later militant rulers such as the First Emperor of Qin and Emperor Wu of the Han justified campaigns of expansion by appealing to the need for frontier security. Moral justification was

${ }^{107}$ For general surveys, see Yang Lien-sheng 1968, pp. 20-33; Wang Gungwu 1968, pp. 34-62. 
based on the principle that "the king leaves nothing and nobody outside his realm" and belief that Chinese culture could convert other peoples to a higher civilization. In the famous debate in 81 B.C.E. on the salt and iron monopoly policy, the Legalist statesman Sang Hongyang praised Zou Yan's theory and claimed that it justified the Qin territorial expansion which was aimed at extending its power over the "nine large continents". ${ }^{108}$ Another justification commonly employed was that expansion was not to enlarge territory but to create buffer zones for national defense, so as to prevent the disaster a barbarian invasion would cause and avoid the resulting harm to the common people. ${ }^{109}$ Frontier expansion could also attract wealth in exotic goods and horses, thus benefiting the country. ${ }^{110}$

As we have previously noted, however, the Qin and Han expansion was severely condemned by the Confucian scholars who participated in these debates during the Han period and by their successors in later ages. These Confucians stressed an inward looking-attitude, arguing that imperialistic endeavors damaged the welfare of the people while failing to solve the problem of incursions, and that the conquered territories were useless, and not a source of enrichment for the Chinese nation.

2. Strengthening frontier defense.

While Confucianism tended to give more value to moral persuasion, it held that military force was legitimate if used for defense. ${ }^{111}$ A Han Confucian minister, Wei Xiang, articulated the different justifications for using military force and favored the use of force for defense:

Forces used to settle chaos and to punish the tyrannous are righteous forces, which will dominate All-under-Heaven. Forces used reluctantly for self-defense are responsive forces, which will win. Forces used to release minor grudges or resentment are resentful forces, which will suffer defeat. Forces used to seize territory and wealth are greedy forces, which will meet destruction. Forces used to display great power and numerical strength to awe the enemy are arrogant forces, which will meet extinction. These five are not only matters of man but also the way of Heaven. $^{112}$

\footnotetext{
${ }^{108}$ Yan Tie Lun Jiaozhu 9, pp. 331-2.

${ }^{109}$ Yan Tie Lun Jiaozhu 4, p. 114; 8, pp. 285-7.

${ }^{110}$ Yan Tie Lun Jiaozhu 1, p. 12; 3, p. 105.

${ }^{111}$ Yang Lien-sheng 1968, pp. 24-6.

112 Yang Lien-sheng 1968, p. 28.
} 
In appealing to defense as a justification for the resort to force it was, of course, necessary to know where to draw the boundary line around China. In the classic pre-Han document, the "Yugong" in the Shujing, the realm subject to the Chinese Son of Heaven extends in concentric squares of diminishing influence to the Four Seas, that is, to All-under-Heaven, in effect, the whole world. ${ }^{113}$ The Qin-Han unification and confrontation with the nomad power in the north forced a more precise definition. In the debate on the salt and iron monopoly policy, the Confucian scholars defined the extent of China's territory in ecological terms, saying that the frontier commanderies were in the mountains and valleys, places not suited to agriculture because their yin and yang were not well balanced; China, the Middle Kingdom, lay in the middle between heaven and earth where yin and yang came together and made possible abundant production. They argued that China should not exert itself beyond its natural boundaries into these frontier commanderies. ${ }^{114}$

Defensive works defining the boundaries between Chinese and non-Chinese were built from early times. While the First Emperor of Qin was notorious for his military expansion he was equally known for the socalled Great Wall, which linked together earlier frontier walls built by Chinese states bordering on the steppe in a connected series of frontier fortifications. ${ }^{115}$ The project was meant to erect a boundary line between agricultural China and nomadic steppe land as well as to defend China from nomadic invasions. This was the policy of "having all the Chinese within and keeping all the barbarians without." During the Period of Disunion the alien rulers of the Northern Wei and Northern Qi continued such construction projects for the purpose of defense. Wall building was accompanied by establishment of garrisons, watchtowers and walled towns.

There were, however, serious difficulties with the policy of building and manning frontier fortifications as a means of controlling the nomads. First, it was impossible to have a sharply defined, physical boundary line as we can often (though not always) do in the modern world of nation states. The intermediary zones between China and its neighbors were always areas for competition. In practice it was impossible to prevent the nomads from crossing in and the Chinese from going out. Second, defending such boundaries placed a heavy logistical burden on the govern-

${ }^{113}$ Shangshu, "Yugong," p. 18, sections 38.

${ }^{114}$ Yan Tie Lun Jiaozhu 3, pp. 100-1.

${ }^{115}$ Waldron 1990, pp. 13-29. On the policy of wall building, see also pp. 30-51. 
ment to maintain large numbers of troops on or near the frontier. Conditions for agriculture were harsh in frontier regions, and population was sparse. The harsh environment adversely affected the morale of soldiers.

3. Alliance strategies.

Policy-makers in traditional China were clearly aware of the universal rule: my enemy's enemy is my friend. They were also aware of the underlying tendency for nomadic power to lack institutional cohesion. They therefore devised the strategy of "using barbarians against barbarians" or "using barbarians to control barbarians." The objectives were to play off one party against another so as to divide the parties and allow China to rule or at least maintain a balance of power, or to obtain foreign support for some specific purpose. Measures adopted to form alliances included offering political and military support, signing peace agreements, marriage contracts, establishment of fictitious kinship relationships, offering rich economic rewards, guaranteeing profitable mutual trade under the framework of the tribute system and in border markets.

The policy of making peace agreements or marriage alliances was often criticized by some as being as costly as the use of military force or more so. Sang Hongyang held that "barbarians" could not be bound by agreements; even the Chinese states in the Spring and Autumn period failed to keep peace agreements, let alone "barbarians." "116 They believed that alliances with non-Chinese could only be temporary expedients. Fundamental conflicts of interest would inevitably generate mutual distrust and hinder any abiding alliances.

4. Appeasement policy.

The Chinese sometimes offered the above inducements in a positive way to secure alliances, but when China was weak and the balance of power had tipped in favor of the non-Chinese, the nomads in particular, such measures were forced upon the Chinese. China had to accommodate the demands of the nomads for payments of silk and other goods, and send princesses into marriage with their rulers in order to have peace on the frontiers, as the history of Han-Xiongnu relations during early Han demonstrated.

In effect, an appeasement policy would treat the foreign country as an equal or superior rather than as a tributary.To pay tribute in order to purchase peace was seen as humiliating politically, expensive financially and ineffective compared to use of military force. Jia Yi, an early Han

${ }^{116}$ Yan Tie Lun Jiaozhu 8, p. 285; pp. 305-6. 
scholar, attacked the appeasement policy as "hanging a person upside down." That is, the Son of Heaven as the head of the state was being made to serve the Xiongnu "barbarians," the feet of the state, through the policy of marriage alliance. ${ }^{117}$ But down through history such a compromise was made frequently and it often bought time for the Chinese to accumulate strength to compete with some foreign power.

5. Settlement and incorporation.

The Chinese also often attempted to bring non-Chinese who had submitted under Chinese administration, with a view to converting them to Chinese ways, and to utilizing their military force for frontier defense. The general spread of Chinese influence was seen not only in the establishment of the Chinese administrative system over the non-Chinese in the south and southwest where agriculture was a major way of life, but also in the resettlement of the submitted nomads on Chinese land in the north. This policy was actively adopted all through the Han dynasty but became particularly important in the Later Han after the submission of the Southern Xiongnu. It worked effectively, given the particular circumstances at that time, but later, it led to revolts by the settled nomads against their Chinese rulers. The resulting establishment of non-Chinese regimes inside China brought China into the Period of Disunion, when North China was under the control of the Five "Barbarians."

The ideal pattern of Chinese foreign relations called for the allembracing rule of the Son of Heaven, to whom other peoples were expected to come and offer tribute. This ideal pattern grew out of the cosmic metaphor by which the early Zhou rulers justified their conquest of Shang, the idea that the ruler of the Chinese people was endowed with a mandate to rule the world (All-under-Heaven) as Heaven's surrogate. Despite fundamental challenges to these ideas during the Warring States period, this ideology became firmly established as a potent myth in all subsequent Confucian political philosophy. With the unification by Qin and the imperial expansion during Han the tribute system was institutionalized and implemented as a regular practice.

Foreign regimes acquiesced in this system in varying degrees according to the political, economic and military benefits that it provided for them. On the Chinese side, other more pragmatic and realistic views,

${ }^{117}$ Yü Ying-shih 1967, pp. 11-2. 
which recognized that China was not after all the center of the world, or that the Chinese Son of Heaven need not extend his rule over non-Chinese, also developed. Han Confucian scholars severely condemned the foreign aggressions of Qin and early Han. Pragmatism was most obvious and dominant in foreign policy when China was in a weak position, as we see in the policy of appeasement through marriage alliances and payment of large subsidies to the Xiongnu in early Han.

New challenges to traditional political doctrine emerged during the Period of Disunion, when North China came under alien rule. Although the various non-Chinese regimes adopted prevailing Chinese political theories as the basis for their legitimacy and treated the tribute system as the norm in their external relations, the fact that the throne was occupied by a non-Chinese required additional rationalization with additional emphasis placed on the doctrine that the mandate of the Son of Heaven depended on virtue rather than heredity.

Tensions also inevitably arose from conflicts between the need to maintain the loyalty of the nomadic warriors on whom the strength of the regimes depended, and the need to encourage the agricultural economy to provide a source of tax revenue instead of treating it simply as war booty, and to gain the cooperation of the Chinese educated class whose expertise was needed to administer the country. The attitude of non-Chinese regimes in China toward rival nomadic powers who remained outside in the steppe was also different from that of native Chinese regimes. Having come from the steppe, and with a more intimate knowledge of it, the nomad conquerers continued to regard it as their own sphere and to attempt, with varying degrees of success, to assert their hegemony there as well as within China.

After the chaotic political turmoil of the fourth century, the Tuoba Wei regime succeeded in uniting North China under a comparatively stable dyarchy between Xianbei rulers and Chinese bureaucrats that not only united North China but also attempted to draw on its nomadic traditions to exert control on the steppe. When contradictions between the sinicizing Tuoba rulers in Luoyang and their frontier garrisons led to civil war, Yuwen Tai, the founder of Western Wei-Northern Zhou, launched his more radical experiment, which attempted to fuse the leading Chinese and Xianbei families within his territory into a unified aristocracy combining military and civil functions.

The usurpation by Yang Jian, a member of one of these Chinese families, made the succeeding Sui dynasty, which proceeded to reunite North and South China after two and a half centuries of separation, more 
acceptable to the Chinese, but both the Sui and Tang ruling houses were also heirs to this Chinese-Xianbei fusion. This mixed background contributed both breadth of outlook and military vigor to Sui and early Tang in their dealings with the outside world.

Buddhism, which was actively promoted by the non-Chinese regimes of the North and also took root in the South, was also an important legacy of the Period of Disunion that eventually worked as a unifying force for China, and contributed an important ingredient to the cosmopolitan, open-minded atmosphere that prevailed in Tang China and strengthened and rendered more subtle Tang's diplomacy.

In the second half of the chapter we discussed the evolution of Chinese foreign relations up to Sui-Tang from an external point of view. The Qin-Han unification created a new situation in which China no longer consisted of rival states looking inward and contending with each other. "Barbarian" internal enclaves had ceased to have much importance. China had come to comprise a unified empire looking outward on non-Chinese neighbors on the periphery, thus beginning the history of China's "foreign affairs."

Inescapable realities of geography meant that in some respects the problems that faced the Sui and Tang rulers were a continuation of those that had faced Qin and Han, but in other respects the situation had greatly evolved and become much more complicated. The most formidable and persistent problems facing Chinese regimes from Qin-Han onward came from the nomadic peoples of the North, beginning with the Xiongnu and ending at the time of the founding of Sui and Tang with the Turks. West of the steppe land were the oasis states of the Western Regions, whose strategic importance to China lay, as in Han times, in their potential role as allies and bases for outflanking the nomadic powers and for controlling the overland trade routes providing access to Western and Southern Asia.

East of the steppe were the Liaodong area in southern Manchuria and the Korean peninsula. Here significant changes had taken place between Han and Sui-Tang. Like the expansion into the Western Regions, the Han expansion in this direction was carried out for the military purpose of outflanking the Xiongnu. Those more southerly parts of the Korean peninsula not conquered by China were inhabited by unorganized tribal peoples. Withdrawal of Chinese colonial occupation from the north at the end of Han was followed, however, by nomadic invasions and the emergence of well-organized territorial states occupying most of the peninsula. By the sixth century the Korean peninsula was divided between 
three competing kingdoms, all more or less influenced by Chinese civilization.

Directly to the west of China and south of the main trade routes to the Western Regions, Tibet remained outside the Chinese sphere of influence until the Tang period, while the intermediate lands continued to be occupied by Qiang and Di tribesmen as during Han. The Tuyuhun, a branch of the Xianbei who established themselves in Qinghai in the fourth century and absorbed Qiang and Di elements, were the main power in that region at the beginning of Sui and they acted as an intermediary in bringing Tibet onto the political scene as a rival of China during the following century.

During the Period of Disunion, a succession of native Chinese dynasties continued to rule in the south. The Chinese population in the south swelled with the influx of refugees and this led to economic advance in the Yangtze valley, foreshadowing its replacement of the North China plain as the economic center during Tang. The gradual sinification of the aboriginal peoples of South China, where the land was suitable for Chinese-style agriculture, proceeded as it had in pre-Han and Han times. The nonChinese peoples did not always submit peacefully but, unlike the situation in the north, no organized non-Chinese state had yet appeared to confront the advancing Chinese before Sui times. The Southern Dynasties also actively encouraged overseas trade and so contributed to the flourishing of seaborne trade during the Tang dynasty. 


\section{Chapter 2}

\section{How Foreign Affairs were Handled During Sui and Tang}

The basic structure of the bureaucracy by which China was governed in imperial times took shape during Qin and Han. Its institutions and their functioning during that period have. been well described by Wang Yü-ch'üan and Hans Bielenstein. ${ }^{1}$ Between Han and Tang these institutions had undergone much evolution and elaboration. The more ample data from the Tang period have also been thoroughly analyzed and discussed by such scholars as Des Rotours, Sun Guodong, and Xie Yuanlu. ${ }^{2}$

After a brief discussion of the general decision-making process of the Tang government and the checks and balances built into the process for ensuring accuracy and effectiveness, this chapter focuses on the way in which Tang dealt with official business involving relations with foreign countries. Who were the individuals and groups principally involved in making policy on such matters? What bureaucratic apparatus on the central level was responsible for handling foreign affairs? How was information on foreign countries collected and utilized in coming to decisions? How did this information provide basic materials for the compilation of accounts of foreign countries in the national history? Answers to these questions show that China had developed a sophisticated set of principles and institutions for dealing with foreign countries, assuring frontier security and securing the rule of the Son of Heaven.

\section{The Decision-Making Process}

There was no special office in traditional China for foreign policy decision-making. Foreign affairs were largely concerned with frontier security, and frontier policies were part of the general decision-making process. The procedure for decision-making in foreign affairs started with the gathering of information from various sources. Based on their assessment of that information, officials would put forward proposals in the form of memorials. On the central level, the memorials would be studied by Chief

\footnotetext{
${ }^{1}$ Wang Yü-ch'üan 1949; Bielenstein 1980; 1986.

${ }^{2}$ Des Rotours 1932; 1947-48; Sun Guodong 1957; Xie Yuanlu 1992.
} 
Ministers, and a decision would finally be arrived at through a sequence of deliberation, drafting, sanction by the emperor, and final scrutiny until the decision was proclaimed in an imperial edict or an instruction from some lesser authority and implemented. ${ }^{3}$

The above decision-making process took definitive shape at the central level during Tang under Taizong but all its main characteristics were inherited from Sui. Three kinds of conferences were held to discuss the feasibility of proposals on such important matters as succession to the throne, appointments, financial policies, military affairs, frontier policies etc.

The first was the regular audience at which the emperor met his high officials. At the beginning of the dynasty, the most important of these was the Consultant Assembly (changcan), held every day or every other day and participated in by officers of the fifth rank and above. After the time of Gaozong, the importance of this large assembly decreased and a smaller meeting between the emperor and his Chief Ministers and other select officials after the court assembly was finished became more important. These smaller meetings were sometimes already being held in Taizong's time. From Suzong's time onward it became the regular practice to hold these meetings in the Yanying Hall (Yanying dian), a venue that had already sometimes been used in Xuanzong's time. Often other officials in addition to the Chief Ministers would participate in such meetings. After mid-Tang the emperor also held irregular meetings with the Hanlin academicians. 4

The second kind of deliberative conference was a formal meeting of Chief Ministers among themselves. These were first held in the Administration Chamber (zhengshi tang) and called the Zhengshi Tang meeting, and then moved to the Office of the Secretariat (zhongshu sheng) in Empress Wu's time. From Xuanzong's time the Zhengshi Tang became an office for the Chief Ministers, and was renamed the SecretariatChancellery (zhongshu menxia); therefore the meeting was also renamed. An important change was the participation of the eunuchs during the postAn Lushan period, when the eunuchs' power increased in the court. ${ }^{5}$

\footnotetext{
${ }^{3}$ Xie Yuanlu 1992, pp. 3-6. For the procedure in Taizong's time, see Wechsler 1974, pp. 95-8. The procedure during the Ming period was similar, see Lo Jung-pang 1969, pp. 702.

${ }^{4}$ Xie Yuanlu 1992, pp. 53-76; Twitchett 1992, pp. 35-8.

${ }^{5}$ Sun Guodong 1957, pp. 58-9; pp. 81-3; Xie Yuanlu 1992, pp. 77-88.
} 
The third, less frequent, type of deliberative meeting was the Court Conference (tingyi) participated in by civil and military officials of the ninth rank and above. ${ }^{6}$

To ensure an effective government the court implemented an elaborate, multi-channel system for communication between the central and local governments. The system enabled local officials to send their memorials, reports and other documents through Territorial Representatives (chaoji shi) ${ }^{7}$ or via the postal service to the central government.

After the An Lushan rebellion, the Capital Liaison Office of Various Regions (zhudao jinzouyuan) was set up in order to make the transmission of reports and information more efficient. An agency known as Touring Brokerage (xunyuan) was established after 758. It was not only charged with administering the salt monopoly but also functioned as a channel to inform the central government of local political, administrative and social conditions. ${ }^{8}$ In addition, a system for soliciting opinions (qiuyan) and for presentation of unsolicited memorials allowed officials at all levels and common people to present their opinions to the court. ${ }^{9} \mathrm{~A}$ parallel mechanism for communication between the central and local governments was provided by the system of censors or special commissioners dispatched by the court down to the local areas, whose tasks were to investigate local conditions, to supervise local official administration, and to verify and confirm the information presented through other channels. ${ }^{10}$

\section{Decision-Makers}

As in all other periods, the decision-making group within the central government of the Tang dynasty was composed of four levels.

1. The emperor. He was the final authority and source of all laws, the head of state; his legitimacy was based on the belief that he was the Son of Heaven, given the Mandate to rule by Heaven. More practically, his power was based on his possession of military force and his command of economic resources. In reality, however, his power was limited by his personal capability and by the technical impossibility for one man to handle the affairs of a government of large scope, by public opinion, and by

\footnotetext{
${ }^{6}$ Xie Yuanlu 1992, pp. 99-103.

${ }^{7}$ A delegate from each prefecture was sent to the capital annually to participate in the New Year's audience and report on local conditions. See Hucker 1985, p. 118.

${ }^{8}$ Xie Yuanlu 1992, pp. 128-42.

${ }^{9}$ Xie Yuanlu 1992, pp. 161-71.

${ }^{10}$ Xie Yuanlu 1992, pp. 146-58.
} 
the concept of propriety, all these obligations serving as a kind of unwritten constitution. Even the most independent-minded or willful emperor was constantly receiving advice from his ministers, as well as from his inner circle of relatives and attendants, and he was morally obliged to at least listen to such people. ${ }^{11}$

In their decisions involving foreign policies, the emperors were influenced by a variety of motives. Their primary responsibility was to maintain internal and external order so as to ensure the stability and security of the whole nation. A second major objective was preservation of the state's political prestige. Prestige yielded a power that could not only awe neighboring peoples into submission but also command the respect and obedience of the emperors' own Chinese subjects. Their claim to sovereignty required that neighboring countries should recognize their possession of the Mandate of Heaven and their right to rule All-under-Heaven. A third motivation was economic. The trade that accompanied tributebearing missions brought into China nomadic specialties such as horses which were needed not only to satisfy the personal appetites of the ruler but also for national defense. On the other hand, tribute from foreign countries, consisting typically of exotic luxury goods, mostly went into the personal treasuries of the emperors, who would distribute it to favored individuals. Tribute did not benefit the state finances. Indeed, emperors were often chided for being excessively attracted by exotic products.

2. The Chief Ministers (zaixiang). Together with the emperor, they formed the core group in decision-making and administering all aspects of state affairs. In place of the Chancellor of early Han times, standing over against the emperor as the head of the bureaucracy, the Sui-Tang had a committee of Chief Ministers. At the beginning of the Tang dynasty, the heads of the three Departments, Director of the Department of State Affairs (shangshu ling), Secretariat Director (zhongshu ling) and Director of the Chancellery (shizhong), were ex officio Chief Ministers. The Three Departments had originated in Han as agencies within the emperor's inner court that had taken over functions of the regular outer bureaucracy and eventually moved out and become recognized as the most important formal parts of the bureaucracy. Instead of dealing with one chancellor the Tang emperors now dealt with a group of Chief Ministers, which provided more flexibility in adjusting the balance between different interests and points of view and in making decisions. The actual power to make particu-

${ }^{11}$ Wang Yü-ch'üan 1949, pp. 138-41; pp. 161-2; Lo Jung-pang 1969, p. 44. 
lar decisions varied and alternated under different circumstances between the throne and the bureaucracy.

After the emperor Taizong, as Crown Prince, held the title of shangshu ling, this position fell into abeyance and was not filled. Until 705, the deputy heads of the Department of State Affairs (puye) took this official position's place as ex officio Chief Ministers, after which they too ceased to function and the title of puye was attached to a sinecure for persons of high rank. It was also customary throughout the dynasty to appoint one or more other high officials, including, most commonly, the head of one of the six Ministries $(b u)$ of the Department of State Affairs, to serve as ad hoc Chief Ministers. ${ }^{12}$

3. Remonstrance officials, whose responsibilities included scrutinizing and commenting on decisions (shenyi fengbo). They held such offices as Supervising Secretary (jishi zhong) under the Department of State Affairs, Policy Adviser (sanqi changshi), Grand Master of Remonstrance (jianyi dafu), Rectifier of Omissions (buque) and Reminder (shiyi). The last four were divided between the Chancellery and the Secretariat. They were also admitted to the conferences held between the emperor and his Chief Ministers. Compared with Han, the Tang remonstrance system was more formalized; the number of officials increased, and they enjoyed relatively more independence. However, on occasions when they, as comparatively low-ranking officials, attempted to confront those in power, including the emperor himself, their position could become quite precarious. $^{13}$

4. Assistants, who did not participate in the deliberations of policies but played important roles in recording the activities of the emperor, transmitting (chuanda) and promulgating (banbu) orders. These assistants held such positions as Imperial Diarist (qiju lang and qiju sheren) and Secretarial Receptionist (tongshi sheren). ${ }^{14}$

The official histories contain materials on policies and decisions, major participants in the deliberations, and major conflicting opinions. We also on occasion have contemporary correspondence or documents sent from the Tang court to frontier officials and to foreign rulers, as for example, in the collected works of Zhang Jiuling, Bai Juyi and Li Deyu, that

${ }^{12}$ Des Rotours 1932, pp. 5-6; p. 10; Wang Yü-ch'üan 1949, pp. 43-6; Sun Guodong 1957, pp. 19-24; pp. 60-5; Xie Yuanlu 1992, pp. 6-10.

${ }^{13}$ Xie Yuanlu 1992, pp. 35-52.

${ }^{14}$ Sun Guodong 1957, pp. 25-9. 
provide us with more detailed information. Li Deyu's works, in particular, provide us with a detailed, step by step, day-to-day account of how the court dealt with the Uighurs between 841 and 845 and how the key decisions were made. ${ }^{15}$

In addition to the above groups, officials throughout the empire could present memorials and reports to the central government with proposals for action. These would be examined and deliberated upon and decisions reached. In the formulation of foreign policy, although frontier officials were not formally included in the decision-making bodies, they often played an important, sometimes decisive, role. They were familiar with frontier affairs and handled much of the actual contact with the nonChinese. It was often they who made proposals, whereupon they might be invited to participate in the deliberations at court and have their proposals approved at the central level. The emperors often consulted the frontier officials for detailed information and advice on strategy. Many of them were promoted to the central level, taking up various positions such as Minister of War, and often becoming Chief Ministers. Examples of the important roles played by frontier officials will be seen in the following chapters.

Tension between the emperor and his bureaucracy was the normal state of affairs. Although emperors had to rely on their bureaucrats for administration and needed the information and advice that they provided in making decisions, no emperor was content to be reduced to merely a figurehead. The bureaucracy, on the other hand, attempted to restrict the power of the throne the better to exert its own influence. In policy matters it was often influenced by ideals and interests that were different from those of the emperors. From the Han period onward, the Confucian principle that a wise ruler should not be an active administrator but rather should content himself with being a perfect moral leader who would select wise and virtuous men and listen to their advice in state affairs prevailed within the Chinese bureaucracy. ${ }^{16}$ Through the civil service examination system which began in the Sui dynasty and was further developed throughout the Tang period, Confucianism sent down deeper roots. Members of the bureaucracy also had their own family connections and economic interests, often as local landlords, which influenced their attitudes toward government policies. Moreover, as everywhere, bureaucratic rou-

\footnotetext{
${ }^{15}$ Drompp 1986.

${ }^{16}$ Wang Yü-ch'üan 1949, pp. 162-4.
} 
tines could create intolerable delays in the handling of the day-by-day business of government, and activist emperors tried to circumvent them.

The bureaucracy always tended to act as a check on the power of the emperor and this was a continuing source of conflict between the throne and the bureaucrats. Such tension could be constructive, conducive to well-thought-out plans and effective government; but it could also lead to destructive power struggles.

Having the heads of the Three Departments as Chief Ministers participating in decision-making lessened the tensions between the emperor and bureaucracy. This prevented any monopoly of power on one side. Instead of dealing with one chancellor the Tang emperors now dealt with a group of Chief Ministers, who provided more alternatives and flexibility in making decisions. The actual decision-making power oscillated irregularly under different circumstances between the throne and the bureaucracy. ${ }^{17}$ An emperor with a strong personality, such as the Sui Emperor Yang and Tang Taizong, was usually prepared to enforce his will. The personal character, abilities and experience of each emperor very much influenced which chief ministers he selected and his subsequent relations with them. A weak emperor could let the power slip into the hands of his ministers. When Xuanzong lost interest in government, first $\mathrm{Li}$ Linfu and then Yang Guozhong were able to exercise dictatorial power.

To strengthen their own power, emperors tended to develop an "inner court" (neiting), relying on imperial relatives, personal secretaries or eunuchs, as opposed to the "outer court" (waiting) of bureaucrats. This distinction has been well described by Wang Yü-ch'üan for the Han period. ${ }^{18}$ Former Han empresses and empress dowagers, along with their male relatives (waiqi), often formed a powerful group behind and around the throne. This was also true during Sui and Tang.

Sui Wendi's Empress Dugu was a powerful influence behind her husband and Tang Taizong's brother-in-law, Zhangsun Wuji, was a prominent figure who became deeply involved in the question of succession to the throne, only to be defeated by Gaozong's Empress, Wu Zetian. She in turn, first dominated her husband and then supplanted her sons and made herself the first and only female emperor in Chinese history. Paradoxically (from the point of view of traditional Chinese patterns of behavior) she despised her own male relatives as much as she did the members

${ }^{17}$ This was a general feature of China's political history. See Lo Jung-pang 1969, p. 45.

${ }^{18}$ Wang Yü-ch'üan 1949, pp. 166-73. 
of the Tang royal family, which no doubt was a factor in frustrating her attempt to replace Tang by her own Zhou dynasty.

Female influence on the throne continued when Empress Wu's elder son, Zhongzong, replaced her in 705, only to be dominated by his own Empress Wei, and when Wu Zetian's daughter, Princess Taiping, was deeply involved in the coup that placed Wu Zetian's second son, Ruizong, on the throne in 710. Ruizong's son, Xuanzong, succeeded in eliminating Princess Taiping. But during the latter part of his reign Xuanzong came under the influence of his favourite concubine, Yang Yuhuan, whose cousin, Yang Guozhong, became Chief Minister with nearly dictatorial powers. Yang Guozhong's rivalry with An Lushan contributed greatly to the disaster that ended Xuanzong's reign. Female influence in government continued under Suzong but became less important as the later Tang emperors fell under the domination of eunuchs.

Former Han emperors' frustration with the bureaucracy and need for more informal advice and assistance led them to rely on private secretaries within the palace. In the course of time these secretaries in turn moved outside the palace and created the most important functioning offices of the regular bureaucracy, replacing the previous "outer" bureaucratic offices, which often survived in name but with reduced or purely honorific functions.

The same tendency to rely on private secretaries repeated itself during Tang. Empress Wu used the Scholars of the Northern Gate (Beimen xueshi) to help her reach decisions, and also had a female private secretary, Shangguan Wan'er, granddaughter of a disgraced and executed Chief Minister, who rose from being a palace slave and not only composed government documents for the empress but gained a name for herself as a poet. She later became deeply involved in court politics under Zhongzong. $^{19}$

The founding of the Hanlin Academy was a more substantial and long-lasting innovation of this kind during Tang. It began under Xuanzong as a miscellaneous assembly of persons with special skills whom the emperor wished to have constantly by him within the palace for his personal edification and entertainment, including not only literary stylists who could compose official documents, but also poets, calligraphers, experts in religion, and even chess players. ${ }^{20}$ After the An Lushan rebellion it devel-

\footnotetext{
${ }^{19}$ JTS 51, p. 2175; Guisso 1979, p. 322.

${ }^{20}$ Twitchett 1979 , p.450.
} 
oped into an important consultative body. See especially Chapters 4 and 10 for the role of Lu Zhi as a Hanlin Scholar advising Emperor Dezong.

As during the Later Han period, however, it was the eunuchs who emerged as the most serious challenge to the role of the regular bureaucrats as partners of the emperor in governing the country. Formally excluded from participation in governmental matters under Taizong, their influence grew in an informal way under Xuanzong. During the An Lushan rebellion soon after Suzong assumed the throne at Lingwu, his eunuch adviser, Li Fuguo, dominated the court in exile and continued to do so after the return to Chang'an. Under Suzong's son, Daizong, a eunuch was put in charge of the palace armies and, though the eunuchs lost this authority briefly at the end of his reign, it was restored to them under Dezong and remained with them until the end of the dynasty.

Another eunuch institution that seems to have begun under Daizong was the office of Comissioner of Palace Secretary (shumi shi), originally set up as a messenger service for transmitting documents between the palace and the outer court. In the ninth century it grew into a fullblown Palace Secretariat (shumi yuan) which became a deliberative body on a par with the Chief Ministers. ${ }^{21}$ After the slaughter of eunuchs at the end of the dynasty it was transformed into a supreme council for military affairs and, as such, became part of the regular bureaucracy from the Five Dynasties through Song and Yuan.

Within the bureaucracy, officials' family backgrounds, education, experiences in government, official status, and factional relationships all influenced their assessments of particular kinds of situations. In his historian's comment at the end of the Monograph on the Xiongnu in the Han$s h u$, Ban Gu remarks that while Confucian officials stick to the policy of marriage alliances, military officers advocate punitive expeditions. They both see one-side and its temporary advantages but do not thoroughly understand the Xiongnu. ${ }^{22}$ The historian's comment in the Jiu Tangshu also holds that Confucian officials talk mostly about marriage alliances and generals only want to conquer by force. ${ }^{23}$ This is oversimplified since neither Sui nor Tang, set a distinct line between civil and military officials. The same persons often acted in both capacities at different stages of their

${ }^{21}$ Wang Gungwu 1963, p. 89 n. 9; Twitchett 1979, p. 20; Dalby 1979, pp. 633-4; Xie Yuanlu 1992, pp. 22-3.

${ }^{22}$ HS 94B, p. 3830.

${ }^{23}$ JTS 196B, pp. 5266-7. 
careers. Chief Ministers in particular were often pragmatic men, some with practical experience in both military and civilian administration.

Although, in Confucian theory, officials supposedly gave disinterested advice to the emperor as individuals, we may be sure that during Sui and Tang, as in all periods of Chinese history, connections based on kinship, marriage, local origins, and patronage, as well as class interests, also affected the advice given. These factors are usually difficult for the historian to sort out. For some brief remarks on the notorious Niu-Li factional struggles in the ninth century, which had an influence on foreign policy, see Chapters 9 and 10.

\section{Central Government Offices for Dealing with Foreigners}

Specialized central government offices handled the formal side of intercourse with foreigners and their states. These offices mobilized the large bureaucratic machine to tightly control the activities of foreign official visitors to China. The most important of these specialized bureaus was the Court of State Ceremonials (honglu si), ${ }^{24}$ a section of the Ministry of Rites (libu) in the Department of State Affairs (shangshu sheng) in Tang. It was in charge of foreign guests to China and functioned roughly as what would in modern times be termed a department of protocol.

This office had its origin in the Zhou Senior Messenger (da xingren), assisted by the Junior Messenger (xiao xingren). The Messengers were to make arrangements for the visits and receptions of feudal lords at the royal court. ${ }^{25}$ The name honglu was first used in 104 B.C.E. under the Han Emperor Wu to designate the office responsible for diplomatic relations as well as for reception of Chinese princes and lords and for their investiture. ${ }^{26}$ The office remained in existence until the Qing period. ${ }^{27}$

Specifically, the Court of State Ceremonials during the Sui dynasty was "responsible for managing the reception at the court of tributary envoys." 28 It was incorporated into the Court of Imperial Sacrifices

\footnotetext{
${ }^{24}$ Hucker 1985 translates honglu si as Court of Dependencies for the Sui period and as Court of State Ceremonials for the Tang. This seems confusing and unnecessary.

${ }^{25}$ Zhouli zhushu 37, pp. 1328-9; pp. 1344-5; Hucker 1985, p. 466.

${ }^{26}$ HS 19A, p. 730; HHS zhi 25, pp. 3583-4; TD 26, p. 153; Hucker 1985, p. 264.

${ }^{27}$ Hucker 1985, p. 264.

${ }^{28}$ Hucker 1985, p. 264.
} 
(taichang si) in 582 and was restored in $592 .^{29}$ There were three branch offices under it: ${ }^{30}$

1. Office of Receptions (dianke shu; dianfan shu under Emperor Yang), responsible for attending to the needs of important foreign visitors; ${ }^{31}$ ficials; ${ }^{32}$

2. Ceremonial Office (siyi shu), responsible for the funerals of of-

3. Office of Daoist Worship (chongxuan shu), responsible for registering and monitoring the activities of all Daoist monks and nuns in the capital area. $^{33}$

During Emperor Yang's reign (605-616) the Hostel for Tributary Envoys (sifang guan) attached to the Court of State Ceremonials was activated from time to time as required by the situation. It was the agency responsible for the greeting of foreign rulers and envoys, their preparation for presentation at court audience and the handling of their tributary gifts. $^{34}$

We have more specific information on the responsibilities of the Court of State Ceremonials during Tang. ${ }^{35}$ The Chamberlain (qing) of the Court of State Ceremonials and his assistants took charge of receiving guests and arranging funeral rites of Chinese officials and foreign rulers who had received Chinese official titles. The Tang Court of State Ceremonials differed from the Sui institution in that it had only two branch offices: the Office of Receptions (dianke shu) and the Ceremonial Office (siyi shu). Their tasks included the following:

1) to assign to each of the Chinese princes and non-Chinese chiefs a proper rank for court audience, and to distinguish between the eldest son and the other sons when the heirs of the previous two dynasties and the princes and chiefs of non-Chinese states received their appointments and their titles of nobility, and to confer official titles on the foreign rulers;

2) to arrange transportation for foreign envoys to come to the capital, to register tributary goods and Chinese imperial presents, and to

${ }^{29}$ SUIS 28, p. 792; TD 26, p. 153.

${ }^{30}$ SUIS 28, p. 777.

${ }^{31}$ SUIS 28, p. 798; Hucker 1985, p. 504.

${ }^{32}$ Hucker 1985, p. 449.

${ }^{33}$ Hucker 1985, p. 196.

${ }^{34}$ SUIS 28, p. 798; Hucker 1985, p. 446.

${ }^{35}$ For more details see Iwami Kiyohiro 1990. 
draw up reports on behalf of foreign envoys if the envoys had some matters to be presented to the emperor. ${ }^{36}$

The Office of Receptions was responsible for keeping records of feudal princes and of non-Chinese who had submitted, to be used for organizing their reception, banquets in their honor, their preparation for court audience and for providing accommodation and looking after foreign rulers when they fell ill or died while in China. ${ }^{37}$ The Ceremonial Office was responsible for funerals of Chinese officials as well as foreign rulers who had received Chinese official titles. ${ }^{38}$ In 754 , the Foreign Relations Office (libin yuan) was brought under the supervision of the Court of State Ceremonials; it is not clear under which office this unit had previously been placed or when it had been set up. It was to give banquets and arrange accommodations for foreign envoys. ${ }^{39}$

The Court of State Ceremonials normally employed twenty interpreters or translators. ${ }^{40}$ One important duty of the office was to collect information on foreign states. It made inquiries from foreign envoys concerning the geographical conditions of their countries, their customs, local products, distance from China, and the names of their rulers, after which it made maps and pictures of foreign peoples and sent reports to the Bureau of Historiography. ${ }^{41}$

The Court of State Ceremonials was headed by a Chamberlain, honglu qing, rank $3 \mathrm{~b}$ in the Tang period. A major part of his duties was to visit foreign lands to cultivate good relations and for such ceremonial purposes as to confer official titles, express condolences at the death of foreign rulers, escort Chinese imperial princesses to establish or maintain marriage alliances, and to handle frontier affairs in general. For example, in 841 the court sent the Chamberlain of the Court of State Ceremonials, Zhang Jia, as Frontier Patrolling Inspector (xunbian shi) to investigate the situation of the Uighurs. ${ }^{42}$

The Chamberlain of the Court of State Ceremonials sometimes even participated in frontier warfare, perhaps because the holders of this position often dealt with non-Chinese and had expertise in foreign affairs.

\footnotetext{
${ }^{36}$ TLD 18, p. 13 ; TD 26, p. 153; JTS 44, pp. 1885-6; XTS 48, pp. 1257-8.

${ }^{37}$ TLD 18, pp. 16-7; JTS 44, p. 1885; XTS 48, p. 1258.

${ }^{38}$ JTS 44, p. 1885 ; XTS 48, pp. 1258-9.

${ }^{39}$ THY 66, p. 1151 ; p. 1152; Xie Haiping 1978, pp. 310-1.

${ }^{40}$ TLD 2, p. 28.

${ }^{41}$ TLD 51, pp. 29-30; JTS 43, p. 1836; XTS 46, p. 1198; THY 63, p. 1089.

${ }^{42}$ ZZTJ 246, p. 7953.
} 
One example is found in the career of Xiao Siye. Xiao was a descendent of the royal Xiao family of the Latter Liang dynasty (555-597). At an early age he went into exile among the Turks to accompany his great-aunt, Empress Yang of the Sui dynasty. He returned to China in 635 and was put in charge of Turkish affairs. He was appointed Chamberlain of the Court of State Ceremonials with a concurrent position as the Aide (zhangshi) of the Protectorate of Chanyu. In 661 he led the Uighurs who had previously submitted to China to participation in the war with Koguryǒ. In 679, when the Turks who had earlier submitted to Tang rebelled, Xiao Siye led troops to suppress them. He failed and was exiled to the deep south.

The position of Chamberlain of the Court of State Ceremonials was often filled by officials like Xiao Siye who had gained expertise through either diplomatic or military contact with the non-Chinese. Around 619, Zheng Yuanshu, who had a military background, was assigned a mission to the Turks to persuade them to break with the anti-Tang forces. He was detained by them for some time, the Turks suspecting him of being involved in an attempt to poison the qaghan. Upon his return to China he was appointed Chamberlain of the Court of State Ceremonials, sent on several difficult peace-preservation missions to the Turks, and nearly died on several occasions. He played an important role in carrying out the Tang appeasement policy towards the Turks. ${ }^{44}$

In 714, Wang Jun, who was Vice Minister of the Court of State Ceremonials and Vice Commander-in-chief of the Shuofang Army, was made concurrently Protector-general of Anbei in command of several frontier armies. ${ }^{45}$ Guo Zhiyun, a capable frontier military official, was rewarded with the position of concurrent Chamberlain of the Court of State Ceremonials in 718 after his battles with the Tibetans. ${ }^{46}$ Wang Zhongsi, whose father was a capable military official, rose to prominence due to his successes in frontier administration and in battles with the Tibetans and the Turks. In 746 he held unprecedented military power as the Military Commissioner of Hexi-Longyou and Shuofang-Hedong, and was appointed Chamberlain of the Court of State Ceremonials. He soon resigned

${ }^{43}$ JTS 63, pp. 2405-6; XTS 101, p. 3952; ZZTJ 200, p. 6323.

${ }^{44}$ JTS 62, pp. 2379-80; XTS 100, p. 3938.

${ }^{45}$ JTS 93, p. 2986; XTS 111, p. 4154; ZZTJ 211, p. 6696.

${ }^{46}$ JTS 103, p. 3190. 
from the post of Commissioner of Shuofang-Hedong, and remained on the frontier defending against the Tibetans. ${ }^{47}$

The title of Chamberlain of the Court of State Ceremonials was sometimes given to non-Chinese who had submitted to China. These nonChinese would be expected to contribute their special knowledge and experience to the conduct of China's foreign relations. A Turkish chief, Ashina Sheer, submitted to Tang in 635 , and then joined several Tang military campaigns. In 645 , following his participation in the war with Koguryǒ, he was given concurrent title as Chamberlain of the Court of State Ceremonials, while his major responsibility still remained military as commander of expeditions against non-Chinese. ${ }^{48}$ After the same war with Koguryǒ a Korean general who had submitted was also given the title of Chamberlain of the Court of State Ceremonials. ${ }^{49}$ In 732, the nephew of the King of Silla was given the title of Supernumerary Vice Minister of the Court of State Ceremonials but remained a member of the imperial guard at the Tang court. ${ }^{50}$ Geshu Han, of non-Chinese origin, was made Chamberlain of the Court of State Ceremonials in 747, due to his military experience in frontier affairs, especially in dealing with the Tibetans. ${ }^{51}$

In addition to the Court of State Ceremonials other offices did work pertaining to foreign affairs. ${ }^{52}$

A. There were four such bureaus under the Department of State Affairs.

1. The Treasury Bureau (jinbu) under the Ministry of Revenue (hubu) was in charge, among other responsibilities, of tribute trade (hushi) and of rewards to foreign guests. ${ }^{53}$

2. The Ministry of Receptions (zhuke bu) in Sui, called the Bureau of Receptions (zhuke si) during Tang, was under the Ministry of Rites. Its job was to take care of the reception of foreign dignitaries at court. ${ }^{54}$ The bureau was a supervisory office ranked above the Court of State Ceremo-

\footnotetext{
47 JTS 103, p. 3199.

48 JTS 109, pp. 3289-90; XTS 110, pp. 4114-5.

49 JTS 199A, p. 5323.

${ }^{50}$ THY 95, p. 1712. From the context it seems that the year should be 734 .

51 JTS 104, p. 3212; XTS 135, p. 4570.

${ }^{52}$ See also Xie Haiping 1978, pp. 314-5.

${ }^{53}$ TLD 3, pp. 48-9; JTS 43, p. 1828; XTS 46, p. 1193.

${ }^{54}$ SUIS 27 , p. 753 ; TLD 4, p. 55 ; p. 57 ; JTS 43 , p. 1832 ; XTS 46, pp. $1195-6$; Hucker 1985, p. 181.
} 
nials. ${ }^{55}$ The office remained as an agency for reception of foreign delegations during the Ming-Qing period under the name of zhuke qingli si. ${ }^{56}$

3. The Bureau of Operations (zhifang si) was under the Ministry of War (bingbu) during both Sui and Tang. It was in charge of frontier defense matters, preservation of maps of foreign states and drawings of foreign peoples. These maps and drawings were made by the Court of State Ceremonials and by this office itself. The Ministry of War, like the Ministry of Rites, was under the Department of the Sate Affairs. ${ }^{57}$

4. The Transit Authorization Bureau (simen) was under the Ministry of Justice (xingbu) and responsible for inspecting the luggage of foreign guests. $^{58}$

B. The Department of Chancellery (menxia sheng) during Tang conveyed greetings to foreign tributaries in accord with imperial orders. ${ }^{59}$

C. The Vice Directors (zhongshu shilang) of the Department of the Secretariat were to receive correspondence and memorials from foreign states and to report them to the throne. They also received gifts and passed them on to the appropriate agencies. ${ }^{60}$ Copies of the correspondence and memorials were to be sent to the Bureau of Historiography. ${ }^{61}$ The Secretarial Receptionists (tongshi sheren) were to introduce personages during court audiences, and to receive tribute and presents to the throne. ${ }^{62}$ The Secretariat had a unit known as the Hostel for Tributary Envoys which had belonged to the Court of State Ceremonials in the Sui period. The Hostel was responsible for the greeting of foreign rulers and envoys and was staffed with Secretarial Receptionists. ${ }^{63}$

D. Under the Palace Domestic Service (neishi sheng), the Palace Treasury (neifu ju) was in charge of the emperor's personal money and

${ }^{55}$ This is according to Yan Gengwang 1969. The traditional view is that the Ministry of Rites, under the Department of State Affairs, and the Court of State Ceremonials ranked parallel to each other and that their duties overlapped.Yan disagrees with this, and argues that the Ministry of Rites' duties were supervisory, and that the Court of State Ceremonials was assigned specific tasks. He demonstrates that after the An Lushan rebellion the responsibilities of various government offices began to blur together.

${ }^{56}$ Rossabi 1975, p. 63; Hucker 1985, p. 181.

${ }^{57}$ TLD 51, pp. 29-30; JTS 43, p. 1836; XTS 46, p. 1198.

58 JTS 43, p. 1839; XTS 46, p. 1201.

${ }^{59}$ TLD 8, p. 10; JTS 43, p. 1843; XTS 47, p. 1205.

${ }^{60}$ TLD 9, p. 13; JTS 43, pp. 1849-50; XTS 47, p. 1211.

${ }^{61}$ THY 63, p. 1089.

${ }^{62}$ TLD 9, pp. 20-1; JTS 43, p. 1850; XTS 47, p. 1212.

${ }^{63}$ Hucker 1985, p. 446. 
goods and was to give imperial gifts to foreign chieftains upon their departure. $^{64}$

E. Placed under the Directorate for Imperial Manufactories (shaofu jian) during Tang, the Directorate of Tributary Trade (hushi jian) supervised trade carried on by tributary delegations. It was under the Hostel for Tributary Envoys during Sui. ${ }^{65}$ From Han times on, border markets had carried on trade with non-Chinese, but under the supervision of local governments rather than the central government. The Sui founded this office and Tang continued it, primarily out of strategic and military rather than economic considerations. Its task was to supervise the cross-border trade in horses and other animals, including examining the animals, making records and transferring them to the capital and other places. ${ }^{66}$

Seaborne trade had also been under the supervision of local governments from Han times onward. As long as the imperial court could obtain exotic goods from overseas through tribute offerings and official purchases, that is, through purchase of goods from foreign maritime merchants by local officials on behalf of the imperial court, it did not seem necessary for the central government to exercise any direct control over maritime trading activities. From 714, the central government appointed a Maritime Trade Commissioner (shibo shi), who was a court envoy, to south China to purchase goods for the court. Overseas trade was, however, still under the supervision of the local government. Normally, the post of commissioner was concurrently held by the prefect of Guangzhou, a major port city. ${ }^{67}$ During the Song dynasty, when overseas trade proved to be so highly profitable to the court that it rivalled other sources of tax revenue, the government set up its own offices in the major sea ports, directly controlling the trade. ${ }^{68}$

\section{Sources of Information on Foreign Countries}

From the Han dynasty onwards the Chinese showed great interest in collecting information on foreign countries. The information was collected from various sources. It formed the basis for the making of foreign policy and it also provided rich basic materials for the compilation of ac-

\footnotetext{
${ }^{64} T L D$ 12, pp. 42-3; JTS 44, p. 1872; XTS 47, p. 1224.

${ }^{65}$ JTS 44, p. 1895; XTS 48, p. 1272; Hucker 1985, p. 259.

${ }^{66}$ TLD 22, pp. 29-30.

${ }^{67}$ Wang Zhenping 1991, pp. 11-38.

${ }^{68}$ Shiba 1983.
} 
counts of foreign peoples in the Standard Histories from the Shiji onwards. The sources of information from the period between Han and Tang include the following: .

\section{Chinese envoys to foreign places.}

Reports from these envoys were the basis for decision-making. In the Former Han period, it was the report from Zhang Qian, the famous Han envoy to the Western Regions, that made Emperor Wu's several great expeditions to Central Asia possible, and aroused the Emperor's interest in opening up a route from Southwest China to India. ${ }^{69}$ His report is incorporated in the chapter on Dayuan (Ferghana? ${ }^{70}$ ) in the Shiji and in the chapter on the Western Regions in the Hanshu. ${ }^{71}$ In 97, Gan Ying, a Han envoy to Parthia, went as as far as the Persian Gulf and brought back information that was later included in the chapter on the Western Regions in the Hou Hanshu. $^{72}$

During the period of the Three Kingdoms, the Sun-Wu regime, with its capital at present Nanjing, took an active interest in the sea routes to the south. Around 227, Zhu Ying and Kang Tai were sent on a diplomatic mission to southeast Asian countries. Kang Tai wrote two traveler's accounts, Wushi Waiguo Zhuan (Account of Foreign Countries of the Wu Period) and Funan Ji (Record of Funan; Funan refers to Cambodia). Zhu Ying wrote Funan Yiwu Zhi (Accounts of Exotic Things of Funan). All three books are lost, but they provided the basic materials for the account of Southeast Asian countries in the Liangshu. ${ }^{73}$ During the Northern Wei, under Emperor Taiwu (r. 424-452), Li Ao was sent as an envoy to Koguryǒ. While in P'yǒngyang, he inquired after the local situation. ${ }^{74}$

Early Sui's strategy to defeat the Turks was designed primarily by Zhangsun Sheng, who went on a mission to escort Princess Qianjin to the

${ }^{69}$ SJ 116, pp. 2995-6.

${ }^{70}$ This is the rather late, traditional, identification of Dayuan based on the Beishi. Pulleyblank 1966, p. 22-6, has proposed to interpret Dayuan as a transcription of *Taxwar, that is, the underlying form of the name of the Tochari, who are referred to in Greek sources as invaders of Bactria and from whom the later name, Tocharestan, for that region was derived. If this is correct, the Dayuan visited by Zhang Qian was not a place but a nomadic people, like the Yuezhi. At the time of Emperor Wu's expeditions against Dayuan in 104 and 102 B.C.E., they seem to have been located in present-day Uzbekistan. This footnote was kindly provided for me by Professor Pulleyblank.

${ }^{71}$ Hulsewé 1979, p. 8.

${ }^{72}$ HHS 88, p. 2910.

${ }^{73}$ Xiang Da 1957, pp. 566-8.

${ }^{74}$ WS 100, p. 2215. 
Turks at the end of Northern Zhou and stayed with the Turks for more than a year, during which time he obtained invaluable first-hand information about the Turks' internal situation. ${ }^{75}$ After his diplomatic mission to Chitu (in modern Malaya) in 608, Chang Jun and others compiled a book Chituguo Ji (Record of Chitu). ${ }^{76}$ Early in Taizong's reign Tang Jian went to the Eastern Turks and upon his return Taizong discussed the situation there with him. ${ }^{77}$ In 641 , Chen Dade, Director of the Bureau of Operations, returned from Koguryǒ. His mission had been to collect information on that country. Through distribution of gifts, Chen was able to find guides to show him around and he acquired information about mountains and rivers there. $^{78}$

Also during Taizong's time, a military officer, Wei Hongji, the great grandfather of the famous historian Wei Shu, went on an embassy to the Western Turks, but was trapped there for three years. Ever loyal to the court, he wrote a book, Xizheng Ji (Record of the Western Expedition), on his own clothes which he tore into pieces to make individual pages. The book was about the various products and customs of the states on the route from Tang to the west. When asked about foreign countries by Taizong on his return, Wei presented the book. Taizong was pleased and rewarded him with a promotion. ${ }^{79}$

The military official Wang Xuance went on three diplomatic missions to India between 643 and 657 and compiled Zhong Tianzhuguo Xingji (Record of Travelling in Middle India). ${ }^{80}$

After the Western Regions were brought under Tang control in the time of Gaozong, the court sent special missions to the Western Regions to collect information on local customs and products and, as a result, the $\mathrm{Bu}-$ reau of Historiography produced the Xiyu Guozhi (Accounts of the States of the Western Regions) with maps and perhaps other illustrations. ${ }^{81}$

$\mathrm{Gu}$ Yin, who went as an assistant to a diplomatic mission to Silla around the middle of the Dali reign (766-778), wrote a book entitled Xin-

\footnotetext{
${ }^{75}$ SUIS 51, pp. 1329-31; ZZTJ 175, pp. 5450-1.

${ }^{76}$ JTS 46, p. 2016; XTS 58, p. 1505.

77 JTS 58, p. 2307.

${ }^{78}$ XTS 220, p. 6187; ZZTJ 196, pp. 6169-70.

${ }^{79}$ JTS 185A, p. 4795; XTS 100, p. 3944.

${ }^{80}$ Cen Zhongmian 1966, pp. 300-3.

${ }^{81}$ XTS 58, p. 1506.
} 
luo Guoji (Record of Silla). This book was referred to by the twelfth century Korean historian Kim Pu-sik when he compiled his Korean history. ${ }^{82}$

Unfortunately, all these books have been lost in the course of time. Nevertheless they must have provided much information that was useful to contemporary Chinese governments in both their diplomatic and military dealings with foreigners and for the compiling of official histories. In 787 when the emperor Dezong asked officials to present opinions on a policy toward Tibet, Cui Huan, who had been to Tibet earlier, reported information on the number of Tibetan troops and horses, which he had obtained while in Tibet by bribing the local servants. ${ }^{83}$ The collection of information continued to be a major mission for Chinese envoys to foreign countries in later times. ${ }^{84}$

2. Chinese frontier officials.

Frontier officials made regular reports and suggestions to the central government or provided their own surveys of foreign countries. Often it was their proposals that eventually became the policy of the court. An example during the Han dynasty is found in Han management of the Western Regions by General Ban Chao, who was in the Western Regions first as Han commissioner then as the Protector-general during 73-102, and by his son Ban Yong, who was there as the Aide of the Western Regions (Xiyu zhangshi) in 123-127. The two played an important role in maitaining Han administration in the area, and their reports were incorported in the Hou Hanshu. The Protector-general of the Western Regions (Xiyu $d u h u$ ) must also have been responsible for collecting the information contained in the chapter on the Western Regions in the Hanshu on distance from China, local population and numbers of troops of different peoples. ${ }^{85}$ It was from Ban Yong's report that the chapter on the Western Regions in the Hou Hanshu drew a large proposrtion of its data. ${ }^{86}$ One can assume that the information was collected not just for the compilation of a history book. It was essential for the central authority to have a clear understanding of the Western Regions in order to design its policy there.

The Sui Emperor Yang sent Wei Jie and Du Xingman to the Western Regions. They went as far as Persia. In his Tongdian Du Yu cites a

${ }^{82}$ XTS 58, p. 1508; 220, p. 6205; Gardiner 1970, p. 15.

${ }^{83}$ JTS 12, p. 356; 196B, p. 5251.

${ }^{84}$ For the examples of Song, see Franke 1983, pp. 137-9; for the examples of Ming, see Rossabi 1975, pp. 15-6.

${ }^{85}$ Biographies of Ban Chao and Yong, HHS 47; Hulsewé 1979, p. 9-11.

${ }^{86}$ HHS 88, p. 2913. 
passage from the book of Wei Jie called Xifan Ji (Record of Western Barbarians). ${ }^{87}$ When Pei Ju served as a Sui official in Zhangye, an important trading center in modern Gansu, he collected information from foreign merchants and compiled a book entitled Xiyu Tuji (Illustrated Record of the Western Regions). It was this book and the suggestions Pei made to the court that helped encourage Emperor Yang's ambition and adventures in the Western Regions. He also wrote another book, Gaoli Fengsu (Customs of Kogury $)$. $^{88}$

During the Tang period, soon after a coup d'état took place in Koguryǒ in 642, Zhang Jian, the Commander-in-chief of Yingzhou, located close to Koguryǒ, reported the event to the Tang court. ${ }^{89}$ After the Tang conquest of the Western Turks, Wang Mingyuan was sent to set up prefectures in Tuhuoluo (Tokharestan, now northern Afghanistan). In 661 he presented to the throne the Xiyu Tuji (Illustrated Account of the Western Regions) and made a proposal for the establishment of area commands, prefectures, districts and garrisons in the area, which the court accepted. His book is not exant. ${ }^{90}$

In Xuanzong's time Gai Jiayun, the Protector-general of Anxi, wrote a book entitled Xiyu Ji or Xiyu Zhi (Record of the Western Regions). Gai was of military background, with a career in the northwestern regions. A passage about the Kirghiz in his lost book is quoted in the Tang Huiyao. ${ }^{91}$ In the famous battle at the Talas River between Tang and the Arabs in $751 \mathrm{Du}$ Huan, a nephew of Du You, was taken captive and did not return to Tang until ten years later. He wrote a book under the title Jingxing Ji (Record of Places Passed Through) about his experience. The book was later lost but some passages were quoted by Du You in his Tongdian. ${ }^{92}$

Jia Dan held various positions such as Chamberlain of the Court of State Ceremonials, Military Commissioner, and Chief Minister in 793-805 under Dezong. He remained interested in geography throughout his career and wrote several geographical works. When foreign envoys arrived or Chinese envoys returned, he would ask them about the topography of the place with which they were associated. One of his books contained a de-

\footnotetext{
${ }^{87}$ SUIS 83, p. 1841; p. 1849; p. 1857; TD 193, p. 1039.

${ }^{88}$ SUIS 67, pp. 1578-81; JTS 46, p. 2016; XTS 58, p. 1506.

${ }^{89}$ ZZTJ 196, p. 6181.

${ }^{90}$ TD 193, p. 1044.

${ }^{91}$ THY 100, p. 1785. Ise 1968, pp. 300-7.

${ }^{92} T D$ 191, p. $1029 ; 192$, p. 1034.
} 
tailed study of the routes between Tang and foreign countries. ${ }^{93}$ Another had the title Tufan Huanghe Lu (Record of Tibet and the Yellow River). ${ }^{94}$ In 843, when the envoys of Kirghiz arrived at the Tang court, the Chinese were not clear who they were since communication with China had been interrupted for sometime and the pronunciation of their name as transcribed in Chinese had changed. It was Jia Dan's work, Siyi Shu (Discussion of the Four Barbarians), that provided the court with clarification. $^{95}$

At least six works on the Nanzhao kingdom were written by local officials and by Chinese envoys to Nanzhao. One of them, Manshu, is still extant. The military commissioner, Wei Gao, wrote a work on the southwestern frontier defense concerning Nanzhao. ${ }^{96}$ When Li Deyu was made Military Commissioner of Xichuan in 830 , he made special efforts through personal interviews and investigations to collect knowledge on the frontier, and compiled a book called Xinan Beibian Lu (Notes on Southwestern Border Defense). ${ }^{97}$ These works became the major sources for the compilation of the "Account of Nanzhao" in the Jiu Tangshu and Xin Tangshu and for Zizhi Tongjian. Some of these lost works are quoted in Sima Guang's kaoyi.

3. Chinese Princesses in the Marriage Alliance System.

From the limited sources we have concerning the roles of these Chinese princesses, we see that they provided useful information to the Chinese court in addition to the other important functions they performed in the marriage alliance system.

During the Former Han dyansty, for example, the Han Princess Jieyou who had married Wusun royality in the Western Regions, and her maid Feng Liao, both played an active role in strengthening Han relations with the Wusun. Through their reports or letters they often kept the court informed of the local situation. ${ }^{98}$ In 615, when the Sui Emperor Yang was on his northern tour, the Turkish Shibi Qaghan planned a sudden attack. The Sui Princess Yicheng, who had married the qaghan, sent a report to

\footnotetext{
93 JTS 138, pp. $3782-7$; XTS 43B, pp. $1146-55$; 58 , p. 1506 ; 166 , pp. 5083-5.

${ }^{94}$ XTS 58, p. 1506.

${ }^{95}$ THY 100, p. 1785; Pulleyblank 1990b, p. 103.

${ }^{96}$ For a study of these works, see Xiang Da 1957, pp. 136-54. For an English translation of the Manshu, see Luce 1961.

${ }^{97}$ Backus 1981, pp. 123-4.

${ }^{98}$ HS96B; Li Hu 1979.
} 
Sui, although it arrived too late. ${ }^{99}$ In 677 the Tibetan btsan-po died but it seems that the Tang court was not informed of this until two years later in 679 when Princess Wencheng, who had married into the Tibetan royal family in 641 , reported the matter through her envoys. ${ }^{100}$ In 717 Princess Jincheng, who had married the Tibetan king in 707, sent a memorial to the Tang emperor Xuanzong explaining the situation in Tibet and the necessity for the two sides to conclude a peace treaty. ${ }^{101}$

4. Foreign merchants and envoys.

As mentioned above, when Pei Ju was in Zhangye, he collected information from foreign merchants about their homelands' customs and geography. This information and his policy suggestions encouraged Emperor Yang's ambitions in the Western Regions.

Information from foreign envoys may not have been directly useful for decision-making, but it was certainly given great importance by the Chinese court. Japanese envoys arrived at the Sui court in 600. Emperor Wen asked the official in charge to inquire after the customs of Japan, and the envoy's detailed answer was incorporated into the Suishu. ${ }^{103}$ Curiosity was surely one motive but acquisition of reliable knowledge of foreign lands for making foreign policy would have been the primary motive.

During the Tang period, continuing a tradition that must have gone back to much earlier times, the various government agencies that dealt with envoys from foreign countries were required to make regular reports to the Bureau of Historiography, as follows:

Appearance at court of tribute-bearing missions from foreign countries: Whenever such a foreign mission arrives, the Court of State Ceremonials should examine them on the natural conditions and customs of their country, on their dress, and the products brought as tribute, and on the distance and route by which they have come. These facts are to be reported together with the names of their leaders.

\footnotetext{
${ }^{99}$ SUIS 4, p. 89; ZZTJ 182, p. 5697.
}

${ }^{100}$ The Chinese sources record the death of the btsan-po as occurring in 679, see JTS 196A, p. 5224; ZZTJ 202, p. 6393; CFYG 979, p. 11498. The Tibetan source records the year as 677 , see Beckwith 1987, p. 43 . The discrepancy might be due to the fact that Princess Wencheng's envoy reached the Chinese court in 679, and the Chinese historians then recorded that as the year when the death of btsan-po occurred.

${ }_{101}^{10}$ XTS 216A, p. 6082.

${ }^{102}$ SUIS 67, pp. 1578-81; JTS 46, p. 2016; XTS 58, p. 1506.

${ }^{103}$ SUIS 81, p. 1826. 
The invasions and submissions of barbarians: The Department of the Secretariat should record and send their memorials and reports [to the Bureau]; the Ministry of War should record and send military reports [to the Bureau]; on the day when armies return, generals should fully record and report [to the Bureau] the cities and fords that have been captured, officials and commoners who have been wounded and killed, and animals and goods that have been plundered. ${ }^{104}$

The Court of State Ceremonials also regularly questioned foreign envoys about their countries and at court audiences the emperor himself would put questions to them. ${ }^{105}$ Although it is not clear how strictly the rules for reporting information were enforced and although after the An Lushan rebellion the collection of material of all kinds by the Bureau of Historiography apparently ceased to function well, ${ }^{106}$ the accounts of foreign countries in the Standard Histories, presumably based partly on such materials, show that the historiographers did receive such reports. Also, we read that in 843 , when Kirghiz envoys arrived at the Tang court, the Court of State Ceremonials interviewed them about the geography and customs of their nation. As a result, a painting of these envoys and an account of the Kirghiz nation were produced. ${ }^{107}$

\section{Buddhist travelers.}

Buddhist travelers' accounts are a rich source of information on foreign countries. The early Tang famous monk Xuanzang left for India around 629 via the Silk Road. Upon his return to the Tang capital over ten years later he was interviewed by Taizong. Greatly impressed, the emperor commissioned him to write an account of his experiences and what he had seen and heard. It can be assumed that the information from Xuanzang helped Taizong in his expansion into the Western Regions, which began in earnest during the 640's. The book entitled Da Tang Xiyu Ji (Record of the Western Regions in the Tang Dynasty) was dictated by Xuanzang to Bianji. The book was completed in 646 and contains invaluable information about Central Asia and India, providing basic materials for the account of the Western Regions in the Xin Tangshu. ${ }^{108}$

\footnotetext{
${ }^{104}$ THY 63, p. 1089. Translation of the first paragraph is based on Twitchett 1992, p. 27. He omits the second paragraph in his translation.

${ }^{105}$ For example, see ZZTJ 202, p. 6368.

106 Twitchett 1992, p. 29.

${ }^{107}$ Drompp 1986, p. 286.

${ }^{108}$ Sato 1958, p. 128; Ch'en, K. 1964, pp. 235-8.
} 
Many Buddhist travelers wrote accounts on foreign countries before Tang. Although they may not have provided direct assistance in the decision-making process on the central level, they contributed to the enrichment of Chinese knowledge of the outside world, and to the compilation of the accounts on foreign countries in the official histories. Faxian and his book on his travels to India are mentioned in Chapter 1. There were other books by Buddhist monks who traveled abroad in the Period of Disunion, such as

1) Shishi Xiyu Ji (Records of the Western Countries by a Buddhist Monk), which probably contained a brief account of the Indus valley, a fuller description of Buddhist holy places in the Ganges valley, and an account of Central Asia, by an unknown monk, probably before Faxian;

2) Waiguo Shi (Matters Concerning the Foreign Kingdoms), a description of kingdoms in North India by Zhi Sengzai, a monk probably from the Yuezhi in the Jin period (265-420);

3) Foguo Ji (Record of the Buddhistic Kingdoms) by Zhu Fawei, who may have lived in the Jin period;

4) Youxing Waiguo Zhuan (An Account of Travels in Foreign Countries) by Shi Zhimeng, who left Chang'an in 404 via the Western Regions to India and arrived back in China in 424;

5) Waiguo Zhuan (Account of Foreign Countries ) by Shi Tanjing or Tanwujie, who left China around 420, traveled for about twenty years from the Western Regions to India and returned to China by sea;

6) Liguo Zhuan (The Account of Countries Passed) by Shi Fasheng, probably from Gaochang in the Song period (420-479).

These books are no longer extant but some were still available in the Tang period and there are quotations from some of them in existing works.

Under the Northern Wei regime, the court sent an envoy, Song Yun, and others, including a monk, Huisheng, to Central Asia to obtain Buddhist sutras. They left China around 518 and returned in 522. Both Song Yun and Huisheng wrote works on their travels. Although they are now lost, there are extensive quotations in the still extant Luoyang Qielan Ji (An Account of Buddhist Monasteries of Luoyang) written in 547. Huisheng's report was used in the compilation of the chapter on the Western Regions in the Weishu and Beishi. ${ }^{110}$ There were other early Buddhist

${ }^{109}$ Petech 1950, pp. 5-6; Xiang Da 1957, pp. 570-7.
${ }^{110}$ WS 102, p. 2279; Chavannes 1903; Luoyang Qielan Ji Jiaozhu, pp. 251-66. 
travelers, of whom Chavannes gives a list in an appendix to his translation of the account of Song Yun's journey. ${ }^{111}$

In addition to Xuanzang, another famous Tang Buddhist traveler was Yijing. He left Canton for India in 671 on board a Persian ship, returned to Canton in 689, and wrote two important historical works in addition to his translations of Buddhist sutras, Nanhai Jigui Neifa Zhuan (A Record of the Buddhist Kingdoms in the Southern Archipelago), and Da Tang Xiyu Qiufa Gaoseng Zhuan (Biographies of Eminent Monks of the Tang Who Sought the Dharma in the Western Regions). ${ }^{112}$ Other surviving accounts of Buddhist pilgrims include a work in Chinese by Huichao, a Korean monk who went to India via sea and returned to China by land in 729, and a work by Wukong who left Chang'an in 751 and returned to China in 790 by land. ${ }^{113}$

6. Miscellaneous works.

Works in this category, like the Buddhist travelers' accounts, may not have direct bearing on the making of foreign policy, but they were important sources for the compilation of official histories. During the Period of Disunion the Chinese interest in geography and in foreign lands produced a large number of books on the subject, as shown in the Monograph on Bibliography in the Suishu. Most of them are not exant but materials from some are scattered in other books, from which one can get a hint of the wide scope of their authors' interests.

The eighteenth century scholar Wang Mo printed a collection of surviving fragments of geographical works of the period from Han to Tang under the title Han-Tang Dili Shuchao (Excerpts of Han-Tang Books on Geography). In his original table of contents he included about 40 titles by envoys or generals on campaign and quoted in accounts of foreign countries, and works on the four "barbarians". Unfortunately none of these works was included in the work as finally printed. ${ }^{114}$

There seems to have been an explosion in books on geography during the Period of Disunion, dealing with both China itself and also with foreign countries. Lu Cheng in the Southern Qi period (479-502) compiled the Dili Shu (The Book of Geography) in 149 chapters based on 160 other works. Ren Fang in the Liang period (502-557) wrote Di Ji (Record of

\footnotetext{
${ }^{111}$ Chavannes 1903, pp. 430-41.

${ }^{112}$ Ch'en, K. 1964 , pp. 238-9.

${ }^{113}$ Chavannes 1969, pp. 141-2.

${ }^{114}$ Han-Tang Dili Shuchao, pp. 19-20.
} 
Land) in 252 chapters, adding more works to Lu Cheng's. Only a fifth of these two works were extant by early Tang. ${ }^{115}$

Interest in exotic things also stimulated the production of books. For example, the monograph on bibliography of the Suishu lists over ten works on exotic things, such as Jiaozhou Yiwu Zhi (Exotic Things of Jiaozhou) by Yang Fu of the Han dynasty, and Nanzhou Yiwu Zhi (Exotic Things of Nanzhou) by Wan Zhen, a local official of the early part of the third century under the Sun-Wu regime. ${ }^{116}$ Prior to Tang several works were written about the southwest, including Yunnan. ${ }^{117}$

In the monographs on bibliography in Sui and Tang official histories, one finds many interesting titles of works concerning non-Chinese. One book entitled Beihuang Junzhang Lu (Record of Chieftains of the Northern Wilderness) was by Li Fan (d. 826), the son of Chief Minister Li Mi under Dezong. ${ }^{118}$ The works recorded in these bibliographies also include the titles mentioned above by Zhu Ying and Kang Tai, and the Buddhist travelers Pei Ju, Jia Dan etc.

In addition to the above-mentioned literary sources, historians used documents of the following kinds in compiling accounts of foreign countries in the Standard Histories.

1. Edicts and orders issued by the Chinese court and letters sent by China to foreign rulers.

2. Biographies of officials involved in foreign affairs and expeditions to foreign countries, and documents contained in their collected works.

3. Correspondence from foreign countries. It is not clear who composed letters sent by foreign rulers to the Chinese court and whether they were originally written in Chinese or were translated into Chinese either at their point of origin or after arrival at the Chinese court. One speculation is that the foreign rulers had them written by Chinese who were living at their courts or by their own people who had learned Chinese. For example, in Taizong's reign, following the marriage of Princess Wencheng to the Tibetan king, Tibet sent young people to Tang to study, and invited Chinese scholars to Tibet to compile official reports to send to the Tang em-

\footnotetext{
${ }^{115}$ Xiang Da 1957 , p. 565.

${ }^{116}$ Xiang Da 1957, pp. 568-70.

${ }^{117}$ Xiang Da 1957, pp. 138-9.

118 JTS 130, p. 3623; XTS 58, p. 1508.
} 
peror on behalf of Tibet. ${ }^{119}$ In 647 , when the Uighurs were brought under the Chinese administrative system, they asked for scholars to compose official letters for them. ${ }^{120}$ Korea and Japan adopted not only the Chinese bureaucratic system but also the Chinese script.

On the other hand, in the Chinese court there were Official Interpreters (yiguan). It is possible that, at least on some occasions, they translated foreign correspondence into proper Chinese both in language and in rhetoric. An example is the letter sent by the Turkish qaghan Qimin to the Sui Emperor Yang in 607. The letter may have been translated from Turkish into Chinese since some sentences bear similarities to the phrases in the Turkish inscriptions. ${ }^{121}$

The question of the proper modes of address for a foreign ruler to use in addressing the Chinese emperor was a vital consideration from the Chinese point of view. ${ }^{122}$ Some letters of foreign rulers demonstrate a strong tendency to insist on equality with China, the most famous example being the letter by the Japanese ruler to Emperor Yang of the Sui period, which began: "The Son of Heaven in the land of the rising sun sends this letter to the Son of Heaven of the land where the sun sets." ${ }^{123}$ Upon reading it, Emperor Yang was displeased and instructed the Chamberlain of the State Ceremonials: "From now on, do not present letters from the Man and Yi (barbarians) which do not have proper etiquette." 124 Letters from Tibet quoted in the Tang histories also contain examples of language that Chinese rulers found unacceptable. Other letters from foreign rulers, however, were written in accordance with Chinese rhetorical forms, the most obvious cases being when the foreign rulers refer to themselves as vassals.

Within the Bureau of Historiography, the works based on the materials collected went through a series of stages of composition. During the Tang dynasty these were the Court Diary ( $q i j u$ zhu), Administrative Record (shizheng ji), Daily Calendar (rili), Veritable Records (shilu) and National History (guoshi), each being a digest of the material produced at the previous stage. ${ }^{125}$ Although these works are largely no longer extant, the last two categories were the principal direct sources for the existing Stan-

\footnotetext{
${ }_{119}^{11}$ JTS 196A, pp. 5221-2; XTS 216A, p. 6074.

${ }^{120}$ ZZTJ 198, p. 6245.

${ }^{121}$ Mori Masao 1967, pp. 441-76.

${ }^{122}$ Kaneko Shūichi 1974; 1988; Wang Zhenping 1994.

${ }^{123}$ Wright 1979, p. 139.

${ }^{124}$ SUIS 81, p. 1827.

${ }^{125}$ Twitchett 1992, p. 33.
} 
dard Histories of Tang, the Jiu Tangshu and the Xin Tangshu, as well as of the Tang section of Zizhi Tongjian.

The Sui-Tang period is noted for its innovations and improvements in the structure of government. Foreign policy was not made in isolation by a separate corps of diplomats lacking meaningful contact with those engaged in domestic policy-making. Indeed, no real distinction was made between domestic and foreign affairs. A larger group of officials than in Han times participated in decision-making for both domestic and foreign policy. Conferences were held regularly between the emperor and his officials and among the Chief Ministers. Responsible officials deliberated on all important decisions and checks and balances were put in place to ensure accuracy and avoid errors. An elaborate communication system linked the center to the most remote offshoots of the empire. Although not part of the central decision-making body, frontier officials often played a very important, sometimes decisive, role in making proposals and contributing their local knowledge and experience to decision-making.

During the Tang period, as in other times, tensions often existed between the emperor and his ministers as a result of their conflicting interests and different points of view. As in other times, the Tang emperors often relied on their inner court of imperial relatives, personal secretaries and eunuchs, to strengthen their power and bypass the bureaucracy. Moreover the composition of the inner court changed over the course of the dynasty, most notably with the growth in the power of the eunuchs after the An Lushan rebellion.

Traditional historians often commented that under the imperial system Confucian officials tended to promote a peaceful policy whereas military men often advocated aggression, but this simple conclusion does not seem to apply to the Sui and Tang period, during which there was much fluidity of movement between civil and military posts and the same persons often acted in both capacities at different stages of their careers.

There was no specific office in the central government for foreign affairs. This did not mean that foreign affairs were not important, but rather that as a would-be universal state the government of China had to integrate foreign with domestic affairs. The need to foster such integration was not peculiar to imperial China. When the issues are crucial enough, even modern states must judge their foreign affairs in term of domestic 
needs and make their domestic policies adjust to the requirements of their foreign involvements. Few governments are fortunate enough to be able to make their foreign policies adjust to their domestic needs.

The government distributed relevant work to various offices that took charge of foreign diplomatic delegations from their arrival at the border to their audience with the emperor and their safe departure from China. The most important office was the honglu si, with its chief officers selected for their background or expertise in dealing with non-Chinese. Border markets for trade with non-Chinese were all under the supervision of local governments rather than the central government. All these offices were supposed to ensure the smooth working of the tribute system, and to exercise a tight control over official contact with foreign countries.

It has often been claimed that the ethnocentric Chinese were not interested in foreign countries but there is abundant evidence, and not just during Sui-Tang times, for the opposite conclusion. In dealing with frontier issues the Chinese simply could not afford to be ill-informed about foreign countries, and from the Han dynasty onwards Chinese governments attached great importance to the collection of information on their neighbors. Large amounts of data were regularly collected from Chinese envoys sent abroad, frontier officials, Chinese princesses in marriage alliances and from foreign envoys to China. During Tang this information was gathered in the Bureau of Historiography. Buddhist travelers and scholars and officials interested in foreign lands also produced a variety of works that enriched Chinese knowledge of the world and broadened the minds of China's ruling elite.

These materials were organized by the bureaucracy into forms easily available to the decision-makers, and they were in fact used in decision-making. Happily for the modern historian, these materials were also the primary sources for the compilation of the accounts of foreign countries in the dynastic histories and encyclopaedias which have come down to us. While persistently maintaining the official rhetoric of sinocentrism and Chinese cultural superiority, the Chinese realistically understood the importance of knowledge of their neighboring peoples and made efforts to increase such knowledge. 


\section{Chapter 3}

\section{The Sui Dynasty: A United Empire Restored and Lost}

In 581 the Regent, Yang Jian, forced the child Emperor Jing of Northern Zhou to abdicate his throne and inaugurated the Sui dynasty, with its capital in Daxingcheng, near Chang'an. Though it began auspiciously by conquering Chen, the last of the Southern Dynasties, in 589 and reuniting the whole of China for the first time since the fall of Western Jin, the Sui dynasty lasted for only two generations. In this chapter we first discuss the generally successful, pragmatic foreign policy of the founding ruler, Emperor Wen, who aimed at consolidating his frontiers, and then the transition under the second ruler, Emperor Yang to an overambitious, aggressive policy aimed at foreign conquest, which led to disaster.

\section{Emperor Wen}

Yang Jian was a native Chinese whose forefathers had served nonChinese regimes for six generations during the Period of Disunion. His wife was from a Xianbei aristocratic family, and his daughter was the empress of the Emperor Xuan of the Northern Zhou. The new Sui Emperor Wen, Yang Jian's posthumous title, soon engaged himself in a whole set of complex tasks to consolidate the dynastic power. The situation was not unfavorable: Northern Zhou had conquered its rival, Northern Qi, just four years earlier, and had thereby unified the whole of north China. Although a usurper of Northern Zhou's throne, Yang Jian had already defeated his major opponents before 581 and had under his control the powerful military machine and the loyal and effective bureaucracy of that semi-nomadic and semi-Chinese regime.

Yet the tasks of consolidation were formidable: from the point of view of geopolitics, three regions of China - Northwest China, the North China Plain, and the Lower Yangtze - were the most important areas for any dynasty of unification to control. ${ }^{1}$ In 581 Sui dynastic power was not yet firmly established in any of these regions: South China was still under

\footnotetext{
${ }^{1}$ Somers 1986, pp. 976-8.
} 

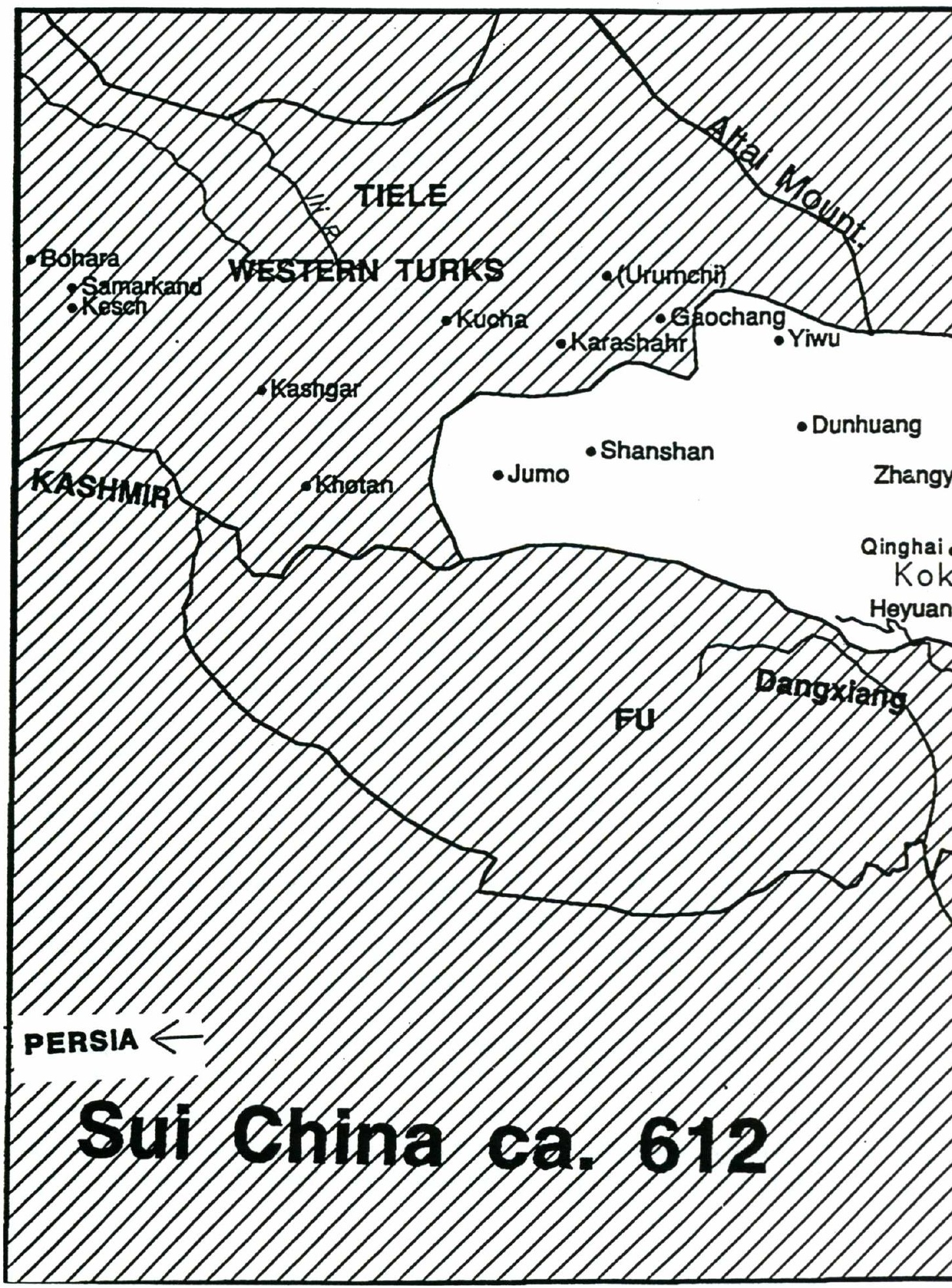


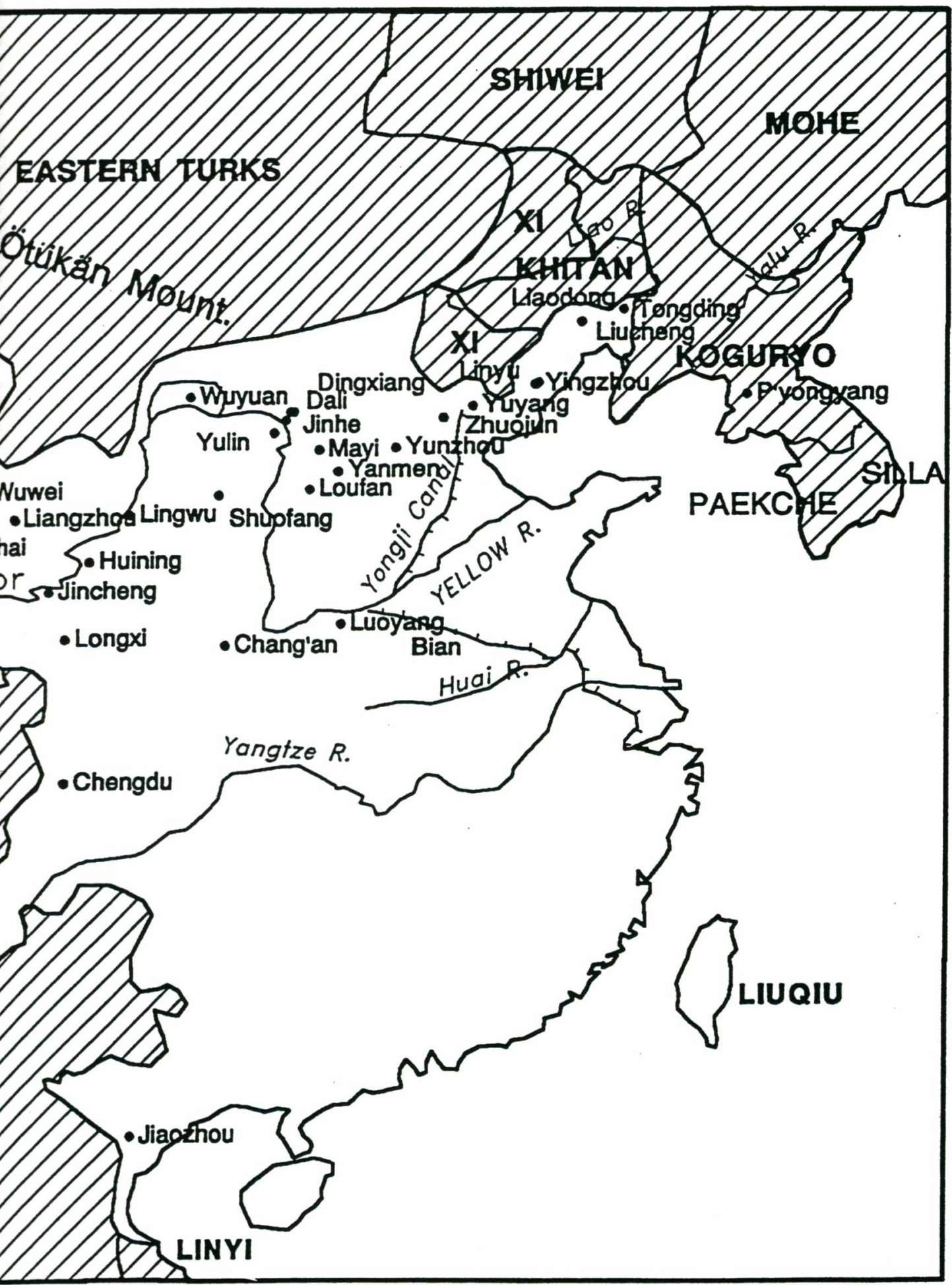


the last of the Southern Dynasties, Chen; Northwest China was menaced by incursions from the nomadic Turks and the Tuyuhun kingdom, and on the borders of the North China Plain there was a potential threat from Koguryǒ, which occupied Liaodong and the northern half of the Korean peninsula. In the realm of foreign affairs the whole of Emperor Wen's reign was devoted to consolidation. Assisted by his advisers, mostly military men of action with a pragmatic assessment of the situation, the Emperor followed a policy aimed at security and defense. One unique adviser was his wife, Empress Dugu. With no official appointment she exercised her influence from the "inner court" on all matters of state policy and her role was so important and lasting that she and the emperor together were referred to as "the two sages."

\section{Military and Frontier Organization}

While retaining the fubing system, inherited from Western Wei and Northern Zhou, Emperor Wen reorganized his military forces so that the central government had stronger control. He restored the Chinese surnames of the generals and reorganized the Sui troops into twelve units, consisting of the palace armies and the fubing, stationed in the capital and in nearby regions. He transformed the fubing into militiamen who were liable for service from the age of twenty-one to sixty (using the Chinese method of reckoning age, which makes a person one year old at birth). Fubing came from both hereditary military families and from ordinary families. They would perform military duties periodically, as guards in the capital or at the frontier posts, and participate in expeditions. When off duty, they engaged in agriculture at home. These militiamen were given land under the equal field system, but were exempt from tax and corvée labor and were expected to provide part of their own equipment. ${ }^{3}$

In reforming local government Emperor Wen reduced the three levels of the local administrative apparatus into two: "prefecture" (zhou) and "county" (xian). To ensure secure and trouble-free frontiers, Sui followed the Northern Zhou practice of establishing "regional military commands" or "area commands" (zongguan fu) in areas of major strategic importance. During the Tang dynasty some of these regional military commands had their own fubing.

The regional military commanders (zongguan) exercised military

\footnotetext{
${ }^{2}$ Wright 1978 , pp. $71-3$; 1979, pp. 63-6.

${ }^{3}$ Gu Jiguang 1962, pp. 98-115; Wright 1979, pp. 100-2.
} 
authority over a cluster of neighboring prefectures. These commanders were ranked military officials, and sometimes were made concurrently civil governors of the prefectures in which they were stationed. They were classified in four grades, as grand regional military commanders, first class, second class, and third class depending on how many prefectures were under their command. By the end of Emperor Wen's reign there were about 36 regional military commands, eight in the north and northwest to defend against the Turks, and seven in the northeast to cope with the Turks and Khitan, a Mongolian speaking people in Manchuria. ${ }^{4}$ One major responsibility of these regional commanders was security in their jurisdiction. The degree of stability directly affected relations with neighboring non-Chinese.

Since the northern frontiers were often subject to nomadic raids, the court would appoint high-ranking officials, some of non-Chinese origin, with superior military ability and good knowledge of frontier affairs to be regional military commanders. For example, Helou Zigan, of Xianbei origin, who served as Yunzhou zongguan, first made his name among the Turks. ${ }^{5}$ Of Du Yan, his successor, it was said in one Chinese source: "When the Turks came to raid, Yan captured and executed them. The northern barbarians were afraid and the barbarian horses did not dare to come to the frontier." " Zhou Yao, of Xianbei origin, was the Youzhou zongguan; he took care to repair the fortifications and kept close watch to safeguard the frontiers. As a result, the frontier people enjoyed peace. Qifu Hui, of Xianbei origin, served as Liangzhou zongguan, guarded the frontiers closely and sent reconnaissance forces so far out that the Turks were awed by his name and stopped raiding. ${ }^{7}$ Wei Chong, experienced in dealing with the non-Chinese, was made Yingzhou zongguan in the northeast. His good treatment of the Khitan and Mohe, a Tungusic tribe in Manchuria, made them willing to fight for Sui; he attracted the $\mathrm{Xi}$, a Tungusic tribe in Manchuria, to come to pay tribute, and led troops to drive away the invading Koreans. ${ }^{8}$ During his career he accumulated knowledge about Korea and left a written work on Korea which was later presented by his

\footnotetext{
${ }^{4} T D$ 32, p. 185; Cen Zhongmian 1957, pp. 7-10; Wright 1979, p. 100.

${ }^{5}$ SUIS 53, p. 1353.

${ }^{6}$ SUIS 55, p. 1372.

${ }^{7}$ SUIS 55, p. 1376 ; p. 1378.

${ }^{8}$ SUIS 47, p. 1270.
} 
son to the Tang emperor Taizong before the campaign against Korea. ${ }^{9}$

\section{Zhangsun Sheng and his Divide and Rule Turkish Strategy}

The nomadic Turkish power, known in history as the First Turkish empire (from mid-sixth century to 630 ), formed the most severe threat to the newly founded Sui dynasty. Emperor Wen had first to deal with the Turks before he could launch any major campaigns into the South to complete China's domestic unification.

Soon after assuming the throne Emperor Wen discontinued the payment of silk products to the Turks, probably because of his belief that a unified north could now risk defying the Turks. The Turkish Shabolue (Ishbara) Shetu Qaghan, felt humiliated. His wife, the Northern Zhou Princess Qianjin, also resented Sui and wanted to use Turkish forces to take revenge for Sui's usurpation of the throne from the Zhou house. In 581 the Turks joined forces with a former Northern Qi officer, Gao Baoning, to attack Linyu Fortress. Gao Baoning had been the Prefect of Yingzhou before Sui and had maintained close contact with the Khitan and Mohe people in Manchuria. In the following year the Turks invaded, penetrating inside the Great Wall. ${ }^{10}$

While Emperor Wen generally followed a defensive strategyimproving fortifications along the Great Wall, and stationing troops along the northern frontiers ${ }^{11}$ - a policy to divide the Turks was also devised. The architect of the policy was Zhangsun Sheng (542-609). Until his death Zhangsun Sheng was Sui's expert on Turkish affairs, and played a crucial role in the formulation and implementation of policies towards the Turks.

Zhangsun Sheng was a native of Luoyang, his family originally being a branch of the Tuoba royal clan of Northern Wei. His daughter was the famous future Empress Zhangsun of the Tang emperor, Taizong, and his son became the highly prestigious minister Zhangsun Wuji under Taizong. As a young man Zhangsun Sheng was not very impressive in literary attainments but was excellent in martial arts, especially archery, making him a typical Northern military man.

In 580, at the end of Northern Zhou, he went on a mission to escort the Zhou Princess Qianjin to the Turks for a marriage alliance. In their fre-

\footnotetext{
${ }^{9}$ JTS 77, p. 2670.

${ }^{10}$ SUIS 84, pp. 1865-6; ZZTJ 175, p. 5450; p. 5456.

${ }^{11}$ Cen Zhongmian 1958, pp. 45-50; for the work on the Great Wall in 581, 582, 586 and 587 , see p. 58.
} 
quent diplomatic exchanges at that time both Zhou and the Turks selected men with good military skills in order to impress the other side. Zhangsun was selected for this mission because of his talent in the martial arts, and because of this talent the Turkish qaghan showed him great favor and invited him to stay over until the next year. Not forgetting the informationgathering side of his mission, he made friends with the qaghan's younger brother, who had had disputes with the qaghan, so that he could obtain invaluable first-hand information about the local geography and the Turks' internal situation. With such information China might be able to exploit the deep internal divisions among the Turks.

After the Turkish invasion of 581 Zhangsun Sheng presented a memorial to the court regarding the Turks. Even now the memorial remains our best source for the complicated internal conflicts within the Turkish empire then. The Turks were not as centralized as the Xiongnu had been. By 581 the Turkish empire had two qaghanates: the Eastern Turks were under Ishbara Qaghan, who had his headquarters in the Ötükän Mountains, and the Western Turks were under Datou (Tardu). In addition, there were other qaghans, nominally subordinate to one or the other of these, but who were disaffected because of disagreements over the succession. Each of them was militarily powerful. On the surface all these chieftains maintained a show of unity, but underneath they were riven by suspicions and ill feelings. The subjects of the Turks who had been conquered and incorporated into their khanates were living under heavy oppression and, being nomads themselves, were quick to rise in revolt when the opportunity presented itself.

Based on his observations, Zhangsun suggested a policy of playing off the Turkish qaghans against one another. In accordance with the balance of power principle of making alliance with the far and attacking the near, and abandoning the strong and joining the weak, his strategy was to make Ishbara the target and to ally Sui with the other qaghans. This, he assured the court, would weaken the Turks and, within ten years or so, China could take advantage of the situation and "empty the country at one stroke." Greatly pleased with the memorial, the emperor summoned him into the court for discussions, during which he analyzed the situation in detail, using maps. Emperor Wen accepted all his suggestions. ${ }^{12}$

Zhangsun Sheng's policy was subsequently put into practice. Sui

${ }^{12}$ SUIS 51, pp. 1329-31; ZZTJ 175, pp. 5449-51. For discussions of the political organizations of the Turks, see Ma Changshou 1957, pp. 23-9; Barfield 1989, pp. 132-6. 
sent envoys to the Western qaghan and Zhangsun himself went to the Xi and Khitan people, who were under the control of the Turks, to persuade them to enter into a friendly relationship with Sui and to guide him to Ishbara's brother. ${ }^{13}$ Soon some results were achieved. In 582, Ishbara launched a major attack on the Sui frontier, but had to abandon his plan for further penetration because the Western qaghan decided to withdraw. ${ }^{14}$

Although Zhangsun Sheng had envisaged a period of ten years before Sui's final strike, the emperor in 583 decided to start a major war against the Eastern Turks, claiming in his edict that the Turkish empire was on the edge of collapse, with all its subjects in the west and northeast rebelling. While the battles went on, Zhangsun Sheng continued to work on the Turkish leaders to stir up further internal conflicts among them. Natural disasters added to the great difficulties that the Turks faced. The junior qaghans under Ishbara went to the Western qaghan for protection. They also sent envoys to the Sui court, suing for peace and requesting Sui military assistance, but Emperor Wen refused their petition. ${ }^{15}$ The hostility between the Eastern and Western qaghans soon came into the open. ${ }^{16}$

Unlike the Han dynasty, which had to wait for the Xiongnu empire to be split by internal struggles before it could take advantage of the situation, the Sui possessed better knowledge of the Turks, and this let them risk taking the initiative so as to drive a wedge into the Turkish ruling groups, and this succeeded in bringing the Turkish problem under control.

\section{The Eastern Turks as Tributaries of Sui}

In 584 the Eastern Qaghan, Ishbara, decided to make peace with Sui, and his wife, Princess Qianjin, asked to change her surname to Yang, the Sui royal family name, as a gesture of submission. This kind of submission, in Barfield's words, was part of the "inner frontier" strategy of the nomads, and aimed at using Chinese support to help them recover their strength. Yang Guang, the future Emperor Yang, proposed that Sui should seize the opportunity to attack the Turks, but Emperor Wen chose to make peace. This cautious decision may have been based on the consideration that Sui had yet to accomplish the unification of China, and needed to use the Eastern Turkish force to deal with the Western Turks.

${ }^{13}$ SUIS 51, p. 1331; ZZTJ 175, p. 5451.

${ }^{14}$ SUIS 51, p. 1331; ZZTJ 175, p. 5459.

${ }^{15}$ SUIS 51, pp. 1329-32; 84, pp. 1867-8; ZZTJ 175, pp. 5463-5.

${ }^{16}$ Ma Changshou 1957, pp. 26-7. 
Ishbara, in his request for a peace settlement in 584, insisted on equal footing with the Chinese, referring to himself as "born from Heaven, the Sage under Heaven, the great Turkish Son of Heaven" in his letter to Sui, and saying: "Our sheep and horses are the emperor's domestic livestock, and your silk products are our property. There is no difference between you and us."17 The Chinese, for their part, addressed Ishbara merely as qaghan, and the envoy managed to demonstrate Chinese superiority by persuading the qaghan to perform the kowtow when he received the sealed letter from Emperor Wen, and to accept the status of vassal of the Chinese emperor. Princess Qianjin was granted the royal Yang surname and was given the title Princess Dayi, interpreted as meaning "sacrifice ties of blood to righteousness." 18

Having accepted Ishbara as an outer subject under the tributary system, Emperor Wen, as suzerain, took on the responsibility for assisting Ishbara politically, economically and militarily. In exchange, he was able to use the Eastern Turks for frontier defense, particularly as a deterrent force against the Western Turks. Then, in 585, when Ishbara was faced with repeated incursions from the Western Turks and from the Khitan, he requested permission to migrate south of the Gobi Desert to the Chinese frontier north of the Yellow River. The emperor permitted this, and sent troops to assist him. Ishbara, now strengthened, launched a successful attack against his rivals. When his people were attacked by the Aba (Apar) tribe, Sui sent troops in upon Ishbara's request and inflicted a defeat upon the Apar. ${ }^{19}$

After this victory Ishbara presented a letter acknowledging himself as a Sui vassal and offering to send hostages and annual tribute to the Sui court. Still, he expressed the wish to maintain his own culture, that is, not to change the Turkish dress, hairstyle and language. Greatly pleased, Emperor Wen, in his edict, claimed that China and the Turks were no longer two countries merely bound by a peace agreement, but that the relationship was now one of unity between a ruler and subject. He ordered that the news be spread widely throughout the country and that a ceremony be held at the ancestral temple to announce the Turkish submission. ${ }^{20}$ In their relations with the Eastern Turks thereafter, the Chinese followed the cere-

\footnotetext{
${ }^{17}$ SUIS 84, p. 1868 ; ZZTJ 176 , pp. 5475-6.

${ }^{18}$ SUIS 51, p. $1332 ; 84$, pp. 1868-9; ZZTJ 176, pp. 5475-6.

${ }^{19}$ SUIS 54, 1368; 84, p. 1869; ZZTJ 176, p. 5482.

${ }^{20}$ SUIS 84, pp. 1869-70; ZZTJ, 176, p. 5483.
} 
monial practices of the tribute system. In 586 the Sui calendar was introduced to the Turks ${ }^{21}$ as a symbol of their acceptance of Chinese rule. The following year, the Chinese agreed to Ishbara's request to hunt inside the Sui frontier. ${ }^{22}$

Even after Ishbara's death in 587, the Eastern Turks continued to act as a force against the Western Turks, which was exactly what the Chinese had hoped for. In 587 the new qaghan, Chuluohou, fought victoriously under the Sui banner against Abo (Apa), a former Eastern junior qaghan now with the Western Turks. After capturing Apa, Chuluohou requested the Sui court to decide on his treatment. Some ministers proposed that he be executed. However, Zhangsun Sheng and Gao Jiong, another major adviser to Emperor Wen, opposed this high-handed attitude. They suggested that Sui spare Apa's life. Emperor Wen agreed, hoping thereby to "cause the people from far away to come."23

Chuluohou died during his western campaign in 588, and was succeeded by Dulan Qaghan, who kept up a close tributary relationship with Sui, and took Princess Dayi as his wife. Border markets were set up at the Turks' request. ${ }^{24}$ With the northern frontiers under control, the Sui switched forces to the south and succeeded in conquering the Chen regime in 589, thus completing the unification of China.

\section{Dividing the Eastern Turks and Attacking the Western Turks}

Tributary relations between Sui and the Eastern Turks entered a rocky period in 593 when a Chinese called Yang Qin fled to the Turks and told them the false story that Liu Chang, with his wife who was a Zhou princess, was planning to rebel against Sui power. He asked Princess Dayi to assist by sending troops to attack the Sui borders. Dulan Qaghan, believing this, stopped sending tribute and began making forays across the border. Zhangsun Sheng went to. the Turks twice and finally was able to seize Yang Qin. ${ }^{25}$

The court now planned to get rid of Princess Dayi, in part also be-

${ }^{21}$ SUIS 1, p. 23; ZZTJ 176, p. 5485.

22 SUIS 84, p. 1870.

${ }^{23}$ SUIS 51, p. $1332 ; 84$, pp. 1870-1; ZZTJ 176, pp. 5489-91.

${ }^{24}$ SUIS 84 , p. 1871 ; BS 99, pp. 3295-6.

${ }^{25}$ This is according to the record in SUIS 51, pp. 1332-3; ZZTJ 178, pp. 5542-3. SUIS 84 and $B S 99$ have a different account. They say that Yang Qin went to the Turks before Sui's 589 conquest of Chen, and that Dulan Qaghan caught Yang Qin and informed Sui of the incident. 
cause she had attempted to make an alliance with the Western Turks. This made Emperor Wen suspect her political intentions. ${ }^{26}$ Ever since the beginning of the Sui period the Princess had actively involved herself in politics, at first remaining loyal to her family, the Zhou ruling house. After the Sui conquest of Chen she wrote a poem lamenting her sorrow as a princess of an eliminated dynasty. Her attitude eventually cost her her life. A woman participating in an international marriage alliance had the difficult task of reconciling her several tasks as diplomat, hostage, intermediary and informant. Such a woman was constantly in danger, and her life could easily be sacrificed when the two countries to which she was linked turned into enemies.

The opportunity to dispose of Dayi arose in 593 when the Turkish Rangan Qaghan (personal name Zamqan, called Tölish Qaghan) asked for marriage with a Sui princess. He was Chuluohou's son, ${ }^{27}$ and a potential rival to Dulan Qaghan. Taking advantage of this request, Sui asked him to persuade Dulan to kill Princess Dayi, which he did. Dulan then himself requested the hand of a Sui princess in marriage.

When court discussion favored giving permission to Dulan, Zhangsun Sheng objected on the grounds that Dulan's submission to Sui was simply because of his ill feelings toward the Western Turks, that a Sui marriage with Dulan would strengthen his position vis-à-vis other Turkish rulers and that Dulan would eventually rebel against Sui. Instead, Zhangsun Sheng favored granting Zamqan's request for a marriage alliance since Zamqan did not possess a strong force and would, therefore, be easy to deal with. Moreover, Sui could entice him to move down to the south, and use him for defense against Dulan Qaghan. Emperor Wen agreed. ${ }^{28}$

With Zhangsun Sheng's plan carried out, a close relationship was established between Sui and Zamqan. Following the marriage between Zamqan and Princess Anyi in 597, Emperor Wen deliberately granted favorable treatment to Zamqan with the intention of further stirring up hostilities between him and Dulan. Zamqan and his people moved south to the old headquarters of the Turks in the Ötükän mountains. Now, although Dulan suspended tributary relations with Sui, Zamqan Qaghan formally became a Sui vassal. The Chinese were quick to use his people as a ready

${ }^{26}$ SUIS 84, pp. 1871-2; BS 99, p. 3296.

${ }^{27}$ SUIS 51, p. 1333; ZZTJ 178, p. 5543. SUIS 84 (p. 1872) says that Rangan was the son of Shetu. This is probably wrong, see Cen Zhongmian 1958, p. 512.

${ }^{28}$ SUIS 51, p. 1333; 84, p. 1872; ZZTJ 178, pp. 5542-3. 
force to watch over the frontiers and guard against any incursion by Dulan. $^{29}$

In 599 when Dulan Qaghan was making ready to invade China, Zamqan reported this to the Chinese, who readied a campaign against Dulan. Hearing this, Dulan allied himself with the Western Turks to attack Zamqan. When Zamqan suffered defeat at the hands of Dulan, he considered taking refuge with the Western Turks, but Zhangsun Sheng succeeded in persuading him to go to Sui. Greatly pleased, Emperor Wen conferred on Zhangsun Sheng the title of general commissioned with special power to protect the Turks. ${ }^{30}$

Emperor Wen then conferred on Zamqan the title of Yili zhendou Qimin Qaghan (hereafter Zamqan is referred to as Qimin) and built the town of Dali for his branch of the Turks in Shuozhou. After Princess Anyi died, Princess Yicheng was sent to wed Qimin, ${ }^{31}$ and 20,000 Chinese troops were stationed to help Qimin Qaghan guard against the Western Turks. $^{32}$ Zhangsun Sheng proposed that the Turks under Qimin should be resettled in Wuyuan with the Yellow River to the north serving as a natural line of defense against the incursions of Dulan Qaghan. The area was turned over to Qimin and his people for pasture. ${ }^{33}$ In 602 walled towns were built in Jinhe and Dingxiang northeast of the Ordos for the Eastern Turks, ${ }^{34}$ and it appears that Qimin moved to this area. ${ }^{35}$

It may seem strange that a Chinese government would build towns for the nomadic Turks. In fact Sui was just following the practice of Northern Wei which built the walled towns known as the Six Garrisons on its frontiers to settle the nomads. Northern Qi and Northern Zhou both also built garrison towns. ${ }^{36}$ The walled towns Sui built for Qimin and his people were intended to function as garrisons under the supervision of Chinese officials leading their own military forces.

The Eastern Turks under Qimin Qaghan assisted Sui in achieving victories over other Turkish powers. In 600 , when Dulan was killed by his

\footnotetext{
${ }^{29}$ SUIS 51, p. $1333 ; 84$, p. $1872 ;$ ZZTJ 178 , p. 5558.

${ }^{30}$ SUIS 51, pp. 1333-4; ZZTJ 178, pp. 5563-4.

${ }^{31}$ SUIS 51, p. 1334; 84, pp. 1872-3; ZZTJ 178, pp. 5568-9.

32 SUIS 74, p. 1697; ZZTJ 178, p. 5569.

${ }^{33}$ SUIS 51, p. $1334 ; 84$, p. 1873 ; ZZTJ 178 , p. 5569.

${ }^{34}$ ZZTJ (179, p. 5572) gives the year as 600 . I follow Cen Zhongmian's opinion that the building of towns was begun in 602 , see his 1958 , pp. $83-4 ; 1964$, p. 12.

${ }^{35}$ Cen Zhongmian 1958, pp. 83-4.

${ }^{36} \mathrm{Gu}$ Jiguang 1962, pp. 58-61.
} 
own men and a time of civil strife ensued among his people, Qimin's men were despatched to entice those Turks to Sui, and many more Turks submitted to Sui. In the following years, at the suggestion of Zhangsun Sheng, Sui launched major attacks on the Western Turks in alliance with Qimin Qaghan and his force. After the Western Turks suffered a severe defeat Zhangsun Sheng advised Qimin to despatch his envoys to the Tiele and other Turkish-speaking tribes who had been under the rule of the Western Turks in order to try to win them over. The envoys were successful and soon the Tiele and more than ten other tribes rebelled and came over to Sui. As a result, Tardu's rule over the Western Turks suffered a major defeat in 603 and he fled to the Tuyuhun in present Qinghai. With the submitted nomads brought under his sway, Qimin's power increased, but until his death in 609 he remained a Sui ally. ${ }^{37}$

\section{The Non-interventionist Policy Towards the Tuyuhun Kingdom}

A buffer state between China and the Western Turks, the Tuyuhun kingdom was not a serious threat during early Sui. After 576 the Tuyuhun suffered internal political instability, which undoubtedly weakened its bargaining position in dealing with China. In 581, when the Tuyuhun qaghan Lükua (or Kualü) raided the frontier, Sui launched a successful military expedition against him, after which the qaghan fled, but thirteen noble princes came to submit. Emperor Wen appointed one of them the Prince of Henan, entrusting him with command of the Tuyuhun who had submitted. Lükua attacked the Sui frontier again in 583. Sui responded with force, which further weakened the qaghan's power.

From then on Emperor Wen followed a policy of non-intervention, avoiding Chinese involvement in the affairs of the Tuyuhun. Unable to deal with Lükua's tyranny, the Crown Prince of the Tuyuhun plotted against his father and applied through the Chinese frontier authorities for assistance, but Emperor Wen refused. When the plot was discovered and the prince was put to death, a Chinese frontier official proposed to intervene but the emperor again refused. In 586, in fear of being killed by his father, the new Crown Prince planned to take fifteen thousand households to submit to Sui. Declining the request, Emperor Wen made a long speech on filial piety to the envoy of the Prince. ${ }^{38}$

Although we know that Emperor Wen held filial piety in high es-

${ }^{37}$ SUIS 51, pp. $1334-5$; 84, pp. 1873-4; ZZTJ 179, pp. 5571-2; p. 5590; p. 5600.

${ }^{38}$ SUIS 83, pp. 1842-4; Molè 1970, his translation of SUIS 83. 
teem and that his favorite handbook of public and private morality was the Classic of Filial Piety, ${ }^{39}$ the Tuyuhun prince's disloyalty to his father does not seem to have been the primary reason for the refusal; it seems that the emperor was aware of the chaotic situation among the Tuyuhun and therefore did not regard them as a threat. In 588 another Tuyuhun noble prince proposed to submit with a thousand households, including that of the qaghan's sister. Emperor Wen ordered that no military protection should be provided them on their way; China should just pacify them when they arrived, but not entice them to submit.

With the death of the Tuyuhun qaghan Lükua in 591, their relations with Sui took a turn for the better. The new king, Fu, decided to abandon his father's hostile attitude and sent a mission to Sui, following the generally expected procedure to declare himself a subject and offer local products and women for the Sui harem. Emperor Wen refused the women with the remark: "This is not completely sincere; the strategy is just an expedient plan." ${ }^{, 40}$ Nevertheless he sent a diplomatic mission in 592 to reciprocate for the Tuyuhuns' visit and four years later formed a marriage alliance by sending Princess Guanghua to $\mathrm{Fu}$. Fu died the next year. His brother Fuyun succeeded him and, following the old practice of the levirate, married Princess Guanghua. Tribute-bearing missions were sent regularly, but their purpose was not so much to demonstrate subordination as to inquire about conditions in China. ${ }^{41}$

\section{A War of Deterrence Against Koguryǒ}

Having achieved relative security on the northwestern and northern frontiers and having conquered the South, Emperor Wen looked to the northeast, to the threat of the Korean kingdom of Koguryǒ.

In the eyes of the Sui Chinese, Koguryǒ was potentially the most threatening among the three Korean states. It occupied the Liaodong region, which had formerly been under Chinese control. In early Sui, the major powers with an interest in Manchuria besides China were the Turkish empire and Koguryǒ. It was a sensitive issue which of the three could command the allegiance of other less well organized tribes, the Mongolian

\footnotetext{
${ }^{39}$ Wright 1978 , p. 65.

${ }^{40}$ SUIS 83, p. 1844. I do not agree with Molè's translation of this passage in SUIS 83 which mistakenly states that Fu requested Chinese women for his own harem and that Emperor Wen saw this strategy as "hasty" rather than expedient. See Molè 1970, p. 43.

${ }^{41}$ SUIS 83, p. 1844.
} 
speaking Khitan and Shiwei and the Tungusic tribes of Mohe and Xi, which had formerly been controlled by either the Turks or Koguryǒ. The Chinese also feared Koguryǒ's influence in the Hebei region where separatist sentiments had surfaced from the time of Northern Qi ${ }^{42}$ Campaigns into the border regions of the Northeast were thus a necessary step for the extension of imperial rule in North China and as an important coercive measure for the full consolidation of dynastic power. ${ }^{43}$

Relations between the newly established Sui dynasty and Koguryǒ began peacefully. Soon after Emperor Wen came to the throne in 581, Koguryǒ sent a tributary mission to the court and King P'yǒngwǒn was appointed Commandery Duke of Liaodong (Liaodong jun gong) and General-in-chief. ${ }^{44} \mathrm{He}$ dispatched seven tributary missions to Sui during the four years from 581 to $584 .^{45}$ But Koguryǒ turned hostile to Sui when the Eastern Turks accepted a tributary relationship with Sui and the Mohe and Khitan people sent envoys to China. Part of the Khitan who had submitted to Koguryǒ now left to seek support from the Sui court. ${ }^{46}$ Koguryǒ sent a tributary mission to the Southern dynasty in $585,{ }^{47}$ and stopped its missions to Sui between 585 and 590. After the Sui conquest of Chen in 589, fearing a Sui invasion, it started preparations for war.

Other "offensive" activities engaged in by Koguryǒ listed in an edict of 597 by Emperor Wen include the following: 1) harassing the Mohe and preventing the Khitan from communicating with Sui, 2) smuggling precious goods to bribe Chinese crossbowmen so as to induce them to assist in secret military preparations, 3) isolating Sui envoys and prohibiting them from learning the true situation in Koguryǒ, 4) sending cavalrymen to attack and kill people on the Sui borders, and 5) despatching envoys as spies to gain information about Sui.

To what extent these accusations were true is difficult to decide, but from the Sui point of view Koguryǒ posed a threat. The edict accused

\footnotetext{
${ }^{42}$ Wright 1979 , pp. 143-4.

${ }^{43}$ Somers 1986, pp. 981-2. Tang to confer on him the title of king. See below.

${ }^{45}$ For the tribute missions from Korea, see Table 2.

${ }^{46}$ SUIS 84, p. 1881.

${ }^{47}$ CS 6, p. 112.
}

${ }^{44}$ SUIS 1, p. 16; CFYG 963, p. 11336. SUIS 81 (p. 1814) says that the title of King of Koguryǒ was conferred on him, see also BS 94, p. 3115 . The title of king might not have been given at this time, for after his death his son inherited all his titles and requested 
of King P×yǒngwǒn of being insincere in submission to the Chinese emperor, and after reiterating the claim that all under heaven were subjects of the Chinese Son of Heaven, the edict ordered Koguryǒ to reform its conduct. It warned of a "punitive" attack. The warning seems to have had some effect because the King P'yǒngwǒn was preparing to send, in Chinese wording, "an acknowledgement of guilt," but he died before he could carry out his intention. His son succeeded to the throne as King Yongyang. Emperor Wen sent an embassy to give him official titles. Upon his request Sui conferred on him the title of king. ${ }^{48}$

In 598 King Yorngyang led the Mohe in raids on Liaoxi. ${ }^{49}$ These became the direct catalyst for Emperor Wen's decision to launch a military expedition, which he justified in terms of Chinese suzerainty over Koguryǒ. Only Gao Jiong, a major adviser to the emperor, raised objection to the decision to go to war. Despite that he was appointed de facto commander of the campaign, with the Prince of Han in nominal charge. ${ }^{50}$ Thirty thousand troops were despatched, some by land and some by sea, and an edict was issued to deprive King Yǒngyang of his titles. Before they reached the Liao River, however, the Chinese were already suffering logistical difficulties and were being devastated by a serious plague. Much of the navy was lost in violent storms.

The expedition cannot, however, be seen as a total defeat; the Korean troops were not strong enough to continue resistance, and King Yǒngyang sent an embassy offering "acknowledgement of guilt." $\mathrm{He}$ is recorded by the Chinese historian as having referred to himself as "your subject in Liaodong who is but excrement."

Emperor Wen was more than happy to withdraw the Chinese troops. ${ }^{51}$ When Paekche offered assistance in the Sui campaign against Koguryǒ, Emperor Wen did not seem interested in an alliance, since the

${ }^{48}$ SUIS 81 , pp. 1815-6; BS 94, pp. 3116-7; ZZTJ 178, pp. 5559-60.

There are discrepancies concerning the dates of the edict and of King P'yǒngwǒn's death. Some sources record that the king died in 590 without mentioning the edict, see SUIS 1, p. 35; BS 11, p. 416. SGSG records that the edict was issued in 590 and the king died in the same year, see $S G S G 19$, pp. 7-8. CFYG has a different account. While volume 963 (p. 11336) states that the king died in 590, volume 996 (p. 11695) states that in 597 Emperor Wen issued the edict to Gao Tang, the King.

${ }^{49}$ SUIS 81, p. 1816.

${ }^{50}$ SUIS 41, p. 1182; ZZTJ 178, p. 5566.

${ }^{51}$ SUIS 2, p. 43 ; 65 , p. 1525 ; 81, p. 1816 ; ZZTJ 178 , p. 5560 ; pp. 5561-2. 
crisis was over. ${ }^{52}$ For Emperor Wen the immediate objective of the war was to deter Koguryǒ from making incursions across the borders. The emperor appears to have made a realistic assessment of the situation. Although he talked about asserting China's claim to superiority, he understood clearly that he was not able to extend Chinese power into Korea.

The other two Korean kingdoms, Paekche and Silla, were not of much importance to Emperor Wen. They were only accessible by sea from the Chinese mainland. To maintain its own power against the expansion of the other two states, Silla kept a friendly relationship with China. This emerged as Silla's long-term strategy, through which it eventually founded the first unified Korean state in the mid-seventh century. During the Sui period, Paekche sometimes allied itself with Koguryǒ and had frequent contact with Japan. It also sent tributary missions to Chen in 584 and $586,{ }^{53}$ but this did not seem to bother Sui at all. In 589 when Paekche offered Sui congratulations on the conquest of Chen, Emperor Wen declined a frequent tributary relationship with this Korean state. ${ }^{54}$

\section{Advance on the Southern Frontier}

The conquest of Chen was accompanied by submission of the aboriginal tribes in the far south and southwest. Knowing that Chen was crushed, the southern tribal chiefs hastened to make their submission. ${ }^{55}$ Sui established prefectures under Chinese officials but kept the tribal groups under their chiefs. In the following years $(590,597$ and 601) several rebellions by aboriginal tribes in Lingnan and the southwest were suppressed either by military force or peaceful means.

In 602 the Chinese sources record that a native people in Jiaozhou made troubles, whereupon Emperor Wen appointed a capable general, Liu Fang, to lead a military expedition. Jiaozhou, the modern HanoiHaiphong, had from Han times been an important seaport for communication with Southeast Asia. During the Han dynasty the Chinese had administered the region, but in the sixth century, when the southern Chinese dynasties were too weak to maintain control, a local satrap of mixed Vietnamese-Chinese stock set up his own dynasty. Liu Fang's campaign successfully destroyed his rule and established Sui administration there, but

\footnotetext{
52 SUI 81, p. 1819; ZZTJ 178, p. 5562.

${ }^{53}$ CS 6, p. 111; p. 113.

${ }^{54}$ SUIS 81, p. 1819.

${ }^{55}$ Wright 1979, p. 111.
} 
the Chinese did not want to stop with this. A widely held opinion at the court was that the emperor should push further south to Linyi, the Kingdom of Champa, in the southern part of present Vietnam, for the land there was known among the Chinese to be rich in "unusual treasures." Emperor Wen consented. ${ }^{56}$ After all there was not much risk involved and there was a possibility of much gain.

\section{Emperor Yang}

In 604 Emperor Wen died, and his second son, Guang, succeeded to the throne. He is known to history as Emperor Yang. With their Confucian criteria and in the usual style of praise and blame, traditional Chinese historians portrayed the two Sui emperors as almost complete opposites: the first emperor being serious, hardworking and prudent in governing, a successful founder and good ruler; the second being licentious, irresponsible in performance of his duties and profligate, a tyrant, a bad last ruler, whose extravagance in huge projects internally and obsession with conquest externally ruined the dynasty. ${ }^{57}$

In challenging the traditional view Arthur Wright in several works points out that the image of Emperor Yang was severely distorted by the biases and stereotypes of the Confucian tradition and by the Tang historians who, in compiling the Sui History, tried to denounce Emperor Yang so as to justify the Tang victory over Sui. In Wright's view, Emperor Yang, though a supremely egotistical monarch, was a poet with a romantic mind and a ruler with political and economic vision as demonstrated in the building of the transport canal linking North and South China. ${ }^{58}$

Although Wright does present two very different images of the two emperors, when discussing foreign policy he concludes: "There was, in fact, no sharp break in the foreign policy of the two Sui emperors. In both emperors' reigns there were two kinds of operations beyond the borders: those started out of a desire for loot or out of personal curiosity, and those aimed at assuring the geopolitical dominance of the new empire in Eastern Asia." He concludes that the first kind was unacceptable by Confucian historians and they criticized Emperor Yang for that, whereas the second "was justified in terms of the old tradition of a central political and cultural

\footnotetext{
${ }^{56}$ SUIS 82, pp. 1831-33; Wright 1979, p. 109.

${ }^{57}$ See SUIS (2, pp. 54-5; 4, pp. 94-6) for the historians' judgment on the characteristics and government of the two emperors; see also Wright 1978, p. 163.

${ }^{58}$ Wright 1960, 1978, 1979.
} 
order whose superiority in all realms excused not only its defense but the conquest of lesser peoples." 59

This conclusion, however, is oversimplified. It is true that Confucian historians did not reject totally the use of military force in frontier affairs for the achievement of peace for All-under-Heaven, but they did draw a line between the Chinese inner group, and the non-Chinese outer group, and between defense-military campaigns to drive away or defeat frontier enemies - and expansion-establishment of Chinese rule over the land inhabited by non-Chinese. They held that any military campaigns which increased taxes and burdens on the people should be restrained.

As we have seen, Emperor Wen was primarily interested in securing his frontiers and took a cautious approach to any initiative that appeared dangerous. The only military campaign which was carried out for economic gains and political ambition was the invasion of Champa, but Champa was so far away from the Sui capital that Emperor Wen may have thought that there was not much risk involved. Since the Chinese troops were already in Jiaozhou, just one step further was needed and Champa could be taken without too much additional cost.

In the history of Chinese dynasties it generally took at least two generations to reach a fully stable and politically integrated regime, ${ }^{60}$ and as a second ruler Emperor Yang assumed the immediate task left by Emperor Wen to complete the consolidation of dynastic power. In internal affairs he continued public works, reinforcing the Great Wall, rebuilding Luoyang as his Eastern Capital, and constructing transport canals. Even before the conquest of the south, Emperor Wen had restored a Han dynasty waterway between Chang'an and the bend of the Yellow River at Tongguan, and taken other steps to facilitate the transport of grain from the east into the capital region within the passes.

Emperor Yang embarked on a more ambitious plan to create a water route, the Bian Canal, linking the Eastern Capital to the Yangtze Valley, partly for his own comfort and pleasure in traveling to Yangzhou, where he planned to build a third southern capital, Jiangdu, but more importantly for the transport of grain from south to north. Though he was later much criticized for the hardships which this enterprise imposed on the male and female laborers who were conscripted to build the canal, the Bian Canal played a vital role in supplying the central government in

\footnotetext{
${ }^{59}$ Wright 1978 , p. $182 ; 1979$, p. 138.

${ }^{60}$ Somers 1978, p. 199.
} 
North China throughout Tang and Northern Song and must be recognized as a lasting achievement of the second Sui ruler. ${ }^{61}$

Another major canal project was the building of the Yongji Canal linking the Yellow River with Zhuojun in the vicinity of present Beijing. This was undertaken, as we shall see, in preparation for the first military campaign against Koguryǒ. ${ }^{62}$

In his reform of the military organization, Emperor Yang abolished the regional military commands and brought all the units formerly under them into the direct control of the twelve guards and commands in the capital. $^{63}$

Under the pretext of defense, Emperor Yang embarked on a course of expansion. He engaged China in foreign adventures not just for the sake of securing his frontiers and controlling hostile external forces but also because he let himself be lured on by the desire to obtain wider knowledge of the world and riches in foreign lands, to restore the glories of the Han empire and to dedicate himself to the imperial purpose of establishing an all-embracing rule as the Son of Heaven. His foreign policy objectives were, therefore, much more complex than those of his father and led to expansion beyond the limits of China's strength, and this led directly to the collapse of the dynasty.

\section{Keeping the Eastern Turks as Sui Tributaries}

When Emperor Yang succeeded his father, he inherited not only a relative stable political situation and a prosperous economy in China but also had the Eastern Turks under Qimin as a military force at his disposal as a counter to the much weakened Western Turks. In 605 the Khitan raided Yingzhou in the northeast. Sui used twenty thousand Eastern Turkish cavalry troops against them in a successful campaign. ${ }^{64}$ When the Eastern Turk Qimin Qaghan made repeated requests to be allowed to adopt Chinese dress and hair style, even though his ministers suggested granting permission since it would be tantamount to a proof of successful sinicization, Emperor Yang refused. In his letter to Qimin he explained to the qaghan that since the north of the Gobi Desert had not yet been made tranquil, expeditionary forces still had to be sent from time to time to quell

\footnotetext{
${ }^{61}$ Bingham 1941, pp. 15-18, citing Chi Ch'ao-ting 1936.

${ }^{62}$ SUIS 68, p. 1595; Wright 1979, pp. 134-8.

${ }^{63}$ TD 32, p. 185, Wright 1979, p. 102.

${ }^{64}$ JTS 75, pp. 2631-2; ZZTJ 180, pp. 5621-2.
} 
disturbances, and that as long as Qimin was sincere and obedient, it was unnecessary to change dress. To retain the good will of the Turks, Emperor Yang continued to grant Qimin the favor under the tribute system of not using his personal name when addressing him as a subject, and of giving him a rank above that of the Chinese princes. Emperor Yang also ordered the building of houses and a walled town for Qimin at Wanshou Fort, between Jinhe and Dingxiang. ${ }^{65}$

The balance of power between the Sui Chinese and the Eastern Turks changed gradually in favor of the latter during Qimin's later years. Some Chinese ministers began to express their worry. Gao Jiong was concerned that the emperor gave too much favor to the Turks, and feared that Qimin, now with inside knowledge about China, might cause trouble in the future. Gao lost the imperial trust toward the end of Emperor Wen's reign. Emperor Yang employed him but he did not have much influence. When he expressed his concern to another minister over the Turkish issue and over other court decisions, he was reported to be slandering the emperor and was executed together with two others in $607 .^{66}$

Around 608 Duan Wenzhen, Minister of War, pointed out in a memorial that it was not advisable for Sui to accept Qimin as a subject, provide him with economic and military aid, and place the Turks inside the Great Wall. He suggested that Sui should move the Turks beyond the Great Wall, and establish frontier garrisons so as to prevent a dangerous situation from developing. But the emperor was not persuaded. ${ }^{67}$ In 609 Qimin Qaghan died and was succeeded by his son Shibi Qaghan. In accordance with Turkish practice, Emperor Yang permitted him to marry Princess Yicheng who had formerly been married to Qimin. ${ }^{68}$ Relations with Shibi were peaceful until 614 .

\section{Southern Expeditions}

Soon after Emperor Yang succeeded to the throne, the expedition into Champa achieved some success in 605 . Then Sui divided the area into three prefectures which were later changed into "commanderies" (jun). The three commanderies, however, were lost during the turmoil at the end

${ }^{65}$ SUIS 84, pp. 1874-5; ZZTJ 180, p. 5627; p. 5632; 181, p. 5641; CFYG 974, pp. $11440-$ 1.

${ }^{66}$ SUIS 41, p. 1184; ZZTJ 180, pp. 5632-3.

${ }^{67}$ SUIS 60 , p. 1459; ZZTJ 181, p. 5661, CFYG 990, p. 11632. Concerning the year of the memorial, see Cen Zhongmian 1958, p. 93.

${ }^{68}$ SUIS 84, p. 1876; ZZTJ 181, p. 5647. 
of Sui, and the king of Champa restored his territory as a kingdom. ${ }^{69}$

The victory over Champa stimulated Emperor Yang's ambition. In 607 , he sent an envoy overseas with the purpose of "seeking and inquiring about foreign customs." ${ }^{, 70}$ The envoy went either to the islands called Liuqiu (J. Ryukyu), present-day Taiwan, or to some other islands in the East China Sea. He was sent there a second time with the mission to pacify the natives, but the king of Liuqiu refused, upon which Emperor Yang resorted to a military expedition in 610 . We are not sure if this was a success or a failure, ${ }^{71}$ but we know that Emperor Yang in the end gave up the attempt to bring Liuqiu into the tributary system. A diplomatic mission was also sent to Chitu (in modern Malaya) in 608, which was cordially received. When the Chinese envoys returned, the prince of Chitu went with them to China for a visit, and the Chinese historian routinely records that in 610 Chitu presented tribute. ${ }^{72}$ More tributary missions came to Sui under Emperor Yang than during Emperor Wen's reign. ${ }^{73}$

\section{Pei Ju as Foreign Policy Adviser}

Early in his reign Emperor Yang also showed his interest in the Western Regions by sending envoys there. They went as far as Kashmir, Kesch, Bohara and Persia. After their return Emperor Yang assigned Pei $\mathrm{Ju}$ (546-627) to be in charge of trade at Zhangye, an important trading center in modern Gansu. ${ }^{74}$

Pei Ju was the most important adviser to Emperor Yang on frontier affairs, although Zhangsun Sheng continued to be entrusted with Turkish affairs until his death in 609. Pei Ju was a native of modern Shanxi. His forefathers served Northern Wei and Qi. At an early age Pei Ju was recognized as a highly learned man. He started with a clerical appointment, went on campaigns in the south and had the experience of dealing with the aborigines there and of being an envoy to the Turks.

${ }^{69}$ SUIS 31, p. 886; ZZTJ 190, p. 5965. Arthur Wright (1979, p. 109) does not mention the establishment of the commanderies and concludes that the Chinese administration there was short-lived. His conclusion is based on SUIS 83. It is not clear whether the king kept part of his territory and other parts were brought under the Chinese commandery or whether the king was under the control of one of the commanderies.

${ }^{70}$ SUIS 81, pp. 1824-5; ZZTJ 180, p. 5627.

${ }^{71}$ Wright 1979, pp. 138-9.

${ }^{72}$ SUIS 3, p. $75 ; 82$, pp. $1834-5$.

${ }^{73}$ Cf. SUIS 81, 82 and 83.

${ }^{74}$ SUIS 83, p. 1841 ; p. 1849 ; p. 1857. 
Unlike Zhangsun Sheng, who was pragmatic and cautious, Pei Ju was an ambitious expansionist, became an influential advocate of an aggressive frontier policy, and a theoretician providing Emperor Yang with justifications for expansion. Knowing that the emperor was interested in foreign expansion, Pei Ju while in Zhangye made special efforts to gather information from foreign merchants. The information covered a wide range of subjects from the political situation and geographical conditions to local customs, food, clothing style and the likenesses of foreign rulers and common people.

He compiled a book entitled Xiyu Tuji or Illustrated Record of the Western Regions based on this information. He also worked out maps showing the southern and northern branches of the Silk Road in the Western Regions leading all the way to West Asia. In the preface to the book he stated that the Han dynasty had opened up the route to the Western Regions and extended its control over the area. Now China's force could reach as far as the Western Regions, but the Western Turks and the Tuyuhun now controlled most of the people there and prevented them from coming to China to pay tribute. He suggested that Sui should entice all these people to give their allegiance to Sui so that the Turks and Tuyuhun could be eliminated.

The emperor was greatly pleased and had discussions with Pei Ju which lasted for several days. Pei Ju stressed that the Western Regions were rich in precious goods and that the Tuyuhun could be easily swallowed up. The emperor then put Pei in charge of the opening up of the Western Regions and appointed him Gentleman Attendant at the Palace Gate (huangmen shilang), which allowed him to participate in court decision-making. ${ }^{75}$

Pei Ju's role in foreign policy-making became so important that Sima Guang, assuming his most severe style, blamed Pei Ju for encouraging Emperor Yang to emulate the achievements of the expansionist First Emperor of the Qin dynasty and Emperor Wu of the Han dynasty. $\mathrm{He}$ concluded "that in the end the Central Kingdom was weakened and thereby brought to ruin was entirely because of the siren songs of Pei Ju." ${ }^{, 76}$ It is not very fair to blame Pei Ju alone for the disasters in frontier affairs; Pei Ju understood the emperor's bent and said what Emperor Yang wanted to hear. Since his strategic plans did support Emperor Yang's

${ }_{75}^{75}$ SUIS 67, pp. 1578-81; JTS 63, pp. 2406-7.

${ }^{76}$ Wright 1979 , p. 127. 
ambitions, as we will see in the following section, surely the emperor must share the blame for the resulting debacle.

\section{Defeat of the Tuyuhun Kingdom and Opening the Western Regions}

On the Western front, a firm decision was taken to persuade the Tiele to attack the Tuyuhun. The Tiele had formerly been under the rule of the Western Turks. In 605 in the context of a temporary decline in Turkish power, the Tiele rose in rebellion against the Western Turks. They established a qaghanate of their own. The power and influence of the Tiele qaghanate expanded over various oasis states in the Western Regions. In 607 the Tiele launched an attack on the Sui frontier. After one encounter, the Tiele offered to make peace with Sui. Seeing this as the opportunity to put his larger plan into effect, Pei Ju went to the Tiele and succeeded in persuading them to wage war on the Tuyuhun. ${ }^{77}$

Because of their location in Qinghai the Tuyuhun were a potential obstacle on the flank of China's route to the Western Regions. They also raided Zhangye from time to time. ${ }^{78}$ Moreover, the Tuyuhun had intermarried with the son of Qimin Qaghan of the Eastern Turks. ${ }^{79}$ So close a relationship was considered a threat to China. Even though the Tuyuhun qaghan Fuyun sent his son, Shun, perhaps persuaded by the Chinese Princess Guanghua, ${ }^{80}$ to pay homage to the court when Emperor Yang assumed the throne, the Emperor nevertheless decided to destroy the Tuyuhun kingdom.

The Sui court detained prince Shun. Following the Tiele's victory over the Tuyuhun in 608, Emperor Yang took personal command in a successful campaign against the Tuyuhun in 609 . The Tuyuhun territory was incorporated into the Chinese empire as the Commanderies of Xihai and Heyuan, under which were established counties, garrisons and frontier posts. A Chinese general in charge of exiled convicts employed on military farms was stationed at Heyuan to guard against the Tuyuhun in order to ensure that the routes to the Western Regions would remain open.

Emperor Yang appointed Shun as the king of Tuyuhun and sent him back with the minister who had accompanied him to China. But the minister was killed on the way and Shun returned to the Sui court. The

\footnotetext{
${ }^{77}$ SUIS 83, pp. $1844-5 ; 84$, pp. 1879-80; ZZTJ 180 , p. 5635.

${ }_{78}^{78}$ SUIS 39, p. 1149.

${ }^{79}$ SUIS 84, p. 1877.

${ }^{80}$ Yamaguchi 1983, pp. 658-9.
} 
qaghan Fuyun and his people took refuge among the Black Dangxiang, a tribe of the Tibeto-Burman Qiang people. ${ }^{81}$

At this time the rising Tibetan kingdom was in the process of extending its power over the tribal states in its northeast. It has been claimed that to gain Tibetan support for himself, Fuyun was influential in obtaining the submission of the country of Fu, another Tibeto-Burman petty kingdom in the region, to Tibet, and so played a role in the establishment of the Tibetan kingdom. ${ }^{82}$ In any case the Tuyuhun acted as a bridge to link China and Tibet and later became deeply involved in relations with China and the Tibetan kingdom.

In 608 a general was sent to subjugate Yiwu (Hami), a major city state in the Western Regions northwest of the Yumen Pass. Qimin and his cavalry were expected to join but they failed to show up. The Chinese army went ahead anyway and succeeded in taking over Yiwu. A garrison of over a thousand soldiers was built there to serve as a base for trading with the Western Regions. In 609 Sui set up the commanderies of Shanshan and Jumo in the Western Regions. ${ }^{83}$

In the same year Pei Ju succeeded in enticing envoys from twentyseven oasis states to Wuwei (in present Gansu) where the emperor granted them an audience after his campaign against the Tuyuhun and made a lavish display of the riches of China. ${ }^{84}$ Among these states was the Gaochang kingdom. It had been under the control of the Turks and then of the Tiele. It now sought a Chinese connection. Its king went to the Sui court and even followed Emperor Yang on his Korean expedition. As a reward Sui sent Princess Huarong to marry the king in late $612 .^{85}$ The Sui court also set up the Commandant of Western Regions (Xiyu jiaowei) to receive envoys from the Western Regions. ${ }^{86}$

The Sui expansion into the Western Regions attracted tributebearing missions to the Sui capital to trade with China. These not only brought exotic luxuries for the emperor and the upper class but their coming also enhanced the political prestige of Sui as a unified empire with no

\footnotetext{
${ }^{81}$ SUIS 63, 1504; 83, p. 1845; ZZTJ 181, p. 5641; pp. 5643-5; Ise 1968, pp. 152-3.

${ }^{82}$ Yamaguchi 1983, pp. 669-71. Beckwith regards the embassies of Fu to Sui in 608 and 609 as the first contacts of Tibetans with the outside world (1987, p. 17). According to Yamaguchi, however, at that time Fu was not yet a part of the Tibetan kingdom.

${ }^{83}$ SUIS 65, pp. 1533-4; 67, p. 1581; ZZTJ 181, p. 5642; p. 5645.

${ }^{84}$ SUIS 67, p. 1580; ZZTJ 181, pp. 5644-5.

${ }^{85}$ SUIS 83, p. 1847 ; ZZTJ 181 , p. 5666.

${ }^{86}$ SUIS 83, p. 1841.
} 
less a reach than the Han dynasty. ${ }^{87}$ The political prestige of restoring the outer boundary of Han may have been achieved, but trade through tribute missions was hardly profitable.

The Chinese historians writing the Sui history complained that envoys of the various countries of the Western Regions came and left continuously, wearing out the prefectures on the way for the cost of their reception which amounted to hundreds of millions. Commanderies in the northwest also had to bear the heavy burden of providing grain to maintain garrisons in the former Tuyuhun territory. ${ }^{88}$ We should note that it was the local government that had to bear the cost of accommodation of these envoys and of maintaining the frontier posts. However, Ise holds that the figures quoted above may be exaggerated. To pay for the supply of the garrisons Sui opened garrison farms on the frontiers and taxed the nonChinese in Qinghai who had submitted. ${ }^{89}$ The cost, nonetheless, was great and emphasizing such costs was always the focal point in the criticisms mounted by Confucian-minded scholar-officials of any emperor's attempts at expansion.

\section{Success in Subduing the Western Turks}

Sui's victory over the Tuyuhun and its success in the Western Regions were accompanied by success in weakening the Western Turks, who, having survived the defeat of 603, were now under Chuluo Qaghan. His lands were in the Ili Basin and his power was on the rise. His mother was Chinese and had been at the Sui court from about 603. In 608, on Pei Ju's advice, Emperor Yang sent an envoy to Chuluo and succeeded in persuading the qaghan to join the Chinese in an attack on the Tuyuhun and to send a tributary mission to Sui. The envoy said that it was Chuluo's mother who was urging the qaghan to submit to Sui. ${ }^{90}$

But it appears that Chuluo did not participate in the campaign. When Emperor Yang, on his tour to the west in 610, asked Chuluo to pay a visit to him, Chuluo refused to do so. Emperor Yang was furious at this act of outright disobedience, but had no way to deal with the problem until a timely falling-out among the Western Turks provided the Chinese with an opportunity to attack. When, in 611 , the tribal leader Shegui of the

\footnotetext{
${ }^{87}$ Ise 1968 , pp. $160-4$.

${ }^{88}$ SUIS 24, p. 687; ZZTJ 181, p. 5645.

${ }^{89}$ Ise 1968 , pp. $155-6$.

${ }^{90}$ SUIS 84, pp. 1876-8; ZZTJ 181, pp. 5636-7.
} 
Western Turks sent an embassy to Sui requesting a marriage alliance, Pei Ju suggested that the request be accepted, so as to divide and rule. His scheme succeeded in making Shegui launch attacks against Chuluo, who then had to come in person to pay his respects to Emperor Yang at the end of the year. ${ }^{91}$

The following year saw the incorporation of Chuluo's people into the Sui hegemonic empire. They were divided into three groups: a) more than 10,000 "physically weak" people led by Chuluo's brother, were settled in the commandery of Huining, b) some stronger forces were stationed in Loufan for frontier defense, and c) Chuluo, in command of 500 calvary men, escorted Emperor Yang on his tours of inspection, and joined in the military campaigns against Koguryǒ. ${ }^{92}$ In 614 Sui gave the hand of Princess Xinyi to Chuluo in marriage accompanied by a gift of a large amount of silk. Emperor Yang even expressed his intention of helping Chuluo recover his territory, no doubt with the long-term aim of making Chuluo responsible for frontier defense. The plan aborted, however, with the collapse of Sui. ${ }^{93}$

\section{Three Wars of Aggression Against Koguryǒ}

After his success on the northern and northwestern frontiers, Emperor Yang directed his troops to the northeastern side. In 607, when Emperor Yang went on a tour of inspection to the residence of Qimin Qaghan of the Eastern Turks, he found that Koguryǒ had an embassy there. Such a liaison between two of China's strongest potential enemies alarmed Emperor Yang.

Pei Ju, who was with the emperor on the tour, reminded him that Koguryǒ had been an integral part of China from antiquity down to the time of the Han and Jin dynasties, but that now it was not conducting its affairs in a manner proper to a subject and was acting like an outer land. It was not proper, he said, that Sui allow this once "civilized" land to revert to control by "barbarians." He advised Emperor Yang to order the Koguryǒ king's attendance at court and to threaten that if the king did not obey, Sui would launch an attack.

The emperor followed this advice and delivered a warning to the king of Koguryor that if the king did not come to the Sui court, Sui would

\footnotetext{
${ }^{91}$ SUIS 84, pp. 1878-9; ZZTJ 181, pp. 5654-5; CFYG 990, p. 11633.

${ }^{92}$ SUIS 84, p. 1879; ZZTJ 181, p. 5658.

${ }^{93}$ SUIS 84, p. 1879.
} 
lead the Turks into the land of Koguryor. ${ }^{94}$ In spite of the demand, King Yongyang did not go to the Sui court and only sent a tributary mission in 609.

Emperor Yang decided to go to war. In an edict issued in $612 \mathrm{Em}$ peror Yang claimed that Koguryǒ had once been a "civilized" area but was now occupied by "barbarians." Then he accused King Yǒngyang of refusing to come in person to the Sui court, fomenting troubles on the frontiers, preventing other people from coming to the Sui court, imposing cruel laws and heavy taxes on his people and having a government manipulated by powerful ministers and clans. ${ }^{95}$

In dramatic contrast to the cautious policy of Emperor Wen, Emperor Yang's reign was marked by three large-scale expeditions aimed at conquering Koguryǒ, and in all three the emperor took personal command. Chuluo of the Western Turks and a ruler of the Mohe who had come over to Sui also participated in these campaigns. ${ }^{96}$ As mentioned above, construction of the Yongji Canal from the Yellow River to Zhuojun was carried out to supply the planned expedition against Koguryǒ. A serious flood of the Yellow River in 611 compounded the hardships endured by the conscript laborers and led to desertions and banditry that eventually grew into the peasant uprisings that flourished in the Hebei region until the early years of Tang. 97

Having assembled his forces at Zhuojun for his first offensive, Emperor Yang asked one of his officers: "The population of Koguryǒ is not equivalent to one of our commanderies. Now that I am leading so massive an army to attack them, do you think we will succeed?" The reply was that Sui would win but the emperor should not campaign in person. This displeased the emperor, who was still full of confidence. Another official holding a minor position strongly opposed the war and was almost put to death for his pains. ${ }^{98}$

In 612 an unprecedentedly large force said to total $1,133,800$ men set out both by land and sea. Their goal was P'yǒngyang, the capital of Koguryǒ. The Sui force crossed the Liao River and besieged a Koguryǒ stronghold but was unable to take it and had to withdraw. It is reported

\footnotetext{
${ }^{94}$ SUIS 67, p. $1581 ; 84$, p. 1875 ; ZZTJ 181 , pp. 5652-3.

${ }^{95}$ SUIS 4, pp. 79-81; CFYG 117, pp. 1395-7.

96 SUIS 81, p. $1822 ; 84$, p. 1879.

${ }^{97}$ Bingham 1941, pp. 39-41.

${ }^{98}$ SUIS 78, p. 1770; ZZTJ 181, p. 5659.
} 
that of the 305,000 troops that had crossed the Liao River only 2,700 returned. The only success of the campaign had been the capture of a Koguryǒ stronghold on the west side of the Liao River where Sui set up the commandery of Liaodong and Tongding Fortress. ${ }^{99}$ So meager a result would seem to suggest that it was time for Emperor Yang to cease further campaigns against Koguryǒ, but his ambition would not allow him to give up. $^{100}$

Another expedition was launched in 613. Once again a court minister remonstrated that China was exhausted and the emperor should not go personally, but the emperor refused to listen. ${ }^{101}$ The campaign soon had to be halted when Yang Xuangan rose in rebellion. The campaigns against Koguryǒ had imposed an extremely heavy burden on the people, causing popular resentment and leading to banditry and violent disturbances inside China. Many men refused to go to war and deliberately injured themselves so as to avoid conscription.

Taking advantage of the tense situation, Yang Xuangan, who was in charge of supplies for the campaign, rose in revolt and headed for the eastern capital Luoyang. Yang Xuangan was the son of Yang Su, a close adviser of Emperor Wen who had helped Emperor Yang to the throne but had then fallen out of favor and been put to death. The Chinese troops of the Koguryǒ expedition had to retreat to suppress the rebellion. Husi Zheng, the Emperor's Vice Minister of War, who was implicated with Yang Xuangan's clique, fled to Koguryǒ. Though it was finally suppressed, the rebellion was the beginning of a series of uprisings that finally led to the total collapse of the dynasty.

Oblivious to the danger inherent in the disturbed situation inside China, Emperor Yang decided on a third expedition in 614. It received so little support that during the discussions on the campaign, nobody dared to speak out for several days. China was now suffering from so much internal turbulence that many troops failed to arrive at the Liao River on time. Nevertheless, the Chinese forces brought enough pressure to bear as to oblige, Koguryǒ to sue for peace. It sent an embassy in the seventh month of 614 , offering to surrender and to hand over Husi Zheng. Emperor Yang

\footnotetext{
${ }^{99}$ SUIS 81, p. 1817 ; ZZTJ 181, pp. 5659-66.

${ }^{100}$ Bingham 1941, p. 42.

101 SUIS 50, p. 1320; ZZTJ 182, p. 5669.

102 ZZTJ 197, p. 6216.

${ }^{103}$ Wright 1979, pp. 144-5.
} 
accepted this, but insisted on the king's coming to court personally. Upon receiving the king's refusal, Emperor Yang prepared for a fourth expedition. ${ }^{104}$ However, this last expedition soon collapsed because of the rapidly deteriorating situation in all parts of China.

Many factors contributed to the Emperor's almost insane obsession with the conquest of Koguryo.. When he began, the national economy was sound and his military force was strong. A recent study shows that the figure of $1,133,800$ men given for the size of the army employed in the first expedition could be true, if the fubing, conscripts and non-Chinese are all counted. ${ }^{105}$ So ambitious and supremely egotistical a monarch must have felt he had to win to rehabilitate his reputation and his self-esteem. ${ }^{106} \mathrm{He}$ also believed frontier defense was an adequate justification for such a war: Koguryǒ posed, he insisted, a threat to Sui border security and challenged China's superiority by its unsubmissive attitude.

An ideological justification for the war was sought in the traditional view of the Son of Heaven being the ruler of the world. In his persistence in taking personal command of the campaigns against Koguryor the emperor was driven by his conception of the majesty and cosmic centrality of the empire, by his urge to restore the glory of the Han and by his image of himself as destined to great victories against all who resisted the benevolent transforming influence of the Central Kingdom. ${ }^{107}$

It was not only the emperor personally who was inspired by the idea of conquest so as to establish a world empire on the Han model; such a belief was held firmly and supported actively by some of his officials as well. Pei Ju was one such official, and not the only one. By the end of Emperor Wen's reign, increased prosperity in China encouraged talk of defeating Koguryǒ to become prevalent inside and outside the court. Such "public opinion" pushed Emperor Yang into the position of a promoter of foreign expansion. Although some officials objected to the invasion, their voices were too few and faint to have any effect on the general fever for war. ${ }^{108}$

Externally, the situation on the Korean peninsula at this time seemed to have reinforced Emperor Yang's ambitions. The three Korean

\footnotetext{
${ }^{104}$ SUIS 4, pp. 84-8; 81, p. 1817; ZZTJ 182, pp. 5689-92.

${ }^{105}$ Asami 1985.

${ }^{106}$ Wright 1960 , p. 58.

107 Wright 1978, p. 194.

${ }^{108}$ SUIS 75, p. 1721.
} 
states were engaged in competition with one another, and both Paekche and Silla hoped that Sui would assist them against Koguryǒ. This provided a convenient pretext for Sui aggression.

In 607 Paekche sent an envoy to Sui, repeating the request made in Emperor Wen's time that China join Paekche in attacking Koguryǒ. While Emperor Wen had not been interested in exploiting the competition among the Korean states, Emperor Yang asked Paekche to "watch over" Koguryǒ. In 611, before Emperor Yang launched the first campaign against Koguryǒ, Paekche again despatched an envoy to ask for details of the plan. Emperor Yang sent an envoy to Paekche with the information. Paekche, however, was also aware of the danger of Chinese aggression and therefore tried to keep secure by maintaining a delicate balance between China and Koguryǒ. In 612 Paekche despatched troops to its border with Koguryǒ, ostensibly to provide assistance to the Chinese but in fact as a precaution against a Chinese invasion. Despite its bellicose posturing, it maintained peaceful relations with Koguryo..

Silla consistently allied itself with China, since it had been under pressure from both Koguryǒ and Paekche. In 608 the king of Silla sent a letter to Sui, asking for troops to attack Koguryǒ, and in 611 a Silla envoy arrived at the Sui court requesting Chinese military assistance. Emperor Yang agreed. ${ }^{110}$

A complication in the situation on the Korean peninsula was Japan's involvement in Korean affairs. In the fourth century Japan had a foothold known as Kaya (Japanese Mimana) on the peninsula between the territories of Paekche and Silla. ${ }^{111}$ While Paekche usually aligned itself with Japan and Kaya, Silla and Koguryǒ were often hostile to Kaya. In 562 Silla destroyed Kaya. For a time Japan continued to make attempts to restore its power base. In 600 it took over five walled towns from Silla but that success did not last long, for Silla soon retook the towns after the Japanese left. ${ }^{112}$ The Japanese threat helped to push Silla toward China.

One should point out, however, that in both Korean and Chinese sources concerning the Sui period, there is no reference to either Paekche

\footnotetext{
${ }^{109}$ SUIS 81, p. 1819; ZZTJ 181, p. 5666.

${ }^{110}$ SGSG 4, p. 10.

111 There is controversy about Kaya's role. Ledyard (1975) argues that it was a source of either infiltrators or conquerors of Japan from Korea, while Edwards (1983) argues against that view.

${ }^{112} \mathrm{Yu}$ Yousun 1957, p. 5.
} 
or Silla actually joining the Chinese campaigns against Koguryǒ. At this time China was not entirely clear about Japan's impact on the international scene in East Asia, although it had felt challenged by Japan when the Japanese envoys first came to the Sui court and presented a letter which began: "The Son of Heaven in the land of the rising sun sends this letter to the Son of Heaven of the land where the sun sets." This displeased Emperor Yang, who instructed that such letters were not to be presented to him in the future. ${ }^{113}$ According to the Japanese sources, the Japanese emperor in his next mission to Sui sent a letter to Emperor Yang with the words "the Eastern Heavenly Emperor respectfully says to the Western Emperor" etc., but there is no record of this in Chinese sources, so we do not know how the Chinese reacted to it. ${ }^{114}$

The situation on the Korean peninsula at this time was totally different from the situation during early Han, which was why Emperor Yang failed where Emperor Wu of the Han dynasty had succeeded. Koguryǒ was not a loose confederation of walled towns, but a militarily strong state with an effective ruling council. It was suspicious and fearful of Chinese expansion as well as conscious of China as standing in the way of its own expansion. At first it offered submission in response to Emperor Wen's deterrent threats. Its submission to Emperor Wen may have reflected both its perception of Sui military power and its fear of Sui retaliation. However, the effect of a deterrent may depend on its not actually being used, since the effectiveness of deterrence depends mostly on the threatened state's perception of it. When Emperor Wen actually launched his attack and failed, the Koreans saw that Sui was unable to mount an effective campaign, and therefore they put up formidable resistance to Emperor Yang's invasions.

Emperor Yang did not have a good understanding of his enemy nor of China's own strength. He and his supporters failed to see that China's economy was still far from adequate to support an all-out expedition at such a distance. When it did go to war, the Sui court had to resort to measures such as taxing the rich merchants in proportion to their property. Local officials resorted to still more outrageous methods to raise funds. The burden of heavy taxation and demands for labor pushed people into slavery and banditry. ${ }^{115}$ The Sui military force, large as it was, was not effec-

\footnotetext{
113 SUIS 81, p. 1827; Wright 1979, p. 139.

${ }^{114}$ Nishijima 1983, p. 436.

${ }^{115}$ SUIS 24, pp. 672-3; pp. 687-8.
} 
tive. Yet Emperor Yang held to the wrong perception that Koguryǒ, a small country equivalent only to a commandery in China, could easily be subdued. In fact China was unable to muster the resources to carry out an effective campaign in a strongly defended land a thousand miles away from the Sui capital, whose terrain and climate were also hostile to the invader. $^{116}$

\section{The Siege of Yanmen}

The outlook in 615 was gloomy. Following his Korean campaign in 614 the tireless Emperor Yang, perhaps worried about the growing power of the Eastern Turks, went on a hunting trip to the north where he was besieged in Yanmen town by the Eastern Turks under Shibi Qaghan.

Turkish hostility had been stirred up by actions of Pei Ju. Just a year before, seeing that the Eastern Turks were growing in strength, Pei Ju devised a strategy to foment discord among Shibi's people in order to weaken him. This proved to be unwise, for Sui at this time needed the military assistance of the Eastern Turks to deal with the Koreans. Nonetheless, at Pei's suggestion, the Sui court offered a Chinese princess to Shibi's younger brother and proposed to confer the title of southern qaghan on him, but the brother was afraid to accept this rank, apparently fearing he was not strong enough to challenge his elder brother. When news of the Chinese plan reached Shibi, he quite naturally resented it.

Pei Ju then suggested that the court should get rid of Shi Shuhuxi, a capable assistant to Shibi of Sogdian (i.e. non-Turkish) origin. Shi Shuhuxi and his men were deceived into coming to trade, only to be killed in a Chinese ambush. Shibi thereupon suspended tributary relations with Sui and decided to retaliate. Shibi planned a sudden attack in 615 , when the Sui emperor was on his northern tour. The Sui Princess Yicheng, who had first been married to Qimin and then to Shibi, sent an envoy to Sui to report the plan, but obviously the report arrived too late.

The Turks not only besieged Emperor Yang in Yanmen, they captured thirty-nine of forty-one walled towns in the commandery of Yanmen. The emperor was so frightened that he could only hold his son and cry until his eyes were swollen. ${ }^{117}$ He remembered Zhangsun Sheng with a sigh: "If Zhangsun Sheng were here, the Xiongnu (the Turks) would not

116 Jamieson 1969 , pp. 32-4.

${ }^{117}$ SUIS 4, p. 89; 67, p. 1582; ZZTJ 182, pp. 5697-8; Bingham 1941, p. 59. 
have been allowed to go so far!"118 To meet the crisis, the emperor's advisers urged him to order the recruitment of rescue troops throughout the empire and to announce the abandonment of the costly campaign against Koguryǒ. A court minister suggested that, since according to the practice of the Turks, the qatun (wife of qaghan) participated in military discussions, Sui should obtain the help of Princess Yicheng. She did not disappoint the Sui court. She gave false information to Shibi that there was an emergency on his own northern border, so Shibi finally withdrew his troops. ${ }^{119}$ The immediate crisis was over, but the emperor then went back on his word and talked again about resuming the campaign against Koguryǒ. $^{120}$

The Turkish attack was the final straw. Coming after the unsuccessful campaigns against Koguryor and the turmoil inside the country caused by various internal uprisings, the Sui dynasty went into a sudden and steep decline and soon after met its end.

\section{The Foreign Policies of the Two Emperors Compared}

The differences between the foreign policies of the two emperors resulted from the evolution of the political and economic situation in China. As the founder of the dynasty Emperor Wen devoted himself to reuniting the whole of China, restoring the economy and securing the frontiers. Emperor Yang inherited his father's achievement. With China reunified, the dynasty secure, the frontiers with the Turks and the Tuyuhun under control, Koguryǒ suing for peace, and China's economy and population recovering, Emperor Yang had not the same concerns as those of his father. He was tempted by adventurous ideas and inspired by the ambition of restoring the Han boundaries through military conquest.

Differences in the personalities of the two emperors also were responsible for their differing decisions in policy. The prudent Emperor Wen was more realistic in assessing the strengths and weaknesses of both China and its rivals; he was ready to draw back when he ran into obstacles. The flamboyant Emperor Yang, on the other hand, was so overconfident that even when China was clearly being devastated by huge internal construction projects and external wars, he would not become discouraged. The restlessness of Emperor Yang, always going about on tours and engaging

\footnotetext{
${ }^{118}$ SUIS 51, p. 1336.

${ }^{119}$ SUIS 63, p. 1492; JTS 63, p. 2399; ZZTJ 182, pp. 5698-9.

${ }^{120}$ SUIS 67, pp. 1572-3; ZZTJ 182, p. 5700.
} 
in military campaigns, can also be seen as reflecting the nomadic side of his inheritance.

Each of these two rulers played equally decisive roles in the making of foreign policy. It is also true, however, that we can discern a coherent working procedure pervading the whole process of foreign policy decision-making during the Sui dynasty. Officials in various capacities presented suggestions in their memorials; court discussions were held; policies deliberated and finally decided upon. Both emperors relied on their circle of advisers and Zhangsun Sheng and Pei Ju were responsible for many decisions in the foreign policy of both rulers.

Yet both emperors also undoubtedly held tightly the power of final decision-making. Being northern military aristocrats, they did not care too much about having the image of a wise Confucian ruler sitting at the top and leaving details to their servants; they had to be in control. The powerful position of the emperor was carefully preserved in the reform of governmental institutions under the reign of Emperor Wen. The Sui court set up various offices on the central level: the three central ministries (sansheng), the Department of State Affairs (shangshu sheng) with its six administrative boards, the Chancellery (menxia sheng) and the Secretariat (neishi sheng, later Neishu sheng), the Censorate (yushi tai), the Inspectorate General of Water Works (dushui tai, later dushui jian), and the nine courts.

But the office of Chancellor (chengxiang) was missing, and that position was the summit and pivot of the Han bureaucratic apparatus. Its holder functioned as de facto chief of government, as supreme arbiter and spokesman for bureaucratic interests as a whole. By not reestablishing this office, Emperor Wen was able to act as his own chancellor and Emperor Yang followed the same practice. ${ }^{121}$ Power was thereby concentrated in the hands of the emperor, and although each of the two emperors relied on his group of advisers, the advisers could not form a unified force able to challenge the emperor. Their competition for the support of the emperor weakened their position as a group. For instance, under Emperor Wen, Gao Jiong was accused by the empress of not exerting all his efforts in the command of the war against Koguryǒ, ${ }^{122}$ and under Emperor Yang power struggles among the bureaucrats ruined several of his advisers.

The despotic style of both emperors was shown clearly in their

\footnotetext{
${ }^{121}$ Wright 1979, p. 82.

${ }^{122}$ ZZTJ 178, pp. 5566-8.
} 
willingness to treat their officials with punitive or even vindictive severity. Emperor Wen was especially likely to vent his anger by ordering the whipping and beating of offending officials at court. ${ }^{123}$ But in decisionmaking Emperor Wen showed more willingness to listen to suggestions and to accept remonstrance. As the founder of a new dynasty such forbearance was needed to win the hearts of all in both the north and the only recently conquered south. Emperor Wen often expressed his wish to harmonize his policies with "public opinion."124 Knowing very well his own limitations as an administrator, Emperor Wen followed the advice of his ministers in such major issues as the conquest of Chen, the pacification of the south, the formulation of tax policy, and formulation of law.

Emperor Yang showed a more despotic attitude when he said:

By nature I do not like remonstration. When those in high and prestigious positions present remonstrance in order to make a name for themselve, I cannot bear it. As for those in low and humble positions, I will treat them with some tolerance but I will still cast these [memorials] down on the ground. You should know this! ${ }^{125}$

His despotism reached its height during the Korean campaigns. He never listened to any objections to the war. As mentioned earlier, in 614 when he assembled his ministers for deliberation about the war, for several days no one dared to say anything. The anti-war proposal of Yu Shiji, a policy adviser, was raised only when the emperor was caught in the siege by the Turks at Yanmen. Yu urged the emperor to abandon the Korean campaign. ${ }^{126}$ When Emperor Yang asked for opinions about resuming the campaign, Su Wei, another adviser, still did not dare to tell him the truth explicitly. He implied that the war should be abandoned by reminding the emperor of his promise during the siege and suggesting that the huge number of bandits and rebels could be pardoned and be sent on the Korean campaign. Even this angered Emperor Yang. Other advisers, such as Pei Yun, knew that Emperor Yang was determined to resume the war and therefore tried to hide the fact that China was in chaos and in no position

${ }^{23}$ Somers 1978, p. 204.

${ }^{124}$ Tang Chengye 1967, pp. 41-5.

${ }^{125}$ ZZTJ 182, p. 5684.

${ }^{126}$ SUIS 67, p. 1572. 
to carry on with hostilities. ${ }^{127}$

Short-lived as it was, the Sui dynasty restored Chinese unity. The government maintained centralized control over the fubing military system and developed "regional military commands" in areas of major strategic importance, following the Northern Zhou practice. It bequeathed to its successor, Tang, the basic institutional framework for its government. The building of the Bian canal linking north and south was a lasting contribution to economic development.

The Sui was initially successful in dealing with the Turks, whose nomadic empire posed a formidable challenge on their northern frontier. The Sui rulers' nomadic heritage gave them a better understanding of their nomadic rivals than their Han predecessors had possessed. The Sui rulers understood that the Turks' lack of a well established rule of succession made it hard for them to maintain a unified leadership. Rather than wait for an internal split to appear spontaneously, Emperor Wen's capable foreign policy adviser, Zhangsun Sheng, familiar with Turkish affairs, actively stirred up divisions among the Turks and thereby succeeded in making the Eastern Turks accept tributary status in 584 .

Such a relationship benefitted both Sui and the Turks, for both could join forces against their common enemy, the Western Turks. The Eastern Turks obtained Chinese support and large amounts of material aid, while Sui could use the Eastern Turks as a frontier defense force. More importantly for Sui, peace in the north enabled Emperor Wen to carry out his successful conquest of the Southern Chen regime.

When the Eastern Turks under Dulan Qaghan again became hostile in 593, Zhangsun Sheng's strategy of divide and rule was again put into practice and Sui formed an alliance with Dulan's rival, Qimin Qaghan. The tributary relationship between Sui and Qimin enabled them to join forces to inflict a severe defeat on the Western Turks in 603.

Emperor Wen's cautious pragmatism also showed itself in his policies of non-intervention towards the Tuyuhun. Koguryǒ, Sui's major rival on the northeastern frontier, with its territory extending to the Liaodong peninsula, its tendency to ally itself with the Turks, its ambition to rule over Manchuria, and its potentially disturbing influence in the $\mathrm{He}$ bei area, required more serious attention. For its part, Koguryǒ was deeply

${ }^{127}$ SUIS 41, p. $1188 ; 67$, p. $1567 ;$ ZZTJ 183, pp. 5703-4. 
concerned with Sui's ambition to expand in its direction. Emperor Wen's unsuccessful military campaign against Koguryǒ in 598 was, however, primarily aimed at posing a deterrent so as to maintain security on the frontier rather than at extending his territory, and could be said to have achieved its objective from that point of view.

Emperor Wen's sanctioning of an expedition against Linyi after reestablishing Chinese control over Jiaozhou in Northern Vietnam was more adventurous, but probably did not involve great diversion of resources or risk of serious loss.

In contrast to his father, Emperor Yang was enthusiastic from the beginning for expansion to restore the political prestige and imperial glories of the Han dynasty. Such an ambition was partly due to his flamboyant personality, but it can be attributed even more to the internal economic recovery of the country, the ideological pressure to extend the sphere of rule of the Son of Heaven and the precedent of Han's achievements. His foreign policy adviser, Pei $\mathrm{Ju}$, dutifully offered encouragement. Under Emperor Yang the peaceful tributary relationship with the Eastern Turks lasted till 614 and the absence of trouble on the northern frontier left him free to undertake a series of moves to recreate the Han empire.

$\mathrm{He}$ abandoned his father's non-interventionist policy towards the Tuyuhun and took personal command in a campaign that subjugated them and brought them into the Sui commandery system in 609. In 609 Sui also established two commanderies in the Western Regions, thus ensuring its control over the area, and in 611 it succeeded in subduing the Western Turks.

In the northeast, abandoning his father's cautious pragmatism and without a rational and sound assessment of the situation, Emperor Yang took personal command in three campaigns against Koguryǒ in 612, 613 and 614 , all of which ended in failure.

While Sui overextended itself and exhausted its strength in a futile attempt to subdue Koguryǒ, the Eastern Turks under Shibi Qaghan grew strong. Pei $\mathrm{Ju}$ attempted to counter this by reviving the divide and rule policy but this time it backfired. His attempt to win over Shibi's younger brother failed and only aroused the resentment of the Qaghan, who laid siege to Emperor Yang at Yanmen while on a tour of inspection. The emperor survived the crisis but as he planned yet another Korean expedition, the turmoil inside the country steadily increased and the Sui dynasty was replaced by Tang in 618 . 


\section{Chapter 4}

\section{Tang's Internal Evolution and its Foreign Policy}

Before discussing in detail the relations between China and its principal foreign rivals during Tang, we need to take an overview of the internal evolution of China during these centuries. We must understand the changes that took place in the internal power structure to understand the ways in which these changes influenced the formation of policy and the making of particular decisions dealing with external problems as they arose.

\section{Gaozu: Dynastic Consolidation}

Even more than Emperor Wen of Sui, Gaozu, the dynastic founder of Tang, displayed a cautious, pragmatic realism in his conduct of foreign affairs. Unlike Yang Jian, who was already at the center of power when he took the ambitious step of usurping the throne, Li Yuan was merely a provincial governor who, despite his aristocratic background, would probably have never conceived the ambition to supplant the Sui dynasty if it had not been for the anarchic breakdown that resulted from Emperor Yang's obsession with conquering Koguryǒ.

While the standard account pictures him as having to be reluctantly pushed into taking up arms by his brilliant son, Li Shimin, the role of the future Taizong may have been exaggerated by historians endeavoring to glorify the latter's achievements. Nevertheless, the standard account seems in general consistent with Gaozu's character as reflected in the decisions he took in dealing with foreign powers. As we shall see, while he was in command of affairs, Gaozu showed little compunction in adopting a submissive attitude towards the Turks and in giving up pretensions to suzerainty over Korea. During this period it was his ministers and not the emperor himself who wanted to insist on the traditional ideal of extending the authority of the Chinese Son of Heaven beyond the frontier.

\section{Building Frontier Defenses}

Following Sui practice, Gaozu kept twelve large standing armies in the capital region. These were staffed with soldiers recruited under the 


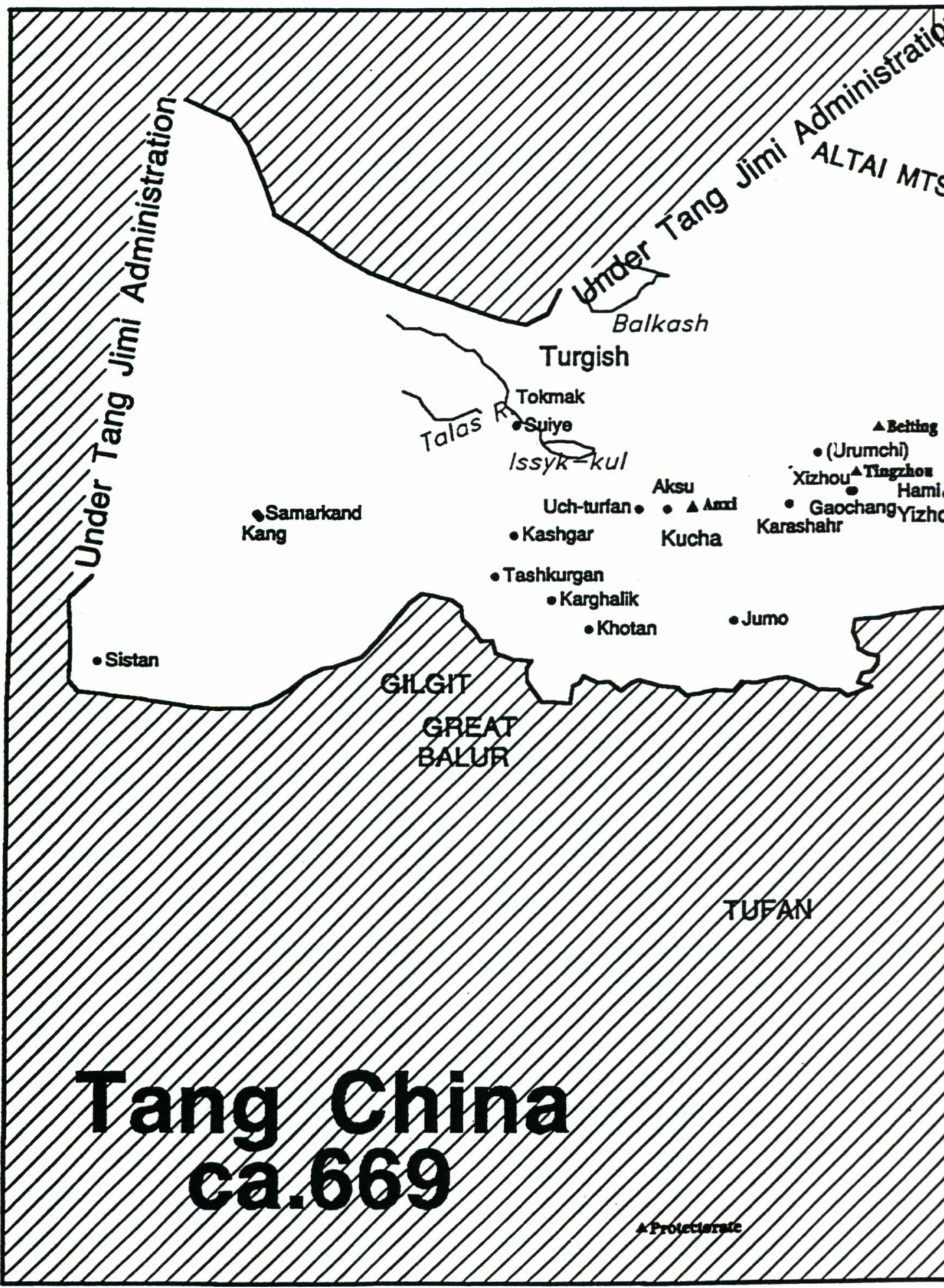


TIELE

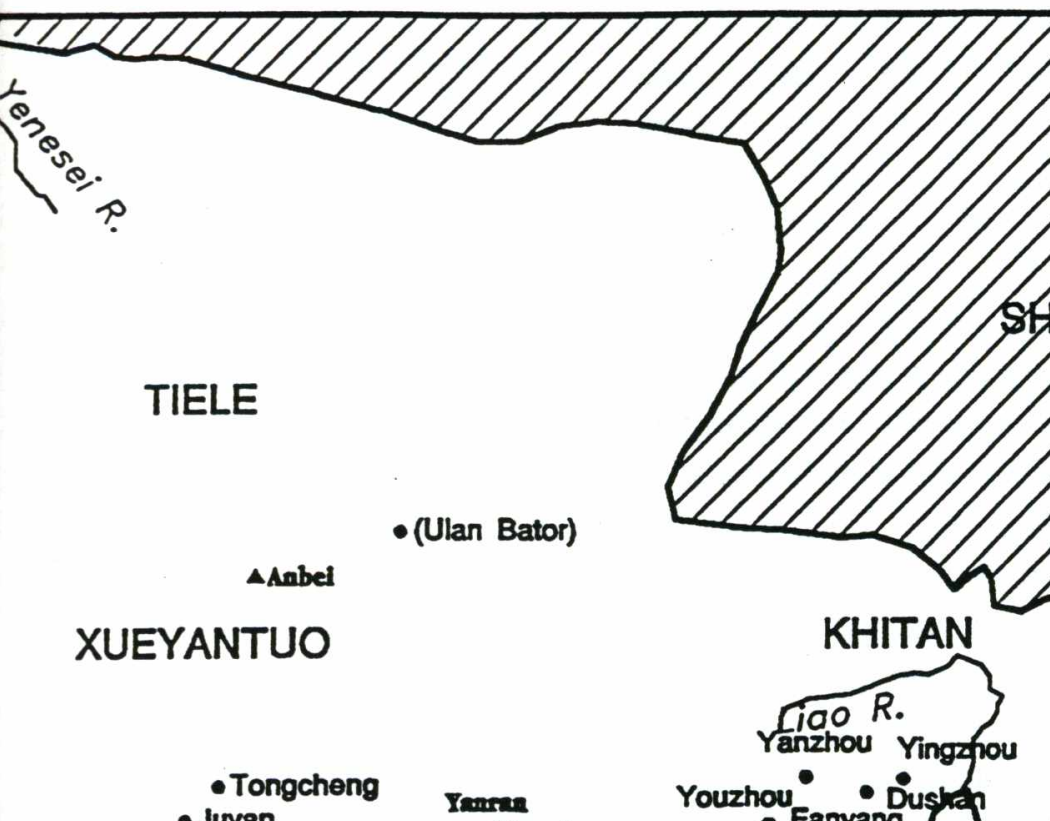

hazhou - Guazhou -Yumen

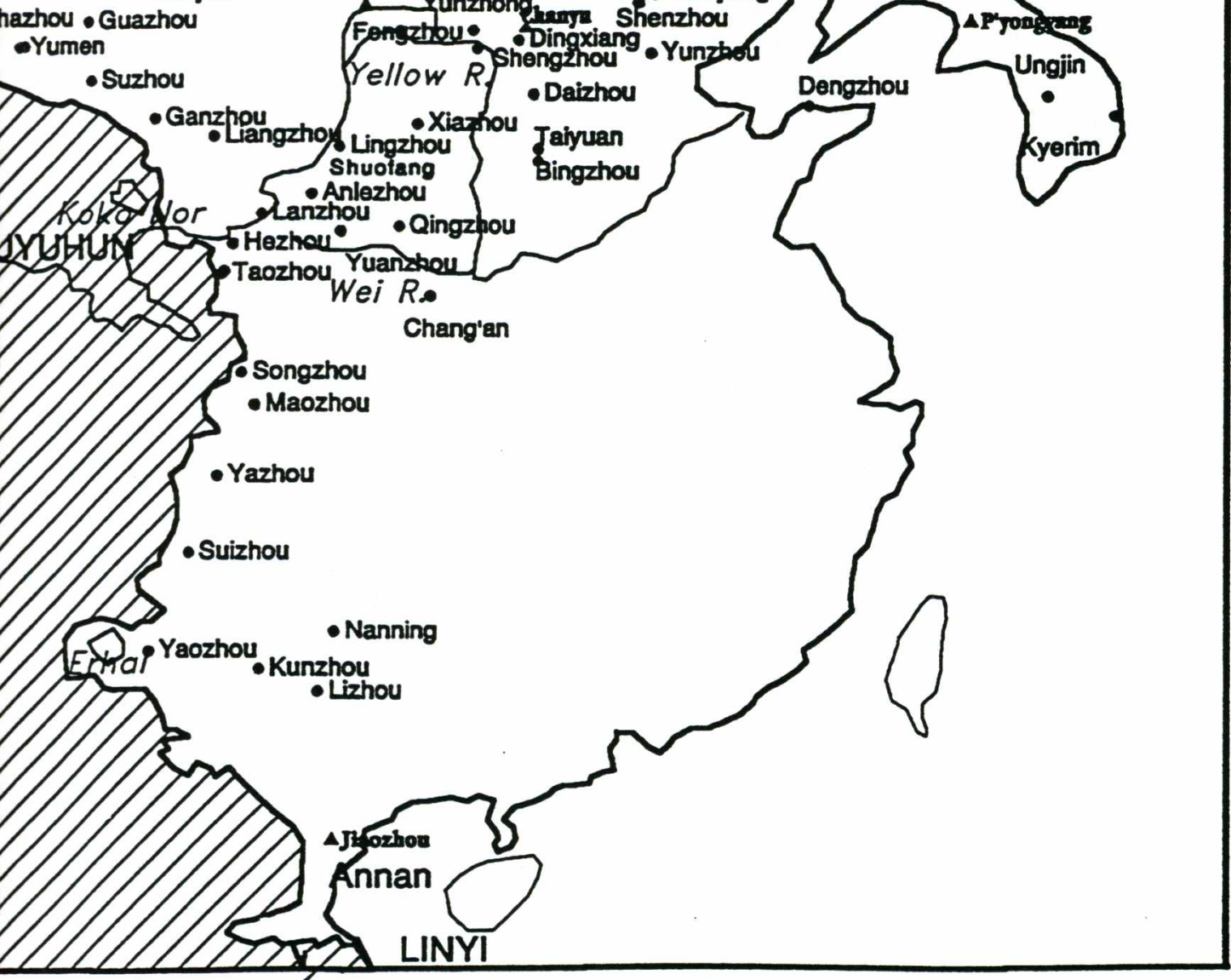


fubing system. Keeping the two levels of local government, the prefecture and county of the Sui system, Gaozu also reestablished zongguan fu ("local regional commands" or "area commands") in frontier regions and interior areas of strategic importance. The label for these changed to $d u d u$ fu ("area commands") after 624. The area commanders (zongguan or $d u d u$ ) were placed over the civilian administration of the area and were responsible for such military matters as taking care of "the walls, moats, soldiers, horses, armor and weapons, food supplies and defense arrangements etc. in the prefectures." Depending on the number of prefectures under them, these $d u d u f u$ were later classified as grand, first, second and third class, respectively. ${ }^{1}$

Gaozu often appointed as area commanders former anti-Tang leaders or former Sui officials who had submitted to Tang, thus also incorporating the military forces under them directly into the Tang chain of command. For example, Zhang Changxun, a former Sui official in Wuyuan, attached himself to the Turks at the end of Sui, but he soon surrendered to Tang with the territory he controlled, and was appointed the Fengzhou zongguan. ${ }^{2}$ Yang Gongren, a former Sui official, submitted in 619, and was appointed the Liangzhou zongguan as he had been the Prefect of Ganzhou in the northwest and was familiar with frontier affairs. Soon after, he was brought to Chang'an and became a Chief Minister from 619 to $626 .{ }^{3}$ Gaozu used the same winning-over policy for non-Chinese leaders. In 618 Gaozu set up Yanzhou where the Mohe lived west of the Liao River, and in 621 the Mohe leader was appointed Yanzhou zongguan. He led his troops into battles against anti-Tang forces. ${ }^{4}$

Gaozu's appeasement policy towards the Turks could not entirely stop border incursions. It was left to the area commanders or local officials to handle such incursions, using the troops already under them. In any event, during that early period Tang was unable to organize major campaigns beyond the frontier. Kang Le has suggested that Tang held its major military forces in the capital region and that frontier area commands were only responsible for providing information and for temporarily checking invading forces. Battles with major invaders were fought mainly

\footnotetext{
${ }^{1}$ TD 32, pp. $185-6$; ZZTJ 185, p. 5795; 190, p. 5977; Wechsler 1979, pp. 174-5.

${ }^{2}$ JTS 57, p. 2301.

${ }^{3}$ JTS 62, pp. 2381-2; ZZTJ 187, p. 5847; Wechsler 1979, p. 172. For former Sui officials made zongguan, see ZZTJ 187, pp. 5851-2.

${ }^{4} J T S$ 199B, p. 5359; ZZTJ 189, p. 5906.
} 
by the troops sent out from the capital region. ${ }^{5}$ Careful examination of the period of Gaozu, however, shows that although it is not clear how large the garrisons under their command were, the area commands often played important roles in driving back the Turks. ${ }^{6}$ In some cases, however, generals of expeditionary armies (xingjun) were stationed on the frontier for defense. $^{7}$

In 623, Dou Jing, Aide (zhangshi) of the Superior Area Command of Bingzhou, presented a proposal to strengthen the frontiers by opening up garrison fields in Taiyuan. Despite rejection by the court, Dou Jing persisted and sent up several memorials arguing for garrison fields, and was eventually summoned to the court to debate with the Chief Ministers. The debate ended in his favor. ${ }^{8}$

After Tang brought all China under its control in 625, Gaozu made plans to build ships for battles on the Yellow River, and to dig tunnels on the northern frontiers to block invasions by the Turks. ${ }^{9}$ The practice of using the term $s h u$, as used for communications between equals, to refer to letters to the Turks was given up in 625 , when China was preparing to attack the Turks. Gaozu ordered substitution of the terms zhao or chi, "to order" or "an order" from the emperor to his subjects. ${ }^{10} \mathrm{He}$ also decided to restore the Twelve Armies of the capital region, which had been established in 619 and disbanded in 623 . Their reestablishment ultimately aimed at defeat of the Turks. ${ }^{11}$

The militia system was further rationalized and improved under the second emperor, Taizong. The militiamen were organized into "assaultresisting garrisons" or "intrepid militias" (zhechong fu). Each militia consisted of $800,1,000$ or 1,200 men. These militias were heavily concentrated in the metropolitan area, and a small proportion of them were based in the frontier regions. For example, Liangzhou had seven units, and thus 7,000 militiamen; Shazhou had three, Guazhou one, and Ganzhou two (all of them in present Gansu). ${ }^{12}$ In addition to these militiamen serving in the

\footnotetext{
${ }^{5}$ Kang Le 1979, p. 19.

${ }^{6}$ See the chronological summary of the battles during Gaozu's reign in Cen Zhongmian 1958, pp. 118-71.

${ }^{7}$ ZZTJ 187, pp. 5860-1.

${ }^{8}$ JTS 61, p. 2369; ZZTJ 190, p. 5974.

${ }^{9}$ CFYG 990, p. 11634.

${ }^{10}$ XTS 215A, p. 6032; ZZTJ 191, p. 5996; CFYG 990, p. 11635.

${ }^{11}$ ZZTJ 191, p. 5995; CFYG 990, p. 11635.

${ }^{12} \mathrm{Gu}$ Jiguang 1955, p. 7659.
} 
frontier garrisons, soldiers were recruited by other methods for the same purpose and there were also long-service garrison troops. For major military frontier campaigns, expeditionary armies would be organized consisting of militiamen, conscripts and non-Chinese troops. ${ }^{13}$

\section{Taizong: Expansion}

The transfer of the throne from Gaozu to his second son, $\mathrm{Li}$ Shimin, known to history as Taizong, was dramatic. In the sixth month of 626 , a band led by Li Shimin ambushed and killed the heir apparent, Li Jiancheng and his younger brother at the Xuanwu Gate of the Imperial Palace. Three days later he became the heir apparent and within two months he made Gaozu abdicate the throne. ${ }^{14}$

There can be no doubt that, unlike his father, Tang Taizong was a man of large vision as well as driving personal ambition, the latter quality demonstrated by his ruthless elimination of two of his brothers and seizure of power. After completing the consolidation of Tang dynastic power within the country, he undertook to expand its frontiers to those of the Han empire by conquering the Turks, establishing Chinese control over the Western Regions and extending Chinese rule over Liaodong and North Korea. Taizong was not uniformly successful in his undertakings, notably in his campaigns against Koguryǒ, and he himself did not live to see theirsuccess, which was achieved, however incompletely, under his successor, Gaozong.

These efforts all seem to be a continuation of Emperor Yang's expansive policies. Yet, instead of being criticized by traditional Chinese historians, Taizong has been held up for admiration as one of the greatest emperors in Chinese history. He has maintained this image among modern Chinese in general as well as among Chinese and Western scholars. He is given credit not only for wise and effective government but also for his conquests that made Tang China into a cosmopolitan world empire.

What made him different from Emperor Yang? The answer seems to be simple: he succeeded in making China internally united and externally powerful, while Emperor Yang was not only defeated abroad but also destroyed his own dynasty's internal stability and left China in chaos.

It has been argued that Taizong's rule constituted a model of good government, in which the emperor encouraged scholar-official participa-

\footnotetext{
${ }^{13}$ Pulleyblank 1955, pp. 61-8; Wechsler 1979, pp. 207-8.

${ }^{14}$ Li Shutong 1965, pp. 153-91; Wechsler 1974, pp. 67-78.
} 
tion in government. Taizong is credited with paying special attention to their advice, criticisms and remonstrance. His government has become famous for the emperor's deep personal rapport with a group of capable administrators. ${ }^{15}$ The formalization of the system of the Three Departments, Department of State Affairs, Secretariat and Chancellery, as the governing body under Taizong, it is held, prevented both the emperor and his Chief Ministers from monopolizing power. ${ }^{16}$

This idealized image of Taizong has, however, been challenged as misleadingly turning him into a larger than life figure, and in any event as appropriate only to the first years of Taizong's reign. ${ }^{17}$ As Wechsler concludes, from the late 630 's on, Taizong was not as willing as before to heed opinions from such officials as Wei Zheng, especially on important issues. $^{18}$

Taizong nevertheless was a capable military leader with a comprehensive vision. Early in his reign, Taizong's policy was generally cautious, and he was unwilling to stretch his forces too far and wide. When some officials in their memorials advocated that the ruler must be the sole authority and power, that he should not delegate any authority to underlings, and should engage in aggressive wars designed to cow the "barbarians" into submission, Taizong approved the opposite policy, relying instead upon the advice of Wei Zheng to "stop wars, promote the values of peace, spread virtue and extend kindness. If the Middle Kingdom was in peace, people from far away would submit willingly."19

In 630, when his ministers proposed an attack against Linyi because of the latter's insubordinate language in its memorial to Tang, Taizong refused, claiming that war was an ill-omened instrument to be used only as a last resort. He pointed out that the repeated and unsuccessful campaigns of Emperor Yang had only resulted in stirring up his own people against him and in bringing about his own death. It was a waste of effort, said Taizong, to launch an expedition just to punish objectionable language. ${ }^{20}$ In 631, when Kang (Samarkand) asked to submit to China, Taizong did not give permission on the grounds that if the request were

\footnotetext{
${ }^{15}$ Wechsler 1979, pp. 190-1.

${ }^{16}$ Sun Guodong 1957, p. 23.

${ }^{17}$ Wechsler 1979 , p. 191.

${ }^{18}$ Wechsler 1974, pp. 149-51.

19 JTS 71, p. 2558.

${ }^{20}$ XTS 222C, p. 6298; ZZTJ 193, pp. 6078-9.
} 
accepted, Tang would have to come to the rescue whenever Kang was in danger. $^{21}$ Taizong made it clear that Tang did not have the ability to stretch its resources that far.

None of this means that Taizong did not have any political ambitions to build an empire, though not necessarily one slavishly imitating the Han model. Taizong was a product of his time, and presented a new image of a ruler which combined Chinese and non-Chinese attributes. He was motivated both by the Chinese belief in the legitimacy of the Son of Heaven to rule All-under-Heaven, and by a desire to be looked up to as a ruler of the non-Chinese as Heavenly Qaghan. He envisioned a grand empire on this dual basis, and step by step he carried out his design. He accepted Wen Yanbo's idea to use the jimi system as a way to gradually sinicize the nomads into the Chinese way (Chapter 5). Taizong also enlisted non-Chinese generals and nomadic military forces into the Tang armies. Without this policy, Tang success would not have been possible.

Always a capable ruler, Taizong kept firm hold on his authority to formulate foreign policy. After the conquest of the Eastern Turks he steadily carried forward his long range plan of empire building. On China's northwestern frontiers, Taizong established Yizhou in Hami in 630. Four years later in 634-635, Tang launched a military expedition to subdue the Tuyuhun and convert their state into an outer subject on the route to the Western Regions. Although Taizong made peace with Tibet, a new rival force, by forming a marriage alliance in 640, in 639 he ordered an attack on Gaochang, and upon its success in 640 he established Xizhou, Tingzhou and the post of Protector-general of Anxi, thus creating a foothold in the Western Regions. This set the stage for the later Tang victory over the Western Turks, whose territory was west of the Altai Mountains, with its influence extending into the Western Regions.

From 644 until the end of his reign five years later, Taizong launched military expeditions every year. In 644 the Protector-general of Anxi attacked Karashahr. In the northeast, Taizong ordered three major expeditions against Koguryǒ in 644-645 under his personal command, and in 647 and 648. All were aimed at establishing Chinese control over the Korean peninsula. In the year 646 Tang conquered the Xueyantuo and imposed the jimi system over all the Tiele people on their steppe land, which meant that Tang administration extended to north of the Gobi Desert. In 648 after a Tang military success over Kucha, the nearby oasis states gave

${ }^{21}$ ZZTJ 193, p. 6091. 
their allegiance to the Tang court. The Western Turks under Helu also submitted to Tang. Taizong was then able to move the seat of the Protectorate of Anxi further west to Kucha and to establish the Four Garrisons in the Western Regions.

Although his reign ended with his failure to conquer Koguryǒ Taizong was on the whole successful in achieving the objectives of his foreign policy. This was due to the strength of the militia system, his success in getting the cooperation of nomadic allies, and his own superior leadership. Growing up as a military man and well experienced in political affairs before he became emperor, he was a master of strategy, cautious and skillful, and showed a much better understanding of the external situation and sounder assessment of events than his predecessors. Seeing the internal political weakness within the Turkish rulership, he knew when to take advantage of it. He first made an alliance with the Xueyantuo and then broke that alliance when the time was ripe. His persistence in launching campaigns to penetrate the Western Regions made possible the eventual conquest of the Western Turks during Gaozong's reign.

\section{The Making of Foreign Policy under Taizong}

Chief Ministers under Taizong were mostly pragmatic men, and some had practical experience in both military and civilian administration. Taizong intentionally excluded imperial relatives from top positions with the one exception of his brother-in-law, Zhangsun Wuji. ${ }^{22}$ These men were not isolated from reality, sitting in the court with knowledge only of beautiful prose and calligraphy. They actively participated in state affairs, and their opinions were not necessarily dependent on their official positions, civil or military.

Zhangsun Wuji, for example, was an able military strategist, but often followed a cautious line. Before the final conquest of the Eastern Turks, he favored keeping the peace agreement, whereas Xiao Yu, with both military and civilian official background, advocated military action. Wen Yanbo, with experience as a civilian official, was expansionist when he rejected Gaozu's. idea that China should not make Koguryǒ a tributary. In the debate on how to settle the Turks after 630, he proposed a plan of gradual sinicization of the nomads aimed at expanding Chinese influence through peaceful means.

${ }^{22}$ For these chief ministers, see Wechsler 1979, pp. 193-200; see also Guisso 1978, pp. 167-98, for a list of chief ministers from 618 to 705 . 
Fang Xuanling, a member of the first generation of civil service examination graduates, was opposed to the wars against Koguryǒ but he had very practical views on the comparative feasibility of war or peace in dealing with the nomads. In his historian's comment in the Zhoushu he says that since the situation changed frequently and the balance of power did not remain the same, in choosing between subjugating "barbarians" or appeasing them, and in in choosing between going to war or forming a marriage alliance, the best strategy was to adapt plans to the actual situation. ${ }^{23}$ Zhang Liang, with both military and civilian experience, strongly opposed Taizong's campaign against Koguryǒ when he was Minister of Justice with the status of Chief Minister in 643. But when his opinions were rejected he became one of the commanders in the campaign. ${ }^{24}$ Among officials outside the Chief Minister rank, there were also military officials, such as Jiang Xingben and Yuchi Jingde, who opposed the war against Koguryǒ. ${ }^{25}$

It is true that military officials were often inclined toward military solutions. Military action was their profession, and promotion for them depended on their military success. As we shall see (Chapter 5), in a court discussion on whether to attack the Turks, Chief Minister Du Ruhui, speaking as the Minister of War, insisted on a bellicose attitude. Chief Ministers Li Shiji and Li Jing were of primarily military background. Both Li Shiji and Li Jing were supporters of the war against Koguryǒ (Chapter 6). They exerted a strong influence on Taizong. ${ }^{26}$

Among Taizong's Chief Ministers, the most Confucian-minded was Wei Zheng. ${ }^{27}$ As a firmly Confucian scholar-official he consistently opposed the policy of extending Chinese rule over non-Chinese. In the debate on how to resettle the Turks, he and many others drew a clear line between the "civilized" Chinese and the "savage barbarians," and insisted that the Chinese were the roots of All-under-Heaven while the "barbarians" were merely like branches and leaves. He opposed Taizong's decision to make Gaochang a Chinese prefecture and upheld the Confucian principle of opposing war.

It is interesting to note that Wei Zheng also opposed Taizong's ef-

${ }^{23} Z S 50$, p. 921. Biographies of the four are in JTS 61, 63, 65, 66; XTS 91, 96, 101, 105.

${ }^{24}$ JTS 69, pp. 2514-5.

${ }^{25}$ JTS 59, p. $2334 ; 68$, p. 2500.

${ }^{26}$ Biographies are in JTS 67, 69; XTS 93, 94.

${ }^{27}$ Wechsler has a detailed study on Wei Zheng, see his 1974. 
forts to entice foreign countries to come to pay tribute to the Tang court, for he held that political prestige gained from the tributary practice would not benefit China economically and would in fact exhaust China's resources. He believed, on the other hand, that trade between the nonChinese and frontier Chinese people should be encouraged, since it benefitted the common people. ${ }^{28}$

Chu Suiliang was another Confucian-minded scholar-official who took over the role of Wei Zheng after Wei's death and became a Chief Minister in 644. He was opposed to the establishment of a prefecture in Gaochang and to war against Koguryǒ. But Taizong did not follow his opinions on all these matters.

Under both Gaozu and Taizong, frontier officials played an important role in the formulation of foreign policy. In $622 \mathrm{Li}$ Daen, the Daizhou zongguan, suggested an attack on Mayi, an important frontier town then under Turkish control. Gaozu followed his advice. ${ }^{29}$ In 623 Dou Jing, a member of the famous northwestern aristocratic Dou family, as Aide of the Superior Area Command of Bingzhou, presented a memorial suggesting opening up garrison fields in Taiyuan to support frontier defense purposes. He persisted with several memorials and was eventually summoned to the court to debate with the Chief Ministers. The debate ended in his favor. In Taizong's time, when he was the Area Commander of Xiazhou, he sent spies into the Turks lands to divide them and enticed them to submit to Tang. In the debate on how to settle the Eastern Turks after 630 he participated in the court discussion. ${ }^{30}$

In the 643 discussion on whether to carry out the marriage promise made to the Xueyantuo, Taizong followed the opinion of Qibi Heli to refuse the marriage. Qibi was then a general in the capital, but as a former chief of the Qibi tribe and having just returned from the capture of the Xueyantuo, he had actual knowledge of the internal situation among the Xueyantuo.

In 644, when the Protector-general of Anxi, Guo Xiaoke, proposed an attack on Karashahr, Taizong agreed. ${ }^{31}$ In the late 640's Taizong adopted an aggressive policy towards the non-Chinese in the region of Nanning. This was suggested by the Area Commander of Suizhou, Liu

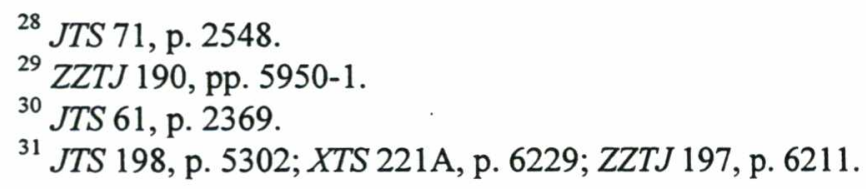


Boying, who in his memorial proposed that Tang send out an expeditionary force to chastise the Man peoples so that Tang could establish communications along the route through the Erhai Lake region in Yunnan to India. $^{32}$

The emperors often consulted the frontier officials for detailed information and recommendations on strategy. In 623 Gaozu asked the former Bingzhou zongguan Liu Shirang, of military official background, about frontier defense, and acted upon his advice. ${ }^{33}$ Before his campaign against Koguryǒ Taizong summoned Zhang Jian, the Area Commander of Yingzhou, and Cheng Mingzhen, the Prefect of Mingzhou, to the court, to tap their first hand knowledge of the geographical conditions of Liaodong and their opinions on military strategy. ${ }^{34}$ Early in Taizong's reign Cui Dunli often acted as Chinese envoy to the Turks and then was appointed the Area Commander of Lingzhou. After he became the Minister of War, he went as commissioner to the Uighurs several times. Because he knew the situation among the nomads very well, his proposals were often adopted. $^{35}$

The important role of the frontier officials can be also seen in the fact that their administration often affected relations with nearby nonChinese. They would often make their own decisions without previous permission from the top. Whether successful or not, these decisions often had lasting consequences for the relations of China with its foreign neighbors. These frontier officials continued to play important roles during subsequent reigns.

\section{Gaozong and Empress Wu: from Expansion to Defense}

After his death in 649, Taizong was succeeded by his son Gaozong. From 660, however, Gaozong's empress, Wu Zetian, became the actual ruler because of the emperor's poor health. She took part in court audiences, albeit from behind a screen. On his death in 684, Gaozong was succeeded by the elder of his two surviving sons by Wu Zetian, later known as Zhongzong. A brief power struggle then ensued between Wu Zetian and the new emperor's consort, Empress Wei, also a strong and ambitious woman who dominated her husband. When Zhongzong began

\footnotetext{
${ }^{32}$ Backus 1981, p. 17.

${ }^{33}$ JTS 69, p. 2523; ZZTJ 190, p. 5968.

${ }^{34}$ JTS 83, p. 2776; p. 2784; ZZTJ 197, p. 6213.

35 JTS 81, pp. $2747-8$.
} 
to give high offices to his wife's relatives, Wu Zetian accused him of planning to hand over the empire to them and, using her authority as Empress Dowager, deposed him and placed her younger son, the later Ruizong, on the throne. Ruizong was not allowed to function as emperor, but was kept sequestered while the Empress Dowager, now dispensing with the pretence of a screen, presided openly over the court. In 690 she proclaimed herself emperor of the Zhou dynasty (690-705), the only female ruler in name as well as fact in Chinese history.

During the early part of his reign Gaozong faithfully continued his father's expansionist policy, carried on by the momentum of China's previous military successes. This policy was in accord with Gaozong's own personal interests and ambitions. As the third choice for succession to the throne, and being in no way as strong as his father, Gaozong felt keenly the need to live up to his father's reputation and to prove himself a worthy ruler. ${ }^{36}$ He succeeded in extending the boundaries of the Chinese empire to the farthest limits that it ever attained in the course of history, with his conquests of the Western Turks in 659, Paekche in 660 and Koguryǒ in 668.

Gaozong and Empress Wu made serious efforts to live up to the ideal of a universal empire. The jimi fuzhou system was extended to the Western Regions and the Korean peninsula. Military actions were resorted to whenever rebellions by subject peoples took place. The trans-frontier administrative system was improved through various adjustments and through the establishment of six major Protectorates surrounding China.

However, this expansion placed a heavy burden on China's resources which were overextended and unable to sustain control over so wide a territory. Empress $\mathrm{Wu}$, while supporting the expansionist policy after 660 , when she took actual control of the central power, gradually changed to a policy with more emphasis on defense than expansion.

From 670 the newly enlarged Chinese empire was forced into retreat when it was severely defeated by Tibet in the battle at Koko Nor. While the court persisted in competing with Tibet for control over the Western Regions, from this time on China under Empress Wu turned away from aggression and concentrated more on defense, accepting the reality that China was in no position to maintain its administration in its overextended territory.

The Protectorate of Andong on the Korean peninsula was with-

${ }^{36}$ Guisso 1978 , pp. 109-10. 
drawn back into Liaodong in 676. In 679 the Eastern Turks broke away from Chinese control and in 682 revived their empire. Empress Wu recognized the qaghan's rule and accommodated the Turkish demands for material goods and a marriage contract so as to appease and prevent them from attacking, so that Tang could concentrate on dealing with the Khitan invasion of Hebei in 696-697.

And yet Empress Wu was by no means a weak ruler. She demonstrated a firm attitude in competing with Tibet over the Western Regions, and did not hesitate to resort to military force in frontier defense. At the same time, though it hardly reflects on Empress Wu personally, the fact that she was a usurper and a woman undoubtedly weakened her position in dealing with external affairs. The Turkish qaghan made it an excuse for using arrogant, insulting language and the Khitan used a demand for the restoration of Tang as propaganda in their invasion (Chapter 8). In the end she was forced to give up her plans to establish her own dynasty and finally, as an old woman, to abdicate in favor of her deposed son.

One major development in the shift of China's foreign policy from aggression to defense was the establishment of permanent armies on the frontiers. Previously under Taizong, militiamen would only serve in the frontier garrisons for a period of time. There were also long-service garrison troops composed of Chinese and of nomads who had submitted. For major military frontier campaigns, expeditionary armies would be organized consisting of militiamen, conscripts from other areas, and non-Chinese troops. $^{37}$

With the more frequent warfare in Gaozong's and Empress Wu's time such an arrangement was not sufficient. From the later part of the reign of Gaozong onwards, the court started to build up larger and permanent defensive units on the frontiers with such labels as "armies" (jun) and "fortresses" (cheng). These units were intended to be permanently ready to do the jobs formerly performed by expeditionary armies. ${ }^{38}$ In 677 the first permanent armies were established in China's northwest under the names of Heyuan, Jishi and Momen. Their primary responsibility was to defend against the Tibetans. ${ }^{39}$ The Protectorate of Anxi in the Western Regions in 640 had 1,000 troops and the size of the permanent garrison reached

\footnotetext{
${ }^{37}$ Pulleyblank 1955, pp. 61-8; Wechsler 1979, pp. 207-8; Lai 1986, pp. 50-1.

${ }^{38}$ Pulleyblank 1955, pp. 67-8.

${ }^{39}$ Pulleyblank 1955 , p. 68 ; p. 147 , note 30 . For more details, see Lai 1986 , chapters 4 and 5 .
} 
30,000 by $692 .{ }^{40}$ The Protectorate of Andong set up in P'yǒngyang after the conquest of Koguryǒ in 668 was manned by 20,000 troops. ${ }^{4}$

The armies in the northwest functioned effectively to defend China against the Turks, other nomads and the Tibetans up to the time of the An Lushan rebellion in 755. During his seven year-tenure as the Commissioner of the Heyuan Army (ca. 677-684), Heichi Changzhi set up garrisons, watchtowers, opened garrison fields and led attacks against the Tibetans in Qinghai. The Tibetans, according to Chinese sources, "were afraid of Changzhi and did not dare to raid again."42

Between 701 and 706, when Guo Yuanzhen was Area Commander of Liangzhou, he set up the Fortress of Herong in the south and the Baiting Army in the north to defend against the Tibetans and Turks, and ordered the Prefect of Liangzhou to open up garrison fields. Thus, an area that was previously troubled by the Turks and Tibetans enjoyed peace and order. Guo's good government won the support of both Chinese and nonChinese. ${ }^{43}$ Before the end of Empress Wu's reign in 705 more armies were set up on the northeastern and northern frontiers to form the basic defense line. $^{44}$

\section{Chief Ministers with Experience in Frontier Affairs under Gaozong and Empress Wu}

Neither Gaozong nor Empress Wu had the kind of experience Gaozu and Taizong had had in military affairs or the same degree of actual contact with the social reality of China. Internal disputes within the leadership during their reigns also sometimes damaged Tang frontier policy, as we shall see in the cases of Liu Rengui and Li Jingxuan in 678 concerning the campaign against Tibet, and Pei Yan and Pei Xingjian in dealing with the Turkish rebellion in 681. Despite these limitations, Gaozong and Empress Wu had some capable Chief Ministers and well-established political institutions inherited from earlier reigns.

Empress Wu relied on a group of Northern Gate scholars (Beimen xueshi), her personal secretaries, for decision-making while at the same time her own intelligence and skillful mastery of court politics were also

\footnotetext{
${ }^{40}$ XTS 221A, p. 6222; p. 6232.

${ }^{41}$ ZZTJ 201, p. 6357.

${ }^{42}$ JTS 109 , p. 3295 ; Sato 1958 , p. 334 ; for military farms, see pp. 367-8.

43 JTS 97, p. 3044; ZZTJ 207, pp. 6557-8.

${ }^{44}$ For the locations, names and dates of these armies, see Pulleyblank 1955, Map II.
} 
assets. Most scholars recognize that her leadership brought innovations and improvements into the bureaucracy. There has been controversy among modern scholars whether and to what extent Empress Wu deliberately adopted policies seeking support from groups formerly excluded from the ruling aristocracy. It does seem clear, however, that the reign of Gaozong and Empress Wu saw a broadening of the ruling class's social background, and Empress Wu showed an obvious talent for choosing capable officials.

During this period, the court increased the number of non-Chinese generals appointed, ${ }^{45}$ but the constant interactions with foreign countries also brought forth a group of experienced and talented Chinese frontier officials and generals. Some of them were promoted to be chief ministers and in that position they continued to perform their duties on the frontiers. Some holding such dual appointments did not participate in decisionmaking at court while others contributed to decision-making at the central level. ${ }^{46}$ The following are some examples.

Cui Dunli was experienced in frontier affairs when he was appointed Minister of War under Taizong. His proposals were often adopted by the court. In 653, under Gaozong he was made Chief Minister. ${ }^{47} \mathrm{He}$ had a family background in frontier affairs. His grandfather Cui Zhongfang had been a Regional Military Commander (zongguan) during the Sui period. $^{48}$

Ren Yaxiang, as the Protector-general of Yanran, participated in military expeditions against the Western Turks in 657, and was promoted to be Minister of War. He became a Chief Minister in 659. In 661 he was one of the commanders of the expeditions against Koguryǒ and died while on active service in the army the following year. ${ }^{49}$

Liu Rengui, of poor and lowly background, rose to be Chief Minister in 665 primarily due to his performance in dealing with Korea. He continued to be in charge of campaigns against Silla and in defense against Tibet. $^{50}$

Cui Zhiwen, with an aristocratic family background, started as a

\footnotetext{
${ }^{45}$ Zhang Qun 1986, pp. 236-7.

${ }^{46}$. For a list and brief summary of the careers of the chief ministers during $681-705$, see Guisso 1978, Appendix B.

47 JTS 81, pp. 2747-8; XTS 106, p. 4044.

${ }^{48}$ SUIS 60, pp. 1449.

49 JTS 194B, p. 5187; ZZTJ 200, p. 6324; p. 6327; Twitchett 1979, p. 254.

${ }^{50}$ JTS 84, pp. 2789-96; XTS 108, pp. 4081-5.
} 
frontier officer. While holding a minor position in Lingzhou he presented fifteen memorials to the court around 664, proposing to move the Tiele tribes back north of the Yellow River because they could not live peacefully with the agricultural Chinese. Eventually the court agreed with him, and according to the Chinese sources, the nomads were also grateful to him because they were moved to good pasture land. When Cui was the Prefect of Lanzhou his good government attracted the Dangxiang people to submit. He was made Chief Minister in $679 .^{51}$

Wei Daijia, from an official family, distinguished himself for his bravery on the battle field. He was then appointed as a frontier official. $\mathrm{He}$ was made Chief Minister under Empress Wu in 685, and continued to lead military campaigns against the Turks. Aware of his lack of literary ability, he requested demotion and expressed the wish to continue his military career, to which Empress Wu agreed. After he suffered a defeat in the war with the Tibetans in 689 he was exiled and died soon after. ${ }^{52}$

Lou Shide, of obscure family background, got his examination jinshi degree before the age of 20 . He later volunteered for service in the army sent against the Tibetans and acted as envoy to Tibet. He distinguished himself through military achievements and good government as a frontier official. In 693 he was made Chief Minister and continued to use his expertise as commissioner for frontier garrison fields and as a general. As a result of defeat in battle against Tibet in 695 he was demoted but was soon reestablished as Chief Minister. ${ }^{53}$

Wang Xiaojie, of an obscure family background, was promoted to Chief Minister in 694 after his success in recapturing the Four Garrisons. An excellent general, he continued to command in battles, and died fighting against the Khitan in $697 .^{54}$

Tang Xiujing, of official family background, was known for his literary and military abilities. He obtained his examination mingjing degree before the age of 20 and became a military officer, participating in several battles against the Turks. He opposed the court's plan to give up Fengzhou, and it was on his advice that China recovered the Four Garrisons. He once served as Vice Protector-General of Anxi and had a good mastery of the frontier situation, being familiar with all the strategic points

\footnotetext{
${ }^{51}$ JTS 185A, p. 4791; XTS 106, p. 4040.

${ }^{52}$ JTS 77, pp. 2671 ; XTS 98, p. 3904.

53 JTS 93, pp. 2975-6; XTS 108, pp. 4092-3.

${ }^{54}$ JTS 93, pp. $2977-8$; XTS 111, p. 4148.
} 
along northwestern frontier. Even before he became Chief Minister in 703 he was often asked to participate in court discussions with the Chief Ministers concerning the Western Regions because of his expertise on the subject. Empress Wu once remarked to her Chief Ministers: "Xiujing has profound knowledge of frontier affairs; ten of you are not his equal." During later reigns he continued to be a Chief Minister. ${ }^{55}$

\section{Xuanzong: from Defense to Aggression}

In 705, already in her eighties, Empress Wu was forced to abdicate the throne in favor of her son, Emperor Zhongzong. The Li royal family restored the name of the Tang dynasty. Political authority was, however, in the hands of Zhongzong's consort, Empress Wei, and her daughter. The throne passed to Ruizong, Empress Wu's other son, after a bloody coup in 710 , and two years later Ruizong abdicated in favor of his third son $\mathrm{Li}$ Longji, the major leader in the coup. The new emperor, known posthumously as Xuanzong, and informally to posterity as Minghuang, the Brilliant Emperor, ruled from 712 to 756 , a long and eventful period which was the high point of the Tang dynasty in terms of internal peace and prosperity. It is also remembered as a golden age for its achievements in arts and literature, but despite the political sophistication of its institutional arrangements, the reign ended in the catastrophe known as the An Lushan rebellion, which changed China drastically and permanently.

During the early years of Xuanzong's reign, Chief Ministers Yao Chong and Song Jing urged caution in foreign policy. But Xuanzong displayed his ambition for military success as early as 714 in supporting the recapture of Yingzhou in the northeast from the Khitan by force, and in proposing to assume personal command in a campaign against Tibet. In 716 a Hu (Sogdian) suggested to the court that the countries "south of the sea" (Southeast Asia) were rich in marvelous treasuries and profitable for trade and asked that he should be sent to go and obtain them. He also proposed to go to Shiziguo (modern Srilanka) to acquire medicines and women doctors who could be brought into the imperial palace. Xuanzong was tempted. He ordered a censor to accompany the Sogdian on such an expedition but changed his mind when the censor memorialized against the plan, arguing that to compete with merchants for profits was not the kingly way. ${ }^{56}$ Such caution was increasingly atypical. Minghuang's nor-

${ }^{55}$ JTS 93, pp. $2978-80 ;$ XTS 111 , pp. $4149-51$.
${ }^{56}$ ZZTJ 211, p. 6718. 
mal tendency was to support aggressive actions by his generals.

Throughout his reign Xuanzong followed the policy of reinforcing frontier defenses as his main strategy for dealing with foreign issues. Several important changes were made in the frontier system. Despite temporary adjustments, there was a steady rise in the number of armies and in their complement of troops. By 722 the total number of frontier soldiers was said to be 600,000 . Chief Minister Zhang Yue proposed a cut of 200,000 on the grounds that there was no severe foreign threat at the time. When the emperor expressed his doubt about this, Zhang, well experienced in military and frontier affairs, insisted that he had been on battle fields for a long time and understood the situation of the Chinese armies well. Excessively large numbers of troops were, he pointed out, often kept by generals for their own private use. Xuanzong was finally persuaded to follow his suggestion. ${ }^{57}$ For 742 alone, however, altogether forty-seven frontier armies are listed by name. ${ }^{58}$

A second major change was the recruitment of permanent, professional soldiers both as palace guards and as frontier troops. ${ }^{59}$ The fubing system, already in decay, continued to exist in name but ceased to function in practice. On the frontier, while some troops were still recruited from the ranks of militiamen for an average period of service of three years, the government also recruited permanent soldiers who would live with their families on the frontiers to meet the needs of frequent military expeditions. $^{60}$ By 742 the total number of troops under the ten Military Commissioners had again grown to around 500,000. ${ }^{61}$ These permanent armies worked garrison fields to support part of their needs. In the Western Regions merchants were taxed to partly supply the garrisons. ${ }^{62}$ The bulk of the expenses of frontier armies, however, was borne by the central government. Around 713 the annual frontier expenditure was approximately $2,000,000$ strings of cash. By 741 it had already reached 10,000,000. By 755 it had again increased to 14 or 15 million, and constituted a heavy financial burden. ${ }^{63}$

${ }^{57}$ JTS 97, p. 3053; XTS 125, p. 4408; ZZTJ 212, p. 6753.

${ }_{58}^{58}$ Pulleyblank 1955, p. 68.

${ }_{59}^{5}$ JTS 97, p. 3053; XTS 125, p. 4408; ZZTJ 212, p. 6753.

${ }^{60}$ Pulleyblank 1955, pp. 69-70.

${ }^{61}$ This is according to ZZTJ 215, pp. 6847-9. JTS 38 (pp. 1385-9) has different figures. It says the frontier troops numbered roughly 490,000 in total.

${ }^{62}$ Ise 1968, pp. 446-50.

${ }^{63}$ TD 148, p. 773; Pulleyblank 1955, pp. 71-2. 
Third, with the decline of the Turks, many non-Chinese came to submit to Tang. They were incorporated into the Chinese armies to serve in frontier garrisons and participate in military expeditions. ${ }^{64}$ At the same time the court, having learned from earlier experience, was on guard against nomads who had submitted, fearing possible rebellions. For example, on the northern frontiers, the Tianbing Army, first set up in 699, was reestablished in 717 in Taiyuan in order to meet the perceived need to guard against the Tiele Turks, who had recently surrendered and were scattered north of Taiyuan. Soon after, the Tiele Turks were organized into Chinese-style military formations, and the Tianbing Army was charged with direct supervision of these non-Chinese armies. ${ }^{65}$

The large number of non-Chinese in the Tang armies can be seen in an edict issued in 714 announcing Xuanzong's taking over personal command of a campaign against the Tibetans. It states that there were 200,000 non-Chinese soldiers in this army. ${ }^{66}$

After their submission, the Khitan were organized into the Jingxi Army in 716 and their chief was appointed Military Commissioner (jinglue dashi). At about the same time the $\mathrm{Xi}$ were organized into the Baosai Army and their chief was appointed Military Commissioner. ${ }^{67}$

This increasing reliance on non-Chinese troops and generals, on the one hand, shows the growing influence of the non-Chinese component of Tang society, and on the other, the weakening of the Chinese component of the military. ${ }^{68}$

The fourth and the most important change was the organization of frontier armies into various "regional commands" (fanzhen or fangzhen) under military commissioners (jiedu shi) on the northern, western and southwestern frontiers. This was intended to increase the effectiveness and coordination of these armies in military manoeuvres. The Military Commissionership eventually became a very powerful post. Its holder was to supervise one of the large frontier armies and coordinate its subordinate units during wartime.

${ }^{64}$ Zhang Qun 1990, pp. 2-3.

${ }^{65}$ JTS 99, p. 3090; XTS 127, p. 4442; ZZTJ 211, p. 6728; CFYG 992, pp. 11651-2; Zhang Qun 1986, pp. 238-9.

${ }^{66} C F Y G 118$, p. 1407.

${ }^{67}$ XTS 219, p. 6170; p. 6174; ZZTJ 221, p. 6720. It is not clear when the Baosai Army of the Xi was established, but in an edict of 718 (CFYG 986, pp. 11583-4) the army is mentioned.

${ }^{68}$ Zhang Qun 1986, pp. 245-6. 
Between 710 and 733 nine regional commands were organized. In the far south a Lingnan jinglue shi was set up. The post was lower in rank than a jiedu shi but the responsibilities were similar. ${ }^{69}$ In 756 , during the An Lushan rebellion, Lingnan was promoted to be a regional command under a jiedu shi. ${ }^{70}$

A military commissioner assumed more military power and was in control of larger standing armies and wider areas than an area commander or protector-general. Among the six major protectorates, the ProtectorsGeneral of Beiting and Anxi were changed to Military Commissioners of Beiting and Anxi. The Protectors-General of Chanyu and Anbei were brought under the Military Commissioner of Shuofang. Andong was under Pinglu, and Annan under Lingnan. ${ }^{71}$ In the Western Regions, the Military Commissioners of Anxi and Beiting by 714 had altogether 44,000 troops. ${ }^{72}$ In 742 the Military Commissioner of Fanyang, on the frontier facing the Khitan and $\mathrm{Xi}$, had the largest command with a force of $91,400 .^{73}$ The power of the Military Commissioner grew to the point that he was given authority to handle financial and supply problems and also had responsibility for civil affairs.

It should be noted here that from Taizong's time on, China had been divided into ten administrative regions called "circuits" (dao), each comprising a cluster of prefectures. Initially, there was no permanent office in a circuit. Each was supervised by a commissioner sent out from the capital at irregular intervals to inspect the operation of local governments and ensure the good performance of local officials. The number of circuits increased to fifteen by 733 , and permanent officials were appointed in the following year with the title of "investigation commissioner" (caifang shi), soon renamed "surveillance commissioner" (guancha shi) ${ }^{74}$ The Military Commissioner of Shuofang was concurrently given the post of Surveil-

${ }^{69}$ Twitchett (1979, pp. 365-7) lists nine frontier commands, not including Lingnan. Ise (1968, pp. 446-7) gives ten, including Lingnan. This is because Lingnan by 733 is lumped in with the other nine military commands, but its commanding officer is referred to as a jinglue shi rather than a jiedu shi. See JTS 38, pp. 1385-9.

${ }^{70}$ ZZTJ 218 , p. 6984.

${ }^{71}$ JTS 38, pp. 1385-9; ZZTJ 215, pp. 6848-51.

${ }^{72}$ Ise 1968 , pp. $266-8$.

${ }^{73}$ For the names of the regional commands and number of troops, horses and clothing, see Ise 1968 , pp. 446-7. Note that Ise relies on JTS 38 (pp. 1385-9), whose figures are different from those in ZZTJ 215, pp. 6847-9.

${ }^{74}$ Twitchett 1979, p. 205; pp. 402-4; Hucker 1985, pp. 487-8. 
lance Commissioner for Guannei circuit in 734 and again in 746, thus having responsibility for civil affairs in the area; the Military Commissioner of Jiannan was simultaneously the Surveillance Commissioner of two circuits. ${ }^{75}$

The changes in the frontier system concentrated huge power in the hands of Military Commissioners, which so improved the efficiency of the frontier forces that passive defense gave way to aggressive defense and then to expansionist expeditions such as the aggressions of Zhang Xuanbiao against Tibet (Chapter 7), Du Xian, Liu Huan and Gao Xianzhi against the Western Regions, and An Lushan against the Khitan in the northeast (Chapter 8).

The famous Tang Chief Minister Du You of the eighth century placed the blame for Tang aggression on the frontier generals, remarking that it was frontier generals, Geshu Han, active on the Tibetan frontiers, Gao Xianzhi, An Lushan in the northeast, and Yang Guozhong in the southwest, who competed in striving to engage China in expansive campaigns in order to obtain favors from the court. ${ }^{76}$ But it is clear that Xuanzong himself cherished dynastic ambitions inherited from his ancestors. $\mathrm{He}$ displayed a quite uncompromising attitude, hoping to restore the boundaries set up under the early reigns, although in the northeast, Xuanzong pragmatically accepted the fact that it was impossible for China to exert any greater degree of control on the Korean peninsula.

These changes also directly affected the power structure of the ruling group at the central level. During Xuanzong's reign, among the thirty-six Chief Ministers at least twelve of them had also held the position of Military Commissioner at one time in their careers. Du Xian was Protector-General of Anxi before he became Chief Minister. ${ }^{77}$ In 735 Chief Minister Zhang Jiuling, famous for his belief that the court should be in the hands of scholar-officials rather than military men, strongly opposed Xuanzong's intention to promote Zhang Shougui to be Chief Minister based on the merit he displayed as Military Commissioner.

Xuanzong agreed, but the next year, when Zhang Juling also opposed the promotion of Niu Xianke, another capable Military Commis-

\footnotetext{
75 Twitchett 1979, pp. 367-9.

${ }^{76}$ TD 185 , p. 985.

77 The calculation is based on Pulleyblank 1955, Appendix V, and on the biographies of these chief ministers.
} 
sioner, to Chief Minister, Xuanzong did not accept his advice. ${ }^{78}$ Between 736 and 752 Chief Minister Li Linfu exercised the role of de facto dictator, since Xuanzong was no longer interested in government. Well aware of the power of the Military Commissioners and the importance of controlling the military, Li himself assumed the title of Military Commissioner of Longyou and Hexi in 738, and controlled the military of both places through his deputies until 740 . The reason for this short tenure is not clear; it may have been the result of a power struggle in the court. ${ }^{79}$

In 746 and 747 as part of his great purge of his political rivals $\mathrm{Li}$ Linfu removed from their official posts two Military Commissioners, Huangfu Weiming and Wang Zhongsi, who had a close relationship with the crown prince, the future Suzong, accusing them of plotting to enthrone the crown prince, whose appointment he had opposed. ${ }^{80}$ Then, in order to prevent Military Commissioners from gaining more power and exerting political influence through military success, Li Linfu persuaded the emperor to appoint non-Chinese generals who distinguished themselves in battles as Military Commissioners. He argued that these non-Chinese of humble origin as a consequence had no political connections at court to challenge the emperor's power and were better fighters. Xuanzong let him have his way. Eventually, except for Jiannan, all the Military Commissioners were non-Chinese, including the half Turkish and half Sogdian An Lushan, his cousin An Sishun, the half Turkish Geshu Han, the Korean general Gao Xianzhi, and Abusi, who was of Turkish origin. ${ }^{81}$

It has been suggested that Li Linfu specially favored An Lushan's advancement so as to use An's support against his political rivals. After the death of Li Linfu in 752, Yang Guozhong assumed the role of dictator at the court. Yang rose to power because his cousin Yang Yuhuan (Consort Yang) was the most favored concubine of Xuanzong. As a political rival of Li Linfu, Yang Guozhong could not command much respect from An Lushan. In order to put An under control, Yang intentionally supported Geshu Han as An's rival. ${ }^{82}$ An Lushan, by then the Military Commissioner of three regional commands, and enjoying great favor from the throne, became involved deeply in court politics, which eventually led

\footnotetext{
${ }^{78}$ Twitchett 1979, pp. 407-8. For a specific study of Zhang Jiuling, see Herbert 1978.

${ }^{79}$ Pulleyblank 1955, pp. 94-5.

${ }^{80}$ Pulleyblank 1955, pp. 89-92.

${ }^{81}$ Pulleyblank 1955, p. 95.

${ }^{82}$ Zhang Qun 1986, pp. 247-52.
} 
to his rebellion in 755 .

\section{Suzong and Daizong: The An Lushan Rebellion and Its Aftermath}

Late in 755, An Lushan led an army of 150,000 men, including Tongra, $\mathrm{Xi}$ and Khitan, from his base in Fanyang on the pretext of having received a secret edict to remove the Chief Minister, Yang Guozhong. He soon captured Luoyang, whereupon he abandoned his pretence of serving the Tang dynasty and declared himself Emperor of Great Yan. The following summer, after a temporary stalemate at Tongguan, the defile where the Yellow River cuts through into the Central Plain, the rebels penetrated into Guanzhong. When Chang'an was about to fall to the rebels, Xuanzong abandoned the capital to take refuge in Sichuan. On the way occurred the famous incident at Mawei post station where his troops mutinied, killed Yang Guozhong and forced the emperor to put to death his favorite concubine, Yang Yuhuan.

The Crown Prince, the future Suzong, remained behind in Guanzhong to organize resistance to the rebels. He was persuaded by Du Hongjian, Deputy Commander (liuhou) of Shuofang, and other officials to make his headquarters at Lingwu, the seat of the Military Commissioner of Shuofang, and to assume the throne there and seek an alliance with the Uighurs. ${ }^{83} \mathrm{He}$ followed this advice, and proclaimed himself emperor. When the news reached Sichuan, Xuanzong abdicated in his favor.

An Lushan's army occupied Chang'an. In 757 An Lushan was killed by his son, An Qingxu, who was himself later killed in early 759 by another rebel leader, Shi Siming. Shi Siming, also of non-Chinese origin, had been left in charge of An Lushan's base in Hebei, surrendered to Tang in late 757, but rebelled again the following year. He, in turn, fell out with his son, Shi Chaoyi, and died in 761 at the hands of one of the latter's officers. The rebellion continued under Shi Chaoyi and was only finally suppressed with the assistance of foreign troops, especially the Uighurs, in 763 under Suzong's successor, Daizong.

The An Lushan rebellion drastically changed China. China not only lost its control over the Western Regions but also suffered losses to Tibet within its own territory. By 763 Tibet had annexed the Hexi and Longyou areas in modern Ningxia and Gansu. From these areas they constantly raided the Tang borders and posed a direct threat to the Tang capital. Defense of the frontier with Tibet took on a new urgency. Tibetan oc- 
cupation of the Gansu corridor also cut off communications between China and the Western Regions. China's control over the Western Regions was in effect ended. The other two major foreign powers were the Uighur empire in the north and the Nanzhao kingdom in the southwest.

China's foreign policy thereafter centered around maintaining a balance of power amongst these four powers. Preoccupied with internal struggles with the provincial governors and severely limited by the lack of economic resources, Tang's rulers became much more pragmatic in dealing with these powerful neighbors, making alliance with one or another of them, and adopting measures that put China in an equal or even inferior position to one or more of them.

A formerly centralized China was changed into a decentralized state with the power of the court severely undermined. In settling the An Lushan rebellion, the court compromised with the rebel forces in the Hebei region and appointed former rebel leaders as Military Commissioners under four regional commands covering areas in present Hebei, part of Shandong and Henan. These were at the time called Youzhou or Lulong, Chengde, Weibo, and Xiangwei (incorporated by Weibo in 775). Known as the three commands of Hebei, the Military Commissioners there only nominally recognized the authority of the Tang central government.

Though accepting titles from Tang as symbols of legitimacy, the generals governed their territories in practice as independent fiefdoms, appointing their own officers and civil officials, collecting taxes and passing on their power to their descendants. They formed alliances among themselves, intermarried, and even preserved a lingering allegiance to the memory of An Lushan and his successors. Until 819 the Pinglu Army, which had been stationed on the frontier in southern Manchuria under An Lushan at the outset of the rebellion but had remained loyal to Tang and crossed into the Shandong peninsula, played the same semi-independent role within its territory and remained outside the effective control of the Tang court.

In the rest of the coutry, regional commands also became permanent during the post-rebellion period, forming a new tier of provinces between the central government and the prefectures, controlled by either military or civil commissioners appointed by the central government but often acting with a good deal of autonomy. In Henan and Shaannan (comprising the valley of the Han river, controlling a vital supply line bringing tax grain to the capital), Military Commissioners, mostly generals with their troops withdrawn from frontier commands in the far west, had 
been set up during the rebellion to contain the rebels and prevent them from penetrating into the still undisturbed grain producing areas farther south. After the rebellion was over these troops remained in place and were sometimes as difficult for the Tang government to control as the former rebels.

Dealing with the provinces continued to be a distraction when defending against foreign threats all through the post-An Lushan period. Throughout this time the court relied mostly on the provinces of the Yangtze and Huai valleys for its tax revenues. The military forces directly under its control were the armies of the northwest and those of the provinces loyal to the court. Doubts about the loyalty of all provincial generals led to emphasis on the Palace Armies which came increasingly under the control of eunuchs. The court also tried, as the occasion arose, to make alliances with the autonomous Military Commissioners and play off one against another. ${ }^{84}$

At the center, the Tang emperors of the post-An Lushan period were more out of touch than were their strong predecessors with the country as a whole. They turned to those closest to them in their inner court for support and advice in decision-making. Breakdown in the recruiting of the regular bureaucracy led to reliance on the Hanlin scholars (see below on Lu Zhi). It was, however, the eunuchs whose role was especially enhanced as a result of the rebellion and who eventually, as in Later Han and Ming times, came to be the dominant force in the Tang government.

The rise of the eunuchs began when Suzong assumed the throne during the rebellion and was enhanced by the continuing mistrust between Suzong's successors and the military. ${ }^{85}$ As Crown Prince, Suzong had had to live a sequestered life because of fears that he might become the focus of a plot by power seekers at court to replace his father prematurely. Moreover, when he assumed the throne at Lingwu, there were few experienced civil officials at hand on whom he could rely to set up his administration. It was natural that he should turn to his eunuch, Li Fuguo, who had been his constant companion in earlier times.

Reliance on eunuchs increased after the establishment of two new Palace Armies in 757. Suzong was trying to reverse the situation under

\footnotetext{
${ }^{84}$ For more on the provinces during the latter half of Tang, see Wang Shounan 1969; Pulleyblank 1976, pp. 49-60; Twitchett 1976 has an extensive bibliographical note on the subject; Peterson 1979, pp. 484-560.

${ }^{85}$ Pulleyblank 1976, pp. 54-5 ; Zhang Qun 1986, pp. 302-6.
} 
Xuanzong, when the capital's defenses had become weak. These Palace Armies were first placed under the command of the Prince of Jianning, but when he fell victim to palace intrigues, Suzong entrusted Li Fuguo with the command. ${ }^{86} \mathrm{Li}$ Fuguo became so powerful that he controlled personal access to the emperor, participated in much government business, and was appointed Minister of War in 761. At the time of Suzong's death, he intervened with the palace guard to foil a plot by the empress and to secure the succession of Daizong as the next emperor. ${ }^{8}$

Earlier, in 758, another eunuch, Yu Chaoen, had been appointed "inspector of the armies" (guan junrong shi) to coordinate the joint forces of nine Military Commissioners in the ill-fated campaign to besiege An Lushan's son, An Qingxu at Anyang. The appointment of eunuch supervisors (jianjun) to accompany generals in the field and report to the throne on their conduct, a function that early in the dynasty had been performed by censors, had begun in the time of Xuanzong and had become a regular practice by this time. Reporting directly to the emperor, the function of the eunuch supervisors was to watch over the Military Commissioners and deter ambitious generals from becoming too powerful, but at the same time this planted seeds of mistrust. ${ }^{88}$

Yu's position, which placed him over nine generals, was unprecedented. Besides being symptomatic of the emperor's mistrust of military men, it reflected the increasing independence of the generals who had been installed as Military Commissioners in command of their own territories. It is not surprising that $\mathrm{Yu}$ was not on good terms with the two most important commanders responsible for the campaign, Guo Ziyi and $\mathrm{Li}$ Guangbi, and that disunity in the command structure led to a complete debacle. ${ }^{89}$ Instead of discrediting the practice of involving eunuchs in military command, however, the behavior of the generals, who retreated in disorder, each to his own home base, served to emphasize the unreliability of the professional military command.

Another illustration of the lack of trust and understanding between the military governors and the court is the case of Pugu Huaien. Of Uighur background, he played an important role in the suppression of the An

\footnotetext{
${ }^{86}$ Liu Yat-ming 1970, pp. 311-2.

${ }^{87}$ JTS 184, pp. 4759-61; XTS 208, pp. 5879-82; ZZTJ 221, pp. 7073-4; 222, p. 7115; pp. 7123-5; Dalby 1979, pp. 572-3.

${ }^{88}$ Liu Yat-ming 1970 , p. 97.

${ }^{89}$ JTS 184, pp. 4763-5; XTS 207, pp. 5863-6; ZZTJ 220, p. 7061.
} 
Lushan rebellion, but due to personal rivalries and for other reasons, he kept his troops inactive during the Tibetan invasion of Chang'an in 763, and a year later rose in rebellion, joining forces with the Uighurs and $\mathrm{Ti}$ betans (Chapter 9).

Although at his succession in 762 Daizong got rid off Li Fuguo, he entrusted another eunuch, Cheng Yuanzhen, with equally great power. Cheng's bad relations with generals Guo Ziyi and Li Guangbi severely weakened Tang's ability to resist the Tibetan invasion in 763 (Chapter 10). Although under considerable pressure, Daizong eventually dismissed Cheng Yuanzhen from all his posts in $763,{ }^{90}$ he entrusted yet another eunuch, Yu Chaoen, with command of the Palace Armies and the Shence Army, a fateful move that in the long run became the foundation of eunuch power.

Incorporation of the Shence Army into the Palace Armies was a major step taken by Daizong's court to strengthen its control over the military. The Shence Army had been established in Longyou on the northwestern frontier during Xuanzong's reign, and moved into the interior during the An Lushan rebellion. At the time of the Tibetan invasion of Chang'an in 763, it was stationed at Shaanzhou, where the emperor sought refuge. In the absence of a regular general, the army was then under Yu Chaoen as the eunuch inspector. He came to the rescue of the emperor and gave him protection until he was able to return to the capital. The Shence Army was then incorporated into the Palace Armies with Yu in command. In 765, Yu Chaoen placed units of the Shence Army west of the capital to guard against another Tibetan invasion.

The court now had stronger Palace Armies at its disposal, but the military power in the hands of the eunuchs was also greatly increased. In a power struggle, $\mathrm{Yu}$ Chaoen was murdered in 770 at the instigation of the Chief Minister Yuan Zai, in cooperation with the emperor. Command of the Shence Army was at first given to another eunuch but, when he too was purged, it passed temporarily to non-eunuch officers. ${ }^{91}$

Daizong was never a strong or capable ruler. He was very much interested in Buddhism, perhaps disillusioned by the turbulent politics and chaos in China. Whenever Tibetans raided, he would order monks to recite the Sutra of the Benevolent King in the hope of warding them off. His in-

\footnotetext{
90 JTS 11, p. 274; ZZTJ 223, pp. 7155-6.

${ }^{91}$ XTS 50, p. 1332; Des Rotours 1947-48, pp. 850-2; Liu Yat-ming 1970, pp. 328-34; Dalby 1979, pp. 573-4. For more on the Shence Army, see also Lai 1986, chapter 6.
} 
terest in Buddhism was shared by some of his Chief Ministers, including Yuan Zai, who exercised a dominant role in the court between 762 and 777. Daizong's government was preoccupied with the urgent financial problems of the post-rebellion period and, in external affairs, was limited by the growing strength of the frontier peoples. The best it could do was to try to maintain the Uighur alliance and to defend the frontiers with whatever means were available. $^{92}$

\section{Dezong: Increasing Influence of the Inner Court and Military System}

When he came to the throne in the middle of 779 , Dezong was determined to reverse the trends of the previous reign. He carried out a series of reform measures to restore the power of the central government. $\mathrm{He}$ instituted the "double-tax" system designed by his Chief Minister Yang Yan, a financial specialist, and adopted a firm policy towards the semiautonomous provinces. To control the unruliness of foreigners at the capital, he ordered that all envoys who had remained in Chang'an and were being housed and fed at Chinese expense should be sent back, and that all the Uighurs and various $\mathrm{Hu}$ (referring mostly to Sogdians) who were at the capital should wear their own costumes and not dress as Chinese. ${ }^{93}$

Dezong's personal resentment at the humiliations he had suffered at the hands of the Uighurs as Crown Prince, was one of the main factors in a major change in his foreign policy: to abandon the Uighur alliance and make peace with Tibet, a policy that was also designed to enable him to divert northwestern frontier troops into the interior to deal with the rebellious provincial governors (Chapter 10). Dezong's firm policy towards the northeastern provinces had touched off a series of internal wars that lasted from 781 to 786 and troops were badly needed there. However, the removal of these troops to the interior placed a heavy burden on the finances of the court, since these armies, now removed from their home bases, had to be supplied by the central government.

Moreover, as Lu Zhi, then a young Hanlin academician (Hanlin xueshi), pointed out, with the frontier troops in the east and the Shence Army being away from the capital to suppress the rebels, Chang'an was vulnerable. He suggested the recall of the Palace Armies back to the capital to defend against a possible Tibetan invasion, but Dezong did not heed

${ }_{93}^{92}$ ZZTJ 224, pp. 7196-7; Dalby 1979, pp. 578-9.

${ }^{93}$ ZZTJ 225, p. 7264; p. 7265. 
his advice. ${ }^{94}$ The dangers in the situation were not long in materializing.

In late 783 when the soldiers of the frontier province of Jingyuan arrived at Chang'an on their way south and found that they were not treated as well as they expected, they rioted and made $\mathrm{Zhu} \mathrm{Ci}$ their leader. $\mathrm{Zhu} \mathrm{Ci}$ was a former Military Commissioner of Jingyuan and brother of Zhu Tao, the rebellious Military Commissioner of Youzhou. When the court discovered that $\mathrm{Zhu}$ Tao had sent a letter to $\mathrm{Ci}$ asking him to join the rebellion, it detained $\mathrm{Zhu} \mathrm{Ci}$ in Chang'an. Vulnerable in the capital, Dezong fled northwest to Fengtian. Zhu Ci occupied Chang'an, proclaimed himself emperor, and pressed on to Fengtian. ${ }^{95}$

Dezong asked the Tibetans for assistance. They came but returned home again before recovering Chang'an (Chapter 10). He also summoned the detachments of the Shence Army still stationed at the capital but none came. It emerged that the commissioner of the Shence Army, Bai Zhizhen, had been corruptly enrolling merchants and shopkeepers who enjoyed the privileges of guardsmen but did not undergo military training and continued with their former occupations. When called to arms in the emergency, they ran away. On his way to Fengtian Dezong was accompanied by only a small group of officials and two eunuchs who managed to organize an escort. $^{96}$

During his exile, with only a small group of officials around him, Dezong relied on the Hanlin scholar, Lu Zhi, as a personal adviser and secretary. With his insights into the situation and sound analyses of political and economic matters, Lu Zhi assisted Dezong in settling the crisis. He played such an important role in court business that he was referred to as an "inner Chief Minister" and overshadowed the titular Chief Ministers of the outer court. After the emperor's return to the capital, Lu Zhi was promoted to a high official post and was appointed Chief Minister in 792, after which his influence over the emperor declined. ${ }^{97}$

Before the rebellion of the Jingyuan troops was over, $\mathrm{Li}$ Huaiguang, one of the generals recalled from the campaign against the rebels in the northeast to rescue the emperor, rebelled (Chapter 10). All this shook the emperor's confidence in the Military Commissioners. After the crisis, Dezong made major changes in the military system. In 786 , he

\footnotetext{
${ }^{94}$ Twitchett 1962, pp. 94-5.

95 ZZTJ 228, pp. 7351-8. For Zhu Ci's revolt, see Peterson 1979, pp. 505-7.

${ }^{96}$ Liu Yat-ming 1970, pp. 127-31; Dalby 1979, pp. 586-7.

${ }^{97}$ For more on Lu Zhi see Twitchett 1962; Chiu-Duke 1992.
} 
again put eunuchs in control of the Shence Army. From then on, eunuch control of the Shence Army became permanent. ${ }^{98}$ Under eunuch control, the Shence Army played a major role in frontier defense as well as in guarding the emperor and his court. Detachments were regularly despatched, along with contingents recruited from provincial military commissioners, as Troops for Autumn Defense to reinforce the permanent garrisons on the frontier at the time of harvest when there was greatest danger of Tibetan raids. Shence detachments were also stationed permanently at strategic walled towns inside the frontier occupied by provincial armies. Eight Shence garrisons near the capital formed a third inner line of defense outside the city itself, where the main body of the Palace Armies was stationed. ${ }^{99}$

The hardships and dangers of his exile during Zhu Ci's rebellion had a traumatic effect on Dezong, and his main concern during the remainder of his reign was enrichment of his treasury by regular or irregular means so as never to be in want again. In dealing with provincial governors, he returned to the laissez-faire policies of his predecessor, relying on eunuch supervisors to exert what control they could over the military commissioners whose appointments were within the scope of the court's effective authority.

\section{Abortive Reform under Shunzong}

Towards the end of Dezong's reign, a reform-minded group of young men, including the famous writers Liu Zongyuan and Liu Yuxi, gathered around his Crown Prince, the future Shunzong, determined to deal with the twin problems of provincial militarism and eunuch influence at court so as to reverse the trend towards dynastic decline. Unfortunately, before he came to the throne in 805 Shunzong suffered a stroke that rendered him mute and incapable of effective participation in government. Though the reformers briefly attained power, the eunuchs were able to resist their attempt to take control of the Palace Armies and to engineer Shunzong's abdication in favor of his son, known to history as Xianzong.

The significance of this brief episode was controversial at the time and will probably always remain so, given the limitations of the sources, which are heavily weighted on the side of the winners and vilify the reformers as a low-minded clique interested only in their own power. What

\footnotetext{
${ }^{98}$ Liu Yat-ming 1970, pp. 127-31; Peterson 1979, p. 512; Dalby 1979, pp. 583-7.

${ }^{99}$ Liu Yat-ming 1970, pp. 376-82.
} 
seems clear is that the power of the eunuchs was entrenched and their determination to hold on to it was enhanced. Their position was not seriously challenged again until the Sweet Dew incident in 833.

This also had a demoralizing effect on the civil bureaucracy, which was divided at the time between the supporters of the reform group and the majority which was left out of the conspiracy. The majority felt threatened by the reformers' subversion of regular procedures and preferred to accommodate themselves to the eunuchs and cooperate with them to maintain the status quo rather than support radical change. This split may have sown the seeds of the factionalism that infected court politics for the next several decades, and which had repercussions on foreign policy from time to time. ${ }^{100}$

\section{Temporary Recovery under Xianzong}

Xianzong came to the throne towards the end of 805 . Young and forceful, he was determined to restore central authority over the independent military commissioners. Between 806 and 819 he engaged in a series of confrontations with the autonomous provinces, and succeeded for the moment in making even Hebei accept court appointees. A modus vivendi was established with the provinces that, on the whole, maintained internal peace in the country until the army mutinies and peasant revolts of the last three decades of the ninth century.

Xianzong concentrated his attention and economic resources on dealing with internal problems. In foreign policy, the court carried out negotiations for peace with Tibet (Chapter 10). The Uighur problem was not so urgent as in Daizong's time and Xianzong was able to decline a new marriage contract with them until 820 when he was finally persuaded by his ministers to an agreement: from a long-term point of view it seemed important and advantageous to continue the alliance relationship (Chapter 9).

Xianzong's reign was looked upon as a period of recovery and resurgence, but it was also marked by entrenchment of the power of the eunuchs. It was during his reign that the position of Palace Secretary (shumi shi) was formally established. Since it was held by eunuchs they now formed a consultative body parallel to the Chief Ministers.

Eventually, the emperor was either murdered by eunuchs or died of

${ }^{100}$ On Shunzong's reign see, among others, Pulleyblank 1960; Dalby 1979. 
a drug overdose. ${ }^{101}$

\section{Decline and Disintegration}

From the next emperor, Muzong, to the end of Tang in 907 the Tang dynasty went from decline to disintegration. In 821 the central government appointees were driven out in Hebei, which returned to semiautonomous status and remained so to the end of the dynasty. ${ }^{102}$ The eunuchs became so powerful that they intervened in almost all the successions until the end of Tang, and continued to exert their influence in military and political affairs. Under these circumstances the abilities and personalities of individual emperors were of less importance for foreign policy than in earlier times.

Wuzong's reign (840-846) coincided with the collapse of the Uighurs and the opportunity it provided to abolish the Manichean temples throughout the country which the Uighurs had sponsored. This was probably a stimulus to the persecution of Buddhism carried out later by that Daoist inclined emperor but this did not have any direct bearing on dealings with foreign countries.

Factional struggles within the bureaucracy became serious from the 820 's on, with rival groups seeking support from the eunuchs. The infamous Niu-Li factional struggles had a direct bearing on the formation of foreign policy at the time of the Weizhou Incident of 831 (Chapter 10) and when the Uighur power was in disintegration during the early 840's (Chapter 9).

The Shence Army, as the main military force under direct control of the central government, deteriorated during the later years of Xianzong's reign. It enjoyed special privileges and higher pay, but was badly disciplined and lost its fighting spirit. Already in 812 Chief Minister Li Jiang had pointed out that the purpose of the Shence Army was to guard against Tibet, but because it was under the control of eunuchs who refused to cooperate with the military commissioners, it was ineffective. He proposed to turn the command of the units of the Shence Army over to the military commissioners where they were stationed. His proposal was blocked by the eunuchs, but over time the provincial armies gradually absorbed the Shence detachments into their own and became the major force

${ }^{101}$ Dalby 1979 , pp. 634-5.

${ }^{102}$ Dalby 1979, pp. 611-2. 
for defense of the northeastern frontier. ${ }^{103}$

From the 820 's peace was maintained on the frontiers to a large extent more due to decline of both of the major foreign powers, than because of the conclusion of marriages with the Uighurs and a peace treaty with Tibet. During the 840's, when the Uighur empire disintegrated, the court under Wuzong and his capable Chief Minister Li Deyu made efforts to exacerbate the collapse, but Tang China at this time did not have the strength to recover its influence on either the steppe lands or in the Western Regions. When the Tibetan kingdom also collapsed during the 840's, the Nanzhao kingdom in the southwest increased its expansion at Tang's expense. Tang was for most of this time on the defensive.

From the mid-ninth century on, army revolts and peasant rebellions broke out, reaching their height in the rebellion of Wang Xianzhi and Huang Chao in 874-884. Although the government under Xizong (r. 873888) was in the hands of loyal and capable men, Tang's foundations were mortally shaken. During the popular rebellions the court had to rely on provincial military commissioners, who now became regional warlords. One of them overthrew the Tang dynasty in 907. China entered another period of disunion known as the period of Five Dynasties and the Ten Kingdoms.

When the Tang dynasty began, it faced challenges both from within and without. Gaozu had to follow a cautious foreign policy, buying time for the consolidation of the dynastic power. This was changed to an expansive policy under Taizong, when China was at peace within and the economy had recovered. He set about restoring the glories of the Han empire and went beyond that to envision a world empire with both Chinese and nomadic peoples as equal subjects. The expansion reached its climax under Gaozong. Sickly physically, he fell under the influence of his empress, Wu Zetian, who became his assistant, and eventually usurped the throne after his death. Handicapped by her position as a woman and a usurper, and faced with the growing power of foreign rivals, she retreated from expansion to defense. Her grandson, Xuanzong, a capable and ambitious ruler with the advantage of having inherited a prosperous and peaceful country, again engaged China in expansion westward, but his capacity to carry out an ambitious foreign policy was more limited than Taizong's

${ }^{103}$ For Details on the decline of the Shence Army, see Liu Yat-ming 1970, pp. 403-13. 
owing to his lack of experience outside the palace. In the end he handed over power to Li Linfu in order to enjoy the good life as de facto retired emperor.

During much of this time the Tang decision-making group had capable ministers, often combining military as well as civilian experience. The militia system was an important factor in Tang's early successes. Its deterioration under the stress of constant wars, especially the long-drawnout Korean campaigns and those caused by the emergence of Tibetan power in the northwest, led to an emphasis on building strong defenses and increased reliance on frontier armies, eventually including many foreign troops and foreign generals, the most ambitious of whom, An Lushan, rose in rebellion against the court in 755 .

The post-An Lushan period contrasts sharply with the first half of Tang in foreign policy. The weakened Tang empire had to follow reactive, pragmatic and compromising, non-aggressive, policies towards the powerful Tibetan kingdom and the Uighur empire. The emperors' personalities and attitudes were still important at times, especially in the reigns of Suzong, Daizong, Dezong, and Xianzong, but militarism in the provinces and growing eunuch power at the center complicated the decision-making process and left the central government weak and incapable of responding aggressively to new opportunities, such as those provided by the collapse of the Uighurs and Tibetans in the 840's. 


\section{Chapter 5}

\section{Tang and the First Turkish Empire: From Appeasement to Conquest}

After the siege at Yanmen, Sui was on the verge of total collapse. A series of internal rebellions quickly turned into a turbulent civil war pitting members of the ruling class against each other, and with different parts of the country under the control of local Sui generals sometimes facing rebel leaders, all of them soon contending for the greatest of all Chinese political prizes, the chance to replace a dynasty which had evidently lost the Mandate.

Those nearest the northern frontier naturally sought the support of the Eastern Turks, just as Turkish leaders had sought Chinese assistance in their own power struggles.

Freed of interference from a strong Chinese power, both the Eastern and Western Turkish qaghanates soon recovered their positions of dominance in their respective regions. The Eastern qaghanate under Shibi Qaghan expanded to bring into its sphere of influence the Khitan and Shiwei in the east and the Tuyuhun and Gaochang in the west. The Western Turks again expanded all the way to Persia, incorporating the Tiele and the various oasis states in the Western Regions, which one after another became their subjects, paying regular taxes to the Western Turks.

After an initial period of appeasement, Tang succeeded in conquering the Eastern Turks in 630 and the Western Turks in 659. This chapter examines the reasons for Tang's military success, and how Tang tried to bring the Turks under Chinese administration so as to build a genuinely universal empire.

\footnotetext{
${ }^{1}$ Liu Wuzhou, on the northern edge of Shanxi and Liang Shidu, north of Chang'an on the Ordos frontier, received the title of qaghan from Shibi Qaghan of the Eastern Turks. To all intents and purposes, they became subjects of the Turks, even though they each assumed the title of emperor of China. Wang Shichong, who held Luoyang also made alliance with the Turks. The Turks also wished to confer the title qaghan on Guo (later Li) Zihe at Yulin, at the southward bend of the northern loop of the Yellow River, but Guo was afraid to accept it. See their biographies in JTS 55, 56; XTS 85, 86, 87.
} 


\section{The Rise of Li Yuan and the Initial Alliance with the Turks}

In the fifth month of $617, \mathrm{Li}$ Yuan, the Duke of Tang, joined the many members of the Sui ruling class who were rising in revolt against Emperor Yang. Li was garrison commander of Taiyuan with control over the fubing and new conscripts in the area. A contingent of Western Turks under Shi Danai were included in the Tang army. Danai and his people had been previously settled in Loufan in northern Shanxi during the Sui period. $^{2}$

Like most other northern warlords, Li Yuan had been obliged to make peace with the Eastern Turks and form an alliance with their powerful regime. This policy was suggested by Liu Wenjing, an important planner of Li's revolt and subsequent founding of the Tang dynasty. ${ }^{3}$ An understanding with the Eastern Turks was necessary to prevent them from invading, to try to stop them from supporting other rebel leaders, and to obtain their cooperation in the wars for the establishment of Tang power.

Li Yuan personally wrote a letter to Shibi Qaghan, which proposed that either the Turks join forces with $\mathrm{Li}$ to suppress other rebels and maintain Sui, in which case the captured children, women and goods would all go to the Turks; or, he suggested, the Turks could just make peace with $\mathrm{Li}$ himself, in which case $\mathrm{Li}$ Yuan would provide generous gifts so that the Turks would receive benefits without having to make any effort. The letter was signed as $q i$, a term used by an inferior to a superior. When his officials objected to this wording and suggested that, since the Turks did not read Chinese, Li Yuan should change the word qi into shu, a term used between equals, Li Yuan did not accept, saying that the Turks knew the rituals of the Chinese, and that:

Even if I show respect to them they will still not believe me. If there is neglect and rudeness, their suspicion will be even deeper. The men of ancient times had a saying, "To bend before one man and stand above ten thousand." What do the barbarians beyond the frontiers amount to in terms of this analogy? They merely amount to one ordinary person. Moreover, the word $q i$ is not worth a thousand measures of gold. Even that I am willing to give away. Why should one worry about one word? ${ }^{4}$

By now, however, Shibi Qaghan had completely lost interest in the Sui

\footnotetext{
${ }^{2}$ XTS 110, pp. 4111-2. See also Bingham 1941, p. 98.

${ }^{3}$ JTS 57, p. 2292; ZZTJ 184, p. 5737.

${ }^{4}$ Da Tang Chuangye Qijuzhu 1, p. 7.
} 
regime. He agreed to assist Tang on the condition that Li Yuan declare himself emperor. Li Yuan was too cautious to accept the condition, but offered a compromise: he declared Emperor Yang a retired emperor, and proclaimed a new Sui emperor. The red flag of Sui was changed for his retinue to a combination of crimson and white to show his difference from Sui. Shibi then despatched an envoy to Li Yuan with horses that were to be sold in China. With the Turks friendship secured, Li Yuan and his troops advanced to Chang'an. Simultaneously he sent Liu Wenjing to the Eastern Turks to ask for more horses and some troops, intending to use the Turkish force to intimidate his rivals. Shibi willingly sent two thousand horses and five hundred cavalry. ${ }^{5}$

Some historical records suggest that, like other rebel leaders, $\mathrm{Li}$ Yuan had accepted the status of vassal to the Turks, and that after his defeat of the Eastern Turks, Li Shimin, the second emperor of Tang, remarked how he had finally taken revenge and wiped out the great shame and humiliation that his father suffered as a subject of the "barbarians." Chen Yinke agrees with this suggestion and conjectures that Gaozu accepted the title of qaghan from the Turks. ${ }^{6}$

Though generally accepted, this idea has been challenged by other modern Chinese scholars. Li Shutong concludes that Li Yuan did not accept the status of vassal to the Turks. He believes that Xu Jingzong, the early Tang historian, on the basis of whose work the Tang official histories were compiled, intentionally distorted his narrative to depict Li Yuan as a weak, incompetent character so as to contrast the father with Li Shimin, the son, who he depicted as a strong, capable and successful leader.

Li Shutong examined the various Tang sources and based the above judgment on the Da Tang Chuangye Qijuzhu, or the Diary of the Founding of the Great Tang Dynasty, an unofficial court journal of Gaozu's reign, compiled by Wen Daya, covering the period from 617 to 626 . There is nothing in this book flatly stating that Gaozu accepted the status of subject of the Turks, nor is there any record of his being given any title by the Turks. ${ }^{7}$

Could Wen Daya have deliberately omitted information of this

${ }^{5}$ Da Tang Chuangye Qijuzhu 1, pp. 5-11; JTS 57, p. 2292; ZZTJ 184, pp. 5737-8; pp. 5740-1; p. 5742; p. 5749.

${ }^{6}$ Chen Yinke 1973, pp. 69-80.

${ }^{7}$ Li Shutong 1965, pp. 214-46; 1968. For a detailed study of Wen Daya's book, see the pioneering work in English by Bingham 1937 and a summary of studies on the book by Twitchett 1992, pp. 38-42. 
kind? Li Shutong does not think that Wen Daya had any motive to do so, but we have to recognize that Wen Daya did make one thing clear: $\mathrm{Li}$ Yuan used the term $q i$ as an inferior to a superior in his letter to the qaghan. This can, however, be interpreted as merely an expedient to gain time.

Whatever his deeper motives may have been, the existing evidence of Li Yuan's conduct in dealing with the Turks does at least show that he felt he had to adopt a very humble attitude towards them, even if some doubt may remain as to the extent to which he actually did intend to yield to them at the time. This policy proved to be both necessary and wise. With the Turks as peaceful allies, Li Yuan was able to eventually proclaim the founding of the Tang dynasty in the fifth month of 618 and himself as its first emperor, with his capital in Chang'an. Even so, several more years of fighting were required before Tang finally succeeded in defeating or winning over all the other contenders for power and bringing the whole of China under its control.

\section{Gaozu's Appeasement Policy in the Face of Turkish Aggression}

During his reign from 618 to $626, \mathrm{Li}$ Yuan, also known to history by his posthumous title Gaozu, was preoccupied with consolidating Tang dynastic rule, and to that end he had to adopt very pragmatic policies toward the non-Chinese on the frontiers, particularly the Turks. A military man who had achieved his position by force and strategy, he knew very well that the formalities and rhetoric of the tribute system to mark the superiority of China over its neighbors were meaningless when China was in fact in a weak position. The new emperor's style of government was highly personal and informal, unlike that of a "proper emperor." He often invited his officials to sit beside him on the imperial dais, and he granted the Turkish envoy the same favor in $618^{8}$ His small group of advisers, mostly pragmatic politicians like Gaozu himself, helped him in decisionmaking and contributed to his distinctive style. ${ }^{9}$

Gaozu consistently followed a policy of appeasement towards the Eastern Turks. The situation during Gaozu's time parallels the situation in early Han when China also had to appease and pay tribute to the Xiongnu in order to prevent them from causing trouble. Gaozu treated the Turks as "an equal adversary" (diguo), and regularly made large payments in goods

\footnotetext{
${ }^{8}$ ZZTJ 186, p. 5816.

${ }^{9}$ For an introduction to his advisers, see Wechsler 1979, pp. 170-4.
} 
to them.

Up until 625 , in all letters from the Tang court to the Eastern Turks, the Chinese used the term shu, symbolizing the equality of status between the two states. ${ }^{10}$ In 618 , when Gaozu sent a diplomatic mission to the Turks, it carried with it women performers as gifts. ${ }^{11}$ The following year, when he learned that presents from Tang had not arrived on time, the qaghan planned a major campaign against Taiyuan with his vassal, Liang Shidu, but Tang immediately forwarded the delinquent payment, and thus headed off the invasion. ${ }^{12}$ In the same year Shibi requested Tang to kill the Western Turkish leader Chuluo, who had submitted to Sui and been resettled in China. Gaozu did not at first agree to the request but later, when several ministers pointed out that if Tang refused, Chuluo himself might survive, but only at the expense of Tang's incurring the hatred of the whole Eastern Turkish qaghanate, Gaozu yielded to the inevitable. ${ }^{13}$

The appeasement policy was necessary since the Turks were not only themselves a rival to Tang but also provided support to other antiTang forces, thus posing a further threat. After the death of Shibi in 619, the Turks became more hostile under the new qaghan, Chuluo, who was Shibi's younger brother. Chuluo was married to the Sui Princess Yicheng, who remained loyal to the Sui house. Apparently under pressure exerted by Chuluo, Tang in early 620 abandoned Fengzhou and conceded Wuyuan and Yulin to the Turks. Ten thousand Turkish households then moved south of the Yellow River. ${ }^{14}$

In 620 , at the request of Princess Yicheng, Chuluo received the remaining members of the Sui royal family, the empress of Emperor Yang and Emperor Yang's grandson, Yang Zhengdao, escorted by Dou Jiande, an anti-Tang military leader. Chuluo established Yang Zhengdao as King of Sui and settled other Chinese who had come to the Turks in Dingxiang

\footnotetext{
${ }^{10}$ XTS 215A, p. 6030; ZZTJ 191, p. 5996; CFYG 990, p. 11635; Mori Masao 1967, pp. $178-9$.

${ }^{11}$ ZZTJ 186, p. 5814.

12 ZZTJ 187, pp. 5847-8.

${ }^{13}$ TD 199, p. 1077; ZZTJ 187, p. 5865; CFYG 999, p. 11721. XTS 215B (pp. 6056-7) records that it was the Western Turks who asked Tang to kill Chuluo. Hou Linbo holds that the XTS is correct. Hou 1976, pp. 37-9. Whatever was the case this event shows the humble attitude and pragmatic values of the Tang court.

${ }^{14}$ The date here given for this is according to Cen Zhongmian 1958, p. 133. The Chinese sources do not give a definite date. See XTS 215A, p. 6029; CFYG 990, p. 11633.
} 
on the northern frontier. ${ }^{15}$ Apparently Chuluo did so partly because Wang Shichong, who was holding out as defender of Sui in Luoyang, had sent an envoy to the Turks to persuade the qaghan to do so. Wang had earlier formed a marriage alliance and trading relations with the Turks. ${ }^{16}$

However, Chuluo also sent 2,000 cavalrymen to assist Tang in fighting against Liu Wuzhou, another rival of Tang, and left several hundred of his men with the Tang general in Taiyuan and in the northern outposts as garrison troops. ${ }^{17}$ The Turks seemed to be using the strategy of playing off the rival forces in China against each other so as to profit themselves. Soon, Liang Shidu advised Chuluo Qaghan to go beyond such balance of power moves and to launch a major attack on the Tang capital so that he could establish a nomadic regime inside China just as the nomadic Tuoba people had done in the fourth century. Fortunately for Tang, the plan did not proceed due to Chuluo's death. ${ }^{18}$

Chuluo was succeeded by another brother, Xieli Qaghan, who also took Princess Yicheng as his wife. Like Chuluo he was aggressive towards Tang, treating the Tang Chinese with disdain, and imprisoning their envoys when they refused to kowtow at the Turkish court. ${ }^{19}$ The Chinese records say that Xieli Qaghan addressed Tang envoys using arrogant language, and made endless demands for presents from Tang. Whenever Xieli Qaghan made such demands, he sent letters using the term "order" (chi). All the prefectures along the frontiers bowed before his commands. ${ }^{20}$ Xieli also continued to support the Sui royal house. Moreover, since parts of the buffer zone along the frontier between China and the Turks were still under anti-Tang regimes, Tang was exposed to easy attacks from the Turks. ${ }^{21}$ From 619 to 626 the Turks raided Tang frontiers every year.

In 623, when Xieli Qaghan was besieging the town of Mayi, a site of strategic importance since Han times and which was under Tang control, he made a proposal for a marriage contract. Gaozu agreed on the condition that the Turks abandon the attack. The qaghan decided to withdraw but when Princess Yicheng persisted in her pleading for an attack,

${ }^{15}$ JTS 54 , p. 2239 ; 194 A, p. 5154 ; XTS 85 , p. $3700 ; 215$ A, pp. $6029-30$; ZZTJ 188 , p. 5878 .

${ }^{16}$ XTS 215A, pp. 6029-30; ZZTJ 188, p. 5884.

${ }^{17}$ JTS 194A, p. 5154; XTS 215A, p. 6029; ZZTJ 188, pp. 5884-5; p. 5898.

${ }^{18}$ JTS 56, pp. 2280-1; XTS 87, pp. 3730-1; ZZTJ 188, pp. 5895-6.

${ }^{19}$ JTS 194A, p. 5155; XTS 215A, p. 6030; ZZTJ 189, p. 5912.

${ }^{20}$ JTS 83, p. 2775; XTS 111, pp. 4132-3; 215A, p. 6030.

${ }^{21}$ Kang Le 1979, p. 17. 
the qaghan gave in to her. Later, however, he returned the captured Mayi to Tang while negotiating for a marriage. ${ }^{22}$ It is not clear whether any marriage agreement was actually concluded during Gaozu's reign. We merely read several times in the sources of a marriage contract being discussed. ${ }^{23}$ Perhaps the Sui Princess Yicheng was concerned that her position would be in danger once a Tang princess came and therefore disrupted negotiations, delaying any actual contract.

In 624 all the major remaining anti-Tang forces inside China were eliminated, except that the Turks still had Yuan Junzhang and Liang Shidu on their side. Both Xieli Qaghan and Tuli (Tölish) Qaghan (Shibi's son) invaded Chinese territory. Li Shimin, the future Tang Taizong, devised a strategy to drive a wedge between the two qaghans by claiming that he had formed a brotherly relationship with Tölish. The Turks retreated for a time, but before long Xieli resumed his incursions. ${ }^{24}$ Traditional Chinese historians suggest that under the threat of a Turkish invasion anxiety mounted to such an extent that Gaozu even considered abandoning Chang'an and moving the capital to a less exposed place. He gave up the plan only after strong and persistent objections from Li Shimin. ${ }^{25}$

Under these circumstances, Gaozu had to follow an appeasement policy. But all this apparently peaceful diplomatic activity between Tang and the Turks did not mean that the Tang rulers had given up the traditional tribute system and accepted the principle of real equality among sovereign states. The Cefu Yuangui records Turkish missions coming to the court of Tang at this time as paying tribute.

In 622, the Turks attacked Taiyuan, but then expressed interest in a peace settlement. While many court officials were in favor of making peace, at the suggestion of the Chief Minister, Feng Lun, Gaozu instead decided to mobilize Tang forces for an attack and to make peace only after a victory. The plan was carried out. After attacking the Turks, Gaozu sent an envoy to the Turks with an offer of peace and rich goods. The Turks

${ }^{22}$ ZZTJ 190, p. 5973.

${ }^{23}$ Kuang Pingzhang 1935, pp. 24-5.

${ }^{24}$ JTS 194A, pp. 5156-7; XTS 215A, p. 6031; ZZTJ 191, pp. 5991-3.

${ }^{25}$ JTS XTS 215A, pp. 6031-2; ZZTJ 191, p. 5989. Li Shutong (1965, pp. 55-60; p. 89) thinks that even though some suggested the removal of the capital, the narrative of Gaozu's agreement and Li Shimin's objection was a forgery by the Tang historian Xu Jingzong, who took every opportunity to make Gaozu look weak and incapable in contrast to Taizong, whom he described as firm, strong and successful. Li Shutong may be too harsh on $\mathrm{Xu}$; if $\mathrm{Xu}$ did falsify his narrative, he surely did so at Li Shimin's order. 
retreated. $^{26}$

In 624, Xieli despatched his uncle to pay a court-visit to Tang, proposing that the Tang emperor should rule the Middle Plain while the qaghan would occupy the territory north of the Gobi. Each would have jurisdiction over his own part and the Turks would not invade unless provoked by the Chinese. The Chinese records go on to say that the Turkish envoy asked that "the Turks should be the outer subjects of Tang for all generations." 27 This last request does not seem to be consistent with the rest of the proposal. It is not unlikely that it was added by the contemporary Chinese historians and never shown to the Turks.

While following an appeasement policy towards the Eastern Turks, Gaozu tried to make the Western Turks an ally. In 620, when the envoy from the Western Turks arrived, Gaozu granted him favorable treatment with rich gifts in the hope of persuading the Western Turks to join in attacks against the Eastern Turks. But when Xieli heard about the Western Turks' agreement to cooperate with Tang, he quickly made peace with his Western rivals and thereby stopped the latter from implementing their plan. In 625, when the Western Turks despatched an embassy to Tang requesting a marriage alliance, on the advice of Pei Ju, the famous Sui specialist on the Western Regions who had transferred his allegiance to Tang and become a Chief Minister, Gaozu agreed to the request, knowing that it would be viewed as a military threat by the Eastern Turks and serve as a deterrent to them. ${ }^{28}$

\section{Using the Tuyuhun Against Li Gui}

Once the Sui dynasty lost its grip on China, the Tuyuhun under Fuyun Qaghan returned to Qinghai and reestablished their state. Remaining consistent with his pragmatic policy, Gaozu chose to make peace with the qaghan. In 618 he sent an envoy to Fuyun, to try to persuade him to attack Li Gui, who had set himself up as a rival emperor at Liangzhou, and promised to send back Prince Shun who had previously stayed at the Sui court and was now in Chang'an.

Fuyun gladly agreed and launched a successful attack on Li Gui.

${ }^{26}$ JTS 62, p. 2380; 63, p. 2397; ZZTJ 190, pp. 5954-5.

${ }^{27}$ CFYG 980, p. 11510.

${ }^{28}$ This is according to ZZTJ 191, p. 5995, which follows the Veritable Records (Shilu) of Gaozu. See also XTS 100, p. 3934; THY 94, p. 1693; CFYG 987, p. 11495. Other accounts say that Feng Lun gave the advice, cf. JTS 194B, pp. 5181-2; XTS 215B, p. 6057; TD 199, p. 1077. 
He then sent repeated missions to Tang asking for his son's return. Gaozu sent Shun back but that freed Fuyun to repeatedly raid Tang's frontiers between 622 and 626, sometimes three or more times in a single year. Tang was too much occupied then by wars with regional warlords at home and by Turkish problems to react. In most cases, it had to leave the frontier authorities to deal with their own defense. ${ }^{29}$

\section{Taizong's Conquest of the Eastern Turks in 630}

A few days after Li Shimin assumed the throne, the Eastern Turkish cavalry galloped down south and appeared on the banks of the Wei River, just over ten miles west of the Tang capital. This attack was launched at the advice of Liang Shidu. Knowing of the succession struggle inside Chang'an, Liang Shidu hoped to take advantage of the situation. It has also been suggested that previously Li Jiancheng had been in command of the defense of the northern frontiers against the Turks, and that his death had weakened the morale of the northern troops, who failed to effectively resist the Turkish invasion. ${ }^{30}$

Faced by the formidable Turks, Taizong had to enter into a covenant with Xieli Qaghan before the Eastern Turks finally withdrew. The basic terms of the treaty were a Tang promise of rich gifts, and a pact of mutual non-aggression. ${ }^{31}$ This incident was referred to by the Tang Chinese as the "Shame of the Wei River," which Taizong was determined to avenge. Despite remonstrance that weapons were forbidden near the emperor, Taizong personally supervised archery training for the palace troops, calling on the soldiers to prepare against Turkish invasion. ${ }^{32}$

Fortunately for Tang, both the Eastern and Western Turkish powers were now beginning to decline. Around 627 the Tiele tribes, including the Xueyantuo, the Uighurs and others, rose in rebellion against their Eastern Turkish overlord. In 628 the Khitan and Xi also rebelled. ${ }^{33}$ In 628 the Western qaghanate was in turmoil. The Xueyantuo tribe, under their chief Yi'nan, left the Western Turks and went over to the Eastern Turks. Soon realizing that the situation of the Eastern Turks was as precarious as that in

${ }^{29}$ JTS 198, p. 5298; CFYG 970, p. 11396; Molè 1970, xviii; p. 49. For the raids, see ZZTJ 190, 191.

${ }^{30}$ Li Shutong 1965, pp. 297-304.

31 JTS 194A, pp. 5157-8; XTS 215A, pp. 6032-4; ZZTJ 191, pp. 6018-20; Li Shutong 1965, pp. 259-66.

${ }^{32}$ ZZTJ 192, pp. 6021-2.

${ }^{33}$ Ma Changshou 1957, p. 44. 
the west, Yi'nan rebelled and made himself independent of the Turks. The Uighurs joined the Xueyantuo. ${ }^{34}$ Both the Xueyantuo and the Uighurs were Turkish speaking peoples, who belonged to the larger confederation known as the Tiele.

Within the ranks of the Eastern Turks, Xieli Qaghan and his nephew Tölish Qaghan fell out amongst themselves. When the Xi people and other tribes, who were under the direct control of Tölish Qaghan, left him to submit to Tang because of the heavy and endless burden of taxation Tölish imposed, Xieli held Tölish responsible for their defection. And when Tölish failed to suppress the Xueyantuo and Uighur uprisings, he was again severely reprimanded by Xieli. As a result, Tölish refused to obey an order to provide troops to Xieli, and began to make plans to submit to Tang. ${ }^{35}$

At his own headquarters, Xieli Qaghan alienated himself from his own people by relying mostly on non-Turks, including a Chinese and various $\mathrm{Hu}$ (Sogdians). These advisers introduced complicated rules and regulations into the Turkish administration and kept their people constantly at war. Moreover, several years of famine as a result of bad weather forced Xieli to increase taxes in order to sustain enough revenue to support his regime. The political and economic problems engendered by this aroused great resentment among the Turks themselves as well as among their subjects, the Tiele tribes in the north and northwest, and among the Khitan, Mohe and Xi in the east. ${ }^{36}$

The Chinese soon learned of this situation. In 627 Yuan Junzhang, the surviving warlord of northern Shanxi, switched his allegiance from the Turks to Tang because of the weaknesses he saw within the Turks. ${ }^{37}$ As Chinese who had gone over to the Turks at the end of the Sui period returned to China, they brought ever more information about the internal

${ }^{34}$ JTS 194 , p. $5158 ; 199$ A, p. 5344 ; XTS 217B, p. 6134 ; ZZTJ 192, p. 6045. Ma Changshou is of the opinion that the Xueyantuo were divided into two major groups, subject to the Eastern and Western Turks, respectively. Those in revolt in 627 were subjects of the Eastern Turks. See Ma Changshou 1957, p. 53, note 1. Cen Zhongmian holds that the Xueyantuo went to the Eastern Turks during Gaozu's reign and rebelled in 627. See Cen Zhongmian 1964, pp. 50-1.

${ }_{35}$ JTS 194A, p. 5158; p. 5160; XTS 215A, p. 6034; p. 6038; ZZTJ 192, p. 6049.

${ }^{36}$ JTS 194A, p. 5159; XTS 215A, p. 6034; ZZTJ 192, p. 6037; Ma Changshou 1957, pp. 39-44.

${ }^{37}$ ZZTJ 192, p. 6035. 
troubles and natural disasters that the Turks were suffering. ${ }^{38}$

Although many at his court suggested an attack against the Turks, Taizong hesitated. Though he was bound by the peace agreement concluded with the Turks in 626 , he knew this was a chance that should not be lost. In the court discussions Chief Minister Xiao Yu advocated an offensive, whereas Zhangsun Wuji, also Chief Minister and brother-in-law of Taizong, suggested that Tang wait for the situation of the Turks to decline further. Taizong decided to wait. ${ }^{39}$ When an envoy returned from his mission to the Eastern Turks, Taizong consulted with him about the situation there. ${ }^{40}$ It was obvious by now that the Turks were in great difficulties. Taizong continued his patient waiting even when another envoy returned from his mission to the Turks and confirmed the Turks' desperate situation. $^{41}$

Meanwhile Tang tried to sow further dissension among the Turks by allying itself with all the rivals of Xieli. One important step was that, at the end of 628, Taizong supported the Xueyantuo, the rivals of the Turks, by investing Chief Yi'nan with the title of qaghan, setting him up as a potential ally against the Turks. Later, in 629, when Yi'nan's brother came to pay respects, Taizong treated him favorably and bestowed a knife and a whip on him, symbols of the power to punish criminals in the Xueyantuo qaghanate. $^{42}$

In 628 , after being attacked by Xieli, Tölish asked for Tang military aid. Du Ruhui, Chief Minister holding the office of Minister of War, insisted that Tang should take advantage of this opportunity to attack the Turks regardless of any previous treaties with the "barbarians." Taizong decided to support Tölish. He ordered a garrison in Taiyuan to prepare to

\footnotetext{
${ }^{38}$ ZGZY 8, pp. 24a-24b.

${ }^{39}$ JTS 65, p. 2447; XTS 105, p. 4018; ZZTJ 192, p. 6037.

40 JTS 58, p. 2307.

${ }^{41}$ ZZTJ 192, p. 6046.
}

${ }^{42}$ It is not clear when the investiture took place. It was either at the end of 628 or in 629 . For 628, see JTS 199B, p. 5344; ZZTJ 193, pp. 6061-2; THY 94, p. 1689; 96, p. 1726; For 629, see XTS 217B, pp. 6134-5; CFYG 964, p. 11337. Cen Zhongmian prefers the second date. He argues that it was after Yi'nan established himself as qaghan in 628 that Taizong invested him with the title. See Cen Zhongmian 1958, p. 181; 1964, pp. 52-3. However, it is possible that Taizong bestowed the title in order to help Yi'nan establish his power. ZZTJ and THY say that Yi'nan was supported as qaghan but was afraid to take up the title. Planning to attack Xieli, Taizong therefore sent an envoy to invest him with the title. 
assist him. ${ }^{43}$.

In 628 , one tribe of the Khitan, formerly under the rule of the Turks, offered to submit to Tang. Xieli proposed to hand over Liang Shidu in exchange for the Khitan, but Taizong refused. Preparations were already underway to inflict a major defeat on Liang Shidu, and Tang succeeded in doing so. ${ }^{44}$

In 629, Tang started to make war on the Eastern Turks despite Xieli Qaghan's offer to become a Tang subject and request for a marriage contract. It was hoped that the Turks could be destroyed once and for all. ${ }^{45}$ By the end of 629 , Tölish came to Tang for refuge. In 630 Tang won a victory over the Turks under Xieli and captured the Sui empress who had once conspired against Tang and Yang Zhengdao. Xieli despatched an envoy to the Tang court, admitting, in the words of the Chinese account, his "guilt" and asking to "surrender as an inner subject together with his land."

The Chinese accounts go on to say that the court accepted the surrender, and sent a friendly envoy to the Turks, but that since Xieli was only pretending to be humble and was merely waiting for an opportunity to flee to the north of the Gobi desert, the Tang generals on campaign, $\mathrm{Li}$ Shiji and Li Jing, made their own decision: they would wait for the Tang envoy to arrive at the Turks' encampment, and when the Turks let down their guard, the Tang troops would launch a sudden attack to eliminate them. The plan went well. The Chinese troops captured Xieli and killed the Sui Princess Yicheng, who had been married to four Turkish qaghans in succession. This Chinese woman who sacrificed her life in the political struggle, in a very real sense was also the last casualty of the Sui dynasty.

Thus ended the Eastern qaghanate. ${ }^{46}$

\section{Taizong as Heavenly Qaghan}

Following the conquest of the Eastern Turks in 630, the chiefs of the non-Chinese peoples in the northwest requested that Taizong assume the title of Heavenly Qaghan (tian kehan), which he did. ${ }^{47}$ There is an opinion that the Heavenly Qaghan system functioned as an international

\footnotetext{
${ }^{43}$ XTS 215A, p. 6034; ZZTJ 192, pp. 6049-50.

${ }^{44}$ JTS 56, p. 2281; XTS 87, p. 3731; ZZTJ 192, p. 6050.

${ }^{45}$ ZZTJ 193, pp. 6065-6.

${ }^{46}$ ZGZY 2, pp. 14a-15a; JTS 194A, p. 5159; XTS 215A, p. 6035; ZZTJ 193, pp. 6066-7; pp. 6070-3.
}

${ }^{47}$ ZZTJ 193, p. 6073. 
institution which maintained peace within the world known to the Chinese and which persisted till 781, a generation after the An Lushan rebellion. According to this thesis, the Heavenly Qaghanate's mission was to resist first Turkish and then Arab aggression in Central Asia. It could do so because under that system the Chinese emperor had the legitimacy to regulate relations among the participating states, both Chinese and nonChinese, to settle their disputes and conflicts, to organize military campaigns with troops from all the states to assist one of the states in an emergency, and to bestow political titles on the rulers of other states. ${ }^{48}$

It is, however, an open question whether such a neatly organized international system ever actually existed. ${ }^{49}$ The practices mentioned under the Heavenly Qaghan system were also the norm under the tribute system, which already governed Han relations with the oasis states in Central Asia. Even under that early version of the tribute system the Protector-general of the Western Regions was Han's representative and was given explicit responsibility for protecting Western Region subordinates, mediating disputes among them and attacking those who did not act in accordance with Chinese moral principles. In return for this, the oasis states had to provide military and labor services to the Chinese, in addition to the payment of tribute. During the Tang dynasty, the conquest of the Eastern Turks brought various non-Chinese tribes and small states into the Chinese sphere and subjected them to some degree of control by China. Whenever the Chinese exercised their hegemonic power over small states, they always adopted such practices whether there was an effectively functioning Heavenly Qaghan system or not.

Yet it should be noted that Taizong's assumption of the title of Heavenly Qaghan did strengthen his legitimacy as a ruler and no doubt had a psychological appeal to the nomads and other inhabitants of the Western Regions. It symbolized his aspiration to be looked on as both the Chinese Son of Heaven and the qaghan of the steppe, rather than simply as a Chinese emperor. No doubt it was the non-Chinese side of his background that enabled him to have a vision of world empire with the agricultural Chinese and nomadic non-Chinese as equal subjects, "each having an equal share and neither dominating the other."50

Modern scholars have pointed out that during the Period of Disun-

\footnotetext{
${ }^{48}$ Luo Xianglin 1955 , pp. 209-43.

${ }^{49}$ Zhang Qun 1986, pp. 342-66.

${ }^{50}$ Pulleyblank 1976, pp. 37-8.
} 
ion the Chinese elite in the north had been profoundly affected by the centuries of alien rule, and the Sui-Tang rulership displayed distinctive features engendered by that experience. Chen Yinke's studies demonstrate that the Sui-Tang system grew out of the system of the Northern dynasties and that the origins of the Tang royal house combined key traits of both Chinese and "barbarians." ${ }^{\text {51 }}$ It is widely recognized that Tang's vitality was based on its eclectic tendency to draw strength from all available sources, Chinese and non-Chinese. ${ }^{52}$

Taizong's success in leadership can be attributed at least partly to the non-Chinese influences that he inherited, and it was such influences as well as Taizong's understanding of steppe politics, "his use of personal charisma, bluff, nomadic ceremonies and battle tactics" that made him able to rule over both China and the steppe as the accepted ruler of both societies. ${ }^{53}$ The new concept of synthesizing Chinese and non-Chinese into one dualistic political entity won respect from the nomads, who accepted Taizong as Heavenly Qaghan. On his death, the nomadic generals Ashina Sheer and Qibi Heli even asked to follow their deceased master to the grave, but this was not allowed. As we shall see, it was that sort of special relationship between the Heavenly Qaghan and the non-Chinese that brought the Uighurs and oasis states to offer their aid when the An Lushan rebellion broke out. ${ }^{54}$

Indeed, Taizong's background as the scion of the intermarriage of Chinese and non-Chinese families gave him a distinctly non-Chinese aura. Even while still just a prince, Taizong formed a relationship of sworn brotherhood with a Western Turkish prince and with Tölish Qaghan of the Eastern Turks, which shows that he could interact personally with the Turks on their own terms, no matter what his motives may have been. ${ }^{55}$

As noted in Chapter 1, ever since non-Chinese first established their regimes inside China during the fourth century, the problem of how to combine rule over both Chinese and nomads had been faced by the Northern dynasties, the most thorough-going attempt at a solution being that of Yuwen Tai of Western Wei. The Sui and Tang royal houses were direct descendants of the northwestern aristocracy formed by the inter-

${ }^{51}$ Chen Yinke, Sui-Tang Zhidu Yuanyuan Luelungao, see his 1971.

52 Twitchett and Wright 1973, p. 1.

${ }^{53}$ Barfield 1989, p. 140; p. 144.

${ }^{54}$ Ise 1968, pp. 546-8.

${ }^{55}$ JTS 194A, p. 5156; 194B, p. 5183. 
marriage of Chinese men with the daughters of non-Chinese leading families at that time. The advantage from the Chinese point of view for the offspring of such marriages was that they bore Chinese family names.

As successor to the Northern dynasty rulers, Taizong could take on the role of being a true ruler of a universal empire in a way different from pre-Northern dynasty rulers. On various occasions Taizong expressed this aspiration. Thus, he once said:

The Yi and Di are also just human beings, and their natures are not different from those of the Chinese. A ruler's concern is that the beneficence of his virtue may not extend to them, and he should not suspect them because of racial differences. If the beneficence of his virtue harmonizes them, then the four barbarians can be made into one family; if suspicions are many, even family members cannot avoid being enemies. $^{56}$

On another occasion he said:

The emperors from ancient times all appreciated the Chinese and depreciated the barbarians. Only I view them as equal. That is why they look upon me as their parent. ${ }^{57}$

Before and during his reign, Taizong actively enlisted non-Chinese generals into the Tang armies, granting them military titles, the royal Li surname, or marriages, and used nomadic forces to help fight Tang's battles, all practices that were continued by later rulers, as we shall see in this and later chapters.

It is clear that Tang China as a whole was very cosmopolitan. Foreign influences can be seen in every aspect of its culture-music, dance, literature, painting, medicine, knowledge of geography and calendar making, food, costume, hairstyle, etc. ${ }^{58}$ It was a time when different religions flourished. ${ }^{59}$ While in 624 and 626, Fu Yi, the Grand Astrologer (taishi ling), presented memorials attacking Buddhism as a foreign religion that was not beneficial to the common people and was harmful to the

${ }^{56}$ ZZTJ 197, pp. 6215-6.

${ }^{57}$ ZZTJ 198, p. 6247.

58 Many works note this feature. See for example, Xiang Da 1957, pp. 1-116; Schafer 1963, pp. 28-39; Lin Enxian 1972; Twitchett and Wright 1973, p. 1; Xie Haiping 1978, pp. 383-446.

${ }^{59}$ Xiang Da 1957, pp. 89-95; Xie Haiping 1978, pp. 366-83; Leslie 1981-83. 
state, ${ }^{60}$ it is interesting to note that, developing the concept of "madhyadesa" as mentioned in Chapter 1, the leading Tang Buddhist scholar, Daoxuan (596-667), in his essay, the Shijia Fangzhi, argued that it was not China but Middle Tianzhu, India, that was the center of the world. $\mathrm{He}$ concluded that it was due to their lack of knowledge, caused by the confining nature of their Confucian ideas, that some scholars held that Luoyang was the center. ${ }^{61}$ His argument was, of course, designed to refute the claims of Confucian scholars and to advance the position of Buddhism in a Chinese society, in which sinocentrism was still dominant. That such arguments needed to be made even after Taizong had created the new and larger ecumene, may be taken as a measure of the incompleteness of that ecumene's dominance.

\section{Debate on the Policy of Resettling the Turks}

Taizong's ambition to be a Heavenly Qaghan and his vision of a multi-ethnic empire were also reflected in his decision on the resettlement of the Turks. The victories over the Eastern Turks in 630 raised an immediate question as to how to resettle the 100,000 or so Turks who had surrendered. It was not a new issue, but it was a difficult and constant one that faced Chinese rulers from the Han onwards.

The Former Han government established the system of dependent states (shuguo) in which to resettle the nomadic Xiongnu who had submitted. Within each dependent state the highest office was in the hands of a Chinese, under whose direction the Xiongnu military force and political organization was placed. During Later Han the Southern Xiongnu moved inside the Chinese frontier. Although their political structure remained intact they were kept under close Chinese supervision.

During the Wei and Western Jin periods still more nomads were resettled in the interior of China. All these nomads periodically staged rebellions against Chinese rule. The most severe one was led by Liu Yuan, a Xiongnu descendant in 304. It ended the Western Jin regime and began the period of "barbarian" rule in North China. ${ }^{62}$ Sui attempted to return to the policy of bringing the Turks who had submitted inside the frontier.

Chinese relations with the nomads displayed an abiding pattern on both sides. When the nomads were strong, they followed "an outer frontier

\footnotetext{
${ }^{60}$ THY 47, pp. 835-6; ZZTJ 191, pp. 6001-2.

${ }^{61}$ Shijia Fangzhi, p. 949.

${ }^{62}$ For a study of the settlement policy before Tang, see Pan Yihong 1992b, pp. 41-56.
} 
strategy", as described by Barfield, forcing the Chinese to meet their demands for subsidies and trade; when they were weak they chose an "inner frontier strategy" to submit to China and utilize Chinese assistance so that they could accumulate goods and recover their strength. ${ }^{63}$ The nomads' inner frontier strategy, however, had certain inherent problems. It could result in increasing reliance on China and finally lead to their losing the chance to recover their own power and to perpetuate their identity.

For their part, the Chinese understood these nomadic strategies. From Han onwards, they realized that resettlement was always problematical. Resettlement was applied only to some nomadic peoples for some varying length of time, and there were always other nomads beyond the borders ready to entice the resettled nomads to leave China. Since the resettled nomads usually lived in border areas without a large Han Chinese population, there was little to prevent these nomads from rising in revolt or returning to the steppe and recovering their state power.

But despite the constant rebellions by nomads who had submitted, the imperial courts persisted in their settlement policies, since the "submission" of the nomadic peoples could be taken as confirmation of the benevolent and virtuous rule of the Son of Heaven, a factor that served to strengthen the legitimacy of the Son of Heaven. The Chinese rulers could not, therefore, afford to refuse the nomads" "submission" and subsequent resettlement, particularly when this was less costly than engaging in wars for the purpose of keeping peace on the frontiers. Also, the Chinese rulers wished to utilize the considerable military force of the nomads for their own purposes.

The Tang court held heated discussions on the matter, which went on for several years. After three centuries of alien rule, now that China was at last unified under a Chinese regime, the issue of redefining Chineseness inevitably arose. In this debate four opinions can be discerned.

1. The opinion that the nomads should be sinicized or assimilated. Many court officials held that the court should scatter the Turks among the Chinese prefectures and counties, make them take up agriculture and change their customs so as to convert the formerly dangerous nomads into Chinese subjects. This would increase China's population while the region north of the Great Wall would become an empty land. The sinicization of the nomads during the previous three centuries of foreign rule in North China must have been in the minds of the advocates of this policy, but it

${ }^{63}$ Barfield 1989, p. 63; p. 91. 
was hardly realistic to suppose that China had the power to empty the Mongolian steppe and keep it from filling up again with other nomads from farther away.

2. The opinion that drew a clear line between the Chinese and nonChinese, insisting on the principle of "having the various states of Xia within and keeping the Yi and Di barbarians without." Holders of this opinion urged that the Turks should be settled outside China under Chinese supervision and their power be kept fragmented. Yan Shigu, Vice Director of the Secretariat (zhongshu shilang), maintained that the "barbarians" had always been in the outermost zone and it was impossible to suddenly change their customs. One ought to control them, he said, in accordance with their own customs. He suggested that the Turks should be settled north of the loop of the Yellow River, that different chiefs should be appointed separately for each tribe, from high to low, that all their territories should be separately delineated by the Chinese, and that separate administrations should be set up for each region.

Dou Jing, now Area Commander of Xiazhou, held that since "barbarians" were like animals, they could neither be disciplined by rules nor taught by benevolence and righteousness. China, he said, would not benefit by gaining their allegiance, but in so far as the nomads had submitted, it was open to the court to grant them favors at its discretion, such as giving them the title of "wise king" (xian wang, the nomads' own rank), and providing them with wives from the imperial clan. He said that China should divide their land and split up the tribes in order to weaken their power, should control them, but with a loose rein, and should turn them into outer subjects defending Chinese frontiers.

Du Chuke, Supervising Secretary (jishi zhong), observed that "barbarians" were difficult to hold by virtue but easy to control by force. If the court accepted their surrender, he said, and settled them south of the Yellow River, they would definitely cause troubles.

Li Baiyao, Vice Minister of Rites (libu shilang), recommended that the court take advantage of the Turks' lack of unity and set up chiefs for each separate group, thereby ensuring that no one group would become dominant. Each group would have to continually protect itself against the others and would have no time or strength to challenge China. China should establish a Protectorate in Dingxiang town to supervise them.

All these men, except for Dou Jing, were civil officials with no experience dealing with nomads. Their cautious, hostile and conservative views towards the Turks were no doubt derived from their reading of ear- 
lier history and their wish to reestablish a clear distinction between Chinese and "barbarians."

3. The opinion that the Turks should be sinicized gradually. Chief Minister Wen Yanbo, who was once captured and taken to the Turks early in his career, was the main advocate of this point of view. While he rejected the idea that the Turks should be scattered further inside China, probably because he foresaw that local governments would have difficulty controlling them, he suggested that the nomads be settled south of the great loop of the Yellow River and be used as a force for defending Tang, but without at first attempting to change their customs. However, he believed, they could and should gradually be sinicized. Wen Yanbo argued that the Son of Heaven should care for all creatures, show pity on the Turks who had come to surrender, settle them south of the Yellow River and provide them with means of livelihood, so they would not rebel.

He believed that the Chinese could make the settled Turks obey Chinese orders, and teach them righteousness and laws, and that after a few years the court should begin to select Turks for service in the Imperial Bodyguard, just as the Later Han had done with the Southern Xiongnu. The cause of the earlier Turkish rebellion, he believed, was to be traced to the restoration of the Turkish qaghanate by Sui Emperor Wen. Now, if the Chinese let the Turks settle at their own will, either south or north of the Yellow River, their tribes would be scattered and their power split. They could not possibly again become a menace.

4. The opinion expressed by Chief Minister Wei Zheng represented a total rejection of the Turks. He would presumably have agreed with the second opinion. His views were mainly in opposition to Wen's proposed policy of gradual assimilation. Wei argued that assimilation was not possible because though the nomads had human faces they had "animal hearts." They plundered when they were strong and submitted only when weak and then only to regain their strength. He was worried that since the Turks now numbered almost 100,000 , within a few years, their population would surely increase, and they would definitely begin to cause trouble again. He cited the sad lessons of earlier times when Western Jin had "barbarians" living inside China. Within a few years, he recalled, the "barbarians" had caused the collapse of the dynasty. ${ }^{64}$

From the historical precedents, the Tang Chinese saw that reset-

${ }^{64}$ ZGZY 9, pp. 18a-20a; JTS 61, p. 2361; pp. 2369-70; 194A, pp. 5162-3; XTS 91, p. 3782 ; 95, pp. 3848-9; 215A, pp. 6037-8; ZZTJ 193, pp. 6075-7; THY73, pp. 1312-4. 
tlement of the nomads who had submitted might have two possible results: their rebellion or their assimilation. Wen Yanbo's opinions, drawing on the Han experience, explicitly advocated that the Turks should be brought within the Chinese frontier and gradually sinicized. The final decisionmaker, Taizong himself, accepted Wen Yanbo's view. In his arrangements to resettle the Turks, Taizong thus showed some bias in favor of his Chinese side despite his aspiration to have equal regard for all the subjects of his world empire.

\section{The Resettlement of the Turks}

The first step in the policy of resettlement was to deprive the Turkish leaders of their native political titles and bring them into the Chinese system of official titles. Taizong did not want to let them retain their own titles, as the Han ruler had done with the Xiongnu title chanyu, and the Sui with the Turkish title qaghan. Xieli was appointed Prefect (cishi) of Guozhou, even though this was an area inhabited by wild animals and most suitable for hunting. When he chose not to go to his prefecture he was given the office of General-in-chief of the Right Guard, with houses and land in the Tang capital. Nevertheless, he was spiritually crushed by memory of his defeat and died in $634 .^{65}$ Tölish was given a dual appointment as General-in-chief of the Right Guard, and Commandery Prince of Beiping with an annual income from 700 households. ${ }^{66}$ When Taizong gave Tölish yet another title as Area Commander of Shunzhou in 630, he clearly stated to Tölish what he intended by the arrangement:

When your affairs came to an extremity, you came to surrender. The reason why I do not make you qaghan is just because of the example of Qimin. In changing the former way I wish to give China permanent peace and your clan permanent security. I therefore make you an area commander. You should follow our laws, discipline your people, and not invade and plunder each other at will. If disobedience occurs, [the offender] will be severely punished. ${ }^{67}$

The tribal leaders were all given Chinese military official titles and responsibilities. More than a hundred whose ranks were above the fifth, ac-

\footnotetext{
${ }^{65}$ JTS 194A, pp. 5159-60; XTS 215A, p. 6036; ZZTJ 194, p. 6099; p. 6105.

${ }^{66}$ JTS 194A, p. 5161; XTS 215A, p. 6038; ZZTJ 193, p. 6073; CFYG 964, p. 11337. CFYG says that the income was from the taxes on 1,000 households.

${ }^{67}$ JTS 194A, p. 5161.
} 
companied by as many as a thousand families, settled in Chang'an. ${ }^{68}$

The second step was to resettle all the nomads into the system of "subordinated area commands and prefectures," or "area commands and prefectures controlled by loose rein" (jimi fuzhou), the nature of which is discussed below. Surviving records concerning the jimi area commands set up to resettle the Turks are too inadequate and too confusing to yield a clear picture. One opinion holds that by 634 , the Eastern Turks were divided into two major groups. One was resettled inside the frontiers under four area commands, namely, Shunzhou, Youzhou, Huazhou, and Changzhou. These were scattered south of the Yellow River in the area from Youzhou (in modern Hebei) to Lingzhou (in modern Ningxia). Another group was outside the frontiers under six prefectures, and all of them were supervised by the Area Commands of Dingxiang and Yunzhong, both north of the Yellow River. Dou Jing, well experienced in Turkish affairs, was appointed Commissioner-in-chief (dashi) of Ningshuo to take charge of the Turks. ${ }^{69}$

The potential threat posed by the pacified Turks was sensed by some Chinese officials right from the beginning. Despite Taizong's decision, some continued to advocate that Tang found a Turkish state north of the Yellow River instead of settling the Turks inside China. Wen Yanbo insisted, however, that since Tang had already accepted the Turks, it would be a pity to send them away without reason. Apparently Taizong accepted Wen's advice. Nevertheless, opposition did not stop, and the debate about the proper way to deal with the Turks and other non-Chinese who had surrendered went on. ${ }^{70}$

\section{Adjustments in the Turkish Settlement}

The policy of resettling the Turks met with its first setback in 639, nine years after it started. That year the younger brother of Tölish Qaghan, who had joined the Imperial Bodyguard after submitting to Tang, made an attempt to attack Taizong. He conspired with Tölish's son, who became the Area Commander of Shunzhou after Tölish. Though it ended in failure, the incident aroused universal opposition at court to the resettlement of the Turks south of the Yellow River. Taizong also voiced his deep regret for

\footnotetext{
${ }^{68}$ JTS 194A, p. 5163; XTS 215A, p. 6038; THY 73, p. 1311. ZZTJ 193 (p. 6078) says that almost 10,000 families settled in Chang'an. That number seems too large.

${ }^{69}$ Iwami 1987, pp. 510-6. For a different opinion, see Zhang Qun 1986, pp. 121-2.

${ }^{70}$ JTS 61, p. 2361.
} 
having neglected Wei Zheng's warning. After reiterating the thesis that the Chinese were like roots while the "barbarians" were like leaves, he changed policy. All the Turks were to be moved north of the Yellow River with headquarters set up in Dingxiang. ${ }^{71}$ They were to be treated as outer subjects, in essence, as a client state, responsible for the defense of the Chinese frontiers. They were placed under Ashina Simo of the Turkish royal clan, the former Area Commander of Huazhou. He was granted the royal surname, $\mathrm{Li}$, and the title of qaghan. The titles of Wise King of the Left and Wise King of the Right, which were titles used by the nomads, were conferred on other Turkish chiefs.

This new arrangement was also partly motivated by a desire to check the power of the Xueyantuo. With the defeat of the Eastern Turks, the Xueyantuo took their place as the dominant power on the steppe land. When Simo did not want to move because he feared an attack from the Xueyantuo, Taizong had a letter sent to the Xueyantuo stating that they were to occupy the territory north of the Gobi Desert, while the Turks should stay south of it, and that Tang was ready to come to the aid of the Turks in case any attacks were made on them by the Xueyantuo. Simo then moved out to the north of the Yellow River in $641 .^{72}$ In 640 , Tang reestablished the position of the Commissioner-in-chief of Ningshuo, with responsibility for Turkish affairs. ${ }^{73}$ In 641 , the Xueyantuo crossed the Gobi desert and attacked Simo. Tang sent troops to the rescue and succeeded in forcing Yi'nan to make peace with Simo. ${ }^{74}$

In 644 Simo's people asked to be allowed to move back to the Ordos region because Simo was unable to resist the attacks from the Xueyantuo, and could not maintain control over his people. Disregarding the objections of his ministers, Taizong again resettled them inside China, claiming that the "barbarians" should be treated as members of the Chinese family. He made a point of asking Chu Suiliang to record his exact words in the court diary. ${ }^{75}$ Taizong's real motive may have been to preserve Li Simo's tribe so that they could continue to function as a force defending the Tang frontier.

\footnotetext{
${ }^{71}$ Iwami 1987, p. 515.

${ }^{72}$ JTS 194A, pp. 5163-4; XTS 215A, pp. 6039-40; ZZTJ 195, pp. 6148-9; 196, p. 6165.

${ }^{73}$ Dou Jing was appointed to this position in 630 , but when he moved on to another post, the position appears to have been abolished. ZZTJ 195, p. 6154; CFYG 991, p. 11638.

${ }^{74}$ JTS 199B, pp. 5344-5; XTS 217B, pp. 6135-6; ZZTJ 196, pp. 6170-2.

${ }^{75}$ JTS 194A, pp. 5164-5; XTS 215A, p. 6040; ZZTJ 197, pp. 6215-6.
} 


\section{The Conquest of the Xueyantuo in 646}

With the defeat of the Eastern Turks, the Xueyantuo grew to be an important nomadic power on the steppe lands. Before moving Simo and his people north of the Yellow River, Taizong had already decided on a divide and rule policy to weaken the Xueyantuo. In 638 he despatched an embassy to confer the title of "minor qaghan" on the two sons of Yi'nan Qaghan, and gave them each drums and banners, "ostensibly to show favor but in reality to divide their power." ${ }^{, 76}$

Then, when Yi'nan in 640 requested a marriage contract with Tang, Taizong refused after a protracted discussion and careful consideration. Fang Xuanling, Taizong's eminent Chief Minister, suggested that Tang consent on the grounds that the dynasty had not yet fully settled its frontier problems. Taizong initially agreed. At this time Qibi Heli, a former chief of the Tiele who had submitted to Tang in 632 and been appointed a general, was forced by his followers to go over to the Xueyantuo. Tang sent an envoy to the Xueyantuo with the promise of a Chinese princess in marriage in exchange for Qibi, and Qibi Heli was as a consequence returned.

But soon after he returned Qibi strongly opposed the marriage to the Xueyantuo, arguing that Yi'nan was already in a weak position, and that by refusing his request Tang could further weaken him so that there would later be an opportunity to defeat the Xueyantuo. He suggested that Tang ask Yi'nan to come to court to receive the bride personally. Tang should decline to go through with the marriage if Yi'nan refused to come to court, for Qibi was sure that Yi'nan would not dare to expose himself by coming to China.

Chu Suiliang, Grand Master of Remonstrance, on the other hand, insisted that Taizong should keep his promise, not only because it was a moral principle that an emperor should keep faith but also because history had shown that there was no way for China to eliminate the nomadic peoples.

Chu was not alone in his opinion, but Taizong preferred to accept Qibi's suggestion. The emperor stated that the policy of marriage alliance was to be used only as an expedient to further Chinese aims; the Xueyantuo ruler's submissiveness was simply because he had recently become ruler of various tribes who were not of his own clan and therefore wanted

\footnotetext{
${ }^{76}$ Cen Zhongmian 1958 , pp. $216-7$. He is of the opinion that Tang conferred on Yi'nan's two sons the titles of qaghan and yabgu, respectively.
} 
to borrow Chinese authority to strengthen his own position. If Tang stopped the marriage, the various tribes would know that the Chinese had abandoned Yi'nan and would rebel against him. Taizong then declined to go through with the marriage on the pretext that Yi'nan had not prepared enough betrothal gifts and had not promised to come personally to receive his bride.

Four hundred years later, Sima Guang severely criticized Taizong for this breach of promise and concluded that even though Taizong eventually destroyed the Xueyantuo, it was shameful to rely on one's strength to break a promise. ${ }^{77}$ As an astute politician, a skillful military leader with a good grasp of the nomadic situation, Taizong knew very well that policies based on peace and moral principles simply did not work in most cases in international affairs, where the decisive factor was the balance of power.

Tang's refusal of a marriage worked effectively to weaken Yi'nan's power. Seven years later, in 645, he died and was succeeded by his son, Duomi Qaghan. While Taizong was occupied with his Korean expeditions Duomi made incursions into the Chinese frontier regions, and there was a danger that Koguryǒ would attempt to bribe the Xueyantuo into an alliance. ${ }^{78}$ This made Tang determine to eliminate the Xueyantuo once and for all. In 646, when Duomi's brutal rule provoked an uprising by other Tiele tribes including the Uighurs, Pugu (Buqu) and Tongluo (Tongra), Tang immediately seized the opportunity to despatch Chinese, Turkish and other non-Chinese troops to attack the Xueyantuo.

When Duomi was killed by the Uighurs, the Xueyantuo qaghanate collapsed. Taizong went to Lingzhou to encourage the troops and to entice the submission of Uighur and other Tiele tribes to forestall any chance that one of them would replace the Xueyantuo as the dominant power on the steppe. Through their envoys, the chieftains of these tribes expressed the wish to be subjects of the Heavenly Qaghan. ${ }^{79}$

Taizong was determined to subjugate all the nomads. In 649 he ordered an attack on an Eastern Turkish tribe under Chebi Qaghan, who had been attached to the Xueyantuo after 630, but since had become indepen-

77 JTS 80, pp. 2732-3; 109, pp. 3291-2; 199B, pp. 5345-6; XTS 105, p. 4027; 110, pp.

4118-19; 217B, pp. 6136-7; ZZTJ 196, pp. 6179-80; 197, pp. 6199-202.

${ }^{78}$ JTS 199B, p. 5346; XTS 217B, pp. 6137-8; ZZTJ 198, pp. 6227-8.

${ }^{79}$ JTS 199B, pp. 5346-8; XTS 217B, pp. 6138-9; ZZTJ 198, pp. 6232-3; pp. 6236-40. 
dent and strong. The Tang attack succeeded in the following year. ${ }^{80}$

\section{Resettlement of the Xueyantuo and Other Tiele Tribes}

In accordance with his grand design for a universal empire, Taizong in 647 established six area commands and seven prefectures for the Xueyantuo and other Tiele people on their own territory, with their chieftains as area commanders and prefects. ${ }^{81}$ As in the Chinese bureaucratic system, the offices of administrator and assistant were also set up for the Tiele. These institutions were placed under the administration of the Protectorate of Yanran north of the great loop of the Yellow River with a Chinese as Protector-general. Over sixty relay stations were set up along the route stretching from south of the Uighurs to the Protectorate of Yanran. Annual payments in the form of marten pelts were levied as tax. ${ }^{82}$

It should be noted that instead of moving the non-Chinese who had submitted inside the frontier, Taizong established a Chinese administrative system in their own areas. In any case, it would have been physically impossible to move so many of them inside China, and after 639 , when the Turks rebelled against Tang, there was not much political will at court to adopt so radical a policy for dealing with the nomads. Even when the Uighurs were brought under the jimi area command-prefecture system, they continued to use the title of qaghan. The Chinese were aware of this fact, but chose not do anything about it. ${ }^{83}$

The aim of the Chinese resettlement of these nomads was to keep them peaceful under the Chinese jimi fuzhou system and to use them in military campaigns. In 648 , when an internal conflict occurred between the Uighur chief Tumidu and his two pro-Turkish nephews, both sons-in-law of Chebi Qaghan, the Vice Protector-general of Yanran had one of the nephews executed. Fearful of the disintegration of the Uighurs, Taizong sent Cui Dunli, the Minister of War, experienced in frontier affairs, as a pacification missioner to the Uighurs. Tumidu's son was appointed General-in-chief, great iltäbär (da silifa) and Area Commander of Hanhai, succeeding his father, who had been killed by the pro-Turkish party. ${ }^{84}$ After

\footnotetext{
${ }^{80}$ JTS 194A, p. 5156; XTS 215A, pp. 6041-2; ZZTJ 199, p. 6265.

${ }^{81}$ For their names, see Cen Zhongmian 1958, pp. 1066-73.

82 JTS 195, p. 5196; 199B, pp. 5348-9; XTS 217A, pp. 6112-3; 217B, pp. 6139-42; p. 6145; ZZTJ 198, pp. 6244-5; Ma Changshou 1957, pp. 57-8.

${ }^{83}$ JTS 195, p. 5196; XTS 217A, p. 6113; ZZTJ 198, p. 6245.

${ }^{84}$ JTS 81 , p. 2747 ; 195 , p. 5197 ; XTS 106, p. 4044; 217 A, p. 6113 ; ZZTJ 199, p. 6262; p. 6263.
} 
resolving their own crisis, the Uighurs joined several Tang frontier expeditions in 649 and during Gaozong's reign. ${ }^{85}$

\section{Tang Expansion into the Western Regions}

At the beginning of Taizong's reign, the Western Turkish qaghanate was divided into a number of contending groups. Each of the various rulers tried to obtain Tang assistance to strengthen himself, but Taizong tried to keep friendly relations with them all. Because of their internal political instability and power struggles, the Western Turks did not pose much of a direct threat to Tang, but collectively they managed to maintain their control over the Western Regions. ${ }^{86}$

Right after the conquest of the Eastern Turks in 630, Taizong appointed Li Daliang, the Area Commander of Liangzhou, as commissioner to attract the submission of the Western Turkish tribes who were scattered around Hami in the Western Regions. He was to accomplish this by providing them with food supplies. Li objected in a memorial, saying that the Chinese people were like the roots of the empire but the "barbarians" were like branches and leaves, and that disturbing the root in an attempt to strengthen the branches and leaves had never been a successful basis on which to seek long-term peace. He criticized the Han and Sui attempts to subjugate the Western Regions, and also disagreed with the settlement policy as it was directed toward the Eastern Turks.

Some accounts state that Taizong accepted Li's analysis. ${ }^{87}$ The Zhenguan Zhengyao, on the other hand, says the opposite, ${ }^{88}$ which seems correct, for in the same year, Hami, formerly a Sui commandery then under the Turks, submitted to Tang. Taizong established the prefecture of Xiyizhou there, later changed to Yizhou. ${ }^{89}$ Control over Hami opened for Tang a gateway to the Western Regions.

However, Taizong was not in a hurry to expand in that direction. During early Tang, the king of Gaochang kept up a friendly relationship with China and acted as informant to China about other oasis states. But the king gradually began to display a quite strong tendency toward independence. He devloped a close relationship with the Western Turks, which

\footnotetext{
${ }^{85}$ See Table 3.

${ }^{86}$ JTS 194B, pp. 5182-5; XTS 215B, pp. 6057-60.

${ }^{87}$ TD 197, p. 1071; JTS 62, pp. 2388-9; XTS 99, pp. 3911-2; ZZTJ 193, pp. 6081-2; THY

73, pp. 1311-2. THY and TD do not say whether Taizong accepted it or not.

${ }^{88}$ ZGZY 9, pp. 20a-21b.

${ }^{89}$ XTS 215A, p. 6036; ZZTJ 193, p. 6082.
} 
is described in the work of Xuanzang, the famous Tang monk then traveling through Central Asia, ${ }^{90}$ and he allied himself with the Western Turks in an attack on Hami and another oasis state, detained Chinese who had fled first to the Turks and then to Gaochang, blocked the way of the envoys of other oasis states to present tribute to Tang, and sent an envoy to the Xueyantuo asking their qaghan not to be subject to Tang.

When the Xueyantuo expressed the wish to guide the Chinese in an attack on Gaochang, Taizong agreed. Ignoring strong opposition from many court ministers Taizong ordered an expedition against Gaochang in 639. The Eastern Turks, the Qibi tribe of the Tiele, and Yanqi (Karashahr), a state in the Western Regions, joined the campaign.

Following the success of this campaign in 640, Taizong established a prefecture-Xizhou-in Gaochang and the Protectorate of Anxi (Anxi $d u h u f u$ ), the first of a series of protectorates established during the Tang dynasty, with more than 1,000 Chinese troops and ex-convicts stationed there. At the same time the garrison of the Western Turks in Futu town (in Jimsa) surrendered to Tang, and Futu was renamed Tingzhou. ${ }^{91}$

Wei Zheng and Chu Suiliang objected strongly to the decision on the grounds that a great number of Chinese troops and supplies would be needed to keep control there, and China would not gain any benefit from the expense. ${ }^{92}$ Both were typical Confucian scholar-officials and both held fast to the conservative view that a line must be drawn between Chinese and non-Chinese. Taizong ignored them. He seems to have understood clearly that Gaochang occupied too strategically important a location for gaining access to the Western Regions to be neglected.

Now that Tang began to press into the Western Regions, it encountered the Western Turks directly. In 642, the Turks attacked Yizhou. Guo Xiaoke, the Protector-general of Anxi and the Area Commander of Liangzhou, drove the Turks back. Taizong expressed regret that he had not listened to Chu Suiliang at the time of the establishment of Yizhou. ${ }^{93}$ But if Tang was to defeat the Western Turks, it simply had to extend its influence into the Western Regions, and once it was there, it had to deal with the problems that arose.

In 644 Guo Xiaoke proposed an attack on Karashahr since its king

\footnotetext{
${ }^{90}$ Lin Enxian 1988, p. 306.

91 JTS 198, pp. 5294-6; XTS 221A, pp. 6221-3; ZZTJ 195, pp. 6146-7; pp. 6154-6.

92 JTS 80, pp. 2736-7; ZZTJ 195, pp. 6155-6; THY 95, pp. 1702-3.

${ }^{93}$ JTS 194B, p. 5185; XTS 215B, pp. 6059-60; ZZTJ 196, pp. 6177-9.
} 
had made contact with the Western Turks. Taizong agreed. Although Guo had a success, after he left, Karashahr turned back to the Western Turks. ${ }^{94}$

In 646 when the Western Turks asked for a marriage, Taizong granted the request on condition that the Turks concede as betrothal gifts the five oasis states: Kucha, Khotan, Shule (Kashgar), Zhujubo (Karghalik) and Congling (Tashkurgan), then under Turkish control. No marriage, however, was arranged. ${ }^{95}$ In 647 Taizong ordered a campaign against Kucha. The Chinese expeditionary force was under the command of Ashina Sheer, a former Turkish chief who had submitted to Tang in 635 , been married to a Tang princess and appointed a general. ${ }^{96}$ Troops from Anxi and contingents from the Tiele, the Eastern Turks, the Tuyuhun and the Tibetans, who had just contracted their first marriage alliance with Tang, also joined the expedition. In $648 \mathrm{Kucha}$ was captured.

Karashahr was also defeated by the Tang armies. The king of Khotan sent envoys to Tang to give his allegiance. ${ }^{97}$ In the same year Ashina Helu seized a chief of the Western Turks and submitted to Tang. Taizong thereupon resettled Helu's people in Tingzhou and made him an area commander. ${ }^{98}$

The seat of the Protectorate of Anxi was moved farther west to Kucha. ${ }^{99}$ Some sources say that to consolidate the Chinese foothold in the Western Regions Ashina Sheer established garrisons in Kucha, Kashgar, Suiye (Tokmak) and Khotan, thereafter known as the Four Garrisons. Due to the conflicting and confusing accounts in the sources, the issue of which oasis states constituted the Four Garrisons and the dates when Tang won and lost control over them is controversial. ${ }^{100}$ In any case we can say that by the end of Taizong's reign Tang influence had penetrated into the heart of the Western Regions.

\section{Gaozong's Conquest of the Western Turks}

Soon after the death of Taizong in 649, Ashina Helu broke away from Chinese control and set up a regime that brought under his authority

\footnotetext{
${ }^{94}$ JTS 198, p. 5302; XTS 221A, p. 6229; ZZTJ 197, pp. 6211-3.

${ }^{95}$ JTS 194B, p. 5185; XTS 215B, p. 6060; ZZTJ 198, p. 6236; THY 94, p. 1694. THY records the request as in 645 whereas ZZTJ has it in 646.

${ }^{96}$ JTS 109, p. $3288 ;$ XTS 110, p. 4115.

${ }^{97}$ Ise 1968 , pp. $185-7$; pp. 197-8.

${ }^{98}$ JTS 194B, p. 5186; XTS 215B, p. 6060; ZZTJ 199, pp. 6256-7; p. 6265.

${ }^{99}$ Ise 1968 , pp. $187-90$.

${ }^{100}$ Ise 1968, pp. 190-1.
} 
the different tribes of the Western Turks and some oasis states in the Western Regions. His power was also felt in the Tarim Basin and extended beyond the Pamirs into present Afghanistan. Helu also made incursions into Tingzhou. In 651 the court had to abandon the Four Garrisons and move the seat of the Protectorate of Anxi back to Xizhou. ${ }^{101}$

Gaozong, however, was determined to continue his father's forceful foreign policy. He sent three expeditionary armies, including Uighur units, to the Western Regions. Finally, in 657, Tang succeeded in defeating Helu, who was captured and died soon after. Two years later, when Zhenzhu, a Western Turkish leader, was killed by Ashina Mishe, who had earlier submitted to Tang, the Western Turks were decisively defeated by Tang. ${ }^{102}$

The victory brought the Western Turks and the states in Central Asia which had formerly been subjects of the Western Turks under the subordinated area command and into the prefecture systems. Between 658 and 661, over a hundred identifiable area commands and prefectures were set up. The vast area under this Tang administration covered Central Asia, reaching as far as the borders of Persia. ${ }^{103}$ For a brief period in Gaozong's time, Chinese suzerainty covered more territory than at any other time in Chinese history.

To consolidate Tang administration over so large an area, the seat of the Protectorate of Anxi was again moved from Xizhou west to Kucha in 658 , from which Tang authorities supervised all the oasis states. The Protectorates of Kunling and Mengchi were established to supervise the Western Turks. ${ }^{104}$ Gaozong appointed as their Protectors-general two formerly rival Turkish leaders, Ashina Mishe and Ashina Buzhen, both of whom had submitted to Tang earlier, during the reign of Taizong. The title of qaghan was conferred on both. Both were entrusted, along with a Chinese minister, with the power to bestow Chinese official titles on the tribal chieftains in the protectorates. ${ }^{105}$ In 662 the Protectorate of Jinshan was set up in Tingzhou to consolidate Tang control over the Western Turks.

From 670 onward Tang control of the Western Regions was con-

\footnotetext{
${ }^{101}$ Ise 1968, pp. 201-4.

102 JTS 194B, pp. 5186-7; XTS 215B, pp. 6060-4; ZZTJ 199, pp. 6273-7; 200, pp. 6301-2; pp. $6305-7$; p. 6311.

${ }^{103}$ This is according to Chavannes 1969, pp. 55-8; pp. 192-202. See also Cen Zhongmian 1958, Xi Tujue Shiliao Buque ji Kaozheng, pp. 139-53; Ise 1968, pp. 207-16.

${ }^{104}$ Chavannes 1969, p. 192; Ise 1968, pp. 207-16.

105 JTS 194B, pp. 5187-90; XTS 215B, p. 6063; ZZTJ 200, pp. 6307-8.
} 
tested by the Tibetans (Chapter 7). Following a period of Tibetan control, the Protectorate of Beiting was set up in 702 , with its headquarters in Tingzhou. ${ }^{106}$

\section{The System of jimi fuzhou and the Protectorate}

As we have seen, the Tang dynasty established the jimi fuzhou or subordinated area commands and prefectures to organize the non-Chinese who had submitted to Tang into the empire's administrative apparatus. This arrangement had its model in the Han dynasty when the Chinese government brought the non-Chinese who had submitted to China under the Chinese bureaucratic system in three ways: 1) by establishing dependent states in which the non-Chinese maintained their traditional way of life under their own chiefs; 2) by organizing them directly under the Chinese "commandery" (jun) and "district" (xian) system, with a xian to be called dao in case there were non-Chinese under its jurisdiction; 3) by organizing the non-Chinese under $b u$, a military subdivision of a commandery; it was usually frontier commanderies that had such subdivisions. Over time, many shuguo and bu were transformed into jun. ${ }^{107}$

The Tang establishment of the jimi fuzhou started in Gaozu's time. For example, Shenzhou was placed over the Mohe tribes in the northeast and Nanningzhou, Kunzhou, Lizhou etc. over aboriginal tribes in the southwest. ${ }^{108}$ After Taizong's conquest of the Turks, more jimi fuzhou were established. The Tang jimi system was more rationalized than the parallel Han system and covered a larger area. Under the jimi system, the non-Chinese, like the Chinese, were organized into districts, several of which were placed under a prefecture, and in strategic areas, prefectures were in turn attached to an area command. Tang systematized the practice by designating these non-Chinese districts, prefectures and area commands with the name "control by loose rein" (jimi) to clearly distinguish them from regular Chinese ones and to make explicit the fact that China would not impose direct control over the jimi institutions. ${ }^{109}$ At its height the jimi fuzhou numbered at least eight hundred and fifty-six in all frontier regions. $^{110}$

\footnotetext{
${ }^{106}$ ZZTJ 207, p. 6561; Ise 1968, pp. 237-9.

${ }^{107}$ Yü Ying-shih 1967, pp. 70-8. For shuguo, see also Zhang Qun 1990, pp. 25-31.

${ }^{108}$ XTS 43B, p. 1127; p. 1140 . For a survy of the Tang jimi fuzhou, see also Lin Chaomin 1985.

${ }^{109}$ XTS 43B.

${ }^{110}$ XTS 43B, p. $1120 ; T H Y 70$, p. 1232.
} 
While the regular Chinese area commands and prefectures were directly under the central government, the jimi fuzhou in the frontier regions were placed under "protectorates" ( $d u h u f u$ ), the highest office in charge of the resettled non-Chinese. Copying the Han institution of the Protectorate of the Western Regions, Taizong set up the Protectorate of Anxi in 640 for administration of the Western Regions, and the Protectorate of Yanran in 647 for the control over the Uighurs and other Tiele tribes. The protectorate combined civil and military administration, and had a civilian staff backed by a standing army to supervise the non-Chinese prefectures and area commands.

It was under the command of a Protector-general, who was either a Chinese or a non-Chinese who had submitted and was serving in the Chinese office. He was to "be in charge of the various barbarians, to pacify them, to take punitive actions, to keep record of their meritorious conduct, to punish their failings and to have overall control of the affairs of the protectorate." $" 111$

The protectorate did not rely totally on military force to maintain control. Rather it followed the principle of "using barbarians to control barbarians" and relied on the non-Chinese local chiefs to exercise most of the control. ${ }^{112}$

The jimi fuzhou system continued, with improvements, during Gaozong's reign. In 650, Chebi Qaghan, who had ruled the remnants of the Eastern Turks, was defeated and Gaozong resettled his people under the jimi fuzhou system in the area of the Ötükän Mountains. The court established the Protectorate of Hanhai in addition to Yanran to govern all the jimi fuzhou over the Eastern Turks including the Tiele. ${ }^{113}$ From then on "the northern frontiers were free of problems for over thirty years," the Chinese sources claim. ${ }^{114}$

After the conquest of the Western Turks, many more jimi fuzhou were established. Obviously now the area to be defended was greatly enlarged, and Chinese control lacked sufficient military force to back it up. Yet Gaozong and Empress Wu made efforts to maintain the jimi system. In 660 the $\mathrm{Xi}$ and Khitan in the northeast rebelled, and were suppressed. ${ }^{115}$

${ }^{111}$ XTS 49B, p. 1317; Wechsler 1979, p. 226.

${ }^{112}$ Hino 1984, p. 23.

${ }^{113}$ The names of the two protectorates are confusing in Chinese sources. This is according to Cen Zhongmian 1958, p. 270.

${ }^{114}$ JTS 194A, p. 5166.

${ }^{115}$ ZZTJ 200, p. 6320. 
From 659 to 663 , the Sijie, Uighurs, Tongra, Buqu and other Tiele people in the north also rebelled, but all were suppressed.

After the final suppression of these rebellions in 663, Tang adjusted the system of protectorates to strengthen its control over the nomads. It moved the Protectorate of Yanran to north of the Gobi and changed its name to Hanhai to exercise a close watch over the Uighurs and other Tiele tribes; later, in 669, the name was changed again to Anbei. The former Protectorate of Hanhai was moved to Yunzhong (present Tuoketuo county, Inner Mongolia) and was renamed Yunzhong to exercise control over the Tujue Turks south of the Gobi, and in 664 it was raised in status to become the Grand Protectorate of Chanyu with a Tang prince as its nominal Protector-general. ${ }^{117}$

By early in the eighth century, a comprehensive system of protectorates had been established in a loose chain surrounding China's frontiers. Altogether there were six protectorates of major importance plus several others of less importance. The six were Anxi (mainly for dealing the Western Turks, the Western Regions and Tibet), Beiting (set over the Türgish of the Western Turks in the northwest), Chanyu (ruling over the Eastern Turks), Anbei (placed over the Uighurs and other Tiele nomads in the north), Andong (over the Koreans, Khitan, Xi and Mohe in the northeast) and Annan (to rule over the non-Chinese in the south). ${ }^{118}$ The Protectorate of Annan was formerly the Area Command of Jiaozhou which was promoted to the rank of protectorate in $679 .{ }^{119}$ Before the rise of the Nanzhao kingdom in present Yunnan during mid-Tang, China's southern frontiers were relatively peaceful.

The jimi institutions were set up with the purpose of pacifying and eventually sinicizing the submitted non-Chinese. Those on the northwestern frontiers had the additional task of "defending the frontiers." ${ }^{120}$ From 634 to 669 , the submitted Eastern Turks and the Tiele joined Tang military campaigns against the Tuyuhun, Gaochang, Koguryǒ, Kucha, Xueyantuo, $\mathrm{Xi}$ and Khitan, and the remnants of both Eastern and Western Turks. ${ }^{121}$

${ }^{116}$ JTS 195 , pp. $5197-8$; XTS 217B, p. 6140; ZZTJ 200, p. 6319; p. 6322; pp. 6327-9; 201, p. 6333.

${ }_{117}^{11}$ Cen Zhongmian 1958, pp. 285-6; p. 1070; Lai 1986, pp. 96-8.

${ }^{118}$ Zhang Qun 1955.

${ }^{119}$ THY 73, p. 1320.

${ }_{120}$ JTS 121 , p. 3477.

${ }^{121}$ See Table 3. One would assume that there would have been many more occasions when the nomads participated in Chinese military activities which are not recorded. 
During Taizong's and Gaozong's reigns, the nomadic area commands not only played an active role in Tang campaigns, but also formed an important defense line, acting both as sentries and as buffer areas within the Tang frontier system. ${ }^{122}$ The oasis states in the Western Regions were also expected to participate in Tang battles or to provide provisions for Tang military expeditions. ${ }^{123}$

The jimi fuzhou differed from Chinese area commands and prefectures in that the non-Chinese were governed autonomously by their own chieftains, who were appointed area commanders and prefects. Though these were offices in the Tang bureaucratic system, the appointments were hereditary. Normally, the registers of the tribute or taxation owed and the household census records were not sent up to the Ministry of Revenue. ${ }^{124}$ Those with noble titles, such as commandery prince, were given an annual income comprised of the taxes from a fixed number of households. That the Chinese often provided these officials with supplies of food is evident from Taizong's edict of 639 which says that the Chinese conferred offices on the Turks, chose fertile land for them, established commanderies and districts to settle them in, opened up granaries to relieve their hunger and cold, and sent people around to inquire about their grievances. ${ }^{125}$

To perform the bureaucratic duty of supervision, the Chinese sometimes intervened in the internal affairs of the settled people. When the Uighur tribe was in danger of attack from the Xueyantuo remnants in 648, the Chinese provided military and political assistance. ${ }^{126}$ And when the Uighurs were endangered by an internal conflict in 648, Taizong, fearful of the disintegration of the Uighurs' dependent state, intervened to support the pro-Tang ruler. ${ }^{127}$

That the Turks in the jimi fuzhou were subject to Chinese laws is shown in Taizong's statement in a speech to the former Turkish qaghan that the Turks were to follow Chinese laws, discipline themselves, and not

\footnotetext{
${ }^{122}$ Kang Le 1979, pp. 44-54.

${ }^{123}$ Ise 1968 , p. $531-2$.

${ }^{124}$ XTS 43B, p. 1119 . Hucker gives a brief definition of the jimi fu-hou, which shows its basic nature: "Subordinated Prefecture, a category of administrative units into which submissive foreign and aboriginal groups were commonly organized to fit into the Chinese governmental hierarchy, usually headed by hereditary native chiefs and subordinated to a Chinese Area Command (tu-tu fu)." See his 1985, p. 132.

${ }^{125}$ CFYG 964, pp. 11338-9.

${ }^{126}$ CFYG 973, p. 11432.

${ }^{127}$ JTS 195, p. 5197; XTS 217A, p. 6113; ZZTJ 199, p. 6262; p. 6263.
} 
invade and plunder each other. If disobedience occurred, Taizong said, the offender would be punished. ${ }^{128}$ In 648 , Taizong personally settled a dispute among the nomadic people over runaway horses. ${ }^{129}$

The non-Chinese under the jimi system were subject to taxation, corvée labor, and payment of tribute just like the Chinese, although in a less regular and systematic way and at lower rates. In the surviving fragments of the Tang Taxation Statutes (fuyi ling) are articles concerning the non-Chinese. These items were applicable to non-Chinese both in the jimi fuzhou and in the regular prefectures, and contain no specific item concerning taxation of the nomads, the Turks and the Uighurs. ${ }^{130}$ Nonetheless we do read that in 644 the Turks and people of Gaochang who were attached to the various Chinese prefectures were granted tax exemption. ${ }^{131}$ In 647 , when the Uighur and other Tiele tribes submitted to Tang and were brought into the area commands and prefectures system, an annual payment in the form of marten pelts was imposed as tax. ${ }^{132}$ The prefectures and area commands in the Western Regions under the Protectorate of Anxi paid tribute rather than taxes until the outbreak of the An Lushan rebellion in $755 .{ }^{133}$ It is assumed that the jimi fuzhou in Eastern Turkestan would have paid taxes. ${ }^{134}$

Some prefectures changed their status from jimi to regular and vice versa. For example, Weizhou (in present Sichuan) was first set up in 618 for the submitted Qiang people, and then in 627 was abolished because of a Qiang rebellion. A year later, at the request of the Qiang chieftain, Weizhou was again set up and brought under the control of the Area Command of Maozhou as a jimi prefecture. In 665 it was promoted to be a regular prefecture. After the suppression of the Qiang rebellion in 677 Weizhou again became a jimi prefecture until 687 . Then it again became a regular prefecture. ${ }^{135}$

Some jimi fuzhou, such as the Area Command of Bosi, and those

\footnotetext{
${ }^{128}$ JTS 194A, p. 5161.

129 JTS 3, p. 61

${ }^{130}$ These fragments are collected and translated in Twitchett 1970, pp. 142-5.

${ }^{131}$ XTS 2, p. 43.

${ }^{132}$ XTS 217A, p. 6113 ; ZZTJ 198, p. 6245. Some modern scholars do not think of this as a tax, but rather as a form of tribute. See Lin Chaomin 1985, p. 55; Yang Shengmin 1991, p. 61.

133 JTS 40, p. 1650.

${ }^{134}$ Ise 1968, p. 531.

${ }^{135}$ JTS 41, p. 1690 ; XTS 42, p. 1085.
} 
which were set up after the conquest of the Western Turks in 659, were just nominally under Chinese control, a control soon weakened by competition from the Tibetans. ${ }^{136}$ Tang also set up some prefectures in which non-Chinese were administered by Chinese officials. For example, the six $\mathrm{Hu}$ (Sogdian) prefectures, Lu, Li, Han, Sai, Yi, and Qi, which were organized in 679 for submitted non-Chinese, all had Chinese as prefects and were not included in the section of the jimi zhou of the Xin Tangshu. ${ }^{137}$

From the time it made its claim to replace Sui, the dynastic house of Tang was faced with the reborn Eastern Turkish empire as well as with Chinese generals as powerful as the Tang founder who had allied themselves with the Turks. Faced with this awkward situation Gaozu demonstrated a remarkably pragmatic and flexible attitude. Soon after rising against Sui, he sought the aid of the Turks, as well as the Tuyuhun, through provision of large subsidies, and throughout his reign he followed a policy of appeasement towards the Eastern Turks so as to deter them from raiding and so as to weaken their support for his rivals. Meanwhile, he made peace with the Western Turks and even attempted, albeit unsuccessfully, to win them over in his struggle against their Eastern cousins. His policy won time for the newly established dynasty to consolidate its frontier defenses and gradually go over to a course of empire building.

Taizong finally succeeded in conquering the Eastern Turks in 630 . The Tang success was first of all due to the internal problems faced by the Eastern Turkish rulership: rebellions of the Xueyantuo and other subjects, power struggles around the qaghan and natural disasters, all of which severely weakened their unity and hence their power. Taizong, himself a great military leader with clear knowledge of the nomadic situation, waited for the decline of the Turks to reach a critical level while making alliance with Xieli Qaghan's rival, Tölish, and the Xueyantuo. The final defeat of Xieli was swift and decisive.

Taizong next took steps, using the strategy of "divide and rule," to prevent the Xueyantuo from consolidating their position as the new power on the steppes. Taizong's policy of expansion into the Western Regions was carried out step by step despite strong opposition at court from Wei Zheng and Chu Suiliang, and was eventually completed by Gaozong's

${ }^{136}$ Chavannes 1969, pp. 192-203.

${ }^{137}$ XTS 37, pp. 974-5. 
conquest of the Western Turks in 659.

After conquering the Eastern Turks, Taizong assumed the title of Heavenly Qaghan to express his wish to be looked upon not merely as the Chinese Son of Heaven but also as the universal ruler of the peoples of the steppes, a claim that was taken over and continued by his successors. The non-Chinese background of the Tang house and the non-Chinese social and cultural legacy that Tang inherited from its non-Chinese maternal ancestors enabled Taizong to conceive a vision of world empire in which Chinese and nomads were equal subjects.

Nevertheless he also accepted Wen Yanbo's concept of using the jimi fuzhou, or subordinated area commands and prefectures, system as a way of gradually converting the nomads to Chinese ways. This system, with its over-arching protectorates, was extended under Gaozong and Empress $\mathrm{Wu}$. In practical terms, the jimi institutions provided China with a frontier defense line, and the non-Chinese incorporated into that defense line played an important role in Tang frontier campaigns.

These institutions could not, however, always maintain permanently effective control over the nomads. As we will see in chapter eight, the Turks eventually broke away from the Tang administration and restored their empire. 


\section{Chapter 6}

\section{Tang and Korea: Expansion and Withdrawal}

While the Turks, as the dominant contemporary nomad power in Mongolia, were inescapably a major concern in Chinese foreign relations until the mid-eighth century, Chinese rulers from Emperor Wen of the Sui dynasty to Gaozong of the Tang dynasty were also obsessed with the conquest of Koguryǒ. They launched massive and costly military expeditions against Koguryǒ on a scale unprecedented in previous Sino-Korean relations. The wars with Koguryor are a prime example of the use of aggressive force as an instrument of Chinese foreign policy. Although ultimately successful under Tang Gaozong in the sense that Koguryǒ was destroyed, the wars were of questionable long-term benefit to China and instead inadvertently contributed to the rise of a unified Korean state which deferred to but was essentially independent of China.

As previous scholars have shown, there were pragmatic as well as ideological reasons for the continued interest of the early Tang rulers in Korea. Pulleyblank holds that the presence of strong separatist sentiments in the Hebei region made the Tang court at Chang'an feel threatened by the possibility of close relations between Hebei and its neighbor, Koguryǒ. ${ }^{1}$ Somers considers Tang Taizong's campaigns into the border regions of the Northeast as a necessary step for the extension of imperial rule into the North China Plain and as an important coercive measure for the full consolidation of dynastic power. ${ }^{2}$ Wechsler concludes that Tang feared that Koguryǒ would unify the whole Korean peninsula, and so it wanted to keep Korea divided and prevent its alliance with other non-Chinese in eastern Manchuria and in Japan. He further suggested that Taizong, facing a crisis following the succession dispute of 643 , simply wanted to be away from the court during this time. ${ }^{3}$

\footnotetext{
${ }^{1}$ Pulleyblank 1955, pp. 76-77.

${ }^{2}$ Somers 1986, pp. 976-978; pp. 981-982. See also Walker 1965, p. 165

${ }^{3}$ Wechsler 1979 , pp. 233-234.
} 


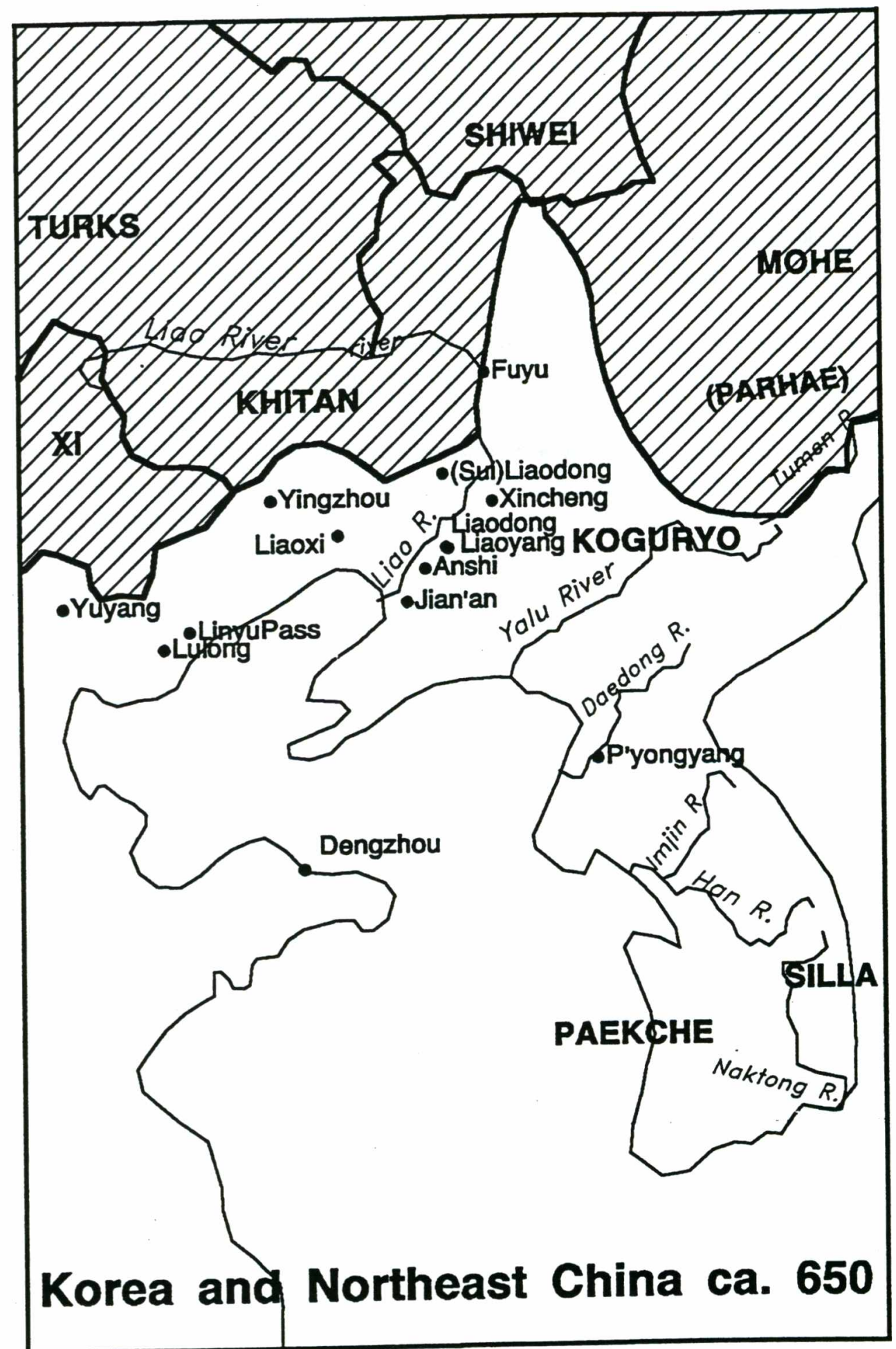


On the other hand, ideology also played a major role. Wechsler stresses Taizong's dynastic ambitions, his insistence that Koguryǒ had been a part of the Chinese empire under Han and therefore had to be brought back under Chinese rule. ${ }^{4}$ Nishijima Sadao emphasizes more the theoretical pattern of the Chinese world order. According to him, the tribute system and the system of investiture regulating Chinese relations with the Korean states held together the East Asian world as an integrated international order, with China as suzerain at the center. Sui and Tang mounted expeditions against Koguryǒ in order to punish the latter when it disturbed the system, and it was China's responsibility, as well as in its interest, to maintain the orderly working of the system so as to sustain peace within the East Asian world. ${ }^{5}$

Modern Korean works, understandably reflecting a Korean point of view, consider the Sui-Tang wars with Koguryǒ as an invasion, a stage in China's grand imperial design to achieve hegemony over all of East Asia. ${ }^{6}$ The wars are seen within the context of the competition for control over Southwest Manchuria and as a means to win over other non-Chinese peoples to the north and northeast of China. ${ }^{7}$

Jamieson draws attention to the important role that Silla played in the Tang military campaigns against Koguryǒ. The three states on the Korean peninsula were often in a state of mutual enmity, with two of them sometimes forging an alliance against the third. During the early Tang period, tensions among the three grew more severe. Silla, which was the most distant from China of the three states, persisted in a pro-Tang policy because of its fierce competition with its rivals, taking the initiative to form an alliance with the Chinese and skillfully maneuvering Tang to assist it in its final unification of Korea during the latter half of the seventh century. ${ }^{8}$

Taken together, much of what these earlier scholars have said is quite convincing in the same way as is the description of the elephant by several blind men in the Indian fable. In what follows we shall see how the various factors they emphasized simultaneously influenced the decisionmaking process of successive Tang rulers, the extent to which each factor

\footnotetext{
${ }^{4}$ Wechsler 1979, pp. 233-234.

${ }^{5}$ Nishijima 1983, pp. 418-444.

${ }^{6}$ Lee Ki-baik 1984, p. 48.

${ }^{7}$ Sohn Pow-key 1970, pp. 45-51.

${ }^{8}$ Cf. Jamieson 1969, part II: the Unification Wars.
} 
was important at different stages and how in the end, after succeeding at great cost in saving face by conquering Koguryǒ and wiping out the disgrace of Emperor Yang's defeat, Tang had to withdraw from the Korean peninsula, yielding the prize of victory to its ally, Silla.

\section{Gaozu's Peaceful Communication with Korea}

While the newly founded Tang regime under Gaozu was largely occupied by the Turkish problems in its frontier affairs, Gaozu maintained peaceful relations with Koguryǒ and the other two Korean kingdoms. Thepolicy of Koguryǒ toward China also took a turn for the better. King Yǒngyang died in 618 and his brother succeeded him as King Yǒngnyu. During the eight years of Tang Gaozu's reign, eight missions from Koguryǒ arrived in Tang, of which six were tributary..$^{9}$ The mission of 624 was to request the Chinese calendar, a gesture implying acceptance of vassal status, and the one in 625 was to study Taoism and Buddhism. ${ }^{10}$

In 622 Gaozu sent a letter, or "edict" in Chinese rhetoric, to King Yǒngnyu, expressing good will, and requesting an exchange of people displaced by the wars. Compared with the edicts issued during the Sui period the tone of this missive was quite different. While insisting on the mandate of the Chinese emperor it expressed the wish to maintain friendly relations, with each side defending its own borders. Gaozu ordered that all people of Koguryǒ origins inside China should be gathered and sent back to their homeland. As a reciprocal gesture, as many as ten thousand Sui Chinese were returned from Koguryǒ. ${ }^{11}$ In 624 Gaozu conferred on King Yǒngnyu the titles of Supreme Pillar of State (shang zhuguo), Commandery Prince of Liaodong (Liaodong jun wang), and King of Koguryǒ.

Paekche and Silla continued to maintain tributary relations with China. The king of Paekche received from China the titles of Commandery Prince of Daifang and King of Paekche, and the king of Silla the titles of Pillar of State, Commandery Prince of Lelang, and King of Silla. ${ }^{12} \mathrm{Su}$ preme Pillar of State was the highest honorific position in the Tang hierarchy, and was equal to rank 2, upper class. Pillar of State was the second highest and was equal to rank 2 , lower class. The titles of nobility given to

\footnotetext{
${ }^{9}$ See Table 2.

${ }^{10}$ ZZTJ 190, p. 5976; CFYG 977, p. 11479; 999, p. 11721.

${ }^{11}$ JTS 199A, pp. 5320-1; XTS 220, p. 6187; ZZTJ 190, p. 5964.

${ }^{12}$ JTS 199A, p. 5321; p. 5329; p. 5335; XTS 220, p. 6187; p. 6199; p. 6203; ZZTJ 190, p. 5976.
} 
the Korean rulers, which were associated with the names of commanderies (jun) in earlier times, were raised from commandery duke (gong) to commandery prince (wang), which was next to prince of a state (guo wang). ${ }^{13}$

Gaozu approached the whole business of investiture and the tribute system with clear-sighted pragmatism. He remarked to his ministers in 625:

Between name and reality there should be a concordance. Koguryǒ called itself subject (chen) of Sui, but in the end opposed Emperor Yang. What kind of subject was that? We respect all creatures and do not wish to be haughty and superior. We only occupy and possess the land, striving to bring peace to all the people. Why should we order Koguryǒ to be our subject in order to acquire for us greatness and honor? You should now make an edict to express this will of mine. ${ }^{14}$

Chief Minister Pei Ju, who had been expansonist policy adviser to the Sui Emperor Yang, and Vice Director of the Secretariat Wen Yanbo were, however, strongly opposed to Gaozu's idea. Insisting on the principle that "the king leaves nothing and nobody outside his realm" Wen argued:

The land of Liaodong (under Koguryǒ) was the state of Jizi in the Zhou period, and the Commandery of Xuantu during Han. Before the Wei-Jin [period], it was as close [to China] as though it was within the territory divided into fiefs [granted by the Son of Heaven]. It cannot be allowed not to be subject. If we allow ourselves to be put on an equal footing with Gaoli (= Koguryǒ), how will the barbarians of the four directions look up to us? Moreover, the Middle Kingdom is, for the barbarians, like the sun to all the stars. There is no reason to descend from superiority to be on a level of equality with those in the barrier zone. ${ }^{15}$

In the face of such opposition, Gaozu had to give up the idea of not making Koguryǒ into a subject territory. ${ }^{16}$ We are presented in the above colloquy with an interesting, if briefly stated, reflection of the tension between restoring China's former frontiers on the one hand, and the exigencies of political reality on the other. The practical-minded Gaozu not only saw no point to insisting on an empty adherence to traditional forms and

\footnotetext{
${ }^{13}$ Nishijima 1983, p. 441.

${ }^{14}$ TD 186, p. 992.

${ }^{15}$ JTS 61, p. 2360.

${ }^{16}$ TD 186, p. 992; JTS 61, p. 2360.
} 
titles supposedly buttressing superficial Chinese suzerainty, but also saw how dearly it had cost Sui to attempt to make such claims stick. He neither wanted to advance such claims nor could he afford to do so, given the political situation in the early Tang. Pei Ju-and Wen Yanbo, on the other hand, who were more deeply influenced by the Confucian political ambition to restore the Han empire, could not accept Gaozu's aphilosophical pragmatism. In hindsight we can see that, had Gaozu's ideas been accepted, this would, in fact, have saved the Tang Chinese from much subsequent trouble.

Gaozu's policy towards Koguryǒ at that time was one of peaceful coexistence. He wanted to stake out a neutral position vis-à-vis the continuous conflicts among the three Korean kingdoms, and wanted the Chinese merely to try to maintain a peaceful order.

\section{Taizong's Peace with Korea, 627-640}

Before 641, Taizong had mostly followed Gaozu's principle of maintaining peace and continued to preserve a neutral position in the conflicts among the three Korean states. In 626, both Paekche and Silla sent envoys to Tang to accuse Koguryor of blocking their way to pay tribute to Tang and to ask for Tang help. The court, by then under Taizong, sent an envoy to mediate between them, upon which, it is recorded, all three sent in an "acknowledgement of guilt." 17 In 627 , Taizong's edict to the king of Paekche expressed his hope for a peaceful order on the Korean peninsula. $^{18}$

A sign of distrust between Tang and Koguryǒ appeared in 631, when Taizong sent an envoy to Koguryǒ to bury the remains of the Sui soldiers. The envoy destroyed the "triumphal mound" (jingguan), built by Koguryǒ over the remains of the Sui soldiers in commemoration of the victory of Koguryǒ over Sui, in order to give them a proper burial. This act alarmed King Yŏngnyu, who then ordered the construction of a great wall from Fuyu (in modern Jilin) all the way to the sea. ${ }^{19}$ From then until the end of his reign in 642, King Yorngnyu sent only three tributary missions to Tang. Still, Taizong granted favorable treatment to a mission that came in 640 , led by the Crown Prince of Koguryǒ.

The major concern of Taizong had been problems inside China and

\footnotetext{
${ }^{17}$ JTS 199A, p. 5321; p. 5329; XTS 220, p. 6199; ZZTJ 192, p. 6030.

${ }^{18}$ JTS 199A, p. 5329; XTS 220, p. 6199.

${ }^{19}$ JTS 199A, p. 5321; XTS 220, p. 6187; ZZTJ 193, p. 6087.
} 
problems on the northern and northwestern borders. He took to heart the disastrous lessons of the Sui. But unlike Wei Zheng who, in the historian's comment in the Suishu, implies that Liaodong had not been under the Chinese commandery-district system for a long time and Sui therefore should have left it alone, ${ }^{20}$ Taizong seems to have believed that the lesson was not that China should be restrained from extending itself into Liaodong and beyond, but that there should be a well worked out strategy and a solid economy and strong armies before undertaking any such campaign.

\section{The Decision for War Against Koguryǒ, 641-643}

Following his conquest of the Eastern Turks in 630, his assumption of the title of Heavenly Qaghan and the establishment of the new administrative system for ruling the Turks who had submitted, Taizong next persuaded the Xi and Shiwei, both formerly subjects of the Turks in Manchuria to submit to Tang. ${ }^{21}$ After his successes on the western front Taizong at last turned his attention to Koguryǒ.

From 641 on, Taizong's intention to wage war against Koguryǒ became ever more clear. An embassy returned from Koguryǒ in that year. Its mission was ostensibly to return the visit of the prince of Koguryǒ, but in fact it was to look for weaknesses in that country. On his return the envoy made his report based on the information he had gathered during his stay. Taizong then expressly stated his intention of undertaking military action against Koguryǒ, justifying his decision with the argument that the territory of Koguryǒ had been placed under four Chinese commanderies during Han, and was thus part of China.

Taizong had his strategy worked out: Chinese troops would attack Liaodong, and when all the forces of Koguryǒ went to the rescue, Tang would send its naval force from Shandong to attack P'yǒngyang, thus easily conquering Koguryǒ. He was only prevented from putting this plan into effect immidiately by his judgment that the Shandong region, an important base for the seaborn wing of the military expedition against Korea, had not yet returned to full economic health. ${ }^{22}$

In the following years, up until 644, when Taizong finally declared war on Koguryǒ, political developments on the peninsula stimulated an increasingly bellicose attitude by Taizong. A coup d'état took place in

\footnotetext{
${ }^{20}$ SUIS 81, pp. 1828-9.

${ }^{21}$ ZZTJ 193, p. 6082.

${ }^{22}$ XTS 220, p. 6187; ZZTJ 196, pp. 6169-70.
} 
Koguryǒ in the eleventh month of 642. King Yongnyu was killed by his official Yorn Kaesomun, who put the king's nephew on the throne and set himself up as the de facto ruler. The news soon reached the Tang court through the report of the Area Commander of Yingzhou, located close to Koguryo. $^{23}$

Concluding that Yǒn Kaesomun's usurpation challenged Tang suzerainty, since the former king had received Tang investiture, some Chinese officials felt it necessary to punish this unlawful act and suggested a "punitive" attack. In 643, after returning from a mission to Koguryǒ, an envoy requested an increase in the number of border troops in order to exert pressure on Koguryǒ. Although Taizong refused to take any action on the grounds that it was not righteous to attack a state in mourning nor to burden the people, since the economy of Shandong was still in bad shape, ${ }^{24}$ he nevertheless expressed the view that Tang had more than enough military force and political legitimacy to punish Yorn Kaesomun, and intended to use Mohe and Khitan troops to do so.

For the time being he followed the suggestion of two of his major advisers, Fang Xuanling and Zhangsun Wuji, to maintain peace. ${ }^{25}$ The Chinese duly performed a mourning ceremony for the dead king. This was a regular practice in the tributary relationship. An embassy was next sent to Koguryǒ bearing imperial gifts. ${ }^{26}$ In the first month of 643 , Koguryǒ sent a tributary mission and Taizong conferred the title of king on the new ruler. $^{27}$

Silla continued to pursue its pro-Chinese policy. In the ninth month of 643 Silla sent a request for Tang military assistance to defend against the joint incursions of Paekche and Koguryǒ. The previous year Paekche had attacked some forty towns of Silla, and entered into a marriage alliance with Koguryǒ, while planning further attacks against Silla. ${ }^{28}$ It seemed possible that Koguryǒ would unify the whole Korean peninsula. This news may have alarmed Tang, in whose own interest it was to keep Korea divided and to prevent any Korean alliance with other non-Chinese

\footnotetext{
${ }^{23}$ JTS 199A, p. 5322; XTS 220, p. 6187; ZZTJ 196, p. 6181.

${ }^{24}$ ZZTJ 196, pp. 6181-2; 197, p. 6198.

${ }^{25}$ XTS 220, p. 6188; ZZTJ 197, p. 6202.

${ }^{26}$ CFYG 974, p. 11442.

${ }^{27}$ JTS 199A, p. 5322; XTS 220, p. 6188; ZZTJ 197, p. 6202.

${ }^{28}$ JTS 199A, p. 5330; XTS 220, p. 6199.
} 
states in eastern Manchuria and in Japan. ${ }^{29}$

Taizong responded to Silla's request by suggesting three alternatives to its envoy for dealing with the situation: 1) sending Chinese frontier troops together with the Khitan and Mohe to attack Liaodong, which was part of Koguryǒ; 2) providing several thousand red uniforms and red flags to Silla to create the impression that Tang troops were being stationed in Silla so as to dissuade the Paekche and Koguryǒ troops from mounting an attack; 3) sending a naval force to attack Paekche to relieve Silla and, since Silla was vulnerable and easily bullied since it was under a female ruler, Tang could send a royal family member to be the ruler in Silla accompanied by a garrison of Chinese troops. When Silla was again at peace, Silla could restore its own ruler to power.

On hearing these alternative plans the Silla envoy said he could not make up his mind which to choose. ${ }^{30}$ His indecision must have been more diplomatic than real. It must have been clear to him that any of the three Tang strategies must have undermined if not directly threatened Silla's independence.

These three alternatives reveal the essentials of Taizong's policy towards Korea: the first one was to use "barbarians" against "barbarians," which might have resulted in an even more direct confrontation between Silla and the other two Korean kingdoms; the second plan could not have been expected to produce much effective relief for Silla and would have set a symbolic precedent for an actual takeover of Silla by Tang forces; the third alternative, which would have been the most effective for dealing with Koguryǒ and Paekche, was fraught with danger for Silla itself. There was a real possibility that Silla might be conquered by China. ${ }^{31}$ No wonder that the envoy from Silla was unable to choose among the three. $\mathrm{He}$ and his country were, as the American slang expression so aptly puts it, caught between a rock and a hard place.

As an interim measure, Taizong sent an envoy to carry a letter to Koguryǒ, in which was contained a threat: if Koguryǒ continued its incur-

\footnotetext{
${ }^{29}$ Wechsler 1979, p. 233.

${ }^{30}$ XTS 220, p. 6188; CFYG 991, p. 11639. CFYG subdivides the third alternative. The attack on Paekche, and the sending of a Tang prince and troops to Silla, are listed as alternatives three and four, respectively. XTS is probably correct in combining these alternatives into one because Taizong probably planned to attack Paekche first, thus opening a route to Silla via Paekche so that Tang could give Chinese assistance to Silla from the sea.

${ }^{31}$ Inoue 1972, pp. 196-8.
} 
sions against Silla, a dutiful subject of Tang, Tang would be forced to mount a punitive attack the following year. In the second month of 644, the envoy returned from his mission and reported back that Yorn Kaesomun refused to stop his incursions into Silla. Taizong took the refusal as a casus belli. From the Chinese point of view, this was a righteous excuse to launch a war against a disobedient Koguryǒ. ${ }^{32}$

In one of the court debates on whether to attack Koguryǒ, Chu Suiliang expressed his doubt that a victory was possible. Later he presented a memorial attempting to dissuade the emperor from taking personal command. Strong support for a war policy came from the Minister of War, Li Shiji. He cited an instance in 641 when Taizong had accepted Wei Zheng's advice not to pursue attacks on the Xueyantuo, thus losing the opportunity to completely defeat them..$^{33}$ Another supporter of war was Li Jing. Like Li Shiji, Li Jing had a strong military background and both Li's were important advisers to Taizong. ${ }^{34}$

Taizong himself adopted a bellicose attitude, and stated his intention to take personal command of the campaign. This evoked widespread opposition from both military and civil officials of different backgrounds who remonstrated in memorials or orally in the emperor's presence. ${ }^{35}$ In 648 , when the war was under way, a palace lady, Xu Hui, presented a memorial opposing the war, for which Taizong duly expressed his appreciation. $^{36}$

Finally, a decision was made that Taizong would personally lead a military expedition against Koguryǒ. War preparations of all kinds were started and Taizong consulted experienced military officials for information and advice on strategies. ${ }^{37}$ He spared no effort to make propaganda through personal remarks and official edicts announced throughout the country to persuade those officials objecting to the campaign and to encourage common people to join his armies. He repeatedly emphasized as a moral justification for the expedition that Liaodong had formerly been part of China and that if Tang failed to act forcefully against this rebellious

${ }^{32}$ JTS 199A, p. 5322; p. 5335; XTS 220, pp. 6188-9; ZZTJ 197, p. 6204; pp. 6206-7.

${ }^{33}$ JTS 80, pp. 2733-6; XTS 105, pp. 4027-8; ZZTJ 197, p. 6207.

${ }^{34}$ JTS 67, p. 2481; XTS 93, p. 3815; Wechsler 1979, p. 199.

35 JTS 59 , p. 2334 ; 62 , p. 2390 ; 68 , p. $2500 ; 69$, p. 2515 ; XTS 89 , p. 3755 ; 91 , p. 3792 ;

94, p. $3829 ; 99$, p. 3912; ZZTJ 197, pp. 6216-7.

${ }^{36}$ ZZTJ 198, p. 6254.

${ }^{37}$ ZZTJ 197, p. 6213. 
subject, China itself could not be well disciplined.

His expedition, he claimed, had several aims: to punish Yǒn Kaesomun, to save the people of Koguryǒ from Yǒn's cruel rule, and to save Silla from the danger of invading enemies. Moreover, Taizong claimed that now All-under-Heaven was at peace except for Koguryǒ. He intended to undertake the conquest of Koguryǒ personally so as not to leave a source of trouble for his descendants. He held that as suzerain it was his responsibility to punish those who disturbed the order of the East Asian world, which formed an international system centering around China.

As a skillful and experienced war leader, Taizong had some idea of what was disadvantageous and advantageous for the campaign. He recognized the difficulties involved. Yet he was confident of the inevitability of victory on the grounds that Tang had a sound economic basis now, that there was much stronger support from the people than in Emperor Yang's time, since Tang's victories over the Turks, Tuyuhun and Gaochang had encouraged people to think that additional rich rewards could be achieved through battles, and that Tang was large while Koguryǒ was small. ${ }^{38}$

The expectation of possible assistance from other non-Chinese, especially from Paekche and Silla, also strengthened Taizong's confidence. In his edicts to Paekche and Silla in 644, Taizong ordered the troops of the two Korean states to be placed under the command of Chinese generals. ${ }^{39}$ That same year Silla had 50,000 troops attacking Koguryǒ from the south and captured a town. ${ }^{40}$ In the seventh month of 644 , before the major expedition began, the Chinese, the Khitan, Xi and Mohe attacked Koguryǒ in order to reconnoiter the situation. ${ }^{41}$ In 645 , Taizong asked the Xueyantuo to join the Tang force. The Xueyantuo agreed, though as it turned out Taizong did not make use of the Xueyantuo troops. During 644 and 645, Koguryǒ attempted to bribe the Xueyantuo into alliance but the Xueyantuo did not dare to make any hostile move against Tang. ${ }^{42}$

${ }^{38}$ XTS 220, pp. 6189-90; ZZTJ 197, p. 6207; p. 6214; pp. 6215-6; pp. 6217-8; TDZLJ 130 , p. 703; pp. 703-4; Nishijima 1983, pp. 442-3.

${ }^{39}$ Wenguan Cilin 664, pp. 261-5.

${ }^{40}$ JTS 199A, p. $5335 ;$; XTS 220, p. 6203.

${ }^{41}$ XTS 220, p. 6189; ZZTJ 197, p. 6209.

${ }^{42} J T S$ 199B, p. 5346; XTS 217B, pp. 6137-8; ZZTJ 198, pp. 6227-8. 


\section{The Three Campaigns Against Koguryǒ, 644-648}

There is little evidence of a hostile attitude on the part of Koguryǒ. From 642 until Taizong's death in 649 Koguryǒ sent six tributary missions to Tang. In the ninth month of 644, before the Tang campaign started, Yorn Kaesomun sent envoys to Tang carrying silver as tribute and asking to be permitted to send fifty officials to be Imperial Bodyguards. Taizong refused the present and imprisoned the Korean officials. ${ }^{43}$

In the winter of 644 , Tang armies were mobilized to attack Koguryǒ by land and by sea. The Tang court ordered Silla, Paekche, the Xi and Khitan to join the attacks. ${ }^{44}$ Taizong took personal command. Stopping in Yingzhou (near present Chaoyang, Liaoning) on his way to the front in 645 , Taizong tried to win over the Khitan tribal leaders. By 648 all the Khitan were brought under Tang command. ${ }^{45}$

In the 645 campaign the Chinese troops pushed as far as Anshi town in Liaodong, but Taizong met with a humiliating failure when he was unable to capture the town before he had to retreat due to lack of supplies and the cold weather. The achievements of the campaign included the taking of ten walled towns in the Liaodong area, the capture of 60,000 households and two generals-in-chief, 3,500 aristocrats and officials. ${ }^{46}$ Taizong regretted his assumption of personal command, saying that if Wei Zheng were still alive he would have prevented him from going. ${ }^{47}$

The submitted people of Koguryǒ were incorporated into the Chinese empire. Tang set up three prefectures in three captured towns. ${ }^{48} \mathrm{Un}$ like the case of the Turks, where there were many objections to the idea of settling the nomads inside the country, the Chinese did not hesitate to resettle seventy thousand Koreans inside China. ${ }^{49}$ Taizong conferred titles on Korean generals, aristocrats and officials who were resettled in China. ${ }^{50}$

The year 646 saw Tang military activity concentrate on the Xueyantuo in the northwest. That year King Pojang and Yǒn Kaesomun sent an

\footnotetext{
${ }^{43}$ XTS 220, p. $6189 ;$ ZZTJ 197 , p. 6212.

44 JTS 199A, pp. 5322-3; XTS 220, pp. 6189-90; ZZTJ 197, pp. 6214-5.

${ }^{45}$ JTS 199B, p. 5350; XTS 219, p. 6168.

${ }^{46}$ JTS 199A, pp. 5323-6; XTS 220, pp. $6190-1$; ZZTJ 197, pp. 6216-21; 198, pp. 6222-

30; CFYG 117, p. 1400-6.

${ }^{47}$ XTS 97, p. $3881 ;$ ZZTJ 198, p. 6230.

${ }^{48}$ XTS 43B, p. 1128; ZZTJ 197, p. 6221; 198, p. 6223; THY 95, pp. 1705-6.

${ }^{49}$ ZZTJ 198, p. 6230; THY 95, p. 1706.

50 JTS 199A, p. 5325; XTS 220, pp. 6192-3; ZZTJ 198, p. 6226.
} 
embassy to Tang to "acknowledge guilt." 51 Yet, unlike Emperor Wen, Taizong did not consider a sincere submission sufficient. He issued an edict stating that Tang would not accept tribute from Koguryǒ, clearly the equivalent of a previous declaration of war being reaffirmed. The court planned a major expedition using the excuses that Yorn Kaesomun had become more arrogant in his behavior, as witnessed by the insolent manner he had displayed to the Tang envoys and had continued his incursions into Silla. $^{52}$

The Chinese armies resumed their attacks in 647. This time Taizong did not go in person. At the end of the year, King Pojang sent his son to pay homage to Tang carrying an offer of "acknowledgement of guilt.",53 Nevertheless, in 648, Tang carried out a third expedition by sending a naval force of 30,000 men to attack Koguryǒ. However, the Tang troops retreated in the autumn without having won any decisive success. ${ }^{54}$

Taizong then decided to launch a fourth expedition the next year so as to crush Koguryǒ with one decisive campaign. He believed that Koguryǒ had already been brought to a state of exhaustion, but what he failed to see was that China had also been disturbed by the wars. Even Sichuan, a region remote from the northeast, was involved in and had its economy upset by ship building for the war. ${ }^{55}$ The non-Chinese Liao people in the southwest rose in revolt when the Chinese officials imposed corvée on them to build ships to be used in the campaigns against Koguryor. The Chinese of Sichuan also suffered hardships from the ship building. Hard pressed by the local officials to pay for the labor involved, people had to sell their houses, land, and even their children. We are told that the price of grain jumped greatly and disorders arose. ${ }^{56}$

Aware of the troubled situation, the senior Chief Minister Fang Xuanling was unable to keep silence, especially because at that time few people dared to object openly to the campaign. His approaching death gave Fang the courage to urge the emperor to abandon the war. He argued in his memorial that Taizong should halt any further expansion since Tang

51 JTS 199A, p. 5326; XTS 220, p. 6194.

${ }^{52} X T S$ 220, p. 6194; ZZTJ 198, p. 6241; CFYG 996, p. 11696.

${ }^{53}$ XTS 220, p. 6194; ZZTJ 198, pp. 6245-6; pp. 6247-8; p. 6251.

${ }^{54}$ JTS 69, pp. $2518-9 ; 199 A$, p. 5326 ; XTS 94, p. $3832 ; 220$, p. $6195 ;$ ZZTJ 198, p. 6252;

p. 6256 ; p. 6261.

${ }^{55}$ ZZTJ 199, pp. 6258-9.

${ }^{56}$ XTS 220, p. 6195; ZZTJ 199, pp. 6261-2. 
had already achieved enough prestige and territory, that the people of Koguryǒ were but "barbarians" of a low sort, neither worth being treated with benevolence and righteousness, nor capable of being held responsible for their conduct. Fang did not think that the war was justified, arguing that Koguryǒ had not failed to perform the duties of a subject, had made no incursions into Chinese territory, posed no long-term danger to China, and that it was not worthwhile to distress China just to wipe out the shame of a former ruler within and take revenge for Silla without. But Taizong did not alter his course of action. ${ }^{57}$

During this period the situation on the Korean peninsula became more difficult for Silla. While Tang and Koguryǒ were engaged in warfare, Paekche did not keep its promise to assist Tang against Koguryǒ. Instead, it initially captured several walled Silla towns, and in 648 took thirteen more. It also stopped sending tribute to Tang. ${ }^{58}$

To deal with the threat from Paekche, Silla first tried to obtain assistance from Koguryǒ, ${ }^{59}$ and failing that it decided to turn to Tang. In the year 648 alone, Silla sent three missions to Tang, the third of which was led by Kim Ch'unch'u (the future King Muyǒl), hoping to obtain Tang military intervention. ${ }^{60}$ To strengthen relations with Tang, Silla agreed to adopt Tang's reign title and Chinese official dress. ${ }^{61}$ The Korean history says that in return Taizong promised Kim to send 200,000 Chinese troops under the command of Su Dingfang. ${ }^{62}$ The Chinese sources do not mention this promise. However, as seen above, in 648 Taizong did send a navy to fight against Koguryǒ, but not under the command of Su Dingfang.

Finally, on his death bed, Taizong left an edict ordering abandonment of the campaign against Koguryǒ. ${ }^{63}$

\section{The Conquest of Paekche in $\mathbf{6 6 0}$}

At first, Gaozong did not attempt any direct attacks against Kogu-

57 JTS 66, pp. 2464-6; XTS 96, pp. 3855-6; ZZTJ 199, p. 6260.

58 JTS 199A, p. 5330; XTS 220, p. 6199; ZZTJ 199, p. 6261.

${ }^{59}$ SGSG 5, pp. 2-3; 41, "Biography of Kim Yusin, Part I;" see also Miike 1974, pp. $107-$ 8.

${ }^{60}$ The Chinese sources record only two missions, see Table 2. The Korean source records three, cf. SGSG 5, p. 5.

${ }^{61} X T S 220$, p. 6203; ZZTJ 199, p. 6265; SGSG 5, p. 6.

${ }^{62}$ SGSG 41, "Biography of Kim Yusin, Part I."

${ }^{63}$ ZZTJ 199, p. 6268. 
ryǒ. For its part Silla made continuous efforts to strengthen its ties with Tang. Its court started to wear Chinese official dress in 649 and in 650 it adopted Tang Gaozong's reign title-Yonghui. ${ }^{64}$ In 650 , Kim Pǒmmin (the future King Munmu) went to Tang as an envoy to report Silla's victory over Paekche, and presented an ode "In Praise of Peace" embroidered on brocade, which attributed the victory to the glory and majesty of Tang. ${ }^{65}$ In 651 , when Paekche resumed its tributary missions to Tang, Gaozong urged Paekche to make peace with Silla and threatened a military attack if Paekche refused and if Koguryǒ assisted Paekche. ${ }^{66}$

Military encounters with Koguryǒ resumed in 654, when Koguryǒ attacked the Khitan, who were then under the jimi system. In the following year, when Koguryǒ joined Paekche and Mohe to capture more than thirty Silla walled towns, King Muyǒl (Kim Ch'unch'u) of Silla sent a request to Tang for assistance. In response, Gaozong despatched his first expedition against Koguryǒ. ${ }^{67}$ The Tang-Silla alliance was thus formed on the initiative of Silla but for the benefit of both states.

The Chinese launched more attacks against Koguryǒ in 658 and 659 with some success. ${ }^{68}$ In 660 , Silla requested that Tang troops be directed against Paekche after Silla had once again been invaded by Paekche and Koguryǒ. It may be that Silla talked Tang into implementing the plan to attack Paekche, but as mentioned above, it was also Taizong's intention, expressed in 643 , to make such an attack. ${ }^{69}$

In any event, this proved to be a strategically crucial plan, for it eventually led to the conquest of Koguryǒ once Paekche fell. The Tang court sent a huge navy of 100,000 under Su Dingfang across the Yellow Sea to the coast of Paekche. Silla troops joined the campaign by land. After all attempts to resist failed, the Paekche King and Crown Prince Yung finally surrendered. ${ }^{70}$

The Korean sources show that even during the conquest of Paekche

\footnotetext{
${ }^{64}$ SGSG 5, p. 6.

65 JTS 199A, p. 5336; XTS 220, pp. 6203-4.

66 JTS 199A, pp. 5330-1; XTS 220, p. 6199; ZZTJ 199, p. 6277.

${ }^{67}$ ZZTJ 199, pp. 6286-8.

${ }^{68}$ ZZTJ 200, p. 6309; p. 6319; CFYG 985, p. 11577.
}

69 Jamieson (1969, pp. 44-5) says that Silla persuaded the Chinese that the first step for the conquest of Koguryǒ was to subdue Paekche but he fails to notice a plan to conquer Paekche in the Chinese sources for Taizong's reign.

${ }^{70}$ JTS 199A, p. 5331; p. 5336; XTS 220, p. 6200; ZZTJ 200, pp. 6320-1. 
signs of strain appeared in the alliance between Tang and Silla. In the Korean history Samguk Sagi we read that in 660, during the war with Paekche, when Silla troops were late for a battle, the Chinese commander $\mathrm{Su}$ Dingfang decided to execute a Silla general, but had to change his mind when another Silla general threatened to attack Tang. ${ }^{71}$

Another chapter of the same work says that after the conquest of Paekche, Su Dingfang suggested that the land of Paekche be divided up among three Silla generals as rewards, but the three refused, on the grounds that it was not righteous for them to accept such an offer. The Korean work goes on to say that the Chinese then made a plan to invade Silla, but had to give it up since Silla was too well prepared. When Su Dingfang returned to the Tang court Gaozong supposedly asked him why he did not attack Silla, to which Su replied that Silla was under a good government and therefore it could not be subdued even though it was a small country. $^{72}$

The Chinese sources, however, make no mention of the confrontation over a delay in the arrival of the Silla troops, or anything about an intention to attack Silla immediately after the conquest of Paekche in 660 . The Chinese sources do indicate that Tang had considered, at least for a while, giving up the land of Paekche, as mentioned below.

The Chinese sources state that after the conquest of Paekche in 660 , the Tang court decided to establish Chinese supervision in the area by setting up in former Paekche five area commands which were further divided into administrative regions. A Chinese official was appointed the Area Commander of Xiongjin (Korean Ungjin) and pro-Tang local chieftains were assigned to other posts. To prevent further problems, Tang transferred members of the royal family, including the King of Paekche and Prince Yung, ministers and commoner men, amounting altogether to more than ten thousand people, to China as captives. The King soon died and an official title was conferred on Prince Yung. ${ }^{73}$

The Chinese commander, Su Dingfang, withdrew from Paekche and then started a major campaign against Koguryǒ in 661. Gaozong even decided to assume personal command of the expedition but was dissuaded by Empress Wu and his ministers. ${ }^{74}$ The Tang armies penetrated as far as

\footnotetext{
${ }^{71}$ SGSG 5, pp. 9-10.

${ }^{72}$ SGSG 42, "Biography of Kim Yusin, Part II."

73 JTS 199A, p. 5331; XTS 220, p. 6200; ZZTJ 200, pp. 6321-2; CFYG 986, pp. 11577-8.

${ }^{74}$ XTS 220, pp. 6195-6; ZZTJ 200, pp. 6323-4.
} 
the capital, P'yǒngyang, which was an unprecedented success, but had to retreat without any result early the next year due to the severe winter weather. $^{75}$

The quick withdrawal of Su Dingfang with some of the Chinese troops made possible a restoration movement in Paekche. It was led by a former Paekche royal family member named Poksin and a monk, Toch'im, who sent for Prince P'ung of Paekche from Japan and established him as king. They were determined to fight, knowing that Tang and Silla both had ambitions to take over Paekche. ${ }^{76}$ When the revived Paekche forces were successful in isolating the Chinese and in driving back the Silla troops, the Tang court decided to withdraw from Paekche altogether.

Gaozong instructed Liu Rengui, then acting Prefect of Daifangzhou, who remained in the former territory of Paekche, to retreat to Silla or even to China, since the Tang army had withdrawn from P'yǒngyang, and therefore there seemed no point in staying in the town of Ungjin which was the only place in Paekche still under Tang control. However, Liu Rengui decided to stay, for he had made a clear assessment of the situation: if Tang wanted to conquer Koguryǒ, it should maintain a military base in Paekche.

At Liu's request, Gaozong sent reinforcements across the sea. In 662 , with the assistance of Silla, Liu Rengui opened up a supply route from Silla. Then a conflict broke out within the ruling group of Paekche pitting the king against Poksin, who had previously killed Toch'im. The king sent envoys to Koguryǒ and Japan asking for military assistance. In 663 the joint forces of Tang and Silla fought fiercely with the Japanese and won four major battles at the mouth of the Kŭm River. The Paekche state was finally destroyed. ${ }^{77}$ Had Liu obeyed the initial order of Gaozong, the result would have been that either Paekche restored its state or that Silla would have taken over Paekche's territory.

In describing these events the Chinese sources pay much less attention to the role played by Silla than do the Korean sources, which have detailed accounts of Silla's part in the conquest of Paekche, in the sup-

\footnotetext{
${ }_{75}^{72}$ ZZJ 200, pp. 6325-7; CFYG 986, p. 11578.

${ }^{76}$ JTS 199A, pp. 5331-2; XTS 220, p. 6200; ZZTJ 200, pp. 6323-4. For a detailed study of the restoration movement see Ikeuchi 1960, pp. 97-245.

77 JTS 84, pp. 2790-4; 199A, pp. 5331-3; XTS 108, pp. 4082-3; 220, pp. 6200-1; ZZTJ 200 , pp. 6323-4; pp. 6329-30; 201, pp. 6336-8. For Japan's encounter with the Chinese, see Yu Yousun 1957.
} 
pression of Paekche's restoration, and in the campaign against Koguryǒ in $661 .^{78}$

Over and above Silla's role, whatever it may have been, it was due to the persistence of Liu Rengui that Tang maintained its base in Paekche. Liu then made efforts to restore the local economy in order to enforce Tang control in the area as a basis for the later conquest of Koguryǒ. In a memorial to Gaozong, he reiterated the importance of the Tang garrison in Paekche: if Koguryǒ was to be destroyed Paekche should not be abandoned, for Prince P'ung was waiting in Koguryǒ, ${ }^{79}$ and another prince was in Japan. ${ }^{80}$ Either one or both would menace China's position, if Japan or Koguryǒ should make an alliance with Paekche.

The court agreed with Liu and in 664 it appointed the Paekche prince, Yung, who was in Chang'an, as the Commandant of Xiongjin in order to win over the remnants of Paekche. ${ }^{81}$

\section{The Conquest of Koguryǒ in 668}

Now that Tang had a strong hold in Paekche, it could direct its forces against Koguryǒ. In 666, Yǒn Kaesomun died. ${ }^{82}$ His death proved decisive in changing the situation in favor of Tang. It not only ended two decades of powerful military rule, but also caused dissension within the ruling group. When his son Namsaeng succeeded to the throne, the other son, Namgǒn, rebelled. Namsaeng sent his son to Tang with a request for assistance. Yǒn Kaesomun's brother offered to surrender to Silla. ${ }^{83}$ Taking advantage of this excellent opportunity, Tang launched a massive campaign led by the esteemed commander Li Shiji, in alliance with Silla. After a series of battles in which Koguryǒ was attacked both overland from China in the north, and from the southern part of the peninsula by Silla and Liu Rengui's troops, P'yorngyang fell into the hands of the Chinese in the

\footnotetext{
${ }^{78}$ SGSG 5, pp. $9-12 ; 6$, pp. $1-2 ; 7$, pp. $1-8 ; 42$.

${ }^{79}$ P'ung fled to Koguryǒ after the final conquest of Paekche. ZZTJ 201, p. 6337.

80 JTS 84, p. 2795.

${ }^{81}$ JTS 84 , pp. $2792-5$; 199A, p. 5333 ; XTS 108, p. 4084 ; 220, p. 6201. ZZTJ (201, p. 6342) records that Yung was appointed "commandant" (duwei), instead of "area commander" ( $d u d u)$ because Liu Rengui was the area commander.

${ }^{82}$ ZZTJ 201, p. 6347; Ikeuchi (1941, pp. 703-11) is of the opinion that Kaesomun died in 665.

${ }^{83}$ XTS 220, p. 6196. XTS does not say clearly to whom Yŏn Kaesomun's brother surrendered. The SGSG says that he offered Silla 12 towns, 763 households and 3,543 people, see $S G S G$ 6, p. 5.
} 
ninth month of 668 . King Pojang and Namgǒn were captured. ${ }^{84}$

Tang transferred the captured Korean nobles to China. The king and others were given official titles while Namgǒn and the former Paekche Prince P'ung, who had taken refuge in Koguryǒ, were exiled to the far south of China. To consolidate Tang control over the newly conquered area the Protectorate of Andong, one of the six major protectorates, was set up in P'yǒngyang. It was manned by 20,000 troops, with Xue Rengui as the Protector-general, supervising nine area commands, forty-two prefectures, and a hundred districts. The area commands and prefectures set up for Koguryǒ had both Chinese officials and local chieftains in their administration. ${ }^{85}$ In 669 , a large number of Koguryǒ people were resettled inside China. These arrangements were intended to dissolve any remaining sense of the country's unity. To permanently eliminate any possibility of reviving Koguryǒ even many of the Koguryǒ farmers were put to work in agriculture inside China. ${ }^{86}$

Though Gaozong was much less capable than Taizong, and had no experience in military affairs, he was carried onward by the momentum of the military conquests begun by his father and finally achieved his father's long cherished goal of the conquest of Koguryǒ. Using a strategy of indirection, he first attacked Paekche and backed Liu Rengui's persistence in the face of initial failure there, and this proved decisive in achieving the final success.

More fundamental factors promoting the Tang success, however, were the suicidal power struggles within Koguryor and the Chinese alliance with Silla. Silla joined in all the major campaigns in the conquest of Paekche and Koguryǒ. It was also responsible for the logistical support without which Tang troops could not have survived much less prevailed so far from home. ${ }^{87}$

\section{Tang's Withdrawal from the Korean Peninsula in 676}

By this time it seemed that Tang had finally succeeded in rebuilding the same degree control over the peninsula as enjoyed by the Han dy-

\footnotetext{
${ }^{84}$ ZZTJ 201, pp. 6347-8; pp. 6350-6.

${ }^{85}$ JTS 199A, p. 5327; XTS 220, p. 6197; ZZTJ 201, pp. 6356-7. XTS 220 says that Fuyu Long (Korean Yung) was exiled. Long should be Feng (Korean P'ung). Hino 1984, pp. 26-7.

${ }^{86}$ Hino 1984 , pp. 56-64.

${ }^{87}$ Details see SGSG 5-6.
} 
nasty. The success, however, soon degenerated into a series of troubles. In 670 , when Xue Rengui was sent on a campaign against Tibet, a revolt in Koguryǒ took place which installed the former king's grandson, Ansǔng, as king. Only in 673 did the Chinese succeed in crushing the revolt. ${ }^{88}$

A more serious problem from the Chinese point of view was that Silla ceased to be a Tang ally. It not only despatched troops to support Koguryǒ's revolt and provided shelter to Ansǔng, ${ }^{89}$ but also conferred on him the title of king in 670. Eventually, so as to win the allegiance of the remnants of Koguryǒ, Silla established him in a dependent kingdom known as Minor Koguryǒ (to be distinguished from the Minor or Lesser Koguryǒ in the Liaodong area, see below) in the southwest of the peninsula, on the former territory of Paekche. Minor Koguryǒ was eliminated by Silla around 684 when it rebelled against Silla. ${ }^{90}$

Signs of conflict of interest between Tang and Silla appeared soon after the conquest of Paekche, but both maintained the alliance to achieve their common goal-the conquest of Koguryǒ. Once this was accomplished, the allies became rivals. For their part the Chinese wanted to bring all non-Chinese into submission. In 663, Tang established the Superior Area Command of Jilin (Korean Kyerim) in Silla with King Munmu as the Superior Area Commander. ${ }^{91}$ Silla was thereby treated as a Tang subject. Two years later, Tang sent the former Prince Yung of Paekche back to Paekche as the Area Commander of Xiongjin, and ordered him to conclude a covenant establishing a boundary with Silla. Silla, of course, resented this, considering it to be the restoration of its former enemy and a check on its own expansion, which may, in fact, have been the intention of the Chinese. This arrangement, however, did not go well since Yung was too timid to coexist with so strong a neighbor as Silla and returned to Chang'an. $^{92}$

Silla, for its part, now took as its goal resistance against Chinese expansion into the peninsula and unification of Korea. Samguk Sagi contains a letter written in 671 by the king of Silla to the Tang Protector-

\footnotetext{
${ }^{88}$ ZZTJ 201, pp. 6363-4. For details of these events, see Ikeuchi 1960, pp. 267-393.

${ }^{89}$ ZZTJ 201, pp. 6363-4; 202, pp. 6370-1.

${ }^{90}$ SGSG 6, pp. 8-10. For details regarding the family background of Ansurng and the establishment of Minor Koguryǒ, see Murakami 1974, pp. 153-84.

${ }^{91}$ JTS 199A, p. 5336; ZZTJ 201, p. 6335; THY 95, p. 1711. XTS (220, p. 6204) records its establishment as as having occurred in 661 , which may be mistaken.

${ }^{92}$ JTS 199A, pp. 5333-4; XTS 220, p. 6201; ZZTJ 201, p. 6344; SGSG 6, pp. 4-5.
} 
general of Andong, Xue Rengui, who had demanded that Silla withdraw from Paekche and cease its protection of the remnants of Koguryǒ. The letter states that on the occasion of Kim Ch'unch'u's mission to Tang in 648, Taizong had promised that when Tang had subdued Koguryǒ and Paekche, the territory south of P'yǒngyang and the land of Paekche would be given to Silla. ${ }^{93}$ The Chinese sources nowhere refer to Taizong's alleged promise, nor do they refer to Silla's letter of 671 or its contents. Whether or not Taizong ever made such a promise, as a strong and virtually independent state, Silla would naturally struggle to expand and try to eliminate Chinese control of any kind on the peninsula.

Silla was at the peak of its ability to carry out expansion on the peninsula. Within a few years after the revolt of Koguryǒ Silla had control of all of Paekche and much of southern Koguryǒ. ${ }^{94}$ Considering Silla to be a rebel against Tang suzerainty, Gaozong dismissed King Munmu from his throne in 674, and sent his brother, who had been kept as a hostage in Chang'an, to replace him. "Punitive" troops led by Liu Rengui were despatched and inflicted a severe defeat on Silla. In 675 King Munmu offered "an acknowledgement of guilt" as well as tribute. Gaozong thereupon restored him to his post. ${ }^{95}$ The Tang court planned another expedition in 678 , but then gave it up after Chief Minister Zhang Wenguan rose from his sickbed and went to see Gaozong. Zhang opposed the campaign on the grounds that there was a more immediate danger of a Tibetan invasion on the western border, and that Tang could not afford to fight two enemies at the same time. ${ }^{96}$

Tang had in fact stretched itself beyond its ability to exert effective control. In 676, the seat of the Protectorate of Andong was moved all the way back from P'yǒngyang to Liaoyang in Liaodong, a more secure place, but well removed from the peninsula. All the Chinese officials formerly in Koguryǒ withdrew as well. The Area Command of Xiongjin was moved to Jian'an (in modern Liaoning). A year later, the Protectorate of Andong was moved again, this time to Xincheng (modern Fushun in Liaoning), thus completing the Tang withdrawal from the peninsula and its de facto recognition of Silla's expansion and its unification of most of Korea.

\footnotetext{
${ }^{93}$ SGSG 7, pp. 1-7; Jamieson 1969, pp. 63-6.

${ }^{94}$ XTS 220, p. 6204; THY 95, pp. 1711-2.

${ }^{95}$ XTS 220, p. 6204; ZZTJ 202, p, 6372; p. 6375.

96 JTS 85, pp. $2815-6$; XTS 113, p. 4187 ; ZZTJ 202, p. 6385

97 JTS 39, p. 1526; XTS 39, p. 1023; ZZTJ 202, pp. 6378-9.
} 
The reasons for the withdrawal are not hard to find. In the first place, the Chinese had to deal with a more acute border problem, one caused by the Tibetans in the west. In 670, Xue Rengui was sent off on a campaign against Tibet. His departure from the Protectorate of Andong must have weakened Chinese control there, for in the same year the revolt in Koguryǒ took place. ${ }^{98}$ Second, it was impossible to supply a military colony on the peninsula when Silla could no longer be relied upon as a logistical base. ${ }^{99}$ As a Chinese official pointed out in 661 , Tang efforts at conquering Koguryǒ were doomed, for if Koguryǒ was to remain conquered, Tang had to station troops there. Tang's dilemma was that if the number of the troops was small, China would be unable to exert enough force to retain control, but if the number was large China would be exhausted trying to supply that force. ${ }^{100}$

With the seat of the Protectorate of Andong moved to Liaodong, Tang decided in 677 to transfer the surrendered Korean royal family members and their people who had settled inside China back to their former land. It was probably hoped that they could impose a check on Silla's expansion. However, Prince Yung of former Paekche was still too much afraid of Silla to go back to the former territory of Paekche and remained in the north. King Pojang of former Koguryǒ went to Liaodong, but once he arrived there, he made contact with the Mohe, and prepared for a revolt. He was recalled and sent into exile in the southwest. ${ }^{101}$

${ }^{98}$ JTS 83, pp. 2782-3; XTS 111, p. 4142; ZZTJ 201, pp. 6363-4. Hino Kaizaburō holds that the Protector-general of Andong, Xue Rengui, left P'yǒngyang for Xincheng as early as 669 , while the official seat remained in P'yǒngyang. The seat was moved to Liaoyang in 670 as a temporary expedient and formally moved there in 676 . It was finally moved to Xincheng in 677 . The reason for this, Hino speculates, is that Xue Rengui had a different opinion from that of the central government: the court wished to control the whole of the peninsula, and so tried to maintain the seat in P'yǒngyang, whereas Xue did not believe that Tang was capable of maintaining its control over the peninsula. Xue decided that it was best to have the seat in Xincheng where it could both defend against Silla's northern expansion and watch over the Mohe people to head off any possible alliance between them and the Turks. The court's final decision to retreat from the peninsula represented an implicit agreement with Xue's opinion. See Hino 1984, pp. 29-32. We do not, however, have much evidence to show how Xue Rengui evaluated the situation as a whole.

${ }^{99}$ Cen Zhongmian 1957, p. 127.

${ }^{100}$ XTS 220, pp. 6195-6.

${ }^{101}$ Some accounts record the title given to them as Commandery Prince, see JTS 5, p. 102; JTS 199A, p. 5328; p. 5334; XTS 220, p. 6198; p. 6201, while some give it as King 
The Protectorate of Andong faced a great threat in 696 and 697 when the Khitan rose in revolt against Chinese control, attacking the Protectorate and adjacent Chinese territory. In 697, Di Renjie, who had been dealing with the Khitan rebellion first as Prefect of Weizhou and then as Area Commander of Youzhou and was now a Chief Minister, suggested in a memorial the abolition of the Protectorate and the appointment of members of the former royal family of Koguryor to take over the defense of Andong. ${ }^{102}$ A year later, the Protectorate of Andong was abolished and the Area Command of Andong was established. Pojang's son became the Area Commander. ${ }^{103}$

The Protectorate of Andong was restored in 704, but its seat was withdrawn further from the peninsula to near the present Beijing and its function was changed from supervising non-Chinese on the peninsula to frontier defense. It was finally abolished in 758 during the An Lushan rebellion. $^{104}$

Silla managed to maintain its independence of Tang. During King Munmu's reign (661-681), Silla sent no regular tributary missions to Tang, except on two occasions: one was in 665, when Silla sent officials to Tang to join in the Feng and Shan ceremony; ${ }^{105}$ the other was the mission of 675 mentioned above. Munmu's successor resumed peaceful contacts with Tang. In 692 Empress Wu sent an embassy to Silla, requesting that Silla abandon the title T'aejong used by their late King Muyǒ (r. 654-661), since T'aejong means Taizong in Chinese. Even though Silla did not take any action along these lines, Empress Wu did not insist on the demand. ${ }^{106}$

For the better part of a century, the Chinese made persistent efforts to establish their administration on the Korean peninsula. After bloody

of Chaoxian or King of Daifang, see JTS 199A, p. 5328; ZZTJ 202, pp. 6382-3; THY 95, p. 1709. Hino holds that the title was commandery king, see Hino 1984, p. 67.

102 JTS 89, pp. 2889-91; XTS 115, pp. 4210-1; ZZTJ 206, pp. 6524-5. THY 73 (pp. 13189) records the date of Di's memorial as 698.

${ }^{103}$ It has been proposed by Hino that this man and his descendants were gradually able to develop what Hino refers to as Minor or Lesser Koguryǒ in Liaodong, which switched its allegiance to the revived second Turkish empire, then to Tang under Xuanzong, and was annexed by the Parhae state during the An Lushan rebellion. See Hino 1984, pp. 74-6; pp. 185-8; pp. 326-35. But it is questionable whether such a state ever really existed. See Furuhara Toru 1992.

${ }^{104}$ Hino 1984, pp. 32-6.

${ }^{105}$ JTS 84, p. 2795; XTS 108, p. 4084; ZZTJ 201, p. 6344.

${ }^{106}$ SGSG 8, p. 4. 
battles and at a cost of countless lives and economic resources they finally gave up the attempt. The final winner in these wars was Silla, which established the first unified Korean state.

\section{Curbing the Parhae State}

Silla's independence was reinforced by the emergence of another state situated between itself and Tang. This was Parhae, at first called Zhen (Korean Chin), established by Tae Choyǒng, who was of Mohe origin and became Koreanized by the end of the seventh century. ${ }^{107}$ The Parhae state established relations with the Turks, who had restored their second empire in 682. Parhae expanded to occupy a large area from modern Jilin down to the 39th parallel on the Korean peninsula. By filling much of the space separating Silla from Tang, Parhae reduced Tang concern about Silla's northern expansion. More significantly, Parhae constituted a new element in the international balance of power, a force that could threaten both Silla and China because it had the potential to become an ally of the Turks.

Tang adopted a policy of preventing Parhae from making incursions and from forming an alliance with the Turks. In 712 Chinese official titles were conferred on the Parhae ruler, Choyǒng, and his territory was given the jimi title of Huhanzhou. ${ }^{108}$ From 713 to 755 Parhae sent fortyeight missions to Tang.

In 719 , Choyǒng died and his son Muye took the throne. ${ }^{110}$ Muye adopted a more independent attitude towards Tang: he honored his father with the posthumous title King Ko, adopted his own reign title, and engaged in territorial expansion. In 726, when the Mohe of the Amur Valley to the north of Parhae sent envoys to Tang and the Chinese set up Heishuizhou with a Chinese administrator to supervise them, Muye decided to strike first at the Mohe, to head off any joint attack by the Chinese and Mohe. However, his brother Munye, who had earlier been a hostage in Chang'an, opposed this anti-Tang act. Dissension arose in the ruling group

${ }^{107}$ This is according to Hino 1984, p. 176. The origins of Tae Choyǒng and the ethnic group to which the majority of the people of Parhae belonged (whether they were from the Mohe, or Koguryǒ, or composed of various peoples) remain controversial questions, see Sun Jinji 1987, pp. 151-65.

${ }^{108}$ ZZTJ 210, p. 6680.

${ }^{109}$ Hino 1984, pp. 160-3.

${ }^{110}$ ZZTJ 212, p. 6735. 
and Munye fled to Tang. ${ }^{111}$ Though the attack on the Mohe did not proceed, in 732 Muye crossed the sea to Shandong and attacked Dengzhou. This was supported by the Turks. ${ }^{112}$

In retaliation, Xuanzong sought and obtained an alliance with Silla. The two sides again joined forces to battle against Parhae. ${ }^{113}$ Silla's own strategic interest led it to compete with Parhae to prevent its expansion. In his letter of 735 to the king of Silla, Xuanzong acceded to Silla's request to establish garrisons as far south as the Daedong River at the narrow waist of northern Korea so as to resist the attacks of Parhae. In 736 Silla sent envoys to express appreciation for Tang's help. ${ }^{114}$

It is generally considered that this shows Tang's final and formal renunciation of opposition to Silla's claim over the peninsula. From then until the end of Tang, the two countries maintained peaceful relations. China had to be satisfied with unified Silla as a tributary state which explicitly acknowledged Chinese suzerainty, performed tributary duties, but maintained its de facto independence, ruling its own state without Chinese interference in its internal affairs.

The problems presented by Parhae seem to have subsided when Bilgä Qaghan of the Turks died in 734 and when the Xi and Khitan turned to the Chinese. These developments left Parhae isolated as the only potential member of any anti-Tang alliance. As a consequence, Xuanzong did not have to contemplate launching any further costly wars. ${ }^{115}$ Moreover, with the death of Muye in 737, his son Hummu succeeded him and changed to a pro-Tang policy, although maintaining his own reign title for the calendar. In response to the new situation in East Asia, Parhae found it advantageous to change its policy. In compensation for the change, it could at least begin to learn from Chinese culture and develop trade with Tang. ${ }^{116}$ In 762, after the An Lushan rebellion, an edict was issued by Tang recognizing Parhae as a state, and Hummu as its king.

\footnotetext{
111 JTS 199B, pp. 5360-1; XTS 219, pp. 6180-1; ZZTJ 213, pp. 6774-5.

112 JTS 199B, pp. 5361-2; XTS 219, p. 6181; ZZTJ 213, p. 6799.

113 ZZTJ 213, p. 6800.

${ }^{114}$ Qujiang Zhang Xiansheng Wenji 9, p. 51; CFYG 971, p. 11410; SGSG 8, p. 11; Pulleyblank 1955, p. 21.

${ }^{115}$ For a detailed study of the conflicts between Tang and Parhae, see Furuhata 1986.

${ }^{116}$ Hino 1984, pp. 164-5.
} 
Located in proximity to both agricultural China and the nomadic steppe land, Liaodong and southern Manchuria had long been an area of instability. During the Qin-Han period, the Liaodong area and part of the Korean peninsula were organized under Chinese administration, but when Chinese power weakened, this administration collapsed. The reunification of China under Sui and Tang fundamentally changed the region's balance of power, and tempted the Chinese rulers to reassert the active hegemony that had been exerted by Han.

Different rulers, constrained by the circumstances of their times and by their own personalities, handled the Korean issue with different policies. During Tang, Gaozu took an openly pragmatic attitude toward relations with the Korean states, seeing no need to pretend to be superior to the non-Chinese, but when his opinion was opposed by his ministers he had to abandon it. Taizong's three campaigns against Koguryǒ were partly motivated by considerations of frontier security. At least in his imperial edicts, he emphasized security as justification for military campaigns. On the other hand, like Emperor Yang of Sui, Taizong also demonstrated a desire for military glory, perhaps influenced by his northwestern aristocratic and military background as well as by his ambition to build a universal empire. He was not satisfied when Koguryǒ offered a nominal submission. The ideological component, a need to tailor events to fit his ideal of empire, made him insist on actual submission and led him to try to reestablish Chinese administration on the Korean peninsula. He failed to conquer Koguryǒ due to the practical difficulties of waging war in a harsh climate at a distance, and because he mis-assessed both China's own strength and that of Koguryǒ.

Tang Gaozong succeeded in conquering Paekche in 660. This proved to be a crucial step in the final conquest of Koguryǒ in 668, after which Tang established the protectorate of Andong in P'yǒngyang. A decisive factor that contributed to the victory was the alliance with Silla. Silla joined Tang forces in conquering both Paekche and Koguryǒ. What made the alliance possible was their short-term common goal of achieving the conquest of Koguryor and Paekche. The alliance could last so long as the interests of the two did not conflict, but it was bound to break down in the long run because the Chinese goal was to bring all non-Chinese into submission no matter in which "barbarian" state they lived, while for Silla, 
the initial goal was to defeat Paekche and then Koguryǒ and later to expand into their territory.

Once it lost Silla's crucial cooperation, Tang had to withdraw its administration from the peninsula. Once it withdrew, the final winner in this costly series of wars was Silla, whose hard struggles for unification pushed the Chinese off the peninsula and established the first unified Korean state in history. China thereafter had to be satisfied with having Korea merely as a tributary state which acknowledged Chinese suzerainty, performed tributary duties but maintained its independence, ruling its own state without Chinese interference in its internal affairs.

After Parhae was founded at the end of the seventh century, even though it too posed a potential threat, the Chinese treated it pragmatically, eventually also accepting a tributary relationship with it and launching attacks only defensively. The Chinese rulers were never as aggressive against Silla as their predecessors had been against Koguryǒ during late Sui and early Tang. This change may in part have reflected the lesson that the Tang rulers had learned from the Korean war. 


\section{Chapter 7}

\section{Competition Between Tang and Tibet Before the An Lushan Rebellion}

While the presence of nomadic powers on the northern frontier was a perennial problem for China from Han until Ming, the rise of a powerful kingdom in Tibet was a one-time phenomenon. During its period of strength from early in the seventh century to about 840 Tibet posed a very serious problem to China, as a direct threat to the security of its frontier as well as to its ideological claims of superiority over its neighbors. Before the An Lushan rebellion, Tang relations with the Tibetan kingdom focused first of all on competition for control of the Tuyuhun kingdom, then on the Western Regions and the southwest.

\section{The Tibetan Challenge}

Tibet, called Tufan in the Chinese sources, rose as a unified and powerful kingdom under the Yarlung dynasty around the end of the sixth century and the beginning of the seventh. The Yarlung dynasty had existed previously for a number of generations as chiefs of a smaller tribal state. During that period the main power lying between China and what became Tibet was the Tuyuhun kingdom. In his study of the establishment of the Tufan kingdom, Yamaguchi Zuihō describes how the hostile policy of the Chinese towards the Tuyuhun during the Sui and Tang periods not only provided the Yarlung dynasty with the opportunity of expanding and evolving into the Tufan kingdom, but also planted in the minds of its rulers the desire to replace the Tuyuhun as an international power. As a result, Tufan, by learning from the Tuyuhun, was able to absorb the latter and eventually surpass it. ${ }^{1}$

No dates can be assigned securely to the history of Tibet before the sixth century of our era. ${ }^{2}$ Some scholars have attempted to reconstruct an earlier history, ${ }^{3}$ but it is clear that until the formation of the Tufan king-

\footnotetext{
${ }^{1}$ Yamaguchi 1983.

${ }^{2}$ Stein 1972, p. 45.

${ }^{3}$ See such works as Beckwith 1977 and Yamaguchi 1983.
} 


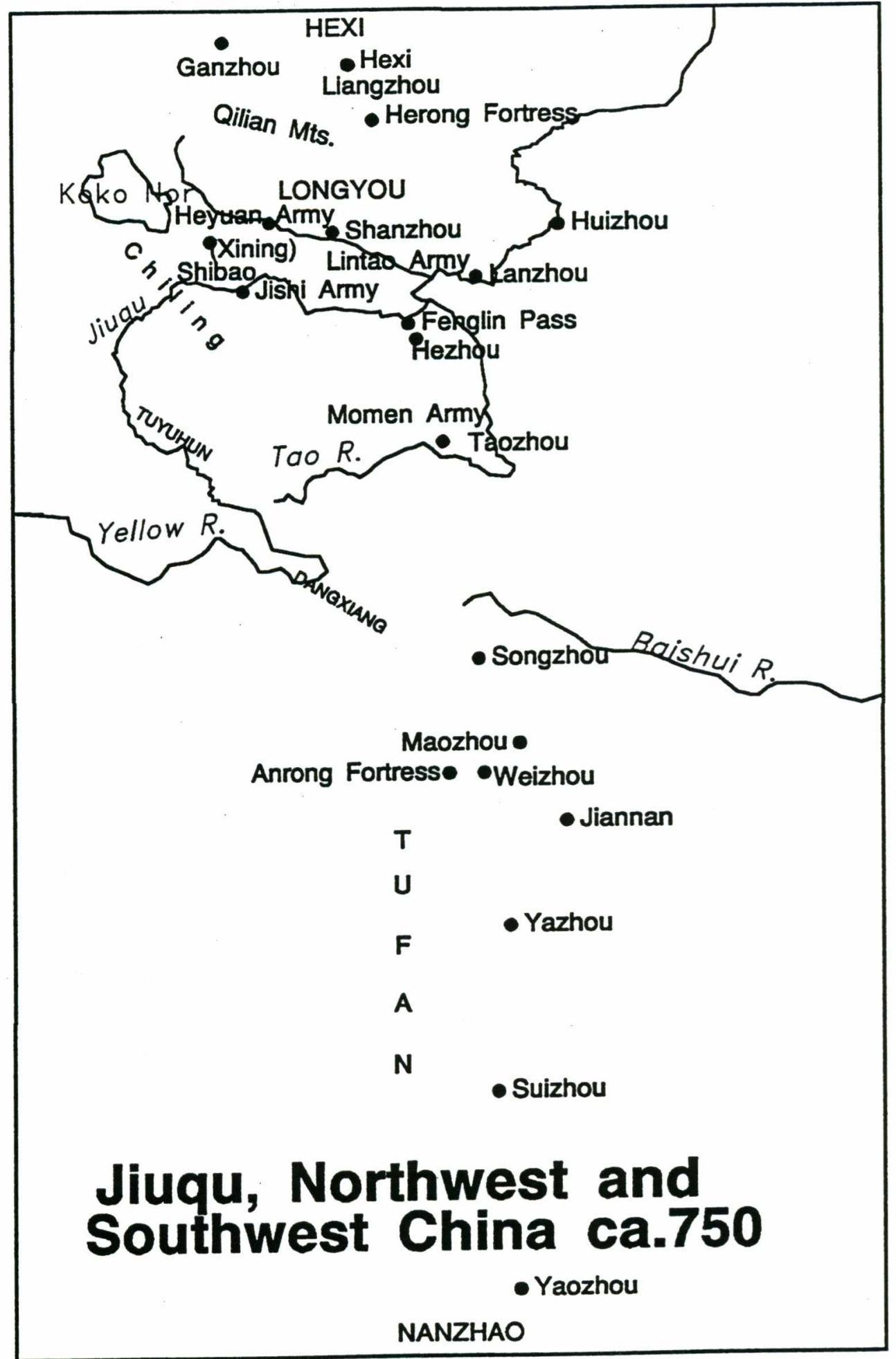


dom there is no record of any powerful political organization in Tibet which could have attracted China's attention or played a role in its foreign policy. When it did finally arise, the Tibetan kingdom presented an unprecedented challenge to China.

In contrast to the nomadic peoples who typically refrained from attempting to occupy the territory of settled peoples, the Tibetans were noted for their territorial ambitions. To the Tibetan rulers, expansion seemed ideologically necessary and economically profitable. ${ }^{4}$ Once in 822 a Tibetan marshal asked a Tang envoy why Tang treated the nomadic Uighurs more favorably than Tibet even though the Uighurs were a smaller country than Tibet and could be defeated very easily. The envoy answered:

The Uighurs have the merit of having rescued the country (China) in times of danger. Also they have never invaded and stolen even an inch of our territory. Why should we not treat them favorably? ${ }^{5}$

It is impossible here to go into a detailed comparative study of the political, military and economic structures of the nomadic and the Tibetan powers. It should be pointed out, however, that basic differences in their natural environment and economic structures made the nomads rely on the Chinese more than the Tibetans had to, and also led the Tibetans to be more ambitious in competing with China for territory. Ise Sentarō concludes that Tibet had a different economic structure from that of the Turks or Uighurs, whose economy was based on unstable nomadism, thus rendering them vulnerable to military defeat and natural disaster. The nomads, therefore, were more easily affected by Chinese influence, and through contacts with China they would gradually lose their advantage as a nomadic people. Ise further concludes that Tibet had a more solid economic structure which was based on three activities: 1) agriculture, animal husbandry, and mining; 2) foreign trade and taxation, applied both internally and to subordinate countries; 3 ) pillage of people, animal and grains, mostly from the Tang Chinese. Culturally, Tibet absorbed elements from the Chinese, Indians, and Western Turks and this cosmopolitanism helped engender a strong sense of independence. ${ }^{6}$

Ise's comparison needs to be supplemented by other considera-

\footnotetext{
${ }^{4}$ Beckwith 1980, p. 30.

${ }^{5}$ JTS 196B, p. 5265. See also XTS 216B, pp. 6103-4; CFYG 660, p. 7900.

${ }^{6}$ Ise 1968 , pp. $373-418$. For trade see also Beckwith 1977 b.
} 
tions. The nomadic empires also had agriculture, engaged in mostly by captured Chinese and sedentary local people who became their subjects in the Western Regions. The nomadic empires imposed a taxation system on their sedentary subjects and conducted very active trading activities between east and west. ${ }^{7}$ But nomadic imperial power was based, to a large extent, on exploiting the Chinese economy, and thus was dependent on China. In his study of the nomadic empires, Barfield observes that the ruling class of nomadic states in particular maintained themselves by exploiting China's economy, and not by exploiting the production of scattered sheepherders. In the early stages of their evolution they did not attempt to conquer Chinese territory, nor did they have the necessary administrative institutions to govern an agricultural society. By continuous raids, plundering or providing military assistance, however, the nomadic rulers demonstrated their strength sufficiently to increase their bargaining power for obtaining large quantities of Chinese goods as subsidies, and made China accommodate their demands for trade.

The Tibetans also traded with China, but their economy was more independent of China's. The difference between the economic structure of the Tibetan kingdom and that of a nomadic empire may have been a matter of degree, and was determined primarily by their different ecological environment. The Tibetans, possessing less pasture and more arable land than the nomads who occupied the steppes, could develop a more extensive and solid agriculture. While the ruling classes of Tibet controlled the agricultural peasantry, they themselves, including both the btsan-po and the noble families, led a nomadic life. Agricultural production was entrusted to the peasantry, who served not only to supply agricultural income to their masters but also as a source of military manpower. ${ }^{9}$ The more balanced semi-agricultural and semi-nomadic economy of Tibet thus could be more independent than that of the nomads. Rather than demanding subsidies as the nomads did, Tibet competed with China for more of the same kind of territory, and its expansion into agricultural land as well as pasture was a natural process. Its collection of taxes in occupied areas was a natural extension of its state's power, a reflection of the nature of the state before such expansion.

As Ise points out, Tibet enriched its culture and reenforced its po-

\footnotetext{
${ }^{7}$ Hayashi Toshio has studied the role of agriculure in Turkish society, see his 1985 .

${ }^{8}$ Barfield 1981, pp. 46-7; 1989, pp. 8-9 and passim.

${ }^{9}$ Sato 1959 , English summary of the contents, p. 30.
} 
litical strength through contacts with India, China, and the several political powers in Central Asia. Even though the Tibetans showed enthusiasm in adopting certain aspects of Chinese civilization-its bureaucratic system, religion, architecture and production skills-unlike the Koreans, for whom China was the sole foreign source of inspiration in matters pertaining to the higher aspects of civilization as well as political and military assistance, Tibet could also draw many cultural elements from Central Asia and India. Tibetan written script was from India, and this is significant since written language is the most important single element of any culture. There were also debates in Tibet between the different Buddhist sects of China and India before Tibet finally developed its own variant of the Buddhist tradition. ${ }^{10}$

Since the Tibetan kingdom was more economically independent, the Chinese could not as easily use their products to buy peace from the Tibetans or to attract them to move and settle close to the frontiers under Chinese supervision as they could with the nomadic people. Nor could they effectively use the political investiture system to persuade the Tibetans into so close a tributary relationship as existed between the Chinese and the Koreans. Tibet, therefore, posed a different kind of challenge to the Tang empire.

\section{Taizong: Subduing the Tuyuhun}

The Tuyuhun were the second major problem on the Tang frontiers after the Eastern Turks during Gaozu's time. Soon after Taizong assumed the throne, the Tuyuhun Fuyun Qaghan sent an envoy to the court, but before his return, the Tuyuhun raided the frontier. In contrast to Emperor Yang, who eliminated the Tuyuhun kingdom, Taizong tried to make it into a buffer state. A Chinese mission was despatched to reprove the Tuyuhun for the raid and summon the qaghan back to the court. Sensing the danger involved, Fuyun did not go. He then requested a marriage for his son Zunwang. With the idea of keeping him under control, Taizong asked the prince to come to the court to receive the bride, but the prince excused himself on account of illness. The marriage did not materialize and the Tuyuhun raids resumed.

Military force then was resorted to subdue the Tuyuhun. In 634 general Li Jing led an expedition army joined by the Turks and the Qibi tribe against the Tuyuhun. In the following year two more military expe-

${ }^{10}$ Demiéville 1952. 
ditions campaigned across the whole of the Tuyuhun territory, ending Fuyun's life. Supported by Tang military force, the pro-Chinese prince Shun became the next qaghan, but he was soon killed by his ministers for his inability to rule effectively. His son Nuohebo succeeded him. ${ }^{11}$ One consequence of these expeditions was that the Tuoba tribe of the Dangxiang Qiang people, a former ally of the Tuyuhun, also submitted to Tang. Most other Dangxiang Qiang had submitted to Tang earlier. The Qiang were organized into jimi prefectures on their own land scattered in modern Sichuan, Qinghai and Gansu. ${ }^{12}$

Nuohebo adopted a pro-Tang policy. In return, Tang supported him with grant of the titles of king and qaghan and military assistance. They gave him the hand of a princess in 640. In 641, his Chief Minister planned a revolt, to begin with a surprise attack on the Tang princess. The Chief Minister hoped to capture Nuohebo and take him to the Tibetans. The Tang troops intervened. The Chief Minister was killed and Nuohebo's position was maintained. ${ }^{13}$ Obviously there was a pro-Tibetan group among the Tuyuhun. It has been suggested that the pro-Tibetan faction developed around Fuyun's second son Zunwang, who had married a Tibetan princess. After the death of Fuyun in 635, the Tibetans continued to support Zunwang's son by the Tibetan princess. ${ }^{14}$ Clearly, the Tuyuhun's complex interactions with Tang were influenced by their relations with the Tibetans.

\section{The First Encounter with Tibet and Achievement of Peace through the Marriage of Princess Wencheng, 634-660}

Official contact between Tibet and Tang started in 634, when the Tibetan btsan-po, Srong btsan sgam-po, despatched a mission to the Tang court. Taizong returned the visit by sending an envoy to Tibet. ${ }^{15}$ When Srong btsan sgam-po heard that both the Turks and Tuyuhun had concluded marriage alliances with Tang, he sent an embassy to Tang to accompany the returning Chinese envoy, and make a marriage proposal, but Taizong turned it down. The Tibetan envoy reported to Srong btsan sgampo that Tang at first had promised the marriage but later changed its deci-

\footnotetext{
${ }^{11}$ JTS 198, pp. 5298-300; XTS 221A, pp. 6224--6.

${ }_{12}$ JTS 198, pp. 5291-2; XTS 221A, p. 6215. See also Dunnel 1994, pp. 158-9.

${ }_{13}$ JTS 198, p. 5300; XTS 221A, p. 6226; Molè 1970, pp. $49-57$.

${ }^{14}$ Yamaguchi 1983, pp. 673-84.

${ }^{15}$ JTS 196A, p. 5221; XTS 216A, p. 6073; ZZTJ 194, pp. 6107-8.
} 
sion after the Tuyuhun qaghan arrived at the Tang court and fomented discord. Srong btsan sgam-po then attacked the Tuyuhun, and subjugated the Dangxiang and the Bailan tribes, who were located close to both Tibet and the Tuyuhun. ${ }^{16}$

Tang's change of attitude may have been due to Taizong's concern with maintaining good relations with the Tuyuhun. In 634, when Tang and the Tuyuhun were at war, Taizong would have welcomed an alliance with Tibet so as to check the Tuyuhun from the rear. However, between 634 and 636 the situation in the Tuyuhun kingdom changed drastically with the establishment of a pro-Tang regime headed first by Shun and then by Nuohebo. When Nuohebo came in person to Tang in 636 to show his loyalty and asked for a marriage alliance, he realized the great danger implied by a Tang-Tibetan marriage alliance, and therefore endeavored to stop it. Once the situation among the Tuyuhun became peaceful under a pro-Tang regime, the necessity to ally with Tibet against the Tuyuhun disappeared. The 636 Tibetan envoy to the Tang court saw the Tuyuhun's interference and its consequences and upon his return to Tibet the following year, he reported this to the Tibetan btsan-po. ${ }^{17}$

Following his attack on the Tuyuhun, Srong btsan sgam-po stationed a large number of troops on Tang's western border at Songzhou in modern Sichuan, and again despatched an embassy to the Chinese court claiming the hand of a Tang princess. A Tibetan source says that Srong btsan sgam-po sent a letter to Taizong, saying that if Tang did not assent to the marriage request, he would lead 50,000 troops to attack Tang, kill the emperor and obtain a princess directly. ${ }^{18}$ The year 638 saw the Tibetans mount continuous attacks on Songzhou and subjugate two Tang jimi prefectures. Finally, as a result of Tang counterattacks, Srong btsan sgam-po withdrew his troops. He petitioned again for a marriage contract in 640 . Even though Tang claimed a victory over the Tibetans, it finally had to accommodate the Tibetan request so as to prevent Tibet from launching

${ }^{16}$ JTS 196A, p. 5221; XTS 216A, p. 6073; ZZTJ 195, p. 6139.

${ }^{17}$ Sato 1958, pp. 248-52. Without referring to Sato's opinion, Beckwith questions the account of Tuyuhun's interference. He conjectures that Taizong "made a private agreement with the Tibetans to conclude a marriage alliance if they would finish off the stilltroublesome "Azha (Tuyuhun)." See his 1987, p. 23, note 53. The fact that the Tibetans launched an attack against the Tuyuhun and then brought pressure on the Chinese frontier to strengthen their demand for a Chinese princess does not support Beckwith's conjecture.

${ }^{18}$ Wang Zhong 1958, p. 29. 
further attacks. $^{19}$

The Chinese princess, Wencheng, left for Tibet in 641, marking the beginning of a period of peaceful and frequent communication between the two states that lasted until 660 , well into Gaozong's reign. ${ }^{20}$ The Tibetan Chief Minister, Ludongzan (Mgar Stong rtsan), who came to the Tang court to receive the princess, was given the Chinese title of general. $^{21}$ The Tibetan sources say that after the confrontation between Tibet and the Chinese in 638, Tang and the Tuyuhun came to Tibet to pay tribute. ${ }^{22}$ However, the Chinese records say that Tibet at this time did not object to taking on vassal status within the tribute system, at least not openly to the Chinese. ${ }^{23}$ During this period, thirteen Tibetan missions arrived at the Tang court, eleven of them being tributary missions, according to the record in the Cefu Yuangui. ${ }^{24}$ After the marriage, Tibet assisted Tang in two wars. The first campaign was in 647 , when Tang launched a "punitive" attack on Kucha. ${ }^{25}$ The second time was in 648, when the Tang envoy Wang Xuance was attacked while on a mission to northern India and the Tibetans sent troops to rescue him and defeated the Indian attackers. $^{26}$

Considering that the reign of Srong btsan sgam-po was for Tibet a time of consolidating state power, one can see that it was in their own interest that the Tibetans joined Tang troops to attack India so as to demonstrate their strength, and cultivated friendship with Tang the better to engage in political, religious and cultural borrowings. Tibet sent young aristocrats to Tang to study the Confucian classics and doctrines, and Chinese scholars were invited to Tibet to compile official reports to the Tang em-

\footnotetext{
${ }^{19}$ Sato 1958, p. 267.

${ }^{20}$ Yamaguchi rejects the traditional view that Princess Wencheng was married from the outset to Srong btsan sgam-po. He concludes instead that Princess Wencheng first married King Gung srong gung rtsan, who was the ruler at that time, bore him a son, Mang slon mang rtsan, and only after the king's death did she marry Srong btsan sgam-po when he re-ascended the throne. Yamaguchi 1983, pp. 547-62.

21 JTS 196A, p. 5223; ZZTJ 196, p. 6164.

${ }^{22}$ Yamaguchi 1983, p. 683.

${ }^{23}$ One example is the memorial of 646 to Tang by the btsan-po's to congratulate Taizong on his return from the Koguryǒ campaign. JTS 196A, p. 5222; XTS 216A, p. 6074; CFYG 970, p. 11400. See also Kaneko 1974, p. 39; 1988, p. 96.

${ }^{24} \mathrm{Su}$ Jinren and Xiao Lianzi 1981, pp. 359-60.

${ }^{25}$ ZZTJ 198, pp. 6250-1; CFYG 985, pp. 11571-2.

${ }^{26}$ JTS 198, pp. 5307-8; XTS 216A, p. 6074; ZZTJ 199, pp. 6257-8.
} 
peror on behalf of Tibet. ${ }^{27}$ Marriage to a Chinese princess allowed the Tibetan btsan-po to demonstrate to his own people the extent of his power, to increase his prestige and reinforce his position vis-à-vis the nobles, who posed a potential threat to the royal family's hegemony. ${ }^{28}$

In 649 , at the beginning of Gaozong'sreign, Tang conferred on King Srong btsan sgam-po the titles of Commandant-escort (fuma duwei), which was the usual title for an imperial son-in-law, Commandery Prince of Xihai and Precious King (baowang). This was, however, the only time throughout the history of Tang-Tibetan relations when the Tibetan king received Chinese political investiture. ${ }^{29}$

\section{Confrontations with Tibet over the Tuyuhun, 660-680}

After the death of Srong btsan sgam-po in 649, his grandson succeeded him. The real state ruler however was the competent minister Mgar Stong rtsan. Taking over full control of the already consolidated kingdom, Mgar Stong rtsan continued the expansion which had started in Srong btsan sgam-po's time. The Tibetans' subsequent expansion in all directions was bound to lead to confrontation with the Chinese. They also challenged Chinese superiority by asking the Tang envoy to perform the kowtow at their court. The envoy refused and was, as a consequence, detained in Tibet for over ten years. He finally died in captivity. ${ }^{30}$

The Tang court under Gaozong took a firm stand against this powerful new rival. In 658 , the Tibetan request for a marriage produced no result, perhaps because Tang was following a policy of supporting the Tuyuhun, who would have hated to see a marriage contract between Tang and Tibet. ${ }^{31}$ Soon, in 660 , the Tibetans launched their first attack on the Tuyuhun. ${ }^{32}$ When at war with each other in 663 , both Tibet and the Tuyu-

${ }^{27}$ JTS 196A, pp. 5221-2; XTS 216A, p. 6074; CFYG 978, p. 11496.

${ }^{28}$ Sato 1958, p. 287.

${ }^{29}$ JTS 196A, p. 5222; XTS 216A, p. 6074; ZZTJ 199, pp. 6269-70; CFYG 964, p. 11340. Concerning the last title, the above sources say that the title is binwang or zongwang instead of baowang. But Wang Zhong holds that these are mistaken readings of baowang, see his 1958 , p. 35 . Beckwith (1987 p. 25 , note 71 ) also discusses these titles. He questions the accuracy of Chinese historians who record the conferring of the title equivalent to the imperial-son-in-law to the Tibetan king.

${ }^{30}$ XTS 216A, p. 6078; CFYG 138, p. 1675. Wang Zhong (1958, p. 50) believes the envoy was detained around 665 .

${ }^{31}$ XTS 216A, p. 6075; ZZTJ 200, p. 6310; Sato 1958, pp. 307-9.

${ }^{32}$ ZZTJ 200, p. 6321. 
hun sent in requests for Chinese military intervention. Gaozong at first refused, but Tibet allied itself with the Tuyuhun's pro-Tibet faction, and inflicted a disastrous defeat on the pro-Tang Tuyuhun qaghan Nuohebo. This forced him to flee with his people to Liangzhou. Gaozong thereupon ordered a Tang general to assist the Tuyuhun, while at the same time Tang stationed troops in Liangzhou and Shanzhou to defend against Tibet.

When Mgar Stong rtsan followed up his occupation of the Tuyuhun lands with an embassy to Tang, making accusations against the Tuyuhun and petitioning for a marriage contract, Gaozong not only refused the petition, but also sent an envoy to Tibet to deliver a sealed letter blaming the Tibetans for their aggression. ${ }^{33}$ In the eyes of the Chinese at that time Tibet could only be a vassal, not an equal. In 665 another Tibetan mission arrived at the Tang court, this time with the purpose of restoring peace with the Tuyuhun. As their reward, the Tibetans requested the land of Chishui in Tuyuhun territory for raising livestock. Gaozong again refused. $^{34}$ The demand of the Tibetans for Chishui may indicate either that the area had not yet been subjugated, or that the Tibetans wished to assuage Chinese fears and anger by requesting Tang recognition of the new de facto situation. ${ }^{35}$

In 669, a court discussion in Chang' an was held to consider a plan for settling the Tuyuhun in the Southern Qilian mountains. General Qibi Heli suggested waging war on Tibet rather than assisting the Tuyuhun. Yan Liben, a Chief Minister but better known for his talent in painting, argued against any war since China had suffered a severe famine the year before. A third opinion, raised by Chief Minister Jiang Ke, was to aid the Tuyuhun so that they would be able to remain a buffer state. However, no decision was reached and the resettlement of the Tuyuhun was not implemented. $^{36}$

It turned out that the final decision was to be for war against the Tibetans, with the Tuyuhun to be restored as a buffer state to check the Tibetan advance into the Western Regions. The Chinese mounted a campaign against the Tibetans in 670 , but Tang suffered a severe defeat, with its entire army lost in battle near Koko Nor. All the territory of the Tuyu-

${ }^{33}$ JTS 196A, p. $5223 ; 198$, p. 5300; XTS 216A, p. 6075; 221A, p. 6227; ZZTJ 201, pp. 6335-6.

${ }^{34}$ XTS 216A, p. 6075; ZZTJ 201, p. 6343.

${ }^{35}$ Sato 1958, pp. 312-3; Beckwith 1987, p. 32.

${ }^{36}$ XTS 216A, p. 6075; ZZTJ 201, p. 6359; CFYG 991, p. 11642. 
hun was brought under the control of Tibet. ${ }^{37}$ The Tuyuhun qaghan Nuohebo and his people had to be resettled within northwest China under Anlezhou and Lingzhou in 672. The Tuyuhun kingdom had disintegrated, never to be revived. ${ }^{38}$

Despite Tang's weakness, Gaozong insisted on maintaining a firm attitude toward the Tibetans. He refused the latter's request for peace in $675 .^{39}$ In 676 and 677 , the Tibetans raided China's northwestern prefectures, causing Gaozong to plan a military campaign against them. ${ }^{40}$ Finally, in 678, 180,000 troops were despatched to do battle with the Tibetans at Koko Nor. Again Tang was defeated. ${ }^{41}$

In a court discussion after Tang's defeat, some suggested a cautious policy of strengthening defense but eschewing attack, while the emperor, though aware of the fact that fighting on two fronts had exhausted China, still insisted on a bellicose attitude: "These bandits are arrogant and ferocious. They do not understand our benevolence and majesty, and ought to be captured right away. Peace-making is obviously impossible."42 The Chinese were caught in a dilemma. If they attacked the invading Tibetans on the frontiers, they would simply waste their resources without solving the problems. On the other hand, if they did not counterattack because they deemed themselves not capable of penetrating into Tibetan areas, they would not be able to root out the source of their problems. No final decision was made. ${ }^{43}$

The weakness of Tang as compared with Tibet at that time was not merely a question of military force, but also stemmed from internal factors. The defeat of 678 can be partly attributed to the internal conflicts among Chinese high-ranking officials. In 677, Chief Minister Liu Rengui was appointed Commissioner for Defending Taohe (Taohe zhenshou dashi, in present Gansu) in preparation for the war with Tibet. His memo-

${ }^{37}$ JTS 83 , pp. $2782-3$; 196A, p. 5223 ; 198, p. 5300; XTS 216A, p. 6076; 221A, p. 6227; ZZTJ 201, pp. 6363-4.

${ }^{38}$ ZZTJ 202, p. 6368; Molè 1970, xxi; p. 59.

${ }^{39}$ XTS 216A, p. 6076; ZZTJ 202, p. 6368; p. 6375; CFYG 980, p. 11512. In the relevant passage of $C F Y G$, Suzong should be Gaozong.

${ }^{40}$ ZZTJ 202, p. 6379; pp. 6383-4; CFYG 991, pp. 11642-3.

${ }^{41}$ JTS 196A, pp. 5223-4; XTS 216A, pp. 6076-7; ZZTJ 202, pp. 6384-6. The passage in THY (97, p. 1731) records the year as "the second year of Shangyuan (675)," which is wrong.

${ }^{42}$ CFYG 991, p. 11643.

${ }^{43}$ JTS 5, pp. 103-4; 196; p. 5224; XTS 216A, p. 6077; ZZTJ 202, p. 6386. 
rials were often disputed by $\mathrm{Li}$ Jingxuan, Director of the Secretariat. Knowing that Li was not good at military affairs, Liu planned to discredit him by insisting that the frontier defense against Tibet must have $\mathrm{Li}$ as commander. Taken in by this ploy, Gaozong sent Li to replace Liu in 678 . It was under the incapable command of Li that Tang troops suffered great losses in the war. Li was demoted as a result. ${ }^{44}$

There were also problems concerning the general quality of leadership, as Wei Yuanzhong, a student from the National University, pointed out in a sealed memorial: 1) those in military service placed their emphasis on the martial arts and had no concern for strategy, and the court selected officials from generals' families and not for their abilities; 2) civil bureaucrats paid attention to prose style, but were not concerned with how to make plans; 3) ever since the time of the Korean wars, the court had not observed carefully the rule of reward and punishment. He suggested that Tang should abolish the order that forbade people to raise horses, and should raise revenues from taxation levied all over the country to purchase horses for a cavalry army of 200,000 to attack the Tibetans. People should also be allowed to buy horses from the nomads, so that the nomads would be weakened by a shortage of horses. Gaozong was impressed and appointed Wei to a position in the Department of the Secretariat. Wei later rose to the status of Chief Minister and led troops to defend against the Turks and Tibetans. ${ }^{45}$

In contrast, Tibet had a well-organized army and an efficient leadership. The Chief Minister, Mgar Ston btsan, was well-known for his talent and skill in leadership. After his death in 670, the Mgar family continued in actual control of the political and military power of Tibet, ensuring the stability of the state to some extent. They were directly responsible for the series of expansions which continued until $699 .{ }^{46}$ In 679 , when he heard of the death of the Tibetan btsan-po, Gaozong wanted to take advantage of the situation to attack, but was dissuaded from doing so on the grounds that the Tibetan ruling group was united and strong. When Princess Wencheng despatched an embassy to inform Tang of the royal death and to request the conclusion of a new marriage contract, Gaozong once

\footnotetext{
${ }^{44} J T S 81$, p. $2755 ; 84$, p. 2795 ; XTS 106, pp. $4052-3 ; 108$, p. 4085 ; ZZTJ 202 , pp. $6384-$ 6.

${ }^{45}$ JTS 92, pp. 2945-53; XTS 122, pp. 4339-44; ZZTJ 202, pp. 6386-8; CFYG 991, pp. 11643-6.

${ }^{46}$ Sato 1958 , pp. $300-61$.
} 
more refused. ${ }^{47}$ This time the Tibetans asked for Princess Taiping, Gaozong's own daughter by Empress Wu, to marry their king. This was refused with the excuse that the Princess was a Taoist nun. ${ }^{48}$

\section{Competition in the Southwest and over the Western Regions, 670-705}

The Tibetans advanced across China's southwestern border by capturing the Anrong Fortress on the western border of Maozhou (in present Mao county, Sichuan) in 680 with the help of the Qiang peoples of this area. Anrong Fortress was built by Tang in 678 at a strategic spot on the major route connecting Tibet and Sichuan. By maintaining control of this point the Tibetans were able to exercise their influence over the many nonChinese peoples in the region. ${ }^{49}$ In 688 Empress Wu planned to open up a route via Yazhou (in Sichuan) in order to attack the Qiang people and then the Tibetans. This was strongly opposed by Chen $\mathrm{Zi}$ 'ang, a native of Sichuan, then holding the rank of proofreader in the palace library, on the grounds that to attack the Qiang would surely lead them to make common cause with the Tibetans, who would use the Qiang as guides to attack Sichuan. Although in a minor position, Chen was on several occasions consulted by the empress. ${ }^{50}$ The plan was not carried out, perhaps because it was obviously impossible given China's position, and also because Chen's opposition represented the dominant opinion.

On the northwest front, after the Tibetans established a base on Tuyuhun territory and thereby secured closer access to both the Tang frontier and the Western Regions, the Tibetans in 670, with the assistance of Khotan, captured eighteen Chinese jimi zhou and the Kuchean fortified city of Aksu in the Tarim Basin. The Chinese had to abandon their bases in the Tarim Basin, and move the seat of the Protectorate of Anxi back to Xizhou. ${ }^{51}$ As mentioned above, the Chinese unsuccessfully attacked Tibet in 670 .

Despite this loss the Chinese tried to maintain their control over the Western Turks north of the Tianshan after the deaths of Ashina Mishe (in 662) and Ashina Buzhen (in 666 or 667), the Protectors-General of

\footnotetext{
47 JTS 196A, p. 5224; ZZTJ 202, p. 6389; p. 6393.

${ }^{48}$ XTS 83, p. 3650; ZZTJ 202, p. 6402.

${ }^{49}$ Backus 1981, pp. 26-8.

${ }^{50}$ JTS 190B, pp. 5021-4; XTS 107, pp. 4071-4; ZZTJ 204, pp. 6455-6.

${ }^{51}$ JTS 198, p. 5304; XTS 216A, p. 6076; ZZTJ 201, p. 6363. See also Ise 1968, pp. 244-5.
} 
Kunling and Mengchi. ${ }^{52}$ Tang appointed tribal leader Ashina Duzhi as general and Area Commander to control the Western Turks in $671 .^{53} \mathrm{Be}$ tween 676 and 678, however, Ashina Duzhi proclaimed himself qaghan and allied with the Tibetans in attacks on the Protectorate of Anxi. Pei Xingjian, a former Protector-General of Anxi back in 665 and familiar with the situation there, devised a strategy to utilize the non-Chinese in the Western Regions, and succeeded in capturing Ashina Duzhi in 679. Before his return, Pei left a general behind to build a fortress in Suiye (Tokmak). ${ }^{54}$ Some modern scholars are of the opinion, based on the narrative in the Cefu Yuangui, that in 679 Tang recovered the Four Garrisons in Tokmak, Kucha, Khotan and Kashgar, but lost them again in 686 or $687 .^{55}$

Empress $\mathrm{Wu}$ wished to maintain Tang dominance in the Western Regions. Around 685 she appointed the son of Ashina Mishe and the son of Ashina Buzhen to succeed to their father's titles of qaghan and Protector-General in order to make them side with Tang against the Tibetans. ${ }^{56}$ When, in 689, the Tibetans captured Kashgar she sent out an expeditionary army which suffered a severe loss. ${ }^{57}$ In 692 , on the advice of Tang Xiujing, Area Commander of Lingzhou and former Vice Protector-general of Anxi, Empress Wu ordered another major campaign against the Tibetans under the command of Wang Xiaojie. As a result, the Chinese recovered the Four Garrisons of Tokmak, Kucha, Khotan and Kashgar, thus ensuring Chinese influence over the area until the mid-eighth century. Thirty thousand Chinese troops stationed under the Protectorate of Anxi with its seat in Kucha, enhanced Chinese control over the Western Regions and intensified the competition with Tibet. ${ }^{58}$

In 697, when Chief Minister Di Renjie presented his memorial suggesting the abolition of the Protectorate of Andong (see Chapter 6), he also suggested abolishing the Four Garrisons in the Western Regions, and using the Western Turks to take over the region's defense on the grounds

52 JTS 194B, pp. 5198-9; XTS 215B, pp. 6064-6.

${ }^{53}$ XTS 215B, p. 6064.

${ }^{54}$ JTS 84, pp. 2802-3; Chavannes 1969, pp. 60-1; Ise 1968, pp. 254-6.

${ }_{55}^{55}$ Ise 1968, p. 256, pp. 260-2; Wu Yugui 1987, pp. 91-3.

${ }^{56}$ JTS 194B, pp. 5188-90; XTS 215B, pp. 6064-6; Ise 1968, pp. 258-9.

${ }^{57}$ ZZTJ 204, p. 6459; Sato 1958, pp. 350-2. The army was led by Wei Daijia. Based on the various accounts in Chinese, Ise (1968, pp. 259-60) thinks that Wei went to the Western Regions twice, in 686 and 689, to fight with the Tibetans.

${ }^{58}$ JTS 93, p. 2977; pp. 2978-9; 196A, p. 5225; 198, p. 5304; XTS 111, p. 4148; p. 4149; 216A, p. 6078; 221A, p. 6232; ZZTJ 205, pp. 6487-8. 
that the "four barbarians" were outside the boundaries established by China's previous rulers. They were separated from the Middle Kingdom by such natural boundaries as the sea to the east, the floating sands to the west, the desert to the north and the Wuling mountains in the south.

On the other hand, Cui Rong, a court historian, forcefully argued against $\mathrm{Di}$, insisting that abandoning the Four Garrisons would give the Turks in the north and Tibetans in the south opportunities to impose their rule over the oasis states, which would in turn expose the Chinese Hexi area to danger and would in the long run cost China more when the time came to defend that region. The situation was like that during the Han dynasty: whenever Han abandoned the Western Regions, the Xiongnu would take over and from there threaten the Hexi region. Di's opinion was rejected. $^{59}$

The Tibetans, allied with the Western Turks, continued their fight for the Western Regions. They also raided China's northwestern frontiers. After a major victory over the Chinese in 696 in Taozhou (in modern Gansu), ${ }^{60}$ Qinling (Mgar Khri 'bring, Mgar Stong rtsan's son), who became the Chief Minister in $685,^{61}$ sent an embassy to the Chinese court with a peace proposal. Empress Wu agreed and sent Guo Yuanzhen, a military officer, to the Tibetan minister to conduct negotiations, which did not produce much of a result. Since both were focusing on the Western Regions, neither was willing to compromise.

The negotiations are recorded in detail in the Tongdian. When Mgar Khri 'bring met Guo Yuanzhen, he demanded that Tang should abandon the Four Garrisons and let each state of the Tarim and the Western Turks become autonomous so that they would be subject neither to Tang nor to Tibet. He also demanded border trade in Yizhou (in present Sichuan). Guo Yuanzhen refused on the grounds that the Four Garrisons were there to ensure peace in the Western Regions, and that the Western Turks had long since been made subjects to Tang. He pointed out that the Tibetan request was intended to establish their own control over the Western Regions at Tang's expense.

Mgar Khri 'bring argued that his demands were based on two con-

${ }^{59}$ JTS 89, pp. 2889-91; XTS 115, pp. 4210-1; 216A, pp. 6078-9; THY 73, pp. 1326-9; ZZTJ 206, pp. 6524-5; Ise 1968, pp. 423-5.

${ }^{60}$ Beckwith 1987, pp. 55-7.

${ }^{61}$ This is according to Sato 1958 , p. 301; p. 344; Beckwith 1987, p. 50. Wang Zhong (1958, p. 38) holds that Mgar Khri "bring was the grandson of Mgar Stong rtsan. However, Tibetan and other Chinese sources provide no evidence to support this supposition. 
siderations: 1) the Chinese frontier generals in the Western Regions often started offensives to further their own interests, so their withdrawal would bring about peace; 2) the Western Turks were a major worry to Tibet for they were separated from Tibet only by a desert, thus being in a position to make quick hit and run raids. Denying any intention of acquiring territory, Mgar Khri 'bring said that if he wanted Chinese territory and Chinese goods, he would make trouble in the Ganzhou and Liangzhou areas within China proper itself, and not contend with the Turks so far away. He insisted that it was China that wanted to extend its territory. ${ }^{62}$ Mgar Khri 'bring was in fact threatening that Tibet could, if it came to that, make constant incursions across the Tang frontiers in Ganzhou and Liangzhou if that was what it took to force Tang to give up control over the Western Regions.

Upon his return, Guo Yuanzhen presented a memorial to Empress Wu suggesting that Ganzhou and Liangzhou were more important to China than the Western Regions and therefore that particular efforts should be made to guarantee stability there. China should reply to Tibet that the Four Garrisons were set up to control the Western Regions and divide the Tibetan forces so they could not join for invasions of China. If Tibet did not have any territorial ambitions, it should return to China the Koko Nor lands and the Tuyuhun people. In return, China would give up the five Nushibi tribes of the Western Turks. In another memorial, he further suggested that the Tibetan people were exhausted by constant wars. If Tang pressed peace proposals every year and Mgar Khri 'bring refused, the people would reject him. ${ }^{63}$

The negotiation did not result in any agreement. Guo Yuanzhen's observation of the Tibetan internal situation was correct. From late 698 to early 699, the Tibetan btsan-po, Khri 'Dus srong, now a grown man, supported by the minister Lun Yan (Mang nyen bzhi-brtsan ${ }^{64}$ ) and other ministers, staged a successful purge of the Mgar clan. Mgar Khri 'bing committed suicide and his younger brother Zanpo fled to China with a thousand people. Khri 'bing's son Gongren, along with 7,000 households of the Tuyuhun who were under his control, also went over to China.

Empress $\mathrm{Wu}$ immediately ordered her officials to receive them and conferred official titles on Zanpo and Gongren. Zanpo was sent to

\footnotetext{
${ }^{62}$ TD 190, pp. 1023-4; ZZTJ 205, pp. 6508-9.

${ }^{63}$ TD 190, p. 1023-4; JTS 97, pp. 3043-4; XTS 122, pp. 4361-2; ZZTJ 205, pp. 6508-9.

${ }^{64}$ Identified by Beckwith 1987, p. 60, note 34 .
} 
Hongyuangu (in Gansu), in command of his own troops, and charged with guarding the Chinese frontiers. ${ }^{65}$ Lou Shide, as Vice Commander-in-chief of the Tianbing Army and Commissioner of the various armies of Longyou, was charged specifically to watch over the affairs of the submitted Tibetans. ${ }^{66}$ In 700, the Tibetans attacked Hongyuangu, where Zanpo stationed his troops, probably with the purpose of punishing the rebel Tibetans. However, the Tibetan troops were newly recruited, and their performance reflected the weakness of the Tibetan military after the Mgar brothers were purged. The Tibetans engaged in six battles with the Chinese and lost all of them. ${ }^{67}$

In between frontier confrontations, Khri 'Dus srong sought peace with Tang. In 702 a Tibetan mission arrived at the Chinese court to request a peace settlement. ${ }^{68}$ In 703 another mission arrived with a thousand horses and 1,000 liang of gold to negotiate a marriage alliance. Empress $\mathrm{Wu}$ agreed to the latter. ${ }^{69}$ In a subsequent series of campaigns against Tang and other neighboring countries, Khri 'Dus srong died during the winter of $704-705 .{ }^{70}$ Empress Wu abdicated in 705 . Both sides were ready for peace.

\section{The First Treaty with Tibet and the Marriage of Princess Jincheng, 706-710}

After 705 the Tibetan royal family and nobles were engaged in a fierce struggle over the succession until 712, when Khri lde gtsug brtsan ascended the throne. During this period, while his grandmother was in actual control, ${ }^{71}$ China's frontier problems with Tibet seemed less pressing. In China, where Emperor Zhongzong had just restored the rule of the $\mathrm{Li}$ royal family, priority was given, among all the frontier issues facing the new government, to halting the Turkish incursions. A peaceful policy was adopted towards Tibet and in 707 it was agreed to give the hand of Prin-

\footnotetext{
${ }^{65}$ Wang Zhong 1958, pp. 55-6; Beckwith 1987, pp. 60-1.

${ }^{66}$ ZZTJ 206, p. 6540. Lou Shide died either that year or in 699, see ZZTJ 206, p. 6541. There is no mention of anyone having been appointed to be in charge of Tibetan affairs after him.

${ }^{67}$ JTS 196A, p. 5226; XTS 216A, p. 6080; ZZTJ 207., p. 6549; Wang Zhong 1958, p. 56.

${ }^{68}$ ZZTJ 207, p. 6560.

${ }^{69}$ ZZTJ 207, p. 6562.

${ }^{70}$ Wang Zhong 1958, pp. 57-8; Beckwith 1987, pp. 63-5.

${ }^{71}$ Wang Zhong 1958, pp. 58-9; Beckwith 1987, pp. 69-70.
} 
cess Jincheng to the Tibetan btsan-po. Tibet had requested this in $703 .^{72}$ The princess left for Tibet in 710 .

The emperor gave her an emotional send-off and in some farewell poems by the court ministers are lines lamenting that "Because there is lack of counsellors [who can provide a better solution to the problem], the sage ruler still has to worry [and adopt this expedient]," and "Even though the western barbarians are not on the same level as we are, the enlightened ruler impartially preserves them [by marrying the princess to the chief]. ${ }^{, 73}$ Princess Jincheng played an active role in diplomacy and politics as we will see below.

Tang concluded a peace treaty with Tibet in 706. Details of the treaty text and the formal ceremony are not available, but from extant sources we can see that the essential items of the treaty were 1) the boundaries of the two countries were to be settled in accordance with convenience; 2) the Chinese had ten participants, including the Chief Minister Doulu Qinwang, and the Tibetan Chief Minister also took part in the oath taking. ${ }^{74} \mathrm{~A}$ letter from the Tibetan ruler in 781 quotes a Tang edict of 708 which stipulates that when the Tang envoy arrived in Tibet, the Tibetan btsan-po was to first swear an oath witnessed by the envoy, and when the Tibetan envoy arrived in Tang, the Chinese emperor would personally conclude the covenant. ${ }^{75}$

The relationship between the edict and the treaty of 706 is not clear. But since this edict was issued only two years after the treaty, it is possible that it was repeating a provision in the treaty of 706 . In any case this reference demonstrates a remarkable degree of reciprocity and equality in the oath-taking ceremony by requiring that each ruler should conclude the ceremony in person in his own territory. To be sure, there is no evidence that such a practice ever did actually take place during the Tang dynasty.

The practice of concluding treaties was not new to the Chinese. There was a traditional Chinese view, however, that the conclusion of a sworn covenant reflected a situation of instability and deterioration of the state. Sworn covenants were concluded most often when trust was in

${ }^{72}$ JTS 196A, p. 5226; XTS 216A, p. 6080; ZZTJ 207, p. 6562; 208, p. 6610; CFYG 979, p. 11498.

${ }^{73}$ Kuang Pingzhang 1935, pp. 34-5.

${ }_{75}^{74}$ Pan Yihong 1992a, pp. 127-8.

${ }^{75}$ JTS 196B, p. 5246; XTS 216B, p. 6093; CFYG 981, p. 11528. 
doubt. ${ }^{76}$ It was also the custom of Tibet to use sworn covenants to ensure stability. The Chinese records say that the Tibetan btsan-po made a minor covenant with his ministers every year and a major one every three years. ${ }^{77}$ In the traditional Tibetan sources, especially the Old Tibetan Annals and the Old Tibetan Chronicle, there are records of sworn treaties among the Tibetans themselves. ${ }^{78}$ There is, however, no record of any Tang-Tibetan treaties in these two histories. It is not clear why. It seems to be a particular Tibetan custom to erect stone tablets with inscriptions of treaty texts. Among the thirteen Tibetan inscriptions of the Tufan period, one was the sworn treaty between Tang and Tibet, four were sworn treaties between the Tibetan btsan-po and his subjects, ${ }^{79}$ and three were sworn texts by the btsan-po and Tibetan nobles to declare their support for Buddhist temples. 80

It was hoped that the marriage alliance and the peace treaty with Tibet would help bring about peace on the frontiers, and would also encourage the Tibetans to cooperate in dealing with the Türgish, a Western Turkish tribe. But the peace policy was not adhered to in a consistent way by the Chinese. In 710, only four years after the conclusion of the pact, China breached it.

In the southwest, Li Zhigu, Acting Investigating Censor (she jiancha yushi), suggested an attack on the "barbarians" in Yaozhou (in modern Yunnan), who had formerly been subjects of Tibet. The court agreed. After bringing them into submission, Li Zhigu further asked to build walled towns establish prefectures and districts there and to impose heavy taxes on the local people. Li's harsh attitude forced the local chieftains to obtain assistance from Tibet and they killed Li. The route from Yaozhou to Suizhou was cut off.

In the northwest, Zhang Xuanbiao, Protector-General of Anxi, plundered the northern borders of Tibet. Though furious, the Tibetans did not immediately retaliate. They bribed the Area Commander of Shanzhou, Yang Ju, who had escorted Princess Jincheng to Tibet and, through him,

\footnotetext{
${ }^{76}$ Pan Yihong 1992a, pp. 125-6.

77 JTS 196A, p. 5220; XTS 216A, p. 6073; THY 97, p. 1730.

${ }^{78}$ For example, in the Old Tibetan Annals, from 650 to 763 , there are 66 years when the Tibetans made covenants among themselves, see Wang Yao 1979, pp. 1-29. According to the Dunhuang documents, when the Tibetans occupied Shazhou they also concluded sworn treaties with the local Chinese, see Ma De 1987, p. 59.

${ }^{79}$ Wang Yao 1982, pp. 1-128.

${ }^{80}$ Wang Yao 1982, pp. 151-81.
} 
asked for the land in the Jiuqu area of Hexi (near modern Xining, Qinghai province) as a bathing place for Princess Jincheng. It was a place suitable for pasture. Upon learning of Yang's proposal the court agreed. The Tibetans soon built fortresses south of the Yellow River and a bridge over the River, thus securing a convenient base for raiding Tang. ${ }^{81}$

\section{Conflicts and Negotiations, 712-719}

After Xuanzong's assumption of power, Tibetan missions arrived at the Tang court in 712 and 713 , the second time with a peace proposal. ${ }^{82}$ Again in 714 the Tibetan Chief Minister Bendayan ('Bon-da-rgyal, = nephew king ? $^{83}$ ) asked to fix the borders on each side and to conclude a sworn covenant based on the earlier one. In response to his request, Xie Wan, an official experienced in frontiers affairs, went to Heyuan to negotiate, bearing with him the treaty with Tibet of 706 .

Before Xie Wan left, he had suggested that the court deploy troops in preparation for Tibetan incursions. ${ }^{84}$ This proved to be necessary. Even though a Tibetan minister arrived at the Tang court with a treaty text, before any peace agreement was confirmed, 'Bon-da-rgyal had launched attacks on the Chinese Lintao Army, and on Lanzhou and Weizhou, where he plundered Chinese livestock. Hearing this, Yang Ju took his own life, because he felt responsible or perhaps because he expected to be made a scapegoat by the court for allowing the Tibetans to have the land of Jiuqu, which provided with easy access to Tang lands. Xuanzong immediately ordered a counter-attack. ${ }^{85}$ In the tenth month of 714 Xuanzong declared his intention of assuming personal command of a major campaign against the Tibetans, with over 100,000 troops including 20,000 non-Chinese. The plan was not carried out, for soon the already present Chinese troops claimed major victories in battles with Tibet. ${ }^{86}$

After the war was over, Tang sent an envoy to Tibet to console

${ }^{81}$ JTS 196 A, p. 5228 ; XTS 216 A, p. 6081; ZZTJ 210, p. 6661. Sato (1958, pp. 427-32) is of the opinion, based on the dates given in the Basic Annals of Zhongzong in the JTS and $X T S$, that the acts of Li Zhigu and Zhang Xuanbiao occurred in 707. I follow the dates given in the ZZTJ.

${ }^{82}$ CFYG 971, p. 11405 ; 980 , p. 11510.

83 Thomas II, 1955, p. 163. He was the king of Tuyuhun and married Khri ma lod's daughter. He was in actual control of state power in Tibet. Wang Zhong 1958, pp. 62-3.

${ }^{84}$ JTS 100, p. 3113; XTS 130, p. 4501; ZZTJ 211, pp. 6699-700; CFYG 981, p. 11526.

${ }^{85}$ ZZTJ 211, p. 6704.

${ }^{86}$ JTS 196A, p. 5228; XTS 216A, p. 6081-2; ZZTJ211, pp. 6704-6; CFYG 118, p. 1407. 
Princess Jincheng. ${ }^{87}$ When a Tibetan minister was sent to the Tao River to mourn the Tibetan soldiers and then to the Tang borders to ask for peace, Xuanzong refused. The Zizhi Tongjian gives as the reason for the refusal that the Tibetans "used the protocol of an equal country" when asking for peace, and the Xin Tangshu says that the Tibetans "relying on their power, asked to be on equal terms with the Son of Heaven and used arrogant language." 88 This was an open challenge to Chinese superiority. To the Chinese, the Tibetans could only be an outer subject. Such an attitude was reflected in the edict of 714 and in all the official letters from Tang to Tibet before $780 .^{89}$

In 715, Tibet allied itself with the Arabs for the first time and established a new king in Ferghana, a tributary state to the Tang court. They launched an attack against the former king, who then fled to Kucha, the headquarter of the Protectorate of Anxi, asking for rescue. A Tang Investigating Censor who was on a mission there, joined with the ProtectorGeneral of Anxi in a military action, fighting successfully all the way from Kucha to Ferghana. ${ }^{90}$

From 716 to 719 , Tibet made several requests for a peace agreement which Xuanzong did not reject, but no specific treaty was concluded until 732. There were two reasons for the delay. First, border conflicts between the two countries remained active, such as the one in Songzhou in 716 and the clashes in Qinghai and the Western Regions in $717 .^{91}$ The second obstacle was Xuanzong's refusal to place his personal signature on a treaty text. To the Chinese, signatures on a treaty agreement may not have seemed so important as they did to the Tibetans. Also, it was considered demeaning for the Chinese emperor to personally sign an agreement. It was a Tibetan custom to have signatures of the sovereigns on a treaty.

${ }^{87}$ XTS 216A, p. 6082; ZZTJ 211, p. 6706.

${ }^{88}$ XTS 216A, p. 6082; ZZTJ 211, p. 6706. Wang Zhong holds that this reason does not seem right since, having been recently defeated, the Tibetans would not have been likely to use arrogant language when asking for peace. The JTS 196A (pp. 5228-9) has a different version of this story, stating that the Tibetans' request for equal terms was raised several years after the peace proposal. Wang Zhong surmises that the reason for Tang's refusal may lie in the fact that the Tibetans continued to make incursions even after they had proposed a treaty agreement. Wang Zhong 1958, p. 64.

${ }^{89}$ Kaneko 1974; 1988.

${ }^{90}$ ZZTJ 211, p. 6713; Beckwith 1987, pp. 81-3. An inscribed stone tablet was erected to commemorate this campaign, see Cen Zhongmian 1964, pp. 166-7.

${ }^{91}$ ZZTJ 211, p. 6716; p. 6728. Regarding the battle in Qinghai, JTS (103, p. 3190) says that Guo Zhiyun was in command during the 718 battle. 
Princess Jincheng presented a memorial in 717 urging a signed treaty:

The Chief Ministers here have told me that the btsan-po very much wants a peace treaty, and that it is also proper that the emperor should personally sign the sworn treaty text. In the past you did not agree to do so personally. When I came to wed, it was for friendship. But now, there are disturbances. The situation is becoming uneasy. Please show pity on me, far away in another country. Your personal signature will not establish a regular practice. It will achieve the long-term friendship of the two countries. ${ }^{92}$

In 718 the Tibetan btsan-po sent a letter to Xuanzong, pressing further his demand for a new sworn treaty bearing the signatures of the emperor and Chief Ministers. The letter stated that it was because the Tang officials Zhang Xuanbiao and Li Zhigu attacked the Tibetan people that Tibet had despatched troops. It accused Tang of violating the treaty by building a fort in Baishui, which was stipulated in the treaty to become a no-man'sland between Tang and Tibet, and said that Tibet had therefore also built a fort in Baishui. The letter also requested that neither Tang nor Tibet should communicate with the Turks. ${ }^{93}$ Obviously, Tang did not agree to write another treaty, for in 719 Tibet made yet another request for one, which Xuanzong refused on the grounds that if there was no good faith, there was no use in having a sworn covenant. ${ }^{94}$

\section{Conflicts from 722 to 729}

Competition continued in the Western Regions, especially over Little Balur (present Gilgit in northern Kashmir), which was a crucial passageway from Tibet to the Tarim Basin. Tang had a father-son relationship with its king and established the Suiyuan Army there around 712. This effectively checked the advance of the Tibetans. ${ }^{95}$ Tang also gave the title of king to the ruler of Great Balur (Baltistan) in $717,{ }^{96}$ southeast of Little Balur. Little Balur had split off from Great Balur some time earlier. The Tibetans several times remarked to Little Balur's king that "It is not that

${ }^{92}$ CFYG 979, p. 11500; QTW 100, pp. 1289-90.

93 XTS 216A, pp. 6082-3; ZZTJ 212, p. 6734; CFYG 981, pp. 11526-7; QTW 999, pp. 13078-9.

94 ZZTJ 212, p. 6736; CFYG 980, p. 11511.

95 Sato 1958 , pp. $442-3$.

${ }^{96}$ Beckwith 1987, p. 87. 
we want your country. We just want to pass through to attack the Four Garrisons."

In 722, the Tibetans laid siege to Little Balur. The king asked for assistance, saying that if Little Balur fell into Tibetan hands, the whole of the Western Regions would belong to Tibet. Accordingly, the ProtectorGeneral of Beiting sent an army made up of Chinese and non-Chinese to drive the Tibetans back. ${ }^{97}$ The uncertainties of politics at the Tibetan court placed Princess Jincheng under considerable pressure. In 724 Tegin, the king of Zabulistan, sent an envoy to Tang bearing a report that in 723 Princess Jincheng had sent a secret letter to the king of Kashmir, asking for asylum. The king of Kashmir had gladly assented to that request, but was afraid of Tibetan attacks, and therefore had asked for military assistance from Tegin. Tegin consented and sent the envoy to Tang for advice. Xuanzong expressed appreciation and awarded him silk. ${ }^{98}$ The princess did not, however, go to Kashmir.

In 724 , clashes with Tibet again broke out along the northwestern border. Wang Junchuo, the Military Commissioner of Longyou, reported success in battles with Tibet and presented captives to the court. ${ }^{99}$ Supported by Wang Junchuo, who was an advocate of a strong-arm policy towards the non-Chinese, Xuanzong became more interested in a bellicose policy even though other officials such as Chief Minister Zhang Yue urged a peace policy. In the winter of 726-727, following a Tibetan raid on Ganzhou, Wang Junchuo fought successfully west of Koko Nor. ${ }^{100}$ Unfortunately, Wang was killed in 727 by the Uighurs. ${ }^{101}$ About the same time, the Türgish, allied with the Tibetans, attacked the headquarters of the Protectorate of Anxi in Kucha. ${ }^{102}$ The period between 727 and 729 saw a series of encounters between Tang and Tibet. Tang recaptured the Fortress of Shibao from Tibet near Koko Nor and set up an army there. ${ }^{103}$

\section{The Second Treaty with Tibet in $\mathbf{7 3 2}$}

In 730 , Tibet made a peace proposal. Xuanzong was going to refuse the request, the reason still being the Tibetans' previous use of arro-

\footnotetext{
${ }^{97}$ XTS 216A, p. 6083 ; 221B, p. 6251 ; ZZTJ 212, p. 6752; see also Sato 1958, pp. 444-6.

${ }^{98}$ ZZTJ 212, p. 6762; CFYG 979, p. 11501.

${ }^{99}$ CFYG 42, p. 480.

${ }^{100}$ ZZTJ 213, pp. 6776-7.

101 JTS 103, p. $3192 ; X T S 133$, p. 4547.

102 JTS 194B, p. 5191; XTS 215B, p. 6067; ZZTJ 213, pp. 6775-6; p. 6779.

${ }^{103}$ Sato 1958 , pp. 459-61.
} 
gant language. Huangfu Weiming, then Companion of Prince Zhong, tried to persuade the emperor to agree to the peace request, blaming the Tibetan frontier generals, who had sought to gain merit through military success, for the arrogant attitude. He pointed out the great losses Tang had suffered from the constant wars and suggested that Tang send envoys to comfort Princess Jincheng and discuss peace with Tibet. This may have been an attempt to use Princess Jincheng to intercede. Xuanzong then despatched Huangfu to Tibet. ${ }^{104}$ Huangfu was later promoted to the position of the Military Commissioner of Longyou and led battles against the Tibetans. ${ }^{105}$

According to the Chinese sources, the Tibetan btsan-po was very pleased to see the Chinese envoys and showed them all the letters sent by Tang since Taizong's time. He sent a high-ranking official, Lun Mingxilie (Blon Mye-slebs ${ }^{106}$ ), who had a good command of the Chinese language, to go to Tang with Huangfu. In the tenth month of 730 Mye-slebs arrived at the Tang court with a letter from the btsan-po to Xuanzong, which was carefully worded in accordance with the proper rhetoric that the Chinese had established, while stating clearly that it was the Chinese who had violated the peace agreement and started hostilities on the border. The btsanpo said he had sent envoys to Tang several times, but that they had been obstructed by the border generals, and that the btsan-po had already ordered the border generals to make no incursions and to return any Chinese who had earlier defected to Tibet. ${ }^{107}$

In reply, Xuanzong gave Mye-slebs favorable treatment and offered him Chinese official dress. Xuanzong despatched Cui Lin, Chamberlain of the Court of State Ceremonial and Censor-in-chief, to Tibet to confirm the peace agreement. Cui Lin left in early 731 , bringing with him letters from Xuanzong to the btsan-po and to Princess Jincheng, imperial gifts and Confucian classics and literary works. These works had earlier

${ }^{104}$ It is not clear when Tibet made the peace request and when Huangfu Weiming went to Tibet. JTS 196A (p. 5230) and THY 97 (p. 1733) record the year as 729, while ZZTJ 213 (p. 6789; pp. 6790-1) records it as 730. XTS 216A (p. 6084) gives no specific time. According to a Tibetan source, in both 729 and 730 there were Tang envoys to Tibet, see Wang Zhong 1958, pp. 72-3.

${ }^{105}$ XTS 5, p. 143.

${ }^{106}$ Francke 1914, p. 39.

107 JTS 196A, pp. 5230-1; XTS 216A, pp. 6084-5; ZZTJ 213, p. 6791; CFYG 979, pp. 11502-3. 
been requested by Princess Jincheng. ${ }^{108}$

In 731, another Tibetan mission arrived at the court. Tang agreed to the Tibetan request to set up a border market at Chiling in modern Qinghai. ${ }^{109}$ A peace treaty was concluded in $732 .{ }^{110}$ Both Tang and Tibet erected steles to mark the borders as discussed below. The Chinese text of the treaty is preserved. ${ }^{111}$

The Chinese treaty text refers to China as uncle and Tibet as nephew. It also says: "We shall establish a calendar," and "The law upholds the principle of having a single calendar, and does not recognize the ritual of two beginnings of the year." This implies that the Chinese attempted to impose the superiority of the Son of Heaven on Tibet by the introduction of their calendar to Tibet. This made the treaty more like a declaration of incorporation from the Chinese point of view rather than a mutual agreement between equals, because in the Chinese hierarchical political system only the Son of Heaven had the right to issue the calendar. This symbolized the relations between Heaven and the Son of Heaven, who was to rule the world on behalf of Heaven, and between the Son of Heaven and the various lords, who were his chief subjects. The Zhouli says that at the end of each year, the Son of Heaven "distributes the calendar to the feudal states." 112 On several occasions during the Sui-Tang period the Chinese calendar was received by foreign countries. ${ }^{11}$

Through a Chinese envoy, Princess Jincheng in 733 requested that the two sides should establish a stone stele in Chiling to mark the demar-

108 JTS 196A, p. 5231; XTS 104, p. 4007; 216A, p. 6085; ZZTJ 213, p. 6794. When the request was first received, Yu Xiulie, with the rank of proofreader, objected, saying that Tang could give the "barbarians" large quantities of material goods but should not give them the classics for fear that the Tibetans would learn from them tactics and military stratagems. But Chief Minister Pei Guangting and other ministers argued that these works would also teach loyalty, faith, proper conduct and righteousness and would gradually "civilize" the Tibetans. Xuanzong agreed with Pei.

${ }^{109}$ XTS 216A, p. 6085; ZZTJ 213, p. 6796.

${ }^{110}$ There is confusion about whether the date was 732 or 733 . In his study of the treaty, Tan Liren (1988, p. 132) convincingly argues that the year should be 732 .

${ }^{111}$ For the treaty text, see $C F Y G 979$, p. 11503; QTW 990, pp. 12962-3. For a translation, see Pan Yihong 1992a, pp. 153-4.

112 Zhouli Zhushu 26, "Taishi," p. 953.

${ }^{113}$ For example, the Sui calendar was issued to the Eastern Turks in the first month of 586 (SUIS 1, p. 23); Nanzhao in 794, after concluding a covenant with Tang, received the Tang calendar for the tenth year of Zhenyuan (794) (Manshu Jiaozhu 10, pp. 251-2). 
cation line between their territories. ${ }^{114}$ In the same year, a Tibetan mission arrived at the Tang court with a letter from the btsan-po to Xuanzong. The letter refers to China and Tibet as both being great countries and to the peace agreement. It expresses the wish that in order to maintain peace as a long term policy, the border generals should be informed of the agreement to prevent them from provoking trouble. ${ }^{115}$

On the day when the stone stele was erected in 733 , both sides had officials present, with Zhang Shougui, a Military Commissioner, and Li Xingyi, a general, on the Chinese side, and Mangbuzhi (Mang po-rje, = "great lord"116) on Tibetan side. Afterwards, the three went to Jiannan and Hexi to inform the various border prefectures that "the two countries are at peace. You must not attack each other." And they went on to the territory of Tibet to proclaim the peace. ${ }^{117}$ Tibet also set up its own stone stele. ${ }^{118}$ In 822, when a Tang envoy passed Chiling on his embassy to (or from) Tibet, he saw that the stele set up by Tibet in 733 was still there, while the one set up by the Chinese had already been destroyed. ${ }^{119}$

\section{Confrontations from 737 to 753}

Peace was preserved between the two states until $737,,^{120}$ when conflict broke out again. Early in 737 Cui Xiyi, Military Commissioner of

\footnotetext{
${ }^{114}$ JTS 112, p. 3336; XTS 78, p. 3531; ZZTJ213, p. 6800; CFYG 979, p. 11503.

${ }^{115}$ XTS 216A, p. 6085; CFYG 979, pp. 11503-4.

${ }^{116}$ Identified by Beckwith 1987, p. 114.
}

${ }^{117}$ JTS 112, p. 3336; THY 6, p. 76; 97, p. 1733; CFYG 979, p. 11503. The two Tang histories differ from these sources in their accounts of these events: in 734 Xuanzong sent $\mathrm{Li}$ Quan, General of the Left Imperial Insignia Guard to erect the stele in Chiling. See JTS 8, p. 201 ; 196A, p. 5233. XTS 216 A (p. 6085) says that following the erection of the stele, Zhang Shougui, Li Xingyi and Mangbuzhi went to make known the agreement. Tan Liren conjectures that, whether the stele was erected in 733 or in 734 , Zhang Shougui could not have been present, since in 733 , he left his post in Longyou, went to Hebei and was involved in battles with the Khitan there. He concludes that Xuanzong ordered that Zhang Shougui and Li Xingyi go to erect the stele in 733 but what in fact happened thereafter is not clear, see Tan Liren 1988, pp. 132-3.

${ }_{118}$ JTS 196, p. 5231; CFYG 981, p. 11527.

${ }^{119}$ XTS 216B, p. 6103.

${ }^{120}$ CFYG 358 (p. 4245) and 396 (p. 4699) state that in 733 the Tibetans made an incursion but were defeated by Wang Zhongsi, who was then promoted to be General of the Left Imperial Insignia Guard. But ZZTJ records Wang's promotion as being made in 738 after battles with Tibet under the command of Du Xiwang, which is more likely to be true. ZZTJ 214, p. 6835. See also JTS 103, p. 3198; XTS 133, p. 4552; CFYG 384, p. 4571 . 
Hexi, went into Tibetan territory, mounted an offensive against the Tibetans west of Qinghai and killed over 2,000.

Before the attack two events were the prelude to this clash. In 737 the Tibetans attacked Little Balur again, and its king immediately called for Tang intervention. Tang asked Tibet to stop the incursion but without success. ${ }^{121}$ This made Tang feel entitled to act on the grounds that Little Balur was a Tang subject, an attack on which was a violation of the peace treaty. $^{122}$

The other incident occurred not long after the peace agreement of 732, when Cui Xiyi suggested to the Tibetan border general Qilixu (Khrigzigs) that since the two countries were at peace the tree-palisade and defense patrols should be moved away in order to not hinder people from ploughing. Despite Khri-gzigs' objection, Cui insisted. Consequently the two concluded a local covenant sealed with the sacrifice of a white dog, and removed the palisade and border guards. Soon Tibetan livestock covered the border fields.

After the Tibetan attack on Little Balur, Sun Hui, a retainer of Cui Xiyi, who was on a mission to the court, proposed to make a sudden attack on Tibet, taking advantage of its unpreparedness. Xuanzong despatched Zhao Huicong, a eunuch, to the frontiers to observe the situation. Upon his arrival in Liangzhou, Zhao Huicong forged a decree ordering an attack on the Tibetans. Cui Xiyi then had to carry out the offensive into the Tibetan land early in 737 .

The fact that Zhao Huicong and Sun Hui were generously rewarded by Xuanzong after the Tang victory showed Xuanzong's approval of the attack. The attack put an end to the peace between the two countries which had been shaky from the start. It is recorded, however, that Cui Xiyi became morose because he had broken the covenant and he was removed to another post. He and Zhao Huicong both saw a bad luck omen-a white dog-which was the sacrificial animal with which Cui had made his covenant with the Tibetans. They both died soon after. Sun Hui is said to have been executed for some other unspecified crime. ${ }^{123}$ The Chinese historian appears to be drawing a moral by implying that the three deserved to die.

The breaking of the treaty does not, however, seem to have been an accidental event that occurred on some officials' own initiative. Rather it

${ }^{121}$ JTS 196A, p. 5233; XTS 216A, p. 6085; ZZTJ 214, pp. 6826-7.

${ }_{122}$ Qujiang Zhang Xiansheng Wenji 11, pp. 68-9.

${ }_{123}$ JTS 196A, p. 5233; XTS 216A, pp. 6085-6; ZZTJ 214, pp. 6826-7. 
may have been intended by the court. After the Tibetans had taken control of Little Balur, Tang felt it necessary to attack the Tibetans on their eastern borders in order to prevent a possible Tibetan alliance with the Türgish. ${ }^{124}$ The prevalent idea was that Confucian norms could be applied only to insiders, that is, to the Chinese, and not to outsiders, the non-Chinese. In Xuanzong's time Liu Kuang said that courtesy and deference were used only in communications between gentlemen and should not be used when dealing with "barbarians." 125

A Chinese general offensive against Tibet was launched in 738 by the Military Commissioners of Hexi, Longyou and Jiannan. The stele bearing the Chinese sworn treaty of 732 was destroyed. ${ }^{126}$ From then until the end of Xuanzong's reign, the Tibetan frontier remained a principal focus of Tang concern. The continual wars brought gains and losses to both sides. In 740, Tang recaptured the Anrong Fortress (in Sichuan). It was besieged by the Tibetans later in the year and attacked again the following year, but the Tibetans were driven off. ${ }^{127}$ In 741, when after the death of Princess Jincheng in 739 (or 740), the Tibetans sent in a request for a peace settlement, Xuanzong refused. ${ }^{128}$

The military expedition of 747 led by Gao Xianzhi, Vice ProtectorGeneral of Anxi, into the region west of the Pamirs not only resulted in Tang taking over control of Little Balur, which had formed a marriage alliance with Tibet in 740, thus enabling Tibet to subdue the nearby states, but also reenforced Tang influence in the regions west of the Pamirs. ${ }^{129}$ Despite the opposition of Wang Zhongsi, the Military Commissioner of Hexi and Longyou, Xuanzong insisted on recapturing Shibao, which had again been lost to Tibet in 741. After Wang was purged by Li Linfu in the power struggle at the Tang court, Xuanzong appointed Geshu Han Military Commissioner of Longyou. In 749 Geshu captured the strategic fortress, but his armies lost half their soldiers. ${ }^{130}$ The area of Jiuqu, handed over to Tibet in 711 as we have seen, was recovered in $753 .{ }^{131}$

\footnotetext{
Beckwith 1987, pp. 114-5.

XTS 215A, p. 6025.

${ }^{126}$ JTS 196A, pp. 5233-4; XTS 216A, p. 6086; ZZTJ 214, p. 6833.

ZZTJ 214, p. 6840; p. 6842; p. 6844.

${ }^{128}$ JTS 196A, p. 5235; XTS 216A, p. 6086; ZZTJ 214, p. 6843; Sato 1958, p. 478.

${ }^{129}$ Chavannes 1969, pp. 215-6; Beckwith 1987, p. 123.

${ }^{130}$ JTS 103, pp. 3199-200; ZZTJ 215, pp. 6878-9; p. 6896.

${ }^{131}$ For a summary of the events in this period, see Twitchett 1979, pp. 432-3.
} 


\section{From Supporting Nanzhao's Unification to Aggression against Nanzhao}

To deal with the Tibetan power, Tang encouraged the unification of the Nanzhao kingdom in Yunnan. From early Tang the Chinese had established jimi administration there, but from the 650's onward the border areas in Yunnan as well as Sichuan had been sites of contention between Tang and Tibet for the allegiance of that region's various non-Chinese peoples. ${ }^{132}$ The establishment of the Military Commissioner of Jiannan in 719 had the clear purpose of resisting the Tibetans in the west and pacifying the "barbarians" in the south. ${ }^{133}$ Under Xuanzong, the allegiance of the various non-Chinese peoples in Yunnan was an issue often discussed in the correspondence between Tang and Tibet. ${ }^{134}$

In 738, Xuanzong conferred the title of King of Yunnan on Piluoge of Nanzhao to encourage the existence of a buffer state between Tang and Tibet. The formation of the Nanzhao kingdom was a complex process in which both Tang and Tibet exerted influence, but it seems clear that at this time it was the positive support of China that ensured the consolidation of Nanzhao. ${ }^{135}$ In 738 the Military Commissioner of Jiannan led an attack on the Anrong Fortress, but failed to take it. Xuanzong, however, persisted, being encouraged by an officer in Jiannan who was made Military Commissioner and finally recaptured Anrong in $740 .^{136}$

Later, this well-thought-out policy was abandoned, due mainly to the power struggle at the court. An occasion for Chinese intervention was provided when, provoked by excessive demands and abusive treatment by the Governor (taishou) of Yunnan Commandery, the king of Nanzhao attacked and killed the governor and seized the commandery. In 751, despite the king's apologies and offers of amends, the Military Commissioner of Jiannan, Xianyu Zhongtong, made this a pretext for a major offensive against Nanzhao, pushing the latter into an alliance with the Tibetans.

Xianyu's aggression may not have been the result of his own decision. His patron, Yang Guozhong, then the dictator at the Tang court, was eager for military success to increase the prestige of the army in Sichuan, where his power base was, and thereby strengthen his position in the

\footnotetext{
${ }^{132}$ Wang Jilin 1976, pp. 125-37; Backus 1981, pp. 22-3.

${ }^{133}$ ZZTJ 212, p. $6738 ; 215$, p. 6850.

${ }^{134}$ Wang Jilin 1976, pp. 166-9.

${ }^{135}$ In his extensive study of the Nanzhao kingdom Backus (1981, chapter 3 ) discusses the rise of Nanzhao and the roles of Tang-Tibetan rivalry in the process.

${ }^{136 .}$ Wang Jilin 1976, pp. 169-72.
} 
power struggle vis-à-vis An Lushan. Xianyu suffered a severe defeat, but Yang Guozhong tried to cover it up and in the following year, having made himself the Military Commissioner of Jiannan, launched a further campaign against Nanzhao which ended in disaster. Wars continued during the next two years, in the course of which the Chinese continued to suffer great losses. ${ }^{137}$ Nanzhao became a vassal of the Tibetans, and together they menaced China's southwestern borders for the next forty years.

While Chinese conflicts with the Turkish peoples who dominated Mongolia during Tang were a continuation of an age-old problem, and the wars with Koguryǒ were also conditioned by traditional attitudes inherited from earlier times, the emergence of a strong military power based in the Tibetan highlands was unprecedented and also unrepeated in later centuries. It therefore presented new problems for Chinese foreign policy. The relatively self-sufficient economic structure of the Tibetan kingdom strengthened the country's independence and reduced the effectiveness of the traditional Chinese policy of using silk and other products to purchase peace from the nomads. Another important factor was the location of Tibet to the west of China and the geographic situation which placed it in contact with other literate civilizations, especially that of India; which, in contrast particularly with Korea, gave it an alternative source for cultural influences. This was no doubt one reason why the traditional Chinese use of political investiture to exert control over non-Chinese polities was ineffective in the case of Tibet.

While Tang gave political titles many times to the rulers of other non-Chinese peoples, nomadic or sedentary, throughout the history of Tang-Tibet relations the conferment of political titles only took place twice and only at the very beginning of the relationship: once in 641 to the Tibetan Chief Minister Ludongzan and once in 649 to the Tibetan btsanpo. Moreover, in contrast with the nomadic peoples, the Tibetans demonstrated their interest in occupation of territory, and were thus bound to clash with the Tang empire.

The frequent military encounters between Tang and Tibet began with competition over the land of the Tuyuhun, and then, after Tibetan occupation of the Tuyuhun lands in 670 , Tang had to cope with Tibetan in-

${ }^{137}$ Backus 1981, pp. 69-77. 
cursions across China's own northwestern frontiers. Tibet and Tang also competed for control over the Western Regions, each side trying to win over the Western Turks and the oasis states. One decisive success was China's recovery of the Four Garrisons in the Western Regions in 692, thus ensuring Chinese influence in that area until the mid-eighth century. To deal with the Tibetans' ambitions on its southwestern frontiers, Tang attempted to win the allegiance of the various non-Chinese peoples in Yunnan. In 738 Xuanzong recognized the king of Nanzhao to encourage the existence of a buffer state between Tang and Tibet, but Tang's aggression towards Nanzhao eventually pushed its king into the arms of Tibet.

Between military encounters, the two sides made efforts to establish peaceful relations. One Chinese policy that had some success was the sending of Chinese princesses to marry the Tibetan kings in 641 and 710 . Each marriage played an important role in maintaining some degree of peace. Sworn treaties were concluded in 706 and 732, but they meant different things to the two sides and were not very effective. While the Tibetans demanded an equal footing and reciprocity with Tang, the Chinese insisted on acceptance of their claims of superiority. Xuanzong refused to sign his name on any treaty, and from China's own point of view the Chinese sworn treaty text of 732 was rather a declaration of incorporation. Moreover, each treaty was violated first by the Chinese. The prevailing idea was that Confucian norms could be applied only to insiders and not to outsiders, the non-Chinese. The changed situation during the second half of the dynasty, when China was riven by civil war and on the defensive, is discussed in Chapter 10. 


\section{Chapter 8}

\section{China, the Second Turkish Empire and the Western Turks, 679-755}

Even as the Tang royal power was passing into the hands of Empress Wu and her family, as always, internal political dissension in China provided the opportunity for nomadic power to reemerge in Mongolia. In this chapter we will examine Chinese relations with the revived Eastern Turkish power, known as the second Turkish empire (682-745), as well as with the Khitan and $\mathrm{Xi}$ on their eastern flank, and with the Türgish, who became the leading force among the Western Turks. A new factor in the far west were the Arabs, who first made their appearance in Central Asia during this period. Other complicating factors that weakened China's ability to respond were the exhausting campaigns in Korea (Chapter 6) and the emergence of Tibet as a major power (Chapter 7).

\section{The Restoration of the Second Turkish Empire}

In 679, the Eastern Turks, then under Chinese sovereignty, began a movement to restore their independent power. Chieftains subject to the Grand Protectorate of Chanyu revolted and set up a descendant of the royal Ashina clan as qaghan. Almost all the Eastern Turks who had formerly submitted joined in and the jimi fuzhou administrative structure quickly broke down. The court under Empress Wu acted immediately by despatching troops to put down the rebellion. However, after initial successes the Chinese general became overconfident and suffered a serious defeat .

The following year, another Chinese general, Pei Xingjian, inflicted a major defeat on the Turks, who put to death their newly created qaghan and offered his head as a sign of their submission. They were not yet ready to return to their subject status, however, and in 681 they set up another scion of the royal clan, Ashina Funian as qaghan. Pei Xingjian succeeded in persuading Funian to surrender with the promise that he would not be punished. In the court, however, Chief Minister Pei Yan, who was jealous of Pei Xingjian's military merit, insisted that Funian be executed. The fact that Funian and other Turkish chiefs lost their lives as a 
result of Chinese court politics, ${ }^{1}$ led to even stronger anti-Chinese sentiment, and the following year saw yet more forceful military attacks on the Tang frontiers led by the new Turkish qaghan Guduolu (Qutlugh). It is generally considered that the second Turkish empire began in 682, when Qutlugh became the qaghan.

As in the Former Han dynasty, when the resettlement of the Southern Xiongnu eventually helped restore the nomadic power, the Turks who had been brought under the Tang jimi administration were able to recover their strength. Chinese control over such people was inherently vulnerable because it was sustained by only a small number of troops and depended mainly on the willingness or cooperation of the non-Chinese themselves. Under the jimi system, the Turks had kept their customs, their military organization and their own cultural identity. The period from 630 to the revival of the Turkish empire in 682 was considered by the Turks as a time of national subjugation and humiliation. The Turkish inscriptions present the perspective of the Turks on their relations with China all too clearly:

Since the lords and peoples were not in accord, and the Chinese people were wily and deceitful, since they were tricky and created a rift between younger and elder brothers, and caused the lords and peoples to slander one another, the Turkish people caused the state which they had established to go to ruin, and their kagan (= qaghan), whom they had crowned, collapse. Their sons, worthy of becoming lords, became slaves, and their daughters, worthy of becoming ladies, became servants to the Chinese people. The Turkish lords abandoned their Turkish titles. Those lords who were in China held the Chinese titles and obeyed the Chinese emperor and gave their services to him for fifty years. For the benefit of the Chinese, they went on campaigns up to (the land of) the Bükli kagan in the east, where the sun rises, and as far as the Iron Gate in the west. For the benefit of the Chinese emperor they conquered countries. $^{2}$

The inscriptions also describe the ways in which the Chinese lured the Turks into acceptance of at least loose control by the Chinese: the Chinese gave the Turks gold, silver and silk in abundance so as to cause them to come close to China's borders. Once the Turks settled close in, the Chinese treated them harshly. Some Turks were deceived by being told that if

\footnotetext{
${ }^{1}$ JTS 84, p. 2804; XTS 108, p. 4088; ZZTJ 202, pp. 6404-5.

2 "The Kül Tigin Inscription." See Tekin 1968, translation, p. 264. His translation, slightly modified, is used here.
} 
a people lived far away, the Chinese gave them cheap goods, but if a people lived close to them, then the Chinese gave them valuable goods, and so they moved close to the Chinese. Subsequently they were killed in great numbers. ${ }^{3}$

The ineffectiveness of settlement policy was pointed out by some Tang Chinese. In his memorial in about 696, Xue Qianguang, a remonstrance official, pointed out that it was for the sake of an empty name with no substance behind it that Chinese rulers had adopted the practice of letting non-Chinese settle close to China. He also opposed the practice of accepting the non-Chinese into the Tang court as hostages on the grounds that the non-Chinese thereby gained strategic geographical information and intelligence about how the Chinese frontiers were guarded. Even when non-Chinese were nominally given Chinese official titles of general, there were few among them who did not make incursions into Chinese territory. He suggested that China should refuse permission for any additional nonChinese to come to the court and not allow those already in China to return home. His opinion, however, was not given much notice. ${ }^{4}$

Liu Kuang, an official historian in Xuanzong's time and the eldest son of the famous historian Liu Zhiji, was sharply critical of the resettlement of non-Chinese inside China. He summed up succinctly the sad dilemma the policy caused: when the "barbarians" were strong, China exhausted its manpower in attacking them. When they became submissive China suffered the expense of nourishing them. The Chinese had been put to work in this fashion by the "barbarians" for thousands of years. ${ }^{5}$ Liu Kuang accurately captured the essence of both the "outer frontier" and "inner frontier" strategies of the nomads. Though the Chinese aimed to use the submitted nomads as a military force to keep peace on the borders and reinforce the legitimacy of the Son of Heaven, in actual fact the Chinese government was not strong enough to effectively control them. Once an opportunity presented itself, the nomads would again rebel. This was the state of affairs that led to the breakdown during Empress Wu's reign of the jimi system controlling the Turks.

\footnotetext{
3 “The Kül Tigin Inscription." See Tekin 1968, translation, pp. 261-2.

${ }^{4}$ TD 200, pp. 1085-6; CFYG 544, p. 6522. Cen Zhongmian (1958, pp. 337-8) is of the opinion that Xue presented his memorial in 697.

${ }^{5}$ TD 200, pp. 1086-7; XTS 215A, pp. 6023-4.
} 


\section{Empress Wu: Compromise for Peace}

Until his death in 691, the Turkish Qutlugh Qaghan waged a series of battles against the Khitan and Tiele, succeeded in driving the Uighurs away from the Ötükän Mountains and in setting up his headquarters there. The Turkish inscriptions record these military campaigns and the Turkish efforts to reestablish and consolidate the second empire. ${ }^{6}$ He also launched constant attacks on the Chinese frontier. In 683, so intense was his attack on Fengzhou that the court considered abolishing the prefecture in order to concentrate on the defense of Lingzhou and Xiazhou. Tang Xiujing, Adjutant ( $\operatorname{sim} a)$ of Fengzhou, expressed strong opposition to this in a memorial, arguing that abandoning Fengzhou would actually open up China even wider to nomadic incursions. The court agreed with him. ${ }^{7}$

In the competition between China and the Turks, the various tribes of the Tiele people followed different strategies for self-protection, some being pro-Turk, others pro-Tang, and thereby influenced the balance of power. In $686,{ }^{8}$ the Buqu and Tongra of the Tiele north of the Gobi rose in revolt against Tang. Tang despatched troops from both Hexi and Western Turks under the Protectorate of Jinshan in the Western Regions and inflicted a crushing defeat on them. The Western Turks, however, also attacked the Uighurs, thus causing chaos in the region.

The court brought those Tiele who submitted under the supervision of the Protectorate of Anbei, the seat of which was then moved to Tongcheng south of the Gobi, but as punishment for their attacks on the Uighurs it refused the request of the Western Turkish chiefs to come to the Tang court. The Tiele, as a whole, were in a weak position. Chen Zi'ang, then a low ranking clerk under the Army Supervisor (jianjun) of the Hexi troops, presented a memorial on behalf of the Army Supervisor urging the court to attract the Tiele people and to accept the Western Turkish chiefs' request. $^{9}$

While no specific measures were taken by Empress Wu with regard to the Tiele, around 685 she appointed the son of Ashina Mishe and

\footnotetext{
${ }^{6}$ See the translations of the "Kül Tigin inscription," the "Bilga Kagan inscription" and the "Tonyukuk inscription" in Tekin 1968, pp. 261-90. See also Ma Changshou 1957, p. 66.

${ }^{7}$ JTS 93, p. 2978; XTS 111, p. 4149; ZZTJ 203, p. 6414.

${ }^{8}$ ZZTJ (203, p. 6435) states that the rebellion occurred in 685 , but Cen Zhongmian's study shows it should be dated 686. See Cen 1958, p. 312 .

${ }^{9}$ Chen Boyu Wenji 4, pp. 32-4; 8, 8, pp. 73-5; ZZTJ 203, p. 6435; Cen Zhongmian 1958, pp. 310-20; Xue Zongzheng 1992, pp. 458-61.
} 
the son of Ashina Buzhen of the Western Turks to succeed to their father's titles of qaghan and Protectors-General in order to maintain some control by the Ashina clan over the scattered Western Turks. Both Mishe and Buzhen had attached themselves to Tang during Taizong'sreign, and had been appointed qaghan and Protectors-general by Gaozong. The titles were later passed on to their sons. ${ }^{10}$

While Empress Wu tried to suppress the revival of the Eastern Turks, she had other preoccupations internally. Having assumed power as Empress Dowager in 684, she was faced with the immediate task of consolidating her own position in the face of a revolt against her by supporters of the Li royal house. Cheng Wuting, an excellent general in charge of Turkish military affairs, was accused of involvement with the anti-Wu group and was executed. The Turks were overjoyed. ${ }^{11}$ In 688 another short-lived revolt staged by Tang princes challenged Wu's rule. Empress $\mathrm{Wu}$, however, prevailed and proclaimed herself emperor of the Zhou dynasty in 690 .

Her assumption of the rulership and the death of Qutlugh in 691 made possible restoration of peace between China and the Turks. ${ }^{12}$ The new qaghan, Mochuo (Bäg Chor), the younger brother of Qutlugh, in 695 despatched an embassy to China to ask, in the Chinese wording, to "surrender." Empress Wu responded by conferring the title of general and duke on Bäg Chor Qaghan. ${ }^{13}$ The actual relationship, however, was obviously between two essentially equal adversaries (diguo). ${ }^{14}$

Between 696 and 697, the Khitan, who had been brought under the jimi system in 648, broke away from China, provoked by ill treatment from the Chinese Area Commander of Yingzhou. With Yingzhou as their base, they launched an invasion, pressing southward to the present Beijing area and into the Hebei region. ${ }^{15}$ Bäg Chor Qaghan volunteered to attack the Khitan on the condition that China send a prince to marry his daughter, and return the Turks who had formerly surrendered and had been resettled in the Hexi area. Obviously, he had his own agenda: to win back his for-

\footnotetext{
${ }^{10}$ JTS 194B, pp. 5188-90; XTS 215B, pp. 6064-6; Ise 1968, pp. 258-9.

11 JTS 83, p. 2785 ; XTS 111 , pp. 4147-8; ZZTJ 203, pp. 6432-3.

12 For details concerning the uprising and battles and the date of Guduolu's death, see Cen Zhongmian 1958, pp. 289-307; 8, pp. 308-25; TD 198, p. 1073; JTS 194A, pp. 5166-8; XTS 215A, pp. 6042-5.

${ }^{13}$ JTS 194A, p. 5168; ZZTJ 205, p. 6503.

${ }^{14}$ Mori Masao 1967, pp. 188-9; 1978, p. 119.

${ }^{15}$ JTS 199B, pp. 5350-1; XTS 219, pp. 6168-70; ZZTJ 205, 206.
} 
mer subjects.

Empress $\mathrm{Wu}$ had to compromise with the Turks so that China could concentrate its forces against the Khitan. She conferred the title of qaghan on Bäg Chor. ${ }^{16}$ This recognized the independent power of the Turks, even though the Chinese wording defined the Turks as subjects. In 697 Empress Wu sent two envoys, Yan Zhiwei and Tian Guidao, on a mission to the Turks. It is interesting to see how the two envoys' differing attitudes towards the Turks showed the vacillation of the Chinese in their treatment of their newly revived enemy. While Yan Zhiwei, at Bäg Chor's headquarters, performed a ritual dance before Bäg Chor, which etiquette prescribed as due only to an emperor, and went so far as to kiss the tip of Bäg Chor's boot, Tian Guidao, on the other hand, still believed that the Turks should be subject. He did not kowtow to Bäg Chor Qaghan and instead only made a respectful bow. Bäg Chor was furious and imprisoned Tian. He was even going to kill him, and was only dissuaded from doing so by his ministers.

After attacking the Khitan, Bäg Chor in 697 made further requests: 1) that he send his daughter to marry a Chinese prince; 2) that China return the surrendered Turks who had settled inside six prefectures, and also return the land under the Protectorate of Chanyu; ${ }^{18} 3$ ) that China provide farming tools, seed-grain and iron to the Turks. At the Chinese court a bellicose response was proposed by some, while others argued in favor of making an agreement because the Khitan were still a major force to contend with on the frontier.

Empress Wu decided to accommodate Bäg Chor's requests. The court moved several thousand households of non-Chinese back to the steppe, provided 40,000 hu of seed grain, 50,000 duan of silks, 3,000 farm

${ }^{16}$ JTS 194A, pp. 5168-9; XTS 215A, p. 6045; ZZTJ 205, pp. 6509-10; CFYG 964, p. 11341.

${ }_{17}^{17}$ JTS 185A, pp. 4794-5; XTS 197, p. 5624; ZZTJ 206, p. 6515.

${ }^{18}$ There is ambiguity about which six prefectures Bäg Chor demanded. According to the "Biography of Tian Guidao" (JTS 185A, p. 4794; XTS 197, p. 5624), he requested the six $\mathrm{Hu}$ prefectures, which, as Pulleyblank concludes, refer to the prefectures of $\mathrm{Lu}, \mathrm{Li}, \mathrm{Han}$, Sai, Yi and Qi. See Pulleyblank 1952, p. 330, note 1, and Cen Zhongmian 1964, pp. 1234. Another opinion is that the six refer to the prefectures of Feng, Sheng, Ling, Xia, Shuo and Dai. See TD 198, p. 1073; JTS 194A, pp. 5168-9; XTS 215A, p. 6045; ZZTJ 206, p. 6516; THY 94, p. 1691; Zhang Qun 1955, pp. 275-9; Hou Linbo 1976, pp. 24-7. Zhang Qun (1955, pp. 327-8) also holds that the six prefectures were under the supervision of the Protectorate of Chanyu. 
tools, 40,000 jin of iron and agreed to conclude a marriage contract. ${ }^{19}$ After this agreement was decided upon by China, Tian Guidao came back to court where he and Yan Zhiwei argued again concerning the proper policy to be pursued in the future. Tian held that the Turks would not abide by any peace agreement and proposed a build-up of the frontier defenses, whereas Yan believed that the agreement would ensure peace. ${ }^{20}$

In 697, Bäg Chor brought the Khitan into submission. He had by then firmly reestablished the second Turkish empire. He made more demands which Empress Wu had to satisfy. In 698, Bäg Chor again requested a marriage between his daughter and a Chinese prince, an arrangement which would give the Turks an equal, if not higher, position by virtue of Bäg Chor's becoming the father-in-law of a Chinese prince. Disregarding a remonstrance that no Chinese prince had ever married a "barbarian woman" before, ${ }^{21}$ Empress Wu decided to send her grandnephew, Wu Yanxiu, to the Turks to receive the lady, accompanied by Yan Zhiwei.

But Bäg Chor refused to recognize Wu Yanxiu as a member of the family of the Son of Heaven. He openly showed his contempt for the Wu family and proclaimed his intention to help reestablish the Li house of the Tang dynasty. He further accused the Chinese of providing boiled seed grain, gold and silver utensils of bad quality, silk textiles which were loosely woven, and of taking away the Chinese official dress which Bäg Chor had given to his ministers. He detained Wu Yanxiu, established Yan Zhiwei as qaghan of the southern front, and launched attacks on the Chinese frontier armies and the Hebei area in the fall of $698 .^{22}$

Empress $\mathrm{Wu}$ decided to react with force. Expeditionary armies were organized under the command of her grandnephew Wu Chonggui. The Chinese sources say that the number of the recruits was no more than a thousand in a month, but when the Empress finally made the Tang prince Li Xian Heir Apparent and supreme commander of the expedition army in place of $\mathrm{Wu}$ Chonggui, people enthusiastically volunteered and before

19 JTS 194A, pp. 5168-9; XTS 215A, p. 6045; ZZTJ 206, p. 6516.

${ }^{20}$ ZZTJ 206, p. 6516.

${ }^{21} J T S 91$, p. 2939 ; XTS 120 , p. 4321 ; ZZTJ 206, p. 6530 . The version in the XTS that no Son of Heaven ever married a "barbarian" woman is probably wrong. The Zhou king married a non-Chinese. Also, in this case it was not the emperor but a prince for whom the Turks proposed a marriage.

22 JTS 194A, pp. 5169-70; XTS 215A, pp. 6045-7; ZZTJ 206, pp. 6530-1; THY 94, pp. 1691-2. 
long 50,000 men had joined the army. The Turks retreated. ${ }^{23}$ Whether this is an exaggeration on the part of the Chinese historians is not clear, but this is not the only instance mentioned concerning the legitimacy of Empress $\mathrm{Wu}$ and the problem of succession. When the Khitan invaded, their leader sent a protest to the court asking the return of the Tang prince to the position as heir. ${ }^{24}$ As we have seen, the Turks also challenged the legitimacy of the Wu family. All this may eventually have contributed to Wu's resignation from the throne.

After raids on the northwest in 700, 701, and 702 Bäg Chor in 703 again asked to marry his daughter to a son of the Crown Prince. This time Empress Wu presented two princes from the Li house for the Turks to choose from. The Turks then sent Wu Yanxiu back the following year. ${ }^{25}$ The marriage did not, however, materialize. It was at this time that Tang, the Western Turks and the Kirghiz, a more northerly Turkish speaking people located on the upper Yenesei river, planned to join forces for an attack on the Eastern Turks. ${ }^{26}$

One severe consequence of the Turkish breakaway from the Tang jimi system was that Tang could no longer use these nomads for frontier defense. Not only did the Chinese have to use more of their own forces, but they also had to reinforce the frontiers against formerly submissive nomads like the Turks. Since these nomads were now familiar with the frontier areas, their incursions could be more effective. Faced with such a situation, Tang had to change to a more defensive policy based on the strengthening of frontier defenses. Before the end of Empress Wu's reign in 705 more armies were set up on the northeastern and northern frontiers to form the basic defense line. ${ }^{27}$

\section{Zhongzong: Building of the Three Shouxiang Fortresses and Alliance with the Türgish}

With the abdication in 705 of Empress $\mathrm{Wu}$, the Li royal family restored the name of the Tang dynasty. In 706, after a Turkish incursion, the

\footnotetext{
${ }^{23}$ ZZTJ 206, pp. 6533-5. See also Guisso 1978, pp. 145-6.

${ }^{24}$ ZZTJ 206, p. 6526.

${ }^{25}$ XTS 215A, p. 6047 ; ZZTJ 207, p. 6553; p. 6556; pp. 6558-9; p. 6562; p. 6573; CFYG 979 , p. 11498 . According to Cen Zhongmian 1958, p. 546, the two princes were Chongfu and Chongjun; Ma Changshou 1957, p. 69.

${ }^{26}$ The Chinese sources do not mention this event. The above narrative is from the Turkish inscription. See Ma Changshou 1957, p. 69; Tekin 1968, translation, pp. 285-6.

${ }^{27}$ For the locations, names and dates of these armies, see Pulleyblank 1955, Map II.
} 
restored Emperor Zhongzong took a firmer stand against the Turks. $\mathrm{He}$ broke off the marriage agreement made by Empress Wu and promised to reward anyone who could kill Bäg Chor with the high rank of General-inChief. $^{28}$

When Zhongzong asked his ministers to present advice as to how to deal with this formidable enemy, a remonstrance official suggested as a defense policy that generals should be disciplined, armies should be drilled and put into readiness, alliances should be made with other non-Chinese against the Turks, people to be settled in frontier areas should be organized as permanent troops, and capable officials should be selected to govern the frontiers. Eventually, Tang could mobilize all its forces to crush the barbarians. $^{29}$

In 708 Zhang Renyuan, Area Commander of Shuofang, proposed that Tang build three fortresses north of or close to the great loop of the Yellow River while the Eastern Turks were on campaign against the Türgish of the Western Turks in the Western Region. Chief Minister Tang Xiujing opposed this on the grounds that to build these fortresses on enemy territory would be a great waste. Zhongzong nevertheless decided to follow Zhang's suggestion. These heavily manned fortresses known as the "Fortresses for Receiving Surrender" (Shouxiang cheng), stretched from Shengzhou to Fengzhou, each occupying a strategic position. They were designed to prevent the Turks from invading southward. Troops in the garrison at Shuofang were significantly reduced in number. Zhang was promoted to the status of Chief Minister, returned to the court in spring, and in autumn went to the frontier to carry out his duties there. ${ }^{30}$

Zhongzong also attempted to make an alliance with the Western Turks. From about 699, the Türgish tribe of the Western Turks, who in 658 had been organized into the area command system, became strong under their leader Wuzhile, while the royal Ashina clan declined. Wuzhile managed to bring under his control all the Western Turks in the region between the Issyk-Kul and Lake Balkash. He captured Suiye, one of the Four Garrisons, in about 703 and moved his headquarters there. The Türgish cooperated with the Tibetans as early as 704 in supporting the city

\footnotetext{
28 JTS 194A, p. 5170; XTS 215A, p. 6047.

${ }^{29}$ JTS 194A, pp. 5170-2; ZZTJ 208, p. 6609.

${ }^{30}$ JTS 93 , pp. $2982-3$; 194A, p. $5172 ;$ XTS 111, pp. $4152-3 ; 215$ A, p. 6047 ; ZZTJ 209, pp. 6620-1. For the significance of the three fortresses, see Kang Le 1979, pp. 81-6.
} 
states of Transoxiana against the Arabs. ${ }^{31}$ In 706 Zhongzong conferred the title of commandery prince on Wuzhile and on his death Tang granted official titles to his son Suoge. His rule, however, was opposed by one of his generals, Ashina Zhongjie.

There was a conflict of opinion at the Tang court as to how to deal with the split. Guo Yuanzhen, Acting Protector-General of Anxi, proposed to support Suoge and remove Zhongjie by recruiting the latter into the Imperial Guard and moving his tribes closer to China. This was approved by the emperor, but on the advice of the Chinese Military Commissioner of the Four Garrisons (sizhen jinglue shi), Zhou Yiti, Zhongjie bribed the Minister of War, Zong Chuke and Chief Minister Ji Chu'na, who then put forward a proposal based on Zhou Yiti's advice to support Zhongjie against Suoge. They wanted to eliminate Suoge by using the troops of the Protectorate of Anxi. They also wanted to seek assistance from Tibet, and to establish a member of the Ashina royal clan to be the qaghan of the Western Turks.

Guo Yuanzhen strongly objected to all this on the grounds that seeking Tibetan assistance would surely lead to Tibetan control over the Western Turks and that previous experience had proved that the Ashina clan was no longer able to control the Western Turks. Zhongzong, however, agreed with Zong Chuke.

When Suoge heard of this plan, he despatched 20,000 cavalry and captured the seat of the Protectorate of Anxi in Kucha. He assumed the title of qaghan in 708. The following year, Zhongzong finally had to adopt Guo Yuanzhen's advice to make peace with Suoge and recognize him as qaghan of the Western Turks. This nominally returned the Tarim Basin to Chinese control. ${ }^{32}$

With the Türgish on the side of Tang, Zhongzong in 710 decided to launch a major attack on the Eastern Turks. The Türgish under Suoge (now bearing the Chinese name Shouzhong) sent 250,000 cavalrymen to join Tang's military campaign, ${ }^{33}$ but the campaign had to be stopped when Zhongzong died and a power struggle began at court in the same year. Soon, Suoge's younger brother rebelled and led the Eastern Turks against Suoge. The Eastern Turks extended their rule into the Türgish territory and

\footnotetext{
${ }^{31}$ Chavannes 1969 , p. 55; p. 64; Beckwith 1987, pp. 66-7.

${ }^{32}$ JTS 92 , p. 2972 ; 97 , pp. $3045-8$; 194B pp. $5190-1$; XTS 109 , p. 4102 ; 122 , pp. $4363-5$; 215B, pp. 6066-7; ZZTJ 209, pp. 6625-9.

${ }^{33}$ TDZLJ 130, p. 705; QTW 253, pp. 1131-2.
} 
the nearby city states, which in turn led to encounters between the Eastern Turks and the Arabs. They had to retreat from the region after a defeat inflicted by the Chinese Protector-General of Beiting in 714. Bäg Chor lost his son in this expedition. ${ }^{34}$

\section{Xuanzong: Bäg Chor's Final defeat, 712-716}

When Xuanzong assumed the throne in 712 , the Eastern Turkish empire, under attack from the west, was in a weakened position. In 711 Bäg Chor Qaghan had asked for a marriage contract. Although Tang agreed, no marriage materialized because this was when Ruizong abdicated the throne to Xuanzong. ${ }^{35}$ In 713 , after Xuanzong had consolidated his power by eliminating the most important of his rivals, Princess Taiping, he again agreed to Bäg Chor Qaghan's request for a marriage. ${ }^{36}$ But in 714, Bäg Chor's troops and Tang clashed in Beiting (see above) as a consequence of which in the third month of the same year Xuanzong ordered the preparation of a major campaign under the command of Chief Minister Yao Chong against the Turks. ${ }^{37}$ Bäg Chor twice asked for a marriage. Xuanzong agreed to send a princess the following year. In exchange, he requested the qaghan to send a prince to join the Imperial Bodyguard. ${ }^{38}$

The decision for peace instead of war was made in the first place due to the reluctance of Yao Chong to use force. ${ }^{39}$ During the early part of Xuanzong's reign, from 712 to 720, Chief Ministers Yao Chong and Song Jing, who were largely responsible for decision-making, urged caution in foreign policy. To refrain from any aggression was a policy specially laid down by Yao Chong, who had already been a capable Chief Minister under Empress Wu. In 713, when Xuanzong invited Yao Chong to be his Chief Minister, Yao is said to have insisted that he would not accept the position unless his ten-point program was also accepted by the emperor. The second point was to refrain from aggressive moves on the frontiers for thirty years. Xuanzong agreed to all ten points. ${ }^{40}$

The peace policy was complicated by frontier pressures on other

\footnotetext{
34 JTS 103 , pp. $3187-8$; 194A, p. 5172 ; XTS 133, p. 4543; 215A, pp. 6047-8; ZZTJ 211, p. 6696; Beckwith 1987, pp. 76-80.

${ }_{35}$ ZZTJ 210, p. 6661; p. 6664; p. 6669; 6671.

${ }^{36}$ XTS 215A, pp. 6047-8; ZZTJ 210, p. 6686; 211 , p. $6699 ;$ p. 6706.

${ }^{37}$ QTW 253, pp. 1132-3; Cen Zhongmian 1958, pp. 384-5.

${ }^{38}$ ZZTJ 211, p. 6699; p. 6706; CFYG 979, p. 11499.

${ }^{39}$ Xue Zongzheng 1992, p. 512.

${ }^{40}$ ZZTJ 210, pp. 6688-9; Twitchett 1979, p. 348.
} 
fronts. In the northeast Tang was attempting to subdue the Khitan and $\mathrm{Xi}$ in Manchuria, and these two peoples had attached themselves to the second Turkish empire after 697. In 712, the Area Commander of Youzhou launched an attack on the Khitan and $\mathrm{Xi}$ in order to win back Yingzhou, but lost his life in the attempt. ${ }^{41}$ In 714 Xue Na, Aide of the Area Command of Bingzhou, whose father was the famed General Xue Rengui, proposed a follow-up attack on the Khitan and $\mathrm{Xi}$, arguing the importance of recapturing Yingzhou so as to detach them from the Turks.

Although Chief Minister Yao Chong and others opposed military action, Xuanzong sided with Xue Na. He promoted Xue to the status of Chief Minister and entrusted him with command of the expedition. This consequently made "the officials not dare to say anything" as the Chinese sources put it. But this campaign was unsuccessful too. Xue $\mathrm{Na}$ was stripped of all his posts as punishment, although he was soon employed in a campaign against the Tibetans and promoted to the rank of general after winning a victory. ${ }^{42}$

Later in the same year, 100,000 Tibetan troops attacked the northwestern frontier. Tang had to concentrate its military forces there, and Xuanzong even declared his intention of assuming personal command of a major campaign against the Tibetans with over 100,000 troops, including 20,000 non-Chinese. Before that plan could be carried out, Chinese troops claimed major victories in battles with Tibet. ${ }^{43}$

As Bäg Chor got older, his rule became more tyrannical and he taxed his people more heavily. His request for a marriage alliance showed the weakening of his power. In 714 and 715, members of the Eastern Turkish ruling group, the Western Turks and the Tiele left him to submit to Tang. Xuanzong conferred Chinese noble and official titles on the tribal leaders, along with houses and income from tax revenue, and resettled some Turks south of the great loop of the Yellow River. ${ }^{44}$ When Bäg Chor engaged in a series of battles against Western Turkish tribes, the Tang Protector-General of Beiting in 715 sent troops to support the anti-qaghan force. ${ }^{45}$ In $715-716$, seeing the decline of Turkish rule, both the Khitan and

\footnotetext{
${ }^{41}$ ZZTJ 210, pp. 6672-3.

${ }^{42}$ JTS 93, pp. 2984-5; XTS 111, pp. 4143-4; 199B, p. 5355; ZZTJ 211, p. 6695.

43 JTS 196A, p. 5228; XTS 216A, p. 6081-2; ZZTJ 211, pp. 6704-6; CFYG 118, p. 1407.

${ }^{44}$ Cen Zhongmian 1958, pp. 380-92.

${ }^{45}$ XTS 215A, pp. 6048-9; ZZTJ211, p. 6710.
} 
Xi left the Turks and went over to Tang. ${ }^{46}$

Early in 716, Xuanzong ordered a major campaign against the Turks. The edict stated that the Nine Surnames of the Tiele had despatched envoys several times to express their wish to throw off Turkish rule and to become vanguards in the attack on the Turks, and it ordered the Chinese troops to cooperate with the Nine Surnames. ${ }^{47}$ Eventually, the Bayegu (Bayïrqu) of the Tiele killed Bäg Chor Qaghan and sent his head to the Tang capital. Those Uighur and other Tiele tribes who had previously been under the Turks came to submit to Tang and were settled north of the Dawu Army (north of Daizhou). ${ }^{48}$ In the battles against Bäg Chor, Chinese troops collaborated with the frontier peoples. A frontier general inflicted a crucial defeat on the Turks. Chief Minister Song Jing did not, however, promote him for fear that such a reward would stimulate the court to push for further expansive efforts. ${ }^{49}$

\section{Continuation of the Settlement Policy}

Xuanzong continued the established policy of resettling the surrendered nomads along the frontier. But unlike the time of Taizong and Gaozong, when the Turks had ceased to have a state power of their own outside China, now there existed the Second Turkish empire ruled by Bilgä Qaghan (r. 716-734). Assisted by a capable adviser, Dunyugu (Tonyuquq), Bilgä strengthened his regime, which began to have success in winning back his former subjects. ${ }^{50}$

In view of this situation, Wang Jun, Administrator of the Area Command of Bingzhou (Chief Minister in 723-724), warned in a memorial in 716 that the many Turks settled in the frontier regions were bound to cause trouble since they could provide intelligence for Bilgä Qaghan and cooperate with his forces in attacking Tang. It was a bad policy, he believed, to keep large numbers of mixed Chinese and non-Chinese troops on the frontiers for defense. He suggest that the court move the nomads

\footnotetext{
${ }^{46}$ ZZTJ 211, p. 6720 ; p. 6727 ; Twitchett 1979 , p. 367 . The date of the Khitan coming over to Tang is confusing in the Chinese sources. According to Cen Zhongmian (1958, pp. 393-4), it should be placed in 715 .

${ }^{47}$ QTW 253, p. 1133; Cen Zhongmian 1958, 395.

${ }^{48}$ For sources on this period, see Cen Zhongmian 1958, pp. 396-8. The Chinese sources give different accounts about who killed Bäg Chor. I follow Cen Zhongmian's conclusion in 1958, p. 398.

49 JTS 147, p. $3980 ;$ XTS 124, p. 4394.

${ }^{50}$ JTS 194A, pp. 5173-4; XTS 215A, p. 6049; 215B, p. 6051; ZZTJ 211, pp. 6719-20.
} 
farther south to Henan and Huainan. Xuanzong did not heed his advice. ${ }^{51}$

Wang Jun's warning of disaster soon proved to be well founded. In the winter of 716, two Tiele chieftains who had gone over to Tang rose in revolt. The immediate cause of their rebellion was that the Vice ProtectorGeneral of Chanyu, Zhang Zhiyun, had confiscated all their weapons when they came to submit. After complaining to the Patrolling Inspector that they needed the weapons for hunting, the Chinese returned their weapons, but soon afterwards they rebelled and captured Zhang Zhiyun. Tang fought with the tribesmen and rescued Zhang, who was then executed by the court. The tribesmen, however, were not appeased, and went over to Bilgä Qaghan. ${ }^{52}$

In his edict, Xuanzong blamed Zhang for improper management of non-Chinese affairs, and stressed that local officials must show great concern for resettled non-Chinese. ${ }^{53}$ Taking the words of the edict at face value, the court seems to have believed that so long as the local government was benevolent the settlement policy could be carried out effectively. However, it was a difficult job for the local officials to control the nonChinese who settled on the frontiers. Zhang Zhiyun's intent in taking away the weapons of the submitted nomads must have been to lessen the potential danger they might pose to the Chinese, to make them docile and induce them to take up agriculture as peaceful settlers. Obviously, such a measure would have encountered resistance from the nomads.

In 720 when the Xietie (Ädiz) and Buqu tribes who had settled near Shouxiang Fortress were about to rise in rebellion with the assistance of the Turks outside the frontiers, the Chinese learned of their intention and killed almost 800 of them. The massacre aroused great fear and suspicion in the Tongra and Bayïrqu tribes, and the Commissioner-in-chief of Tianbing (Tianbing jiedu dashi) had to go in person to console them so as to avoid further troubles. ${ }^{54}$ A year later, the Sogdian people who had settled in the former six $\mathrm{Hu}$ prefectures in the Ordos also rose in revolt. It took a year for Tang to suppress their rebellion. The remnants of the nonChinese, about 50,000 of them altogether, were then moved into the interior. ${ }^{55}$ Later, however, in 738 the court set up Youzhou in the former six

${ }^{51}$ JTS 93, pp. 2986-8; XTS 111, pp. 4154-5; ZZTJ 211, pp. 6720-1.

52 JTS 194A, pp. 5173-4; XTS 215A, p. 6051; ZZTJ 211, pp. 6721-2.

${ }_{54}^{53}$ QTW 27, p. 368.

${ }^{54}$ JTS 93, p. 2988 ; 97 , p. 3052 ; XTS 111, pp. $4155-6 ; 125$, p. 4407 ; ZZTJ 212, pp. $6740-$ 1.

${ }^{55}$ ZZTJ 212, p. 6745; pp. 6746-7; p. 6752. 
$\mathrm{Hu}$ prefectures in a move to encourage non-Chinese to relocate there and move from inside China. ${ }^{56}$

\section{Peace with The Eastern Turks, 717-740}

While Bilgä Qaghan attempted to attract the Turks who had submitted to Tang back under his control by both peaceful means and military measures, ${ }^{57}$ he himself chose to make peace with China so as to obtain Chinese material goods through diplomatic means. He sent envoys to Tang in 717 , and again in 718 . Xuanzong responded positively to the peace proposal of $718 .^{58}$ But the Tang court planned a major campaign against the Eastern Turks in 719 or 720 to be joined by the Basmïl, Kirghiz, Khitan, $\mathrm{Xi}$ and the Nine Surnames of the Tiele. There were, however, no coordinated attacks on the Turks. Only the Basmil tribe launched an actual attack, and they were defeated by Bilgä Qaghan. ${ }^{59}$ After leading one raid on the frontiers, Bilgä Qaghan sued for peace again in $721 .^{60} \mathrm{He}$ proposed to establish a father-son relationship with Tang and form a marriage alliance. In response, Xuanzong sent a letter to him recalling the days when Tang and the Turks had been at peace, and when both had benefited from the bilateral trade exchanging Turkish horses for Chinese silk. As for the father-son relationship, it was set up in name, but no marriage was arranged. $^{61}$

Use of kinship terms to describe Chinese relations with their nonChinese neighbors was quite common. Han and the Xiongnu were sometimes characterized as elder and younger brothers; Tang and Tibet were viewed as uncle and nephew; the relationship of father-in-law and son-inlaw in marriage alliances and father-son sometimes characterized the relationship between Tang and the Turks. These ties "functioned in the international field on the basis of a tacitly accepted principle of equality,"62 for

\footnotetext{
${ }^{56}$ Details see Cen Zhongmian 1958, pp. 453-6.

${ }^{57} \mathrm{Ma}$ Changshou 1957, pp. 80-1.

${ }^{58}$ Cen Zhongmian 1958, pp. 402-4.

59 The date of the edict for the campaign is different in different sources. See Cen Zhongmian 1958, pp. 404-7; Xue Zongzheng 1992, pp. 531-4. In any case, no major joint campaign was undertaken.

${ }^{60}$ Cen Zhongmian 1958, pp. 402-11.

${ }^{61}$ JTS 194A, p. 5175; XTS 215B, p. 6053; ZZTJ 212, p. 6744; CFYG 980, p. 11511; QTW

40, p. 189. For trade between China and the Turks, see also Mori Masao 1978, pp. 81-96;

Chen Ching-lung 1981, pp. 38-44.

${ }^{62}$ Suzuki 1968, p. 186.
} 
they did not imply that the non-Chinese were vassals, though they implied a superior-inferior familial relationship, and therefore could be used as justification for reaching an agreement with certain foreigners without upsetting China's traditional world view.

Peace was kept by the two sides until 741, except in 733 , when the Turks joined the Khitan in a clash with Tang in Dushan (in modern Liaoning). ${ }^{63}$ From 723 until the death of Bilgä in 734, some twenty-eight missions went to Tang from the Turks. About five hundred and nineteen titles were given to Turkish officials and tribal leaders. ${ }^{64}$ The Chinese attitude is revealed in seven letters written by Zhang Jiuling on behalf of Xuanzong to the Turks between 734 and 736. These stressed a mutual commitment to the maintenance of peace and a harmonious father-son relationship. One letter in 736 suggested that if the Turks sent troops to attack the Türgish, Tang would cooperate, although such a plan was not carried out. $^{65}$

A regular horse-silk trade was established and became a major factor in consolidating peaceful relations. In 727, when the Turks refused to join the Tibetans in making an incursion on a border area, and sent Tang the letter the qaghan had received from the Tibetans, as a reward, Xuanzong allowed the Turks to trade with the Chinese at West Shouxiang Fortress. Every year the Chinese would pay several tens of thousands of rolls of silk to purchase horses there to be used in the armies and for breeding in the state pastures. The supply of horses was thus improved. ${ }^{66}$

But soon the horse-silk trade increased to such an extent that it became a burden to the Chinese. In 736 three letters written by Zhang Jiuling on behalf of Xuanzong were sent to the Turks discussing the matter. In these letters Zhang complained that during the previous two years the Turks had sent several times as many horses as called for by the regular quota $(3,000$ to 4,000$)$ that had been adhered to under the previous qaghan and that some of the horses were old, weak, sick or too small. Zhang held that Tang did the Turks a favor in buying so many horses. ${ }^{67}$

${ }^{63}$ ZZTJ 213, pp. 6801-2.

${ }^{64}$ The number is based on the account in Cen Zhongmian 1958, pp. 421-40.

${ }^{65}$ Herbert 1978, p. 12. For these letters, see Qujiang Zhang Xiansheng Wenji 11; QTW 286, pp. 1282-4.

${ }_{67}^{66}$ JTS 194A, p. 5177; XTS 215B, p. 6053; ZZTJ 213, p. 6779.

67 Qujiang Zhang Xiansheng Wenji 11, pp. 66-7. For the dates of the letters, see Cen Zhongmian 1958, pp. 450-1; p. 452. Chen Ching-lung (1981, p. 42) says that in 736 the new qaghan pledged himself to the Chinese emperor as his sworn father and for the sake 
There was still no marriage contract despite continuous requests from the Turks. Tang made the excuse that Bilgä had not sent an envoy of high enough rank to make the request, and had not prepared adequate betrothal gifts. Also, since Tang and the Turks had a father-son relationship, they could not enter into a father and son-in-law relationship. ${ }^{68}$ In 734 , Xuanzong did finally agree to a marriage because of the persistence of the Turks, ${ }^{69}$ but with Bilgä's death the plan was permanently shelved.

\section{The End of the Second Turkish Empire, 741-745}

Bilgä Qaghan was poisoned by one of his own officers in $734 .^{70}$ After his death constant internal power struggles seriously weakened the empire. The final days of the second Turkish empire were chaotic. Three Turkish tribes, the Qarluq, Basmill and Uighurs became powerful and severely challenged the rule of the Turkish Tujue clan. The Chinese for their part tried to win over these three tribes while launching their own attacks on the Turks. In 741 Xuanzong sent envoys to the Qarluq tribe with the aim of enticing them and the Basmil and Uighurs over to the Chinese side with the promise of rich rewards and official positions. The Military Commissioner of Shuofang also sent envoys to persuade them into launching further attacks in support of his own campaign.

The court bestowed official titles on the chiefs of these three tribes in 742. The Uighur chief Guli Peiluo (Qulligh Boila? ${ }^{71}$ ), together with the Qarluq, then eliminated the chief of the Basmil in 744, and proclaimed himself qaghan. Xuanzong immediately recognized his position by presenting him with the title of qaghan. In 745, Guli's force killed the last Turkish Baimei (Bolmïs) Qaghan. Relations between Tang and the Uighurs remained peaceful until the end of Xuanzong's reign. ${ }^{72}$ Eventually, it was the Uighurs who were the winners. They founded their own

of this relationship, the Chinese allowed the Turks to sell three to four thousand horses, "which were many times [the number] of the regular exchange." Chen does not seem to read the text correctly. It says that in the time of the late qaghan Tang bought horses in amounts not exceeding three to four thousand, but since the present qaghan came to the throne, Tang had bought as many as 14,000 to show its paternal affection for the Turks.

${ }^{68}$ JTS 194A, pp. 5175-6; XTS 215B, p. 6053; ZZTJ 212, p. 6761; pp. 6764-5; CFYG 979, p. 11501.

${ }^{69}$ XTS 215B, p. 6054.

${ }^{70}$ JTS 194A, p. 5177 ; XTS 215B, p. 6054; ZZTJ214, p. 6809.

${ }^{71}$ Hamilton 1988, p. 139.

${ }^{72}$ For the sources on this period, see Cen Zhongmian 1958, pp. 456-70. 
empire, known as the third Turkish empire, and became the new masters of the Mongolian steppe.

\section{Bringing the Khitan and $\mathrm{Xi}$ under Chinese Control}

On the northeast front, Tang's major concerns were the Khitan and $\mathrm{Xi}$ in Manchuria, who turned to Tang in 715-716 (see above). Xuanzong set up jimi institutions for the Khitan. Tang restored Yingzhou in 717, and the Military Commissioner of Pinglu was set up in 719 and based in Yingzhou. ${ }^{73} \mathrm{~A}$ third major power was Parhae farther east, whose rise as a buffer state between China and Silla is discussed in Chapter 6 .

Tang struggled to keep these people under Chinese dominance. While consolidating frontier defense, Xuanzong tried to maintain peaceful relations with the Khitan through conferring official titles on their chiefs, three marriages, and intervention when an internal power struggle occurred. In 730 the Khitan again joined the Turks. Finally, in 734, by stirring up internal conflicts among the Khitan, the Chinese got the chief of the Khitan killed and brought the Khitan back into the jimi system. The following year, when the Turks attacked the Khitan and $\mathrm{Xi}$, they were driven back. $^{74}$

The relationship between Tang and the Xi followed the same pattern. Tang set up jimi institutions, and concluded three marriages. One of the Tang princess brides, Princess Gu'an, was a strong character. Having discovered that a $\mathrm{Xi}$ official was plotting against Tang she put poison in his wine. In 730, the Xi were forced by the Khitan to switch to the Turks but under the attacks of the Chinese, submitted to Tang again in $732 .^{75}$

However, relations between Tang and the Khitan remained unstable. China had to station a large number of armies on the northeastern frontier under the Military Commissioner of Youzhou (Fanyang from 742). In official letters from the emperor to the Vice Military Commissioner of Youzhou, Zhang Shougui, we see that the court trusted Zhang to handle actual relations with the Khitan, and allowed him to make decisions on both defensive and aggressive moves. Although the court preferred a cautious, non-interventionist approach, the Military Commission-

\footnotetext{
${ }^{73}$ ZZTJ 211, p. 6720; p. 6727; Twitchett 1979, p. 367.

${ }^{74}$ JTS 199B, pp. 5351-4; XTS 219, pp. 6170-2; ZZTJ 213, p. 6797; 214, pp. 6807-9; pp. 6812-3.

75 JTS 199B, pp. 5354-6; XTS 219, pp. 6174-5; ZZTJ 213, p. 6797; Kuang Pingzhang 1935, pp. 40-2.
} 
ers and military officials under them did not always take the same line. ${ }^{76}$ Frontier officials had a tendency to provoke conflicts for the sake of receiving rewards for military success.

In 738 two generals forged an order they attributed to Zhang Shougui to attack the $\mathrm{Xi}$ while Zhang was away in the capital. Zhang tried to cover up their defeat, but it was found out and Zhang was dismissed from his post. ${ }^{77}$ In 745 , Tang again sent one princess to the Khitan and one to the $\mathrm{Xi}$ so as to maintain peaceful relations, but the chiefs killed the princesses and rebelled anyway. The Chinese sources blame this on An Lushan, the Military Commissioner of Fanyang, who made provocative attacks in order to achieve a name for himself. He crushed the revolt in $746 .^{78}$

Indeed, An Lushan may have intended to establish his political dominance in the area through military means. When clashes occurred in 750 , the Chinese sources again accuse An Lushan of provoking the troubles. In 751, An Lushan organized a great expedition against the Khitan which, however, ended in his complete defeat. He was nearly killed. But by then he enjoyed such favor from the emperor that he was not punished. In the following year he was bent on another campaign to revenge his defeat, but it did not go well because Abusi, the general whom An asked to cooperate in the campaign, rebelled. ${ }^{79}$ In 753 An Lushan forced some of Abusi's followers to surrender.

$\mathrm{He}$ then asked that rewards be given to his non-Chinese generals and soldiers for their accomplishments in dealing with the rebels. ${ }^{80}$ In 755 , he asked to replace Chinese generals with thirty-two non-Chinese generals. Xuanzong consented. ${ }^{81}$ By this time, as Military Commissioner of three commands, An Lushan had accumulated solid economic and military power. He founded his power base among non-Chinese, keeping a private army of eight thousand Tongra, $\mathrm{Xi}$ and Khitan, and attracting ever more non-Chinese into his force. ${ }^{82}$ In 755 he rose in rebellion.

\footnotetext{
${ }^{76}$ Qujiang Zhang Xiansheng Wenji 8, pp. 48-9.

77 ZZTJ 214, pp. 6837-8.

${ }^{78}$ ZZTJ 215, p. 6864; p. 6868; Pulleyblank 1955, p. 93.

79 JTS 199B, p. 5353; Pulleyblank 1955, pp. 98-9; p. 101.

${ }^{80}$ ZZTJ 216, pp. 6917-8; 217, p. 6924.

${ }^{81}$ ZZTJ 217, p. 6929.

${ }^{82}$ XTS 225A, pp. 6414-7.
} 


\section{Xuanzong: Making the Türgish Allies}

Early in Xuanzong's reign, the Türgish of the Western Turks were ruled by Sulu. He succeeded in drawing together as many as 200,000 Western Turks under his control. This ended the chaos among the Türgish following the defeat of Bäg Chor by the Protector-General of Beiting in 714. A very capable political leader, Sulu kept the Türgish an influential power in Central Asia until his death. On several occasions he allied with Tibet and in 734 took a Tibetan princess in marriage ${ }^{83} \mathrm{He}$ also married a princess of the Eastern Turks. ${ }^{84}$ In addition, he had relations with the Arabs to whom he was known as the "Father of Competition, because he competed with them." 85

Aware of Sulu's strength, Tang had to guard against him while trying to keep up a friendly relationship. When Sulu sent an embassy to Tang in 715 , the court conferred on him several official titles. ${ }^{86}$ In 716 , he assumed the title of qaghan. ${ }^{87}$ In 717, Ashina Xian, a Tang general and grandson of Ashina Mishe, requested Xuanzong's permission to attack the Türgish. The emperor rejected this belligerent plan and decided instead to send an envoy to confer a noble title on Sulu. But before that could be done, a report arrived that the Türgish had allied themselves with the Arabs and the Tibetans, and had laid siege to Bohuan (Aksu) and Dashicheng (Uch-turfan). The allies had also attempted to attack the Four Garrisons, but they had been driven off by Ashina Xian and the Qarluq tribes under the Protectorate of Anxi. ${ }^{88}$ Nevertheless, in 719, Tang confirmed Sulu's title of qaghan and three years later sent Princess Jiaohe of the Turkish Ashina clan to marry him.

The Tang frontier generals did not adhere closely to the peace policy. In 726, a quarrel broke out between Sulu and Du Xian, the ProtectorGeneral of Anxi. When a Türgish envoy came to sell horses in Anxi, Prin-

\footnotetext{
${ }^{83}$ Beckwith 1987, p. 111.

${ }^{84}$ JTS 194B, p. 5192.

${ }^{85}$ Beckwith 1987, p. 85.

${ }^{86}$ JTS 194B, p. 5191; ZZTJ 211, pp. 6714-5. XTS 215B (p. 6067) says that the Sulu sent his first envoys to Tang in in 717.

${ }^{87}$ ZZTJ 211, p. 6720.

${ }^{88}$ XTS 215B, p. 6065; ZZTJ 211, pp. 6727-8; Ise 1968, p. 331.

${ }^{89}$ ZZTJ 212, p. 6737; QTW 21, p. 106. JTS 194B (p. 5191) says that the conferring of the title qaghan was in 715. Princess Jiaohe was a daughter of the nominal Western Turkish qaghan, Ashina Huaidao, the grandson of Ashina Buzhen. See JTS 194B, p. 5191; XTS $215 B$, p. 6067 ; ZZTJ 212, p. 6754. Some Chinese sources refer to her as Jinhe, see Kuang Pingzhang 1935, p. 46; Cen Zhongmian 1964, p. 179.
} 
cess Jiaohe sent a letter phrased as an instruction. Du was enraged, saying: "How can the woman of the Ashina give an instruction to me!" the envoy and detained him and the horses. Thereupon Sulu decided to retaliate. In the winter of 726-727, Sulu joined forces with the Tibetans, attacking the headquarters of the Protectorate of Anxi and plundering Chinese livestock. When Sulu heard that Du Xian had left Anxi to take up the position of Chief Minister, he withdrew and sent a tribute mission to the Tang court. ${ }^{91}$

A conflict arose between Tang and the Türgish again in 734 . That year the Türgish sent an envoy to bring livestock for trading with Tang but, when he arrived at Beiting, he planned an armed attack. The Protector-General of Beiting, Liu Huan, put him to death. The Tang court, however, did not wish to have any conflict with the Türgish, so it decided to execute Liu Huan and sent his head to the Türgish in the hope of settling the matter. The effort did not have the desired result, for the Türgish soon formed an alliance with Tibet for retaliation. ${ }^{92}$ In 735 , the Türgish made further attacks on Beiting and Aksu. Defeated by the Chinese in the following year, the Türgish made a peace proposal, to which Tang agreed. ${ }^{93}$

As mentioned above, in the course of these encounters, the Tang court once in 736 sent a letter to the qaghan of the Eastern Turks proposing an alliance against the Türgish. The court also instructed the Military Commissioners of Hexi and Anxi to make an alliance with the Arabs to attack the Türgish. ${ }^{94}$ But this alliance does not seem to have taken effect. In the course of time, the Türgish were weakened as Sulu grew old. In his youth, Sulu had held the allegiance of his tribesmen by his generosity in distributing booty but eventually overextended himself and no longer had the resources to keep up this practice. A rival faction arose and Sulu was killed in $738 .^{95}$ In the following year, the Chinese Military Commissioner of Jixi, Gai Jiayun, allying with Ferghana, Tashkent and Kesch, inflicted a severe defeat on Sulu's son and successor. From then on, the Türgish ceased to be a major threat on the Chinese frontiers, and maintained a

${ }^{90}$ ZZTJ 213, p. 6775. Beckwith $(1987$, p. 98$)$ translates the word xuanjiao as "proselytize the princess' religion." But according to $\operatorname{THY}(26$, p. 504), the word jiao is the term used by a prince and princess in formal written communications to an inferior.

91 JTS 194B, p. 5191; XTS 215B, p. 6067; ZZTJ 213, pp. 6775-6; p. 6779.

${ }_{92}^{92}$ Quejiang Zhang Xiansheng Wenji 8, pp. 46-8; Wu Yugui 1987, pp. 106-7.

${ }_{93}$ ZZTJ 214, p. 6812; p. 6813; p. 6821.

${ }^{94}$ QTW 284, p. $1275 ; 285$, p. 1280.

95 TD 199, p. 1080; ZZTJ 214, pp. 6833-4. 
tributary relationship with Tang. ${ }^{96}$

\section{Encounters with the Arabs}

Tang's activities in the Western Regions were bound eventually to clash with another contender for dominance in the area, the Arabs.

Soon after the start of the Arabian conquests and the spread of Islam in the early seventh century, the impact of the first conquests became known to the Chinese when in 638 the last Sasanian king, under pressure from their invasion, sent a mission to the Tang court. He was killed by the Arabs in 651 while fleeing to Tokharestan. His son Pērōz took refuge in Tokharestan and sent a mission to China asking for aid, but Gaozong declined, with the excuse that it was too far away. In 661, after conquering the Western Turks, Tang set up a series of jimi fuzhou, among which was the Area Command of Bosi (Persia) with its seat in Sistan, and appointed Pērōz as the Area Commander. He was given the title of the king of Persia in 662, but he was unable to hold out against the advance of the Arabs. It appears that he took refuge in Chang'an after 673 and died there. ${ }^{97}$ The Arabs sent their first envoys to Tang in 651 after the collapse of the Persian empire. ${ }^{98}$ They continued to advance northward into Central Asia.

Tang's reaction to the Arab advance was to give at least moral support to the requests of the western states over which it had earlier sought to establish a nominal suzerainty. In 705 Tang bestowed the title of king on the ruler of Tokhara and accepted the king's younger brother into the imperial bodyguards. Thereupon the king led other states in fighting with the Arabs. ${ }^{99}$ Not until 715 did the Chinese for the first time directly clashed with the Arabs when, allied with the Tibetans, the Arabs attacked Ferghana, and the Chinese troops launched a successful counterattack. ${ }^{100}$

This event drew the Chinese into Transoxiana, west of the Pamirs, where the city states, hard pressed by the Arabs, turned to Tang for aid. In 719, Bukhara, Kumedh and Samarkand, west of the Pamirs, sent envoys to Tang, hoping that Tang could use its influence on the Türgish to expel the

${ }^{96} J T S$ 194B, p. 5192; XTS 215B, pp. 6068-9; ZZTJ 214, p. 6833-4; p. 6838; p. 6841; p. 6843.

${ }^{97}$ For the conferring of the title of king, see CFYG 964, p. 11341. CFYG (999, p. 11718) says that in 673 and 674 King Pērōz came to pay homage at the court. According to Chavannes (1969, pp: 126-7), Pērōz was still in Chang'an in 677 and died soon after.

${ }^{98}$ Twitchett 1979, p. 280.

${ }^{99}$ Chavannes 1969, pp. 210-4.

${ }^{100}$ ZZTJ 211, p. 6713; Beckwith 1987, pp. 81-3. 
Arabs. From 719 Xuanzong repeatedly invested the title of king on rulers of the city states in Transoxiana, both to mobilize them against the Arabs and to win them over from Tibetan influence. ${ }^{101}$ In 727 , Tokhara, suffering heavy taxation under Arab occupation, sent an embassy to the Tang court, asking Xuanzong to order the Türgish troops to drive away the Arabs. ${ }^{102}$

As they expanded against the city states of Sogdiana, the Türgish also had to resist the Arabs. In 724, the Türgish won a crushing victory over an Arab expedition sent against Transoxiana in the battle known to the Arab historians as the "Day of Thirst." ${ }^{\text {"103 }}$ After 730, both Tibet and the Türgish made peace with China for some years. This was because both were preoccupied with the Arabs in Transoxiana. ${ }^{104}$ With the subduing of the Türgish, China began to exert its influence in Ferghana and in the Talas basin west of the Pamirs. In 744 Xuanzong gave the hand of a princess to the king of Ferghana to further consolidate the relationship.

To the south, in 747 Gao Xianzhi, Vice Protector-General of Anxi, took over Little Balur from its pro-Tibetan rulership, and in 750, at the request of the king of Tokhara, he launched an attack on the pro-Tibetan kingdom of Qieshi (Kashgar), further expanding Chinese influence west of the Pamirs, and drawing the Chinese into confrontation with the Arabs. With his military success, Gao Xianzhi became unrestrained and assumed a harsh attitude towards the temporarily subdued states. His high-handed policy towards Tashkent caused strong resentment among the other states in the region and they joined with the prince of Tashkent in making an alliance with the Arabs. The Qarluq also joined the Arabs.

In the famous battle of the Talas River in 751, Gao's army was wiped out by the Arabs and their allies. This marked the end of Tang involvement west of the Pamirs. ${ }^{106}$

After half a century as subjects of Tang in the jimi fuzhou system, the Eastern Turks successfully restored their steppe empire under Qutlugh Qaghan in 682. Though supervised by Chinese garrisons, the Turks kept their nomadic lifestyle, their military organization and customs. Their

\footnotetext{
${ }^{101}$ Chavannes 1969 , pp. 210-4.

${ }^{102}$ CFYG 999, p. 11722 ; p. 11723.

${ }^{103}$ Beckwith 1987, pp. 96-7.

${ }^{104}$ Beckwith 1987, pp. 109-11.

${ }^{105}$ ZZTJ 215, p. 6862; Kuang Pingzhang 1935, p. 48.

${ }^{106}$ Chavannes 1969, pp. 214-7.
} 
subjugation by China may even have strengthened their consciousness of their ethnic identity.

When attempts at military suppression failed, Empress $\mathrm{Wu}$, preoccupied with internal problems, had to make a series of compromises with Qutlugh and Bäg Chor, who succeeded Qutlugh in 691, while trying to maintain some control over the scattered Western Turks to counterbalance the resurgent Eastern Turks. Chinese foreign policy as a whole switched from aggressive advance to the building of a strong defense system by establishment of permanent armies on the frontiers.

Difficulties in dealing with Bäg Chor played a part in forcing Wu Zetian to give up her plan to establish her own dynasty. When at last she was forced to abdicate, Zhongzong was able to take a firmer stand against the Eastern Turks by building the three Shouxiang Fortresses on the Ordos frontier and developing the alliance with the Türgish who now led the Western Turks. But internal power struggles at court still inhibited the undertaking of any major military campaign against the Eastern Turks.

Early in Xuanzong's reign plans were made for a major campaign against the Turks, but there were also advocates of a peaceful settlement, since there was danger of a Tibetan invasion and since Chinese troops were also engaged against the Khitan in the northeast. The situation turned in Tang's favor when subject tribes, alienated by the aging Bäg Chor's tyrannical rule, began to defect, and he himself was murdered in 716 and replaced by Bilgä Qaghan, who was more peaceable in his inclinations.

Between 717 and 740, Tang and the Second Turkish empire maintained a peaceful relationship. The Turks sent frequent tributary missions to the Tang court, with the pragmatic purpose of obtaining the Chinese goods that accompanied investiture with Chinese official titles. These goods could be purchased through border markets and the regular horsesilk trade. The Chinese court welcomed this peace, since it freed their forces to deal with urgent problems on other frontiers.

After three generations of strong qaghans, the Eastern Turks declined in the early 740's. Tang responded to this by supporting opposition forces headed by the Uighurs, who eliminated the last qaghan of the second Turkish empire in 745 , and replaced the Turks as the masters of the steppe.

Xuanzong's policy toward the Türgish was to guard against them while trying to keep up a friendly relationship through marriage alliance and title investiture so as to counterbalance the expansion of Tibetans and Eastern Turks in the Western Region. In the late 730's, however, when the 
Türgish came into conflict with Tang, Tang attempted to form an alliance against them with the Eastern Turks and the Arabs. Although no such alliance was effected, the decline of the Türgish power itself provided an opportunity for Tang to launch attacks and expand further into the Western Regions.

This in turn brought Tang into confrontation with the Arabs, whose continuing advance into Central Asia made the states in Transoxiana west of the Pamirs turn to Tang for support. Eventually, defeat at the battle of the Talas River in 751, followed soon after by the outbreak of the An Lushan rebellion, put an end to Chinese involvement west of the Pamirs. 


\section{Chapter 9}

\section{Tang and the Uighurs: An Unstable Alliance}

The second Turkish Empire ended in 745 when its last ruler was eliminated by the Uighur leader Guli Peiluo (Qullïgh Boila? ${ }^{1}$ ), who had assumed the title of qaghan the previous year and immediately been recognized by Xuanzong. Qulligh Boila then went on to occupy all the former Turkish territory north of the Gobi Desert and establish his headquarters at the foot of the Ötükän Mountains. ${ }^{2}$ This Uighur or third Turkish Empire lasted until 840 .

In this chapter, we shall see how the Uighurs remained at peace with China during the remainder of Xuanzong's reign and played an important role in assisting the Tang court to suppress the An Lushan rebellion. The uneasy alliance between Tang and the Uighurs persisted during the post-rebellion period. Though often burdensome, it was advantageous to Tang at a time when the dynasty remained weakened by provincial warlordism, and when Tibet presented a much more formidable external threat to its territorial integrity than did the Uighurs.

The Uighurs, who were competing with Tibet in Central Asia, also found it to their advantage. Relations between Tang and the Uighurs thus constituted a new variant on the perennial interplay between Chinese regimes and their nomadic neighbors.

\section{The Tradition of Alliance Between China and the Uighurs Before $\mathbf{7 4 5}$}

The alliance between the Uighurs and Tang had its roots in earlier times. $^{3}$ The Uighurs emerged from the Tiele, a confederacy of Turkish speaking tribes, known already in Han times as the Dingling (based on an earlier pronunciation of the same name). As the Tiele or Gaoche (High Carts) they played a role in the competition between Northern Wei and the Rouran. When the first Turkish empire was founded by the Ashina clan of the Tujue Turks in 552, the Tiele were brought under its rule. In 605 they rebelled against the Western Turks and established a qaghanate of their

\footnotetext{
${ }^{1}$ Hamilton 1988, p. 139.

${ }^{2}$ Haneda 1957, pp. 181-92.

${ }^{3}$ On this see also Mackerras 1972, p. 8.
} 


\section{KIRGHIZ}

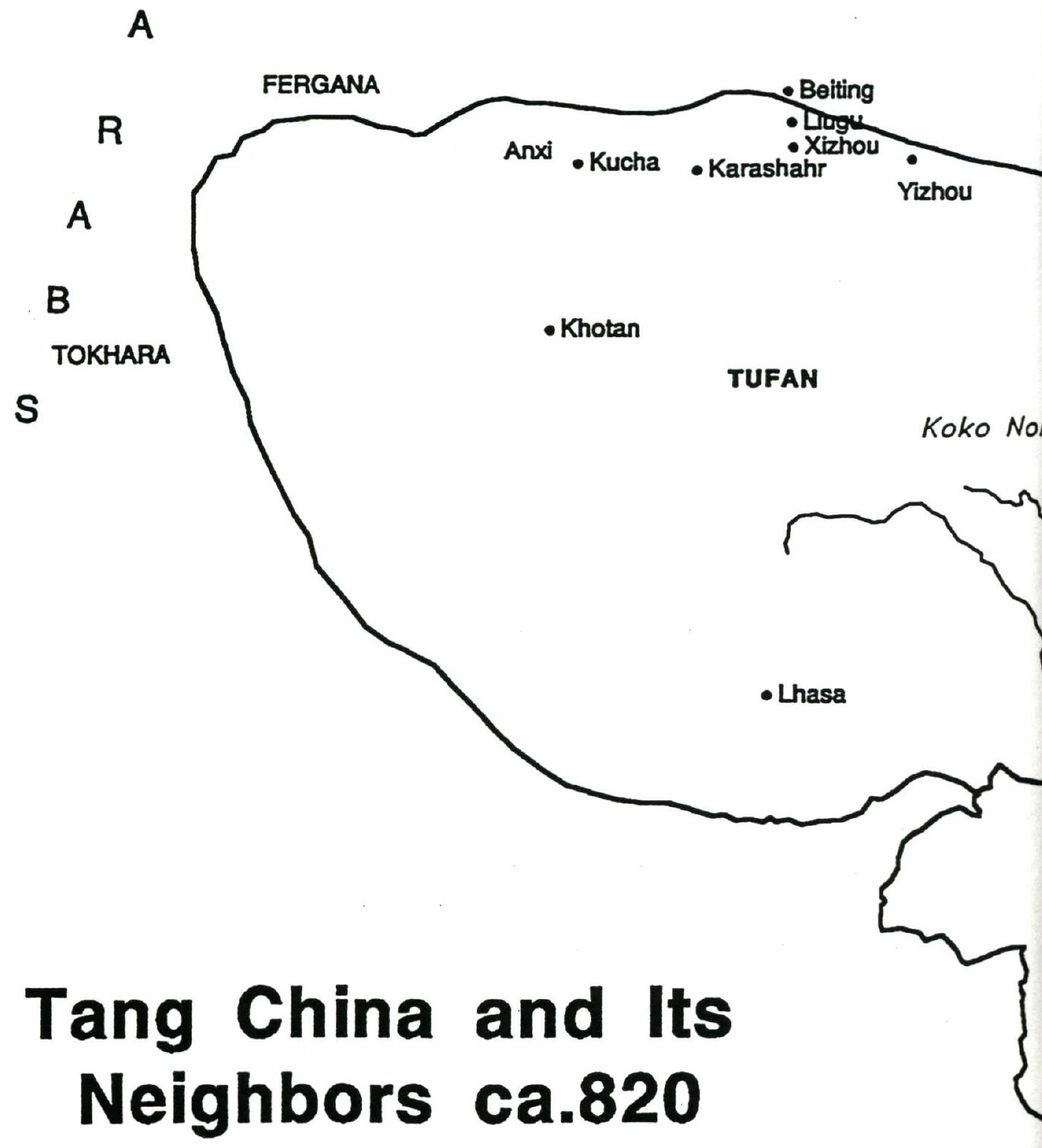




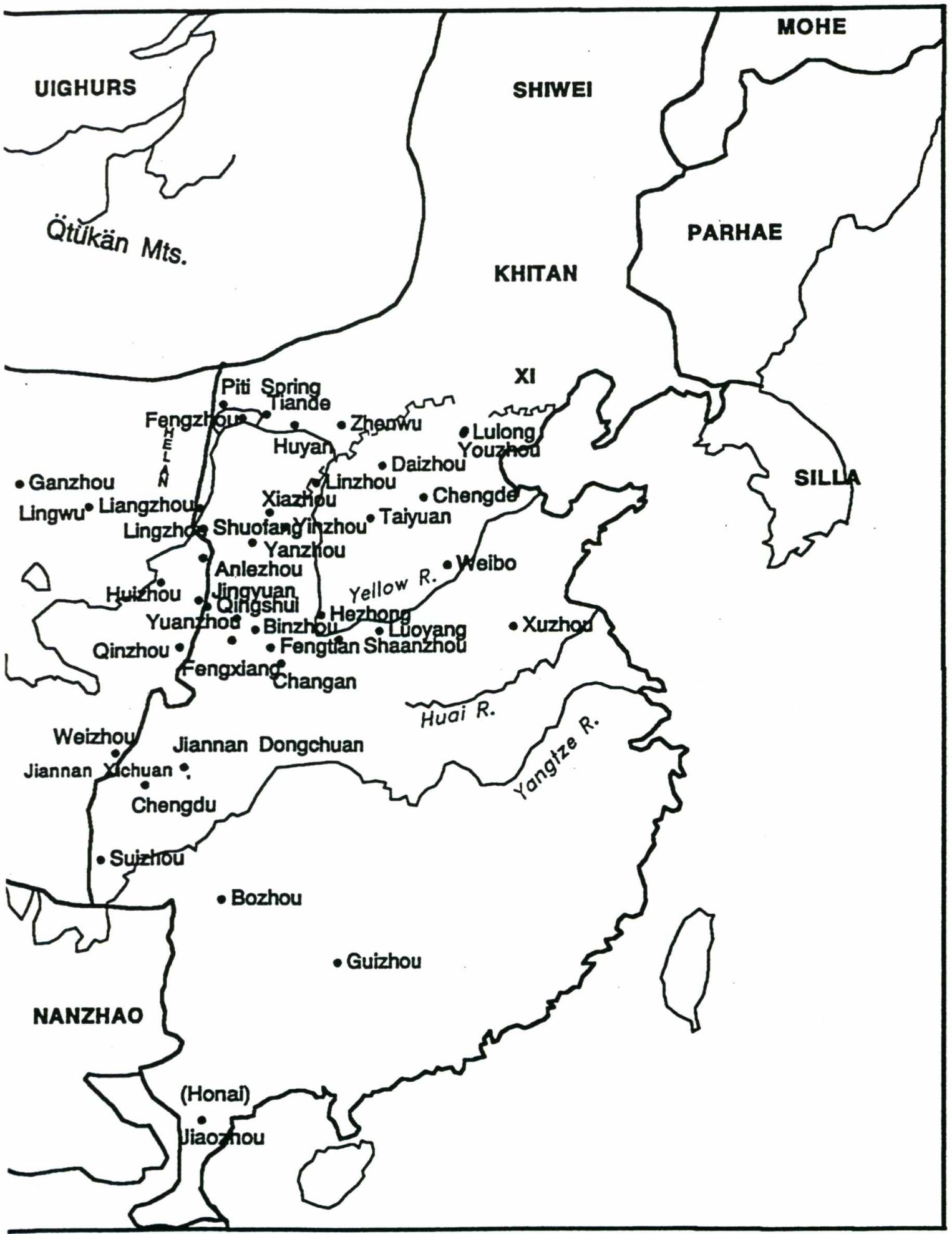


own, and in 608 they assisted Emperor Yang in defeating the Tuyuhun. However, the Tiele qaghanate dissolved when the Western Turks revived. The Tiele again became subject to the Western Turks by $619 .^{4}$

At the beginning of Tang, the Uighurs became a power of importance as the leading tribe of the Nine Surnames, a confederacy of Tiele tribes. The Chinese term "Nine Surnames" (jiuxing) first appears in 630. It corresponds to the term "Toquzoghuz" in the Turkish inscriptions. ${ }^{5}$ In 627-628, the Uighurs joined forces with the Xueyantuo and other Tiele tribes in a revolt against their Turkish rulers. This revolt was crucial for Taizong in his conquest of the Eastern Turks in 630. The Xueyantuo founded their own qaghanate around 628, but in 646 the Uighur and other Tiele tribes rose in revolt against the tyrannical rule of the Xueyantuo qaghan. This enabled Taizong to repeat his success of 630 and overthrow the Xueyantuo, whom he perceived as the new threat succeeding that of the Tujue Türks.

Between 647 and 679, the Uighurs and other Tiele were under the Chinese jimi administration. The Uighurs privately retained their own system of ranks and the title of qaghan, ${ }^{6}$ but both in theory and in reality the Uighurs were subjects within the Chinese empire. The Uighurs joined a Tiele rebellion against Tang in the early 660's, but for most of the time they acted as an important military force on the side of Tang in frontier affairs, in exchange for which Tang intervened in an internal power struggle in 648 to maintain the unity of the Uighurs. ${ }^{7}$

In the competition between Tang and the Turks after the restoration of the Second Turkish empire, the various Tiele tribes followed different strategies for self-protection. According to the Turkish inscriptions, after Qutlugh founded the second Turkish empire, the Turks were surrounded by hostile peoples, among them the Chinese in the south, the Khitan in the east, and the Toquzoghuz, that is, the Nine Surnames of the Tiele, in the north, headed by a certain Baz Qaghan. After a series of battles, the Toquzoghuz were brought under Turkish rule. ${ }^{8}$ Some of the Uighurs and other

\footnotetext{
${ }^{4}$ Ma Changshou 1957, pp. 34-6.

5 There are quite a few studies of the Nine Surnames, among which see Pulleyblank 1956, pp. 35-42; Haneda 1957, pp. 325-94; Hamilton 1962.

6 JTS 195, p. 5196; XTS 217A, p. 6113; ZZTJ 198, p. 6245.

${ }^{7}$ JTS 195, p. 5197 ; XTS 217A, p. 6113 ; ZZTJ 199, p. $6262 ;$ p. 6263.

${ }^{8}$ Cen Zhongmian 1958, pp. 857-926. For an English translation of the inscriptions, see Tekin 1968. For Baz Qaghan, see Cen Zhongmian 1958, p. 881; pp. 895-6; Tekin 1968, p. 265.
} 
Tiele tribes-the Qibi, the Sijie and the Hun - came to settle on the Chinese frontier in Ganzhou and Liangzhou after 690, and were in communication with the Tang court. The later qaghans of the Uighur empire were descendants of the Liangzhou chieftains. These Tiele tribes were again used by the Chinese army as a military force during Xuanzong's time. Around 715, the Uighur chief Fudifu was appointed Vice Military Commissioner of Hexi and Commander of the Chishui Army. ${ }^{9}$ In 716, the Bayïrqu of the Nine Surnames killed Bäg Chor Qaghan of the Turks. The Uighur and other Tiele tribes who had previously been under the Turks came to submit to Tang and were settled near the Dawu Army north of Daizhou. $^{10}$

The Uighurs who had been in Ganzhou and Liangzhou did not engage in any hostilities against the Chinese until 727. A conflict arose at that time mainly through the mismanagement of a Chinese frontier general, Wang Junchuo. Earlier, while holding a lower rank in the Liangzhou border area, Wang had not been treated with much respect by the Uighurs and other Tiele tribes in the region. After he was promoted to the rank of Military Commissioner of Hexi, he adopted a high-handed policy towards these tribes and they sent secret envoys to the Tang court to complain of him. When he learned of this, Wang reported that these tribes intended to rebel.

Xuanzong sent an imperial commissioner to investigate the matter and the Tiele were found guilty. The Uighur chieftain and the chieftains of other three Tiele tribes were exiled. The court then appointed Fudinan of the Uighurs as the Area Commander of Hanhai. However, this did not prevent further confrontations. Hushu, a distant nephew of the exiled Uighur chief, organized his people to take revenge on Wang Junchuo. They laid an ambush when he returned from an attack on the Tibetans. Wang and one of his assistants were killed and the rebels blocked the route from Anxi to Chang'an. Pursued by the Liangzhou troops, Hushu fled back to the north of the Gobi with his people. ${ }^{11}$

After 727, Hushu's son Qullïgh Boila succeeded him as the leader of the Uighurs. As we have seen, he ruled as qaghan from 744 to his death in 747. It was under him that the Uighurs put an end to the second Turkish

\footnotetext{
${ }^{9}$ Haneda 1957, pp. 174-8.

${ }^{10}$ Cen Zhongmian 1958, pp. 374-98.

${ }^{11}$ JTS 103 , p. $3192 ; 195$, p. 5198 ; XTS 133 , p. $4547 ; 217$ A, p. 6114 ; ZZTJ 213, pp. 677980; Haneda 1957, pp. 179-81.
} 
empire. ${ }^{12}$ The fact that he was immediately recognized by Tang seems to indicate that the traditional alliance between the Uighurs and Tang was stronger than the breach that had occurred during the time of his father.

\section{Suzong: Securing the Uighur Alliance}

When Suzong assumed the throne at Lingwu during the An Lushan rebellion in 756, he faced a very difficult situation. Apart from the small bodyguard that had accompanied him on his flight from Mawei and the local garrison, the only major Tang military force that was still loyal and effective and within reach were the armies from Shuofang under Guo Ziyi and Li Guangbi. Before the fall of Tongguan, they had been successfully campaigning on the rebels' flank in Hebei but were now recalled. Troops were also summoned from Anxi and Ferghana, with whose king, as we have seen, a marriage alliance had been made in 744 , and rich rewards were promised to other city states in the Western Regions if they would send help. The arrival of these troops, including a contingent of Arabs, is recorded at the beginning of 757. More importantly, in the eighth month of 756, the Uighur qaghan Moyanchuo (Bayan Chor? r. 747-759) and the Tibetan btsan-po both sent envoys requesting a marriage alliance and offering assistance to defeat the rebels. Suzong responded quickly and positively to the Uighur offer but not to that of Tibet. ${ }^{13}$

It is not difficult to understand why the Chinese actively sought help from the Uighurs, but tried to keep the Tibetans at arm's length. Before the rebellion, large Chinese armies had been stationed on the northwest frontier to resist any Tibetan invasion and, as we shall see in Chapter 10 , Tibetan forces were already pressing into the vacuum created by their withdrawal to oppose the rebel approach to Chang'an. The Uighurs, on the other hand, had been traditional allies of Tang against the Tujue Turks. Though they had now become the dominant power on the Mongolian steppe, the Uighurs had shown no sign of territorial ambitions against China. Securing their cooperation offered Tang the possibility of using their strong cavalry for the counterattack against An Lushan's forces, as well as for resisting Tibetan incursions. It was also important to forestall any alliance between the Uighurs and provincial separatists inside China. ${ }^{14}$ In order to obtain military assistance from the Uighurs, the Chinese

\footnotetext{
${ }^{12}$ Haneda 1957, pp. 181-92.

${ }^{13}$ ZZTJ 218, p. 6992; p. 6998; CFYG 973, p. 11434; 979, p. 11504.

14 Jagchid Sechin 1971, p. 22; Ma Junmin 1984, p. 69.
} 
adopted several unusual measures. In the ninth month of 756, Suzong made the great grandson of Gaozong, Li Chengcai, the Commandery Prince of Dunhuang, and sent him and General-in-Chief Pugu Huaien to the Uighurs to cultivate their friendship and ask for military assistance. The qaghan was pleased and adopted his own sister-in-law as daughter and married her to Li Chengcai. Suzong gave the title of Princess Bilgä to the Uighur princess in order to show his favor to her adoptive father-in-law. ${ }^{15}$ The court sent Pugu Huaien to carry out that mission because he was descended from the Buqu tribe related to the Uighurs which had come to be under the Area Command of Jinwei in Taizong's time. He had inherited the position of Area Commander from his grandfather and father. ${ }^{16}$

Though Suzong also received troops from Ferghana, Khotan, Tokhara and other nearby states, as well as from the Arabs and unspecified southern "barbarians," "17 the Uighur assistance proved to be by far the most important. Toward the end of 756 , the Uighur qaghan led his troops to join the Tang general Guo Ziyi in defeating an anti-Tang force of Tongra and other tribesmen on the banks of the Yellow River. When the qaghan met Guo in the Huyan Valley north of the Yellow River, he paraded his troops and made Guo pay respect to his wolf pennons before he would see him. ${ }^{18}$

Despite this arrogance, in 757 Guo Ziyi suggested that Tang request more Uighur cavalry. In response, the qaghan sent his Heir Apparent and 4,000 crack troops to join the Chinese. The Uighur Heir Apparent and the Prince of Guangping, the future Emperor Daizong, made a pact of brotherhood with him. ${ }^{19}$ The Tang troops, joined by the Uighurs and troops from Ferghana, Khotan and the Arabs, recovered Chang'an.

After the recapture of Chang'an, in order to persuade the Uighurs not to carry out the pillage that had been promised to them, the Prince of Guangping prostrated himself in front of the Uighur Heir Apparent, who was on horseback. The Uighur Heir Apparent returned the prostration and

${ }^{15}$ JTS 195 , p. 5198 ; XTS 217A, p. 6115; ZZTJ 218, p. 6998; 219, p. 7005. For more on Li Chengcai, see Mackerras 1972, p. 128, note 14.

${ }^{16}$ JTS 121, pp. 3477-8; XTS 224A, pp. 6365-6.

${ }^{17}$ JTS 10, p. 247 ; XTS 6, p. 158 ; ZZTJ 218 , p. $6998 ; 219$, p. $7010 ;$ p. 7014 ; CFYG 973 , p. 11434.

${ }^{18}$ This is according to XTS 217A, p. 6115; Mackerras 1972, p. 17; pp. 55-7. According to other accounts in JTS 120 , p. 3451 ; XTS 137, 4600; ZZTJ 219, p. 7007, the qaghan did not personally participate in the campaign. See also Haneda 1957, pp. 194-5.

${ }^{19}$ JTS 195, p. 5198 ; XTS 217A, p. 6115; ZZTJ 220, pp. 7032-3. 
agreed not to plunder the city, but to continue the campaign against the rebels by advancing east to Luoyang. Seeing this, commoners, soldiers and non-Chinese present all said: "The Prince of Guangping is a real master of both Chinese and Yi [barbarians]!"

The eastern capital, Luoyang, was recovered soon after. There the Prince of Guangping was unable to restrain the Uighurs, who engaged in savage plunder for three days. The people of the city had to pay heavy bribes before the pillage could be stopped. ${ }^{20}$ Tang provided rich rewards for the Uighurs' assistance and conferred the noble title of prince on the Uighur Heir Apparent, along with an annual payment of 20,000 rolls of silk. ${ }^{21}$

To further reward the Uighurs, the court in 758 conferred the title of Qaghan on Bayan chor, and at the request of the Qaghan a Tang princess was sent to marry him. This was Princess Ningguo, the daughter of Suzong himself. At her emotional farewell the princess said tearfully to the emperor: "The affairs of the state are serious. Even should I die, I shall not regret going."22 The marriage of Princess Ningguo to Bayan chor was the first time in Chinese history that a Chinese emperor sent his own daughter, not just someone from the imperial clan, to marry a non-Chinese ruler. This shows the great importance that the court attached to its relationship with the Uighurs. ${ }^{23}$ The emperor also sent the Prince of Rong's daughter to accompany Ningguo as a secondary wife.

After Bayan chor Qaghan died, his officials wanted Princess Ningguo to be buried with him, but the princess refused on the grounds that this was not a Chinese custom. A compromise was made according to which she observed the nomadic custom of slashing her face and weeping loudly. She returned to Tang in 759 , since she had not born a child to the qaghan, whereas the daughter of the Prince of Rong remained, and became the wife of the next qaghan. The Uighurs called her Younger Princess Ningguo. ${ }^{24}$ The Uighur Qaghan Bayan chor also asked to contract a marriage for his younger son, the future Mouyu (Bögü? ${ }^{25}$ ) Qaghan. Suzong sent Pugu

\footnotetext{
${ }^{20}$ JTS 10, p. 247; 195, p. 5199; XTS 217A, pp. 6115-6; ZZTJ 220, pp. 7034-5; p. 7041.

21 JTS 195, pp. 5199-200; XTS 217A, p. 6116; ZZTJ 220, pp. 7043-4; CFYG 965, p. 11350.

${ }^{22}$ Mackerras 1972, p. 62.

${ }^{23}$ Kuang Pingzhang 1935, p. 49.

${ }^{24}$ JTS 195, p. 5200; p. 5210; XTS 83, p. 3660; 217A, pp. 6116-7; p. 6125; ZZTJ 220, p. $7059 ; 221$, p. 7076.

${ }^{25}$ Haneda 1957, p. 203.
} 
Huaien's daughter to marry him. ${ }^{26}$

In 758 and 759, the Uighurs again joined the Chinese in battles, this time against An Lushan's son, An Qingxu, and were generously rewarded. $^{27}$ A horse-silk trade was established. Starting from this time, the Uighurs regularly sent embassies with large numbers of horses, forcing the Chinese to take them in exchange for an agreed price in Chinese silk. ${ }^{28}$

The Uighurs had several motives for assisting Tang. First, they would get to attack some of the Tiele people who were serving under An Lushan. Before he rebelled, An Lushan had included the Tongra, a Tiele tribe, in his armies. They had been serving under An up to the time of An's capture of Chang'an but then deserted him and moved northward to arouse the six Hu (Sogdian) prefectures in the Ordos against Tang. They were eventually defeated by Tang and Uighur troops at the end of $756 .^{29}$ Second, the Uighurs preferred to ally themselves with Tang rather than with Tibet, for they understood that alliance with Tibet was not of much economic benefit to them. By assisting Tang they could retain the material benefit of subsidies and compel the Chinese to keep up the lucrative horsesilk trade which provided them with constant supplies of Chinese silk for use in their intermediary trade between east and west. ${ }^{30}$ Third, the prestige which Chinese titles and marriage alliances conferred upon them would also enhance the moral authority of the Uighur rulers in dealing with their own people. A stable relationship with China was especially necessary during the early period of expansion when Bayan chor Qaghan was trying to establish his hegemony on the steppe and was engaged in constant warfare with such other tribes as the Qarluq and Kirghiz farther west.

It appears that from this time on the Uighurs also incorporated the Khitan and Xi into their realm. ${ }^{31}$ Both Khitan and Xi acknowledged the Uighurs' overlordship by accepting their seal of office, and by sometimes acting as spies on their behalf. The Xi king married an Uighur lady some time before the late 770's. The Uighurs sent supervisors to ensure the payment of annual tribute. This did not prevent the Khitan and Xi from

${ }^{26}$ JTS 195, p. 5202; XTS 217A, p. 6117; ZZTJ 222, p. 7131.

27 JTS 195, p. 5201; XTS 217A, pp. 6116-7; ZZTJ 220, p. 7060; 221, p. 7072; CFYG 973, pp. 11434-5.

${ }^{28}$ JTS 195, p. 5207; XTS 50, p. 1339; 217A, p. 6120; CFYG 999, p. 11727.

${ }^{29}$ ZZTJ 218, p. 6986; pp. 6997-8; 219, p. 7007. See also Moses 1976, p. 78.

${ }^{30}$ Jagchid Sechin 1971, pp. 22-3.

${ }^{31}$ Haneda 1957, pp. 197-202. 
sending regular "tribute-bearing" missions to the Tang court via Youzhou after the An Lushan rebellion. ${ }^{32}$ Located in the northeast the Khitan and Xi were now separated from the territory under direct Tang control by the independent Military Commissioners of Hebei and relations with them became mainly the latter's responsibility. Chinese sources provide very limited information, but the frontier appears to have become much more peaceful than it had been in the time of Xuanzong. Without the incentive to win military honors from the Tang court that had inspired An Lushan, the military governor at Youzhou kept a close watch on the frontier, but refrained from adventurous probings beyond it, while the nomads also refrained from raids.

\section{Daizong: The Appeasement Policy's Effect and Expense}

Daizong came to the throne in the spring of 762 . Soon after, he sent an envoy to the Uighurs to renew friendship and solicit military assistance against the last of the rebel rulers, Shi Chaoyi. The Uighurs were then under Bögü Qaghan (r. 759-779), who as prince had married the daughter of Pugu Huaien. The most aggressive toward Tang of all the rulers of the Uighur empire, he demanded more subsidies and greater equality in status from them.

When Daizong's envoy met the qaghan, he found that the Uighurs under Bögü Qaghan had been enticed by Shi Chaoyi to come to China for plunder, taking advantage of the death of Xuanzong and Suzong. By then the Uighur troops had already passed the three Shouxiang Fortresses in Shuofang. The envoy immediately sent a report to the court, upon which Daizong sent Pugu Huaien, father-in-law of the qaghan, to meet Bögü Qaghan in Taiyuan in the hope of persuading him to remain true to the alliance with Tang. Pugu succeeded in diverting the Uighurs from their invasion of Tang and making them join instead in suppressing Shi Chaoyi. The qaghan assumed personal command of his troops and joined the Tang forces in retaking Luoyang, then still under rebel occupation. Shi Chaoyi fled and following a series of defeats committed suicide in early 763 , thus ending the disastrous period of the An Lushan rebellion. ${ }^{33}$

Even while agreeing to assist Tang, Bögü displayed his arrogance.

32 JTS 180 , p. 4678 ; 199B, p. 5354 ; p. 5356 ; XTS 212 , p. 5972 ; p. $5980 ; 219$, p. 6172 ; THY 96, p. 1710.

${ }^{33}$ JTS 121 , pp. $3479-81 ; 195$, pp. 5202-4; XTS 217A, pp. 6117-9; 224A, pp. 6367-8; ZZTJ 222, pp. 7131-40. 
When he arrived to join the campaign in 762 , he was met by the Tang Prince of Yong, the future Dezong. An Uighur official insisted that the Prince should perform a ceremonial dance in front of the qaghan on the grounds that the qaghan had the status of a younger brother of the Tang Son of Heaven, which would oblige the Prince to pay his respects to his uncle, the qaghan.

Yao Zi'ang, a Tang official, sought to excuse the prince on the grounds that he was in mourning for the late emperors Xuanzong and Suzong, so it was not proper for him to perform a ceremonial dance. He also argued that the Prince of Yong, as the heir apparent, was a future Son of Heaven, and could not carry out such a rite in front of a foreign ruler. Upon hearing this, the Uighur official arrested Yao and three other Chinese officials, and gave each one hundred strokes of the rod. Two of them died as a result. ${ }^{34}$ Although the Prince of Yong stopped his officials from attempting to retaliate since Tang needed the Uighurs' assistance, he remembered the humiliation and later as emperor tried to break off the alliance with the Uighurs.

During the campaign against Shi Chaoyi, the Uighurs engaged in heavy plunder. After they had taken the eastern capital, Luoyang, they pillaged the city and killed many people. At the capital, the Uighurs abused the Chinese officials, attacked the gate of the imperial city and broke into the Court of State Ceremonials. On their way back they plundered the people of the surrounding areas. ${ }^{35}$

Despite all these disturbances, Daizong still extended official ranks and enfeoffment to the Uighurs. Both the qaghan and his wife, the qatun, were given honorific titles. Other high Uighur officials were given titles of nobility. Together they received a total office lands' income of 20,000 households. ${ }^{36}$ The court did not feel able to take a strong position toward the Uighurs.

In the unstable situation that prevailed at the time, there was always the possibility that the Uighurs might abandon the alliance and join the Tibetans or some other anti-Tang force. In 763, as a result of private feuds and a lack of trust and understanding within the Tang government,

\footnotetext{
${ }^{34}$ JTS 195, pp. 5203-4; XTS 217A, p. 6118; ZZTJ 222, p. 7133; CFYG 997, pp. 11703-4.

${ }^{35} J T S 134$, p. 3690 ; 195 , p. 5204 ; XTS 155 , p. 4884; 217 A, p. 6119 ; ZZTJ 222, p. 7135 ; pp. 7140-2.

${ }^{36}$ JTS 195, p. 5204; XTS 217A, p. 6119; ZZTJ 223, p. 7145; CFYG 965, pp. 11350-1. JTS 195 says that the tax income was from 2,000 households but XTS 217A and CFYG 965 record the number as 20,000 . Other sources do not give any number.
} 
Pugu Huaien did not lead his troops to assist the court when it faced the crisis of the Tibetan invasion, and in 764 he rose in rebellion against Tang. His connections with the Uighurs, which had served Tang well in the past, he now turned to his own advantage. He found ready support not only from the Uighurs but also from Tibet, and led them as part of a joint force against the Tang capital. He retreated when he encountered a determined defending army under the command of Guo Ziyi. ${ }^{37}$

The following year, he again led a combined force of Uighurs, Tibetans, Dangxiang Qiang and Tuyuhun against Chang'an. When Pugu fell ill and died suddenly en route, the Uighurs and the Tibetans disputed the leadership. Taking advantage of this discord in the enemy camp, Guo Ziyi succeeded in persuading the Uighurs to leave the Tibetans, and after a sworn covenant was made between Guo and the Uighurs the two joined forces, inflicting a heavy defeat on the Tibetans in two battles. Thus was the danger for Chang' an relieved. ${ }^{38}$

To reward the Uighurs for returning to join Tang against the Tibetans as well as to pay for Uighur horses, the court had to give up as much as 100,000 rolls of silk. As a result, the treasuries were empty, obliging the court officials to give up their salaries. In the following months, the emperor had to use the taxes paid for exemption from corvée labor to pay the officials and then had to tax the officials' income from this source for three months in order to supply the Uighurs. ${ }^{39}$

The policy of alliance with the Uighurs was of vital importance in turning a potential enemy into an ally, first against Shi Chaoyi and then against the Tibetans, but it was achieved at a high price. Some modern scholars have, therefore, questioned the merits of Daizong's acquiescent attitude. ${ }^{40}$ It would certainly have been ideal if the court could have relied on its own forces to suppress the rebels, but the Tang court was so weak that it was desperate for help from any possible source. Faced with Tibetan aggression, it could not afford to have the Uighurs as yet another enemy. It had to make peace and ally itself with the less threatening power in order to maintain the dynasty.

37 JTS 121 , pp. 3477-8; XTS 224A, pp. 6365-6; ZZTJ 223, p. 7166; pp. 7167-9. For details of Pugu Huaien's career and rebellion, see Peterson 1970-71, pp. 423-55; 1979, pp. 490-1.

${ }^{38}$ Mackerras 1972 , pp. 26-9.

39 JTS 195, pp. 5206-7; ZZTJ 223, p. 7184; Mackerras 1972, p. 84.

${ }^{40}$ Mackerras 1972, p. 35; Moses 1976, p. 79. 
Also, during the early part of his reign, Daizong continued to face the problem of both a severe shortage of funds and the challenge from the semi-independent warlords at a time when the court was only beginning to rebuild a military force under its own control.

In contemporary records of the court discussions we do not find objections raised against the compromise made by the court, although the marriage alliance policy was criticized in an unofficial way. Upon the return of Princess Ningguo to Tang in $759, \mathrm{Du} F u$ wrote a poem lamenting: "We hear that even the Uighurs were defeated [in the battle with the antiTang rebels]; So the marriage alliance did not turn out to be advantageous." 41 Rong Yu, a prefect in the early 780 's, wrote a poem implying that it was shameful that China had to rely on women to achieve peace.

In the history of Han

The clumsy plan was heqin [marriage alliance].

The state depended on an enlightened ruler

But security was entrusted to women.

How could one plan to use beautiful faces

To calm the barbarian turmoil?

Among the bones underground for a thousand years

Who were the supporting ministers? ${ }^{42}$

Daizong continued all the measures of appeasement almost to the end of his reign. In 769, at the request of the Uighurs, Daizong bestowed the title of Princess Chonghui on another daughter of Pugu Huaien and married her to the qaghan as his second wife. Twenty thousand rolls of silk were given. Because of his lack of financial resources, Daizong taxed some mules and camels from the dukes and court ministers and gave them to Princess Chonghui for her transport. ${ }^{43}$ In 772 , when an Uighur prince who had been in the Tang Imperial Guard was about to die, he was given the title of commandery prince and the royal surname Li. The cost of his funeral was borne by the Tang court. ${ }^{44}$ In 777 the wife of an Uighur Chief Minister was rewarded with the posthumous title of Consort of the Min State (minguo furen). ${ }^{45}$

\footnotetext{
${ }^{41}$ Mackerras 1972 , p. 137 , note 70.

${ }_{42}^{42}$ QTS 270, p. 674.

43 JTS 11, p. 293; XTS 217A, p. 6120; ZZTJ 224, p. 7208.

44 JTS 11, p. 299; CFYG 976, p. 11461.

${ }^{45}$ CFYG 976, p. 11462.
} 
The court made great efforts to accommodate the Uighurs in the horse-silk trade. The Uighurs yearly sent 100,000 horses, for which they were paid over a million rolls of silk. China's financial resources were exhausted and were in arrears every year. ${ }^{46}$ Since Tang could not afford to pay for all the horses sent to China, many of the Uighur envoys stayed in the Court of State Ceremonials in Chang'an waiting for the payment and causing the Chinese a great deal of trouble in Chang'an.

The Chinese sources record in detail the "illegal" deeds of the Uighurs: in 771 or 772 they came out of the Court of State Ceremonials without permission into the market places, kidnapped children and beat the Chinese officials who tried to stop them. Three hundred Uighur cavalrymen even attacked the gates of the imperial city. Again in 772 , they came out of the Court of State Ceremonials, performed brutal deeds in the marketplace and abused the magistrate of Chang'an. ${ }^{47}$

In 773, Daizong decided to buy all the horses, probably with the purpose of inducing the Uighur envoys to leave, but an Uighur envoy brought in 10,000 more horses for trade. The officer in charge suggested that the court buy 1,000 only. Guo Ziyi was afraid that this would offend the Uighurs and therefore offered to donate one year's salary to pay for all the horses. Daizong did not agree and decided to only increase the number purchased to $6,000 .^{48}$ The Uighurs did not, however, seem to be satisfied.

In 774 the Uighur envoys in Chang'an again came out of the Court of State Ceremonials and killed some Chinese civilians. They were arrested by the Chinese officers but Daizong set them free without any punishment. $^{49}$ The next year they again came out, killing some Chinese. After they were imprisoned, other Uighurs broke into the jail and rescued them. Daizong once more ignored the incident. ${ }^{50}$

To reinforce their bargaining position with the Chinese, in 775 the Uighurs made an incursion into Xiazhou, ${ }^{51}$ and in 778 they raided Taiyuan, plundering Chinese livestock. Daizong did not question the Uighurs about the invasion. Soon another conflict occurred when the Uighur en-

\footnotetext{
46 JTS 195, p. 5207; XTS 51, p. 1348; 217A, p. 6120.

47 JTS 195, p. 5207; XTS 217A, pp. 6120-1; ZZTJ 224, p. 7218; p. 7219; CFYG 997, p. 11704.

48 JTS 120 , p. $3464 ; 195$, p. 5207 ; XTS 137, p. 4607 ; 217A, pp. $6120-1$; ZZTJ 224, p. $7221 ;$ p. 7224.

49 ZZTJ 225, p. 7228; CFYG 997, p. 11704.

50 JTS 195, p. 5207; XTS 217A, p. 6121; ZZTJ 225, p. 7232; CFYG 997, p. 11704.

${ }^{51}$ ZZTJ 225, p. 7236.
} 
voys were robbed as they passed Hezhong at the southeastern bend of the Yellow River on their way back home. This time the provocation was on the part of the Chinese. ${ }^{52}$

Toward the end of his reign Daizong tried to take a firm stand. $\mathrm{He}$ decided to strengthen frontier defenses against the Uighurs and gave a secret order to Zhang Guangsheng, the Commander of the Zhenwu Army (in present Tuoketuo county, Inner Mongolia), to work out a plan to ward off the Uighurs. ${ }^{53}$

\section{Dezong: Deterioration in Tang-Uighur Relations, 779-787}

After Dezong came to the throne in the middle of 779 , he chose to make an alliance with Tibet rather than the Uihgurs. He still harbored resentment toward the Uighurs. The memory of the humiliation he suffered in 762 as prince at the hands of the Uighur qaghan was still fresh. Before 787 he did not make particular efforts to cultivate the alliance, which as a result deteriorated.

Soon after the death of Daizong in 779 , the Sogdians, who were very influential in Uighur state politics, persuaded Bögü Qaghan to take advantage of the situation while China was in mourning to launch a military incursion. The qaghan mobilized his entire nation for an expedition. But he was opposed firmly by his Chief Minister Dun Mohe Dagan (Ton? Bagha Tarqan ${ }^{54}$ ), who preferred keeping a friendly relationship with Tang.

The Chief Minister's opposition to the qaghan seems also to have resulted from his anti-Sogdian and anti-Manichean attitude. The Manichean religion was favored by the qaghan. ${ }^{55}$ Failing to dissuade the qaghan from the campaign, Bagha Tarqan staged a coup d'état, killed the qaghan and two or three thousand of his followers, including many Sogdians, and established himself as qaghan (r. 779-789). He sent an embassy to Tang, expressing, according to the Chinese records, his wish to continue to be a Tang subject. In response, Dezong sent Yuan Xiu as a commissioner to give the certificate of appointment as qaghan to Bagha Tarqan. ${ }^{56}$

The establishment of Bagha Tarqan as qaghan could have been good for Tang, since he was opposed to an aggressive policy, but Dezong

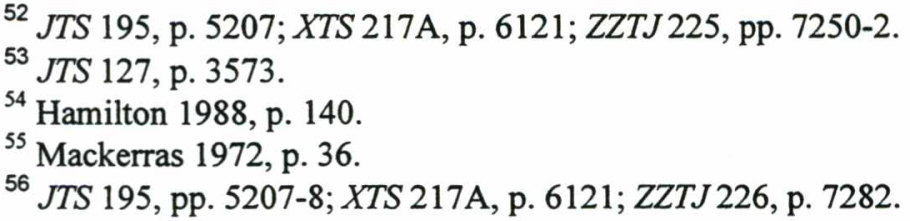


did not take the opportunity to develop a better relationship. In 780, when the Uighur envoys, who had previously been in Chang'an, were on their way back home, they stopped at the border post of the Zhenwu Army for several months. They were headed by Tudong, who was Bagha Tarqan's uncle. When they heard of the coup d'état, the Sogdians among them did not want to go back to the new qaghan, but being under close watch by Tudong, they could not flee. They tried to persuade Zhang Guangsheng, the Commander of the Zhenwu Army, to attack Tudong and his followers.

As mentioned above, Zhang had previously been instructed by Daizong to work out a plan to ward off the Uighurs. He presented three memorials, suggesting that the court take advantage of the situation and eliminate the Uighurs at Zhenwu. Dezong did not agree to his proposal, but Zhang went ahead anyway, making an attack on the Uighur party in the eighth month of 780. As a result, Tudong and his people, 900 in all, were killed. Under pressure from the Uighurs, Dezong recalled Zhang Guangsheng and reduced him in rank as punishment. ${ }^{57}$ Zhang knew Dezong's personal hatred of the Uighurs. The fact that he dared commit such a massacre may imply the court's acquiescence.

Despite others' urging vengeance on the Chinese, Bagha Tarqan was not willing to start any direct confrontation with Tang. Instead, he requested through the Tang envoy that Tang should pay its debt in the horsesilk trade of 180,000 rolls of silk immediately as compensation. This suggests the instability of his position even early in his rule. In 782, Dezong ordered the payment of 100,000 rolls of silk, and 100,000 liang of gold and silver for the Uighur horses. ${ }^{58}$

During the time of the revolts of the Military Commissioners in 781-786 touched off by Dezong's firm policy towards the semiautonomous regional commands, the Uighurs were enticed to aid Zhu Tao, the Military Commissioner of Youzhou. Zhu Tao had married an Uighur lady and the Uighurs helped him in several battles, presumably with the primary purpose of obtaining plunder.

Mackerras conjectures that the Uighur leader who supported Zhu Tao was probably related to Zhu's Uighur concubine or belonged to the faction which wanted to avenge Zhang Guangsheng's massacre, and that tribal allegiances were at the root of this curious case of Uighur assistance. Mackerras further surmises that a local leader probably did it behind

57 JTS 11, 326; 127, pp. 3573-4; XTS 217A, pp. 6120-1; ZZTJ 226, pp. 7287-8.

58 JTS 127, p. 3575; XTS 217A, p. 6122; ZZTJ 227, pp. 7330-1. 
Bagha Tarqan Qaghan's back. ${ }^{59}$ His conjecture is plausible, since there were often conflicts between a nomadic ruler and his followers over their attitudes towards China. In any case; the Tang court sent an envoy to the Uighur ruler after the submission of Zhu Tao in 784 to patch up the relationship. The Uighurs then sent envoys to Tang. ${ }^{60}$

\section{Alliance with the Uighurs Against Tibet, 787-804}

Dezong's policy of alliance with Tibet proved to be a failure when the Tibetans kidnapped Chinese officials in the treaty conclusion ceremony in $787 .{ }^{61}$ Yet in 787 , when the Uighurs asked for a marriage contract with Tang, Dezong refused, for he was still brooding over his resentment for the humiliation of 762 . Li Mi, Chief Minister, urged the emperor to consider a policy of resuming alliance with the Uighurs against Tibet, as well as alliances with the Nanzhao kingdom, the Arabs and India. He saw the Tibetans as more to be feared than any of these other peoples. It was also Li Mi who suggested in 784 that the Tang court should not reward the Tibetans with land as promised.

Li Mi had fifteen discussions with the emperor, in which he persisted in this line of argument. He realized that the Uighurs were at that time eager to contract a marriage with a Chinese princess, and therefore suggested that the court should lay down the following conditions for such a marriage alliance: 1) the Uighurs should call themselves subjects of Tang; 2) the qaghan should have the status of a son to the Tang emperor; 3) each Uighur embassy should not exceed 200 people; 4) the horses sent to Tang for trade should not exceed 1,000 annually; 5) the Uighurs should not escort Chinese and foreign merchants outside the Tang frontiers.

Dezong expressed his doubts over the possibility of Uighur acceptance of such a proposal on the grounds that Tang had been on bad terms with the Uighurs, and that when the Uighurs heard about the "False Treaty of Pingliang" of 787 , they might very well refuse the Tang request for peace. If they did, Dezong feared that Tang would be laughed at by the "barbarians." He doubted that having previously been a brother state of Tang, the Uighurs would want to accept vassal status.

Li Mi seems to have known very well how much the Uighurs desired a peace agreement. Finally Dezong was persuaded and was delighted

\footnotetext{
${ }^{59}$ Mackerras 1972, pp. 39-41.

${ }^{60}$ Lu Xuangong Hanyuanji 10, pp. 65-6; CFYG 980, p. 11514.

${ }^{61}$ See Chapter 11.
} 
when he heard that the qaghan had agreed to all five conditions. The Emperor thereupon promised to send his own daughter, Princess Xian'an, to marry the qaghan and paid 50,000 rolls of silk for the Uighur horses.

The alliance was resumed. The Uighurs showed enthusiasm for the change. In 788 Bagha Tarqan Qaghan sent an embassy of a thousand to Tang to receive the Chinese princess. During their stop in Zhenwu on the Tang border, when the Xi, Khitan and Shiwei attacked Zhenwu, the Uighurs helped Tang mount a counter-attack. When they arrived at the Tang court, their envoys presented the qaghan's memorial, expressing his wish to help Tang to defeat the Tibetans. The qaghan requested to change the name of the Uighurs in Chinese characters from Huihe to Huihu, since the character $h u$ meant swift birds of prey, like falcons. A court minister accompanied the other Tang officials who were sent to escort Princess Xian'an to the Uighurs. He was sent to bestow honorary titles on Bagha Tarqan and on Princess Xian'an as his qatun. ${ }^{62}$

There may be some exaggeration in the account in the Zizhi Tongjian of Li Mi's conversations with the emperor and of the importance of his role in the peace agreement with the Uighurs, in which we read that he claimed to have a good personal relationship with the Uighur Chief Minister and so was confident that he could persuade the Uighurs to accept Tang's conditions for peace. One should note that the Uighurs had their own reasons for making peace. Also, the Zizhi Tongjian incorporated a major part of its information from the Yehou Jiazhuan, a family biography of Li Mi, written by his son Li Fan, who may have intentionally glorified his father's role. ${ }^{63}$ Nonetheless, we should not dismiss the whole of the account as fiction and reject conceding any role for $\mathrm{Li} \mathrm{Mi}^{64}$

The year 788, when the marriage alliance was made between the Chinese and the Uighurs, was a significant turning point in the history of Tang's relations with the Uighur empire. Before her death in 808 , Princess Xian'an married four Uighur qaghans in succession. ${ }^{65}$ Until 840 , when the Uighur empire collapsed under the attacks of the Kirghiz, there was no military confrontation between Tang and the Uighur empire.

62 JTS 130, p. 3629; 195, p. 5208; 199B, p. 5354; XTS 217A, pp. 6123-4; ZZTJ 233, pp. 7501-6; pp. 7514-5; p. 7516.

${ }^{63}$ ZZTJ 231, p. 7456; Junzhai Dushuzhi 9; Mackerras 1972, p. 3; p. 156, note 159; Dien 1974 , p. 236.

${ }^{64}$ Lü Simian (1959, pp. 313-4) holds that the account by Li Mi's son is not reliable and therefore dismisses the role of $\mathrm{Li} \mathrm{Mi}$.

${ }^{65}$ XTS 217A, p. 6126. 
Moreover, the peaceful relationship between Tang and the Uighurs joined the two as the common enemy of Tibet in the Western Regions. The Uighurs had early on been interested in the Western Regions. In 758, they defeated the Kirghiz, occupied some of their territory and cut off Kirghiz communication with Tang. This pushed the Kirghiz into seeking alliances with the Qarluq as well as the Tibetans and Arabs in pursuit of international trade and the lines of communication to gain access to such trade. $^{66}$

For their part, the Chinese had learned in 781 that some of their armies in the Western Regions were still holding out against the Tibetans, when Li Yuanzhong, the Military Commissioner of Beiting, found he could send messengers to Chang'an via Uighur territory. ${ }^{67}$ This route provided a way around the Tibetan stoppage of the Silk Road to Chang'an. It also provided the Uighurs with an opportunity to exercise control over both Beiting and communications between the Western Regions and Tang.

Beiting was a strategically important place on the Silk Road, and whoever occupied the city would obtain economic benefits. Once they took control of the place, the Uighurs imposed exorbitant fees on the merchants engaged in this trade. The Shatuo people, who were of Turkish origin and had been dependents of Beiting, and the three tribes of the Qarluq and the so-called White-clothed Turks who had been subjects of the Uighurs, strongly resented Uighur rule and secretly submitted to the Tibetans.

The Uighurs had their first direct clash with the Tibetans in 789. In the winter of that year the Tibetans, with the assistance of the Shatuo and other Turks, attacked Beiting and brought it under their control. In the autumn of 790 the Uighurs mobilized a large number of troops, said to be every adult male in the nation and, joined by a Chinese army commanded by Yang Xigu, the Protector-general of Beiting, launched an expedition to recover Beiting. But this campaign ended in a disastrous failure. For some unknown reason, Yang Xigu was later murdered by the Uighur general, thus ending Chinese control in the area.

In 791 the Uighurs succeeded in driving back a Tibetan invasion of Lingzhou and retaking Beiting, and they continued their successful attacks

\footnotetext{
${ }^{66}$ Li Futong 1963, pp. 60-1; Beckwith 1987, pp. 147-8.

${ }^{67}$ The Chinese sources display some confusions about the date 781, at least according to an opinion common among modern scholars, see Haneda 1957, pp. 212-3; Mackerras 1972, p. 163, note 199.
} 
on the Tibetans in the following year. ${ }^{68}$ This conflict between the Uighurs and Tibet over Beiting unquestionably eased Tibetan pressure on China.

\section{The Uighur Alliance Kept: Reasons and Effects, 805-840}

After the death of Dezong in 805, the Tang court kept up the Uighur alliance despite perturbations caused by Uighur behavior. Whenever Uighur delegations passed the Tang frontier on their way to the Chinese capital or to engage in trade, the Chinese were on their guard for fear of disturbances. They always received and sent the Uighurs off under surveillance by strong military escorts. ${ }^{69}$ When the Uighurs made raids along the way, only a few Chinese frontier officials were able to stop them. ${ }^{70}$

The Tang court, nevertheless, tried to maintain the peace. Between 805 and 839 , there were five Uighur rulers on the throne. All routinely received investiture with the title of qaghan from the Chinese. ${ }^{71}$ When a qaghan died, the Chinese court very often observed the rite of suspending court business for three days. Civil and military officials ranking third level and above went to the Court of State Ceremonials to mourn the deceased qaghan. ${ }^{72}$ Diplomatic embassies went back and forth frequently. ${ }^{73}$

The Uighurs, for their part, only accepted vassal status in a nominal way. Just like the Xiongnu and the Turks, they had their own ideological perspective on their position vis-à-vis the Chinese. The Shine-usu inscription begins: "The wise qaghan, born from heaven to govern the people." ${ }^{, 74}$ The Chinese part of the Karabalghasun inscription also refers to the Uighur ruler as "Heavenly Qaghan", 75 the title Tang Taizong had assumed for himself. Even the Chinese at home acknowledged the Uighur ruler's assumption of such a title. The imperial edict to the Uighur ruler written by Bai Juyi on behalf of Emperor Muzong in 821 says to the man Bai must still deep in his soul have thought of as a barbarian chief:

Though you honor yourself as the favored Son of Heaven, it does not yet match up to the fullness of your merit. Though you honor yourself as

\footnotetext{
${ }^{68}$ Haneda 1957, pp. 217-21; Beckwith 1987, pp. 152-7.

${ }^{69}$ ZZTJ 244, p. 7870.

70 JTS 180, p. 4675; XTS 212, p. 5978; ZZTJ 244, p. 7885.

${ }^{71}$ Haneda 1957, pp. 301-2.

${ }^{72}$ CFYG 976, pp. 11462-6.

${ }^{73}$ Mackerras 1969, pp. 231-8.

${ }^{74}$ Wang Jingru 1938, p. 26.

${ }^{75}$ Haneda 1957, pp. 308-9.
} 
Heavenly Qaghan, it does not yet fully express your excellence. It is right that we bestow on you a splendid title in order that you can boast your fame to later generations.

The letter not only recognized the title of Heavenly Qaghan, but also tried to woo the Uighurs and make them believe that the Chinese conferring that title on their ruler could enhance their prestige. The letter does not insist on a Chinese claim to superiority, which shows a tremendous change in the Chinese attitude towards the Uighurs between Taizong's time and the later Tang period.

Fully aware of the Uighurs' strength and their actual equal status in the mutual relationship, the Chinese realistically maintained a distrustful, suspicious and cautious attitude toward them. In a court discussion with Xianzong in 809, Li Jiang, then a Hanlin academician, opposed a bellicose policy towards the Hebei separatist Wang Chengzong for fear that the Uighurs and the Tibetans would take advantage of the situation and launch attacks which would place the Tang troops fighting in Hebei in great danger. In 810 , Bai Juyi, then serving as a remonstration official, made the same argument in a memorial. ${ }^{77}$

In 813 , when the Uighurs requested a marriage contract, Xianzong at first refused on the grounds that the marriage would be very costly and that he was preoccupied with expensive internal campaigns against the independent Military Commissioners. In the winter of the same year, the Uighurs attacked the Tibetans in Liugu and several thousand Uighur cavalry men reached Piti Spring, near West Shouxiang Fortress. The Chinese frontier official was alarmed when he reported this development to the court, but it appears that the Uighur expedition was indeed intended only against the Tibetans. ${ }^{78}$

At the court, Li Jiang, Chief Minister from 811 to early 814 and now Minister of Rites, proposed that the Uighur request for a marriage be

${ }^{76}$ Baishi Changqing Ji 33, p. 167.

${ }_{77}$ Baishi Changqing Ji 42, pp. 225-6; ZZTJ 238, p. 7664; p. 7673.

${ }^{78}$ JTS 148, p. 3996; ZZTJ 239, pp. 7701-2. Haneda (1957, pp. 221-2) argues that the Uighur arrival at Piti Spring was to press Tang to agree to a marriage contract. Mackerras (1972, p. 44) and Beckwith (1987, pp. 164-6), however, do not agree. Beckwith maintains that this demonstration was intended more for the Tibetans than for the Chinese. It was a response to an event four years earlier when the Tibetans went via Piti Spring to plunder an Uighur embassy in the Dashi valley. Given the overall balance of power between the three states, China, Uighur, and Tibet, Beckwith's opinion is the more credible one. 
accepted lest the Uighurs invade or make an alliance with the Tibetans. Moreover, according to $\mathrm{Li}$, the Tang frontier defense system was so weak that peace was much preferable to hostility. A marriage alliance would have three advantages: 1) it would bring peace to the frontier and allow the troops there to build up their strength; 2) it would allow the court to concentrate on dealing with internal rebels; and 3) an alliance with the Uighurs would stir up more distrust and hatred between the Uighurs and Tibet, of which Tang could take advantage.

However, Xianzong still did not agree, since the marriage would cost as much as five million strings of cash. Li Jiang insisted that spending tax revenues for the marriage would be less costly than starting a war with the Uighurs. In 820, toward the end of his reign, when China's internal situation had become calm and Tibet was making continuous attacks, Xianzong finally changed his mind and permitted the marriage to go forward. $^{79}$

Mackerras holds that the difficulty in coming to a decision was because of a struggle within the court between Li Jiang and his enemy, the powerful eunuch Tutu Chengsui, who was a great advocate of the use of military force in settling problems, and that it was Tutu's fall that resulted in the change on Xianzong's part. ${ }^{80}$ It is possible that Li Jiang and Tutu had different opinions regarding the marriage, but we should note that the Chinese sources never mention Tutu's supposed intention to use military force to settle the Uighur problem, nor do they record him as opposed to the marriage. Tutu was charged with the responsibility of eliminating the military governors of Hebei, and it may be that it was his demands for funds to carry out this task that made Xianzong delay in agreeing to the marriage proposal.

The marriage finally took place in 821 under the next emperor, Muzong. Tang sent Princess Taihe, the daughter of Xianzong, to the Uighur qaghan. The Uighurs sent a large delegation to receive the princess. ${ }^{81}$ The marriage strengthened the peace between the two states, but by this time the need and the willingness of Tang to rely on the Uighurs for suppressing internal disorders had lessened. When, shortly after the marriage, the Uighurs offered to assist Tang in suppressing some internal reb-

\footnotetext{
${ }^{79}$ JTS 195 , pp. 5210-1; XTS 152, p. 4843; 217A, pp. 6126-7; 217B, p. 6129; ZZTJ 239, p. $7704 ; 241$, p. 7779.

${ }^{80}$ Mackerras 1972, p. 45 ; pp. 176-7, note 268.

81 JTS 195, pp. 5211-2; XTS 217B, pp. 6129-30; ZZTJ 241, pp. 7791-2.
} 
els, the court discussed the matter and decided to refuse, recalling with bitterness how on previous occasions the Uighurs had demanded exorbitant compensation for such help. Emperor Muzong sent an envoy to stop the Uighurs, who had already reached Fengzhou and did not wish to return. Only when Tang gave them 70,000 rolls of silk, did they leave. ${ }^{82}$ In the end, the court decided to come to terms with the rebellious separatists.

How could the alliance have survived as long as it did despite all the distrust on both sides? The reasons, which are complex, reflect the interests of both the Chinese and the Uighurs within the particular international and domestic situations each faced.

For their part, the Chinese were well aware that the Uighurs were involved in frequent struggles with Tibet and other non-Chinese peoples over control of the Western Regions, and were also competing persistently with each other for commercial reasons. If the court was to benefit from a situation which set "barbarians against barbarians," it made sense for it to keep up good relations with the Uighurs.

The horse-silk trade functioned to keep the Uighurs a relatively peaceful neighbor. The court continued the horse-silk trade at considerable expense: the total amount of silk that was paid as the price for the Uighur horses from 780 to 829 was over $2,012,000$ rolls. ${ }^{83}$ It has often been considered an onerous burden without much benefit for China. The Tang accounts indicate that the Chinese considered the horse-silk trade as a favor that they extended to the Uighurs, while the Uighurs believed that the Chinese owed them a debt for their past military assistance which they had to repay by buying horses. ${ }^{84}$

A letter written by Bai Juyi on behalf of Xianzong to the Uighur qaghan in about 809 says that according to the document sent by the Uighurs, they were to send 6,500 horses, but the horses that had arrived and had been branded amounted to 20,000 and were worth 50,000 rolls of silk, but that China could only pay 25,000 rolls of silk for these 20,000 horses. The letter also expresses the wish to have a fixed agreement concerning the horse-silk trade so as to keep a good relationship with the Uighurs. ${ }^{85}$

${ }^{82}$ JTS 195, p. 5212; XTS 217B, p. 6130; ZZTJ 242, p. 7815.

${ }^{83}$ Mackerras 1969, pp. 238-9.

${ }^{84}$ For these disputes, see JTS 146, p. 3962; XTS 151, p. 4819; 159, p. 4951; ZZTJ 224, p.

7201; p. 7208; CFYG 980, p. 11513.

${ }^{85}$ Baishi Changqing Ji 40, p. 217. 
During the decade 820-830 alone, a time when the Uighurs were in decline, the silk paid from China exceeded the amount during the much longer time when the Uighurs were strong. Mackerras believes that the difference in the amount of trade for that period and other periods might not be so great as the sources indicate. Records for other periods might not be complete. He also thinks that the Chinese paid for unwanted horses out of their fear of the Uighurs. ${ }^{86}$ Moses suggests that it was their ignorance of the Uighur decline, and their ongoing fear of the Uighurs that made the Chinese continue to send them enormous amounts of silk. ${ }^{87}$

One should not forget, however, that China always needed horses, especially after losing its good pastures in the Longyou region to Tibet as a result of the An Lushan rebellion. Purchase seems to have been the way selected by the Tang government to meet this demand. The questions then are how many horses Tang needed, and whether it could afford to buy as many as it wanted. In 787, when Tang decided to change its pro-Tibetan policy to one of seeking an alliance with the Uighurs, one of the supporting arguments for the change was that China was in need of horses. $\mathrm{Li} \mathrm{Mi}$, the advocate of the pro-Uighur policy, said that if Tang adopted the policy of the Uighur alliance, the price of horses inside China would decrease by ten times (90 per cent) within a few years. ${ }^{88}$ In 815 and 816 , according to the Chinese records, a large quantity of silk was given to the Uighurs in payment for horses.

Mackerras holds that it was because the court deemed it wise to pay up as a means of discouraging the feared invasion. ${ }^{89}$ But the fact was that in 816 the court did need to buy horses for a campaign to suppress an internal rebellion started by a Military Commissioner. It sent eunuch envoys to purchase horses in the Hequ region (in modern Shanxi) with 20,000 rolls of silk. Upon the arrival of Uighur horses, the court paid 60,000 rolls of silk for them. ${ }^{90}$ In 842 , when the court decided to attack the Uighurs, it had to purchase horses from other non-Chinese along the border. $^{91}$

It is, therefore, plausible to conclude that China kept the horse-silk

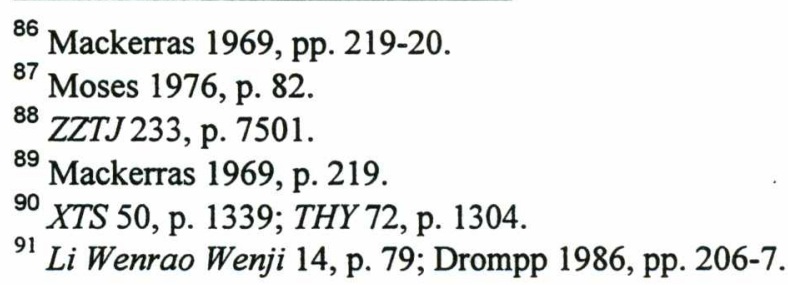


trade not only because the trade would make the Uighurs a peaceful neighbor, but also because China itself did need horses, though it often could not afford to purchase a great number of them.

On the side of the Uighurs, in 779 and 790, there were succession crises, ${ }^{92}$ which might have made each of the contenders for power over the Uighur state to hope for peace with Tang. Also, the Uighurs would have wanted to maintain peaceful relations with Tang because of their own competition with Tibet, as we have seen. Several battles between the Uighurs and Tibetans took place between 808 and 821 .

The first two decades of the ninth century were, under Baoyi Qaghan (r. 808-821), a time of renewed strength and prosperity for the Uighur empire. ${ }^{93}$ Their dominion expanded to its greatest east-west extent, and cities like Beiting, Xizhou, Kucha and Karashahr became dependencies of the Uighurs. All of these cities were important posts on the Silk Road. $^{94}$

The conflict between the Uighurs and Tibet over Beiting may have made the Tibetans decide to conclude the peace treaty with Tang in 821 . Following their sworn treaty with China in 821 , the Tibetans made a peace agreement with the Uighurs and with the Nanzhao kingdom as well. ${ }^{95}$ From then on, hostilities between the Uighurs and Tibet seem to have lessened.

Perhaps the most fundamental reason for the Uighurs' making peace with China was that through their contacts with China they underwent a gradual transformation from their nomadic life to a more settled, city life-style. Earlier the Uighurs, unlike the Turks, had kept up rather peaceful relations with China, and during their time of empire the military assistance they gave Tang made the Chinese rulers eager to accommodate their demands for trade, provision of goods and marriage contracts. Although the immediate motive of the Chinese was to purchase military assistance and peace in the frontier regions rather than to deliberately try to change the nature of the nomads, in the long run, these measures did have such an effect.

\footnotetext{
${ }^{92}$ Haneda 1957, pp. 234-8; Moses 1976, p. 81.

${ }^{93} \mathrm{He}$ is known as Ai tängridä qut bulmïsh alp bilgä Qaghan in the inscription of Karabalghasun. Hamilton 1988, p. 141.

${ }^{94}$ Haneda 1957, pp. 220-30; Mackerras 1972, p. 12; Beckwith 1987, pp.163-7.

${ }^{95}$ Li Fang-kuei 1955, pp. 22-3; Richardson 1969, p. 35; Szerb 1983; Beckwith 1987, p. 167.
} 
In his study of the Xiongnu empire, Barfield points out the success of the Xiongnus' China policy, which was aimed at exploiting the Han state from a distance, and which also set up a model for the later nomadic empires of the Turks and the Uighurs. He correctly concludes: "Without the Chinese economy to exploit, there could have been no great Xiongnu state." ${ }^{.96} \mathrm{He}$ also points out that the Uighurs were successful in employing the same outer frontier strategy of exploiting China at a distance. ${ }^{97}$

There was, however, one important inherent weakness in this strategy, as Pulleyblank observes: Chinese goods could also represent a dangerous form of economic seduction, and one which could destroy the basis of nomadic military superiority. He further points out that the attraction of Chinese goods did in fact result in changes within the Xiongnu economy and society, which were reflected in their going over to city-building and development of a limited practice of agriculture. ${ }^{98}$ Barfield also concludes that city building with storage of goods as one of its purposes was a factor leading to the fall of the Uighur empire. ${ }^{99}$

The seductive power of Chinese goods was well recognized by both the Chinese and non-Chinese from early Han times onward. Zhonghang Yue, a Chinese of the Han dynasty who had defected to the Xiongnu, once gave the reasons for the advantage held by the nomads over the agricultural Chinese. He noted that the Xiongnu population did not amount to that of a single commandery of Han, yet they could coerce the Chinese because their food and clothing were different, and they needed nothing from the Chinese. He warned that if the chanyu changed his customs and grew to like Chinese goods, the Chinese could make the Xiongnu submit without burdensome expenditure. ${ }^{100}$ For their part, the Han Chinese believed that they could use Chinese goods to seduce the nomads and weaken their power, and therefore Jia Yi, the famous Han thinker, suggested the policy of "five baits," namely to provide material goods to the Xiongnu in order to corrupt them. ${ }^{101}$

The Turks realized that they should keep their distance from the Chinese, fully aware of the seductive effect that Chinese goods could have

\footnotetext{
${ }^{96}$ Barfield 1981, p. 59.

${ }^{97}$ Barfield 1989, p. 151.

98 Pulleyblank Forthcoming.

${ }^{99}$ Barfield 1989, pp. 157-60.

${ }^{100}$ SJ 110, p. 2899; HS 94A, p. 3759.

${ }^{101}$ Yü Ying-shi 1967, pp. 36-7.
} 
on nomads, as is graphically described in one of the Old Turkish inscriptions. ${ }^{102}$ They intentionally kept their mobility. When Bilgä Qaghan of the second Turkish empire wanted to build walled towns, his minister Tonyuguq rejected the idea firmly on the grounds that the Turkish population was small, not equal to one percent of the Tang Chinese. But they could constantly resist Tang precisely because they moved about, and therefore, when they were strong they could advance their forces and plunder, and when they were weak they could hide away in the mountains and forests. Though the Tang had large armies, they had no way to employ them. He warned that if the Turks built towns, settled down and changed their old customs, once they suffered a defeat, they would certainly be swallowed up by the Chinese. ${ }^{103}$

The Uighurs felt secure in their own identity and took seriously to heart the lessons on the dangers of settled culture. Von Gabain points out that the Uighurs were confident of their power and ability to combine a nomadic and city life-style. Their founding father, Bayan chor, built a capital city, and the Uighurs built palaces and towns. ${ }^{104}$ Villages and agricultural production also developed. ${ }^{105}$ The presence of such things was noted by the Arabic traveler Tamim ibn Bahr, who visited the capital of the Uighurs and saw that

this is a great town, rich in agriculture and . . full of cultivation and villages lying close together. The town has twelve iron gates of huge size. The town is populated and thickly crowded and has markets and various trades. Among its population the Zindiq religion [Manichaeism] prevails. $^{106}$

The Zizhi Tongjian concludes that it was because of the rich rewards from the Chinese that the qaghan began to build palaces and as a consequence the Uighur customs deteriorated due to the newly luxurious life-style. ${ }^{107}$ City building must have gradually resulted in a loss of mobility, thus weakening the basic advantage of the nomads. But city-building became a

\footnotetext{
102 "The Kül Tigin Inscription." See Tekin 1968, pp. 261-2.

103 JTS 194A, p. 5174; XTS 215B, p. 6052; ZZTJ 211, p. 6722.

${ }^{104}$ Von Gabain 1949; Mackerras 1972, p. 13.

${ }^{105}$ Mackerras 1972, pp. 13-4. For more information concerning the changes the Uighur empire underwent, see Feng Jiasheng and others 1981, pp. 23-31.

${ }^{106}$ Minorsky 1947, p. 283.

${ }^{107}$ ZZTJ 226, p. 7282.
} 
necessity for them in order to store the goods they were accumulating.

The influence of the Sogdians was also a very important factor in the process of transition. The Sogdians were famous for their role in international trade on the Silk Road. Their role as intermediary merchants can be traced as far back as the Han dynasty. Such intermediary commerce had, therefore, long since become a way of life for the Sogdians. During the period of the Turkish empire, the Sogdians exerted important influences, both economic and political, on the Turkish rulers. ${ }^{108}$ In the time of the Uighur empire, their influence continued and became even more profound and penetrating. Many modern historians give evidence for this influence. $^{109}$

Although the Sogdians in 779 encouraged Bögü Qaghan to launch a military attack on Tang, for the most part, their role seems more to have been to stimulate Uighur interest in trade with China. The large quantities of silk that the Uighurs received through trade with China obviously could not all be consumed within the empire. Most of the silk products must have been re-exported to other states, or even sold to the Chinese frontier troops. ${ }^{110}$ Many Sogdian and Uighur merchants took up residence in Chang'an and became money-lenders. ${ }^{111}$ As their economy and state power depended more and more on trade with China, the Uighurs would naturally come to prefer peace rather than war.

It remains a question whether their conversion to Manicheanism "civilized" the Uighurs and reduced their belligerence. ${ }^{112}$ Bögü Qaghan was converted to the religion, perhaps through Sogdian priests, when he was in Luoyang in 763. In the trilingual inscription at Karabalghasun on the River Orkhon, Manicheanism is praised as a civilizing influence because it turned the Uighurs from a people who practiced "the abnormal custom of blood sacrifices into a region of vegetarians, from a state which indulged in excessive killing to a nation which exhorts righteousness." In the long run, the religion may have functioned to reduce the belligerence of the empire, but certainly not in the short run. Bögü Qaghan was the most aggressive in his policy towards China of all the Uighur qaghan. His

\footnotetext{
${ }^{108}$ Pulleyblank 1952; Mori Masao 1967, pp. 61-93.

${ }^{109}$ Feng Jiasheng and others 1981, pp. 28-9; Mackerras 1972, p. 10; Barfield 1989, pp. 157-60.

${ }^{110}$ Jagchid 1971, pp. 21-4.

${ }^{111}$ Mackerras 1972, pp. 48-9.

112 For example, Grousset (1970, p. 122) holds that the conversion to Manicheanism made the Uighurs less aggressive.
} 
reliance on the Sogdians and his consequent favoring of their religion caused resentment among his own people and led to his downfall in 779 when Dun Mohe Dagan overthrew the rule of Bögü Qaghan. ${ }^{113}$

\section{End of the Uighur Empire: China Abandons the Alliance, 840-847}

Between 832 and 840, a series of succession crises among the Uighurs gravely weakened their empire. In 840 , an Uighur general led 100,000 Kirghiz cavalry to attack the Uighur qaghan. The empire had already suffered a natural disaster, and this crushing blow caused its final collapse. The Uighurs dispersed.

One branch moved westward to the Hexi region, Kucha and the Qarluq area. ${ }^{114}$ Two other groups decided to go southward to China. One of them was headed by prince Wamosi (Ormïzt), Chief Ministers Chixin and Pugu, and Prince Najiechuo (Naghïd Chor). Another was led by Ögä Qaghan, enthroned in early 841 . These two groups were rivals. ${ }^{15}$

Chief Minister Li Deyu (in office 833-834; 840-847) played an important role in the decision-making process during this period, and on behalf of Wuzong, he drafted many important orders and letters pertaining to relations with the non-Chinese, ${ }^{116}$ which provide us with detailed information for the study of the events of this period.

Ormïzt's group arrived at the fortified town of Tiande, (near the great loop of the Yellow River), ${ }^{117}$ in the autumn of 840 and asked to submit to Tang. The imperial commissioner of the Tiande Army reported this to the court. Uncertain of the real intentions of the Uighurs, the court gave orders to reinforce the frontier defense. ${ }^{118}$ In the following year, the Imperial Commissioner of the Tiande Army, Tian Mou, and the Army Supervisor proposed an attack on this group with Tang troops being joined by the Tuyuhun, Shatuo Turks and Dangxiang, all traditional enemies of the Uighurs.

\footnotetext{
${ }^{113}$ Von Gabain 1949; Haneda 1957, p. 307; Mackerras 1972, pp. 9-10; p. 36; pp. 152-3, note 146; Feng Jiasheng and others 1981, pp. 34-6; Liu, S. N 1985, pp. 193-4.

114 Haneda 1957, pp. 265-71; Moriyasu 1977, pp. 105-30; Feng Jiasheng and others 1981, pp. 39-61; Yang Shengmin 1991, pp. 208-22.

115 Drompp 1986, p. 13.

${ }^{116}$ For a detailed study of Li's role in Tang-Uighur relations during this time, see Drompp 1986; for a detailed textual study of relations between Tang and the Uighurs from 840 to the end of Tang, see Haneda 1957, pp. 249-64.

${ }^{117}$ ZZTJ 239, p. 7700.

${ }^{118}$ ZZTJ 246, p. 7947; p. 7953; Haneda 1957, pp. 241-2; Drompp 1986, pp. 10-1.
} 
In the discussion at court, many agreed with this bellicose policy. Li Deyu, on the other hand, argued that the Uighurs had previously performed meritorious services for China and that therefore Tang should deal peacefully with them and make them submissive. The basic point in Li's argument was that the Tiande armies were not strong enough to launch an attack and if they were defeated, the walled town itself might be lost. At the same time, he believed that Tian Mou's plan was motivated by his wish for personal revenge against the Uighurs. Li insisted that no attacks should be launched, since the Chamberlain of the Court for State Ceremonials who was on a mission to investigate the situation, had not yet returned from the frontier, and no one was sure of the Uighurs' real situation.

Wuzong decided to follow Li's advice. ${ }^{119}$ In his letter to Ormïzt, Li Deyu, on behalf of the emperor, urged Ormïzt to support the newly established qaghan and withdraw from the Chinese frontier. ${ }^{120}$

Toward the end of 841, conflicts sprang up within Ormizt's group. Ormïzt informed Tian Mou of Chixin's intention to attack across the Tang frontier and, having enticed them into his encampment, Tian Mou killed Chixin and Pugu. Naghïd Chor fled eastward to Youzhou, hard against the Chinese frontier. Li Deyu suggested military action against him.

In the spring of 842 , armies under the Lulong Military Commissioner, now on good terms with the central government, decisively defeated Naghïd Chor. His troops received assistance from the Khitan and $\mathrm{Xi}$, who now turned to Tang. Naghïd Chor fled but was captured and killed by Ögä Qaghan. ${ }^{121}$ The Khitan were given Tang official titles in 842. ${ }^{122}$ Urged on by Li Deyu, the court decided to accept Ormïzt's submission. He was given official titles, his troops were reorganized as the Guiyi Army and the Li surname was bestowed on him and his brothers. ${ }^{123}$ In 843 , he asked for permission to return to the Tang capital from the frontiers, and his troops, the Guiyi Army, were ordered to disband. But the army refused to obey and, because considered rebellious, many of them

\footnotetext{
${ }^{119}$ Haneda 1957, pp. 241-2; Li Wenrao Wenji 13, pp. 68-9; Drompp 1986, pp. 20-5.

${ }^{120}$ Li Wenrao Wenji 5, pp. 25-6; Drompp 1986, pp. 28-31.

121 JTS 180, pp. 4677-8; XTS 212, p. 5980; ZZTJ 246, pp. 7959-62; Haneda 1957, pp. 243-8; Drompp 1986, pp. 56-8; pp. 108-11, notes 150, 151.

122 JTS 180, p. 4678; 199B, p. 5354; XTS 219, p. 6172.

${ }^{123}$ Li Wenrao Wenji 13, p. 73; ZZTJ 246, pp. 7960-3; pp. 7965-6; Drompp 1986, pp. 5865 .
} 
were executed. $^{124}$

Relations between the Tang court and Ögä Qaghan were more complex. The qaghan and his followers crossed the Gobi Desert to arrive at the Tiande Army on the Tang frontier in the winter of 841-842. The Chinese Princess Taihe, who had gone to marry the former Uighur qaghan, asked the Tang court to invest Ögä as qaghan and Ögä also sent a request for permission to settle in Tiande. ${ }^{125}$ Holding the Princess as a hostage, Ögä Qaghan repeatedly made requests for Tang supplies of food, for permission to borrow a frontier town, for Tang to hand over Ormïzt, and for support in recovering his political power. He also expressed concern for the Manicheans within China, whose temples in southern China had been closed by the Tang government.

Yet there is no evidence in the record to suggest that he really intended to submit to the Chinese. In response to all these requests, Tang only agreed to provide some grain. The court at first planned to recognize the qaghan's position. In the third month of 842 , an envoy was sent to deliver a diploma of appointment as qaghan to Ögä, but he was ordered to proceed at a leisurely pace and to wait until Ögä had firmly established his power before completing his mission. However, Ögä made constant raids on the Chinese frontiers. The envoy never did reach the Uighurs.

Evidently, the court did not intend to accept the Ögä Qaghan as the Han had accepted the Southern Xiongnu, the Sui the Eastern Turks under Qimin qaghan, or Tang Taizong the Eastern Turks. Instead, it urged the qaghan to leave the Chinese frontier and return to the region south of the Gobi. Since Ögä feared an attack by Naghïd Chor, the court eliminated the Naghïd Chor's group so that the qaghan would feel secure in returning to his land. It also sent full payment for the purchase of the horses he had delivered, hoping that the Uighurs would leave once they got the payment. ${ }^{126}$

Ögä refused to leave. His people continued to engage in raids on the Chinese border areas. ${ }^{127}$ It is clear that the Uighurs made these raids because they needed food supplies to survive. Seeing the weakness of the Uighurs, Li Deyu now proposed the use of force. This was also urged by $\mathrm{Du} \mathrm{Mu}$, the famous prose stylist, then holding office as Secretariat Drafter

\footnotetext{
${ }^{124}$ Li Wenrao Wenji 7, p. 39; ZZTJ 247, p. 7973; p. 7976; Drompp 1986, pp. 245-8.

${ }^{125}$ Haneda 1957, pp. 238-41; Drompp 1986, pp. 37-8.

${ }^{126}$ Li Wenrao Wenji 5, pp. 21-2; pp. 22-3; ZZTJ 246, pp. 7959-63; Drompp 1986, pp. 43-

50; p. 56; pp. 116-22; pp. 131-4.

${ }^{127}$ ZZTJ 246, p. 7963.
} 
(zhongshu sheren). ${ }^{128} \mathrm{Li}$ Deyu was also worried over the possibility of a Uighur-Tibetan alliance.

In the court discussions held in the latter part of $842, \mathrm{Li}$ Deyu's aggressive policy was opposed by his factional rival Niu Sengru, a former Chief Minister, but now with no actual power, who favored a defensive policy. Wuzong agreed with Li. The court decided to launch an attack the following spring with Ormïzt in command of the Qibi, Shatuo and Tuyuhun tribesmen, and the Military Commissioner of Lulong leading the Chinese troops, joined by the Xi, Khitan and Shiwei in the northeast. ${ }^{129}$

An imperial letter written by Li Deyu and addressed to the Princess Taihe said that the Uighurs had recklessly invaded and plundered Chinese borders. It went on: "You are their queen, able to command. If the Uighurs cannot accept your command, then this is [tantamount to] renunciation of our good marriage connections. From today hence, they must not use you, Our Paternal Aunt, as an excuse." 130 The letter was in fact a declaration severing the relationship between the Uighurs and the Chinese.

Early in 843 , the Chinese inflicted a decisive defeat on Ögä. Ormïzt, as Uighur Bandit-Suppression Commissioner of Southwest Direction (Huihu xinanmian zhaotao shi), joined in. Ögä Qaghan fled northeast to the Heichezi Shiwei. Princess Taihe returned to Tang and 20,000 Uighurs submitted to China. After this victory, Tang ordered that all the properties inside China owned by Uighurs and all of the Manichean temples built mainly for the Uighurs should be confiscated. ${ }^{131}$

By 842 the Kirghiz had already taken control over Beiting, Anxi and five tribes of Tatars. ${ }^{132}$ In 843 , after Ögä's defeat, Wuzong intended to ask the Kirghiz to return Anxi and Beiting, but Li Deyu did not agree on the grounds that Tang did not have enough troops to station there and that material goods should not be expended for the sake of an empty name. When the Kirghiz expressed the wish to have Tang confer on their leader the title of qaghan and to move to the former Uighur territory, the emperor was afraid that this would lead to demands from the Kirghiz like those earlier made by the Uighurs.

\footnotetext{
${ }_{128}^{128}$ JTS 147, p. 3986; XTS 166, p. 5097.

${ }^{129}$ Li Wenrao Wenji 14, p. 75; ZZTJ 246, pp. 7966-7; Drompp 1986, pp. 148-50. For the specific points raised by Li Deyu and Niu Sengru on this matter, see Drompp 1986, pp. 177-84.

${ }^{130}$ Drompp 1986, p. 160.

${ }^{131}$ Li Wenrao Wenji 3, p. 13; XTS 217B, p. 6133; Drompp 1986, pp. 236-7.

132 ZZTJ 246, p. 7968.
} 
Li Deyu argued that if Tang wanted to use the Kirghiz force to defeat the Uighurs, they had better recognize their leader as qaghan. The emperor agreed. ${ }^{133} \mathrm{Li}$ Deyu then had a letter sent on behalf of the emperor to the Kirghiz, urging them to destroy the Uighurs and promising to confer the imperial title on their chieftain. ${ }^{134}$

In 845, the court decided to send a mission to the Kirghiz to confer the title of qaghan on their ruler. The mission was stopped when Wuzong died. The new emperor Xuanzong removed Li Deyu from his post, and abandoned the plan of title conferment. ${ }^{135}$ Soon after in 847 , however; Xuanzong returned to the original plan. This move was perhaps intended to encourage the Kirghiz to overthrow the Uighurs, since only a month before the departure of the mission, Tibet had joined the Uighurs in making an incursion into Hexi. ${ }^{136}$

Ögä Qaghan was killed in 846, either at the hands of his Chief Minister or of the Heichezi Shiwei, who had initially provided him with refuge and had then fallen out with him. ${ }^{137}$ Other Uighurs had migrated to the Western Regions and settled down, engaging in agriculture as well as pastoralism and trade. No longer steppe nomads, their threat to the agricultural society of China had disappeared.

The Kirghiz, for their part, kept up a peaceful relationship with China. Unlike other nomadic peoples, such as the Turks, the Uighurs or the Khitan, who exploited Chinese support to sustain their state power, the Kirghiz never developed a state organization and never posed much threat to China. The reason may lie in the fact that their political center was geographically distant from China, so that they could or would not develop a secondary state on the periphery of China. They were not interested in, or familiar with, the techniques for dealing with an agricultural society. ${ }^{138}$

In Central and East Asia's international politics, the alliance between China and the Uighurs, even when the latter were still part of the Tiele people, was conspicuously different from Chinese relations with

\footnotetext{
${ }^{133}$ ZZTJ 247, pp. 7973-4; Drompp 1986, pp. 283-6.

${ }^{134}$ ZZTJ 247, pp. 7975-6; Li Wenrao Wenji 6, pp. 26-7; Drompp 1986, pp. 276-82.

${ }^{135}$ XTS 217B, p. 6150; Drompp 1986, p. 332.

${ }^{136}$ XTS 172, p. 5204; ZZTJ 248, p. 8030; Drompp 1986, pp. 332-3.

${ }^{137}$ ZZTJ 248, p. 8025; Haneda 1957, pp. 262-4; Drompp 1986, pp. 333-4.

${ }^{138}$ Barfield 1989, pp. 164-5.
} 
other peoples. Although often subjugated to the Tujue power, the Tiele kept their cultural identity, and were often allies of the Chinese against the Turks. The Tiele helped Sui win a decisive victory over the Tuyuhun in 608-609, and in 627-628 the rebellions of the Tiele against their Turkish rulers provided an excellent opportunity for Taizong to exploit in his conquest of the Eastern Turks. Taizong's success in the conquest of the Xueyantuo in 646 should also be attributed partly to the rebellion of the Uighurs against the Xueyantuo.

From 647 to 679, like the submitted Turks, thirteen Tiele tribes, including the Uighurs, were brought under the Chinese jimi fuzhou system. Though they sometimes rebelled the Uighurs played an important role in Tang frontier campaigns as a supporting force. During the second Turkish empire, while some Tiele were incorporated by the nomadic power, others came over to China to settle on the frontier. Finally, under Qullïgh Boila in 744, the Uighurs succeeded in overthrowing the Tujue and replacing them as the dominant power on the steppe. They soon grew to be a strong steppe power, and even subjugated the Khitan and Xi peoples in Manchuria.

Compared with the Turks in the time of their first and second empires, the Uighur empire during its century-long existence had a very different pattern of relationship with China. The Uighurs did not resort to war or raids as often. They had demonstrated their military superiority in their military assistance to Tang's suppression of the An Lushan rebellion, and as a consequence were able to make Tang provide large subsidies and keep up the horse-silk trade, which developed on a much more stable basis than in the time of the earlier Turkish empires.

The alliance was kept going because the Chinese and Uighurs had a common enemy in Tibet, as they had in the Turks earlier. The alliance was mostly due to Tang initiatives, especially including its highly tolerant attitude towards the Uighur demand for equality and the series of compromises it made. The Chinese provided large subsidies, kept up the horsesilk trade, and on three occasions sent daughters of the emperor himself to marry the qaghans. At a high price, the policy diverted the Uighurs from becoming an enemy and kept them as allies.

Although Tang and the Uighurs followed the formalities of the tribute system, with regular political investiture of the Uighur rulers by the Chinese emperors and frequent tributary delegations from the Uighurs, thus maintaining the outward appearance of Chinese superiority, in reality the Chinese accepted the Uighur empire as an equal power. The Chinese 
sometimes even had to accept an inferior status.

It is important to note that although the Chinese accommodation to the Uighurs was primarily for the purpose of purchasing military assistance and maintaining peace in the frontier regions, in effect it functioned as a catalyst in the economic and social transition of the Uighur empire from a nomadic into a more sedentary society. In addition to reducing their propensity to raid Chinese territory, this made the Uighurs rely more on the Chinese economy than had any previous nomadic power.

When the Uighur empire finally collapsed under the attacks of their traditional enemy, the Kirghiz, the Khitan and Xi also turned against their Uighur overlords. At this point, Tang was anxious to dispose of the Uighurs as quickly as possible. The court accepted the Uighurs under Ormïzt only when this group was weakened by internal disputes, but Tang launched attacks with the assistance of the Khitan and $\mathrm{Xi}$ on other groups of Uighurs. It refused to take in the Uighurs under Ögä Qaghan, while keeping up relations with the Kirghiz who finally helped Tang to crush Ögä Qaghan. Remnants of the Uighurs settled in the oases of Central Asia and ceased to be a threat. 


\section{Chapter 10}

\section{Tang, Tibet and Nanzhao in the Post-An Lushan Period}

From the end of the An Lushan rebellion until the 820's, Tibet became the most formidable foreign threat to Tang. It occupied the Hexi and Longyou areas in modern Ningxia and Gansu, directly threatening the Tang capital, and cut off communications between China and the Western Regions. With the change of the balance of power in favor of Tibet, Tang's rulers struggled to cope with the Tibetan invasions on their own and through alliances with the Uighurs and the Nanzhao state. A number of treaties were made which are of interest for the history of foreign relations but which, except for the last one in 822, had little effect in maintaining peace. When Tibet finally declined in power, Nanzhao emerged as a new threat on the southwestern frontier.

\section{Coping with the Tibetan Invasions, 756-764}

When Suzong assumed the throne at Lingwu in 756, a new btsanpo in Tibet also began his reign. In 756 and 757, the btsan-po volunteered to provide assistance to Tang in suppressing the rebels and asked to contract a marriage. ${ }^{1}$ While Tang made a matrimonial ${ }^{2}$ and military alliance with the Uighurs, Suzong merely expressed his appreciation to the Tibetans and sent a mission to them in $757 .^{3}$

The reason for Tang's distrust of the Tibetans was obvious. Soon after the outbreak of the rebellion, Tang's northwestern frontiers had been left vulnerable and exposed when all the major armies were withdrawn in order to confront the rebels. The Tibetan forces that had previously pressed against the frontiers were carried on into the vacuum by their momentum, and without much additional effort, expanded into the Chinese He-Long region. Almost overnight, Tang had seemingly lost all the advantage it had previously enjoyed over Tibet. In 756, Tibet captured several

\footnotetext{
${ }^{1}$ JTS 10 , p. 243 ; p. 246 ; XTS 216A, p. 6087 ; ZZTJ 218 , p. $6992 ; T H Y 97$, p. 1733 ; CFYG 973, p. $11434 ; 979$, p. 11504.

${ }^{2}$ JTS 10 , p. 244 ; 195, p. 5198 ; XTS 81, p. 3592; 217A, p. 6115; ZZTJ 219, p. 7005; CFYG 979, p. 11504.

${ }^{3}$ JTS 10, p. 246; XTS 216A, p. 6087; CFYG 979, p. 11504.
} 
army stations and towns inside the Tang northwestern frontiers, ${ }^{4}$ and by 763 had annexed all the land under the administration of the Military Commissioners of Hexi and Longyou. ${ }^{5}$ On the southwestern frontier, Tibet allied itself with Nanzhao to capture Suizhou, and from the 750's to the 770's, Nanzhao remained an ally of Tibet.

A Tibetan embassy arrived at the Tang court in 762 with an offer of peace and Tang agreed to conclude a treaty. Unfortunately, there is no information in the sources about discussions that must have gone on at the Chinese court before this proposal was accepted. Presumably, there was a hope that such a treaty would slow or stop the Tibetan advance towards the Chinese capital.

On this occasion, Tibet made Tang accept Tibetan ritual practice. Suzong ordered Chief Ministers Guo Ziyi and two others to hold a banquet for the Tibetans in the Secretariat and to go to the Guangzhai Temple to conclude the sworn covenant. The Tibetan envoy insisted that according to Tibetan custom, if a sworn treaty was made by getting blood from the three victims and smearing it on one's lips, it should not be done in a Buddhist temple. He asked to have the ceremony performed again the next day in the Court of State Ceremonials in order to complete the requirements of the rituals of Tibet. Suzong agreed, with the hope of appeasing the "barbarians."6 Even though the Chinese accepted the Tibetan request, there was deep distrust of and hostility toward the Tibetans. Well aware of the Tibetan threat, Guo Ziyi repeatedly warned the court of the necessity to prepare for war. ${ }^{7}$

No sooner had the oath been taken than the Tibetans launched a formidable offensive. In 763, they detained two Chinese envoys of high rank and did not send them back until two years later. ${ }^{8}$ In the autumn, the Tibetans pressed forward toward the Tang capital with their own troops

\footnotetext{
${ }^{4}$ ZZTJ 218, p. 7011.

${ }^{5}$ JTS 196A, p. 5236; XTS 216A, p. 6087; ZZTJ218, p. 7000.

Cen Zhongmian in Sui-Tang Shi has a table of when the Chinese prefectures were lost to Tibet, see his 1957 , pp. 275-6.

${ }^{6}$ JTS 196A, pp. 5236-7; XTS, 216A, p. 6087; ZZTJ 222, p. 7118; CFYG 981, p. 11528. Previously scholars have misread the texts at this point and have taken them as evidence that blood sacrifice was a Tibetan custom. Stein (1988, pp. 134-5) argues convincingly that the animal sacrifices carried out by the Tibetans on the occasion of treaties with the Chinese were performed in order to conform to Chinese custom and were not a relic of native Tibetan practice from pre-Buddhist times.

${ }^{7}$ ZZTJ 222, p. 7143.

${ }^{8}$ JTS 196A, p. 5237; XTS 216A, p. 6087; ZZTJ 222, p. 7143.
} 
and contingents of Tuyuhun and Qiang. Emperor Daizong had to flee to Shaanzhou before he could organize any resistance. A Tang general rebelled, hoping to establish a Tang prince as emperor and have him surrender to the Tibetans. The plan failed and the prince was sent to Daizong and executed. $^{9}$

In the tenth month, however, the Tibetans, guided by the surrendered Prefect of Jingzhou, entered Chang'an. The prefect and the Tibetan general Ma Chongying ${ }^{10}$ established Li Chenghong, Princess Jincheng's brother, as emperor, started a new reign title, and appointed Chief Ministers and other court officials. During their fifteen day occupation, they plundered the city and burned down many of its houses. The Tibetans were going to take with them Chinese officials, women and artisans, but the plan failed when they had to withdraw in haste out of fear of a Tang counterattack led by Vice Marshal Guo Ziyi. ${ }^{11}$ Chenghong was exiled and soon died. ${ }^{12}$

Although the Chang'an crisis was over, the Tibetans achieved success on another front: they captured some prefects on Tang's southwestern border. ${ }^{13}$ According to the Tibetan Ngan Lam Stag Sgra Klu Khong Inscription, the military campaigns that Tibet carried out against China had compelled the Emperor Suzong to offer a perpetual yearly tribute of fifty thousand rolls of silk, and when the next emperor Daizong did not continue the tribute the Tibetans launched the attack on Chang'an. ${ }^{14}$

The Tibetan invasion of Chang'an exposed a basic problem within the Tang government: the mistrust between the emperor, represented by

${ }^{9}$ JTS 11 , pp. $273-4$; 107 , p. 3270 ; XTS 82 , p. 3614 ; ZZTJ 223 , pp. $7150-1$.

${ }^{10} \mathrm{Li}$ Fang-Kuei conjectures that Ma Chongying was the Chinese name of Ngan Lam Stag Sgra Klu Khong. See his 1956, pp. 1-8.

${ }^{11}$ The above sequence of events follows the account in ZZTJ 223, pp. 7150-4. ZZTJ says that Chenghong was the grandson of Prince Bin, Li Shouli. See also CFYG 39, p. 439; 358 , p. 4248 . But this must be mistaken because, according to the following sources, Chenghong was the son of Shouli. See JTS 86, p. 2834; 196A, p. 5237; XTS 81, p. 3592. Chenghong's sister was Princess Jincheng, who was the daughter of Li Shouli.

${ }^{12}$ JTS 86, p. 2834; XTS 81, p. 3592; ZZTJ 223, p. 7158.

${ }^{13}$ ZZTJ 223, pp. 7158-9.

${ }^{14}$ Richardson 1952, p. 21; Sato 1959, pp. 523-6; Wang Yao 1982, pp. 91-2. Wang Yao says that the annual payment of fifty thousand rolls of silk was agreed to by the Chinese in order to obtain Tibetan assistance in suppressing Zhu Ci's rebellion. This is impossible because the rebellion took place between 786 and 787, which was during Dezong'sreign, and according to the inscription the payment was made before the Tibetan invasion of Chang'an. 
his eunuch adviser, and the military. Under Daizong, the eunuch Cheng Yuanzhen assumed great power. Cheng eliminated those who opposed him or threatened his position, including the famous general Guo Ziyi, who was removed from his post at this time. ${ }^{15}$ When the Tibetans invaded, Cheng Yuanzhen at first kept the emperor from learning of the imminent danger. Guo Ziyi was reappointed, but was able to muster only a small force of twenty cavalrymen and could not prevent the Tibetan advance on the capital. ${ }^{16}$ When Daizong sent orders to the various armies in the east to come to the rescue, the powerful general Li Guangbi and others in command of large armies did not come because of their resentment of the eunuchs. $^{17}$.

The critical situation at court and the urgency of reform were forcefully expressed in a memorial by Liu Kang, Erudite of the Chamberlain for Ceremonials (taichang boshi), who urged Daizong to execute Cheng Yuanzhen, drive out all the eunuchs and issue an edict of self-blame so as to summon rescuing troops. In response to this pressure, Daizong dismissed Cheng Yuanzhen from all his posts in $763 .^{18}$ But after his return to the capital, Daizong entrusted Yu Chaoen with command of the Palace Armies and the Shence Army, thus further increasing the power of the eunuchs.

\section{Tibetan Support for Pugu Huaien's Rebellion in 764-765 and the Treaty of 765}

Soon after the Tibetan occupation was over, another crisis occurred. When Pugu Huaien rose in rebellion in 764, the Tibetans joined him in moving against the Tang capital. However, their joint force retreated after encountering Guo Ziyi.

Despite this latest betrayal, in the third month of 765 Tang concluded another sworn covenant for peace with Tibet but, on the advice of Guo Ziyi, distrusted Tibetan intentions and prepared to defend the capital against yet another attack. ${ }^{20}$

The Tibetans did indeed soon again join Pugu Huaien, along with the Uighurs, Dangxiang Qiang and Tuyuhun in an expedition aimed at

\footnotetext{
${ }^{15}$ JTS 120, pp. 3455-6; XTS 137, p. 4603; ZZTJ 222, p. 7130.

${ }^{16}$ JTS 120, pp. 3455-6; ZZTJ 223, pp. 7150-1.

${ }^{17}$ JTS 110, pp. 3310-1; XTS 136, p. 4590; ZZTJ 223, p. 7155.

${ }^{18}$ JTS 11, p. 274; ZZTJ 223, pp. 7155-6.

19 JTS 121, pp. 3477-8; XTS 224A, pp. 6365-6; ZZTJ 223, p. 7166; pp. 7167-9.

20 JTS 196A, p. 5239; XTS 216A, p. 6088; ZZTJ 223, p. 7174; CFYG 980, p. 11512.
} 
Chang'an. As mentioned in the last chapter, when Pugu fell ill and died, the Chinese pursuaded the Uighurs to change sides, allowing Tang to inflict a heavy defeat on the Tibetans in two battles. Thus was the threat to Chang'an relieved. ${ }^{21}$

\section{China on the Defensive, 766-778}

After the confrontation during Pugu Huaien's rebellion, Tibet and Tang again exchanged envoys and negotiated for peace in 766 and 767, though Tibet continued to launch raids on the border. ${ }^{22}$ In the fourth month of 767 the Chinese concluded a covenant with a Tibetan envoy in the Xing Tang Temple. ${ }^{23}$ This was the third time within five years that the two sides had held an oath-taking ceremony, and for the third time nevertheless failed to maintain any lasting peace. Following raids on Lingzhou in the ninth month, a Tibetan mission arrived at the Tang court accompanied by the Chinese envoy to Tibet, through whom the btsan-po requested demarcation of the border at Fenglin Pass. Daizong did not, however, give any reply to him. $^{24}$

From then until 778, shortly before the end of Daizong's reign, several more peace missions were exchanged, while Tibet continued to make frequent border incursions, mostly in autumn during the Chinese harvest season when the Tibetan horses were well fed. Though the Tibetan court apparently had the intention of making peace, the Tibetan frontier generals preferred constant raids. The situation was such that "no sooner have the ritual gifts of Tibet reached the court than the beacon fires are lit right up to the suburbs of the capital.",25

To cope with the Tibetan incursions, Chief Minister Yuan Zai, who was familiar with the northwestern frontier situation, since he had formerly been Prefect of Xizhou, suggested in 773 that Tang build walled towns in Yuanzhou (in modern Ningxia). He also repeatedly suggested the removal of the capital to Hezhong (in southern Shaanxi), both moves being intended to assure a better defense. His suggestions were opposed by a Military Commissioner on the grounds that a scholar's advice should not be trusted on such an important affair. In the end, nothing was done. Yuan

\footnotetext{
${ }^{21}$ Mackerras 1972, pp. 26-9.

${ }^{22}$ JTS 11, p. 284; 196B, p. 5243; XTS 6, p. 172; ZZTJ 224, p. 7190.

${ }^{23}$ JTS 11, pp. 286-7; XTS 216B, p. 6091; ZZTJ 224, p. 7195; CFYG 980, p. 11512.

${ }^{24}$ JTS 196B, p. 5243; XTS 216B, p. 6091; ZZTJ 224, p. 7196; CFYG 997, p. 11704

${ }^{25}$ CFYG 992, p. 11656.
} 
lost favor and was ordered to commit suicide in $777 .^{26}$

For the most part, the Chinese assumed a passively defensive position. Their military force was far less strong than that of the Tibetans. In 774 when holding discussions with Daizong, Guo Ziyi talked about the Tibetan problem with tears running down his cheeks. He offered to resign as commander because of his inability to defend the country, but the emperor would not allow it. ${ }^{27}$

\section{Dezong: Alliance with Tibet, 779-783}

On his accession, Dezong made a drastic change in policy towards Tibet. During Daizong's time the Tibetans had sent several diplomatic missions proposing peace while engaging in constant hostilities on the borders. Daizong's response was to detain the envoys and send war captives to exile in the south. Soon after assuming the throne, instead of just passively defending the borders, Dezong took the initiative in making peace. He sent a friendly mission to Tibet headed by Wei Lun, ordered frontier troops not to make provocative attacks, and returned more than 500 Tibetan prisoners. ${ }^{28}$ Wei Lun later used his experience as envoy to Tibet to offer advice and make proposals about Tibetan affairs. ${ }^{29}$

The change of policy may have resulted from two considerations. One was that peace with Tibet would alleviate the severe situation on the frontier so that the Chinese troops could be redeployed to suppress internal rebellions staged by provincial governors. Another was that to Dezong the Uighurs were a worse enemy than the Tibetans and, since he could not afford to have both as enemies at the same time, he had better win over the Tibetans. As mentioned in Chapter 9, he held a personal grudge against the Uighurs because in 762 , before ascending the throne, he had suffered a great humiliation at their hands.

Before Wei Lun arrived in Tibet, however, the Tibetans had already made an alliance with Nanzhao and launched a major offensive on Tang's southwestern border. In the ensuing battles, Tang won a major victory. ${ }^{30}$ The peace proposal put forward then by Tang received a positive response and produced an immediate result in the Tibetans' refusal to as-

\footnotetext{
${ }^{26}$ JTS 118, pp. 3411-2; XTS 145, pp. 4712-3; ZZTJ 224, p. 7224.

${ }^{27}$ JTS 120, pp. 3464-5; XTS 137, pp. 4607-8; ZZTJ 225, p. 7226.

${ }^{28}$ JTS 12, p. 323 ; 196B, p. 5245; XTS 7, p. 184; 216B, p. 6092; ZZTJ 226, pp. 7267-8; THY 97, p. 1734; CFYG 980, p. 11513.

29 JTS 138 , p. $3782 ;$ XTS 143, p. 4688.

${ }^{30}$ JTS 196B, p. 5245; XTS 216B, p. 6092-3; ZZTJ 226, pp. 7270-2.
} 
sist a rebellious Chinese official in his attempt against the court in $780 .^{31}$

To strengthen the peace, or perhaps pressed by Tibet, Wei Lun asked the emperor himself to compose the text of a sworn treaty. But Chief Minister Yang Yan objected, arguing that the two sides should not be put on an equal footing. ${ }^{32}$ Except for this, Dezong was eager to accommodate the requests raised by the Tibetans. In the negotiations the Tibetans demanded to be treated as equals.

They made the following points: 1) because Tibet and Tang had a nephew-uncle relationship, Tibet should not be treated as a subject; 2) the demarcation line should be the Helan Mountains, west of Lingzhou; 3) each side should follow the rules stipulated in the Chinese decree of 708 requiring that when Tibetan and Tang envoys arrived at each other's capitals, the Tibetan btsan-po and the Chinese emperor should personally participate in the conclusion of any covenant. They also asked the Chinese to change some specific wordings in official correspondence to reflect the equality of the relationship between the two parties. ${ }^{33}$

In his reply Dezong agreed to all these demands. As Kaneko points out, from the Kaiyuan period on, the Tibetans had requested that Tang treat them as an equal power, but Tang's agreement to this came only in 781 with the change of wording in official letters. ${ }^{34}$ As for the third request, since neither the Chinese emperor nor the Tibetan btsan-po actually participated personally in the ceremonies at the two capitals, one must ask the question whether the word qin "personally" simply meant that the ruler was represented by his ministers.

The court learned through the reports of the Chinese envoys that the Tibetans were having internal troubles. Tibetan Chief Minister Shang Jiexi (Zhang rGyal-zigs? ${ }^{35}$ ) took a militant attitude towards Tang, while minister Shang Jiezan (Zhang rGyal tshan) maintained that Tibet should decide on a demarcation line with Tang and make peace. The btsan-po had agreed with the latter and replaced Zhang rGyal-zigs with Zhang rGyal tshan. $^{36}$

A peace treaty was concluded in 783 . The Chinese sources provide

${ }^{31}$ JTS 118, pp. 3422-3; XTS 145, p. 4725; ZZTJ 226, p. 7279; p. 7281.

${ }^{32}$ ZZTJ 226, p. 7280.

${ }^{33}$ JTS 196B, p. 5246; XTS 216B, p. 6093; CFYG 981, p. 11528.

${ }^{34}$ Kaneko 1988, p. 97.

${ }^{35}$ Demiéville 1952, pp. 290-1, note 3.

${ }^{36}$ JTS 122, pp. 3502-3; 196B, p. 5246; XTS 216B, p. 6093; CFYG 980, pp. 11513-4. 
much more detailed information concerning this treaty than for any previous agreements with Tibet. In the Chinese text of the oath, the Tang-Tibetan relationship is still referred to as between uncle and nephew, but the text also demonstrates the change of attitude by treating the Tibetans in a more serious way. Compared with the text of 732 , which insisted on Chinese superiority, this text adopted a very pragmatic attitude, stating that China would renounce its former territorial claims, make firm the covenant and follow the treaty. The treaty provided for making a demarcation line straddled by a neutral territory, and stipulated that the places that theretofore had not had troops should not have new garrisons, nor should walled towns or fortifications be built, nor should there be plowing and sowing in the neutral territory. $^{37}$

Three ceremonies were held in concluding the treaty. For the first ceremony, we have the most detailed information. It was held in the first month of 783 in Qingshui (in modern Gansu province), at that time within Tibetan territory. Each side despatched two thousand people to the ceremony with seven high-ranking officials participating in the oath taking. The Chinese side was headed by Zhang Yi, the Military Commissioner of Fengxiang and Longyou, a former Chief Minister. The Tibetans were led by the Chief Minister, Zhang rGyal tshan.

The Chinese sources say that Zhang Yi felt ashamed at having to make a treaty with Tibet. He tried to diminish the significance of the ceremony by suggesting that instead of the Chinese using an ox and the Tibetans using a horse as previously decided, they should use a sheep, pig and dog as sacrifices because the ox was the most prestigious sacrificial animal. He made the excuse that the Chinese could not plow without oxen and the Tibetans could not go anywhere without horses. Zhang rGyal tshan agreed. As a result, the Chinese used a dog and a white sheep and since no pig could be found there, Tibet used a wild ram.

On the Tibetan side, Zhang rGyal tshan also produced a text, which is no longer extant. After the blood sacrifice was carried out according to Chinese custom, Zhang rGyal tshan asked Zhang Yi to enter a tent at the southwest corner of the altar and burn incense to a Buddhist image and again swear an oath solemnizing the treaty.

The second ceremony was held in Chang'an between the Chief

${ }^{37}$ For the treaty text, see JTS 196B, pp. 5247-8. For its translation, see Pan Yihong 1992a, pp. 155-6. 
Ministers of both sides. The third was in Tibet. ${ }^{38}$

\section{Tibetan Assistance in Tang's Suppression of the Rebellion of 783-784}

The peace treaty of 783 stabilized the frontier situation and made it possible for the Tang court to withdraw frontier troops and imperial armies and use them for the suppression of the internal rebellions by the semiindependent provincial governors in the northeast. This, however, also weakened the defenses of Chang'an. The Jingyuan troops rebelled in late 783 and, led by Zhu Ci, occupied Chang'an (Chapter 4). Dezong fled west to Fengtian. ${ }^{39}$ He was forced to recall his armies from the northeast. ${ }^{40}$

During this crisis, Dezong also asked for military assistance from Tibet. ${ }^{41}$ The Tibetans promised to assist, but this was not really because of the treaty of 783. Rather it was in response to a promise that Tang would make an annual payment of 10,000 rolls of silk, ${ }^{42}$ and would cede to Tibet the territory of the Military Commissioners of Beiting and Anxi in the Western Regions. ${ }^{43}$ The Chinese court had found out in 781 that the two Military Commissions there were still holding out against the Tibetans long after the An Lushan rebellion. ${ }^{44}$

The alliance with the Tibetans was difficult from the beginning.

38 JTS 125 , pp. $3547-8$; 196B, pp. 5247-8; XTS 152, p. 4831; 216B, pp. 6093-4; ZZTJ 228 , p. 7338 ; pp. $7343-4$; p. 7347; CFYG 981, pp. 11529-30. The Chinese accounts say that there were seven Tibetan officials at the Qingshui ceremony, but the punctuation of the text creates some problems. According to the Zhonghua Shuju edition of the JTS, there are only six names of Tibetan officials. Some studies punctuate the text differently, see Bushell 1880, p. 488; Pelliot 1961, p. 43; Lee, Don Y 1981, p. 95.

${ }^{39}$ Liu Yat-ming 1970, pp. 127-31; Dalby 1979, pp. 582-4.

${ }^{40}$ Peterson 1979, p. 506.

${ }^{41}$ ZZTJ 228, p. 7368.

${ }^{42}$ Lu Xuangong Hanyuanji 10, pp. 66-7.

${ }^{43}$ This is according to $L u$ Xuangong Hanyuanji 10, pp. 64-5; pp. 66-7; ZZTJ 231, p. 7442; Sato 1959, pp. 641-2. Some sources say that Tang was to give up the land of four prefectures including Jingzhou and Lingzhou. See JTS 196B, p. 5252; XTS 216B, p. 6094; CFYG 981, p. 11531. Lü Simian (1959, p. 309) holds that Tang's supposed promise to give up Anxi and Beiting may have been a mistake in the sources, since Tibet would soon capture Anxi and Beiting by force, and would not have to ask Tang to hand those territories over. Lü also rejects the account of the concession of the four prefectures on the grounds that Jingzhou was so close to Chang'an that Tang could not have promised to give it up to Tibet.

${ }^{44}$ The Chinese sources are somewhat confused about the date of 781 , according to a number of modern scholars, see Haneda 1957, pp. 212-3; Mackerras 1972, p. 163, note 199. 
Zhang rGyal tshan insisted that, according to Tibetan custom, the mobilization of an army rested with the minister commanding the army. But the Tang edict did not have the signature of Li Huaiguang, the Military Commissioner of Shuofang and Hezhong. Li had been withdrawn from the campaign against the rebel Commissioners in the northeast to rescue the emperor and was then camped at Xianyang facing $\mathrm{Zhu} \mathrm{Ci}$. The Tibetans would not start to advance without his signature on the edict.

Unfortunately, $\mathrm{Li}$ was dissatisfied with the treatment he had received for relieving the emperor when besieged at Fengtian and was procrastinating over advancing on Chang'an with his own troops. He therefore refused to sign. He argued that if the Tibetans joined in the campaign, they would hang back and not commit their troops until they saw that the imperial troops were winning and would then join in to share in the credit, allow their troops to pillage the city, and demand the rewards that had been promised. ${ }^{45}$ Soon after he himself withdrew east to Hezhong and rebelled against the court.

Dezong fled to Liangzhou, southwest of Chang'an. Finally the Tang envoy to Tibet, who was now with the Tibetan troops, had to forge a letter from the Chinese Vice Marshal on campaign, asking the Tibetans to act. After some hesitation, Zhang rGyal tshan despatched his troops to join the Tang force in recovering Wugong near Chang'an. He crushed a major force led by $\mathrm{Zhu} \mathrm{Ci}$ in 784. This let the Tang troops march on to Chang'an. ${ }^{46}$ The crisis ended in mid-784 when $\mathrm{Zhu} \mathrm{Ci}$ was killed and the emperor returned to the capital.

It was during his exile that Dezong began to rely heavily on the Hanlin scholar, Lu Zhi, as personal adviser and secretary. Lu does not seem to have agreed with the plan to obtain Tibetan aid. Before the court recovered Chang'an from rebel occupation the Tibetans had withdrawn from China. They were suffering from plague and had also been bribed by Zhu Ci. When he heard of the retreat of the Tibetan troops, Dezong was worried, but Lu Zhi reassured him, saying that this was to be welcomed. $\mathrm{He}$ argued that the Tibetans were untrustworthy and that the Chinese generals had been worried that the Tibetans would attack from the rear or would not keep to the plan for joint action, and instead would try to reap all the merits of the campaign. The common people, who had been in fear

\footnotetext{
45 JTS 121, p. 3493; XTS 224A, p. 6377; ZZTJ 230, p. 7403.

${ }^{46} J T S 134$, p. 3707 ; 196B, p. 5249; XTS 155, p. 4894; 216B, p. 6094; ZZTJ 230, p. 7416; p. 7422 .
} 
of Tibetan raids, would be relieved at their departure. ${ }^{47}$

\section{The Breakdown of the Tibetan Alliance, 784-787}

Soon after Zhu Ci's rebellion was suppressed, the Tibetans asked Tang to fulfill its promise to cede territory to them. Dezong was going to recall the Military Commissioners of Beiting and Anxi, but Li Mi, who had been an important personal adviser to Suzong and Daizong, and was now the Left Policy Adviser, raised a strong objection on the ground that withdrawal of these troops would endanger the Guanzhong area, whereas their continued presence in the Western Regions would oblige the Tibetans to divide their forces. Dezong then sent an envoy to Tibet, bearing a letter written by Lu Zhi on his behalf, which promised only to provide a large amount of silk to Tibet, but implied that Tang would not make the land concession, because the Tibetan troops had not assisted Tang in recovering Chang'an as they had promised. ${ }^{48}$

The Tibetans decided to retaliate for the Tang refusal to cede territory. In 786 , Zhang rGyal tshan raided the frontiers and approached Chang'an. The capital was on alert for a time. The Tibetans then captured the seats of Yanzhou, Xiazhou, Yinzhou (already an empty city), and Linzhou, all in the Ordos region. This posed a great threat, since Tibetan forces now formed a half circle to the west and north of the Tang capital. ${ }^{49}$ Tang sent three letters to the Tibetan Chief Minister Zhang rGyal tshan, insisting that Tibet had violated the treaty of 783 by this invasion and had not fulfilled its earlier promise to assist Tang to recover Chang'an. The disputed land concession could, Tang insisted, be discussed without Tibet having to resort to violence. ${ }^{50}$

Zhang rGyal tshan now planned to get rid of three Chinese generals, Li Sheng, Ma Sui and Hun Jian, who held powerful positions as Military Commissioners of several provinces. Li Sheng and Hun Jian were appointed Chief Ministers in 784 and Ma Sui in 785. In 787 Zhang rGyal tshan asked for a peace settlement and, through heavy bribes, persuaded Ma Sui that the Tibetans would reaffirm the agreement of Qingshui and return the captured cities of Yanzhou and Xiazhou in return for peace. Ma

\footnotetext{
${ }^{47}$ ZZTJ 231, pp. 7429-30.

${ }^{48}$ Lu Xuangong Hanyuanji 10, pp. 66-7; XTS 139, pp. 4634-5; 216B, p. 6094; ZZTJ 231, p. 7442 .

${ }^{49}$ Beckwith 1987, pp. 149-51.

${ }^{50}$ Lu Xuangong Hanyuanji 10, pp. 67-8.
} 
Sui thereupon presented several memorials advocating peace with Tibet. ${ }^{51}$

The Tibetan occupation of Yanzhou and Xiazhou was a factor that made Tang consider a peace settlement. ${ }^{52}$ It should be noted, however, that due to logistical problems, the Tibetans had left only a thousand or so troops in Yanzhou and Xiazhou, so that their occupation was not very secure. $^{53}$ Zhang rGyal tshan himself had only a modest military force of 30,000 . $^{54}$

In the court debate, Chief Minister Li Sheng proposed going to war. Han Yougui, Military Commissioner of Binning, held that the peace proposal must be a false one. Chief Minister Han Huang also supported Li. Dezong was persuaded. Ma Sui, however, urged a peace agreement. He brought Tibetan envoys to the court to support his request. Chief Minister Zhang Yanshang supported the peace policy. Both Ma Sui and Zhang Yanshang held a personal grudge against Li Sheng. This, together with Han Huang's death, helped get the peace policy approved by the emperor.

Dezong had his own motives for wanting peace: he was weary of constant wars, suspicious that the generals wanted to achieve merit through war, and inclined toward an alliance with Tibet rather than with the Uighurs. Zhang persuaded Dezong to relieve Li Sheng of his military power as Military Commissioner of Fengxiang on the grounds that $\mathrm{Li}$ Sheng had disagreed with the peace settlement and therefore should not hold this post on the Tibetan border. ${ }^{55}$ This was just what the Tibetans had hoped to see happen.

Negotiations were held for the conclusion of the treaty. Zhang rGyal tshan stated that the demarcation stele had been destroyed, so Tibet wished for a new peace agreement. He promised to return the captured cities of Yanzhou and Xiazhou when the peace agreement had been concluded. Also, he argued that the Qingshui agreement could not be maintained because there had not been enough participants in the oath-taking ceremony. The Tibetans this time would have 21 ministers and generals present, and they named the Tang military commissioners of Lingzhou and Jingzhou as officials whom they particularly wanted to be present for the

${ }^{51}$ JTS 134 , p. $3700 ; 196$ B, p. 5250 ; XTS 155, pp. 4889-90; 216B, p. 6095 ; ZZTJ 232, pp. 7482-3.

52 Beckwith 1987, p. 151.

${ }^{53}$ ZZTJ 232, p. 7482.

${ }^{54}$ JTS 12, p. 356; 196B, p. 5251.

${ }^{55}$ JTS 129 , p. 3602 ; pp. $3608-9 ; 133$, p. $3672 ; 134$, p. $3700 ; 196 \mathrm{~B}$, p. $5250 ; X T S 127$, pp. $4445-6 ; 154$, pp. $4870-1 ; 155$, pp. $4889-90 ; 216$ B, p. 6095 ; ZZTJ 232 , pp. $7482-3$. 
oath taking ceremony.

The Tang court, for its part, proposed that the ceremony be held in Pingliangchuan (in Yuanzhou, in modern Gansu), rejecting the Tibetan choice of Tulishu because they deemed Tulishu (in Yuanzhou) to be in a dangerous geographical location which might be used by the Tibetans to lay an ambush. The court did not send the Military Commissioners Tibet wanted. It merely appointed Hun Jian as commissioner for the treaty. ${ }^{56}$

On the day the ceremony was to take place, while Ma Sui argued in the court at Chang'an that it would ensure lasting peace, Chief Minister Liu Hun expressed his dislike of the proceedings with the familiar argument that sworn covenants were made only when a dynasty was declining. When Li Sheng agreed with this, Dezong became enraged. ${ }^{57}$

But a report soon reached the court that the Tibetans had indeed laid an ambush. The Tibetan peace proposal turned out to be an intrigue purposely designed to weaken the Tang military forces and to capture Hun Jian, so that Tibet could launch a major attack on Chang'an. Sixty Chinese officials were kidnapped. Hun Jian managed to escape. Dezong was so frightened that he was preparing to flee from Chang'an, and was only barely dissuaded from doing so by his ministers. ${ }^{58}$ Zhang rGyal tshan further stirred up Tang internal dissension by releasing the nephew of Ma Sui as a way to thank Ma Sui for his peace settlement. Hearing this, Dezong relieved Ma Sui of his military office, which was precisely what Zhang rGyal tshan wanted. ${ }^{59}$

Hostility became intense between the two states. Dezong sent an envoy bearing a letter to Zhang rGyal tshan, but the envoy was turned back at the Tibetan border. When the Tibetans returned a Tang official and asked for peace, the Chinese also turned back their envoys at the border. ${ }^{60}$ Suffering from lack of supplies and from illness, the Tibetans withdrew from Yanzhou and Xiazhou, but in the eighth month of 787 they launched renewed attacks. Chang'an was once again seized with panic. From then on, the Tibetans often went back and forth across the border to plunder

${ }^{56}$ JTS 134, p. 3708; 196B, pp. 5250-1; XTS 155, p. 4894; 216B, pp. 6095-6; ZZTJ 232, pp. 7483-5.

${ }_{57}$ JTS 125, p. 3555; XTS 142, p. 4673; ZZTJ 232, p. 7487.

${ }^{58}$ JTS 196B, pp. 5251-3; XTS 216B, pp. 6095-6; ZZTJ 232, pp. 7486-7.

${ }^{59}$ JTS 134, pp. 3700-1; XTS 155, p.4890; ZZTJ 232, p. 7488.

${ }^{60} J T S$ 196B, p. 5253; p. 5254; XTS 216B, p. 6096; p. 6097; ZZTJ 232, p. 7488; 233, p. 7496. 
Chinese territory. ${ }^{61}$

\section{Alliance with Nanzhao and the Uighurs against Tibet}

Since the policy of alliance with Tibet had proved to be a failure, new policies were proposed. Soon after the Pingliang disaster, Chief Minister Li Mi suggested changing to a policy of alliance with the Uighurs, Nanzhao, the Arabs and India. Dezong was eventually persuaded, and as we saw in the last chapter, a decision was reached to form a marriage alliance with the Uighurs.

There is no evidence that the Tang Chinese at this time formed an alliance with any part of India, though there had been diplomatic contacts between India and Tang throughout the 750's. ${ }^{62}$ The Arabs had frequent contacts with Tang in Dezong's time, and sometime after 786, a long war between the Arabs and Tibetans began, which may suggest that the alliance advocated by $\mathrm{Li} \mathrm{Mi}$, whether formal or informal, did take shape. ${ }^{63}$

An alliance with Nanzhao was, in fact, achieved. After their joint invasion of Tang at the beginning of Dezong's reign in 779, Nanzhao's relations with Tibet had deteriorated. In 779, a new king of Nanzhao, Yimouxun (d. 808), came to the throne. As a prince, he had been under the strong influence of his Chinese tutor, and had acquired pro-Tang tendencies to complement his growing resentment of the excessive financial and military demands of the Tibetans. ${ }^{64}$ It was under his rule that Nanzhao switched partners to form an alliance with China against Tibet. His primary aim was, of course, to maintain Nanzhao as an independent power by balancing out the two larger powers.

On the Chinese side, Wei Gao, who became the Military Commissioner of Xichuan in 785, worked hard to win over Nanzhao. In 787, before the Pingliang incident, Wei Gao proposed a policy for pacifying Nanzhao and the other non-Chinese on the southwestern frontier to keep them from joining Tibet. ${ }^{65}$ Until his death in 805 , Wei played an active role in winning over Nanzhao, and in manipulating the disputes between Nanzhao and Tibet in order to weaken Tibet and stabilize the situation on the southwestern border.

\footnotetext{
${ }^{61}$ JTS 196B, pp. 5254-6; XTS 216B, pp. 6097-8; ZZTJ 233, p. 7501.

${ }^{62}$ Backus 1981, p. 89.

${ }^{63}$ Beckwith 1987, p. 152.

${ }^{64}$ Wang Jilin 1976, pp. 253-5; Backus 1981, pp. 84-7.

${ }^{65}$ ZZTJ 232, p. 7480; p. 7495; 233, pp. 7501-6. See also Backus 1981, pp. 87-90.
} 
The alliance with Nanzhao was more effective in weakening Tibet than was the alliance with the Uighurs. ${ }^{66}$ The major results of the alliance may be summarized as follows: Nanzhao refused to join forces with Tibet in attacking Sichuan in 788, and thus the Tibetan invading troops could be defeated by Wei Gao; within a few years thereafter Wei Gao was also able to recover Suizhou from Tibetan occupation; in 794 Tang and Nanzhao concluded a treaty, thereby marking Nanzhao's official break with Tibet.

In the early 790's, when Tibet had suffered heavy casualties in battles with the Uighurs in the Western Regions, the Tibetans demanded that Nanzhao send soldiers as reinforcements. Yimouxun despatched troops, but they made a surprise attack on the Tibetans on the Upper Yangtze. ${ }^{67}$ Since Wei Gao's attacks drew off Tibetan forces to the southwest, the Chinese were able to build a walled town at Yanzhou in the northwest in 793, which proved to be effective in guarding against Tibetan incursions. $^{68}$

The most significant battles took place in 801-802 when the joint forces of Tang, Nanzhao and other southwestern tribes attacked Tibet on China's southwestern borders and forced Tibet to withdraw its invading forces from China's northwest. From this time on Tibet was definitely on the road to decline as a great power. ${ }^{69}$

The Tang alliances with Nanzhao and the Uighurs were on the whole effective in weakening Tibet. Tibetan power was on the decline towards the end of the eighth century, with the death of the capable Zhang rGyal tshan in 796 and of the Tibetan btsan-po in the following year. ${ }^{70}$ The new btsan-po sent an envoy to Tang, asking for a peace settlement, but Dezong refused, still deeply distrusting Tibet. ${ }^{71}$ In 799 this btsan-po also died, and his successor, following a heavy defeat in Weizhou (in modern Sichuan), sent an envoy to Tang in 803. Dezong in turn dispatched an envoy to Tibet, thus ending the period of military conflict. ${ }^{72}$

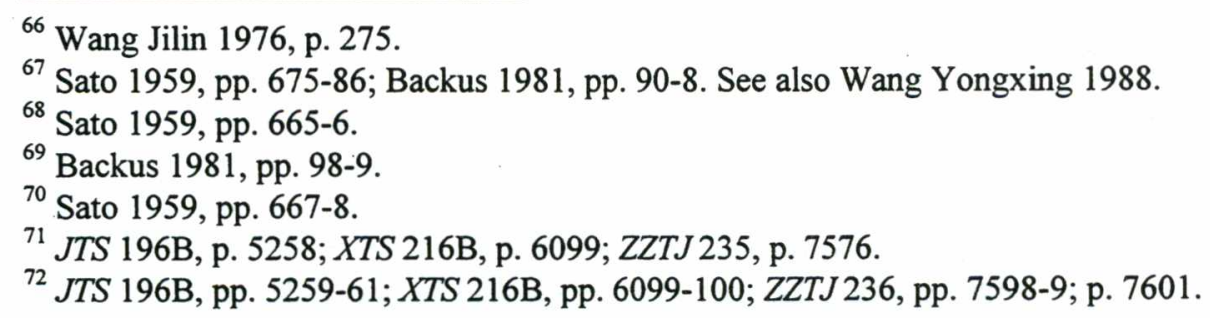




\section{Making Peace with Tibet, 806-822}

The Tibetans put forward two requests for renewing the sworn covenant in 806 , the second time even offering border concessions, but Emperor Xianzong refused, following the advice of Li Jifu, then the Secretariat Drafter, who argued that, since Tang had a good relationship with Nanzhao, Tibet no longer dared to make border incursions, and that a Tang covenant with Tibet would only serve to alienate Nanzhao. As for the border land, he argued that it was difficult for Tang to keep and therefore it was useless to have it in name. ${ }^{73}$ In 809 , when Tibet again asked for a peace settlement, Lu Sui, whose father had been kidnapped at the time of the "False Treaty of Pingliang," presented five memorials, pleading with the emperor to agree to peace. Several other court ministers also tried to persuade Xianzong, who finally gave in and sent an envoy to Tibet. ${ }^{74}$

Negotiations followed. In 809 and 810, two letters written by Bai Juyi on behalf of the emperor were delivered to the Tibetan chief ministers. They set out the principles which should be followed in negotiating a peace settlement: invasions by either side should be forbidden and boundaries decided; Tibet should return the three Chinese prefectures of Qinzhou, Yuanzhou and Anlezhou; envoys should be exchanged to discuss important matters. The letter of 809 also asked for the return of Chinese officials who had been captured in the "False Treaty of Pingliang" incident. $^{75}$

In reply, the Tibetans returned the coffins of two deceased officials, together with thirteen Chinese officials who were still alive. They also agreed to the return to Tang the three prefectures mentioned in Bai Juyi's letter. ${ }^{76}$ Being in competition with the Uighurs and having broken with the Shatuo in 808, Tibet wished for peace with Tang. In 815 the Tibetans arrived at the border of Longzhou and asked for trade, to which the court agreed. $^{77}$ At the same time the Tibetans launched several raids on China's borders (in 812, 813, 818, 819, and 820) even as the two sides were exchanging envoys, probably in order to force China into accepting the peace treaty. The incursions in 819 started even before a mission that

${ }^{73}$ XTS 146, p. 4739.

${ }_{74}^{74}$ JTS 159, pp. $4190-1$; ZZTJ 237, p. 7660.

${ }^{75}$ Baishi Changqing Ji 39, p. 203; p. 207. Between 808 and 810, Bai Juyi wrote at least four letters to the Tibetans on behalf of the Chinese central and local authorities. For a study of these documents, see Kolmas 1966, pp. 375-410.

${ }^{76}$ JTS 196B, p. 5261; XTS 216B, p. 6100; THY 97, p. 1737; CFYG 980, p. 11515.

${ }^{77} X T S 216$ B, p. $6100 ;$ ZZTJ 239, p. 7720. 
had been sent to cultivate friendship could leave Tang. ${ }^{78}$

In the general amnesty after Muzong's accession to the throne in 820 , the Tibetan captives were allowed to return. ${ }^{79}$ The Military Commissioner of Jiannan and Dongchuan, under the pressure of the Tibetan incursions, suggested that the court use generous rewards to attract the Uighurs to ward off the Tibetans, to which Muzong did not agree. ${ }^{80}$ After a long period of deliberation, the court instead decided to permit a marriage with the Uighurs in 821. Upon hearing the news the Tibetans attacked the Tang frontier. $^{81}$

In 821 , Muzong agreed to the request from Tibet to conclude a peace treaty. The treaty proved to be the last between Tang and Tibet. ${ }^{82}$ There are several important features about this treaty to distinguish it from previous ones. ${ }^{83}$. As in 783 , the oath taking ceremony was performed in the territories of both states, once in 821 in the western suburb of Chang'an and once in 822 in Migu, the Tibetan summer capital, east of Lhasa. A stone stele was erected in Lhasa in 823. At the Chang'an ceremony both sides followed the Chinese ritual by smearing blood on the lips. In Tibet, in addition to the blood smearing ceremony, both sides performed the Buddhist rituals of Tibet. ${ }^{84}$ Using both Chinese and Tibetan rituals at the ceremonies in 762,783 and $821 / 822$ implied reciprocity and equality. ${ }^{85}$

There are four important documents extant for the 821/822 treaty, more than for any previous treaty. These documents include: (a) a Chinese sworn treaty text preserved in Chinese written sources; (b) a Tibetan treaty text preserved on the east side of the Lhasa stele; (c) a joint text of both rulers with versions in both Chinese and Tibetan languages on the west side of the stele; (d) a bilingual version of the names of the Chinese and Tibetan officials who participated in the conclusion of the treaty with the Tibetan names on the northern side and the Chinese on the southern side

${ }^{78}$ JTS 196B, p. 5162; XTS 216B, p. 6101. For records of Tibetan incursions, see ZZTJ $239,240,241$.

${ }^{79}$ CFYG 90, p. 1073.

${ }^{80}$ JTS 169, p. 4402; XTS 179, pp. 5317-8; CFYG 993, p. 11668.

${ }^{81}$ JTS 196B, p. 5263; XTS 216B, p. 6102; ZZTJ 241, pp. 7791-2.

${ }^{82}$ Concerning the $821 / 822$ treaty, see JTS 196B, pp. 5264-5; XTS 216B, pp. 6102-3; ZZTJ 242, p. 7800; CFYG 981, pp. 11531-3; Richardson 1952; Li Fang-kuei 1955; 1980.

${ }^{83}$ Pan Yihong 1992a, pp. 144-7.

${ }^{84}$ CFYG 981, pp. 11531-3; Stein 1988, p. 129.

${ }^{85}$ Stein 1988 , pp. $127-8$. 
of the stele. ${ }^{86}$ An additional document has been found among the Tibetan texts from Dunhuang which records the building by the Tibetans of a Buddhist monastery to commemorate the peace treaty. ${ }^{87}$

The joint text added to the two individual texts certainly enhanced the solemnity of the treaty, and it was a significant innovation, since the earlier treaties did not have a joint text. Such a joint treaty text between contracting parties does not seem to have existed in the Song period either. ${ }^{88}$ In the bilingual version of the joint text each recognizes the other as a legitimate ruler, with Tang in the east and Tibet in the west, and it is stipulated that the two sides shall not struggle like enemies, shall not lead armies into war, and shall not invade and seize each other's territory. ${ }^{89}$

It is important to note that the joint text has an item recognizing the legitimacy of retaliation, which did not exist in previous treaties. The treaty text does not contain any items regarding boundary demarcation. The boundary rules may have remained essentially the same as in the treaty of $783 .^{90}$ The Chinese participants in Chang'an all signed their names on the treaty, and through the Chinese envoy to Tibet for the Lhasa ceremony, the Tang Emperor Muzong requested that the Tibetans also sign their names. ${ }^{91}$ As discussed earlier, during Xuanzong's time the Tibetans asked several times for the Chinese emperor's signature on a peace agreement but Xuanzong refused. The signatures on this treaty show a new Chinese willingness to compromise.

Following their sworn treaty with China in 821 , the Tibetans also made peace agreements with the Uighurs and with the Nanzhao kingdom. ${ }^{92}$

\footnotetext{
${ }^{86}$ For the translation of (a), see Pan Yihong 1992b, pp. 156-8. For (b), (c), and (d), see Richardson 1952; Li Fang-kuei 1955.

${ }^{87}$ Li Fang-kuei 1955. Thomas (II, 1951, p. 106) thinks that the monastery was built to commemorate the treaty signed during the early 730 's. This is incorrect. He mistook the Tibetan king who ruled in 821 for the one who ruled in 730 .

${ }^{88}$ Franke 1970, p. 57, note 2.

${ }^{89}$ Li Fang-kuei 1955, p. 56. See also Richardson 1952, p. 71.

${ }^{90}$ Li Fang-kuei 1955, pp. 6-8.

${ }^{1}$ JTS 196B, p. 5265; XTS 216B, p. 6102.

${ }^{92}$ Li Fang-kuei 1955, pp. 22-3; Richardson 1969, p. 35; Beckwith 1987, p. 167.
} 


\section{The Weizhou Incident in $\mathbf{8 3 1}$}

Even after the treaty was concluded, border conflicts still occurred in 821 and $822 .{ }^{93}$ Peace, however, prevailed most of the time from 822 to 847 , interrupted only by a Tibetan incursion in 830 and by the incident of Weizhou (in modern Sichuan) in 831.

In 831, Xidamou, the Tibetan Vice Commissioner of Weizhou, asked to submit to Tang. Weizhou had strategic importance to China. A route extended from there without much geographical hindrance all the way to the Tibetan capital. The Chinese recovery of the city would force Tibet to station a large force in that area, thus alleviating the pressure on other Chinese frontiers. Li Deyu, then Military Commissioner of Xichuan, despatched troops to occupy the town of Weizhou and requested permission from the court to send 3,000 Qiang troops to penetrate into Tibet.

At a court discussion, the majority of the officials agreed, but Chief Minister Niu Sengru raised an objection. Niu conceded that Tibet had a large territory and losing Weizhou would not be a serious matter. However, he warned that if China violated the peace agreement by taking Weizhou, the Tibetans could easily invade from the northwest, posing a threat to the Tang capital. Violating the treaty, he believed, would cause great harm without any benefit. Emperor Wenzong agreed with Niu Sengru and ordered the return of Weizhou. Xidamou and his followers were executed by the Tibetan court when they reached the border. ${ }^{94}$ In $843 \mathrm{Li}$ Deyu, reviewing the Weizhou incident, pointed out that in 830 the Tibetans had made incursions across China's border, thus breaking the peace agreement. ${ }^{95}$ The attack of 830 had certainly provided the Chinese with an excuse to discard the treaty.

On the surface, this argument between $\mathrm{Niu}$ and $\mathrm{Li}$ reflects the conflict between Confucian moralistic ideology and pragmatic considerations in Chinese foreign relations. It also involves, however, a more complex question. Did Niu. Sengru insist on keeping faithfully to the agreement because he believed in it or because he would have objected to any proposal by Li Deyu. Using Confucianism against Li's pragmatic strategy was controversial, since Niu and Li were engaged in factional strife, the notorious "Niu-Li factional quarrel." Wenzong, though persuaded by Niu

\footnotetext{
${ }^{93}$ JTS 196B, p. 5265; ZZTJ 242, p. 7802; p. 7818.

94 JTS 172, p. 4471 ; 174, p. 4519 ; XTS 174, p. 5231 ; 180, pp. 5332-3; 216B, p. 6104; ZZTJ 244, p. 7878; 247, pp. 7976-8.

${ }^{95}$ Li Wenrao Wenji 12, pp. 64-5.
} 
Sengru at the time, soon regretted his decision and dismissed Niu from his post of Chief Minister when some officials pointed out that the return of the submitted Tibetans would discourage future defections, and when the $\mathrm{Li}$ group insisted that Niu's objection was simply intended to harm $\mathrm{Li}$ Deyu. ${ }^{96}$

In 847, taking advantage of Tang's being in mourning at Wuzong's death, the Tibetans, in alliance with the Dangxiang and Uighurs, made an incursion. ${ }^{97}$ However, by this time Tibet was itself in chaos. When Khri gtsug lde brtsan was in power, he devoted himself to promoting Buddhism. In 842, his successor, who opposed Buddhism and promoted the Bon religion, was assassinated by a Buddhist hermit. The central authority rapidly dissolved in the subsequent struggles over the succession. Tibet suffered the disaster of a civil war between two generals, Lun Kongre (Blon Gung bzher) and Shang Beibei, which lasted at least until $8500^{98}$ Blon Gung bzher went to the Tang court to ask for aid and political investiture so that he could reestablish central control of Tibet. Upon Tang's refusal he too lost power. ${ }^{99}$ He was captured by Tang in $866 .{ }^{100}$

From 849 , the prefectures in modern Ningxia and Gansu which had been under Tibetan control since the An Lushan rebelllion returned to Tang. In 851, Zhang Yichao of Shazhou led local people to drive the Tibetan generals away and submitted to Tang. From then on, Tibet ceased to be a power threatening China's frontiers.

\section{Peace and War with Nanzhao}

With the collapse of the Tibetan state and the Uighur empire, Nanzhao became the next major foreign threat to Tang China.

Until the 820's, relations between Tang and Nanzhao were peaceful. In 820 , when the Tibetans attacked China's southwestern borders before the Tang-Tibetan treaty came into effect, Nanzhao offered to send 20,000 troops to help the Chinese. ${ }^{101}$ But between 829 and 830, Nanzhao plundered Sichuan and briefly occupied Chengdu. This invasion was mainly provoked by actions of the Chinese Military Commissioner of

${ }^{96}$ JTS 174, p. 4519; XTS 180, pp. 5332-3; ZZTJ 244, p. 7880.

${ }^{97}$ ZZTJ 248, p. 8030.

${ }^{98}$ For details concerning the Tibetan internal situation, see Wang Zhong 1958, pp. 14558; Beckwith 1987, pp. 168-72.

${ }^{99}$ ZZTJ 249, p. 8047.

${ }^{100}$ ZZTJ 250, p. 8115.

${ }^{101}$ Backus 1981, pp. 103-4. 
Jiannan, Du Yuanying, who mismanaged the relationship with Nanzhao, neglected frontier defense, and displayed his military incompetence. In addition, the Nanzhao rulership was motivated by its desire for the material riches of Sichuan. In 831, another border clash took place. During the tenure of Li Deyu as the Military Commissioner of Xichuan between 830 and late $832, \mathrm{Li}$ diligently fulfilled his responsibilities and stabilized the frontier situation. Peace was maintained until the 850 's. ${ }^{102}$

While Nanzhao maintained peace with Tang along the border with Sichuan, it continued the advance southward which it had started after 829, expanding its influence and territorial control to Guangxi and northern Vietnam, then under the loose control of Tang through the Protectorate of Annan (Vietnamese Annam) with its seat in present Hanoi. Some late sources say that Nanzhao launched its attack on Annan as early as 846, but this is uncertain. ${ }^{103}$

During his brief tenure as the Protector-General of Annan in 853855 , Li Zhuo mismanaged frontier defense and relations with the aboriginal peoples. He caused strong resentment among the Man people, who sought aid from Nanzhao, thus making possible Nanzhao's further advance into the area. In 858 a Nanzhao force invaded Annan, but soon retreated.

More serious conflicts followed. In 859, Du Cong, the Military Commissioner of Xichuan, proposed that Tang reduce the number of Nanzhao youths permitted to come to Chengdu as students as well as the number in each tribute-bearing delegation to the court on the grounds that both placed a heavy economic burden on the local government for their accommodation. The court agreed. This enraged the king of Nanzhao, who decided on retaliatory action. Although he died in the same year, the new king, Shilong, adopted a more aggressive attitude towards Tang.

Trouble arose because the first character in Shilong's name was part of Tang Taizong's personal name (Shimin) and the second had the same pronunciation as one of the characters in Xuanzong's personal name (Longji). The personal names of emperors were taboo. The Chinese sources all refer to Shilong as Qiulong. Because of this, the Tang court refused to invest him with the title of king. It may have also been because, on the one hand, the Chinese were aware of the growing power of Nanzhao and wished to restrain it by not recognizing the new king, and on

\footnotetext{
${ }^{102}$ Backus 1981, pp. 101-30.

${ }^{103}$ Backus 1981, p. 130
} 
the other hand, because the collapse of Tibet removed the need to have Nanzhao as an ally.

However, Nanzhao had developed into a strong regional power, and one capable of confronting Tang at the margins of Tang power. Shilong soon went beyond nibbling at the margins of Tang power. He proclaimed himself emperor, renamed his state Dali $(859-877$, to be distinguished from the later Kingdom of Dali, 937-1253) and adopted his own reign name for the calendar rather than following the Chinese ones as his predecessors had done, all of which symbolized his independence.

He launched an attack on Bozhou in present Guizhou in 859, and in $860-861$ the Nanzhao troops, responding to an appeal by a local rebel leader, attacked and briefly occupied Hanoi. A more serious invasion of Annan was mounted in the winter of 862-863, resulting in the capture of Hanoi after a siege. Annan was recovered and Hanoi eventually retaken in 866 by Gao Pian, a brilliant general, as well as a poet, from a family of Parhae extraction that had been serving in the Tang Palace Armies since early in the ninth century. ${ }^{104}$

Annan remained under Chinese control for the remainder of the Tang dynasty but dissatisfaction with Chinese rule and aspirations for independence that gave rise to the revolt in 860-861 foreshadowed the foundation of the independent Vietnamese state there in 939.

In 861, Du Cong, now Chief Minister, urged measures to bring Nanzhao back into good relations with Tang, but it was too late. Wars between Tang and Nanzhao lasted until 875, with the focal point first in Annan and then in Sichuan. During this period, Tang was on the defensive. Personal jealousy and spite among frontier officials and between the frontier officials and eunuch army supervisors, as well as the generally deteriorating situation inside China all contributed to the weakening of China's military power on the frontiers. Long years of fighting and being stationed in the south exhausted both Chinese troops and the treasury.

In 868, unbearable conditions led to the rebellion of Pang Xun, who led a mutiny by troops who had been sent from Xuzhou several years before to Guizhou (in present Guangxi) to defend against Nanzhao. Earlier, these soldiers had been told that their period of service would be three years, but after six years they were told they had to stay in service for another year. Resentment exploded into revolt. ${ }^{105}$ Although the rebellion was

${ }^{104}$ Wang Jilin 1976, pp. 335-9; Backus 1981, pp. 131-5; Hayashi 1992, p. 127-31.

${ }^{105}$ Somers 1979, pp. 695-700; Backus 1981, pp. 135-53. 
suppressed the following year, waves of popular uprisings, the most significant being one led by Wang Xianzhi and Huang Chao (874-884), grievously weakened the Tang dynasty.

Song Qi in his historian's comment in the Xin Tangshu concludes: "Tang perished because of Huang Chao, but the root of the disaster was in Guilin (where Pang Xun rose in rebellion)."106 Though this may seem exaggerated, Pang Xun's rebellion and its connection with Nanzhao was certainly one of the more important factors that contributed to the collapse of the Tang dynasty in 907.

After the loss of Annan, Nanzhao continued to attack China more directly in Sichuan, even threatening Chengdu. Once more the situation was saved by Gao Pian, who was made Military Commissioner of Xichuan in 875. After restoring the military situation and forcing the Nanzhao forces to withdraw, he initiated peace negotiations, sending a Buddhist priest as his envoy and promising (apparently without authorization by the Tang court) to send Shilong a Tang princess for marriage. Shilong welcomed the gesture, but insisted on an equal footing with China. However, he died in 877 . This marked the beginning of the end of military hostilities between the two countries.

The many wars had exhausted both Tang and Nanzhao. The new king sent a diplomatic mission to the Tang court to negotiate a peace settlement the next year. At the Tang court, controversy arose as to whether Tang should accept the request of Nanzhao to be treated as younger brother rather than as a subject. On this demand for equality, the court could reach no decision. Finally, in 880 , Tang gave in. It sent a Tang prince with rich gifts as an envoy to the king of Nanzhao. Tang accepted the proposal for marriage and acknowledged Nanzhao as an equal. That is, Nanzhao would no longer have to refer to itself as a subject. However, the promised marriage never took place. Nanzhao, for its part, did not commit any further aggression on the Tang borders even when Tang China dissolved into chaos.

The kingdom of Nanzhao thereafter devoted itself to religious and cultural development until the royal family was overthrown and replaced in 902. This ended the Nanzhao kingdom. In 937 the Dali kingdom was founded in Yunnan, and was to last for the next three centuries.

${ }^{106}$ XTS 222B, p. 6295.

${ }^{107}$ Backus 1981, pp. 153-64. 
The An Lushan rebellion tipped the balance decisively against Tang in its military confrontation with Tibet, which by that time also had Nanzhao as its ally on China's southwestern flank. The Chinese had to adopt a very pragmatic attitude in order to maintain a balance of power among its strong neighbors. While Suzong and Daizong accepted assistance from the Uighurs and others for the suppression of internal disturbances, they resisted Tibetan help, since Tibet was obviously more interested in seizing Chinese territory than in helping the court. Sworn treaties made with Tibet in 762,765 , and 767 on Tibetan terms were of even less effect than those of 706 and 732, which had been followed by peace for about four and five years respectively.

Because of the personal humiliation he had suffered in the past, Dezong attempted to break with the Uighurs and make an alliance with Tibet instead. This resulted in the treaty of 783, which recognized the Tibetan occupation of Chinese land. It was followed by three years of peace, during which time the Tibetans refused to assist a Chinese rebel against the court and, on being promised concessions in land, sent military assistance to relieve the crisis of Zhu Ci's rebellion in 783-784. When Tang refused to fulfill the land concession promise on the grounds that Tibet had not fully carried out its part of the bargain, Tibet retaliated and the pro-Tibetan policy ended with the disaster of the "False Treaty of Pingliang" in 787.

Thereafter, the court had to return to the Uighur alliance and also to make an alliance with Nanzhao against Tibet. China shared more common interests with these states than with Tibet. From early in the ninth century, Tibetan power was on the decline. It tried to make peace with Tang, and the treaty of $821 / 822$ was indeed followed by peace, with only brief interruptions, for over twenty years. To a large extent, however, the absence of hostilities was a result of the pacific attitude of the Tibetan ruler then and the weakened position of his country.

The ineffectiveness of the Tang-Tibetan treaties was due to the lack of common interests between the two parties and the limited rewards that conclusion of treaties seemed to offer to both sides. Nevertheless, the act of treaty-making was itself a remarkable innovation. In concluding their treaties with Tibet in the post-An Lushan period, the Chinese had to abandon their claims of superiority. In revising the wording in the official letter from Tang to Tibet in 781 and in the sworn treaty of 783, China re- 
cognized Tibet as an equal power. The $821 / 822$ covenant made this concession even more apparent. The inclusion of both Chinese and Tibetan rituals in the ceremonies in 762, 783 and 821/822 implied reciprocity and equality. Some of the articles in the treaties of 783 and 821/822 resemble the characteristics of a modern treaty concluded between sovereign equals.

Just as peace seemed ensured with the Uighurs and Tibet, the Nanzhao kingdom in the south from the 820's raised a new challenge. Like the Tibetan state, Nanzhao became interested in territory and in raiding Chinese frontiers. It plundered Sichuan in 829-830, and expanded eastward, coming close to the Chinese Annan Protectorate. Moreover, it competed with Tang for control over the local aboriginal peoples. Relations with Nanzhao were to a large extent handled by local Chinese officials. The effectiveness of their management often determined the degree of danger in the local situation.

When both the Uighur empire and Tibet disintegrated as states in the 840's, Tang, taking advantage of the situation, resorted to force to speed up the process, but in the south, Tang did not have much leverage. From 858 until 877, confrontations with Nanzhao persisted, and Annan was occupied for a time. China was on the defensive. In 868, the Chinese troops sent to the far south rebelled under the leadership of Pang Xun. This touched off a series of rebellions which proved to be fatal for the

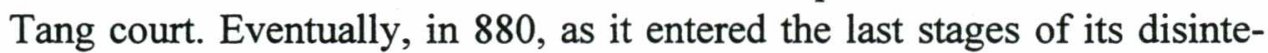
gration, the Tang court formally recognized Nanzhao as an equal. 


\section{Chapter 11}

\section{Characteristics of Foreign Policy During the Sui-Tang Period}

To the Sui and Tang Chinese, the world around their Middle Kingdom was much enlarged compared to earlier times and their knowledge of that world was more intimate and solid. The Sui and Tang royal houses were heirs of the alien rulers of North China, not just in the mixture of non-Chinese and Chinese blood that ran in their veins, but also in their political, economic and military systems, as well as in their religious beliefs. The Sui and Tang emperors, while proclaiming themselves Sons of Heaven in the Confucian tradition, relied heavily on Daoism and the foreign religion of Buddhism to enhance the legitimacy of their rule, and the early Tang rulers from Taizong on also assumed the title of Heavenly Qaghan. The two titles presented them as legitimate rulers of both the Chinese of the Middle Kingdom, and the non-Chinese on the steppes and in the Western Regions.

Within the ruling class there were not only officials from nonChinese families of the Northern dynasties, but also foreign generals and chiefs recruited during the Tang period. At least 372 identifiably foreign generals served in Tang armies, including both those from states which had submitted to Tang as well as Tang's allies. ${ }^{1}$ The number of nonChinese soldiers in Chinese armies must have been many times larger.

This non-Chinese component in both the ruling and ruled classes, together with the importation of foreign goods and ideas from countries all over Asia, gave China an open, cosmopolitan air during the Tang period, especially before the An Lushan rebellion.

At the same time there were always many advocates of the inwardlooking attitude, the attitude of "having all the Chinese within and keeping all the barbarians without" and drawing a clear line between the "civilized Middleland" and the "savage, useless" land of the "barbarians," and between the Chinese as "roots" and the non-Chinese as "branches and leaves." Among the Tang Chinese, the idea always prevailed that Confu-

\footnotetext{
${ }^{1}$ For a list, see Zhang Qun 1986, pp. 37-95.
} 
cian norms could be applied only to insiders, the Chinese, and not to outsiders, the non-Chinese. And yet, distrust or hatred of foreigners coexisted with a love of exotic things. ${ }^{2}$ In early Tang, there were anti-Buddhist scholars such as Fu Yi, and in the post-rebellion time, the Confucian polemicist, $\mathrm{Han} \mathrm{Yu}$, attacked Buddhism in his famous memorial on the bone of Buddha in 819 as a "barbarian" importation that must be rejected in order to restore the traditional sinocentric doctrine. ${ }^{3}$

Both ideological purity and pragmatism were at work in foreign policy all through the dynasty's tenure, but generally speaking, to those responsible for making the decisions, the basic principle underlying foreign policy was the pragmatic assumption that the best strategy was to adapt plans to the actual situation at the time, since circumstances changed frequently and the balance of power did not remain the same. Pragmatism was most in evidence at the beginning of the Tang dynasty under Gaozu and during the post-rebellion time, when the government had to accommodate itself to the foreign powers and recognize them as equals in reality. The Sui-Tang regimes followed policy measures which fit into the same five categories discussed above in Chapter 1 as characteristic of earlier times-aggressive military expansion, frontier defense, alliance, appeasement and settlement and incorporation-and, in accordance with circumstances, made adjustments, changes and innovations in policy whenever they were necessary.

\section{Aggressive military measures to expand Chinese territory.}

Military aggression was carried out on a much larger scale than in earlier times. Since there were no well-defined physical boundaries between China and its neighbors, aggression and defense were fluid concepts. All Chinese governments claimed that it was their objective to maintain security on the frontiers and to achieve political prestige in the world known to them. In reality, they varied in the degree to which they used aggressive military force to reach their goals.

Under the pretext of achieving national security, the Sui Emperor Yang attempted to expand Chinese power to the Western Regions, to the islands off the South China coast, and to Korea in three disastrous wars against Koguryǒ.

The Tang emperor Taizong started his reign with a cautious atti-

\footnotetext{
${ }^{2}$ Schafer 1963, p. 23.

${ }^{3}$ Hartman 1986, pp. 84-6; p. 153.
} 
tude towards military campaigns, but cherished the ambition to be a real universal ruler, and to restore an empire on the Han model. After the conquest of the Eastern Turks in 630, he steadily carried out his program of empire-building using the militia system, then in its full vigor, and the incorporation of nomadic cavalry generals and soldiers into the Chinese armies.

The momentum of aggressive expansion under Taizong carried on into the early years of Gaozong's reign, and succeeded in stretching Tang administration far beyond previous limits, including the Mongolian steppe land, the Western Regions and beyond, and the major part of the Korean peninsula. In Xuanzong's time, although Tang switched its foreign policy from aggression to frontier defense, with huge armies of both Chinese and non-Chinese generals and soldiers permanently stationed in the frontier regions, passive defense led to aggressive defense and new or revived expansionist adventures.

The An Lushan rebellion abruptly halted Tang's foreign adventures. Seriously weakened by the fragmented internal situation, the Tang rulers were forced to turn to accommodation in their dealings with neighboring peoples. Any aggressive use of military force was likely to be directed against the autonomous Military Commissioners in the provinces, rather than foreign powers.

\section{Strengthening frontier defense.}

While active aggression was a major feature of the conduct of foreign affairs during Sui and the first half of the Tang dynasty, for practical reasons, the Sui-Tang rulers always attached great importance to building strong frontier defenses. The two Sui emperors several times repaired the Great Wall and built frontier fortifications, while inside China, following the practice of the Northern Zhou dynasty, the Sui government strengthened the fubing militia system so as to exercise better central control over the armies of the state. Sui established regional commands in control of military affairs in several prefectures in areas of major strategic importance in order to ensure secure and trouble-free frontiers. Emperor Yang abolished the regional commands but Tang Gaozu reinstated them. The militia system was further rationalized and improved under Taizong.

After the success of Tang expansion in the 650's, the area to be defended was greatly enlarged. Under Gaozong and Empress Wu, efforts were made to maintain Chinese control through suppression of rebellions and readjustment of the jimi administrative system. From 670 on, Tang 
was seriously challenged by the powerful Tibetan kingdom, whose territorial ambitions led to its annexation of the Tuyuhun and to its swallowing of some of the oasis states.

While the court persisted in competing with Tibet for control over the Western Regions, under Empress Wu, China turned from aggression to building up a strong defense line along the northern frontiers through construction of fortifications manned by large numbers of stationary troops. The court withdrew its administration from the Korean peninsula in 676, and in 682 when the Turks broke away from Chinese control, China ended its administration in the steppe.

The policy of building strong frontier defenses continued under Xuanzong. By now the system of rotating fubing militiamen for frontier service had collapsed and larger numbers of permanent, professional soldiers than at any earlier time in history were stationed on the frontiers. The frontier armies were organized into regional commands under Military Commissioners. Successful for a time, this system was developed at the devastating cost of a weakened domestic defense for the capital. At the same time, the power of the Military Commissioners also increased inordinately, creating the conditions that led to the rebellion of one of their number, An Lushan.

After the rebellion, challenged by strong internal regional powers, the court had no choice but to cope with external threats by passive defense: it recognized Tibetan occupation of the He-Long region and concluded peace treaties with this powerful kingdom on an equal basis, and it maintained at enormous cost the alliance with the Uighur empire for the sake of its military assistance. Meanwhile the court relied on the loyal Military Commissioners for frontier defense and made efforts to build strong Palace Armies with the Shence Army as their backbone. From 786 on, Tang developed a new frontier defense system of four frontier lines in the northwest: outer garrisons, major strategic walled towns, Shence garrisons near the capital, and Shence armies in the capital. In the southwest it was the Military Commissioners who dealt with the Nanzhao kingdom.

\section{Alliance strategies.}

In military encounters with foreign powers, the Sui-Tang rulers did not just rely on their own armed forces; in most cases, in fact, success was achieved more often by alliance strategies. Compared with their Han predecessors, the Sui-Tang rulers were much more familiar with nomadic society and had more intimate knowledge about what was going on among 
the nomads through more frequent interactions with them. Alliance strategies were responsible for the successes of Sui Emperor Wen in bringing the Eastern Turks into the tributary system, and for Tang Taizong's series of successes in defeating the Eastern Turks and the Xueyantuo. Without the alliance with Silla, Gaozong would not have conquered Paekche and Koguryǒ. Alliance with the Uighurs was a prominent feature of Tang times both before and after the An Lushan rebellion.

Marriage alliance was more widely and frequently used than in other periods of Chinese history: altogether six marriages were concluded during the Sui dynasty with the Turks, Tuyuhun and Gaochang; during the Tang period before the An Lushan rebellion, about twenty such contracts were made with the Turks, Tuyuhun, Tibet, Gaochang, Xi, Khitan, Türgish, Khotan and Ferghana. ${ }^{4}$ Even from the sparse records on these marriages, we see that some of these princesses, such as the Zhou Princess Qianjin and the Sui Princess Yicheng, who married Turkish qaghans, and the Tang Princesses Wencheng and Jincheng, married to rulers of Tibet, played important roles in international politics and in cultural exchange.

Before the An Lushan rebellion, the Sui and Tang courts utilized marriage alliances in a more positive way than did Han. The marriages were for the purpose of using "barbarians against barbarians" or as rewards to the non-Chinese. Several times the court refused the requests of non-Chinese rulers for marriage alliances when they would not benefit Tang. The courts had a quite open, and positive view of the policy of marriage alliance, and did not consider it a policy of humiliation.

The royal families of the Sui and early Tang had both intermarried with non-Chinese. Taizong once remarked that among the northern "barbarians" decisions were often influenced by the wives of the rulers, and that if these women were from China and had children, their sons would be grandsons of the royal family and would not invade China. ${ }^{5}$ In at least two cases, however, China was forced into agreeing to marriages. One was the marriage of Princess Wencheng to the Tibetan ruler, which was agreed to by Taizong only after the Tibetans had made a military demonstration on the border. The other was when the Turkish qaghan Bäg Chor in 698 requested a marriage between his daughter and a Chinese prince.

\footnotetext{
${ }^{4}$ Kuang Pingzhang 1935; Zhang Zhengming 1987, pp. 6-7. For marriage alliances with the Turks, see also Lin Enxian 1988, pp. 183-224.

${ }^{5}$ ZGZY 9, p. 6a.
} 
It is interesting to note that marriage between Chinese men and non-Chinese women for political purposes was common during the Northern dynasties, and continued to be common during Sui and Tang, although such marriages had much less importance then. In 584, the Turkish qaghan, Ishbara, gave the hand of his cousin to a Sui envoy. ${ }^{6}$ Another such marriage occurred under empress $\mathrm{Wu}$, as mentioned above. In 756, when the Tang court was faced with the crisis of An Lushan's rebellion, it sent a prince to marry an Uighur lady as a step toward forming an alliance.

The An Lushan rebellion switched Tang China into a disadvantageous position vis-à-vis its neighbors. The policy of marriage alliance continued, but only with the Uighurs. Among the seven dynastic marriages with the Uighurs that took place, an unprecedented three princesses (Ningguo, Xian'an and Taihe) sent to the Uighurs were the true daughters of Tang emperors. Two others were daughters of Pugu Huaien, a descendent of a former Uighur chief who had submitted to Tang in Taizong's time.

\section{Appeasement policies.}

When China was weak, the Chinese rulers demonstrated a remarkable flexibility in adapting their policies to the situation at hand, and did not hesitate to resort to open appeasement. In dealing with powerful foreign rivals, Taizong while still a prince formed a relationship of sworn brotherhood with a Western Turkish prince and with Tölish Qaghan of the Eastern Turks. Faced with a Turkish challenge, Tang Gaozu assumed a humble attitude toward the Turks. During the An Lushan rebellion, China was definitely in a weak position. Appeasement, therefore, had to play a major role in its foreign policy. Appeasement was necessary to ensure Uighur assistance in suppressing the rebellion and to maintain a balance of power in China's relationships with Tibet, the Uighur empire and the Nanzhao kingdom.

The court adopted several other measures besides marriage contracts to appease the Uighurs and keep them as allies, including political investiture and payment of lavish subsidies. Also, despite the great strain on the economy, the Chinese kept up the horse-silk trade. These measures achieved their intended effect of purchasing military assistance and peace with the Uighurs in the frontier regions. There was also an unintended side effect: they contributed to the gradual economic and social transition of

${ }^{6}$ SUIS 84, p. 1869; ZZTJ 176, p. 5477. 
the Uighurs from a mobile and nomadic society to a settled semiagricultural society, and made the Uighurs rely more on the Chinese economy than had any previous nomadic power, so that they found it as necessary to maintain peace with Tang as Tang did to preserve good relations with them.

For the sake of peace, the Tang court concluded several peace treaties with the Turks, one in 794 with the Nanzhao kingdom, and on a more frequent basis with Tibet. Seven sworn covenants were made with the Tibetan kingdom. The two before the An Lushan rebellion were violated by the Chinese. The specific terms of the first treaty are not available but it is clear that the Tang court insisted on explicit recognition of its superiority of status in the treaty of 732. After the rebellion, however, when Tang was in a weakened position, the next four treaties concluded were all soon broken off by the Tibetans and only the last had any effect at all in maintaining peace. The Chinese official attitude also changed. Especially in the last treaty of 821 , they recognized Tibet as an equal. At the same time, however, the Tang Chinese retained the traditional Chinese view that the conclusion of a sworn covenant reflected an unstable situation and deterioration of the state, and a belief that sworn covenants were concluded mostly when trust was in doubt.

Nevertheless the act itself was remarkable in history. Throughout the period from the founding of the Qin empire in 221 B.C.E. to 1689 C.E., when the Qing government concluded the treaty of Nerchinsk with the Russian empire, the Chinese entered into many treaties with nonChinese states. However, in no case did they conclude as many sworn covenants as late Tang did with the Tibetans: the Xiongnu and Han made frequent peace agreements but the only sworn treaty between them was an unofficial one concluded in 43 B.C.E. between the Xiongnu and Han envoys on the latter's own initiative and without the previous approval of the court; the Khitan-Liao (916-1125) concluded two sworn treaties with Northern Song (960-1127), and the Jurchen-Jin (1115-1234) three with the Southern Song (1127-1279) governments. ${ }^{7}$

\section{Settlement and incorporation.}

The policy of settlement and incorporation of non-Chinese into the Chinese state and their gradual assimilation to Chinese ways, was actively pursued by the Sui-Tang rulers before the An Lushan rebellion. Even

\footnotetext{
${ }^{7}$ For a study of the treaties of the Song period, see Franke 1970.
} 
though the history of Western Jin had shown that settling non-Chinese, especially nomads, close to or within Chinese territory, could cause disaster for China, and even though there were constant objections from critics at court, the Sui-Tang rulers persisted with the policy of resettlement.

The Tang frontier administration made impressive innovations in the systemization of institutions. Non-Chinese who submitted to Tang were organized into jimi fuzhou with the aim of pacifying and gradually sinicizing them while using their military strength. Through this kind of arrangement, Tang administration of non-Chinese expanded to cover more people and a much larger area than during the Han dynasty. In the frontier regions, the highest office in charge of the resettled non-Chinese was the Protectorate, which had its precedent in the Han Protectorate of the Western Regions. Six Protectorates of major importance were founded during Tang plus several others of lesser importance. Up to Xuanzong's time it was these Protectorates that assumed the main responsibility for Chinese frontier defenses.

Incorporation of non-Chinese was given moral justification by the concept of universal kingship. In his resettling of Turks and Koreans, Taizong does indeed reveal something of an ambition to be a true world emperor who did not distinguish between his Chinese and non-Chinese subjects. It was partly the non-Chinese background of the Li-Tang family that evoked such formulations. But the extent to which Taizong really believed in equality of Chinese and non-Chinese is open to question.

From a practical point of view, it was often the case that the Chinese rulers could not afford to refuse non-Chinese offers of submission and requests for resettlement, particularly when such practices were less costly than engaging in wars for the purpose of keeping peace on the frontiers. Also, the Chinese rulers could then utilize the considerable military force of the nomads. In this respect, both Sui and Tang rulers, especially the latter, made much more active use of non-Chinese forces in their military campaigns, and showed less compunction in doing so than had Han.

Such a defense system was, however, severely challenged in the closing decades of the seventh century when the Turks earlier placed under the jimi fuzhou system rose in rebellion. The policy broke down almost altogether after the An Lushan rebellion. Towards the end of the Tang dynasty the policy of resettlement was no longer favored by Tang even when the non-Chinese favored it. When the Uighur empire collapsed and the Uighurs asked the Tang court to arrange some kind of resettlement for them, the court accepted the Uighurs under Ormïzt only after his group 
was weakened by internal disputes and refused the Uighurs under Ögä Qaghan, while keeping up relations with the Kirghiz, the enemy of the Uighurs, who finally helped Tang to crush Ögä Qaghan. 


\section{Chapter 12}

\section{Epilogue}

By the end of the Tang dynasty, China's international situation had changed. The Korean problem had long been settled by China's abandonment of its earlier policy of military conquest of the peninsula. The Tibetan kingdom collapsed on its own and Tibet never afterwards became a threat to China. The Uighur steppe empire also collapsed and the Uighurs left the steppe and settled in the Western Regions and ceased to be a military threat. The Nanzhao royal family was overthrown in 902. Five other non-Chinese peoples, however, grew to the extent that they eventually became contenders for political supremacy inside China or on its borders.

One was the Shatuo Turks, whose rise and eventual establishement of three short-lived dynasties during the period of the Five Dynasties was an important consequence of the Tang resettlement policy. Of Western Turkish origin, the Shatuo submitted to Tang at the end of Taizong's reign. They took part in the Tang suppression of the An Lushan rebellion, but joined the Tibetans after 790. In 808 they again went over to Tang and settled in Yanzhou in the Ordos region. The following year 1,200 Shatuo cavalrymen were stationed in Taiyuan as part of a Chinese defense force. The rest were settled in northern Shanxi.

From then on the Shatuo played an important role in Tang northern frontier defense, but the turning point in their establishment of a power base in China came after they had taken part in the suppression of the Pang Xun rebellion. In 869, the court rewarded the Shatuo leader, Chixin, with the royal surname, calling him Li Guochang, and appointed him Military Commissioner of Yunzhou. After a period of hostility between Li and the court, he and his son Keyong came to terms with Tang and participated in the suppression of the Huang Chao rebellion. Both father and son were subsequently made Military Commissioners. It was from the Shatuo-Li that rulers of Later Tang (923-936), Later Jin (936-941) and Later Han (947-950) arose during the period of the Five Dynasties. ${ }^{1}$ As at the end of Han, nomads who had been incorporated near the frontier under Chinese

${ }^{1}$ XTS 218; Pulleyblank 1953, pp. 592-7; Zhang Qun 1986, pp. 324-31. 
administration were able to turn inwards and intervene in Chinese affairs during a time of dynastic collapse.

A second new power were the Dangxiang Qiang, a Tangut people, their rise was also related to the Tang settlement policy. They were originally from the Tao River region east of Koko Nor. In the seventh century, they came under pressure from the newly established Tibetan kingdom and were to resettle at Qingzhou, northwest of Chang'an in the upper Wei Valley. ${ }^{2}$ From 758 onward, taking advantage of the disturbances of the An Lushan rebellion, they constantly raided nearby areas and even the metropolitan region. ${ }^{3}$ The Dangxiang Qiang joined the Tibetans and Uighurs in supporting Pugu Huaien in 764-765. After the defeat of Pugu Huaien, on the advice of Guo Ziyi, the Dangxiang Qiang tribes and the remnants of the Tuyuhun were removed into the Ordos east of Xiazhou and north of Yinzhou so that they would be cut off from the Tibetans. From then until the ninth century the Dangxiang remained on the whole peaceful. ${ }^{4}$

They kept their nomadic lifestyle while engaging in frequent trade with the Chinese, including illegal trade in weapons. They increased in strength and population. Friction often occurred between them and the Chinese government during the ninth century. Around 873, one tribal chief, Tuoba Sigong, occupied Youzhou and proclaimed himself Prefect. He helped suppress the Huang Chao rebellion by lending his military force to the Tang court, and was appointed general with the status of Military Commissioner in command of Xiazhou, Suizhou, Yinzhou and Youzhou. In 883 he was ennobled as the Duke of Xia and given the imperial Li surname. ${ }^{5}$ During the Five Dynasties, the Dangxiang Li regime maintained its position by accepting subject status to the successive dynastic powers in north China. Eventually, its ruler assumed the title of emperor and established the Xia state in 1038. Xia lasted until 1227, encompassing at the height of its power a vast area in the Ordos, Ningxia, Gansu, and Qinghai. ${ }^{6}$

A third power was created by the Khitan. The Khitan were subject to the Uighurs during the post-An Lushan period when relations between Tang and the Khitan remained peaceful, except for an isolated incident in 788 when the Khitan, $\mathrm{Xi}$ and Shiwei raided the Chinese Zhenwu Fortress.

\footnotetext{
${ }^{2}$ JTS 198 , p. $5292 ; X T S 221$ A, p. 6215.

${ }^{3}$ ZZTJ 220, p. 7060; 221, p. 7090; p. 7092; p. 7093; p. 7100; 222, p. 7105; 223, p. 7164; p. 7172 .

${ }^{4} X T S 221 \mathrm{~A}$, pp. 6216-7.

${ }^{5}$ XTS 221A, pp. 6217-8; ZZTJ 254, p. 8249.

${ }^{6}$ For the rise of the Dangxiang-Xia state see Wu Tianchi 1980, chapter 1; Dunnel 1994.
} 
When the Uighurs disintegrated, the Khitan turned to Tang, which conferred official titles on their chief in 842. From the 880's, the Khitan became expansionary, attacking the $\mathrm{Xi}$ and other tribes, and raiding the $\mathrm{He}$ bei region. In 907, the year Tang ended, Yelü Abaoji became the qaghan of the Khitan, and in 916 he proclaimed himself emperor. It was under him that the Khitan developed their state organization.

For hundreds of years the Khitan tried to maintain their independence from the great powers surrounding them. They eventually succeeded in becoming an imperial power themselves, but only when there was no other imperial nomadic power on the steppe to oppose them and when China was in chaos. Just before his death in 926 Abaoji conquered the Parhae state. His successor changed the state name to Liao and gained a foothold in north China in 937 when the Later Jin regime ceded sixteen prefectures in northern Shanxi and Hebei to him. This powerful Liao empire confronted the Five Dynasties and then Northern Song for the next two centuries until 1125 . $^{7}$

The fourth new state was in the southwest. In 937 the Dali kingdom was founded in Yunnan. It was to last for the next three centuries until it was conquered by the Mongols.

The fifth power rose in the far south. After the fall of Tang, the Protectorate of Annan ceased to be under Chinese rule and in 939 the independent kingdom of Annam was founded. China lost the political control over what is now northern Vietnam that it had held for over a thousand years, though the new native regime remained thoroughly sinicized in its institutions and outlook.

At the end of the Tang dynasty in 907, a new international order emerged in East and Central Asia. China was internally divided as never before since Warring States or Northern and Southern Dynasties times, and far more sharply than during the civil wars at the end of Western Han, or at the end of Sui. This new period of disunity is called the period of the Five Dynasties and Ten Kingdoms. Unlike the chaotic situation of the socalled Sixteen Kingdoms in the fourth century, which inaugurated nearly three hundred years of non-Chinese rule in North China, a regime of Chinese origin took over within a little over fifty years. Song succeeded in reestablishing a stable regime over most of Chinese territory in 960.

The Song empire (960-1279) was, however, hemmed in on all sides by newly developed non-Chinese states, whose emergence had been very

${ }^{7}$ XTS 219, pp. 6172-3; Zhang Zhengming 1979, pp. 23-9; Barfield 1989, pp. 168-72. 
much stimulated by frequent interactions with China during Tang, and which were much under the influence of the Chinese political system and Chinese culture. The most serious rival of Song was the Khitan-Liao empire (916-1125), occupying part of the former Tang territory in northern Hebei and Shanxi. To the west was the Tangut Western Xia state (10321227). The Jurchen, formerly subjects of Liao in Manchuria, overthrew their overlords and went on to occupy the whole of North China and found the Jin empire (1115-1234), challenging the Southern Song.

These non-Chinese dynastic powers, especially Liao and Jin, differed fundamentally from anything Sui and Tang had had to deal with. Although they had their own languages and scripts, they all adopted Chinese dynastic names and developed bureaucratic systems based on the Chinese model. Their rulers all aspired to be Sons of Heaven and, as Tang Taizong and the other early Tang rulers had done, to rule over the steppe land as well as China. ${ }^{8}$

Interstate relations were based on maintenance of a balance of power. Under the resulting multi-state international system, Song and Liao and later Jin had to accept the coexistence of two Sons of Heaven, and had to interact through negotiations, treaties, alliances, diplomacy, and trade, though interrupted often by wars. During this age of treaties, Song demonstrated tremendous pragmatism and flexibility, and increasing interest in foreign trade, not only as a means to facilitate peace but also as a way to profit the Song state, whose territory was much shrunken as compared to Tang. ${ }^{9}$ The expansion of the Tang dynasty was criticized by the Song NeoConfucian scholar-officials. ${ }^{10}$ Yet, as during Tang, the traditional ideology persisted. Song still maintained its claim of superiority whenever it could.

Song followed three different patterns in its relations with these three neighbors. It maintained a relatively equal relationship with the KhitanLiao empire as stipulated in the treaty concluded in 1005, under which the two states established a brotherly relationship. Song made annual payments of silver and silk to Liao as "military compensation" rather than "tribute." Compared to the Tang-Tibet treaties, the first Song-Liao treaty and treaties concluded later were more specific in their terms and in specifying the rewards to both sides, and thus were more effective in keeping

\footnotetext{
${ }^{8}$ Franke and Twitchett 1994, p. 16.

${ }^{9}$ For Song foreign trade see Shiba, 1983.

${ }^{10}$ Tao Jing-shen 1988, p. 41.

${ }^{11}$ For Song-Liao relations, see Tao Jing-shen 1983; 1988, especially chapters 2, 4 and 5; Twitchett and Tietze 1994.
} 
the peace. Equality was carefully preserved in the official terminology employed in written and ceremonial communications.

The two states often addressed each other as "the northern dynasty" and "the southern dynasty." Terms such as "Great Song" and "Great Liao" appear throughout Northern Song official writings, including state letters and imperial edicts. After 1005 Song abolished all place names containing degrading ideographs, such as "caitiffs" (lu) and "barbarians" (rong). Bilateral trade was regulated and was conducted on a regular basis.

In reality, however, Song was in an inferior position due to its relatively weak military strength. In the second peace treaty, concluded in 1042 , the term for Song payment to Liao was changed from "give (a gift)" (zeng) to "pay" (na). Fully aware of the weakness of Song, most officials for most of the time favored the use of peaceful tactics in dealing with the "barbarians." They preferred to believe that the "barbarian" menace was not as serious as internal problems. Moreover, Song Chinese officials commonly believed that Liao was to a large extent sinicized, and that the Khitan differed from the ancient "barbarians," and thus that Khitans should be treated as equals.

While Song was highly realistic in its relationship with Liao and made a series of compromises in order to keep the peace, it did not make any marriage alliances with Liao. To some Song Chinese, a marriage alliance would have been more of an insult and humiliation than payment of goods. ${ }^{12}$ This was in sharp contrast to Tang, whose ruling house was itself a mixture of Chinese and non-Chinese blood and hence was not prejudiced against marriage alliances with foreigners. The use of the language of equality in diplomacy did not mean that the Song emperors and their ministers had accepted the concept of equality and peaceful coexistence with other peoples. In documents meant exclusively for internal circulation among Chinese officials and in private writings, foreigners were still often referred to by the traditional degrading terms.

In its relationship with the Western Xia empire, the Song dynasty insisted on assuming suzerainty as called for in the traditional Chinese world order. In the treaty with Xia of 1044 Song recognized the Xia emperor, but it was stipulated that Xia should retain nominal status as vassal to Song. In return, Song was to provide Xia with a large annual subsidy of silk, silver and tea. The two sides also resumed regular trade in the ten border mar-

\footnotetext{
12 Tao Jing-shen 1988 , pp. 60-2.

${ }^{13}$ Tao Jing-shen 1983; 1988, chapter 4.
} 
kets, but border warfare still erupted from time to time. Xia also accepted the status of vassal to Liao, and in 1124 became vassal to Jin. ${ }^{14}$

In 1123, not long after the rise of the Jurchens, Song made an alliance with them against Liao, but the collapse of Liao in 1125 was soon followed by the expansion of Jin farther into North China and the end of Northern Song in 1127. For the next hundred years, China was divided between Jin and Southern Song.

The relationship between the two was unequal from the beginning. Under the terms of the 1142 treaty, Southern Song had to make annual payments of silver and silk as tribute to Jin and the Song ruler accepted Jin investiture with the title of emperor. The treaty brought about a peace that lasted until 1160. After Jin failed in an attempt to invade the South in 1161 , the two sides reached another peace agreement in 1165 . This time the terms improved for Song. The Song emperor was no longer a Jin subject but a metaphorical nephew of Jin, which still implied an unequal status. The annual payments were reduced and were no longer referred to as tribute. A new treaty was concluded in 1208 after Southern Song's unsuccessful northern campaign. Song had to increase its annual payments and, as a guarantee of future peace, it also had to present to Jin the head of the councilor who was held responsible for the war. The two sides maintained the border on the Huai River. ${ }^{15}$ The Jin empire, however, was soon faced with a new challenge from the Mongols and collapsed in 1234.

After he assumed the supreme rulership over the Mongols in 1206, Chinggis Khan devoted his life to military conquests, and these were continued by his successors. When his grandson Khubilai became the great khan in 1260, the Mongol empire extended from Korea to Western Asia and had already occupied north and southwest China. Khubilai Khan, now supreme ruler of the steppes, adopted the Chinese title, Son of Heaven, when he founded the Yuan dynasty in 1271 . He completed the conquest of Southern Song in 1279.

In contrast to Tang Taizong and Gaozong, who added the title of Heavenly Qaghan to that of the Chinese Son of Heaven and extended their rule over the steppes and the Western Regions through the system of jimi, or subordinated area commands and prefectures, it was now the Mongol khans who claimed universal rulership over the whole of agricultural China as well as the steppe. Both Mongol and Chinese rulers made a

\footnotetext{
${ }^{14}$ Dunnel 1994.

${ }^{15}$ Franke 1994.
} 
similar ideological claim to universal rulership with the Mandate of Heaven, but in reality the Mongol concept was far more ambitious than that of any Chinese emperor.

To the Mongol khans, All-under-Heaven was not just the Middle Kingdom extending outward to the surrounding areas but meant any part of the world to which their military force could carry them, including all of Asia and even parts of Europe. While Chinese emperors such as Emperor Wu of Han, Emperor Yang of Sui and Tang Taizong only sometimes launched military campaigns to impose their demands, the Mongols relied almost exclusively on military force to establish their domain over foreign countries.

While the submission demanded by the Chinese was to a large extent only nominal, requiring foreign rulers merely to acknowledge Chinese suzerainty by making a symbolic payment of tribute and accepting Chinese investiture, the Mongol demand for submission was total, as can be seen in Khubilai's demands to Annam and Champa (present Vietnam). The ruler was to come to audience personally and to send sons as hostages. A Mongol governor was to be in charge of taking a census of the population, levying a military corvée and collection of taxes. When these terms were refused, Khubilai resorted to military force. ${ }^{16}$ These terms were also imposed on other dependent states such as the Uighurs of Turfan. ${ }^{17}$

The Yuan dynasty in China collapsed in the face of internal uprisings, and Mongol rule ended with the founding of the Ming dynasty (13681644). The Mongols, who had retreated to the steppe, resumed the role of a nomadic power threatening China and became the main perceived threat in Ming frontier policy. Before 1449, Ming foreign policy was primarily to engage in active campaigns striking at the Mongol capital in Khara Khorum, and attempting to destroy the Mongol force.

The Hongwu emperor (r. 1368-98), founder of the Ming dynasty, launched expeditions into the steppes and the Yongle emperor (r. 1403-24) personally led five campaigns to chastise the Mongols. The Yongle emperor also utilized the traditional device of divide and rule ${ }^{18}$ and sought to reduce Mongol raids by inviting the Mongols to trade under the tribute

\footnotetext{
${ }^{16}$ Wang Gungwu 1968, pp. 48-9. For more on the Mongol-Yuan expansion, see Rossabi 1988; Franke and Twitchett eds. The Cambridge History of China, volume 6, chapters 46.

${ }^{17}$ Allsen 1983.

${ }^{18}$ Waldron 1989 , p. 57 ; pp. 74-6.
} 
system. ${ }^{19}$ These efforts, however, had little success in weakening Mongol power or in reducing Mongol incursions on the northern borders. By the early 1440's, the Mongols were again united under a leader from the Western Mongols. Because of disputes over trade, the Mongols launched a large-scale invasion of China in 1449. The young Zhengtong emperor personally led his armies into battle against the Mongols, and was severely defeated, taken prisoner and carried back to the steppe. ${ }^{20}$

The active offensive policy towards the Mongols was part of the early Ming expansionism which began under the Yongle emperor. He moved the capital from Nanjing to Beijing and made an unsuccessful attempt to conquer Annam. Both Hongwu and Yongle were also enthusiastic about enlarging the Ming tribute relationship with the East and Southeast Asian countries via maritime expeditions, and with the Central Asian countries through diplomatic missions.

By far the most spectacular endeavour under Yongle and his immediate successors were the seven maritime expeditions led by the eunuch Zheng $\mathrm{He}$ and his colleagues between 1405 and 1431 which went as far as the east coast of Africa. ${ }^{21}$

It has been argued that the early Ming military policies resembled those of its Mongol predeccessors and that the Ming emperors were ambitious to incorporate Mongolia into the Chinese empire. ${ }^{22}$ It should also be pointed out that whether it was the Mongol model or traditional Chinese ideology or a combination of the two that inspired the aggressive policy of the early Ming emperors, the Mongol problem was a practical threat that had to be dealt with in order to maintain peace within the empire.

After the 1449 crisis, the Ming's Mongol policy alternated between offense and defense. In the decade from 1470 to 1480 , China had several successful military encounters with the Mongols, who from the 1450's had disintergrated into different groups. As during Tang, when the government from the 670's on began building a strong defense system through permanent armies and garrisons, following a series of debates the Ming government decided on a defense policy focusing on repairing and extending the Great Wall.

Unlike Tang, the Ming Chinese chose not to keep up economic con-

\footnotetext{
${ }^{19}$ Chan, Hok-lam 1988, pp. 264-6.

${ }^{20}$ Waldron 1989 , pp. 88-90.

${ }^{21}$ Chan, Hok-lam 1988, pp. 221-36.

${ }^{22}$ Waldron 1989, pp. 72-6.
} 
tacts with the nomads, since they considered that to do so would be like the humiliating compromises made in the Song treaties with the nonChinese states and would strengthen their rivals. As a reaction to the Mongol conquest of China, the idea of keeping the "barbarians" out and the Chinese within was prevalent. The defensive policy was also preferred because Ming did not possess enough force to carry out effective offensives. It was ill-informed about the internal situation among the Mongols and hence unable to exploit internal divisions among them through the strategy of divide and rule. ${ }^{23}$ For the rest of the dynasty, wall building and the garrisoning of the wall defense zone became the preoccupation of the Ming state. Chinese-Mongol relations were finally stabilized by a peace agreement in 1571. There were a few disruptions thereafter, but on the whole the new agreements ensured peace on the northern borders. ${ }^{24}$

While the northern borders were a major concern, from the 1520's on, a new issue rose along the Chinese coastal line, piracy. The problem is traditionally known as that of the "Japanese pirates," although many Chinese joined the Japanese too. The Ming response to this growing disorder on the coast was to issue a prohibition of maritime trade. During the 1540 's groups of pirates and traders became more organized, and their activities reached a peak in the 1540's and 1550's. At first, force was used to deal with the problem, but after repeated discussions, the Ming government finally decided to open up maritime trade in 1567 . Thereafter piracy ceased to be a serious problem. ${ }^{25}$

The last imperial dynasty, Qing, founded by the Manchus, who were semi-nomadic descendants of the Jurchen-Jin, displayed vigor in its foreign policy during its early years. Heirs to both nomadic and Chinese cultural and political traditions, the Manchu-Qing rulers developed the tribute system into an elaborate framework for China's relations with East and Southeast Asian countries, and one serving both political and commercial purposes. The early Manchu emperors secured control of their long Inner Asian frontiers through alliance, trade and force. In the eighteenth century, Qing managed to incorporate the Tarim basin into the empire as the province of Xinjiang, extended indirect control over distant Tibet, and brought the Mongol problem to an end after the Chinese and Russian empires through the Treaty of Kiakhta in 1727 encircled Mongol territory and

\footnotetext{
${ }^{23}$ Mote 1988, pp. 389-402; Barfield 1989, pp. 248-50; Waldron 1989, pp. 95-139.

${ }^{24}$ Rossabi, 1975, 45-46; Waldron 1989, pp. 185-8.

${ }^{25}$ Geiss 1988, pp. 490-505.
} 
thereby made the nomads lose their mobility. ${ }^{26}$

A fundamentally new issue in Qing foreign policy was how to deal with the West. On the northern frontier, came the encounter with the Russian empire. In 1689 and 1727, Qing and the Russian empire concluded two peace treaties. The 1689 Treaty of Nerchinsk is of significance to our story since it was signed as between two equal sovereign states operating in Inner Asia. On the southern coast, Qing was confronted by increasing demands for trade on the part of Europeans coming by the sea route. In the early dynasties, notably Tang, the Chinese empire was open to foreigners, who traded and resided not only in ports but also in the cities of the interior and the capital. Under the Ming and then the Qing Emperors, however, the Europeans were carefully restricted, eventually to a single city, Canton, and its immediate environs, and were prohibited from traveling or residing in other parts of the empire. Such restrictions, plus conflicts in culture, economy, political and legal institutions, caused tensions between China and the West that grew in the course of time and eventually led to military encounters in the two Opium Wars (1839-1842; 1856-1860), the outcomes of which forced China to open to the West.

The Chinese traditional theory of foreign policy underwent a painful process of rethinking which ended in its disintegration. In 1861 a new office to handle foreign affairs was set up in Peking, called the Zongli Yamen (Office of general management). In the early 1860's, international law was introduced into China. After 1876, Chinese diplomatic missions were established abroad. By 1880, China maintained legations in most of the leading Western states and Japan. The most significant change was the Chinese abandonment of the tribute system. This occurred after the SinoFrench War of 1883-85 over the status of Annam, which China previously considered a tributary, and after the Sino-Japanese War with Japan in 1894 over the status of Korea, also a tributary state to China. Only after China was forced to acknowledge its loss of tributary overlordship in Annam and Korea did it finally acknowledge abolition of the tributary sysem in principle with the establishment of a Western-style foreign office in $1901 .^{27}$

By the end of the imperial era, the Chinese world order had broken down and the Chinese view of their superiority underwent a fundamental change. Chinese policy-makers during this century have had to accept the modern concepts of the nation-state and the equality of sovereign states.

\footnotetext{
${ }^{26}$ For details, see Fletcher 1978.

${ }^{27}$ For details, see Hsu 1980; Hao 1980.
} 


\section{Appendix}

\section{Secondary Literature}

\section{The Chinese Tribute System}

Any study of China's foreign relations cannot avoid discussing the tribute system, the preferred traditional pattern employed to regulate the relations between China and foreign countries. The following describes selected modern works bearing on the tribute system, its theory, practice and implications.

Modern scholars trace the origins of the tribute system as far back as the Shang dynasty. The studies of the Shang dynasty by Chen Mengjia (1956) and David Keightley $(1979-80 ; 1983)$ show that Shang relations with its world implied an embryonic form of tribute system. The dependents of Shang came to have audience with the king. They were also expected to bring tribute, support the king's affairs, and join in military campaigns.

L. I. Duman (1981) holds that there is no doubt that a tribute system existed in Shang times, and that the system was further developed during the Zhou period. Choon S. Lee's Ph. D. dissertation, "The origin, functions, and nature of the tributary system in the Chou times" (1980), contrasts the role of the tributary system during Western Zhou, when the feudal lords paid regular court visits to the Zhou Son of Heaven, to the situation in the Chunqiu period when one of the major states assumed the role of hegemon in the name of the Son of Heaven and expected smaller feudal principalities to bring tribute when they visited the hegemon's court.

Yü Ying-shih in his excellent work, Trade and Expansion in Han China (1967), explores how the tribute system took full shape during the Han dynasty, and what were the political principles and economic and cultural implications embodied in the system. Through analyses of Han's relationship with its neighboring peoples he points out an important feature in the tribute system: although the tribute system became an allembracing framework to regulate Chinese foreign relations, non-Chinese "acceptance" of Chinese imperial rule involved not only different levels of "acceptance," but also different categories of "rule." Countries were treat- 
ed differently under the tribute system according to their distance from China and their relative importance in Chinese frontier politics.

Ise Sentarō in his Chūgoku Seiiki Keieishi Kenkyū (1st. ed. 1955; 2nd. ed. 1968), a study of the history of Chinese administration in the Western Regions, shows in detail how the tribute system functioned to attach the states in the Western Regions to Tang before the An Lushan rebellion. He concludes that Tang policies were more tolerant than those of the Han dynasty because the Tang rulers, especially Tang Taizong, were more accepting of the cultures of the non-Chinese states and envisioned combining Chinese and non-Chinese into one transcendent universal state. $^{1}$

The role of ideological purity in the theory of the tribute system is a central issue of several works. In The Chinese View of Their Place in the World (1964), a brief survey of Chinese views throughout history, C. P. Fitzgerald argues that even though the Chinese had frequent contact with the outside world, the absence of any nearby rival center of civilization contributed most powerfully to maintaining traditional Chinese sinocentricity. However, Fitzgerald overemphasizes the continuity of such dominance and fails to examine the many periods when alternatives to the tribute system prevailed.

The Chinese World Order (1968), edited by John K. Fairbank, is an important collection of essays revolving around the tribute system, focusing mainly on the Ming and Qing periods. In his introduction Fairbank stresses the elements of ideological continuity in the tributary system, but neglects the pragmatism and flexibility embodied in it. The strength of the book is in its detailed and insightful examination of how the Chinese world order was justified, explanation of why the tribute system was so persuasive a part of traditional Chinese political ideology, and its detailed description of the system's basic features in theory and in practice, as shown in China's relationships with various countries in three zones: East Asia, Inner Asia and the regions beyond. Of particular interest for the study of the tribute system as a framework for understanding Chinese foreign policy are the essays in the Fairbank volume by Lien-sheng Yang, Wang Gungwu and Mark Mancall.

Nishijima Sadao, in his Chūgoku Kodai Kokka to Higashi Ajia Sekai (1983: part II), claims that the tribute system and the system of investiture maintained by China in its relations with the Korean kingdoms

\footnotetext{
${ }^{1}$ See in particular his chapter 8 .
} 
formed an integrated international order holding together the East Asian world with China as suzerain at the center. It was to maintain this system that Sui and Tang mounted expeditions against Koguryǒ.

Concentrating on the realism and pragmatism that then lay behind certain imperial foreign policy decisions, China among Equals edited by M. Rossabi (1983), an important collection of essays on Chinese foreign relations focusing on the tenth to fourteenth centuries, challenges the myths that, from the Han dynasty onward, the Chinese uniformly and rigidly applied a single ideology in their foreign relations, that they lacked interest in foreign commerce and that they were ignorant of foreign lands. It concentrates on the realism and pragmatism that lay behind Song imperial foreign policy decisions.

Larry W. Moses, in his article "T'ang tribute relations with the Inner Asian barbarians" (1976), stresses that the nomads of the Tang period had a history of their own and evolved their own foreign policy mechanisms. Their acceptance of vassal status in the tribute system was determined by their own political needs. This insight is further elaborated by Thomas Barfield ("The Hsiung-nu imperial confederacy: organization and foreign policy," 1981; The Perilous Frontier: Nomadic Empires and China, 1989) as the "inner frontier strategy," that is, submission to China when the nomads were weak so as to use Chinese assistance to recover their strength. According to Barfield, this was in contrast to the "outer frontier strategy," which was to force the Chinese into accommodating their demands for subsidies and trade when the nomads were strong.

Articles by Kaneko Shūichi $(1974 ; 1988)$ and Wang Zhenping (1994) also deal with the tribute system from the point of view of the nonChinese. Kaneko examines changes in the protocols of correspondence between Tang and Tibet as Tibet pressed its demands for equality. Wang shows how before 608 Japan's letters to Sui similarly attempted to assert equal status.

\section{The Nomadic Peoples and Sui-Tang China}

The long and fascinating history of the nomadic peoples and their relationships with the sedentary societies have attracted great interest among generations of modern scholars and stimulated numerous works. The bibliographies of Lin Enxian's book Tujue Yanjiu (1988) and in the chapters on the Turks by Denis Sinor and the Uighurs by Colin Mackerras in The Cambridge History of Early Inner Asia (1990) list important works in Chinese, Japanese and Western languages, most of which deal more 
with the origins, culture, and internal evolution of the nomadic peoples than with their external relations with the Chinese agricultural society.

For my purposes, the Inner Asians' interactions with and their impact on China as well as the effects on the nomads themselves are the central issues. Xiao Qiqing's article "Beiya youmu minzu nanqin gezhong yuanyin de jiantao" (1972) is a very useful survey of the various theories that seek to explain the constant nomadic invasions of the agricultural society. Owen Lattimore's Inner Asian Frontiers of China (1951; first edition 1940) remains a basic work for its study of the cyclical patterns of interaction between China and its nomadic and semi-nomadic neighbors to the north and west in contrast to the agricultural south. It provides an insightful framework of analysis in terms of ecological systems, and its main contribution is to treat the non-Chinese on their own terms. Building upon Lattimore's work, Thomas Barfield $(1981,1989)$ explores the history of non-Chinese powers on the northern frontiers of China from the Xiongnu to the Manchus, developing the theory that in order to sustain their state power, the nomads could not rely solely on their own pastoralism but depended on obtaining goods from China by trading, raiding or extracting subsidies, so that their states often rose and fell in parallel with changes in Chinese politics.

A. M. Khazanov, in his excellent work, Nomads and the Outside World (1994; first edition 1984), a comprehensive study of the nomadic societies of various types in Eurasia and Africa, points out that it was the highly specialized economy of pastoralism that made the nomads dependent on neighboring agricultural societies for economic survival and for political stability, and that made the nomads use trade, submission, raids and pillage to acquire the agricultural goods they needed. Works by Mori Masao (1978) and Hilda Ecsedy $(1968 ; 1974 ; 1981)$ deal with the importance of trade and the different perspectives on trade of the agricultural and nomad peoples. Works by Jagchid and Hyer (1979), and Jagchid and Symons (1989) also stress the importance of trade for nomadic society, and insist that Chinese disruption of the smooth working of mechanisms for trade stimulated the nomads to launch raids or wars. Nicola Di Cosmo's recent article (1994) further argues that Xiongnu nomadic power was based on a mixed economy and depended on trade relations and control of settled populations on all sides.

For the study of China's relations with the Turks, Edouard Chavannes' Documents sur les Tou-Kiue [Turcs] Occidentaux and Cen Zhongmian's Xi Tujue Shiliao Buque ji Kaozheng and Tujue Jishi are 
comprehensive in their collections of materials and detailed annotations. Mori Masao in his Kodai Toruko Minzokushi Kenkyū (1967), a collection of previously published articles, provides an insightful discussion on the relationship between China and the Turks. His work Kodai Yüboku Teik$o k u(1978,2$ nd ed.) is a narrative history of the Turks and their interactions with neighboring agricultural society. Iwami Kiyohiro's "Tō no Tokketsu imin ni taisuru sochi o megutte" (1987) investigates Tang's resettlement of the Turks after its conquest of the Eastern Turks in 630. Lin Enxian's Tujue Yanjiu (1988) is a general history, with chapters on the Sui-Tang policies of divide and rule, and marriage alliance. It also has an interesting chapter on how the Turks themselves adopted the policy of using the Chinese against the Chinese during the rise of the Tang dynasty. Another chapter is on the influence of Turkish culture on Tang China. Ma Changshou's Tujueren he Tujue Hanguo (1958) provides a succinct and useful narrative history. Hayashi Toshio's survey (1985) documents the evidence of agriculture in Turkish society.

Zhongguo Beifang Minzu Guanxishi (1987) is a general history of the non-Chinese peoples in the frontier regions from ancient Xia-Shang times until the Qing period. The book follows the orthodox Communist view that treats early histories of the nomads on the Mongolian steppe and the non-Chinese in the Western Regions and in Manchuria as part of Chinese history, and their relations with the Chinese government as those of local regimes with the central court.

Xue Zongzheng's Tujue Shi (1992) recognizes the danger of the above view in that, as he says, it in fact treats the justified wars of the Chinese against nomadic invasions as internal struggles between different ethnic groups. But Xue does not succeed in resolving the contradiction, since he remains bound by the modern political assumption that historical China must include all the territories now comprising the People's Republic. Xue's book is the most comprehensive study so far in mainland China of the history of the Turks from their origins to the collapse of the second Turkish empire in the mid-eighth century. The book reflects the revival of Chinese historical scholarship after the Cultural Revolution.

For the study of the Uighurs and their interactions with China in the Tang period, Haneda Tōru's "Tōdai kaikotsushi no kenkyū" (1957) is a valuable general discussion based on critical textual study of Chinese and Turkish sources. Wang Jingru's annotated translation of the Uighur inscription with introduction (1938) provides the Uighur perspective. Colin Mackerras' The Uighur Empire According to the T'ang Dynastic Histories 
(1972), an annotated translation of the Uighur chapters in the two Tang official histories, on the other hand, provides the Chinese point of view. Weiwuerzu Shiliao Jianbian by Feng Jiasheng and others is a collection of selected primary materials on Uighur history.

Mackerras' article "Sino-Uighur diplomatic and trade contacts (744 to 840)" (1969) and his chapter on the Uighurs in The Cambridge History of Early Inner Asia (1990) are also important in English scholarship. Duan Lianqin's Dingling, Gaoche yu Tiele (1988) is a narrative history of these peoples from ancient times until the mid-eighth century when the Uighurs founded their empire. Yang Shengmin's Huihe Shi (1991), also a general history of the Uighur people, begins with the Northern Di in Shang-Zhou times, treated as ancestors of the Uighurs, and ends with the Uighur settlement in the Western Regions after the collapse of the Uighur empire in the 840's. It is an introduction to the Uighurs' life, society, economic development, religious and political evolution, and interactions with China, Tibet and other peoples. In his dissertation (1986), "The writings of Li Te-yü as sources for the history of T'ang-Inner Asian relations," Michael R. Drompp presents a detailed study of Tang relations with the Uighurs in the 840 's, focusing on the process of Chinese policy formation and implementation.

Minorsky's "Tamim ibn Bahr's journey to the Uyghurs" (1948) and Von Gabain's "Steppe und Stadt im Leben der ältesten Türken" (1949) are important for the light they shed on the Uighurs' transformation from a nomadic into a sedentary society as a result of frequent interactions with China. Such interactions particularly involved the horse-silk trade between the Tang China and the Uighurs. Many works deal with this topic. For example, see Yang Shengmin's work and the articles by Jagchid Sechin (1971), Liu Yitang (1974), Fu Lecheng (1977; first published 1953), Cui Mingde (1986), Zhang Qun (1990: chapter 4) and Christopher I. Beckwith (1991). The marriage alliance between Tang and the Uighurs is discussed by Lin Enxian (1970) and by Jagchid (1989).

\section{Western Regions}

On the Western Regions, Ise Sentarō's Chūgoku Seiiki Keieishi Kenkyu (1968) is comprehensive and critical in its treatment of primary sources, covering the period from the Han dynasty to the ninth century. Also valuable is Edouard Chavannes' Documents sur les Tou-Kiue [Turcs] Occidentaux. Ise's is still the most important work on the subject, although one could add other works published in recent years, such as Mori- 
yasu Takao (1973; 1977), Wu Yugui (1987), Lin Chaomin (1985), and Beckwith (1987).

\section{Korea and Sui-Tang China}

For China's relations with Korea before the end of the Tang period, the two Korean histories Samguk Sagi compiled in the twelfth century by Kim Pu-sik and the Samguk Yusa compiled by Iryorn towards the end of the thirteenth century are studied by modern scholars as primary sources. Jamieson examines the sources of these histories in his dissertation "The Samguk sagi and the unification wars" (1969) and his article "Collapse of the T'ang Silla alliance-Chinese and Korean accounts compared" (1970), and shows from the way in which parallel events are recorded that the Chinese and Koreans had different perspectives on their relations with each other. K.H.J. Gardiner's "The Samguk-sagi and its sources" (1970) discusses the Chinese and early Korean sources and points out the Chinese influence in the compilation of the Samguk Sagi. The Chōsen Shi, compiled by Chōsen Shi Henshū Kai of Japan (the first four volumes covering the period to the Unified Silla were published in 1932-1933), is a collection of highlights from all available materials in Chinese, Korean and Japanese traditional sources arranged in chronological order. The editor notes discrepancies when they occur but does not go into detailed discussion of them.

For general history, Hatada Takashi's A History of Korea (1969) provides a concise and valuable survey from prehistory to 1950 . K.H.J. Gardiner's The Early History of Korea: the Historical Development of the Peninsula up to the Introduction of Buddhism in the Fourth Century AD (1969) is a short history which pays attention to interactions between China and Korea. It has an appendix of sources in Chinese, Korean and Japanese. The History of Korea (1970) by prominent Korean scholars, Sohn Pow-key, Kim Chol-choon, and Hong Yi-sup, centers around political developments from prehistory to 1961. Lee Ki-baik's $A$ New History of Korea (1984) describes political, social, economic and cultural features in different periods from prehistory to 1960 .

For specific aspects of Sino-Korean interactions, there are Ikeuchi Hiroshi's Man-Sen Shi Kenkyū (1960, including articles published earlier), and Hatada Takashi and Inoue Hideo's Kodai no Chōsen (1974). John Charles Jamieson's dissertation (1969) discusses in detail how Silla took the initiative in forming the alliance with Tang China, and so succeeded in unifying the Korean peninsula. The Sui-Tang invasions of Korea are also 
an important issue in Cen Zhongmian's Sui-Tang Shi (1957) and Arthur Wright's The Sui Dynasty (1978). The intricate relations between Tang and Korea are placed in the larger context of East and Inner Asian international politics in the works of Hino Kaizaburō (mostly in the 1950's), Sakamoto Yoshitane (1978) and Nishijima Sadao (1983: part II). Hugh D. Walker's "Traditional Sino-Korean diplomatic relations" (1965) argues that Chinese expansion into Korea in the Han, Tang and Yuan periods stimulated the internal political development of Korea, and that Korea's acceptance of the Chinese tribute system before the foundation of the Yi dynasty in 1392 was just a diplomatic strategy having as its primary goal preservation of the independence of Korea. Chun Hae-jong's articles $(1966 ; 1968)$ provide a brief survey of the different patterns in the SinoKorean tributary relationships from the Han period to Qing.

\section{Peoples of Manchuria}

The existence of the Khitan, Xi and Mohe (to the latter of which the Jurchens are related ) people in Manchuria, and the rise of the Parhae state in Manchuria in the seventh century further complicated the relations between China and Korea. Hino Kaizaburō and Furutata Torū (1986) have articles on Parhae. Ishii Masatoshi (1984) examines the four letters written by Zhang Jiuling on behalf of Xuanzong to the king of Parhae. A recent work, Dongbei Minzu Yuanliu (1987), by a Chinese scholar, Sun Jinji, deals with the early evolution of these and other peoples in present northeast China.

In English scholarship, Barfield (1989) discusses how the Xianbei, Khitan, Jurchens and Manchus founded their states. Herbert Franke's chapter "The forest peoples of Manchuria: Kitans and Jurchens" in The Cambridge History of Early Inner Asia (1990) devotes some pages to the histories of the Khitan and Jurchens before the founding of their dynasties. The recently published The Cambridge History of China, Volume 6: Alien Regimes and Border States, 907-1368 (1994) also deals briefly with the predynastic history of the Khitan. It has very useful bibliographical essays that summarize the studies of the various peoples in Manchuria.

\section{Tibet and Sui-Tang China}

Several collections of Chinese sources in official histories are available: Su Jinren and Xiao Lianzi, Cefu Yuangui Tufan Shiliao Jiaozheng (1981), Chen Xiezhang and others, Zangzu Shiliao Ji (1982), and Su Jinren, Tongjian Tufan Shiliao (1982). In addition to the studies of pri- 
mary materials for the Tufan period mentioned in the Introduction, there are numerous other works mentioned in Beckwith's The Tibetan Empire in Central Asia (1987), which has a critcial summary of modern studies of Tibet and of traditional sources.

For Tibetan interactions with Sui-Tang China, Sato Hisashi's Kodai Chibetto shi Kenkyu (1958-1959) is the first major history of the internal evolution of Tibetan politics, military organization and economic structure, and how all these factors affected its relations with China. The Xin Tangshu Tufanzhuan Jianzheng (1958) by Wang Zhong is an annotated work with references to, Tibetan and other Chinese sources. Kolmas's "Four letters of Po Chu-i to the Tibetan authorities (808-810 A. D.)" (1966) is a substantial study, with translation, of these letters as compared with other sources. The article sheds light on how specific issues regarding territory were dealt with in official communications between Tang and Tibet. Ise Sentarō, in his Chūgoku Seiiki Keieishi Kenkyū (1968), analyzes the rapid development of the Tufan kingdom, and how this made Tibet play an important role in the Western Regions in opposition to both China and the Arabs. Ren Yucai's Tufan yu Tangchao Guanxi zhi Yanjiu (1971) outlines the relationship between Tang and Tibet and studies the impact of each culture on the other. Yamaguchi Zuiho in his Toban Okoku Seiritsu shi no Kenkyü (1983) reviews earlier studies on the founding of the Tufan kingdom and has carried further the analysis of the sources with emphasis on the impact of Chinese policy towards the Tuyuhun. Christopher Beckwith's dissertation, "A study of the early medieval Chinese, Latin, and Tibetan historical sources on pre-imperial Tibet" (1977), and his The Tibetan Empire in Central Asia (1987), drawing from sources in Tibetan, Arabic, Old Turkish, and Chinese, present a narrative history of Tibet before and during the Tufan period. His book examines the history of Tibetan expansion and confrontations with the Chinese, Turkish, and Arab powers with a view to placing Tibet in the contemporary international scene. As mentioned above, Kaneko Shūichi $(1974 ; 1988)$ has a detailed examination of the changes in official correspondence between Tang and Tibet, which shows the pragmatism of the Chinese side.

In the recently published The Cambridge History of Early Inner Asia (1990), H. Hoffman has a chapter "Early and medieval Tibet," which focuses on the origins and political history and religious development of Tibet until the fourteenth century. The most recent work listed in his bibliography was published in 1973. 


\section{Nanzhao}

Charles Backus's The Nan-chao Kingdom and T'ang China's Southwestern Frontier (1981) is a comprehensive study of the history of Nanzhao, including a full bibliography of previous works of both Eastern and Western scholarship. Wang Yongxing's article (1988) discusses the role of Wei Gao in Tang relations with Tibet and Nanzhao. Hayashi Ken'ichiro in his article of 1990 deals mainly with the founding of Nanzhao and how this affected Tang policy towards that state. His 1992 study examines the relations of the Nanzhao kingdom with Tang China in the latter half of the ninth century with emphasis on Nanzhao's expansion. For a study of works compiled in Tang on Nanzhao such as the Manshu, see Xiang Da's article (1957) and his annotated study of the Manshu (1962). An English translation of the Manshu is available by G. E. Luce and Ch'en Yee Sein (1961).

\section{The Frontier Military System in Sui-Tang China}

Tang foreign policy was closely related to the frontier military system. E. G. Pulleyblank, in chapter 5 of his The Background of the Rebellion of An Lu-shan (1953), presents a clear description of the military situation, especially as involving the fubing or militia system, during the Tang period up to the An Lushan rebellion. Gu Jiguang's Fubing Zhidu Kaoshi (1962) examines in detail the fubing system from its beginning in the sixth century to its collapse in the eighth century. Chapters in The Cambridge History of China, Volume 3 (1979) provide further discussion of the evolution of the military system based on previous studies in Japanese, Chinese and Western languages. Kang Le's Tangdai Qianqi de Bianfang (1979) specifically deals with the frontier system of the first half of the Tang period. Liu Yat-ming's dissertation, "The Shen-Ts'e Armies and the palace commissions in China, 755-875 A.D" (1970), is useful particularly for the frontier and domestic military system in the post-An Lushan period. Lai Swee Fo's dissertation "The military and defense system under the T'ang dynasty" (1986) investigates the changes in the fubing, the palace armies and the Shence Armies, and the frontier defense system. Zhang Qun in his Tangdai Fanjiang Yanjiu (1986) and Tangdai Fanjiang Yanjiu Xubian (1990) provides a voluminous and comprehensive examination of non-Chinese generals under Tang. He illustrates placement of the nomadic peoples in the frontier regions as defending forces with useful maps (1986), and also addresses changes in frontier systems. 


\section{Table 1:}

\section{Sui-Tang Emperors and Major Events During Their Reigns SUI}

Emperor Wen

584

589

596

597

599

602

603

603 or 604

Emperor Yang

604-5

608

609

610

612

613

614
Eastern Turks make peace with Sui. Conquest of Chen

581-604

Expedition against Koguryǒ Princess Guanghua married to the Tuyuhun qaghan. Princess Anyi married to Zamqan Qaghan of the Eastern Turks. Princess Yicheng married to Zamqan (Qimin) Qaghan. Jiaozhou brought under Sui control Major defeat of the Western Turks by Sui Expedition against Champa 605-617 Expedition against Champa Hami brought under Sui control Sui defeats the Tuyuhun.

Expedition against Liuqiu Western Turks brought under Sui control Expedition against Koguryǒ Expedition against Koguryǒ Expedition against Koguryǒ

Princess Xinyi married to the Western Turkish Qaghan 615 Eastern Turks' siege of the Emperor at Yanmen

Emperor Gong

617
617-618

Tang alliance with Eastern Turks

TANG 
618 Succession of King Yǒngnyu in Koguryǒ, peace with Tang

Taizong

627

630

634

$634-5$

640

641

$644-5$

646

647

648

Gaozong

660

668

670

676

679

682

Zhongzong

Wu-Zhou (Empress Wu)

684

686-7

688

692

696-7

696

627-649

Eastern Turks besiege Chang'an

Conquest of the Eastern Turks First official contact between Tibet and Tang

Tang defeats Tuyuhun. Gaochang brought under Tang control Establishment of Protectorate of Anxi Princess Honghua married to the Tuyuhun Qaghan Princess Wencheng married to the Tibetan btsan-po.

Expedition against Koguryǒ Conquest of the Xueyantuo Expedition against Koguryǒ Expedition against Koguryǒ Tang capture of Kucha 650-683 Conquest of Western Turks Conquest of Paekche Conquest of Koguryǒ Tibet annexes Tuyuhun. Protectorate of Andong withdrawn from Pyǒngyang to Liaodong Tang recovers the Four Garrisons in the Western Regions. Restoration of the Second Turkish Empire 
703-5

Tibet makes peace with China.

Zhongzong

705-710

706

The first Tang-Tibet treaty

708

Building of the three Shouxiang Fortresses

709

Tang recognition of the Türgish qaghan

710

Princess Jincheng married to the Tibetan btsan-po

Wen Wang

710

Ruizong

710-712

Xuanzong

712-756

732

The second Tang-Tibet treaty

744

Assumption of the title of qaghan by the Uighur chief

745

Collapse of the Second Turkish Empire

751

Tang's defeat by the Arabs at the Talas River

755

An Lushan rises in rebellion.

Suzong

756-762

756-7

Uighurs assist in the suppression of the An Lushan rebellion.

758

Princess Ningguo married to the Uighur qaghan.

758-9

Uighurs assist in the suppression of the An Lushan rebellion.

762

The third Tang-Tibet treaty

Daizong

762-779

762-3

Uighurs assist in the suppression of the An Lushan rebellion

763

Final suppression of the An Lushan rebellion

Tibetan invasion of Chang'an

764 Pugu Huaien's revolt and alliance with Tibet and the Uighurs to attack

Chang'an

The fourth Tang-Tibet treaty

Pugu Huaien's alliance with Tibet and the Uighurs to attack Chang'an 767

The fifth Tang-Tibet treaty

Dezong

780-805

781-6

Revolts of Military Commissioners

The sixth Tang-Tibet treaty 
Shunzong

805

805

Abortive reform movement

Xianzong

806-820

806-19 Partial restoration of Tang authority over autonomous provinces

Muzong

821-824

821

$821-2$

Jingzong

Wenzong

829-30

Wuzong

840

After 842

Xuanzong

Yizong

868-9

Xizong

874-884

880

Zhaozong

902

Emperor Zhaoxuan

907
Princess Taihe married to the Uighur qaghan. The seventh Tang-Tibet treaty

825-827

827-840

Nanzhao's invasion of Chengdu

840-846

Collapse of the Uighur empire Disintegration of the Tibetan kingdom

847-860

860-874

Rebellion of Pang Xun

874-888

Rebellion of Wang Xianzhi-Huang Chao Tang's recognition of Nanzhao as an equal

889-904

End of the Nanzhao kingdom

905-907

Abdication of the last Tang emperor 


\section{Table 2}

Tribute Missions of the Three Korean Kingdoms to Sui and Tang (from 581 to 712)

(Sources: SUIS, BS, JTS, XTS, CFYG.)

\begin{tabular}{|c|c|c|c|}
\hline Year & Koguryǒ & Paekche & Silla \\
\hline 581 & 1 & 1 & \\
\hline 582 & 2 & 1 & \\
\hline 583 & 3 & & \\
\hline 584 & 1 & & \\
\hline 588 & & 1 & \\
\hline 591 & 2 & & \\
\hline 592 & 1 & & \\
\hline 594 & & & 1 \\
\hline 597 & 1 & & 1 \\
\hline 598 & & 1 & \\
\hline 600 & 1 & & \\
\hline 607 & & 2 & \\
\hline 608 & & 1 & \\
\hline 609 & 1 & & \\
\hline 611 & & 1 & \\
\hline 614 & & 1 & \\
\hline 615 & & & 1 \\
\hline \multicolumn{4}{|l|}{ Tang } \\
\hline 619 & 1 & & \\
\hline 621 & 1 & 1 & 1 \\
\hline 622 & 1 & & \\
\hline 623 & 1 & & 1 \\
\hline 624 & 1 & 1 & \\
\hline
\end{tabular}


Korean Tribute Missions to Sui and Tang

\begin{tabular}{|c|c|c|c|}
\hline Year & Koguryǒ & Paekche & Silla \\
\hline 625 & & 1 & 1 \\
\hline 626 & 1 & 1 & 1 \\
\hline 627 & & & 1 \\
\hline 628 & 1 & & \\
\hline 629 & 1 & 1 & 1 \\
\hline 631 & & 1 & 1 \\
\hline 632 & & 1 & 1 \\
\hline 635 & & 1 & \\
\hline 636 & & 1 & \\
\hline 637 & & 1 & \\
\hline 638 & & 1 & \\
\hline 639 & 1 & & 1 \\
\hline 640 & 1 & & \\
\hline 642 & 1 & 1 & 1 \\
\hline 643 & 1 & 1 & 1 \\
\hline 644 & 2 & 1 & 1 \\
\hline 646 & 1 & & \\
\hline 648 & 1 & & 2 \\
\hline 650 & & & 1 \\
\hline 651 & & 1 & \\
\hline 652 & 1 & 1 & 1 \\
\hline 653 & & & 1 \\
\hline 656 & 1 & & 1 \\
\hline 665 & 1 & & \\
\hline 675 & & & 1 \\
\hline 686 & & & 1 \\
\hline 699 & & & 1 \\
\hline 703 & & & 1 \\
\hline 705 & & & 3 \\
\hline 707 & & & 1 \\
\hline
\end{tabular}


Year

Koguryǒ

Paekche

Silla

709

710

1

711

1

712

1 


\section{Table 3}

\section{Participation in Tang Expeditions by Non-Chinese (618-669)}

$\begin{array}{lll}\text { Year } & \text { Expeditions } & \text { Those Paricipating } \\ 618 & \text { Xue Ju } & \text { W. Turks } \\ 620 & \text { Liu Wuzhou } & \text { Tujue }^{2} \\ 621 & \text { Dou Jiande } & \text { W. Turks }^{3} \\ & \text { Liu Heida, Gao Kaidao } & \text { Mohe }^{4} \\ 622 & \text { Liu Heida } & \text { W. Turks } \\ 634-5 & \text { Tuyuhun } & \text { Tujue, Qibi, Qiang }^{6} \\ 639 & \text { Gaochang } & \text { Tujue; Yanqi }^{7} \\ 641 & \text { Xueyantuo } & \text { Xi, Khitan, Tujue } \\ 644 & \text { Koguryǒ } & \text { Xi, Khitan, Mohe, Hu }^{9} \\ 645 & \text { Xueyantuo } & \text { Tujue }^{10} \\ 646 & * * & \text { Tujue, Qibi, Hu, Mohe }^{11} \\ 647 & \text { Kucha } & \text { Tiele,Tujue,Tibet, Tuyuhun }^{12} \\ 648 & \text { Xueyantuo } & \text { Tiele }^{13}\end{array}$

${ }^{1}$ These were the Western Turks under Danai who had submitted to Sui in 611. JTS 194B, p. 5180; Chavannes 1969, p. 22.

${ }^{2}$ JTS 194A, p. 5154; XTS 215A, p. 6029; ZZTJ 188, pp. 5884-5.

${ }^{3}$ The Western Turks under Danai, see JTS 194B, p. 5180; Chavannes 1969, p. 22.

${ }^{4}$ JTS 55, pp. 2259-60; 199B, pp. 5358-9.

${ }^{5}$ The Western Turks under Danai, see JTS 194B, p. 5180; Chavannes 1969, p. 22.

${ }^{6}$ JTS 198, p. 5298; XTS 221A, p. 6225; ZZTJ 194, p. 6108; Zhang Qun 1986, pp. 230-1.

${ }^{7}$ JTS 198, p. 5295; XTS 221A, p. 6221; p. 6229.

${ }^{8}$ ZZTJ 196, pp. 6171-2.

${ }^{9}$ ZZTJ, 197, p. 6209; CFYG 117, p. 1398.

${ }^{10} X T S 110$, p. 4116; 217B, p. 6138; ZZTJ 198, pp. 6232-3; CFYG 991, p. 11640.

${ }^{11}$ JTS 199B, p. 5347; ZZTJ 198, p. 6237; CFYG 985, pp. 11570-1; 991, p. 11640.

${ }^{12}$ The JTS 198 (p. 5303) records this event as in 646 while other sources record it as in 647, see XTS221A, p. 6231; ZZTJ 198, pp. 6250-1.

${ }^{13}$ CFYG 973, p. 11432 ; 985, p. 11573. 
Year Expeditions

649 Chebi Qaghan

651-652 Western Turks

656-657 Western Turks

658

660

661

662

668

669

\section{Koguryǒ}

Xi, Khitan

Koguryǒ

Rebelled Tiele

Koguryǒ

Xueyantuo

\section{Those Paricipating}

Huihe, Pugu ${ }^{14}$

Huihe $^{15}$

Huihe $^{16}$

Khitan $^{17}$

Tujue, Xueyantuo ${ }^{18}$

Huihe $^{19}$

Shatuo $^{20}$

Huihe $^{21}$

Tujue $^{22}$

${ }_{14}^{14}$ JTS 194A, p. 5165; XTS 215A, pp. 6041-2; ZZTJ 199, p. 6265; THY 94, p. 1690.

${ }^{15}$ JTS 194B, p. 5186; XTS 215B, p. 6061;ZZTJ 199, pp. 6274-7.

${ }^{16}$ TD 199, p. 1078; JTS 194B, p. 5187; 195, p. 5197; XTS 111, pp. 4137-8; 215B, p. $6062 ; 217$ A, p. $6113 ;$ ZZTJ 200, p. 6301; p. 6306; CFYG 973, p. 11433.

${ }^{17}$ ZZTJ 200, p. 6309.

${ }^{18}$ XTS 3, p. 60; 219, p. 6174; ZZTJ 200, p. 6320; CFYG 986, p. 11577.

${ }^{19}$ JTS 195 (p. 5197) says that the campaign was in 655 but Tang did not launch any campaign that year. XTS 217A, p. 6113; ZZTJ 200, p. 6323; CFYG 986, p. 11578.

${ }^{20}$ They were Western Turks. XTS 218, p. 6154.

${ }^{21}$ JTS 109, pp. 3293-4.

${ }^{22}$ THY 96, p. 1728. 


\section{WORKS CITED}

\section{Abbreviations}

BQS Bei Qishu 北齊書. [Tang] Li Baiyao 李百藥. Beijing: Zhonghua Shuju, 1972.

BS Beishi 北史. [Tang] Li Yanshou 李延壽. Beijing: Zhonghua Shuju, 1974.

CFYG Cefu Yuangui 册府元龜. [Song] Wang Qinruo 王欽若. Beijing: Zhonghua Shuju, 1960. Photocopied from the edition of 1642.

CS Chenshu 陳書. [Tang] Yao Silian 姚思廉. Beijing: Zhonghua Shuju, 1972.

HHS Hou Hanshu 後漢書. [Liu Song] Fan Ye 范曄. Beijing: Zhonghua Shuju, 1965.

HS Hanshu 漢 書. [Han] Ban Gu 班 固. Beijing: Zhonghua Shuju, 1962.

JS Jinshu 晉書. [Tang] Fang Xuanling 房玄齡. Beijing: Zhonghua Shuju, 1974.

JTS Jiu Tangshu 舊唐書. [Later Jin] Liu Xu 劉昫. Beijing: Zhonghua Shuju, 1975.

QTS Quan Tangshi 全唐詩. Shanghai: Guji Chubanshe, 1986. Based on the 1706 edition.

QTW Quan Tangwen 全唐文. [Qing] Dong Gao 董誥 and others eds. Shanghai: Guji Chubanshe, 1990. Reproduction of 1814 edition.

SGSG Samguk Sagi三國史記. Kim Pu-sik 金富軾(1073-1151). Keijo: Chosen Shi Gakkai ed., 1928.

SGZ Sanguozhi 三國志. [Jin] Chen Shou 陳 壽. Beijing: Zhonghua Shuju, 1959.

SJ Shiji 史記. [Han] Sima Qian 司馬遷. Beijing: Zhonghua Shuju, 1959.

SUIS Suishu 隋書. [Tang] Wei Zheng 魏徵. Beijing: Zhonghua Shuju, 1973. 
TLD Tang Liudian 唐六典. Kyoto: Kyoto Imperial University, photographed reprint of 1515 edition, 1935.

TD Tongdian 通典. [Tang] Du You 杜佑. Shanghai: Commercial Press, 1935.

TDZLJ Tang da Zhaoling Ji 唐大詔令集. [Song] Song Minqiu 宋敏求, ed. Beijing: Commercial Press, 1959.

THY Tang Huiyao 唐會要.[Song] Wang Pu 王溥, ed. Shanghai: Commercial Press, 1935.

WS Weishu 魏書. [Northern Qi] Wei Shou 魏收. Beijing: Zhonghua Shuju, 1974.

XTS Xin Tangshu 新唐書. [Song] Ouyang Xiu 歐陽修 and Song Qi 宋 叔. Beijing: Zhonghua Shuju, 1975.

ZGZY Zhenguan Zhengyao 貞觀政要. [Tang] Wu Jing 吳嗔. Included in Sibu Congkan edition.

ZS Zhoushu 周書. [Tang] Linghu Defen 令狐德菜. Beijing: Zhonghua Shuju, 1971.

ZZTJ Zizhi Tongjian 資治通鑒. [Song] Sima Guang 司馬光. Beijing: Guji Chubanshe, 1956.

\section{Traditional Chinese Works Listed by Titles}

Baishi Changqing Ji 白氏長慶集. [Tang] Bai Juyi 白居易. Included in Sibu Congkan edition.

Chen Boyu Wenji 陳伯玉文集. [Tang] Chen Zi'ang 陳子昂. Included in Sibu Congkan edition.

Da Tang Chuangye Qijuzhu 大唐創業起居注. [Tang] Wen Daya 溫大 雅. Included in Congshu Jicheng Chubian. Vols. 3828-31. Shanghai: Commercial Press, 1937.

Gongyangzhuan 公羊傳. Included in Combined Concordances to Ch'unCh'iu, Kung-yang, Ku-liang and Tso-chuan. Reprinted Taipei: Harvard-Yenching Institute Sinological Index Series, Supplement No. 11,1966 . In the footnote, the year is followed by the number of the sentence.

Guliangzhuan 轂梁傳. Included in Combined Concordances to Ch'un- 
Ch'iu, Kung-yang, Ku-liang and Tso-chuan. Reprinted Taipei: Harvard-Yenching Institute Sinological Index Series, Supplement No. 11, 1966.

Guoyu 國 語. Included in Congshu Jicheng Chubian. Vols. 3680-82. Shanghai: Commercial Press, 1937.

Han-Tang Dili Shuchao 漢唐地理書鈔. [Qing] Wang Mo 王謨. Reprint Beijing: Zhonghua Shuju, 1961.

Foguo Ji 佛國記. [Liu-Song] Faxian 法顯. Included in Wang Yunwu 王 雲五, ed. Wanyou Wenku. Shanghai: Commercial Press, 1937.

Junzhai Dushuzhi 郡齋讀書志. [Song] Chao Gongwu泉公武. [Qing] Wang Xianqian 王先謙 annotated edition. Reprint Taipei: Guangwen Shujue, 1967.

Li Wenrao Wenji 李文饒文集. [Tang] Li Deyu 李德裕. Included in Sibu Congkan edition.

Liji 禮記 (The Li Ki or Collection of Treatises on the Rules of Propriety or Ceremonial Usages). Translated by James Legge, included in F. Max Muller ed. The Sacred Books of the East, Vols. 27-28. Oxford: The Clarendon Press, 1885.

Lu Xuangong Hanyuanji 陸宣公翰苑集. [Tang] Lu Zhi 陸䞇. Included in Sibu Congkan edition.

Lunyu 論語 (Confucian Analects ). Translated by James Legge, included in The Four Books. Shanghai: the Chinese Book Company, 1930.

Luoyang Qielan Ji Jiaozhu 洛陽伽藍記校注. [Wei] Yang Xuanzhi 楊 街之. Annotated by Fan Xiangyong 范祥雍. Shanghai: Gudian Wenxue Chubanshe, 1958.

Manshu Jiaozhu 蠻書校注. [Tang] Fan Chuo 樊綽. Annotated by Xiang Da向達. Beijing: Zhonghua Shuju, 1962.

Nianershi Kaoyi 廿二史考異. [Qing] Qian Daxin 錢大昕. Beijing: Commercial Press, 1937. Reprint 1958.

Nianershi Zhaji 廿二史笭記. [Qing] Zhao Yi 趙翼. Included in Congshu Jicheng Chubian. Vols. 3547-48. Shanghai: Commercial Press, 1937.

Qujiang Zhang Xiansheng Wenji 曲江張先生文集. [Tang] Zhang 
Jiuling 張九齡. Included in Sibu Congkan edition.

Shangshu 尚 書 (The Book of Documents). Translated by Bernhard Karlgren. Stockholm: reprinted from the Museum of Far Eastern Antiquities, Bulletin, 22, 1950.

Shijia Fangzhi 釋 迦方志 [Tang] Daoxuan 道宣. Included in Taishō Shinshū Daizōkyō 大正新脩大藏經. Vol. 51, pp. 948-975. Tokyo, 1924-1934.

Shijing 詩 經 (The Book of Odes). Translated by Bernhard Karlgren. Stockholm: Museum of Far Eastern Antiquities, 1950.

Shiqishi Shangque 十七史商榷. [Qing] Wang Mingsheng 王鳴 盛.Beijing: Zhongguo Shudian, 1987, photocopied from Shanghai Wenruilou edition.

Wenguan Cilin 文館詞林. [Tang] Xu Jingzong 許敬宗 and others eds. Tokyo: Koten Kenkyūkai, 1969, photocopied from Konin (810824) edition.

Xunzi Jijie 荀子集解. Included in Zhuzi Jicheng. Vol. 2. Reprint Beijing: Zhonghua Shuju, 1954.

Yan Tie Lun Jiaozhu 鹽鐵論校注 . [Han] Huan Kuan 桓寬. Annotated by Wang Liqi 王利器. Shanghai: Gudian Wenxue Chubanshe, 1958.

Zhaode Xiansheng Junzhai Dushuzhi 昭德先生郡齋讀 書志. [Song] Chao Gongwu 泉公武. Included in Wang Yunwu ed. Wanyou Wenku. Shanghai: Commercial Press, 1937.

Zhizhai Shulu Jieti 直齋書錄解題. [Song] Chen Zhensun 陳振孫. [Qing] Wuyingdian edition. Reprint Taipei: Guangwen Shuju, 1968.

Zhouli Zhushu 周 禮注疏. Included in Shisan Jing Zhushu. Reprint Beijing: Zhonghua Shuju, no date.

Zuozhuan 左傳. Translated by James Legge, included in Chinese Classics. Vol. 5, the Ch'un Ts'ew, with the Tso Chuen. London: Oxford University Press, 1865. Page numbers are first given for the Chinese text and then for the translation. 


\section{Modern Works Listed by Authors}

Allsen, Thomas T. 1983. "The Yüan dynasty and the Uighurs of Turfan." In Morris Rossabi ed. China among Equals. Berkeley: University of California Press, pp. 243-280.

Asami, N 淺見直一郎 1985. “Yōtei no dai ichiji Kōkuri enseigun” 煬帝 の第一次高句麗遠征軍. Tōyōshi Kenkyū 東洋史㸴究 44: 1, pp. 23-44.

Backus, Charles 1981. The Nan-chao Kingdom and T'ang China's Southwestern Frontier. Cambridge: Cambridge University Press.

Barfield, Thomas J. 1981. "The Hsiung-nu imperial confederacy: organization and foreign policy." Journal of Asian Studies 41:1, pp. 45-61. 1989. The Perilous Frontier: Nomadic Empires and China. Mass. : Basil Blackwell.

Bazin, Louis 1963. "Man and the concept of history in Turkish Central Asia during the eighth century." Diogenes 42, pp. 81-97.

Beasley, W. G. and E. G. Pulleyblank eds. 1961. Historians of China and Japan. London: Oxford University Press.

Beckwith, Christopher I. 1977. "A study of the early medieval Chinese, Latin, and Tibetan historical sources on pre-imperial Tibet." $\mathrm{Ph}$. D. dissertation. Indiana University.

1977b. "Tibet and the Early Medieval Florissance in Eurasia: a preliminary note on the economic history of the Tibetan empire." Central Asiatic Journal 21, pp. 89-104.

1980. "The Tibetan empire in the west." In Michael Aris and Aung San Suu Kyi eds. Tibetan Studies in Honour of Hugh Richardson. Warminster: Aris and Phillips, pp. 30-38.

1987. The Tibetan Empire in Central Asia. New Jersey: Princeton University Press.

1991: "The impact of the horse and silk trade on the economics of T'ang China and the Uighur empire: on the importance of international commerce in the Early Middle Ages." Journal of the Economic and Social History of the Orient 34: 2, pp. 183-198. 
Bielenstein, Hans 1980. The Bureaucracy of Han Times. Cambridge: Cambridge University Press.

1986. "The institutions of Later Han." In Denis Twitchett and Michael Loewe eds. The Cambridge History of China, Vol. 1. Cambridge: Cambridge University Press, pp. 491-519.

Bingham, Woodbridge 1937. "Wen Ta-ya: the first recorder of T'ang history." Journal of the American Oriental Society 57, pp. 568-574.

1941. The Founding of the T'ang Dynasty: the Fall of Sui and Rise of T'ang. Baltimore: Waverly Press.

Bodde, Derk 1938. China's First Unifier. Leiden: E. J. Brill.

Bushell, S. W. 1880. "The early history of Tibet." Journal of the Royal Asiatic Society, new series, 12: 4, pp. 435-541.

Cen Zhongmian 岑仲勉 1957. Sui-Tang Shi 隋唐史. Beijing: Gaodeng Jiaoyu Chubanshe.

1958. Xi Tujue Shiliao Buque ji Kaozheng 西突厥史料補關及 考證. Beijing: Zhonghua Shuju.

1958. Tujue Jishi 突厥集史. Beijing: Zhonghua Shuju.

1964. Tongjian Sui-Tangji Bishi Zhiyi 通鑒隋唐紀比事質疑. Beijing: Zhonghua Shuju.

1966. “Wang Xuance: Zhong Tianzhuguo Xingji"王玄策: 中天 筑國行記. First published in 1933; included in Zhongwai Shidi Kaozheng 中外史地考證. Hong Kong: Taiping Shuju.

Chan, Hok-lam 1988. "The Chien-wen, Yung-lo, Hung-hsi, and Hsüan-te reigns, 1399-1435." In Frederick W. Mote and Denis Twitchett eds. The Cambridge History of China, Vol. 7. Cambridge: Cambridge University Press, pp. 182-304.

Chavannes, Edouard 1903. "Voyage de Song Yun dans l'Udyāna et le Gandhāra." Bulletin de l'Ecole Française d'Extrême-Orient 3, pp. 379-441.

1969. Documents sur Les Tou-Kiue [Turcs] Occidentaux. Translation entitled Xi Tujue Shiliao 西突厥史料 based on the edition of 1903 with revisions and comments by the translator, Feng Chengjun 馮承鈞. Taipei: Commercial Press. 
Chen Ching-lung 1981. "Trading activities of the Turkic peoples in China." Central Asiatic Journal 25, pp. 38-53.

Ch'en, Kenneth 1964. Buddhism in China: A Historical Survey. Princeton: Princeton University Press.

Chen Mengjia 陳夢家. 1956. Yinxu Buci Zongshu殷虛卜辤綜述. Beijing: Kexue Chubanshe.

Chen Xiezhang 陳煌章, Suo Wenqing 索文清, and Chen Naiwen 陳乃 文 1982. Zangzu Shiliao $J i$ 藏族史料集. Vol. 1. Chengdu: Sichuan Minzu Chubanshe.

Chen Yinke 陳寅恪. 1971. Sui-Tang Zhidu Yuanyuan Luelungao 隋唐制 度淵源略論稿. First published in 1944. Included in Chen Yinke Xiansheng Lunji 陳寅恪先生論集. Taipei: Zhongyang Yanjiuyuan Lishi Yuyan Yanjiusuo, pp. 1-104.

1971. Tangdai Zhengzhishi Shulungao 唐代政治史述論稿. First published in 1944. Included in Chen Yinke Xiansheng Lunji, pp. 105-209.

1973. “Lun Tang Gaozu chengchen yu Tujue shi” 論唐高祖稱臣 於突㷧事. First published in 1951. Included in Chen Yinke Xiansheng Wenshi Lunji 陳寅恪先生文史論集. Vol. 2. Hong Kong: Wenwen Publications, pp. 69-80.

Chi Ch'ao-ting 1936. Key Economic Areas in Chinese History as Revealed in the Development of Public Works for Water-Control. London: Allen and Unwin.

Chiu-Duke, Josephen 1992. "To rebuild the empire: Lu Chih (754-805), his response to the mid-T'ang predicament." Ph.D. dissertation. University of British Columbia.

Chōsen Shi Kenshū Kai 朝鮮史㸴修會. Chōsen Shi 朝鮮史. Keijō, 1932-1940.

Chun Hae-jong 1966. "A historical survey of the Sino-Korean tributary relationship." Journal of Social Sciences and Humanities 25, pp. 131.

1968. "China and Korea-an introduction to the Sino-Korean relations." Journal of Social Sciences and Humanities 29, pp. 1-15.

Creel, Herrlee G. 1970. The Origins of Statecraft in China, Volume One: 
the Western Chou Empire. Chicago: University of Chicago Press. Crespigny, Rafe de 1984. Northern Frontier: The Policies and Strategy of the Later Han Empire. Canberra: Australian National University.

Dalby, Michael T. 1979. "Court politics in late T'ang times." In Denis Twitchett ed. The Cambridge History of China, Vol. 3. Cambridge: Cambridge University Press, pp. 561-681.

Demiéville, Paul 1952. Le Concile de Lhasa. Paris: Presses Universitaires de France.

Des Rotours, Robert 1932. Le Traité des Examens. Paris: Librairie Ernest Leroux.

1947-48. Traité des Fonctionnaires et Traité de l'Armée. Leyde: E. J. Brill.

Di Cosmo, Nicola 1994. "Ancient Inner Asian nomads: their economic basis and its significance in Chinese history." Journal of Asian Studies 53: 4, pp. 1092-1126.

Dien, Albert E. 1974. "The use of the Yeh-hou chia-chuan as a historical source." Harvard Journal of Asiatic Studies 34, pp. 221-247.

1977. "The bestowal of surnames under the Western Wei-Northern Chou: a case of counter-acculturation." T'oung Pao 63: 2-3, pp. 137-177.

Dreyer, June T. 1976. China's Forty Millions. Cambridge, Mass. : Harvard University Press.

Drompp, Michael R. 1986. "The writings of Li Te-yü as sources for the history of T'ang-Inner Asian relations." Ph.D. dissertation. Indiana University.

Duan Lianqin 段連勤 1988. Dingling, Gaoche yu Tiele 丁零, 高車與鐵 勒. Shanghai: Renmin Chubanshe.

Duman, L. I. 1981. "Ancient Chinese foreign policy and the origins of the tribute system." In S. L. Tikhvinsky ed. China and Her Neighbours: From Ancient Times To the Middle Ages, pp. 17-42. Moscow: Progress Publishers.

Dunnel, Ruth 1994. "The Hsi Hsia." In Herbert Franke and Denis Twitchett eds. The Cambridge History of China, Vol. 6. Cambridge: 
Cambridge University Press, pp. 154-214.

Eberhard, Wolfram 1982. China's Minorities: Yesterday and Today. Belmont, California: Wadsworth Publishing Company.

Ecsedy, Hilda 1968. "Trade-and-war relations between the Turks and China in the second half of the 6th century." Acta Orientalia Hungarica 21, pp. 130-180.

1974. "Cultivators and barbarains in ancient China." Acta Orientalia Hungarica 28, pp. 327-349.

1981. "Nomads in histroy and historical research." Acta Orientalia Hungarica 35, pp. 201-227.

Edwards, Walter 1983. "Event and process in the founding of Japan: the horserider theory in archeological perspective." Journal of Japanese Studies 9: 2, pp. 265-295.

Fairbank, John K. 1968. The Chinese World Order. Cambridge, Mass.: Harvard University Press.

Feng Jiasheng 馮家昇 and others 1981. Weiwuerzu Shiliao Jianbian 維吾 爾族史料簡編. 2nd edition. Beijing: Minzu Shubanshe.

Fitzgerald, C. P. 1964. The Chinese View of Their Place in the World. London: Oxford University Press.

Fletcher, Joseph 1978. "Ch'ing Inner Asia, c. 1800." In Denis Twitchett and John K. Fairbank eds. The Cambridge History of China, Vol. 10. Cambridge: Cambridge University Press, pp. 35-106.

1978. "The heyday of the Ch'ing order in Mongolia, Sinkiang and Tibet." In Denis Twitchett and John K. Fairbank eds. The Cambridge History of China, Vol. 10, pp. 351-408.

Francke, A. H. 1914. "Notes on Sir Aurel Stein's collection of Tibetan documents from Chinese Turkestan." The Journal of the Royal Asiatic Society, pp. 37-59.

Franke, Herbert 1970. "Treaties between Sung and Chin." In Françoise Aubin, ed. Sung Studies, Ser. 1, History and Institutions. France: Mouton and Co., pp. 55-84.

1983. "Sung embassies: some general observations." In Morris Rossabi ed. China among Equals, pp. 116-148. 
1990. "The forest peoples of Manchuria: Kitans and Jurchens." In

D. Sinor ed. The Cambridge History of Inner Asia, pp. 400-423.

1994. "The Chin dynasty." In Herbert Franke and Denis Twitchett eds. The Cambridge History of China, Vol. 6, pp. 215-320.

Franke, Herbert and Twitchett, Denis 1994. "Introduction." In Herbert Franke and Denis Twitchett eds. The Cambridge History of China. Cambridge: Cambridge University Press, Vol. 6, pp. 1-42.

Fung Yu-lan. 1952. A History of Chinese Philosophy. Translated from Chinese by Derk Bodde. London: Allen \& Unwin.

Fu Lecheng 傅樂成 1977. “Huihema yu Shuofangbing”回紀馬與朔方 兵. Included in his Han-Tangshi Lunji 漢唐史論集. Taipei: Lianjing Chuban Gongsi, pp. 305-317. First published in 1953.

Furuhata Tōru 古 火田 徹 1986. "Tō Botsu funsō no tenkai to kokusai jōsei”唐渤紛爭の展開と國際情勢. Shūkan Tōyōgaku 集刊 東洋學 55, pp. 16-34.

1992. “Iwayuru 'Sho Kōkurikoku' no sonpi mondai”いわゆる “小高句麗國”の存否問題. Tōyōshi Kenkyū 51:2, pp. 30-55.

Gale, Esson M. 1931. Discourses on Salt and Iron. Translation from the Chinese of Huan K'uan with introduction and notes. Leyden: E. J. Brill Ltd.

Gardiner, K. H. J. 1969. The Early History of Korea. Honolulu: University of Hawaii Press.

1970. "The Samguk-sagi and its sources." Papers on Far Eastern History 2. Canberra: Australian National University Press, pp. 142.

Gardner, Charles S. 1938. Chinese Traditional Historiography. Cambridge, Mass.: Harvard University Press.

Geiss, James 1988. "The Chia-ch'ing reign, 1522-1566." In Frederick W. Mote and Denis Twitchett eds. The Cambridge History of China, Vol. 7, pp. 440-510.

Goodrich, Chauncey S. 1953. Biography of Su Ch'o. Berkeley: University of California Press.

Grousset, René 1970. The Empire of the Steppes. Translated from French 
by Naomi Walford. New Jersey: Rutgers Uinvesity Press.

Gu Jiguang 谷霄光 1955. “Tang zhechongfukao jiaobu” 唐折衝府考校 補. Ershiwu Shi Bubian二十五史補編. Beijing: Zhonghua Shuju, pp. 7648-60.

1962. Fubing Zhidu Kaoshi 府兵制度考釋. Shanghai: Renmin Chubanshe.

Guisso, R. W. L. 1978. Wu Tse-t'ien and the Politics of Legitimation in T'ang China. Bellingham, Washington: Program in East Asian Studies, Western Washington University.

Hamilton, James Russell 1962. "Toquz-Oyuz et On-Uyyur." Journal Asiatique 250, pp. 23-63.

1988. Les Oüghours à l'Époque des Cinq Dynasties. Paris: Collége de France. Reprint from the 1955 edition with nine pages of corrections by the author.

Haneda Tōru 呵田亨 1957. “Tōdai kaikotsushi no kenkyū”唐代回鶻史 の研究. In Haneda Hakushi Shigaku Rombun Shū 呵田博士史 學論文集. Vol. I. Kyoto: Kyoto University.

Hao, Yen-p'ing 1980. “Changing views of Western relations, 1840-95." In Denis Twitchett and John K. Fairbank eds. The Cambridge History of China, Vol. 10. Cambridge: Cambridge University Press, pp. 142-201.

Hartman, Charles 1986. Han Yü and the T'ang Search for Unity. Princeton: Princeton University Press.

Hatada Takashi 1969. A History of Korea. Translated and edited by Warren W. Smith Jr. and Benjamin H. Hazard. Santa Barbara: ABC Clio.

Hatada Takashi 旗田巍 and Inoue Hideo 井上秀雄eds. 1974. Kodai no Chōsen 古代の朝鮮. Tokyo: Gakuseisha.

Hayashi Kenichirō 林謙一郎 1990. “Nanshōkoku no seiritsu”南詔國の 成立. Tōyōshi Kenkyū 49: 1, pp. 87-114.

1992. "Nanshōkoku kōhanki no taigai ensei to kokka kōzō" 南詔 國後半期の對外遠征と國家構造. Shirin 史林 75: 4, pp. 114-145. 
Hayashi Toshio 林俊雄 1985. "Ryakudatsu, nōkō, kōeki kara mita yūboku kokka no hatten”掠奪, 農耕, 交易から觀た遊牧國家 の發展. Tōyōshi Kenkyū 44: 1, pp. 110-136.

Herbert, Penelope Ann 1978. Under the Brilliant Emperor-Imperial Authority in T'ang China as Seen in the Writings of Chang Chiu-ling. Canberra: Australian National University Press.

Hino Kaizaburō日野開三郎 1980. Tōyō Shigaku Ronshū 東洋史學論 集. Vol. 1. Tokyo: Sanichi Shoho.

1984. “Tō no Kōkuri tōmetsu to Antō togofu”唐の高句 麗討 滅と安東都護府. First published in 1954. Included in Hino, Tōyō Shigaku Ronshū. Vol. 8, pp. 21-55.

1984. “Kōkurikoku imin han Tō bunshi no shochi” 高句麗國遺 民反唐分子の處置. First published in 1955. Included in Hino, Tōyō Shigaku Ronshū. Vol. 8, pp. 56-78.

1984. "Tokketsu Hika kagan to Tō Gensō to no tairitsu Shō Kōkurikoku” 突劂毗伽可汗と唐玄宗との對立小高句麗. First published in 1959. Included in Hino, Tōyō Shigaku Ronshū. Vol. 8, pp. 159-191.

1984. "Anshi no ran ni yoru Tō no tōhoku seisaku no kōtai to Bokkai no Shō Kōkurikoku senryō" 安史の亂による唐の東北 政策の後退と渤海の小高句麗國佔領. First published in 1963. Included in Hino, Tōyō Shigaku Ronshū. Vol. 8, pp. 303337.

Hoffman, Helmut 1990. "Early and medieval Tibet." In D. Sinor ed. The Cambridge History of Early Inner Asia, pp. 371-399.

Holsti, K. J. 1983. International Politics. 4th ed. Englewood Cliffs N.J.: Prentice-Hall.

Hong Junpei 洪鈞培 1971. Chunqiu Guoji Gongfa 春秋國際公法. Reprint Taipei: Chung Hwa Book Company.

Hou Linbo 侯林柏 1976. Tang Song Liangchao Bianjiang Shiliao Bishi Zhiyi 唐宋兩朝邊疆史料比事質疑. Hong Kong: Nantian Shuye Gongsi.

Hsü, Immanuel C. Y. 1980. "Late Ch'ing foreign relations, 1866-1905." In Denis Twitchett and John K. Fairbank eds. The Cambridge History 
of China, Vol. 11, pp. 70-141.

Hucker, Charles O. 1985. A Dictionary of Official Titles in Imperial China. Stanford: Stanford University Press.

Hulsewé, A. F. P. 1979. China in Central Asia, An Annotated Translation of Chapters 61 and 96 of the History of the Former Han Dynasty. Leiden: E. J. Brill.

Ikeuchi Hiroshi 池内宏. “Ch’ǒn Kaesomun no shi to ryō Tōsho no kiji” 泉蓋蘇文の死と兩唐書の記事. Rekishigaku Kenkyū 歷史學 研究 92:10, pp. 703-711.

1960. Man-Sen Shi Kenkyū 滿鮮史研究. Vol. 2. Tokyo: Yoshikawa Kobunkan.

1960, pp. 97-245. "Kudara metsubō go no dōran oyobi Tō, Ra, Nichi sangoku no kankei” 百濟滅亡後の動亂及ひ”唐, 羅, 日三國の關係. In his Man-Sen Shi Kenkyū. Vol. 2. First published in Man-Sen Chiri Rekishi Kenkyū Hōkō 滿鮮地理歷史 研究報告. Vol. 14.

1960, pp. 267-393. "Kōkuri tōmetsu no yaku ni okeru Tōgun no kōdō”高句麗討滅の役に於ける唐軍の行動. In his ManSen Shi Kenkyü. Vol. 2. First published in Man-Sen Chiri Rekishi Kenkyū Hōkō. Vol. 16.

Inoue Hideo 井上秀雄 1972. Kodai Chōsen 古代朝鮮. Tokyo: Nihon NHK Books.

Ise Sentarō 伊瀨仙太郎 1968. Chūgoku Seiiki Keieishi Kenkyū 中國西 域經營史研究. 2nd ed. (1st. ed. 1955). Tokyo: Gannando Shoten.

Ishii Masatoshi 石井正敏 1984. “Chō Kyūrei saku 'Choku Bokkai Ō Dai Bugei sho' ni tsuite” 張九齡作“敕渤海王大武藝書”につい て. Chōsen Gakuhō 朝鮮學報112, pp. 65-105.

Iwami Kiyohiro 石見清裕 1987. “Tō no Tokketsu imin ni taisuru sochi o megutte”唐の突劂遺民に對する措置おめく”て. In Runshū Chugoku Sekai, Seito, Benkashi no sho Mondai 論集中國 社會, 制度, 文化史の諸問題. Fukuoka: Chugoku Shoten.

1990. “Tō no Kōroji to Kōrokyakkan” 唐の鴻臚寺と鴻臄客館. 
Kodai Banka 古代文化 42: 8, pp. 48-56.

Jagchid Sechin 札奇斯欽 1971. “Dui Huihuma wenti de yige kanfa” 對 回鶻馬問題的一個看法. Shi-Huo 食貨, new series 1: 1, pp. 21-28.

Jagchid Sechin and Hyer, Paul 1979. Mongolia's Culture and Society. Boulder Co.: Westview Press.

Jagchid Sechin and Symons, Van Jay 1989. Peace, War, and Trade along the Great Wall: Nomadic-Chinese Interaction through Two Millennia. Bloomington, Ind.: Indiana University Press.

Jamieson, John Charles 1969. "The Samguk sagi and the unification wars." Ph. D. dissertation. University of California, Berkeley.

1970. "Collapse of the T'ang Silla alliance-Chinese and Korean accounts compared." In Frederic Wakeman, Jr. ed. "Nothing Concealed": Essays in Honor of Liu Yü-yün. Occasional Series 4. Taipei: Chinese Materials and Research Aids Service Center, pp. 8194.

Kaneko Shūichi 金子修—1974. “Tōdai no kokusai monjo keishiki ni tsuite"唐代の國際文書形式について. Shigaku zasshi 史學 雜 誌 83: 10, pp. 29-51.

1988. "T'ang international relations and diplomatic correspondence." Acta Asiatica 55, pp. 75-101.

Kang Le 康樂 1979. Tangdai Qianqi de Bianfang 唐代前期的邊防. Taipei: Taiwan University.

Keightley, David N. 1979-80. "The Shang state as seen in the oracle-bone inscriptions." Early China 5, pp. 25-34.

1983. "The Late Shang state: when, where, and what?" In D.N. Keightley ed. The Origins of Chinese Civilization. California: University of California Press, pp. 523-564.

Khazanov, A. M. 1994. Nomads and the Outside World. Translated by Julia Crookenden. Madison: The University of Wisconsin Press. First edition published by Cambridge University Press, 1984. The second has an introduction, which refers to some important works on pastoralism published since 1984 .

Kolmas, Josef 1966. "Four letters of Po Chu-i to the Tibetan authorities 
(808-810 A. D.)." Archiv Orientalni 34, pp. 375-410.

Kuang Pingzhang 痹平樟 1935. “Tangdai gongzhu heqin kao"唐代公主 和親考. Shixue Nianbao 史學年報 2:2, pp. 23-68.

Lai, Swee Fo 1986. "The military and defense system under the T'ang dynasty." Ph.D. dissertation. Princeton University.

Lattimore, Owen 1951. Inner Asian Frontiers of China. New York: Capitol Publishing Co. First edition 1940.

Lee, Choon S. 1980. "The origin, functions, and nature of the tributary system in the Chou times." Ph. D. dissertation. University of Kansas.

Lee, Don Y. 1981. The History of Early Relations between China and Tibet. From Chiu T'ang-shu, a Documentary Survey. Bloomington: Eastern Press.

Lee Ki-baik 1984. A New History of Korea. Translated by Edward W. Wagner with Edward J. Shultz. Cambridge, Mass.: Harvard University Press.

Ledyard, Gari 1975. "Galloping along with the horseriders: looking for the founders of Japan." Journal of Japanese Studies 1: 2, pp. 217-254.

Legge, James 1965. A Record of Buddhistic Kingdoms. First published in 1886. Republication New York: Paragon Book Reprint Corp. and Dover Publications.

Leslie, Donald Daniel 1981-83. "Persian temples in T'ang China." Monumenta Serica 35, pp. 275-303.

Li Fang-kuei 1955. "The Inscription of the Sino-Tibetan treaty of 821822." T'oung Pao 44, pp. 1-99.

1956. “Ma Chongying kao”馬重英考. Wenshizhe Xuebao 文史 哲學報, pp. 1-8.

1980. "A problem in the Sino-Tibetan treaty inscription." Acta Orientalia Hungarica 34 (1-3), pp. 121-124.

Li Futong 李符桐 1963. Huihu Shi 回鶻史. Taipei: Wenfeng Chubanshe.

Li Hu 黎虎 1979. “Jieyou Gongzhu chusai de lishi gongxian”解懮公主 出塞的歷史貢獻. Beijing Shifan Daxue Xuebao 北京師範大 學學報 4,pp. 40-50。 
Li Shutong 李樹桐 1965. “Tang Gaozu chengchen yu Tujue kaobian” 唐 高祖稱臣於突㷧考辯. First published in 1963. Included in Li Shutong, Tangshi Kaobian 唐史考辯. Taipei: Zhonghua Shuju, pp. 214-246.

1968. “Zaibian Tang Gaozu chengchen yu Tujue shi” 再讋唐高 祖稱臣於突厥事. Dalu Zazhi 大陸雜誌 37:8, pp. 16-34.

Li Zongye 李宗業 1982. Zhongguo Lishi Yaoji Jieshao 中國歷史要籍 介紹. Shanghai: Guji Chubanshe.

Lin Chaomin 林超民 1985. “Jimi fuzhou yu Tangdai minzu guanxi” 羇縻 府州與唐代民族關係. Sixiang Zhanxian 思想戰線 5, pp. 4958. This article is based on his Ph.D. dissertation, "Anxi, Beiting duhufu yu Tangdai xibu bianjiang”安西, 北庭都護府與唐代 西部邊疆, which has not been published.

Lin Enxian 林恩顯 1970. “Tangchao dui Huihu de heqin zhengce yanjiu" 唐朝對回鶻的和親政策研究 Guoli Zhengzhi Daxue Xuebao Bianzheng Yanjiusuo Nianbao 國立政治大學學報邊政研究所 年報1, pp. 259-289.

1972. “Tujue wenhua jiqi dui Tangchao zhi yingxiang” 突厥文化 及其對唐朝之影響. Shih-Huo, new series 2: 7, pp. 341-366. Included in his 1988.

1988, pp. 183-224. "Sui-Tang liangdai dui Tujue de heqin zhengce" 隋唐兩代對突厥的和親政策. Included in his 1988. The article was first published in 1970.

1988. Tujue Yanjiu 突厥㸴究. Taipei: Commercial Press.

Lin Guanqun 林冠群 1985. “Tangdai Tufanshi shiliao yanjiu” 唐代吐蕃 史史料硎究. Talu Zazhi 70: 4, pp. 20-32.

Liu Naihe 劉乃和 1983. “Xu” 序. In Liu Naihe ed. Cefu Yuangui Xintan 册府元龜新探. Henan: Zhongzhou Shuhuashe, pp. 1-28.

Liu, Samuel N. C. 1985. Manichaeism in the Later Roman Empire and Medieval China, A Historical Survey. Manchester: Manchester University Press.

Liu Yat-ming 1970. "The Shen-Ts'e Armies and the palace commissions in China, 755-875 A.D." Ph. D. dissertation. University of London.

Liu Yitang 劉義棠 1974. “Huihu yu Tang hezhan yanjiu” 回鶻與唐和 
戰㸴究. Guoli Zhengzhi Daxue Xuebao 國立政治大學學報 29, pp. 93-125.

Lo Jung-pang 1969. "Policy formulation and decision-making on issues respecting peace and war." In Charles O. Hucker ed. Chinese Government in Ming Times: Seven Studies. New York: Columbia University Press.

Lü Simian 呂思勉 1959. Sui-Tang Wudai Shi 隋唐五代史. Beijing: Zhonghua Shuju.

Luce, G. E. and Ch'en Yee Sein 1961. The Man Shu (Book of the Southern Barbarians). Translated from Chinese. Ithaca: Southeast Asia Program, Department of Far Eastern Studies, Cornell University.

Luo Xianglin 羅香林 1955. “Tangdai tiankehan zhidu kao"唐代天可汗 制度考. Xinya Xuebao 1:1, pp. 209-243.

Luttwak, Edward N. 1976. The Grand Strategy of the Roman Empire. Baltimore and London: Johns Hopkins University Press.

Ma Changshou 馬長壽 1957. Tujueren he Tujue Hanguo 突㷧人和突嫄 汗國. Shanghai: Renmin Chubanshe.

Ma De 馬德 1987. “Tufan tongzhi Dunhuang chuqi de jige wenti” 吐蕃 統治敦煌初期的幾個問題. Dunhuang Yanjiu 敦煌研究 1, pp. 58-61.

Ma Junmin 馬俊民 1984. “Tang yu Huihe de juanma maoyi” 唐與回紀 的絹馬貿易. Zhongguoshi Yanjiu 中國史研究 1, pp. 67-76.

Mackerras, Colin 1969. "Sino-Uighur diplomatic and trade contacts (744 to 840)." Central Asiatic Journal 13, pp. 215-240.

1972. The Uighur Empire According to the T'ang Dynastic Histories: A Study in Sino-Uighur Relations 744-840. Canberra: Australian National University Press.

Mather, Richard B. 1959. Biography of Lü Kuang. An annotated translation of Chinshu, chapter 122. Berkeley: University of California Press.

Miike Yoshikazu 三池賢一 1974. “Kim Ch'unch'u shōden”金春秋小 傳. In Hatada Takashi and Inoue Hideo, eds. Kodai no Chōsen. Tokyo: Gakusei Sha, pp. 97-152. 
Minorsky, V. 1948. "Tamim ibn Bahr's journey to the Uyghurs." Bulletin of the School of Oriental and African Studies 12:2, pp. 275-305.

Molè, Gabriella 1970. The T'u-yü-hun from the Northern Wei to the Time of the Five Dynasties. Roma: Istituto Italiano per il Medio ed Estremo Oriente.

Moriyasu Takao 森安孝夫 1973. “Uiguru to Toban no Hokutei sōdatsusen oyobi sono go no Seiiki jōsei ni tsuite" ウイクルと吐蕃の 北庭爭奪戰及ひ”その後の西域情勢について.Tōyō Gakuhō 東洋學報 55, pp. 466-493.

1977. “Uiguru no seisen ni tsuite” ウイクルの西遷について. Tōyō Gakuhō 59, pp. 105-130.

Mori Masao 護雅夫 1967. Kodai Toruko Minzokushi Kenkyū 古代トル 工民族史研究. Tokyo: Yamakawa Shuppansha.

1978. Kodai Yūboku Teikoku 古代游牧帝國. 2nd ed. Tokyo: Chūō Kōron.

Moses, Larry W. 1976. "T'ang tribute relations with the Inner Asian barbarians." In John Curtis Perry and Bardwell L. Smith eds. Essays on T'ang Society. Leiden: E. J. Brill, pp. 61-89.

Mote, Frederick W. 1988. "The Ch'eng-hua and Hung-chih reigns, 14651505." In Frederick W. Mote and Denis Twitchett eds. The Cambridge History of China, Vol. 7, pp. 343-402.

Murakami Yoshio 村上四男 1974. “Shinra to shō Kōkurikoku” 新羅と 小高句麗國. In Hatada Takashi and Inoue Hideo eds. Kodai no Chōsen. Tokyo: Gakusei Sha, pp. 153-184.

Needham, Joseph 1956. Science and Civilization in China, Vol, 2. Cambridge: Cambridge University Press.

Nishijima Sadao 西島定生 1983. Chūgoku Kodai Kokka to Higashi Ajia Sekai 中國古代國家の東アシア世界. Tokyo: Tokyo University Press.

Pan Yihong 1991. "The development of the tribute system in the pre-Qin and Han periods." Larry N. Shyu ed. East Asia Inquiry: Selected Articles from the Annual Conferences of the Canadian Asian Studies Association 1988-1990. Montreal: Canadian Asian Studies Association, pp. 193-221. (Unfortunately all the footnotes in the 
article were lost in the process of printing.)

1992a. "The Sino-Tibetan treaties in the Tang dynasty." T'oung Pao 78, pp. 116-161.

1992b. "Early Chinese settlement policies towards the nomads." Asia Major 3rd. ser. vol. 5, part 2, pp. 41-78.

Pelliot, Paul 1921. "Notes sur les T'ou-yu-houen et les Sou-p'i." T'oung Pao 20, pp. 323-331.

1938-39. "Le nom du Xwarizm dans les textes chinois." T'oung Pao 34, pp. 146-152.

1961. Histoire Ancienne du Tibet. Paris: Librairie d'Amérique et d'Orient.

Perry, John Curtis and Smith, Bardwell L. 1976. "A bibliographic note on T'ang history and society." In Perry and Smith eds. Essays on T'ang Society, pp. 110-141.

eds. 1976. Essays on T'ang Society. Leiden: E. J. Brill.

Petech, L. 1950. Northern India According to the Shui-ching-chu. Roma: Istituto Italiano per il Medio ed Estremo Oriente.

Peterson, Charles A. 1970-71. "Pu-ku Hai-en and the T'ang court: the limits of loyalty." Monumenta Serica 29, pp. 423-455.

1979. "Court and province in mid- and late T'ang." In D. Twitchett ed. The Cambridge History of China, Vol. 3, pp. 464-560.

Pulleyblank, E. G. 1952. "A Sogdian colony in Inner Mongolia." T'oung Pao 41, pp. 317-356.

1953. "Gentry society: some remarks on recent work by W. Eberhard." Bulletin of the School of Oriental and African Studies 15, pp. 588-597.

1955. The Background of the Rebellion of An Lu-shan. London: Oxford University Press.

1956. "Some remarks on the Toquzoghuz problem." Ural-Altaische Jahrbücher 28, pp. 35-42.

1960. "Neo-Confucianism and Neo-Legalism in T'ang intellectual life, 755-805. " In Arthur F. Wright ed., The Confucian Persuasion. Stanford: Stanford University Press, pp. 77-114. 
1963. "The consonantal system of Old Chinese." Asia Major 9, pp. 58-144.

1966. "Chinese and Indo-Europeans." Journal of the Royal Asiatic Society, pp. 9-39.

1969. "Book Review: The Chinese World Order." Journal of the American Oriental Society 89: 2, pp. 423-425.

1976. "The An Lushan rebellion and the origins of chronic militarism in late T'ang China." In John Curtis Perry and Bardwell L. Smith, eds. Essays on T'ang Society, pp. 33-60.

1983. "The Chinese and their neighbors in prehistoric and early historic times." In D. N. Keightley ed. The Origins of Chinese Civilization, pp. 411-466.

1990a. "The 'High Carts': a Turkish-speaking people before the Türks.” Asia Major 3rd series 3, pp. 21-26.

1990b. "The name of the Kirghiz." Central Asiatic Journal 34: 1-2, pp. 98-108.

1991. Lexicon of Reconstructed Pronunciation in Early Middle Chinese, Late Middle Chinese, and Early Mandarin. Vancouver: U. B. C. Press.

Forthcoming. "The Hsiung-nu and the nomads in China and Central Asia in post-Han times." To appear in Philologiae Turcicae Fundamenta, vol. 3.

Rao Zongyi 饒宗儀 1976. Zhongguo Shixue shang zhi Zhengtong Lun 中 國史學上之正統論. Hong Kong: Longmen Shudian.

Ren Yucai 任育才 1971. Tufan yu Tangchao Guanxi zhi Yanjiu 吐蕃與 唐朝關係之研究. Taipei: Zili Chubanshe.

Richardson, H. E. 1952. Ancient Historical edicts at Lhasa and the Mu Tsung/Khri Gtsug Lde Brtsan Treaty of A. D. 821-822, from the Inscription at Lhasa. London: Royal Asiatic Society of Great Britain and Ireland.

1969. "The inscription at the tomb of Khri IDe Srong brTsan." Journal of the Royal Asiatic Society 1, pp. 29-38.

Rossabi, Morris 1975. China and Inner Asia, From 1368 to the Present 
Day. London: Thames and Hudson.

1983. "Introduction." In M. Rossabi ed. China among Equals, pp. $1-13$.

1983. China among Equals. Berkeley: University of California Press.

1988. Khubilai Khan: His Life and Times. Berkeley: University of California Press.

Sakamoto Yoshitane 土反元義種 1978. Kodai Higashi Ajia no Nihon to Chōsen 古代東亞細亞の日本と朝鮮. Tokyo: Yoshikawa kōbunkan.

Sato Hisashi 佐藤長 1958-59. Kodai Chibetto shi Kenkyū 古代チへツ 卜史研究. Kyoto: Kyoto University. Two volumes. Vol. I, 1958; Vol. II, 1959.

Schafer, Edward H. 1963. The Golden Peaches of Samarkand. Berkeley: University of California Press.

Shiba Yoshinobu 1983. "Sung foreign trade." In M. Rossabi ed. China among Equals, pp. 89-115.

Sinor, Denis 1990a. "Introduction: the concept of Inner Asia." In Denis Sinor ed. The Cambridge History of Early Inner Asia. Cambridge: Cambridge University Press, pp. 1-18.

1990b. "The establishment and dissolution of the Türk empire." In Denis Sinor ed. The Cambridge History of Early Inner Asia, pp. 285-316.

Sohn Pow-key, Kim Chol-choon, and Hong Yi-sup 1970. The History of Korea. Seoul: Korean National Commission for Unesco.

Somers, Robert M. 1978. "The Sui Legacy." In Arthur F. Wright, The Sui Dynasty. New York: Alfred A. Knopf, pp. 198-206.

1979. "The end of the T'ang." In D. Twitchett ed. The Cambridge History of China, Vol. 3, pp. 682-789.

1986. "Time, space, and structure in the consolidation of the T' ang dynasty (A. D. 617-700)." Journal of Asian Studies 45: 5, pp. 971994.

Stein, R. A. 1972. Tibetan Civilization. Trans. by J. E. Stapleton Driver. 
Stanford: Stanford University Press.

1988. "Les serments des traités sino-tibétains (8e-9e siécles)." T'oung Pao 74: 1-3, pp. 119-138.

Su Jinren 蘇晉仁 1982. Tongjian Tufan Shiliao 通鑑吐蕃史料. Xizang: Renmin Chubanshe.

Su Jinren and Xiao Lianzi 蘇晉仁, 蕭鍊子. 1981. Cefu Yuangui Tufan Shiliao Jiaozheng 册府元龜吐蕃史料校證. Sichuan: Minzu Chubanshe.

Sun Guodong 孫國棟 1957. "Tangdai sanshengzhi zhi fazhan yanjiu" 唐 代三省制之發展㸴究. Xinya Xuebao 新亞學報 3: 1, pp. 17121.

Sun Jinji 孫進已 1987. Dongbei Minzu Yuanliu 東北民族源流. Harbin: Renmin Chubanshe.

Suzuki Chusei 1968. "China's relations with Inner Asia: the Hsiung-nu, Tibet." In J. K. Fairbank ed. The Chinese World Order, pp. 180197.

Szerb, J. 1983. "A note on the Tibetan-Uigur treaty of $822 / 823$ A.D." Wiener Studien zur Tibetologie und Buddhismuskunde. Nos. 10-11. Ernst Steinkellner and Helmut Tauscher eds. Contribution on Tibetan Language, History and Culture. Vienna, pp. 375-387.

Tan Liren 譚立人 1988. “Youguan Tang-Fan huimeng shishi de jige wenti” 有關唐蕃會盟史實的幾個問題. Zhongguoshi Yanjiu 2, pp. 128-136.

Tan Qixiang 譚其駲 ed. 1982. The Historical Atlas of China. Beijing: Cartographic Publishing House.

Tang Changru唐長孺 1955. “Wei-Jin za-Hu kao”魏晉雜胡考. Wei-Jin Nan-Beichaoshi Luncong 魏晉南北朝史論叢. Beijing: Shenghuo, Tushu, Xinzhi Sanlian Shudian.

Tang Chengye 湯承業 1967. Sui Wendi Zhengzhi Shigong zhi Yanjiu 隋 文帝政治事功之研究. Taipei: Commercial Press.

Tang Lan 唐蘭 1976. “Hezun mingwen jieshi” 砢尊銘文解釋. Wenwu 文物 1, pp. 60-63.

Tao Jing-shen 1983. "Barbarians or Northerners: Northern Sung images of 
the Khitans." In Morris Rossabi ed. China among Equals, pp. 6686.

1988. Two Sons of Heaven: Studies in Sung-Liao Relations. Tucson: University of Arizona Press.

Tekin, Talat 1968. A Grammar of Orkhon Turkic. Bloomington: Indiana University.

Thomas, F. W. 1935. Tibetan Literary Texts and Documents Concerning Chinese Turkestan. Part I. London: Royal Asiatic Society.

1951. Part II.

1955. Part III.

Twitchett, Denis C. 1956. "The derivation of the text of the Shih-huo Chih of the Chiu T'ang-shu." Journal of Oriental Studies 3, pp. 48-62.

1961. "Chinese biography writing." In W. G. Beasley and E. G. Pulleyblank eds. Historians of China and Japan. London: Oxford University Press, pp. 95-114.

1962. "Lu Chih (754-805): imperial adviser and court official." In Arthur Wright and Denis Twitchett eds. Confucian Personalities. Stanford: Stanford University Press, pp. 84-145.

1970. Financial Administration under the T'ang Dynasty. Second ed. Cambridge: Cambridge University Press.

1976. "Varied patterns of provincial autonomy in the T'ang dynasty." In John Curtis Perry and Bardwell L. Smith ed. Essays on T'ang Society, pp. 90-109.

1979. "Kao-tsung and the empress Wu." In D. Twitchett ed. The Cambridge History of China, Vol. 3, pp. 242-289.

1979. "Hsüan-tsung (reign 712-56)." In D. Twitchett ed. The Cambridge History of China, Vol. 3, pp. 333-463.

1979. ed. The Cambridge History of China, Vol. 3. Cambridge: Cambridge University Press.

1986. ed. The Cambridge History of China, Vol. 1. Cambridge: Cambridge University Press.

1992. The Writing of Official History Under the T'ang. Cambridge: Cambridge University Press. 
Twitchett, Denis and Wright, Arthur F. 1973. "Introduction." In Denis Twitchett and Arthur F. Wright eds. Perspectives on the T'ang. New Haven: Yale University Press, pp. 1-43.

Twitchet, Denis and Tietze, Klaus-Peter 1994. "The Liao." In Herbert Franke and Denis Twitchett eds. The Cambridge History of China, Vol. 6, pp. 43-153.

Von Gabian, Annemarie 1949. "Steppe und Stadt im Leben der ältesten Türken.” Der Islam 29, pp. 30-62.

Waldron, Arthur 1990. The Great Wall of China: from History to Myth. New York: Cambridge University Press.

Walker, Hugh D. 1965. "Traditional Sino-Korean diplomatic relations." Monumenta Serica 24, pp. 155-169.

Walker, Richard Louis 1953. The Multi-State System of Ancient China. Hamden, Conn.: Shoe String Press.

Wan Guoding 萬國鼎 1978. Zhongguo Lishi Jinianbiao 中國歷史紀年 表. Beijing: Zhonghua Shuju.

Wang Gungwu 1963. The Structure of Power in North China during the Five Dynasties. Kuala Lumpur: University of Malaya Press.

1968. "Early Ming relations with Southeast Asia: a background essay." In J. K. Fairbank ed. The Chinese World Order, pp. 34-62.

1973. "Some comments on the later Standard Histories." In Donald D. Leslie, Colin Mackerras and Wang Gungwu eds. Essays on the Sources for Chinese History. Columbia, South Carolina: University of South Carolina Press, pp. 53-63.

Wang Jilin 王吉林 1976. Tangdai Nanzhao yu Li-Tang Guanxi zhi Yanjiu 唐代南昭與李唐關係之研究. Taipei: Dongwu University.

Wang Jingru王靜如 1938. “Tujuewen Huihe Yingwu Weiyuan Piqie Kehanbei yishi” 突厥文回紇英武遠毗伽可汗碑譯釋. Furen Xuezhi 輔仁學誌 7: 1-2, pp. 185-240.

Wang Shounan 王壽南 1969. Tangdai Fanzhen yu Zhongyang Guanxi zhi Yanjiu 唐代蕃鎭與中央關係之研究. Taipei.

Wang Yao 王堯 1979. Dunhuang Gu Zangwen Lishi Wenshu 敦煌古藏 文歷史文書. Qinghai: Qinghai Minzu Xueyuan. 
1980. “Tang-Fan huimengbei shushi”唐蕃會盟碑疏釋 . Lishi Yanjiu 4, pp. 93-108.

1982. Tufan Jinshi Lu 吐蕃金石錄. Beijing: Wenwu Chubanshe.

Wang Yao and Chen Jian 陳踐 1986. Tufan Jiandu Zonglu 吐蕃簡牘綜 錄. Beijing: Wenwu Chubanshe.

Wang Yongxing 王永興 1988. “Lun Wei Gao zai Tang he Tufan, Nanzhao guanxi zhong de diwei”論韋鼻在唐和吐蕃, 南昭關 係中的地位. Beijing Daxue Xuebao 北京大學學報 2, pp. 3947, p. 78.

Wang Yü-ch'üan 1949. "An outline of the central government of the Former Han dynasty." Harvard Journal of Asiatic Studies 12, pp. 134-187.

Wang Zhenping 1991. "T'ang maritime trade administration." Asia Major 3rd ser., 4, pp. 7-38.

1994. "Speaking with a forked tongue: diplomatic correspondence between China and Japan, 238 - 608 AD." Journal of the American Oriental Society 114: 1, pp. 23-32.

Wang Zhong 王忠 1958. Xin Tangshu Tufanzhuan Jianzheng 新唐書吐 蕃傳箋證. Beijing: Kexue Chubanshe.

Wechsler, Howard J. 1974. Mirror to the Son of Heaven: Wei Cheng at the Court of T'ang T'ai-tsung. New Haven: Yale University Press.

1979. "The founding of the T'ang dynasty: Kao-tsu (reign 61826)." In D. Twitchett ed. The Cambridge History of China, Vol. 3 , pp. 150-187.

1979. "T'ai-tsung (reign 626-49) the consolidator." In D. Twitchett ed. The Cambridge History of China, Vol. 3, pp. 188-241.

1985. Offerings of Jade and Silk. New Haven: Yale University Press.

Wright, Arthur F. 1959. Buddhism in Chinese History. Stanford: Stanford University Press.

1960. "Sui Yang-ti: personality and stereotype." In Arthur Wright ed. The Confucian Persuasion. Stanford: Stanford University Press, pp. 47-76. 
1962. Confucian Personalities. Stanford: Stanford University Press.

1978. The Sui Dynasty. New York: Alfred A. Knopf.

1979. "The Sui Dynasty." In D. Twitchett ed. The Cambridge History of China, Vol. 3, pp. 48-149.

Wu Tianchi 吳天墀 1980. Xi-Xia Shigao 西夏史稿. Chengdu: Sichan Renmin Chubanshe.

Wu Yugui 吳玉貴 1987. “Tangdai Anxi duhufu shilue”唐代安西都護 府史略. Zhong-Ya Xuekan 中亞學刊 2. Beijing: Zhonghua Shuju, pp. 76-135.

Xiang Da 向達 1957, pp. 1-116. “Tangdai Chang'an yu Xiyu wenming” 唐代長安與西域文明. First published in 1933. Included in Xiang Da, Tangdai Chang'an yu Xiyu Wenming. Beijing: Shenghuo, Dushu, Xinzhi Sanlian Shudian.

1957, pp. 136-154. “Tangdai jizai Nanzhao zhushu kaolue” 唐代 記載南昭諸書考略. First published in 1951. Included in Xiang $\mathrm{Da}$, Tangdai Chang'an yu Xiyu Wenming.

1957, pp. 565-578. "Han-Tang jian Xiyu ji Hainan zhuguo gu dilishu xulu” 漢唐間西域及海南諸國古地理書敘錄. First published in 1930. Included in Xiang Da, Tangdai Chang'an yu Xiyu Wenming.

Xiao Qiqing 蕭啓慶 1972. “Beiya youmu minzu nanqin gezhong yuanyin de jiantao" 北亞游牧民族南侵各種原因的檢討. Shih-Huo, new series 1:12, pp. 609-619.

Xie Haiping 謝海平 1978. Tangdai Liuhua Waiguoren Shenghuo Kaoshu 唐代留化外國人生活考述. Taipei: Commercial Press.

Xie Yuanlu 謝元魯 1992. Tangdai Zhongyang Zhengquan Juece Yanjiu 唐代中央政權決策研究. Taipei: Wenjin Chubanshe.

Xue Zongzheng 薛宗正 1992. Tujue Shi 突劂史. Bejing: Zhongguo Shehui Kexue Chubanshe.

Yamaguchi Zuihō 山口瑞鳳 1983. Toban Ōkoku Seiritsu Shi no Kenkyū 吐蕃王國成立史の研究. Tokyo: Yiwa Nami Shoten.

Yan Gengwang 嚴耕望 1969. “Lun Tangdai Shangshusheng zhi zhiquan 
yu diwei”論唐代尚書省之職權與地位. First published in 1953. Included in Yan Gengwang, Tangshi Yanjiu Conggao 唐史 研究叢稿. Hong Kong: Xinya Yanjiusuo.

Yang Lien-sheng 1961. "The organization of Chinese official historiography: principles and methods of the standard histories from the T'ang through the Ming dynasty." In W. G. Beasley and E. G. Pulleyblank eds. Historians of China and Japan, pp. 44-59.

1968. "Historical notes on the Chinese world order." In J. K. Fairbank ed. The Chinese World Order. Cambridge, Mass.: Harvard University Press, pp. 20-33.

Yang Shengmin 楊聖敏 1991. Huihe Shi 回紇史. Changchun: Jilin Jiaoyu Chubanshe.

Yu Yousun 余又蓀 1957. “Baijiang kou zhi zhan”白江口之戰. Dalu Zazhi 15:10, pp. 5-12 (pp. 317-324).

Yü Ying-shih 1967. Trade and Expansion in Han China. Berkeley: University of California Press.

1990. "The Hsiung-nu." In Denis Sinor ed. The Cambridge History of Early Inner Asia, pp. 118-150.

Zhang Qun章群 1955. “Tangdai xiang-Hu anzhi kao”唐代降胡安置 考. Xin Ya Xuebao 1:1, pp. 234-329.

1986. Tangdai Fanjiang Yanjiu唐代蕃將研究. Taipei: Lianjing Chuban Shiye Gongsi.

1990. Tangdai Fanjiang Yanjiu Xubian 續 編 . Taipei: Lianjing Chuban Shiye Gongsi.

Zhang Weihua 張維華 1980. “Xihan yidai zhi zhuhou wangguo”西漢一 代之諸侯王國. In Zhang Weihua, Hanshi Lunji 漢史論集. Jinan: Qilu Shushe.

Zhang Zhengming 張正明 1979. Qidan Shilue 契丹史略. Beijing: Zhonghua Shuju.

1987. “Heqin tonglun”和親通論. In Minzushi Luncong 民族論 叢. Vol. 1. Ed. by The Research Institute of Ethnics under the Social Science of China's Acedemia. Beijing: Zhonghua Shuju, pp. 324. 
Zhao Lingyang 趙令揚 1976. Guanyu Lidai Zhengtong Wenti zhi Zhenglun 關於歷代正統問題之爭論. Hong Kong: Xuejin Chubanshe.

Zhongguo Beifang Minzu Guanxishi bianxiezu 中國北方民族關係史 編 寫組 1987. Zhongguo Beifang Minzu Guanxishi. Beijing: Zhongguo Shehui Kexue Chubanshe.

Zürcher, E. 1959. The Buddhist Conquest of China. Leiden: E. J. Brill.

Zurndorfer, Harriet T. 1988. "Book Review: China among Equals." T'oung Pao 74: 1-3, pp. 141-143. 


\section{Index}

Ädiz (Xietie), 275

Aba 阿拔, see Apar

Abo 阿波, see Apa

Abusi 阿布思, 155, 280

Acting Investigating Censor (she jiancha yushi), 249

Administration Chamber (zhengshi tang), 67

Administrative Record (shizheng ji), 92

Agricultural school (nongjia), 28

Aide (zhangshi), 78, 137

Aide of the Western Regions (Xiyu zhangshi), 84

Aksu (Bohuan), 241, 281, 282

An Lushan 安祿山, 1, 3, 73, 154, 155, 156, $157,260,280,295,296,350$; and throughout

An Qingxu 安慶緒, 156, 159, 295

An Sishun 安思順, 155

Anagui 阿那搜, 46, 47, 48

Andong 安東, 153

Anlezhou 安樂州, 241, 337

Annan 安南, 153, 343, 344

Anrong 安找, 243, 244, 258, 259

Anshi 安市, 215

Ansǔng 安舜, 223

Anxi 安西, 153, 195, 291, 292, 318, 330, 332

Apa (Abo), 104

Apar (Aba), 103

appeasement, 29, 42, 61, 62, 78; towards the Turks, 171-5; 299, 352, 353

Arab/Arabs, 4, 8, 251, 271, 272, 281, 282, 283, 284, 292, 293, 303, 305, 335

Area Command of Bosi 波斯, 201, 283

Area command (dudu fu), 136, 197

Area commander (dudu), 136, 153

Armies (jun), 146, 147, 151

Ashina Buzhen 阿史那步真, 196, 243, 244, 266

Ashina Duzhi 阿史那都支, 244

Ashina Funian 阿史那伏念, 262

Ashina Mishe 阿史那彌射, 196, 243, 244, 265, 266

Ashina Sheer 阿史那社爾, 79, 181, 195

Ashina Simo 阿史那思摩 (also Li Simo), 189,190

Ashina Xian 阿史那獻, 281

Ashina Zhongjie 阿史那忠節, 271

Ashina, 48, 262
Assault-resisting Garrisons or Intrepid Militias (zhechong fu), 137

'Bon-da-rgyal (Bendayan), 250

Bai Juyi 白居易, 11, 70, 306, 307, 309, 337

Bai Zhizhen 白志貞, 162

Bailan 白蘭, 237

Baimei 白眉, see Bolmïs

Baiting 白亭, 147

Ban Chao 班超, 84

$\mathrm{Ban} \mathrm{Gu}$ 班固, 30, 74

Ban Yong 班勇, 84

banbu 頒布, 70

Baosai 保塞, 152

baowang 寶王, see Precious King

Baoyi 保義, 311

Basmill, 276, 278

Bayan Chor (Moyanchuo), relations with Tang, 291-4; 313

Bayegu, see Bayïrqu

Bayïrqu (Bayegu), 274, 275, 291

Baz, 290

Beihuang Junzhang $L u$ 北荒君長錄, 10, 91

Beimen Xueshi 北門學士, see Scholars of the Northern Gate

Beiting 北庭, 305, 306, 311, 318, 330, 332

Bendayan 公達延, see 'Bon-da-rgyal

Bian canal 泣渠, 113, 114

Bianji 讋機, 88

Bilgä, 228; relations with Xuanzong, 274-8; 313

Bingbu 兵部, see Ministry of War

Bingzhou 并州, 137, 143, 144

Blon Gung bzher (Lun Kongre), 341

Blon Mye-slebs (Lun Mingxilie), 254

Bohara, 116

Bohuan 撥換, see Aksu

Bolmïs (Baimei), 278

border markets, $81,104,255,360-1$

Bozhou 播州, 343

$B u$ Guoshi 補國史, 10

Buddhism, 30, 36-7, 53, 58, 182, 183, 207, $341,347,348$

Bukhara, 283

Bumïn, 48

Buqu (Pugu), 191, 199, 265, 275

Buque 補開, see Rectifier of omissions

Bureau of Historiography (shiguan), 8, 10, $77,80,83,87-8,92$

Bureau of Operations (zhifang si), 80 
Bureau of Receptions (zhuke qingli si), 80

Bäg Chor (Mochuo), relations with China, 266-9, 272-4; 351

Bögü (Mouyu), 294, 296, 297, 301, 314, 315

Caifang Shi 採訪使, see Investigation commissioner

Capital Liaison Office of Various Regions (zhudao jinzou yuan), 68

Cefu Yuangui 册府元龜, 8, 17, 174, 238, 244

Censorate (yushi tai), 129

Censors, 68

Ceremonial Office (siyi shu), 76, 77

Chamberlain of the Court of State

Ceremonials (honglu qing), 76, 77, 78, 79

Champa, 112, 113, 115-6, 362

Chancellor (chengxiang), 129

Chang Jun 常駿, 83

Changcan 常參, see Consultant assembly

Changzhou 長州, 188

Chaoji shi 朝集使, see Territorial representatives

Chebi 車鼻, 191, 192, 198

Chen Dade 陳大德, 83

Chen Hong 陳翁, 9

Chen Yue 陳嶽, 10

Chen Zi'ang 陳子昂, 243, 265

Cheng Mingzhen 程名振, 144

Cheng Wuting 程務挺, 266

Cheng Yuanzhen 程元振, 160, 325

cheng 城, see fortresses

Chengde 承德, 157

Chengxiang 丞相, see Chancellor

chi 敕, 137, 173

Chief Ministers (zaixiang), in decisionmaking, 66-67, 69-71; 72, 74, 75, 137; under Taizong, 141-3; under Gaozong and Empress Wu, 147-50; under Xuanzong, 150,154 ; and throughout

Chile 敕勒, 35, 49

Chiling 赤嶺, 255, 256

Chinggis Khan, 361

Chishui 赤水, 240

Chitu 赤土, 83, 116

Chituguo Ji 赤土國記, 83

Chixin (of Shatuo) 赤心, see Li Guochang

Chixin (of the Uighurs) 赤心, 315,316

Chongxuan Shu 崇玄署, see Office of Daoist worship

Chōsen Shi 朝鮮史, 16

Chošn, 54, 55
Chu Suiliang 褚遂良, 143, 189, 190, 194, 213

chuanda 傳達, 70

Chuluo (of Eastern Turks), 172, 173

Chuluo (of Western Turks) 處羅, 120, 121, 122, 172

Chuluohou 處羅侯, 104, 105

circuit (dao), 153

Cishi 刺史, see prefect

Commandant of Western Regions (xiyu jiaowei), 119

Commandant of Western Rong (Xirong jiaowei), 53

Commandant-escort (fuma duwei), 239

Commandery Duke of Liaodong (Liaodong jungong), 109

Commandery Prince of Liaodong (Liaodong junwang), 207

commandery (jun), 115, 120, 208

commandery-district system, $28,55,57$, 197,210

Commissioner for Defending Taohe (Taohe zhenshou dashi), 241

Commissioner-in-chief of Ningshuo 寧朔, 188,189

Congling 葱嶺, see Tashkurgan

Consort of the Min State (Minguo furen), 299

Consultant Assembly (changcan), 67

county (xian), 98

Court Conference (tingyi), 68

Court Diary ( $q i j u z h u), 92$

Court of Imperial Sacrifices (taichang si), $75-76$

Court of State Ceremonials (honglu si), 7 , 75-77, 79-80, 87, 88, 297, 300, 306, 323

Cui Dunli 崔敦禮, 144, 148, 192

Cui Hao 崔浩, 35

Cui Huan 崔 瀚, 84

Cui Lin 崔琳, 254

Cui Rong 崔融, 245

Cui Xiyi 崔希逸, 256, 257

Cui Zhiwen 崔知溫, 148

Cui Zhongfang 崔仲方, 148

$\mathrm{Da}$ Qin 大秦, 12

Da Tang Chuangye Qijuzhu 大唐創業起 居註, 7,170

Da Tang Xiyu Ji 大唐西域記, 88

Da Tang Xiyu Qiufa Gaoseng Zhuan 大唐 西域求法高僧傳, 90

Da Xingren 大行人, see Senior messenger

Daifang 帶方, 55, 207, 220 
Daily Calendar (rili), 92

Daizhou 代州, 143, 291

Daizong, government, 160-1; politcy towards the Uighurs, 296-301; relations with Tibet, 323-7

Dali 大厲, 106

Dali 大禮, 343

Dali 大理, 343, 344, 358

Dangxiang, 119, 149, 237, 315, 341

Dangxiang Qiang 黨項姜, 57, 236, 237, 298, 325, 357

dao 道, see circuit

Daoxuan 道宣, 183

Dashicheng 大石城, see Uch-turfan

Datou 達頭, see Tardu

Dawu Army 大武, 274, 291

Dayuan 大宛, 82

Dengzhou 登州, 228

Department of Chancellery (menxia sheng), $70,80,129$

Department of State Affairs (shangshu sheng), 70, 75, 79, 80, 129

Dependent state (shuguo), 42, 183, 197

deputy commander (liuhou), 156

Deputy head of the Department of State Affairs (shangshu puye), 70

Dezong, policies, 161; defense, 161-3; relations with the Uighurs and Tibet, 161, 301-6; relations with Tibet, 327-36; alliance with the Uighurs and Nanzhao, 335-6

Di 氐, $45,56,57$

Di Renjie 狄仁傑, 226, 244, 245

Dianfan Shu 點蕃署, see Office of receptions

Dianke Shu 點客署, see Office of receptions

diguo 敵國, see equal adversary

Diji 地記, 90-1

Dili Shu 地理書, 90

Dingling 丁零, 49, 287

Dingxiang 定襄, 106, 115, 172, 185, 188, 189

Director of the Chancellery (shizhong), 69

Director of the Department of State Affairs (shangshu ling), 69, 70

Directorate for Imperial Manufactories (shaofu jian), 81

Directorate of Tributary Trade (hushi jian), 81

district, 197

Dou Jiande 實建德, 172
Dou Jing 實靜, 137, 143, 185, 188

Doulu Qinwang 豆盧欽望, 248

Du Chuke 杜楚客, 185

Du Cong 杜悰, 342, 343

$\mathrm{Du} \mathrm{Fu}$ 杜甫, 299

Du Hongjian 杜鴻漸, 156

Du Huan 杜環, 8, 85

$\mathrm{Du} \mathrm{Mu}$ 杜牧, 317

Du Ruhui 杜如晦, 142, 178

Du Xian 杜僬, 154, 281, 282

Du Xingman 杜行滿, 84

Du Yan 杜彥, 99

Du You 杜佑, 8, 84, 85, 154

Du Yuanying 杜元穎, 342

Duan Wenzhen 段文振, 115

Duan Xiushi Biezhuan 段秀實別傳, 10

Dudu Fu 都督府, see area command

Dudu 都督, see area commander

Duhu Fu 都護府, see protectorate

Dulan 都藍, 104-7

Dun Mohe Dagan 頓莫賀達干, see Ton

Bagha Tarqan

Dunhuang 敦煌, 11, 14, 339

Dunyugu 敦欲谷, see Tonyuquq

Duomi 多彌, 191

Dushan 都山, 277

Dushui tai 都水臺 (or dushui jian), see Inspectorate general of water works

Eastern Turks, relations with Sui, 100-107, 109, 114-5, 127-8; in Tang, 140, 146, 168; relations with Gaozu, 169-75; Taizong's conquest, 176-9; resettlement, 183-9; assistance to Tang campaign, 194, 195; under the jimi system, 197-203; restoration of the second empire, 262-4; relations with Empress Wu and the Khitans, 265-9; relations with Zhongzong, 269-72; with Xuanzong and the Khitans and $\mathrm{Xi}, 272-9$; horse-silk trade with Tang, 276, 277; the end, 278-9; and throughout

Emperor Wen, 87, 95; military organization, 98-100; relations with the Turks, 99-107; with Tuyuhun, 107-8; with Koguryo,, 108111; southern expedition, 111-2; compared with Emperor Yang, 112-3, 128-30; 186; and throughout

Emperor Wu (of Han), 25, 29, 30, 41, 42, $50,54,58,75,82,117,126,362$

Emperor Xiaowen of the Northern Wei, 34

Emperor Yang, 36, 72, 76, 84, 85, 86, 92, 102; government, 113-4; relations with the Eastern Turks, 114-5, 126-7; southern 
expedition, 114-6; with Tuyuhun, 118-9; with the Western Regions, 116-20; with the Western Turks, 120-1; with Koguryor, 121-8; compared with Emperor Wen, 1123, 128-30; compared with Taizong, 138-9, 170; and throughout

Empress Dugu 獨孤, 72, 98

Empress Wei 韋, 73, 144, 150

Empress Wu 武, 67, 72, 73; policy, 144-7; relations with Tibet and the Western Turks, 243-7; relations with the Eastern Turks and Khitans, 262-9; and throughout equal adversary (diguo), 171, 266

Erhai 洱海, 144

Erudite of the Chamberlain for Ceremonials (taichang boshi), 325

Eunuch Supervisor (jianjun), 159, 163, 343

eunuchs, $67,72,73,74,158,159,160,162$, $163,164,165$

Expeditionary Armies (xingjun), 137, 138, 146, 196, 268

Fang Xuanling 房玄齡, 142, 190, 211, 216, 217

fanguo 蕃國, 21

Fanyang 范陽, 153, 156, 279

Fanzhen 蕃鎭 (also fangzhen 方鈨), see regional command

Faxian 法顯, 37, 89

Feng Liao 馮嫽, 86

Feng Lun 封倫, 174

fengjian 封建, 19

Fenglin Pass 鳳林, 326

Fengtian 奉天, 162, 330

Fengzhou 䁗州, 136, 149, 172, 265, 270, 309

Fenyang Wang Jiazhuan 汾陽王家傳, 9

Ferghana, 251, 282, 283, 284, 292, 293

Foguo Ji 佛國記, 37, 89

Foreign Relations Office (libin yuan), 77

fortresses (cheng), 146

Four Garrisons, 141, 149, 195, 196, 244, $245,246,253,270,281$

Frontier Patrolling Inspector (xunbian shi), 77

Fu 伏, 108

$\mathrm{Fu}$ (country of Fu) 附, 119

Fu Jian 苻堅, 45, 52, 53, 57

$\mathrm{Fu} \mathrm{Yi}$ 傅亦, 182, 348

fubing 府兵, $10,34,35,98,124,136-7$, 151,169

Fudifu 伏带匐, 291

Fudinan 伏帝難, 291
Fuma Duwei 駙馬都尉, see Commandantescort

Funan $J i$ 扶南記, 82

Funan Yiwu Zhi 扶南異物志, 82

Futu 浮圖, 194

Fuyi ling 賦役令, see Taxation Statutes

Fuyu 扶餘, 209

Fuyun 伏允, 108, 118, 119, 175, 176, 235, 236

Gai Jiayun 蓋嘉運, 85, 282

Gan Ying 甘英, 82

Ganzhou 甘州, 136, 137, 246, 253, 291

Gao Baoning 高䆩寧, 100

Gao Huan 高歡, 36, 47

Gao Jiong 高穎, 104, 110, 115, 129

Gao Pian 高駢, 343, 344

Gao Xianzhi 高仙芝, 154, 155, 258, 284

Gaochang 高昌 (see also Karakhoja), 52, $53,89,119,140,142,143,168,193,194$, 199, 201

Gaoche 高車, 35, 49, 50, 287

Gaoli Fengsu 高麗風俗, 85

Gaozong (Tang), 2, 67; policy, 144-7; conquest of Paekche, 217-21; encounters with Koguryð, 218, 219; alliance with Silla, 218-22; conquest of Koguryǒ, 2212; relations with Tibet and with Tuyuhun, 239-43; and throughout

Gaozu (Tang), 7, 8; defense, 133, 136-8; rise, 169; relations with the Eastern Turks, 169-71; appeasement policy toward the Eastern Turks, 171-5; policy toward the Western Turks, 175; relations with Tuyuhun, 175-6; policy toward Korea, 207-9; and throughout

Gentlement Attendant at the Palace Gate (huangmen shilang), 117

Geshu Han 哥舒翰, 79, 154, 155, 258

Gongren 恭仁, 246

Grand Astrologer (taishi ling), 182

Grand Master of Remonstrance (jianyi dafu), 70

Grand Protecorate of Chanyu 單于, 199, 262

Great Balur (Baltistan), 252

Great Wall, 29, 60, 61, 100, 113, 115, 184, $349,363,364$

Gu Yin 顧愔, 83, 84

Guan Junrong Shi 觀軍容使, see Inspector of the armies

Guancha Shi 觀察使, see Surveillance commissioner 
Guangzhai Temple 光宅, 323

Guannei 關内, 154

Guazhou 瓜州, 137

Guduolu 骨咄祿, see Qutlugh

Guiyi Army 歸義, 316

Guizhou 桂州, 343

Guli Peiluo 骨力裴羅, see Qullïgh Boila

Guo Xiaoke 郭孝恪, 143, 194, 195

Guo Yuanzhen 郭元振, 8, 147, 245, 246, 271

Guo Zhiyun 郭知運, 78

Guo Ziyi 郭子儀, 9, 159, 160, 292, 293, $298,300,323,324,325,327,357$

Guogong Jiazhuan 郭公家傳, 9

Guoshi 國史, see National history

Guoyu 國語, 21

Guozhou 艩州, 187

Hami (Yiwu) 哈蜜, 119, 140, 193, 194

Han Huang 韓滉, 333

Han Yougui 韓游瓖, 333

$\mathrm{Han} \mathrm{Yu}$ 韓忿, 348

Han-Tang Dili Shuchao 漢唐地理書抄, 90

Hanhai 瀚海, 192

Hanlin 翰林, 158, 162, 331

Hanlin Academician (Hanlin xueshi), 67, 161,307

Hanlin Academy, 73

Hanlin xueshi 翰林學士, see Hanlin academician

Hanoi, 342, 343

Heavenly Qaghan (tian kehan), 2, 3, 15, 140; Taizong's assumption of the title, 179-83, 191, 210; 306, 307, 347, 361

Heichi Changzhi 黑齒常之, 147

Heishuizhou 黑水州, 227

Helan 賀蘭 Mountains, 328

Helou Zigan 賀婁子幹, 99

Helu 賀魯, 141, 195, 196

heqin 和親, see marriage alliance

Herong 和戋, 147

Hexi 河西, 155, 156, 245, 250, 256, 265, $315,322,323$

Heyuan 河源, 118, 146, 147, 250

Hezhong 河中, 300, 326, 331

Honglu Qing 鴻臄卿, see Chamberlain of the court of state ceremonials

Honglu Si 鴻臚寺, see Court of state ceremonials

Hongwu emperor, 362, 363

Hongyuangu 洪源谷, 247

Hostel for Tributary Envoys (sifang guan),
$76,80,81$

$\mathrm{Hu}$ 胡, 23, 24, 30

$\mathrm{Hu}$ 胡, see Sogdians

Huangfu Weiming 皇甫惟明, 155, 253

Huangmen Shilang 黄門侍郎, see

Gentlement attendant at the palace gate

Huazhou 化州, 188, 189

Hubu 戶部, see Ministry of revenue

Huhanzhou 忽汗州, 227

Hui Shi 惠施, 28

Huichao 慧超, 90

Huihe 回紇, 304

Huihu 回鶻, 304

Huining 會寧, 121

Huisheng 慧生, 89

Huiyao 會要, 8

Hummu, 228

Hun 渾, 291

Hun Jian 渾堅, 332, 334

Hushi 互市, see tribute trade

Hushi Jian 互市監, see Directorate of tributary trade

Hushu 護輸, 291

Husi Zheng 斛斯政, 123

Huyan 呼延 Valley, 293

iltäbär, 192

Imperial Diarist (qiju lang, qiju sheren), 70

India, $25,30,31,37,57,82,88,89,90$, $144,183,235,238,303,335$

inner court (neiting), 69, 72, 98, 158, 161

Inspector of the Armies (guan junrong shi), 159

Inspectorate General of Water Works (dushui tai, dushui jian), 129

Investigation Commissioner (caifang shi), 153

Iryǒn 伊然, 14

Ishbara (Shabolue), 100-4, 352

Istämi, 48

Japan, 4, 26, 87, 92, 111, 125, 126, 204, $212,220,221,365$

Japanese pirates, 364

Ji Chu'na 紀處納, 271

Jia Dan 賈耽, 85, 86

Jia Yi 賈誼, 61,312

Jian'an 建安, 224

Jiang Ke 姜恪, 240

Jiang Xingben 姜行本, 142

Jiangdu 江都, 113

Jianjun 監軍, see eunuch supervisor

Jiannan 劍南, 154, 155, 256, 259, and throughout 
Jianyi Dafu 諫議大夫, see Grand master of remonstrance

Jiaozhou 交州, 111, 113, 199

Jiaozhou Yiwu Zhi 交州異物志, 91

Jiedu Shi 節度使, see Military commissioner

Jilin 雞林 (Kyerim), 223

jimi fuzhou 羈糜府州 (see also subordinated area commands and prefectures), 145, 192, 262, 283, 354

jimi 羈糜, 140, 192, 236, 237, 243, 259, $263,264,266,267,279,349$

Jimsa, 194

Jinbu 金部, see Treasury bureau

Jin dynasty, relations with Song, 353, 361

jingguan 京觀, see triumphal mound

Jinglüe Dashi/ Jinglüe Shi 經略大使, see military commissioner

Jingxi 靜析, 152

Jingxing $J i$ 經行記, 85

Jingyuan 涇原, 162, 330

Jinhe 金河, 106, 115

Jinwei 金微, 293

Jishi 積石, 146

Jishi Zhong 給事中, see Supervising secretary

Jiuqu 九曲, 250, 258

Jiu Tangshu 舊唐書, 7, 8, 9, 15; and throughout

Jiuxing 九姓, see Nine Surnames

Jumo 且末, 119

Jun 軍, see Armies

jun 郡, see commandery

Junior Messenger (xiao xingren), 75

Kang 康, see Samarkand

Kang Tai 康泰, 82

Karakhoja (Gaochang), 52, 53

Karashahr (Yanqi), 53, 140, 143, 194, 195, 311

Karghalik (Zhujubo), 195

Kashgar (Shule), 195, 244, 284

Kashmir, 116, 253

Kaya (Mimana), 125

Kesch, 116, 282

Khitan, 3; in Sui, 99-103, 109-114; in Tang, $146,150,152,153,156,168,176,177$, 179, 198, 199; relations with Taizong, 211-15; in Gaozong's time, 218, 226, 228; relations with Turks and Empress Wu, 265-9; relations with Xuanzong and the Turks, 273, 276, 277, 279-80, 290; under the Uighurs, 295-6; 304; assistance to
Tang, 316; 318; later development into Liao, 357-8; and throughout

Khitan-Liao, relations with Song, 353, 35960

Khotan (Yutian), 45, 54, 195, 243, 244, 293

Khri 'Dus srong, 246, 247

Khri gtsug lde brtsan, 341

Khri-gzigs (Qilixu), 257

Khri lde gtsug brtsan, 247

Khubilai, 361, 362

Kim Ch'unch'u 金春秋, 217, 218, 224

Kim Pǒmmin 金法敏, 218

Kim Pu-sik 金富軾, 14, 15, 84

Kirghiz, 85, 86, 88, 269, 276, 295, 304, $305,315,318,319,355$

Koguryǒ, 4, 15, 16, 55-6, 79, 82, 83, 85; relations with Sui, 108-11, 121-30; in Tang, 138, 139, 140, 141, 142, 143, 144, 145, 147, 191, 199; reasons for Tang campaigns, 203, 206-7; peace with Gaozu, 207-9; relations with Taizong, 209-17;

Tang conquest, 221-2, 223, 224, 225

Koko Nor, 45, 145, 240, 241, 246, 253, 357

Kŭm river, 220

Kucha (Qiuci), 53, 140, 141, 195, 196, 199 , 238, 244, 251, 253, 271, 311, 315

Kumarajiva, 53

Kumedh, 283

Kunzhou 昆州, 197

Lanzhou 蘭州, 149, 250

Lelang 樂 浪, 55, 207

li 禮, see propriety

Li Ao 李敖, 82

Li Baiyao 李百藥, 185

Li Chengcai 李承案, 293

Li Chenghong 李承宏, 324

Li Daen 李大恩, 143

Li Daliang 李大亮, 193

Li Deyu 李德裕, $11,70,71,86,166,340$, 341,342 ; role in Tang policy toward the Uighurs and Kirghiz, 315-9

Li Fan 李繁, 10, 91, 304

Li Fuguo 李輔國, 74, 158, 159, 160

Li Guangbi 李光怩, 159, 160, 292, 325

Li Gui 李軌, 175

Li Guochang (Chixin) 李國昌, 356

Li Huaiguang 李懷光, 162, 331

Li Jiancheng 李建成, 138, 176

Li Jiang 李綘, 165, 307, 308

Li Jifu 李吉甫, 337

Li Jing 李 靖, 142, 179, 213, 235

Li Jingxuan 李敬玄, 147, 242 
Li Keyong 李克用, 356

Li Linfu 李林甫, 7, 72, 155, 156, 258

Li Mi 李泌, 10, 91, 303, 304, 310, 332, 335

Li Sheng 李戟, 332, 333, 334

Li Shiji 李世勣, 142, 179, 213, 221

Li Shimin 李世民, see Taizong

Li Xian 李憲, 268

Li Xingyi 李行禕, 256

Li Yuan 李淵, see Gaozu

Li Yuanzhong 李元忠, 305

Li Zhigu 李知古, 249, 252

Li Zhuo 李㻟, 342

Liang Shidu 梁師都, 172, 173, 174, 176, 179

Liangzhou 梁州, 331

Liangzhou 涼州, 52, 53, 99, 136, 137, 147, $175,193,240,246,257,291$

Liao 獠, 216

Liao river 遼, 54, 110, 122, 123

Liaodong 遼東, 54, 55, 108, 123, 138, 144, $146,208,210,212,213,215,223,224$, 225

Liaodong Jungong 遼東郡公, see Commandery Duke of Liaodong

Liaodong Junwang 遼東郡王, see Commandery Prince of Liaodong

Liaoxi 遼西, 110

Liaoyang 遼陽, 224

Libin Yuan 禮賓院, see Foreign relations office

Libu 禮部, see Ministry of Rties

Libu Shiliang 禮部侍郎, see Vice Minister of Rites

Liguo Zhuan 歷國傳, 89

Lin En 林恩, 10

Lingnan 嶺南, 111, 153

Lingwu 筑武, 156, 158, 292

Lingzhou 郘州, 144, 149, 188, 191, 241, $265,305,326,328$

Lintao Army 臨洮, 250

Lintun 臨屯, 55

Linyi 林邑 (Champa), 112, 139

Linyu 臨渝, 100

Linzhou 橉州, 332

Little Balur, 252, 253, 257, 257, 258, 284

Liu An 劉安, 30

Liu Boying 劉伯英, 143-4

Liu Chang 劉社, 104

Liu Fang 劉方, 111

Liu Gongquan 柳公權, 15

Liu Huan 劉澳, 154, 282

Liu Hun 柳渾, 334
Liu Kang 柳伉, 325

Liu Kuang 劉貺, 258, 264

Liu Rengui 劉仁軌, 147, 148; role in

Korea, 220-2, 224; 241

Liu Shirang 劉世讓, 144

Liu Wenjing 劉文靜, 169, 170

Liu Wuzhou 劉武周, 173

Liu Yuan 劉淵, 33, 44, 183

Liu Yuxi 劉禹錫, 163

Liu Zhi 劉秩, 8

Liu Zhiji 劉知已, 264

Liu Zongyuan 劉宗元, 163

Liugu 柳谷, 307

liuhou 留後, see deputy commander

Liuqiu 琉球, 116

Lizhou 黎州, 197

Local Regional Commands (zongguan fu), 136

Longyou 隴右, 155, 156, 160, 310, 322, 323

Longzhou 隴州, 337

Lou Shide 婁師德, 149, 247

Loufan 樓煩, 121, 169

Loulan (also Shanshan) 樓蘭, 53, 54

Lu Cheng 陸澄, 90, 91

Lu Sui 路隨, 337

Lu Zhi 陸䞇, 11, 74, 158, 161, 162, 331, 332

Ludongzan 祿東贊, see Mgar Stong rtsan

Lulong 盧龍, 157, 316, 318

Lun Kongre 論恐熱, see Blon Gung bzher

Lun Mingxilie 論名悉獵, see Blon Myeslebs

Lun Yan 論䉷, see Mang nyen bzhi-brtsan

Luoyang Qielan Ji 洛陽伽藍記, 89

Lü Guang 呂光, 52, 53

Lükua 呂夸(Kualü), 107, 108

Ma Chongying 馬重英, 324

Ma Sui 馬燧, 332, 333, 334

$\mathrm{Ma} \mathrm{Yu}$ 馬宇, 10

madhyadesa, 30, 31, 183

Mang nyen bzhi-brtsan (Lun Yan), 246

Mang po-rje (Mangbuzhi), 256

Mangbuzhi 莽布支, see Mang po-rje

Manichean religion, 301

Manichean temples, 165, 318

Manicheanism, 314

Manshu 䗗書, 86

Maozhou 茂州, 201, 243

Maritime Trade Commissioner (shibo shi), 81

marriage alliances, $29,35,44,46,47,48$, 
$49,61,62,74,77,86,100,105,108,140$, $142,173,211,236,237,240,258$; between Tang and the Uighurs, 292-5, 299, 303-4, 307-9; negotiations between Tang and Nanzhao, 344; 351, 352; Song and Liao, 360; marriage, negotiations between Sui and the Turks, 105-6, 121; negotiations between Tang and the Eastern Turks, 173-4, 179; request from the Western Turks, 175, 195; negotiation with the Xueyantuo, 190-91; request from Tuyuhun, 235; request from Tibet, 236-7, 239, 242, 247; request from the Eastern Turks, 266, 267, 268, 269, 272, 276, 278; between Tang and the Khitans, 279; between Tang and the Xi, 279; Türgish, 281

Mawei 馬鬼, 156, 292

Mayi 馬邑, 143, 173, 174

Menxia Sheng 門下省, see Department of chancellery

Mgar Khri 'bring (Qinling), 8, 245, 246

Mgar Stong rtsan (Ludongzan), 238, 239, $240,242,245$

Migu 糜谷, 338

Military Commissioner (jiedu shi), development of, 151-6; in post-An Lushan time, 157-8, 162, 164, 165, 166, 350

Military Commissioner (jinglue dashi, jinglue shi), 152, 153, 154

Militia (fubing, also militiamen), 10, 137, $141,146,151,348,350$

Mimana (Kaya), 125

Ming dynasty, foreign relations of, 362-4

Mingjia 名家, see School of Dialecticians

Minguo furen 珉國夫人, see Consort of the Min state

Mingzhou 洺州, 144

Ministry of Justice (xingbu), 80

Ministry of Receptions (zhuke bu), 79

Ministry of Revenue (hubu), 79, 200

Ministry of Rites (libu), 75, 79, 80

Ministry of War (bingbu), 80

Minor Koguryǒ, 223

Mochuo默啜, see Bäg Chor

Mohe 靺鞨, 99, 100, 109, 110, 122, 136, $177,197,199,211,212,214,218,225$, 227, 228

Momen 莫門, 146

Mongols, 50; rise and the Yuan dynasty, 361-2; relations with the Ming dynasty, 362-64
Mouyu 牟呵, see Bögü

Moyanchuo 磨延啜, see Bayan Chor

Munmu, 223, 224, 226

Munye, 227, 228

Murong Wei 慕容瑋, 33

Murong, 33, 44, 45, 55

Muye, 227, 228

Muyǒ, 226

Muzong, policy, 338

Naghïd Chor (Najiechuo), 315, 316, 317

Najiechuo 那頡啜, see Naghïd Chor

Namgð̌n, 221, 222

Namsaeng, 221

Nanhai Jigui Neifa Zhuan 南海寄歸内法 傳, 90

Nanning 南寧, 143

Nanningzhou, 197

Nanzhao 南昭, 3, 4, 57, 86, 157, 166; relations with Xuanzong, 259-60; alliance with Tibet, 322, 323, 327; alliance with Tang against Tibet, 303, 335-6; relations with Tang from 820, 341-4; and throughout

Nanzhou Yiwu Zhi 南州異物志, 91

National History (guoshi), 92

Neifu Ju 内府局, see Palace treasury

Neishi Sheng 内侍省, see Secrateriat

Neishi Sheng 内使省, see Palace domestic service

neiting 内廷, see inner court

Nine Surnames (jiuxing), 274, 276, 290

Niu Sengru 牛僧孺, 318, 340, 341

Niu Xianke 牛仙客, 154

Nongjia 農家, see Agricultural school

Northern Wei, 31, 32, 34, 35, 36, 46, 47, 50, $52,53,54$

Nuohebo 諾曷鉢，236, 237, 238, 240, 241

Nushibi 姢失畢, 246

Ögä, relations with Tang, 315-9; 355

Office (or Department) of the Secretariat (zhongshu sheng), 67, 70, 88

Office of Daoist Worship (chongxuan shu), 76

Office of General Management (Zongli Yamen), 365

Office of Receptions (dianfan shu, dianke $s h u), 76,77$

Official Interpreter (yiguan), 92

Old Tibetan Annals, 14, 15, 249

Old Tibetan Chronicle, 14, 15, 249

Ormïzt (Wamosi), 315, 316, 317, 318, 354

outer court (waiting), 72 
Pyǒngyang, 16, 82, 122, 147, 210, 220, 221, 222, 224

Paekche, 4, 16; in the Period of Disunion, 55-6; relations with Sui, 110-1, 125-6; in Tang, 145; relations with Gaozu, 207-9; in Taizong's time, 209-14; Tang conquest, 217-21, 223, 224, 225

Palace Armies, 158, 159, 160, 161, 163, 325, 350

Palace Domestic Service (neishi sheng), 80, 81

Palace Secretariat (shumi yuan), 74

Palace Secretary (shumi shi), 74, 164

Palace Treasury (neifu ju), 80, 81

Pang Xun 龎勛, 343, 344, 356

Parhae, relations with Tang and the Turks, 227-7, 358

Parthia, 25

Pērōz, 283

Pei Ju 裴矩, 85, 87; role in policy-making, 116-21; 124, 127, 129, 175, 208, 209

Pei Xingjian 裴行儉, 147, 244, 245, 262

Pei Yan 裴炎, 147, 262

Pei Yun 裴蘊, 130

Persia, 31, 48, 84, 116, 168, 196, 283

Piluoge 皮邏閣, 259

Pingliang 平涼, 303, 334, 337

Pingliangchuan 平涼川, 334

Pinglu 平盧, $153,157,279$

Piti Spring 牁 樢, 307

Pojang, 215, 216, 222, 225, 226

Poksin, 220

Policy Adviser (sanqi changshi), 70

Precious King (baowang), 239

Prefect (cishi), 187

prefecture (zhou), 98, 99, 111, 120, 136, $153,197,267$

Prince of Guangping 廣平, 293, 294

Prince of Yong 庸, 297

Prince P'ung 豐 (Paekche), 220, 221, 222

Prince Yung 隆, 218, 219, 221, 223, 224, 225

Princess Anyi 安義, 105, 106

Princess Bilgä, 293

Princess Chonghui 崇徽, 299

Princess Dayi 大義 (also Princess Qianjin), 103-5

Princess Gu'an 固安, 279

Princess Guanghua 光化, 108, 118

Princess Huarong 華容, 119

Princess Jiaohe 交河, 281, 282

Princess Jieyou 解懮, 86
Princess Jincheng 金城, 87, 247, 248, 249, $250,251,252,253,254,255,258,324$, 351

Princess Ningguo 寧國, 294, 352

Princess Pingyang 平陽, 36

Princess Qianjin 千金, 49, 82, 100-2, 351

Princess Taihe 太和, 308, 317, 318, 352

Princess Taiping 太平, 73, 243, 272

Princess Wencheng 文成, 87, 91, 236, 238, 242, 351

Princess Xian'an 咸安, 304, 352

Princess Xinyi 信義, 121

Princess Yicheng 義成, 86, 106, 115, 127, 128, 172, 173, 174, 179, 351

propriety (li), 19, 23

Protector-general of Anbei 安北, 78, 153

Protector-general of Anxi 安西(Xiyu duhu), $85,140,143,153,251$; and throughout

Protector-general of Beiting 北庭, 153, 253, 272, 273

Protector-general of Chanyu, 153

Protector-general of the Western Regions (Xiyu duhu), 84, 180

Protector-general, responsibilities of, 153 , 198

Protectorate (duhu fu), 145, 153, 197-9, 354

Protectorate of Anbei, 199, 265

Protectorate of Andong 安東, 145, 146, $147,199,222,223$; changes in location, 224-6; 244

Protectorate of Annan 安南, 199, 342, 358

Protectorate of Anxi, 141, 149, 194, 195, 196, 197, 198, 199, 201, 243, 251, 253, 271, 281, 282; and throughout

Protectorate of Beiting 北庭, 197, 199, 282

Protectorate of Chanyu 單于, 78, 199, 267

Protectorate of Hanhai 瀚海, 198, 199

Protectorate of Jinshan 金山, 196, 265

Protectorate of Kunling 昆陵, 196, 244

Protectorate of Mengchi 濛池, 196, 244

Protectorate of Western Regions (Xiyu duhu $f u$ ), 51, 198, 354; and throughout

Protectorate of Yanran 燕然, 192, 198, 199

Pugu 僕固, see also Buqu, 315, 316

Pugu Huaien 僕固懷恩, 159, 293, 294, 296, 297, 298, 299, 325, 326, 352, 357

Puye 僕射, see Deputy head of the department of state affairs

Puyǒ, 55

Qarluq, 278, 281, 284, 295, 305, 315

$q i$ 啓, 169, 171

Qian Daxin 錢大昕, 16 
Qiang 姜, 45, 51, 56, 201, 243, 324, 340

Qibi 契畢, 143, 194, 235, 291, 318

Qibi Heli 契畢何力, 143, 181, 190, 240

Qieshi, see Kashgar

Qifu Hui 乞伏慧, 99

Qifu 乞伏, 45, 46

Qiju Lang 起居郎, see Imperial diarist

Qiju Sheren 起居舍人, see Imperial diarist

Qiju Zhu 起居注, see Court diary

Qilixu 乞力徐, see Khri-gzigs

Qimin 啓民, 92, 106-7, 114-5, 118, 119, 121, 187

Qing dynasty, foreign relations, 364-5

Qingshui 清水, 329, 332, 333

Qingzhou 慶州, 357

Qinling 欽陵, see Mgar Khri 'bring

Qinzhou 秦州, 337

Qiuci 龜茲, see Kucha

Qiulong 酋龍, 342

qiuyan 求言, 68

Quan Tangshi 全唐詩, 11

Quan Tangwen 全唐文, 11

Qullïgh Boila (Guli Peiluo), 278, 287, 291

Qutlugh (Guduolu), 263, 265, 266, 290

Rangan 染干, see Zamqan

Rectifier of Omissions (buque), 70

Regional Command (fanzhen, also fangzhen), 152, 153, 157-8, 350

Regional Military Command (zongguan fu), $98,99,114,349$

Regional Military Commander (zongguan), 98, 99

Reminder (shiyi), 70

Ren Fang 任昉, 90

Ren Yaxiang 任雅相, 148

Rili 日曆, see Daily calendar

Rong Yu 找昱, 299

Rouran 柔然, 35, 46, 47, 48, 49, 50, 53, 56, 287

Ruizong, power struggle, 145, 150

Samarkand (Kang), 139, 140, 283

Samguk Sagi 三國史記, 14, 15, 16, 219, 223

Samguk Yusa 三國遺事, 14

Sang Hongyang 桑弘羊, 59, 61

Sanqi Changshi 散騎常侍, see Policy adviser

Sansheng 三省, see Three Departments

Scholars of the Northern Gate (Beimen xueshi), 73, 147

School of Dialecticians (Mingjia), 28

School of Yin and Yang and of Five Phases,
28

Secretarial Receptionist (tongshi sheng), 70, 80

Secrateriat (neishi sheng), 129

Secretariat Director (zhongshu ling), 69

Secretariat Drafter (zhongshu sheren), 317

Secretariat-chancellery (zhongshu menxia), 67

Senior Messenger (da xingren), 75

settlement, 42, 46; policy, 62 ; debate in

Taizong's time, 183-7; resettlement of the

Turks, 187-9; of the Tiele, 192-93; Han resettlement, 197; of the Koreans, 215, 222; Tang resettlement policy, 262-4; Xuanzong's resettlement of the Turks, 274-6; 353, 354

Shaanan 陝南, 157

Shaanzhou 陝州, 160, 324

Shabulue, see Ishbara

Shang Beibei 尚卑卑, 341

Shang Jiexi 尚結息, see Zhang rGyal-zigs

Shang Jiezan 尚結贊, see Zhang rGyal tshan

Shang Zhuguo 上柱國, see Supreme pillar of state

Shangguan Wan'er 上官婉兒, 73

Shangshu Ling 尚書令, see Director of the department of state affairs

Shangshu Sheng 尚書省, see Department of State Affairs

Shanshan (Loulan) 鄯善, 53, 54, 119

Shanzhou 鄯州, 240

Shaofu Jian 少府監, see Directorate for imperial manufactories

Shatuo 沙陀, 305, 315, 318, 337, 356

Shazhou 沙州, 137, 341

She Jiancha Yushi 攝監察御使, see Acting investigating censor

Shegui 射匮, 120, 121

Shence Army 神策, 160, 161, 162, 163, $164,165,325,350$

Shengzhou 勝州, 270

Shenyi fengbo 審議封駁, 70

Shenzhou 慎州, 197

Shetu 攝圖, 49

Shi Chaoyi 史朝義, 156, 296, 297, 298

Shi Danai 史大奈, 169

Shi Fasheng 釋法盛, 89

Shi Shuhuxi 史蜀胡悉, 127

Shi Siming 史思明, 156

Shi Tanjing 釋畫景, 89

Shi Zhimeng 釋智猛, 89 
Shibao 石堡, 253, 258

Shibi 始畢, 86, 115, 127, 128, 168, 169, 170,172

Shibo Shi 市舶使, see Maritime trade commissioner

Shiguan 史館, see Bureau of Historiography

Shijia Fangzhi 釋迦方志, 183

Shilong 士龍, 342, 343, 344

Shilu 實錄, see Veritable records

Shine-usu inscription, 14, 306

Shishi Xiyu Ji 釋氏西域記, 89

Shiwei 室韋, 109, 168, 210, 304, 318, 319, 357

Shiyi 拾遺, see Reminder

Shizheng 時政記, see Administrative record

Shizhong 侍中, see Director of the chancellery

Shiziguo 獅子國 (Srilanka), 150

Shouxiang 受降 Fortresses, the building of, 269-70; 275, 277, 296, 307

shu書, 137, 169, 172

shuguo 屬國, see Dependent state

Shule 疏勒, see Kashgar

Shumi Shi 樞密使, see Palace secretary

Shumi Yuan 樞密院, see Palace secretariat

Shun 順 of the Tuyuhun, 118, 176, 236, 237

Shunzhou 順州, 187, 188

Shunzong, reform, 163-4

Shuofang 朔方 Army, 78

Shuofang, 153, 156, 158, 270, 278

Shuozhou 朔州, 106

Sifang Guan 四方館, see Hostel for tributary envoys

Sijie 思結, 199, 291

Silla, 4, 16, 55-6, 83; relations with Sui, 111, 125-6; pro-Tang policy, 206; relation with Gaozu, 207-8; envoys to Taizong, 209; pro-Tang policy, 211-4, 217; alliance with Gaozong, 218-22; conflicts with Tang, 223-7; relations with Parhae, 227-8

Sima Guang 司馬光, 9, 16, 117, 191

Simen 司門, see Transit authorization bureau

Sinocentrism, 22-3

Siyi Shu 四夷述, 86

Siyi Shu 四夷署, see Ceremonial office

Sogdians (Hu), 150, 161, 177, 202, 275, $276,295,301,302,314$

Song dynasty, foreign relations, 358-9; relations with Liao, 353, 358-60; with
Western Xia, 360-1; with Jin, 353; 361

Song Jing 宋懪, 150, 272, 274

Song Minqiu 宋敏求, 9

Song Yun 宋雲, 89, 90

Songzhou 松州, 237, 251

Srong btsan sgam-po, 236, 237, 238, 239

$\mathrm{Su}$ Chuo 蘇綽, 34

Su Dingfang 蘇定方, 217, 218, 219, 220

Su Mian 蘇冕, 8

Su Wei 蘇威, 130

subordinated area commands and

prefectures (jimi fuzhou), 8, 188, 196;

system, 197-202; 361

Suiye 碎葉, see Tokmak

Suiyuan Army 綏遠, 252

Suizhou 部州, 143, 249, 323, 336

Sulu 蘇祿, 281, 282

Sun Hui 孫晦, 257

Suoge 婆葛, 271

Supervising Secretary (jishi zhong), 70, 185

Supreme Pillar of State (shang zhuguo), 207

Surveillance Commissioner (guancha shi), 153

Suzong, 67; assuming the throne, 156; eunuchs in government, 158-9; relations with the Uighurs, 292-6; relations with Tibet, 322-3

T'aejong, 226

Tae Choyǒng, 227

Taichang Si 太常寺, see Court of imperial sacrifices

Taichang Boshi 太常博士, see Erudite of the chamberlain for ceremonials

Taishi Ling 太史令, see Grand astrologer

Taizong, 2, 7, 8, 15, 16, 36, 67, 70, 72, 74, $83,88,100,138$; government 138-9; foreign policy, 139-41; decision-making, 141-44, 170; conquest of the Eastern Turks, 140, 174, 176-9; conquest of the Xueyantuo, 190-2; policy towards the Western Turks and Western Regions, 1935; peace with the three Korean states, 20910; decision for war against Koguryo, 210-14; Silla and Paekche in Taizong's time, 211-7; wars with Koguryor, 215-7; campaigns against Tuyuhun, 235-6; relations with Tibet, 236-9; and throughout

Talas River, 8, 85, 284

Tamim ibn Bahr, 313

Tang Da Zhaoling $J i$ 唐大詔令集, 9

Tang Huiyao 唐會要, 8, 85 
Tang Jian 唐儉, 83

Tang Liudian 唐六典, 7

Tang Tongji 唐統記, 10

Tang Xiujing 唐休譩, 149, 150, 244, 265, 270

Tangut, 57, 357

Tanshihuai 檀石槐, 43, 44

Tanwujie 䰹無竭, 89

Tao river 洮, 251, 357

Taohe Zhenshou Dashi 洮河鎭守大使, see Commissioner for defending Taohe

Taozhou 洮州, 245

Tardu (Datou), 101, 107

Tashkent, 282, 284

Tashkurgan (Congling), 195

Taxation Statutes (fuyi ling), 201

Tegin, 253

Territorial Representatives (chaoji shi), 68

Three Departments (sansheng), 69, 72,129, 139

Tian Guidao 田歸道, 267, 268

Tian Mou 田牟, 315, 316

Tian Kehan 天可汗, see Heavenly Qaghan

Tianbing Army 天兵, 152

Tiande Army 天德, 315, 316, 317

Tibet, 3, 4, 10, 11, 16, 38, 50, 56, 84, 91, $92,119,140,145,146,150$; expansion, $156-7$; 160, 165, 166, 199, 231, 233; compared with the nomadic powers, 233 5; relations with Taizong and Tuyuhun, 236-9; relations with Gaozong and with Tuyuhun, 239-43; competition with Tang in southwest and in the Western Regions, 243-8; treaty with Tang in 706, 248-50; marriage of Princess Jincheng, 247-8; relations with Xuanzong, 250-58; relations with Türgish, 281-282; relations with Suzong, 292; 322-23; with Daizong, 323-7; with Dezong, the Uighurs, Nanzhao, 303, 305-6, 323, 327-36; with Tang in 806-51, 337-41; end, 341; and throughout

Tibetan inscriptions, 14, 15, 249

Tibetans, 9, 10, 78, 79, 147, 161, 162, 195, 225; and throughout

Tiele 鐵勒, 49, 50, 107, 118, 119, 140, 149, $152,168,176,177,191$; resettlement under Tang, 192-3; assistance to Tang campaign, 194, 195; under the jimi system, 199, 201; revolt against Tang, 199, 275; conflicts with the Turks, 265 , 273, 276; Uighurs and the Tiele, 287, 290,
291, 295; and throughout

tingyi 廷議, see Court conference

Tingzhou 庭州, 194, 195, 196, 197

Tölish (Tuli), 174, 176, 177, 178, 179, 181, 187,188

Toch'im, 220

Tokhara, 283, 284, 293

Tokharestan (Tuhuoluo), 85, 283

Tokmak (Suiye), 195, 244, 270

Ton Bagha Tarqan (Dun Mohe Dagan), 301, $302,303,304,315$

Tongdian 通典, 8, 85, 245

Tongding 通定, 123

Tongra, 156, 191, 199, 265, 275, 293, 295

Tongshi Sheren 通事舍人, see Secretariat receptionist

Tonyuquq (Dunyugu), 274, 313

Toquzoghuz, 290

Touring Brokerage (xunyuan), 68

Transit Authorization Bureau (simen), 80

Transoxiana, 271, 283, 284

Treasury Bureau (jinbu), 79

Treaty of Kiakhta, 364

Treaty of Nerchinsk, 353, 365

tribute (or tributary) trade, $27,40,79$

tribute system, $5,9,12,18,21,22,24-8,32$, $58,104,115,116,171,174,180,206$, $208,238,362-3,364,365$

triumphal mound (jingguan), 209

Türgish, 199, 249, 253, 258; relations with Tang and the Turks, 269-72; with Xuanzong, 277, 281-4

Tudong 突董, 302

Tufa 秃髮, 45

Tufan Huanghe $L u$ 吐蕃黄河錄, 86

Tuli, see Tölish

Tulishu 土梨樹, 334

Tumidu 吐迷度, 192

Tuoba Gui 拓跋珪, 45

Tuoba Sigong 拓跋思恭, 357

Tuoba 拓践, 31, 36, 44, 45, 46

Turfan, 11, 362

Turkish inscriptions, 13, 14, 15, 263, 265, 290, 312-3

Turks, 2, 3, 4, 8, 9, 14, 48, 49, 50, 78, 82, $83,85,98,99,100,122,138,143,147$, and throughout

Tutu Chengcui 吐突承璀, 308

Tuyuhun 吐谷渾, $4,45,46,53,57$; relations with Sui, 98, 107-8, 117-20; with Tang, 140, 168, 195, 199; with Gaozu, 175-6; Taizong's campaign, 235-6; 
relations with Tang and Tibet, 231, 237-8, $239-43,246,315,316,318,324,325$, 357; and throughout

Uch-turfan (Dashicheng), 281

Uighurs, 3, 9, 10, 14, 71, 77, 78, 92, 144, $156,157,161,166$; relations with the Turks, 176-7; against the Xueyantuo, 191, 290; under the Tang jimi system, 192-3, 196, 197-202, 290; conflicts with Tang, 253; early development before Tang, 287, 290; relations with Tang and the Turks before $745,265,278,290-2$; relations with Suzong, 292-96; horse-silk trade, 295, 300, 302, 309-11, 352; the Khitans and Xi under the Uighurs, 295-6; relations with Daizong, 296-301, 325-326; relations with Dezong, 301-6, 335-6; conflicts with Tibet, 305-6, 307, 311; relations with

Tang in 805-840, 306-15, 341; reasons for the alliance with Tang, 309-15; end, 3159; and throughout

Ungjin (Xiongjin), 220

Veritable Records (shilu), 92

Vice Director of the Secretariat (zhongshu shilang), 80, 185

Vice Minister of Rites (libu shiliang), 185

Waiguo Shi 外國事, 89

Waiguo Zhuan 外國傳, 89

waiqi 外戚, 72

waiting 外廷, see outer court

Wamosi 嗢没斯, see Ormïzt

Wan Zhen 萬震, 91

Wang Chengzong 王承宗, 307

Wang Jun 王晙, 78, 274, 275

Wang Junchuo 王君莫 , 253, 291

Wang Mingsheng 王鳴盛, 16

Wang Mingyuan 王名遠, 85

Wang Mo 王謨, 90

Wang Pu 王溥, 8

Wang Qinruo 王欽若, 8

Wang Shichong 王世充, 173

Wang Xianzhi and Huang Chao rebellion 王 仙芝, 黃巢, 166, 344, 357

Wang Xiaojie 王孝傑, 149, 244

Wang Xuance 王玄策, 83, 238

Wang Zhongsi 王忠嗣, 78, 155, 258

Wanshou fort 萬壽戍, 115

Wei Chong 韋沖, 99

Wei Daijia 韋待價, 149

Wei Gao 韋皋, 86, 335, 336

Wei Hongji 韋弘機, 83

Wei Jie 韋節, 84, 85
Wei Lun 韋倫, 327, 328

Wei Man 衛滿, 54

Wei Shu 韋述, 83

Wei Xiang 魏相, 59

Wei Yuanzhong 魏元忠, 242

Wei Zheng 魏徵, 139, 142, 143, 186, 189, 194, 209, 213, 215

Weibo 魏博, 157

Weizhou 渭州, 250

Weizhou 維州, 165, 201, 336, 340, 341

Wen Daya 溫大雅, 7, 170, 171

Wen Yanbo 溫彥博, 140, 141, 186, 187, 188, 208, 209

Wenguan Cilin 文館詞林, 7

Western Regions, 4, 26, 37, 42, 52-4, 82, $83,84,85,86,87,88$; in Sui, 116-20; in Tang, 138, 139, 140, 145, 146, 153, 157, $168,175,180$, 193-5; Tibet and Tang competition over, 243-7, 251-3, 305, 332; and throughout

Western Turks, in Sui, 101-7, 117, 118, $120-1$; in Tang, 140, 141, 145, 168, 175, 193-5; Gaozong's conquest, 195-7; situation under Empress Wu, 243-7, 265, 266, 269; and throughout

Western Xia, relations with Song, 360-1

White-clothed Turks, 305

Wu Chonggui 武重規, 268

Wu Jing 吳嗔, 7

Wu Yanxiu 武延秀, 268, 269

Wu Zetian 武則天, see Empress Wu

Wuhuan 鳥桓, 43, 44, 46

Wukong 悟空, 90

Wushi Waiguo Zhuan 吳時外國傳, 82

Wusun 鳥孫, 86

Wuwei 武威, 119

Wuyuan 五原, 106, 136, 172

Wuzhile 鳥質勒, 270, 271

Wuzong, government, 165 ; policy toward the Uighurs and Kirghiz, 315-9

$\mathrm{Xi}$ 突, 3, 99, 102, 109, 152, 153, 156, 176, $177,198,199,210$; assistance to Taizong, 214-5; relations with Xuanzong and the Turks, 228, 273-4; 276, 279-80; under the Uighurs, 295-6; 304, 315, 318, 357, 358; and throughout xian 縣, see district

Xianbei 鮮卑, 31, 33, 34, 35, 43, 44, 45, 46

Xiangwei 相魏, 157

Xianyu Zhongtong 鮮于仲通, 259

Xianzong, government, 164-5; relations with the Uighurs, 307-8; with Tibet, 337 
Xiao Siye 蕭嗣業, 78

Xiao Xingren 小行人, see Junior messenger

Xiao Yu 䐸㻦, 141, 178

Xiazhou 夏州, 143, 185, 265, 300, 332, $333,334,357$

Xichuan 西川, 86

Xidamou 悉怛謀, 340

Xie Wan 解琬, 250

Xieli 頴利, relations with Tang, 173-9, 187

Xietie 爽跌, see Ädiz

$X i f a n J i$ 西蕃記, 85

Xihai 西海, 118, 239

Xin Tangshu 新唐書, 7, 8, 9, 15, 251

Xinan Beibian $\mathrm{Lu}$ 西南備邊錄, 86

Xincheng 新城, 224

Xing Tang Temple 興唐, 326

Xingbu 刑部, see Ministry of justice

Xingjun 行軍, see expeditionary armies

Xinluo Guoji 新羅國記, 83-84

Xiongjin 熊津 (Ungjin), 219, 221, 223, 224

Xiongnu 匈奴, 3, 24, 25, 26, 27, 29, 33, 38, $41,42,43,44,49,50,51,55,61,62,74$, $101,171,183,186,245,263,311,312$; and throughout

Xirong Jiaowei 西戎校尉, see Commandant of Western Rong

Xiyizhou 西伊州, 193

Xiyu Duhu 西域都護, see Protectorgeneral of the Western Regions

Xiyu Guozhi 西域國志, 83

$X i y u J i$ 西域記, 85

Xiyu Jiaowei 西域校尉, see Commandant of Western Regions

Xiyu Tuji 西域圖記, 85, 117

Xiyu Zhangshi 西域長使, see Aide of the Western Regions

$X i y u$ Zhi 西域志, 85

Xizheng $J i$ 西征記, 83

Xizhou 西州, 140, 194, 196, 243, 311

Xu Hui 徐惠, 213

$X u$ Huiyao 續會要, 8

Xu Jingzong 許敬宗, 7, 170

Xuantu芝菟, 55, 208

Xuanwu Gate 玄武, 138

Xuanzang 玄牀, 88, 89, 194

Xuanzong, 67, 72, 73, 74; poicy, 150-1; frontier system, 151-4; relations with Parhae and Silla, 227-8; relations with Tibet, 250-8; treaty with Tibet in 732, 253-6; relations with Nanzhao, 259-60; relations with the Turks, 272-9; with the
Khitans and $\mathrm{Xi}, 273,276,277,279-80$;

with the Türgish, 281-84; encounters with the Arabs, 283-4; and throughout

Xue $\mathrm{Na}$ 薛昞, 273

Xue Qianguang 薛謙光, 264

Xue Rengui 薛仁貴, 222, 223, 224, 225, 273

Xueyantuo 薛延陀, 140, 141, 142, 143; relations with the Turks and Tang, 176-8, 189, 194, 200, 214; Tang conquest, 190-2, 199; resettlement, 192-3; and throughout

Xunbian Shi 巡邊使, see Frontier patrolling inspector

Xunyuan 巡院, see Touring brokerage

Xunzi 荀子, 21

Xuzhou 徐州, 343

Yan Liben 閻立本, 240

Yan Shigu 顏師古, 185

Yan Zhiwei 閻知微, 267, 268

Yang Fu 楊孚, 91

Yang Gongren 楊恭仁, 136

Yang Guang 楊廣, see Emperor Yang

Yang Guozhong 楊國忠, 72, 73, 154, 155, $156,259,260$

Yang Jian 楊堅, see Emperor Wen

Yang Ju 楊矩, 249, 250

Yang Qin 楊欽, 104

Yang Shaofu 楊紹復, 8

Yang Su 楊素, 123

Yang Xigu 楊希古, 305

Yang Xuangan 楊玄感, 123

Yang Yan 楊炎, 161, 328

Yang Yi 楊憶, 8

Yang Yuhuan 楊玉環, 73, 155, 156

Yang Zhengdao 楊政道, 172, 179

Yanmen 鴈門, 127, 130, 168

Yanqi 焉耆, see Karashahr

Yanran 燕然, 148

Yanying Dian 延英殿, see Yanying hall

Yanying Hall (Yanying hall), 67

Yanzhou 燕州, 136

Yanzhou 䜿州, 332, 333, 334, 336, 356

Yao Chong 姚崇, 150, 272, 273

Yao Zi'ang 藥子昂, 297

Yaozhou 姚州, 249

Yazhou 雅州, 243

Yehou Jiazhuan 鄴侯家傳, 10, 304

Yelü Abaoji 耶律阿保機, 358

Yi'nan 夷男, 176, 177, 178, 189, 190, 191

Yiguan 譯官, see Official interpreter

Yijing 義淨, 90

Yimouxun 異牟尋, 335, 336 
Yingzhou 營州, 85, 99, 100, 114, 144, 150, 211, 215, 266, 273, 279

Yinzhou 銀州, 332, 357

Yiwu 伊吾, see Hami

Yizhou 伊州, 140, 193, 194

Yizhou 盆州, 245

Yŏn Kaesomun 泉蓋蘇文, 211, 213, 214, 215, 216, 221

Yongji 永濟 canal, 114, 122

Yongle emperor, 362, 363

Younger Princess Ningguo 寧國, 294

Youxing Waiguo Zhuan 遊行外國傳, 89

Youzhou 佑州, 188

Youzhou 幽州, 99, 157, 162, 188, 273, 279, 296, 316; and throughout

Youzhou 有州, 275, 357

Yu Chaoen 魚朝恩, 159, 160, 325

Yu Shiji 虞世基, 130

Yuan Junzhang 苑君璋, 174, 177

Yuan Xiu 源休, 301

Yuan Zai 元載, 160, 161, 326, 327

Yuanzhou 原州, 326, 337

Yuchi Jingde 尉遲敬德, 142

Yuezhi 月氏, 50, 89

Yugong 禹貢, 21

Yulin 榆林, 172

Yunzhong 雲中, 188, 199

Yunzhou 雲州, 99

Yushi Tai 御使臺, see Censorate

Yutian 于閶, see Khotan

Yuwen Tai 宇文泰, 33, 34, 181

Yuwen Yong 宇文画, 49

Zabulistan, 253

Zaixiang 宰相, see Chief ministers

Zamqan, 105-6

Zanpo 贊婆, 246, 247

Zhang Changxun 張長遜, 136

Zhang Guangsheng 張光戟, 301, 302

Zhang Jia 張賈, 77

Zhang Jian 張儉, 85, 144

Zhang Jiuling 張九齡, 11, 70, 154, 155 , 277

Zhang Liang 張亮, 142

Zhang Qian 張塞, 25, 50, 57, 82

Zhang Renyuan 張仁愿, 270

Zhang rGyal tshan (Shang Jiezan 尚結贊 人, $328,329,331,332,333,334,336$

Zhang rGyal-zigs (Shang Jiexi 尚結息), 328

Zhang Shougui 張守珪, 154, 256, 279, 280

Zhang Wenguan 張文瓘, 224

Zhang Xuanbiao 張玄表, 154, 249, 252
Zhang Yanshang 張延賞, 333

Zhang Yi 張鎰, 329

Zhang Yichao 張義潮, 341

Zhang Yue 張說, 151, 253

Zhang Zhiyun 張之運, 275

Zhangshi 長使, see aide

Zhangsun Sheng 長孫是, 82, 83; role in

Turkish policy, 100-7, 116, 117, 127, 129

Zhangsun Wuji 長孫無忌, 72, 100, 141, 178,211

Zhangye 張掖, 85, 116, 117, 118

zhao 詔, 137

Zhao Huicong 趙惠琮, 257

Zhao Yi 趙翼, 16

Zhechong Fu 折衝府, see assault-resisting garrisons (intrepid militias)

Zhenfan 員蕃, 55

Zheng He 鄭和, 363

Zheng Yuanshu 鄭元 璕, 78

Zhengdian 政典, 8

Zhengshi Tang 政事堂, see Administration chamber

Zhengtong emperor, 363

Zhenguan Zhengyao 貞觀政要, 7, 193

Zhenwu 振武, 301, 302, 304, 357

Zhenzhu 葚珠, 196

Zhi Sengzai 支僧載, 89

Zhifang Si 職方寺, see Bureau of operations

Zhong Tianzhuguo Xingji 中天竺國行記, 83

Zhonghang Yue 中行說, 312

Zhongshu Ling 中書令, see Secretariat director

Zhongshu Menxia 中書門下, see Secretariat-chancellery

Zhongshu Sheng 中書省, see Office (or Department) of the secretariat

Zhongshu Sheren 中書舍人, see

Secretariat drafter

Zhongshu Shilang 中書侍郎, see Vice director of the secretariat

Zhongzong, power struggle, 144-5, 150; treaty and alliance wiht Tibet, 247-50; relations with the Turks and the Türgish, 269-72

zhou 州, see prefecture

Zhou Yao 周搖, 99

Zhou Yiti 周以悌, 271

Zhouli 周禮, 21

Zhu Ci 朱泚, 161, 163, 330, 331, 332

Zhu Fawei 筑法維, 89 
Zhu Tao 朱滔, 161, 302, 303

Zhu Ying 朱應, 82

Zhudao Jinzou Yuan 諸道進奏院, see

Capital liaison office of various regions

zhuhou 諸侯, 19

Zhujubo 朱俱波, see Karghalik

Zhuke Bu 主客部, see Ministry of receptions

Zhuke Qingli Si 主客清吏司, see Bureau of receptions

Zhuke Si 主客司, see Bureau of receptions

Zhuojun 浄郡, 114, 122

Zizhi Tongjian Kaoyi 資治通擥考異, 9 ,

$10,16,86,251$

Zizhi Tongjian 資治通㯺, 9, 10, 11, 15, 17, 304, 313

Zong Chuke 宗楚客, 271

Zongguan, see regional military commander

Zongguan $\mathrm{Fu}$ 總管府, see regional military command, area command, local regional command

Zongli Yamen 總理衙門, see Office of general management

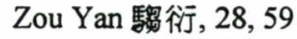

Zunwang 酕王, 235, 236 


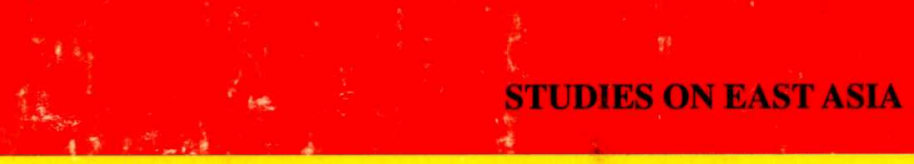

Opuscula Altaica: Essay s Presented in Honor of Henry Schwarz, edited by Edward H. Kaplan and Donald W. Whisenhunt. 1994. xvi, 691 p., ill., bibliographies. Hardcover. ISBN 0-914584-19-7. \$85. Vol. 19.

A collection of essays by thirty-1hree scholars from a dozen countries presented to Henry G. Schwarz on the occasion of his retirement from academic life. Most of them deal with subjects that Professor Schwarz has been deeply involved in during his long professional career, from Central Asia eastward through Mongolia and China's northern border areas to the Pacific Ocean.

A Chapge in Dynasties: Loyalism in Thirteenth-Century China, by Jennifer W. Jay. 1991. xiv, 309 p., maps, notes, bibl̨iography. glossary-index. Hảrdcover. ISBN 0-914584-18-9. \$35. Vol 18.

"The book's chicf contribution is the debunking of the myth of a widespread ... loyalism.' American Historical Review

Reminiscences, by Nicholas Poppe, edited by'Henry G. Schwałz. 1983. vii, 330 p., ill., notes, person index. Hardeover. ISBN, 0-914534-16-2. \$25. Vol. 16.

“... definitely deservés purchase and reading by all parties who deal with Mongolia, and will have interest for students of Soviet life, and, indeed, the whole human condition." Mongolian Studies

\section{EAST ASIAN RESEARCH AIDS AND TRANSLATIONS}

\section{[FORTHCOMING]}

Through the Ocean Waves: The Autobiography of Bazaryn Shirendev, by Bazaryn Shirendev, translated by Temujin Onon. 1997. ISBN 0-914584-80-4. Vol. 6.

The memoirs of the Mongolian Republic's most distinguished scholar. A fascinating blend of historical, political and ethnographic information by a scholar who was "present at the creation" of much of twentieth century Mongolia's history.

A Monetary History of China, by Peng Xinwei, translated by Edward H. Kaplan. 1994. 1, 932 p., ill. ISBN 0-914584-81-2. \$50. Vol. 5.

"... will become the single most important work on the subject in English. ... The book is packed with'new information and insights and is a pleasure to read. Also unlike many books published in China, this work includes footnotes and the translation includes an index." Journal of East Asian Numismatics

"... the single most important work on Chinese money in any language." Oriental Numismatic Society Newsletter 